


\section{得淂 \\ THE LIBRARY \\ OF \\ THE UNIVERSITY \\ OF CALIFORNIA RIVERSIDE \\ GIFT OF \\ John W. Olmsted}




$$
10 \$ 2568626
$$




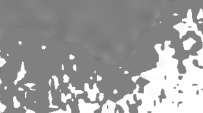

$$
\begin{aligned}
& \text { ats } \\
& \therefore \text { ? } \\
& -8
\end{aligned}
$$

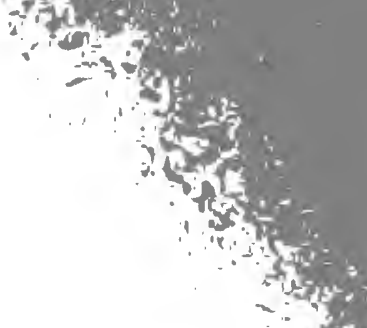$$
\text { at. }
$$$$
30
$$$$
\text { tis }
$$$$
\text { - } 7=
$$ 


\title{
THE BEGINNINGS OF MODERN EUROPE
}

\section{$(1250-1450)$}

\author{
BY
}

EPHRAIM EMERTON, PH.D.

PROFESSOR OF HISTORY IN HARVARD UNIVERSITY

GINN AND COMPANY

BOSTON - NEW YORK - CHICAGO - LONDON

atlaNta - DALlas - COLUMBUS - SAN FRANCISCO 


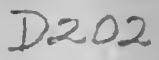

E5

COPYRIGHT, 1917, BY EPHRAIM EMERTON

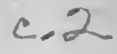

ALL RIGHTS RESERVED

PRINTED IN THE UNITED STATES OF AMERICA

$331 \cdot 3$ 
TO

THE SHOP-CLUB

MOST PATIENT OF LISTENERS

KINDEST OF CRITICS

DEAREST OF FRIENDS 


\section{PREFACE}

The period of which this volume treats differs fundamentally both from that which precedes and from that which follows it. In each of those periods we are able to fix our attention upon a certain well-defined set of institutions which completely control its activities In the former, the strictly mediæval, we see Europe wholly under the sway of two vast ideas, feudalism and the Roman church system. In the latter, the purely modern period, Europe has almost wholly lost those ideas and has come out into the familiar political structure of a family of independent national states and into the freer air of religious toleration, if not yet of religious liberty.

Between these two lies the period which is the subject of our present study. It is a chapter in human history of which no brief general description can be given. It is impossible to point to any peculiar institutions that govern its life. As we try to unfold the tangled thread of its history we seem to find only confusion and disorder. It reminds one in many ways of that other and even greater confusion that lies between the records of Rome and those of the Germanic Middle Ages. There we are conscious of a mighty civilization passing away and of another just vaguely taking shape in rude barbaric forms which, however, contain the germs of a new and more vigorous life. So here again we find two opposing currents in the stream of human history, and already at the beginning of our study it is clear which of them is destined to prevail. The vast, picturesque structure of the Middle Ages has done its service and is beginning to crumble. In every direction the resistless forces of the modern world are undermining its foundations or with bolder front are beating in open assault :against. its walls. . . 
To the careful student there is neither disorder nor confusion in the process. It is simply a natural development working out. its results by the method of inevitable compensation. In the earlier transition - that from Rome to the Middle Ages - the shock of change is the greater because there is a change also in the race which is to be the bearer of the world's civilization. That whole transition may be summed up dramatically in the contrast of Roman and Teuton. Not only do institutions disappear, but the very race which created them disappears also as a historical unit. A new Europe is brought into the ken of history by a new race actually, in physical fact, emerging out of the darkness and taking its place in the great procession of historic peoples. In the present transition there is no such dramatic moment. The nations which make the modern world are the same that had brought mediæval culture to its height. They have simply been going through a process of education and are now just beginning to see the meaning of it. The new succeeds the old through the silent working of development. Not that this period is without its great conflicts. There is enough of the dramatic in the sharp contrast of ideas and in the clashing of ancient rights with newly asserted claims to make every chapter of this transition alive with vivid interest.

It will be of service to us at the outset to formulate these contrasts and these conflicts into some general expression which may serve us as a guide in our study of details. Our period has never been better characterized than by Michelet in the phrase: "The Discovery of the World and of Man," a phrase which seems at first only a mystic symbol of nothing in particular but which, understood, lets us in to the very heart of the apparent puzzle of this period. The theories of mediæval life represented Man as subject, in all his relations, to the domination of certain great general ideals to which the individual must surrender himself. A deep distrust of Man, as of a being essentially unworthy, pervades mediæval thought. Ideas then had value only as they stood related to a certain ideal Truth vaguely comprehended, it is true; but 
nevertheless firmly believed in, - nay, believed in the more firmly because it was not comprehended. For, to the mediæval mind there was a distinct element of error and of wrong in anything that depended upon observation through the senses or upon the reflection of the human intellect. All that world of phenomena which we call "real" because, as we say, we can grasp it by our senses and make it our own by some act of the reasoning mind, all this was to the mediæval man unreal and untrustworthy. For him the only "reality" was the unseen ideal of which these phenomena of the sense and reason were only the illusive shadows. The result was that blindness of the eyes and dullness of the mind became to him a kind of solemn duty. He hardly dared open his eyes wide upon the world of beauty and order about him lest it might turn him from those higher contemplations in which he hoped by some specific divine inspiration to catch the secret of the Infinite.

Naturally these conceptions solidified into institutions. Out of the notion of the "reality" of abstract ideas grew up the great system of the scholastic philosophy. If it were indeed true that there was a determined volume of religious truth, then it followed that there must be some human organization by which that truth should be made known to men, and that was the Church, an abstraction made concrete in the Roman papal system. If the idea of power were indeed a divine concept, then there must be some human order in which the divine will should have made this abstraction also concrete, and there was the beautiful feudal hierarchy, indedependent of all limitations of country or of race, culminating in that mysterious idea of the Mediæval Empire, which was to be, above all other earthly powers, the interpreter of the divine order in human affairs, responsible to God alone.

So in the realm of human law. It was not for any man, not even a king, to declare this or that principle in law because, in his opinion, it was right or just or expedient. The law was there, a body of tradition received from the fathers, to be practiced, not improved. The Law was above all laws, and it would have been 
presumption for any individual to claim the right to change it. In the world of art it was the same. The Middle Ages produced perhaps the grandest expression of the artistic spirit the world has known, the Gothic architecture; and yet we are in almost total ignorance of the individual genius that inspired and carried out those wonderful designs.

Whichever way we turn in the middle period we are impressed with the fact that individual thought and action had only a subordinate place. The individual was of value only in so far as he made himself the agent of some one of the great dominant ideals by which society was ruled. There was throughout this time a something positively impious in the idea that a man was worth something for himself because he was a thinking being, with a mind given him to use and therefore worthy of his respect. The most vivid expression of this feeling is seen in the immense hold of the ascetic principle. The typical man of the Middle Ages is he who can most completely deaden himself to all natural impulses. The more completely a man could repress his self and sink himself in the mass according to one or another of the accepted methods, the more nearly he approached to the medirval idea of perfection.

We come to realize all this only when we begin to contrast the mediæval spirit with that which animates every great undertaking of the period we are studying. In every field of human effort one perceives now a significant change. The individual human being begins to assert his right to weigh and measure the universe by the standards of his own intelligence. A bold spirit of inquiry and of assertion begins to take the place of a timid yielding to existing authority. Grand general ideas, such as the sole and sufficient authority of the Church in matters of thought, begin to lose their hold. Uniformity of life ceases to be the highest ideal of society, and diversity begins to be respected. A man is no longer crushed when he puts forward an idea, but may at least be heard and has a fighting chance of winning his way. The two splendid fictions of 
the Middle Ages, the universal Empire and the universal Church, have both ceased to command an absolute allegiance and are adjusting themselves to a changing order of things. The nations are escaping from the leveling theory of a universal Christian state under ecclesiastical control and are declaring their right to exist, each for itself, and to work out, each in its own way, the problems of administration and of social progress that lie before them. An immense material advance - the effect chiefly of the growth of a great vigorous and determined middle class - is carrying the European populations forward to ever-new demands upon life and ever-fresh exertions to satisfy them. New lines of trade and manufacture are widening the intelligence and capacity of the productive classes. Science, which under both ancient and mediæval conditions had existed chiefly as philosophy, now begins to venture upon the method of experiment. All men are no longer satisfied with saying, "These things are so because according to certain premises they ought to be so"; some bold spirits are daring to say, "These things are so because we see or feel them to be so." Human powers of observation and reflection; human energy ; a confidence in human evidence; a desire to cultivate oneself as a human being, a worthy creation of God, - all these are taking the place of the mediæval distrust of all that was human.

Our period has often been well called, from one of its most important phenomena, the Age of Humanism. The same impulse that was leading scholars away from the dull theological traditions of the "schools" into the larger freedom of the revived classical study with its fresh human interests was moving also through all classes of European society. Wherever we turn we find the same impatience of traditional restraint, the same restless struggle to throw off the fetters of a past that had had its day. The fourteenth century is seething with rebellion, - nations against the Papacy, Humanism against Scholasticism, trading cities leagued against feudal rights that would check their progress, great masses of laboring people rising here and there in blind fury against legalized 
oppression. Everywhere, to use another antithesis, the struggle of common sense against a kind of sense which claimed to be too high and too sacred for the common man. For the first time since the end of the ancient world that peculiar kind of argument which we can describe in no other way than as the appeal to common sense was beginning vaguely and hesitatingly to make itself heard and to win a following.

This, then, will be the natural thread of our narrative: the working out, consciously in literature and unconsciously through social and political conflict, of the idea that individuals or bodies of men voluntarily united in a common interest might, if they pleased, speak and act for themselves. The following pages are an attempt to illustrate this principle by means of the most striking phenomena of the transition period. That such a study forms the best introduction to the history of the Protestant Reformation of the sixteenth century is evident. So far as possible, however, the more purely theological aspects of the time have been omitted here, since they may be studied more intelligently in connection with the Protestant movement itself.

No attempt has been made to give a continuous narrative of events either in the history of Europe as a whole or of the several European countries. England has been left out almost entirely because her national development, largely independent of continental movements, has been abundantly treated in special works. The history of Germany after $135^{6}$ has been touched upon rather slightly and only with a view to bringing out certain important phases, such as the Hussite wars and the working of the principle of voluntary association in the Hanseatic League. The German dynastic conflicts of the period are as unimportant as they are unedifying.

The topical method here employed implies inevitably a certain amount of repetition, but it is hoped that this will be useful in showing the interrelation of the several historical movements described, 
I desire to express my obligation to many friends who have helped me with their learning and their counsel. Especially my thanks are due to my colleague, Professor Charles Homer Haskins of Harvard University, and to the Reverend Father Paschal Robinson of the Catholic University of America, who have had the great kindness to read my proofs and whose suggestions have added much of accuracy and fairness to the treatment of a subject necessarily involving many differences of opinion and of judgment.

E. E.

Cambridge, Massachusetts 


\section{CONTENTS}

CHAPTER

PAGE

I. The Principle of the Modern State . . . . I

II. The New EMpire . . . . . . . . . 47

III. The New Papacy . . . . . . . . . . . Io6

IV. The Rise of a Middle Class . . . . . . . 164

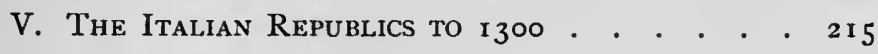

VI. The Hundred Years' War . . . . . . 252

VII. The Age of the Councils . . . . . . . $3 \mathrm{II}$

VIII. The Age of the Despots in Italy . . . . $35^{8}$

IX. The Renaissance in Italy . . . . . . . 461

X. The Northern Renaissance . . . . . . 509

INDEX . . . . . . . . . . . . . 535 


\section{LIST OF MAPS}

Europe in the $14^{\text {th Century }}$. . . . . . . . . . . 42 Austrian Lands to 1527 . . . . . . . . . . . $5^{8}$ Germany in the $14^{\text {th }}$ Century . . . . . . . . . . 90 The Swiss Confederation . . . . . . . . . . . 170 The German Hansa about 1400 . . . . . . . . 186 France during the Hundred Years' War . . . . . 256 Ecclesiastical Provinces of Europe about the Year 1500 . $33^{\circ}$ Italy in the $15^{\text {th Century }}$. . . . . . . . . . . 394 


\section{THE BEGINNINGS OF MODERN EUROPE}

\section{CHAPTER I}

\section{THE PRINCIPLE OF THE MODERN STATE}

The principle of the mediæval, feudal state is to be found in the division of what we call "sovereign powers" among a great number

\section{Sovereign}

of persons. These powers are chiefly the military, the Powers in the judicial, and the financial. The military power includes Middle Ages not merely the defence of the country against a foreign enemy, but also the maintenance of order within the country or, in our modern usage, "police." The judicial power means the right and the corresponding duty to administer justice in all "civil" cases, - that is, cases involving questions of right as between one man and another, - and also to punish offences against the welfare of society, or, to speak technically, "crimes." The possession of judicial power implies also the existence of a sufficient military force to carry out the decisions of the court, whether this force be in the hands of the court itself or of some power on which it can depend to work in harmony with it.

The financial power means the right to tax the people for public purposes, and the variety of ways in which this can be done is infinite. In practice, of course, this power also cannot be applied without a sufficient working force to carry it into effect. It is by far the most difficult to regulate of the three attributes of sovereignty because it is never quite easy to define just what are public purposes or how far the financial superior may go in his demands. 
Under the feudal system of the Middle Ages these rights were generally combined in one hand. The same person was military The MediaThe Medix- leader, judge, and tax gatherer, and there was a vast
val King and number of such persons, separated one from the other
the Sover-
eign Rights divisions of territory or by the gradations of rank.
It is true that these scattered territories were held The Mediz- leader, judge, and tax gatherer, and there was a vast
val King and number of such persons, separated one from the other
the Sover-
eign Rights divisions of territory or by the gradations of rank.
It is true that these scattered territories were held eign Rights together in larger groups, the great principalities or kingdoms, and that the different ranks within such a larger territorial unit were bound to each other by a chain of allegiance to the prince or king at the head. In theory the king had the supreme military, judicial, and financial control of the kingdom. He appears as the head of the national army, he is the "fountain of justice" for all the people, and he has a right to demand from the people a contribution of their wealth to carry on the business of government. Or, to begin at the other end, in theory the people paid taxes to support persons who should see that justice was done them and who should defend them against their enemies or lead them out to war for their advantage. All this in theory; in practice the society of the Middle Ages felt but slightly the bonds of this larger association in what we call the "State." It felt very strongly the bonds which held individuals together in the smaller territorial groups or in the grades of social rank. It was a matter of comparative indifference to the mediæval man whether he were called a Frenchman, a German, or an Englishman. He might as well pay his taxes or serve in the army or get his justice under one of these names as the other; but it was a matter of great moment to him whether he were a Gascon, a Norman, a Picard, a Burgundian, a Swabian, or a Saxon. So, again, he was keenly conscious whether he was a freeman or a serf, a "villain " or a knight, a crown vassal or a vassal of the Church, and he felt a certain community of interest with all his brethren in rank, no matter under what ultimate sovereignty they might be living.

The story of Roger Bigod, Earl of Norfolk and Marshal of England, told in the quaint language of Walter of Hemingburgh, shows 
the temper of feudal independence. Called by King Edward I to serve in Gascony while the king was fighting in Flanders, he refused.

"At the feast of St. Matthew the Apostle, in the year 1297 the king summoned the lay chiefs of the realm to a parliament at Salisbury and called upon certain of the barons to go to Gascony; but they began, one by one, to excuse themselves. Then the king was wroth and threatened some of them that if they refused to go he would give their lands to others who would go. At this many were scandalized, and a division began among them. For the Earl of Hereford and the Earl Marshal made their excuse, saying that they would gladly pay the service to which they were bound by hereditary obligation and would go with the king's person. And a second time the demand was made of the Earl Marshal that he should go. Then he said: 'Freely will I go with you, O King! as my hereditary duty requires.' And the king said: 'Without me too you shall go with the rest.' He replied: 'To this I am not bound, and it is not my will to take the field without you.'

"Then the king in his wrath broke forth, it is said, in these words : 'By God, Sir Earl, you shall either go or hang!' And he: 'By the same oath, Sir King, I will neither go nor hang!' "'

When the emperor Frederic Barbarossa was gathering his forces for his great struggle with the cities of Lombardy, he ordered, begged, entreated, even went on his knees to his subject, Henry the Lion, duke of Bavaria and Saxony, to persuade him to join his army, but Henry refused, and there was no process by which either he or his fighting men could be compelled to obedience. The crushing defeat of Barbarossa in the fatal day of Legnano (I 176 ) was largely owing to this refusal.

It is evident that under such a system of government great national undertakings were impossible, and in fact the chief military achievements of the Middle Ages were either feats of arms under single princes, like the conquest of England by William of Normandy and that of Southern Italy by other Normans, or else 
they were great schemes having a universal character, such as the Crusades in the East and the overrunning of Languedoc in Beginnings the early thirteenth century in the name of orthodox of a National Christianity. The system could survive only so long Sentiment

as the sentiment of nationality remained weak. As soon as national limits became fairly well determined and men were beginning to feel themselves as belonging primarily within these territories rather than primarily as members of a race, then the instinct to express this territorial allegiance by service began to assert itself. That is what we mean by Nationality, and it is a sign of the coming of the modern world in distinction from the world of the Middle Ages. It takes a long time for this sentiment to become practical and to work itself out into institutions, but the thing itself is unmistakable from the first, and the growth of the institutions that embody it can be traced with entire distinctness.

Let us go back to one of our illustrations. After the return of Frederic Barbarossa from his defeat in Italy, he proceeded to Insufficiency punish Henry the Lion for his disobedience. He first of the Feudal called an assembly of the German princes, many of Principle

whom he had bought by great concessions of land and power, and gained from them as a court of peers a judgment against Henry for violating his feudal obligation. Then acting upon this as his authority he declared Henry to have forfeited his feudal estates. Finally, with the help of other princes who expected to share the spoil, he drove him from his dukedoms and divided these among his own fideles. That was the mediæval method. Henry was a traitor, not to Germany but to his feudal superior. He had violated the contract by which he held his principalities, and the penalty was the loss of these and their redistribution to more faithful vassals. But the price of victory for the crown was one that it could not often afford to pay. There could not be an unlimited supply of crown fiefs with which to buy the support of one vassal against another, and a crown dependent upon this kind of support would not be worth the having. 
The system worked only so long as there was not much for kings to do, and while society was constituted on this basis, it produced some very splendid results. The moment, however, that governments, royal or not, began to be conscious of their rights and duties, the weakness of it became unendurable.

It is obviously impossible to fix upon any point of time as marking the beginnings of modern government. They go well

Earliest back into the period commonly described as "medi"Modern" reval," but wherever they appear, we may be quite State, I23I sure that the mediæval character is disappearing from the society that produces them. One of the earliest attempts at creating a modern out of a mediæval government is that made by the emperor Frederic II in his hereditary kingdom in southern Italy and Sicily. Frederic was the grandson of Barbarossa and the son of that emperor Henry VI who had married Constance, the heiress of the Norman kingdom. He had had ample opportunity in the years between his accession to the Empire in 1215 and the year 1 231 to learn all the weaknesses of the mediæval system. He was an ambitious, energetic young prince, filled with the vast schemes of his Hohenstaufen ancestors for building up a real monarchy in Germany and Italy. Like his father and his grandfather he had found himself checked at every point by the Church. The Papacy had made itself the champion of local, especially of municipal, rights, and had fostered every combination against the Hohenstaufen policy. In 1230 the peace, or rather truce, of San Germano, had been patched up between the pope and the emperor, and Frederic improved the opportunity to carry out his idea of what a state ought to be in the only part of his dominion where he could have free hand, in his own southern lands.

It was a singular region in which this earliest modern constitution was put forth. The main element of its population was a graft of the Greek upon the more ancient Italic stock. During the whole Roman period the Italian portion had been known as Magna Graecia. When the center of gravity of the Roman Empire 
was transferred from Rome to Constantinople this country remained for centuries as an outpost in the West from which frequent

The Land

and the

People of

Southern

Italy and

Sicily attempts were made to recover imperial control. Byzantine culture dominated throughout Apulia and Calabria, and exerted important influence upon the learning and the arts of Europe. Sicily was repeatedly raided and conquered by the African Moors, who had left here permanent traces of their blood, their religion, and their civilization. Jews driven from other lands had found here a hospitable welcome. The great northern Germanic migrations had swept down into these far southern lands many a wandering fragment of Teutonic life. Lombard princes had occupied and governed the greater part from the sixth century onward. The armies of the Holy Roman Empire from Otto I (936-973) had ventured well down into the region southward from Salerno. Finally the Normans of Robert Guiscard (d. 1085) had come thither in force, had settled and conquered both the mainland and the island of Sicily, and had brought the country under an orderly administration. Here, more perhaps than in any other quarter of Europe, had been displayed that curious principle known as the "personality of law." According to Germanic traditions, represented here by the governing Normans, each of these widely differing populations, Greek, Arab, Jew, and Teuton, had a native right to be judged, as far as possible, by its own law. It was the duty of the government to see to it that this principle was respected so far as was consistent with safety to the state; but it is evident that it was a principle totally at variance with the whole idea of a powerful and united government. It was as if, in New York for example, Germans should claim the right to do business under German law, Italians under Italian law, and so on, while the government of the state should undertake to administer this medley of foreign laws through officers more or less under its own control. Such a system seems to us of the modern world 
very like organized anarchy and not very well organized at that. The only important remnant of it is seen in the "extra-territoriality" of certain districts lying outside the group of so-called civilized nations; as, for example, the territory under the direct control of European embassies in oriental countries. Within such districts the subjects of the European state are amenable only to the law of that state. The excuse for such an irregularity is the fear, justified or not, that such foreign subjects could not be sufficiently protected by the law of the land. So long as feudalism with its wide divisions of power went on, personality of law seemed quite in harmony with its spirit; but when feudalism began to give way before the growing sentiment of national unity, then the new idea of one law for all the inhabitants of a territory under one general government began to make its way. The "territoriality" of law was to take the place of its personality. Especially in a territory like this, where the variety of population was so great, the need of unity was sure to be felt earlier and more keenly.

The Norman predecessors of Frederic had already done much in the way of unifying legislation, and Frederic was careful to The Basis of reënact such of their laws as seemed to work in his Frederic's direction. In addition he published in the form of a Legislation, revised code what amounted to a complete re-casting 123x

of the form of government. The spirit of this legislation is well indicated in the preamble. Here the king sets forth his conception of the royal function. Man, he says, was originally created pure and free from selfishness, but by the fall of Adam he became greedy for gain and hence arose contentions, and so, "by the very necessity of things and by the impulse of the divine foreordination the princes of the nations were created, through whom the licence of the wicked might be controlled; who, as arbiters of life and death for the people, should establish what fortune, what portion, and what station each one should hold, executors, 
as it were, of divine Providence." This is a declaration of the divine right, but also of the absolute responsibility of kings. To carry out such a proclamation it was necessary above all things that the king should have no rivals. The execution of justice by every mediæval king was always hampered by two competing jurisdictions: that of the clergy and that of the feudal lords. Frederic cleared the way for himself by limiting both these jurisdictions as far as the conditions of the place and the age would bear.

The abuses of clerical jurisdiction had come to be a danger to any self-respecting state. Beginning with the theory that good

Limitation Jurisdiction of Clerical

Christians ought to keep out of the public law-courts and submit their differences to the arbitration of their clergymen, the Church had supported the clergy in building up a widespread system of courts. The states, with their feebly defined notions of their own rights, had allowed this to go on. The people in times of confusion had been more than willing to submit to a jurisdiction that was at least as likely to be equitable as was that of their lay lords, and so it had grown. In Frederic's time ecclesiastical courts claimed exclusive jurisdiction over the persons of clergymen. Over laymen they claimed control in so far as the case in hand could in any way be described as involving religion. In a day when most human actions had a more or less religious character there was serious danger that the rights of lay courts would be so far diminished as to lose all influence. Frederic met this danger with great fairness. $\mathrm{He}$ did not attempt to abolish the clerical courts, but rather to restrict them to purely religious matters and to clerical persons. He renewed a law of King William II (1 166-1189) that a clergyman accused of a crime for which his person was in danger should be tried by the Church and according to the canon-law, excepting, however, cases involving treason or any crimes affecting the king's majesty, for which the clergyman must appear in the king's court. On the other hand, a clergyman sued on account of landed property not held of the Church must answer in the court of the lord in whose 
territory the lands in dispute lay; but his person could not be taken or imprisoned on this account. If any person, cleric or layman, should bring before any other court matters belonging to the king's court, he was to be punished with confiscation of his property, real or personal, feudal or hereditary.

An ancient provision of the Norman kings, grown antiquated in the troublous times before Frederic and now renewed by him, Laws of provided that no person, lay or clerical, should convey Mortmain landed property to the Knights of the Temple or of the Hospital or to any other religious house which was not bound to pay a definite revenue to the crown. If such property should be left by will, the religious house receiving it was bound to sell it within a year on pain of confiscation to the crown. This was a so-called "law of mortmain," designed to prevent the Church or even a semireligious corporation from receiving land that was not bound to a definite service to the king. It was bitterly complained of by Pope Gregory IX, but Frederic defended it on the ground that to require taxes from clergy and laity alike, from both hereditary and feudal property, could not be called an abuse, but only a due enforcement, of law. When Gregory complained of certain confiscations of the property of Knights Templar, Frederic replied that if the Templars were to be allowed to acquire the property of citizens without restraint, it would not be long before they would own the whole kingdom of Sicily. It was, further, a distinct invasion of the clerical jurisdiction when Frederic undertook to legitimate the children of clergymen. He defends this action as justified by his supreme royal right, in order that these unfortunates may inherit the property of their parents and thus become useful servants of the state. If clergymen must have children contrary to the church law, at least they must pay for the privilege. Thus, on the one hand, clergymen were compelled in a great range of cases to seek the lay courts; on the other hand, laymen were completely exempted from the clerical jurisdiction except in the one case of adultery. 
Frederic's fairness of intention toward the Church is witnessed by an enactment relating to churches deprived of their pastors.

"Whereas it has come to our knowledge that bailiffs who formerly were placed over churches without pastors to hold and preserve the church property have not so faithfully discharged their duty as was directed by our court, but have abused their trust and kept back the goods of the Church,

"And whereas we hold all the churches of our kingdom, but especially those which lack pastors, under the protection of our own hand, and it is our will that the property of these churches shall in no wise be diminished,

"We order and decree that henceforth, whenever an archbishop or bishop of the kingdom shall die, the property of that church shall be entrusted to the care of three of the best, the wisest and the most trustworthy men of that church to be guarded and held for the benefit of the church until a pastor be provided. So much of the income as is reasonably necessary for the use of the clergy there shall be paid over to them for the good and reasonable service of the church; the remainder shall be held safe and undiminished by the guardians until a pastor be appointed. When that is done whatever remains, both principal and income, shall be paid over to the pastor and a full accounting made."

So far as the powers of the lay lords were concerned, this Norman kingdom in the South had followed largely the theory of The Feudal its sister state in England. The monarchy, because it Jurisdiction was a new one made to suit a new set of conditions, had been able to assert itself decidedly more than in countries where, as in France, it had to get on with a group of longestablished feudatories, stronger than itself and fiercely jealous of their rights. The formal rights of the Sicilian feudatories were limited by many enactments of the kings before Frederic, but since the time of the powerful King Roger (d. I I54) these great vassals had become more and more dangerous rivals of the crown. 
They were living, each according to the law of his fathers-Lombard law, Frank law, or new Norman law, as it might be. An attempt had been made by King Roger in 1140 to reduce the system to unity by making careful registers of fiefs, a work somewhat resembling Domesday Book in England, and passing measures to restrict sub-infeudation, a process whereby the rights of the crown over the land were continually endangered. Frederic had, therefore, a precedent for the much stricter measures which he had in mind. His aim was to take away from the barons as much jurisdiction as possible. In criminal cases he claimed absolute control for his royal courts, and in civil cases he required proof that the baron in question had a good title for his right. In every way he tried to diminish the power of resistance of the nobles, while at the same time he exacted from them the utmost service in the defence of the state. It was an act of surprising courage to require that all baronial castles built since the death of King William II ( I 189) should be straightway demolished. Such strongholds were, of course, the natural resort of all feudal holders who desired to bring pressure upon their immediate subjects. Within his own domain or crown lands Frederic forbade the building of any strong places that might hinder free entrance or exit, adding, "We believe that our own defences will furnish sufficient protection to our subjects."

One of the most precious privileges of the mediæval gentleman had been that of righting his own wrongs. To bring a suit in a court had seemed to him, as it seems still to some semibarbarous communities, to be a dishonorable confession of weakness. Frederic positively forbade all such self-help. "Any count, baron, knight or any other person who shall openly make war within the kingdom shall be punished with death and the confiscation of all his goods. He who shall undertake to make reprisals shall forfeit the half of his goods." All quarrels must come before the royal courts. Still more curious is the prohibition against carrying weapons. It illustrates as well as any other measure the singular mixture of mediæval 
with modern notions that marks all this transitional legislation. He desires, the king says, rather to prevent evils than to remedy Prohibition them after they have happened, and therefore he forof Personal Justice

bids all men to carry weapons of offence or defence which are made rather for causing injury than for serving any lawful purpose. He exempts, however, officers of the court engaged in their proper business and also knights or citizens journeying on their own affairs; but these must lay aside their swords immediately on entering an inn or on reaching home. Strangers coming into the kingdom are to be warned of these rules and are then subject to the same penalties for violating them. If a man draw a prohibited weapon on another without injuring him, he is to pay a double fine; if he hurt him, but not fatally, he must lose his right hand, "for it is just that the offender be punished in that part of his body with which, in contempt of law and government, he has committed the offence." If the man attacked were killed, the murderer, if he were a knight, was beheaded; if a commoner, he was hanged. The new laws, however, expressly recognize the right of self-defence and provide that a person attacked by superior force may defend himself by calling on the king's name. This process was technically called a defensa, and it was extended to cases in which any one feared an injury to his person or his property from a superior. All royal officials were enjoined to see to it that such appeals to the royal protection were promptly answered, "so that we, since we cannot be everywhere present in person, may be held to be everywhere present by our power."

These declarations suggest at once a comparison with the numerous mediæval proclamations of the Landfrieden, or the "king's The King peace," but the difference is a most important and as the vital one. Those earlier manifestoes of mediæval "Fountain of kings and princes were hardly more than protests

against a lawlessness they had no real power to control. The purpose of Frederic went far beyond any mere proclamation. It is expressed in one title as follows: 
"Not without great care and deliberation did the ancient Roman people hand over to the Roman Prince by the Lex Regia the right and power of making laws, so that the source of justice might reside in the same person from whom its defence proceeded. So it can be shown that not so much from expediency as from necessity it was provided that these two things, the source and the maintenance of justice, being in one person, force should not be lacking to justice, nor justice to force. Cæsar must therefore be both the father and the son of justice, its lord and its servant; father and lord in publishing justice and preserving it after it has been published; but in reverencing justice its son and in administering it in its fullness its servant. Taking counsel, therefore, of these reasons, we who have received from the hand of God the sceptre of the Empire and the rule of the kingdom of Sicily, declare of our own will to all our faithful subjects of the kingdom, that we propose in our heart to deal justice to them one and all without respect of persons, with ready zeal, so that they may find justice in plenty everywhere through our own officers, to whom we have committed its administration, some in civil, others in criminal affairs."

There could hardly be a better expression of the relation of a strong government to the whole problem of justice. A governChecks upon ment, to be of any use, must have the force to compel the Feudal its subjects to live according to the law; but in doing Institutions this it must itself be subject to the higher law of justice. That is the keynote to Frederic's whole plan of administration. The feudal jurisdiction was restricted at every point, yet not so much by denying its legality as by keeping watch over it and controlling it by the royal courts. For example, in the very difficult subject of claims on land, injustice of a baron toward his vassal was made less easy by requiring first the approval of a royal court before action could be taken and by keeping always open a way of appeal to the king himself. As to criminal matters, 
here, as in the case of the Church, all jurisdiction was taken from the barons, excepting only such of them as could show a clear title to it. No crown vassal could marry or give in marriage his children or any person over whom he had nuptial rights without the royal permission. Upon the death of a vassal, his lord must at once notify the king, giving a full inventory of the vassal's property, and the king would then direct to whom the fief was to be assigned. Thus the whole mechanism of the feudal society was to be directed by royal control. We must not, however, suppose that it lay within Frederic's intention to abolish the feudal principle. On the contrary, he provided for its indefinite continuance by allowing succession in the female line, assuming charge of daughters in the absence of sons and seeing to it "in the sight of God" that at a suitable age they be married without diminution of their father's goods. So also he permitted collateral succession to the third degree, a measure calculated greatly to increase the fixity of feudal landed rights. That Frederic could afford to do this in express terms shows the confidence he had that his new system in general would be strong enough to keep the barons in check.

Another interesting illustration of Frederic's respect for the feudal traditions is in his guarantee of trial by his peers to "any

Frederic's

Moderation towards

Feudalism count, baron or other military person." If such an one be brought to trial on either a criminal or a civil charge, he is not to be condemned except by a court of counts, barons, or royal tenants in capite (that is, tenants holding directly from the crown). Even where a case of this sort has been heard in first instance by a royal judge, he is bound to lay it before a court of peers, who in their turn are bound to render a decision, "according to our sacred constitutions, or, in default of these, according to approved customs of the realm and according to principles of law not contrary to our statutes or those of our predecessors, 
and finally when the opinion of our Eminence has been given - if the uncertainty of the case require this - according to God and to justice." In other words, the laws of precedent and of statute were to be followed as far as they would go; but beyond all this there was always to be an appeal to abstract justice or equity, of which the divinely ordained king was the sole interpreter.

In regard to the cities Frederic's problem was a very difficult one. On the one hand, here was evidently his best ally against Frederic's a too powerful nobility and clergy. On the other Treatment hand, the experience of his grandfather, his father, of the Cities and himself with the cities of northern Italy had shown him what dangers must come from too great encouragement of civic freedom. Cities were of two kinds : royal cities, in which the king was the direct overlord, and feudal cities, where a lord, either lay or clerical, had immediate sovereign rights. As to the first class the king's course was clear; he could place his officers in the town by the side of the local officials and deal directly with these if they seemed to be gaining too much freedom of action. In the feudal cities he could only set up what we call a "concurrent jurisdiction"; that is, place his officials as a watch on those of the lord and keep open a way of appeal to his higher courts and finally to himself. He confirmed the cities in their right to a "communal" organization (universitas), represented by a council of some sort; but, reverting to the same point for which Frederic Barbarossa had contended in vain in Lombardy, he positively forbade that " any podestà, consul, or rector should be set up in any place, or that any person, relying upon any precedent or by choice of the people, should usurp any office or jurisdiction; but it is our will that everywhere throughout our kingdom officials be established only by ourselves or by our order and that they administer as well our law as that of our vassals. Whatever commune (universitas) shall in future take any such 
action shall be made desolate forever, and the citizens thereof shall be held in servitude. But he who shall accept any such office shall be punished with death." Frederic, we see, had learned all too well the lesson of Legnano. $\mathrm{He}$ even tried to apply it in Lombardy, but the hard-won victory of Cortenuova (1 237) showed that success there was to be had only at a price he could ill afford to pay. In the South, on his own ground, the situation was different, and although in this same edict he alludes to attempts at independence in some places, we hear of no serious difficulties until after Frederic's death (1250), when several cities improved the resulting confusion to assert political rights of their own.

The modernness of Frederic II is evidenced by his care for the great laboring, peasant class. He hears, he says, that many Frederic's lords, both lay and clerical, are abusing their power Care for the to exact arbitrary taxes from their peasantry. He Peasantry therefore renews a law of King William II fixing the occasions on which a lord might ask such "aids"; namely, to ransom his person if he were captured while fighting in the king's service, at the knighting of his son, at the marriage of his daughter or his sister, in case of special services for the king requiring a purchase of land. The clerical lord might exact aids only at his consecration, when summoned by the pope to a council, when engaged in the service of the king either in war or peace, or when called upon to entertain the king in his territory. But in all these cases the lords are to be moderate in their demands. It meant very much in that day that Frederic opened freely the way into the clerical life for all except the lowest orders of the peasantry, and even here, a lord refusing permission for the ordination of a serf especially qualified for the clerical office might be compelled by the king to give it; but the son of such an ordained serf remained in the servile condition. It seems to have been Frederic's intention to relieve the half-servile population everywhere by regulating the demands which the lord might make upon them; but 
it was only within his own "domain" that he could carry out one measure which marks him as a man ages ahead of his time; namely, the complete abolition of serfdom. Slavery, in the strict sense of the word, seems not to have existed in the kingdom, but that there was danger of its revival is shown by a law of Frederic prohibiting under severe penalties the sale of a free man. The economic measures in which he took great interest were also calculated to affect in every way favorably the great agricultural class, provided only that it could have effectual protection against its natural oppressors.

Let us now see by what official machinery these class restrictions were to be enforced. In Sicily we find the earliest modFrederic's ern attempt at bureaucratic government; that is, the Administra- administration of public affairs by means of a spetive System cially created official class distinct from the existing orders of society, owing its existence to the king, receiving its maintenance from him alone, and therefore owing to him a kind of fidelity wholly different from that of the landholding aristocracy whether lay or clerical. Throughout the Middle Ages no such official class had existed anywhere on the Continent. Where we find beginnings of one, as in the case of the Missi of Charlemagne or of : the Pfalzgrafen under the Ottos, it had failed to develop, because under mediæval financial arrangements the only way to pay such officials was by grants of land, and thus they were in their turn converted into local landlords and so made ineffective servants of the king. We shall see how Frederic contrived to get around this difficulty. In the first place he tried, as far as possible, to recruit his officials from outside the dominant classes. The mediæval ruler had by preference employed clergymen for his royal purposes, partly because of their learning, partly because they were provided for by the income of their benefices. Frederic, in excluding clergymen from the office of bailiff (bajulus), expressly says, "Clergymen, whose clerical character excludes them from public business, are not admitted to the-function of bailiff, and 
we extend this same prohibition to the judices." So, again, in regard to the higher official, the "justiciary":

"What belongs to the special dignity and the very sovereignty of our Eminence, we will not have usurped by any one through unlawful presumption. We therefore by royal and perpetual edict positively forbid prelates, counts, barons, knights, and corporations of towns from holding the office of justiciary within their lands and from appointing any one to such office; but let them obey the supreme justiciary and the justiciaries appointed by our Excellency."

This intention of Frederic was furthered by the rapid growth since the middle of the twelfth century of a class of men edurated in the law, a class practically unknown in the Middle Ages. These were largely men of burgher origin, sons of prosperous tradesmen in the cities, and they were now offering themselves everywhere as the ready agents of governments in their struggle against the landed aristocracy. It was mainly out of this class that King Frederic gathered the men who were now to serve his turn. Chief among them was Petrus de Vinea, his legal adviser in the preparation of his code of laws.

Then, again, to keep this army of functionaries regular salaries were necessary, and that was a thing almost unknown to the Salaried mediæval world. In place of salaries there had been Officials incomes derived from land or from some endowment like a church benefice, which generally went back to land as its foundation. Frederic regulates with painful exactness the sources of these salaries. All moneys coming from legal fines or fees are to be paid into the royal treasury, and from this fund a suitable monthly payment is to be made to the officials. Ready money is to take the place of diverse and uncertain incomes, and thus the official class is to be bound up with all the financial interests of the crown. There could hardly have been a more effectual device to secure loyalty and faithful service. 
At the bottom of the official hierarchy we find (I) the officer called bajulus, corresponding, as we shall see later, to the French The Official prévot and closely related to the English "sheriff." Hierarchy The bajuli were the fingers of the king's hand, reaching out into the remotest corners of the kingdom. Their function had already been defined by a law of King William II. They had jurisdiction in all civil cases concerning persons or property which had no reference to fiefs or to feudal questions; also in lesser criminal cases not involving loss of life or limb; but the bajulus was bound to capture greater criminals and hand them over to the superior judge. He had the powers of a royal representative in many legal matters. He was chief of police in his district, with control of weights and measures and the regulation of trade. $\mathrm{He}$ had to collect the taxes and give account of them to the royal treasury. He was personally responsible for his function, but, like every other official, was advised at every turn by a judex and a notary. (2) The chamberlain (camerarius) was the superior of the bailiff in all matters not pertaining to criminal jurisdiction. $\mathrm{He}$ was the chief royal representative in a larger district, as the bailiff was in a city or more limited locality. There were six of these chamberlains in the kingdom. (3) The justiciary (justitiarius) was equal in rank with the chamberlain. He had charge of the criminal business and also of lesser feudal cases. There was one justiciary in each of eleven provinces. (4) The royal proctor (magister procurator curiae) was a provincial officer specially intrusted with the care of all royal properties or sources of revenue within his province. It was his business to manage all the king's farms, vineyards, forests, fisheries, cattle, warehouses, etc., to rent these, collect rents, and keep account of them. (5) The castellanus was, as his name implies, the responsible guardian of a royal castle, with the especial duty of keeping prisoners of state. If he allowed a prisoner to escape through negligence, his goods were to be sold, and he was to be imprisoned for a year; but if he had connived at the escape, he should lose his head. 
These five officials were local in scope and function. They were the nearest to the people in general and hence, on the one Checks upon hand, more likely to oppress them and, on the other, the Power of more likely to connive with them to their own profit the Officials and the disadvantage of the crown. Frederic provides against both these dangers. In almost every law relating to his lower local officers he speaks of the welfare of the people as his chief aim. No official is to receive. gifts of any kind from parties to a case, except food and drink for two days, on penalty of a fourfold fine. At the close of the administration of a justiciary or of a chamberlain he must remain fifty days in the province and hold himself liable to answer all complaints of injustice to subjects or infidelity to the king. If guilty he must restore the amount of damage done and be punished besides, at the king's discretion.

"As we order the wrongdoer and the unjust man to be accused by the voice of complaint and punished by the force of our reproof, so it is our will that officers who are specially fair and watchful be rewarded by public approval and decorated with the prizes of our generosity."

All of these officials who had judicial functions were to hold office but one year, in order that this revision and oversight might be as effective as possible. All were aided in their duties by persons known as judices, that is, men learned in the law, and by notaries, men trained in the technical forms of legal procedure and owing their appointment, which was permanent, directly to the king.

Above all this local machinery Frederic constituted a complete system of higher central administration in three main departThe Higher ments: (I) A Supreme Court with a chief justice Executive and four associates, whose business it was to hear Departments appeals from all the lower courts in both civil and criminal cases ; to protect all miserabiles, that is, all such persons as on account of poverty or for any other reason could not obtain 
justice elsewhere; to answer inquiries from the lower courts; and to represent the interest of the state in all legal controversies. (2) The Royal Chamberlains, one for Sicily and one for Naples, whose function it was to represent the king in all matters pertaining specially to his royal rights and interests. They were the immediate superiors of the bailiffs and provincial chamberlains, overlooked their actions, and attended to whatever was not specifically intrusted to these. They had, for instance, the care of treasure trove, of abandoned property, of the goods of shipwrecked strangers; it was their duty to see that responsible persons were appointed to administer vacated church property; they had the oversight of harbors and the general conduct of the public monopolies, which under Frederic's system began for the first time to play a considerable part in providing revenues for the state. Their functions might be compared to those of a Secretary of the Interior and of the Treasury in one. (3) The Magna Curia Rationum, or Supreme Chamber of Accounts, resembling our Boards of Auditors or Comptroller's office. All the accounts of the lower officials passed through this bureau and had to be approved by it before they could be settled.

In short, we have here, so far as it could be secured by legislation, a complete bureaucratic system, devised with great ingenuity

\section{Measures to} protect and and with remarkable adaptation to the conditions of to control the ordinates and culminating in the person of the king. Official Class

In all the enactments of Frederic the same principles of duty and responsibility are constantly referred to which we have noticed in his conception of his own royal function. The officials are presented to the people as, in their degree, a kind of sacred class. Offences against them are to be punished by a double fine. The old mediæval distinction of rank on the basis of birth is here extended to degrees of official dignity. A new nobility resting upon the notion of public service is rising into view. On the other hand, the same idea of personal honor which 
underlay the distinctions of feudal society is here transferred to the new hierarchy of officials. The local official might not acquire land, create debts, or take a wife within his district. He owed to the people of that district an account of his administration, and the king would see that this account was strictly rendered. $\mathrm{He}$ must present every year to his superior an elaborate report of his doings, and the superior must do the same to the supervising board which stood for the king. The king reserved the right to appoint frequent committees of inquiry into the stewardship of suspected officials, and for any defect of duty the official must answer with his whole property and even that of his wife if she had married him before he entered upon the office.

Frederic's system has often been harshly criticized as a despotic scheme for getting the most money out of his subjects to advance The Parlia- his own personal and family interests. An argument ments for the opposite opinion may be found in the plan for a series of regular assemblies to which it would hardly be an exaggeration to give the name "popular." Under feudal arrangements everywhere there had been occasional gatherings of the privileged orders, the clergy and the nobility, ordinarily to give their approval and promise their aid in the military undertakings of the kings. Nowhere as yet had the great industrial and commercial elements of the people, the real producers of wealth, been called upon to share in the responsible work of government in any fashion. Frederic provided that twice a year, in five cities of the realm, there should be held parliaments (parlamenta), at which the privileged orders, the clergy and the nobles, should appear in person and the cities should be represented by chosen men, four from the larger, two from the smaller, and one from the villages. These assemblies were to be under the presidency of a royal commissioner, and all officials, high and low, were entitled to be present. Every member had the right freely to criticize the actions of the royal officers and to make propositions of reform. We are not for a moment to suppose that any action of these parliaments 
had the force of law or could go beyond a mere suggestion which the king might or might not adopt. The important thing is that here, for the first time in human history if we except certain rather strikingly similar local attempts in Norman England, we have an attempt to govern a country by the aid of a representation of its constituent parts. It is doubtless true that taxation was the most important question to come before them, but so it has been in all representative bodies. Their significance in any given case depends upon the degree to which they could improve the occasion of granting money to gain other important rights. When we remember that the first English Parliament is to be set in the year 1265, and the first meeting of the French Estates General in 1302, we realize how greatly Frederic was in advance of his age. Certainly the plan of free criticism of government officials, in a true representative assembly not divided into separate bodies like the French Estates but deliberating together in the presence of representatives of government, is in a high degree enlightened and forward-looking:

All these institutions depended in the last resort upon the possession by the king of a sufficient military force upon which he

A Permacould implicitly. rely. No such force had ever been nent Miliat the disposal of a mediæval ruler. The defect in tary Force of mediæval military service had always been that the Mercenaries

relation of the king to the fighting man had been an indirect one; between him and the soldier had always stood the baron, the middleman in the most important of mediæval industries. Frederic met this difficulty as he had met those of judicial and financial independence by attaching the fighting force to himself by the only permanent tie, that of money payment. $\mathrm{He}$ created in addition to the troops bound to him by feudal ties a solid body of mercenary soldiers, whose term of service was not limited, who owed no allegiance to other lords, and who looked to this service for the honors and rewards of their lives. It was an $\epsilon$ special scandal to the clerical enemies of Frederic that a great part 
of these mercenaries were Saracens, some 20,000 of them, held together in a permanent camp at Lucera and ready to be employed at any moment against any adversary. To this criticism the king replied that these men were none the less good subjects because they were not Christians, and that as subjects of the state they might properly be employed in the service of the state. The whole doctrine of modern, individual citizenship is contained in this defence. Further, the Sicilian kings were the earliest of modern rulers to create a naval force permanently employed in the defence of commerce and the protection of the coast from public enemies. Frederic's measures to this end are recorded in his dealings with the coast towns of the kingdom, which were exempted from many of the ordinary forms of taxation in consideration of their supplying ships, provisions, and sailors for this new navy.

So we come lastly to mention with a word the system of taxation by which all this elaborate machinery of government was to Frederic's be upheld. Feudal taxation in distinction from modern System of may be described as irregular, uncertain, and costly in Taxation the collection. It consisted of an infinite variety of special contributions, mostly in kind, due at irregular intervals, greatly affected by special circumstances, such as failure of crops, disorders in the land or the inevitable shiftings of trade. What Frederic needed above all else was ready money to pay his officials and his mercenary troops, on whom the success of his scheme of government absolutely depended. Without, therefore, changing the form of the earlier contributions, he tried as far as possible to convert them into cash and added from time to time special new demands to meet new emergencies. The change in this regard was not so much in the nature of the obligations of his subjects as in the means he had ready to enforce them. Where most mediæval kings had been thrown upon the good will of their people, he was able, by means of his official system, to watch over the tax-producing powers of the land at every point. It is this 
feature of Frederic's administration which has brought most severe criticism upon it by modern writers. It has been described as a mere machine for squeezing the last penny out of an oppressed people and has been contrasted unfavorably with the greater freedom of mediæval arrangements. The real question, however, must be, not whether Frederic was able to get more out of his subjects, but whether the use he made of their payments was a proper compensation for their sacrifice. We may have what opinion we like as to the wisdom of paternal government and the divine function of kings; but it seems clear that the only way out of the confusions of the medixval state into the freedom of the modern democratic societies in the same countries was through a period of strong royal governments. The test of any one of these experiments must be sought in the loftiness and sincerity of the purpose which dictated the policy of the monarch.

In this regard the legislation of Frederic II is especially instructive. To express in one word the peculiar quality which makes his work best worth studying, we may call it as a Man of above all else a work of "enlightenment," meaning Enlighten- by that a purpose to do whatever he did because it
ment

seemed to him the best thing to do, not because it had always been done. A striking illustration of this is seen in his directions as to the method of gaining evidence to be employed in the courts of justice. Throughout the Middle Ages evidence had been curiously connected with the notion of a divine supervision of human affairs which would not allow wrong to go unpunished, but would declare the right by some mysterious divine process. With all its braggadocio about "honor," the feudal period had little confidence in the word of a man. It professed to have great respect for oaths, but the oath of a man in his own case must be supported by the oaths of a considerable number of other persons to the effect that they believed him to be a truthtelling person - not at all that they had any knowledge of the 
point in question (compurgation). Besides this method of getting at the truth two others were especially popular, the ordeal and the wager of battle. The underlying principle in both these was the same: that the forces of nature and the power of a man's right arm were alike expressions of that mysterious divine will which was the last appeal of human justice. In both cases the issue had a certain miraculous character, which to the mediæval kind of mind in all ages has seemed to carry with it a deeper conviction than the mere working of a natural law. Like everything else in the Middle Ages this sort of appeal to divine justice had specially belonged to the rights of the higher classes of society; but in one or another form it had extended itself through the whole structure of judicial administration. Not only had one party in a case the right to fight with the other or with his or her champion, but the witness might challenge the opposing witness, and the losing party was supported by public opinion if he challenged the judge who had decided against him. To decline such a challenge was felt to involve a loss of honor, just as it is to-day regarded by a German student or an-officer in most continental armies.

Frederic abolished at a stroke this whole fabric of superstition. He decreed that henceforth judicial truth should be established by Abolition of the simple method of personal witness and by docuMediæval ments. The word of a witness was, to be sure, still Evidence measured partly by his social rank, the lower person requiring the corroboration of several of his kind to make his word outweigh that of a superior; but the principle was established, and it was placed upon the broad ground that the mediæval methods were a tempting of Providence and an insult to common sense. The same idea runs through various other reforms by which Frederic sought to get rid of many superstitious practices, long officially opposed by the Church, - necromancy, potions designed to affect the emotions of another person, and all that class of practices in which the mysterious powers were called upon in 
the service of man. That he at the same time kept an astrologer and consulted him in important affairs may fairly be taken as proof that he was a man of "scientific" spirit, for astrology was in that day the nearest approach to a scientific basis of life as related to a continuous divine governance. Frederic's enlightenment is further witnessed by his foundation of the new university of Naples. He had the experience of Paris, Bologna, Salerno, and Oxford to work upon, and we find him anticipating many of the difficulties that had come up in these places in the course of a long history. The students and teachers were endowed with many privileges and exemptions. A commission of citizens and students fixed reasonable rates of house rent, thus preventing the uproars that had so often endangered the very existence of the older schools. The most distinguished teachers were called from every quarter. Even the doubtful method of "fostering infant industries" was attempted by an order that young subjects of the king studying at other universities should come back and study at the home school.

It could not, of course, fail to happen that a man so independent of the traditions of the past should incur the charge of Religious heresy, even of infidelity. Frederic's lifelong struggle Toleration with the Papacy as a political institution has given a handle to his critics in all times for accusations of this sort. $\mathrm{He}$ has been called a Mohammedan, a Jew, a mere scoffer at all religion. For all this, there seems to be no further basis than his willingness to allow to men of another religion their right to believe and worship as they pleased, and a certain quality of originality which was likely to lead him into dangerous experiments. One of his most severe critics, the Franciscan chronicler Fra Salimbene, sums up one aspect of his indictment in the word curiositates, that is, an inordinate desire for novelty, good evidence, from this critic's point of view, of an excessive self-appreciation. We shall find this same charge often made against the leaders of Renaissance thought. In short, it is hardly too much to say that Frederic was "the first modern man." 


\section{LOUIS IX AND THE FRENCH STATE}

The French state began its modern phase under conditions in many respects different from those in the kingdom of Frederic II. Conditions of The French population in the late thirteenth century the French had come to be to a greater extent homogeneous in Monarchy character and united in sentiment. It is true that the
in the Thisteenth Century great distinction between North and South persisted and showed itself in diversities of speech, of customs, and of laws; but the sentiment of a common nationality had been growing steadily since Philip Augustus (d. 1223) and found its expression in the universal respect and affection felt for the person of his grandson, the sainted king Louis. Louis IX came to the French throne in 1226 , with considerable resistance from the great barons, as the feudal ruler of a feudal state. The student of mediæval affairs is often tempted to ask how the feudal state, with its division of power in many hands, could have found room for a royal power at all. The answer is that the feudal king was himself a link in the intricate chain of checks and balances which held feudal society together. His suzerainty over the higher vassals was the warrant for their suzerainty over their own vassals. His sovereignty over the people as a whole represented an idea of unity, without which even the most reckless baron of them all would have found something lacking in his sense of political attachment. Nor, unless all semblance of unity were to be given up, was there any-other possible form under which it could be expressed. This interdependence of the monarchy and the feudal hierarchy is the key to the process by which the monarchy in France gradually set itself free from feudal restraints and put itself at the head of a nation made up of individuals and corporations, not of sharply defined and graded social classes. Not by opposing feudal rights and privileges, but by first recognizing them, then supplementing and controlling them, and finally by replacing them, the kings of France from Philip Augustus down laid that 
wonderful foundation of royal rights upon which was to be built the sordid tyranny of Louis XI and the splendid absolutism of Louis XIV.

It began with the creation by Philip Augustus of royal officials called baillis or sénéchaux, words having the same meaning but Creation of used in different localities, who were to represent the Royal Offi- interests of the king, primarily in the domaine, that cials by Philip is, the territory belonging to the king directly, but
Augustus, is $1180-1223$ were readily available for the king's service elsewhere. Under the baillis and sénéchaıs were lower and more ancient offcials called prévôts. Both the bailli and the prévôt were primarily judges at law, but combined in themselves also the functions of military leaders, of tax collectors, and of general administrators. To prevent the baillis from identifying themselves too closely with their bailiwicks, the kings tried to attach them to the royal person by regular salaries, short terms of service, and frequent changes of district. Of especial interest to us is the process by which the justice of the king came in time to take the place of the justice of the numerous lords on the royal domaine. For one thing, it was more "scientific." The seigneurial jurisdiction rested almost entirely on local custom and hence was less adapted to new social conditions. It was administered normally by the lord himself, who was not a person "learned in the law," but.was bound only to see to it that the law as it was should be applied in a given case. The royal law, administered by persons at least semiprofessional and educated more and more in the Roman Law as a science, learned rapidly to borrow from this inexhaustible source principles to cover every possible kind of new case. The famous jurist, Philippe de Remi, sire de Beaumanoir (d. 1296), was bailli to Count Robert of Clermont, a son of St. Louis. In this capacity he compiled for his master the so-called "Customs of the Beauvaisis" about ı280. Beaumanoir served during his life as bailli, or seneschal, in various provinces, so that what he says as to the nature of these offices carries the weight of long and successful personal experience. In the Introduction to his code he gives a 
picture of the ideal bailli which shows plainly what possibilities of good lay in this office if it could be administered by such men

The Ideal

Bailli of

Beaumanoir as he has in mind. He lays down ten virtues which his model official ought to have. The first, which he says ought to be the lady and mistress of all the rest, is "sapience," or, in plain English, common sense. The second is the love of God; such love as a man has for his father, for from such love and service comes every good thing. The bailli must be gentle and amiable (dous et debonaires) toward the well-meaning; but he must seem hard and cruel toward the evildoer. The bailli who is patient and ready to listen lets the parties say all they will that he may the better come at the evil and know the good. He needs bravery and activity without laziness, which might cause him to leave many things to others that he ought to do himself. He must be brave that he may not favor the rich against the poor, nor stand in fear of evil men. Yet his bravery should be wise, not foolhardy (folhardement). He should be generous, yet not after the manner of a spendthrift whose largesse brings no good to any, but sagely and in proportion to what he has. The bailli is bound to obey his lord except to the peril of his soul, without inquiry whether the cause in which he is ordered be good or bad; for the other party, if he be aggrieved by the bailli's action, may appeal to the lord. Yet this does not apply to cases involving death or maiming. He must further be thoroughly informed as to the character of his lord and of the lord's counselors, as to his own character and that of all his subordinate officers, that he may know just how to govern himself in all these relations. He ought to be clever in getting as much out of the land as possible without injury to others, that he may return his land to the lord not diminished but improved in value. Finally comes a virtue which Beaumanoir again declares to be the chief of all, loyalty or sense of duty; for if a man be loyal, though he have little learning and little of the other virtues, he will be loved and valued for this virtue alone; but if he have not this all the rest avail him little. 
Like the podestà in an Italian city the bailli was forbidden to marry or allow any of his family to marry within his bailiwick, to place a relative in a church office or to employ him in any subordinate function. He must avoid annoying his subjects by change of residence, by unnecessary exactions, or by delegating his duties to others without cause. At the close of one administration he must remain forty days in the province and be subject to prosecution for malfeasance in office. If fined for such evildoing his heirs were made responsible for payment.

A royal judge of this description found little difficulty in a case of conflict of laws in discovering a legal fiction suited to his need.

Legal

One of the most important of these fictions was that Fictions in of the cas royaux; that is, cases in which the king as Aid of the sovereign was specially concerned. For example, cases Monarchy of lèse-majesté, or offence against the kingly office as such; counterfeiting money as an invasion of the royal prerogative ; crimes committed on the "king's highway." Some went so far as to include usury and blasphemy because these were crimes against which special royal edicts had been made. Especially was the king represented as the supreme guardian of the public peace, and whatever violated this was said to be under his special jurisdiction. It is easy to see that rights like these, never strictly defined, opened up opportunities for endless expansion. A singular idea was that of "anticipation" (prevention). If the king was indeed the fountain of all justice, then he had properly the right to judge in all cases whatsoever. This right he ordinarily did not enforce, since he was supposed to have committed its execution in part to the seigneurs; but if these at any time failed to do their duty, then the latent right of the king came into force again, and if the royal judge could get ahead of the local justice, this was good evidence of neglect on the part of the latter. So also the royal law seized not only upon cases, but upon persons formerly subject to local law. Under the term bourgeois du roi we find a whole class of citizens who were thus permanently taken under 
the king's protection as against the jurisdiction of the seigneur to whom the city itself belonged. Still more effective than these direct attacks upon seigneurial justice was the right of appeal, a right implied in the "fountain of justice" theory, but in the times before Louis IX seldom enforced. Under him it was revived so distinctly that the picture of the sainted king hearing cases in his own person, as drawn by his biographer, is that by which King Louis is best remembered.

"It often happened in summer that he took his seat after Mass under an oak tree in the forest of Vincennes and made us all sit about him, and all who had any business came to him without any hindrance from huissiers or any other person. Then he asked: ' Has any one here a suit ?' and those that had suit arose. Then he" said: 'Keep silence all of you, and I will give you judgment one after the other.' And then he called monseigneur Perron de Fontenines and monseigneur Geoffroy de Villette and said to one of them: 'Decide this case for me.' And when he saw anything to correct in the words of those who spoke for him or of those who spoke for another, he amended it with his own lips." 1

Directly in line with this strong conviction of duty in dealing justice is Louis's attempt to control that scourge of mediæval

Prohibition of Private Warfare society, the practice of private warfare. The evil had long been felt by all good men. The Church had done what it could through the "Truce of God" to enforce peace during at least a part of the time, but there was no point upon which the mediæval spirit made so stout a resistance as this. Certain steps had been taken by the crown even before St. Louis. The right of security (droit d'assurement) was a device by which one party in a quarrel could demand of the seigneur - who might be the king - an assurance of protection. Later the lord could

${ }^{1}$ Jean, Sire de Joinville, Histoire de St. Louis (text and translation), ed. N. de Wailly, 1874, p. 35 . 
summon both parties and bind them over to keep the peace on pain of confiscation of property. A similar device was the quarantaine le roi, a rule by which forty days must elapse after a declaration of private war before relatives of either party could be attacked, - a relief, but not a remedy. Finally Louis IX went so far as absolutely to forbid all private warfare within the royal domaine (1257), but repeated renewals of this decree indicate that it could not be thoroughly enforced.

Like Frederic II, Louis IX attempted to do away with the mediæval methods of proof in court, whereby the value of all Abolition of evidence was made dependent on prowess in arms. the Wager According to mediæval ideas the stronger man was of Battle always right, or, to put it in the language of the time, the will of God was declared through victory in personal combat. So profound was this conviction that there was no kind of difference of opinion among men that could not be settled in this way. Even persons incapable, on account of their rank, of carrying knightly weapons (roturiers) might settle their disputes by combat with shield and staff. A party to a suit might challenge a hostile witness or even the judge whose sentence was against him. A vassal might call out his lord, or the lord his vassal, provided the bond of allegiance between them were first declared off. As in a barbaric society, all notions of right were personal, not national. To beat the judge was the direct way of declaring his decision unjust. St. Louis tried to substitute for this savage method the appeal to the suzerain as to a higher instance. This was possible for him only within his own domaine, as the famous ordinance shows.

"We forbid the wager of battle throughout our domaine in all suits; but we do not exclude ... the forms of procedure customary up to this time in lay courts according to the usage of the several districts, excepting that we exclude the combat; and in place of the combat we order the proof by witnesses and by written 
evidence. And we do not exclude the other good and "loyal" proofs which have been customary in the lay courts up to the present time." 1

We have spoken frequently of the domaine; that is, the territory of the king which he held directly as suzerain. The most Increase of the Royal Domaine important way in which the king of France became actual ruler over all French territory was by continually adding to this domaine. It is actually true that the king of France had to gain the land of France as his own before his kingly power could be enforced and respected. The most striking thing about this long process is that it was carried on by utilizing the very methods it was designed to replace. French feudalism was broken up by following out to their end several strictly feudal principles. For example, the principle of "reversion," by which upon the death of a vassal without heirs his fief fell back to the lord of whom he held it. If this lord was the king, the fief thus gained was never lost, for the king never died. Only one apparent exception to this rule interests us. After all, the kingdom in France could not quite get away from the earliest Germanic notion that kingship belonged, not to an individual in his own right, but to a family, of which the king at any moment was the representative. This idea had led to the fatal divisions and subdivisions of the Merovingian and Carolingian periods, and the Capetian kings during the twelfth and thirteenth centuries were struggling to maintain a single kingly power without offending too deeply this earlier habit of the peoples out of which the French nation was being made. No sooner was the royal power in a fair way to make itself supreme than it was forced to provide for the younger sons of the ruling family by considerable grants of royal territory. These were called "apanages." They established in some of the remoter districts of France almost independent principalities, as to which the question was, Would

1 Etablissements de St. Louis, ed. Viollet, I, 487-II, 8. 
the separatist forces of society begin to work over again as they had done in the early feudal period, or had the monarchy become strong enough to hold the allegiance of these great family feudatories? The answer of history justified the kingdom, but the struggle was a long and bitter one. The most striking instance is the Duchy of Burgundy, given by Hugh Capet to his brother Robert. The dukes of Burgundy of the second line carried on for centuries a policy of expansion in every way like that going on in the kingdom itself. Where the two came into conflict it is at times hard to see any real difference between them. Only in the fifteenth century, by the ruin of Duke Charles the Bold through his rash attempts at overexpansion, did the monarchy of Louis XI find itself freed from the danger of dismemberment. On the other hand, it ought to be said that the apanage was sometimes a distinct service to the crown by standing firm for the family interest against dangerous neighbors. From an early date the apanages were declared heritable in the direct male line only, failing which they were to revert to the crown.

With this exception of the apanages, the principle of the inalienability of the crown lands was early declared. All other hold-

Methods of acquiring Domaine Lands ings in the country were alienable. The king was therefore, so to speak, always in the market as buyer, never as seller. He watched his chance and whenever a fief was open, from whatever cause, he was ready to put in his claim. Sometimes he bought the land outright; sometimes he loaned money on it as security and took it by foreclosure; sometimes he took advantage of a failure of allegiance, as already in 1203 in the case of King Philip Augustus against Duke John of Normandy, king of England, who had failed to answer a summons to appear on a charge of violating his feudal duty. For this failure his immense feudal estates in the north were declared forfeited to the crown and remained with France henceforth. Sometimes an estate was left to the crown by will. Only rarely was French territory actually taken forcibly by the French 
king by process of war, and even in such cases the war was not thought of as a conflict for land, but rather as the execution of a right against a subject who had violated the law.

So we see at every point that the processes used in making the modern kingdom in France were such as the people were familiar The "Salic with, while the objects aimed at with astonishing perLaw" "sistency, generation after generation, were new. The declared the kingdom was commending itself more and more as French Crown the need of a strong central rallying point for all that was distinctively French made itself felt. The great problem of the crown was to utilize the very flexible ideas of mediæval feudalism to fix the rigid rules of the modern monarchy. This is very well seen in the establishment, once for all, of what is called the "Salic Law" in regard to the inheritance of the crown. The three sons of Philip IV (d. 13 14 ) succeeded him in this order: Louis X (1314-1316), Philip V (1316-1322), and Charles IV (1322-r328). All three died without male heirs. Already on the death of Louis X claims to the succession were made by certain side branches, and this led to a decree of the Court of Peers that no woman might succeed to the crown of France. The name "Salic Law" was later given to this principle on account of some similar provision in the ancient law of the Salic Franks in regard to the holding of landed

Claims to the French Crown in 1328

Louis IX (1226-1270)

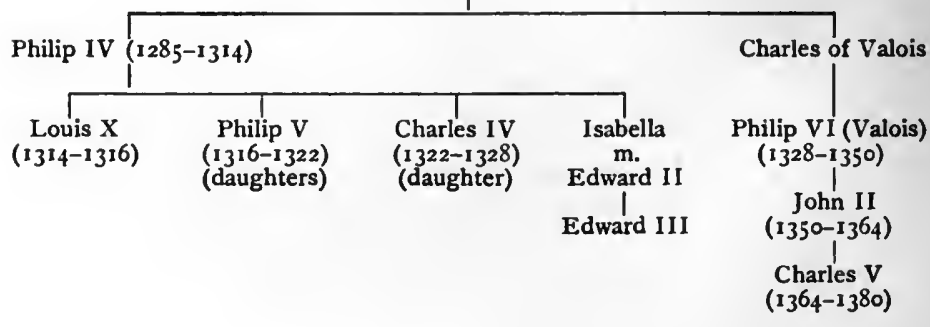


property. When, then, the two brothers of Louis $\mathrm{X}$ also died without male heirs, the right of their cousin, Philip of Valois, as the eldest descendant of King Philip III in the male line seemed constitutionally fixed, and he was accepted by the great barons with considerable readiness. A daughter of Philip IV, however, Isabella, was the mother of Edward III of England, and this served as a pretext for him to set up a "claim" to the French crown. The fact was that Edward III was already one of the largest landholders in the south of France. He was backing the cities of Flanders in their double fight against France and their own count, who was a vassal of France, and he was the kind of man to welcome this chance to extend his power. According to all feudal ideas there was no reason why Philip of Valois should be king rather than Edward of Aquitaine. The only question was whether there was enough French national sentiment in France to rally the forces of the crown against a claimant who could be made to appear as a foreigner and an invader. The answer to that question is the history of the Hundred Years' War, which does not belong here. ${ }^{1}$

We are now concerned only with the beginnings of the modern French state. So far we have dealt with the attempts of the

Restraints on Clerical Jurisdiction crown to hold its own against the feudal jurisdiction and the feudal rights of inheritance in land. Equally clear was its position toward the clergy. In many ways all that we have said of the feudal limitations applies to the clergy as well, for the clergy as a landholding body were as completely involved in feudal ties as were the lay barons. But in other ways they were an even more dangerous element, since they added to all the other powers of resistance the support of a great religious institution. It is especially interesting, therefore, that we find at the outset in France a man at the head of affairs who could never for a moment be suspected of hostility to the Church or to religion. The kind of personal abuse lavished upon 
Frederic II could never be employed against Louis IX, and yet his position on the great questions of the national Church was essentially the same. He aimed, in all his dealing with the religious question, to draw the line clearly between the Church as a religious institution and the Church as a political and economic unit. In the former sense he was ready to show it unbounded reverence; as a part of the national political structure, he proposed to see that it was kept within proper limits.

Joinville, in his personal memoirs of St. Louis, gives us many picturesque illustrations of this attitude:

Sect. 669. "I will tell you of his wisdom. It was said that there was no one in his council so wise as he, and the proof of this was that, when certain matters were brought before him, he did not say: 'I will take counsel of the case,' but when he saw the right clearly and evidently, he answered alone, without advice and immediately. For instance, I have heard that he gave the following reply to all the prelates of the realm of France to a request which they had made to him.

"Bishop Guy of Auxerre, speaking for them all, said: 'Sire, these archbishops and bishops here present have charged me to say to you that the Christian faith is declining and perishing under your direction and that it will decline still further if you do not take care; for there is no one nowadays who fears an excommunication. We, therefore, demand, Sire, that you give orders to your bailiffs and sergeants to compel excommunicated persons who have been under sentence for a year and a day to make their peace with the Church.' And the king answered them alone, without taking advice, that he would gladly give the orders they demanded, provided he might have the decision as to whether the sentence of excommunication had been justly imposed or not.

"So they took counsel together and made answer to the king that they would not give him the right to judge in matters 
belonging to religion. And the king answered that in matters belonging to him he would not give them the right to judge, and he would not order his sergeants to compel excommunicated persons to make their peace with the Church, right or wrong. 'For if I should so act I should be acting against God and against the right. And I will give you an example: The bishops of Brittany held the Count of Brittany under excommunication for seven years, and then he was absolved by the court of Rome. Now if I had forced him to seek absolution after the first year, I should have forced him contrary to the right." "

The following illuminating instances of the king's habitual fairness and firmness in dealing with the subject of clerical rights are given by the faithful Joinville, who had occasion himself to test the justice of his lord in more than one case.

Joinville, Sect. 673. "At the next parlement after this all the prelates prayed the king that he would talk with them apart, and when he came back from talking with the prelates he came to us who were waiting in the Hall of Pleas and told us laughing of the trouble (tourment) he had had with them.

"The archbishop of Rheims had said to the king:- 'Sire! What will you do for me about the wardship of St. Remi at Rheims, which you have taken from me? For by the relics within there, I would not have upon my soul a sin such as you have, for all the kingdom of France!' 'By the relics within there,' replied the king, 'you would do as much even if you could get Compiègne because of the covetousness that is in you. Now, then, one of us two is a man forsworn.' "

Sect. 674. "The bishop of Chartres is asking me," said the king, "to cause to be returned to him property of his which I hold. And I tell him I will not do it until he pays me what he owes me. I tell him he has done me homage, his hands in mine, and he is not acting loyally to me when he tries to take my heritage." 
Joinville himself had a quarrel with the bishop of Châlons in regard to the nomination of an abbot to a monastery of which he claimed the lordship. The case was brought before the king.

Sect. 675. "' The bishop of Châlons said to me,' said the king, 'Sire! What will you do for me about the lord of Joinville, who has deprived this poor monk of the abbey of St. Urbain?' 'Sir Bishop,' answered the king, 'you have agreed among you that no excommunicated person ought to be heard in a lay court. Now I have read in a letter sealed with thirty-two seals that you are excommunicated. Therefore I will not hear you until you are absolved.'

"But this abbot Geoffrey of St. Urbain, after I had done him this service, rendered me evil for good and appealed to the king against me. He represented to the king that he was under the king's wardship. I asked the king to declare the truth on this point, whether the wardship belonged to him or to me. 'Sire I' said the abbot, 'please God you shall not do that but shall hold us (both) and give order that the case be tried between me and the lord of Joinville, for I would rather have my abbey in your wardship than in that of the man who holds the inheritance.' Then the king said to me: 'It may be that the inheritance is yours, but that you have no right to the wardship of this abbey. Now the wardship must belong, if you please,' said he to the abbot, 'according to what you both say, either to me or to him. Therefore I will not fail, in spite of what you have said, to declare the truth about it. For if I should compel him to plead in court I should be doing wrong to one who is my man by putting in jeopardy a right as to which he has asked me to declare the exact truth.' Then he declared the truth, and when the truth was known he delivered the wardship of the abbey to me and confirmed it with his own hand."

The attitude of Louis IX on the Church question is well expressed in a document now generally admitted to be of much 
later date, but so consistent with all his actions that it has kept its traditional name as the "Pragmatic Sanction of St. Louis."

The "Pragmatic Sanction of

St. Louis" In the several articles of this supposed decree it is provided, first, that all persons having rights of nomination to clerical offices in France shall enjoy these rights henceforth in full measure. In all the churches there is to be absolutely free election of all clergy, free especially "from the fatal crime of simony, which is the ruin of the Church."

"All promotions, collations, provisions and dispositions of prelacies, dignities and other benefices or offices whatever in our kingdom are to be made in conformity with the precedents, ordinances and regulations of the common law, the sacred councils of the Church of God and the ancient decrees of the Holy Fathers."

"We forbid that the heavy taxes and money charges laid or to be laid upon the churches of our kingdom by the court of Rome, by which our kingdom is miserably impoverished, shall be raised or gathered in any way whatsoever, except for a reasonable, pious and pressing cause or inevitable necessity and with the free and express consent of ourselves and of the Church of our kingdom."

All the privileges granted to the churches and monasteries or to the clergy within the kingdom by previous kings are renewed and confirmed.

Whatever doubts may be cast upon the genuineness of the "Pragmatic Sanction of St. Louis," other documents confirm the

Other Cases of Anticlerical Action royal attitude therein implied. As early as 1235 an assembly of northern barons at St. Denis, in the presence of the king, had drawn up a formal protest to Pope Gregory IX against the claims of French clergymen to exemption from royal and baronial jurisdiction in temporal matters. The king's sympathy with this action is shown by the pope's reply, in which he reproves Louis for making laws against the liberties of the Church. 
A similar movement in 1246 went a step further by the formation of a permanent executive committee of barons with power to raise funds and to take action against clerical aggression. What the king's attitude toward this demonstration was is not clear. It may well have seemed to him to be going rather far and to threaten the creation of a dangerous rival to the royal authority. It is significant also that this northern protest was made with the connivance of the emperor Frederic II, and the saintly Louis may perhaps have hesitated to sanction so questionable an alliance.

Still another stage of the same situation is seen a few months later (1247), when a group of French clergymen of both the higher and lower orders, with the king's sanction, sent a protest to Pope Innocent IV against papal usurpations of local clerical rights, - such as invasion of jurisdiction, appointment of Italians to profitable benefices, and ruinous taxation. It is obvious, therefore, that the evils complained of in the so-called "Pragmatic Sanction of 1269 " had long been acutely felt by the French people, both lay and clerical, and that the king was prepared to defend his countrymen against dangerous aggression from Rome. It is not proved, however, that he ever went so far as to legislate in precise terms to this end.

It must not be supposed that Louis's enforcement of the royal authority met with no resistance from the feudal barons against

Louis IX and Enguer- rand de Coucy is the best illustration of this. It is rand de Coucy whom it was directed. The famous story of Enguertold in all its details by the Confessor of Queen Margaret in his "Life of St. Louis."

Enguerrand, lord of Coucy, had caused three young men of Flanders who had been found in his forest with bows and arrows, but without dogs or other apparatus of the chase, to be hanged. The neighboring abbot of Coucy Forest and certain women relatives of the murdered youths brought their complaint to the king. Louis promptly summoned Enguerrand to Paris and had him 


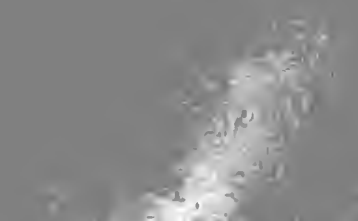

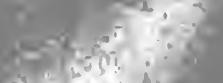

e) $+t^{2}$

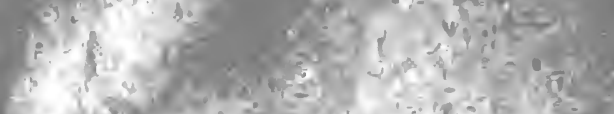

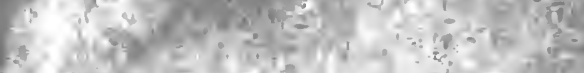

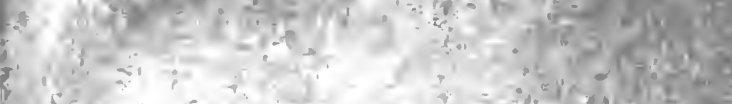

$\left\{\begin{array}{l}1 \\ 3\end{array}\right.$

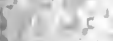

$\{1=2,50$

$-2+2,+1,-2$

$-3 \times 14$

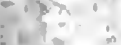

$\lim ^{-\infty}, 1$.

$\{=$

1

$-1$

'?

$\left\{\begin{array}{l}3 \\ 5 \\ 5 \\ 5\end{array}\right.$

ind

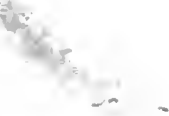

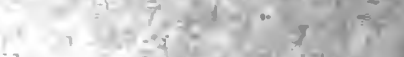

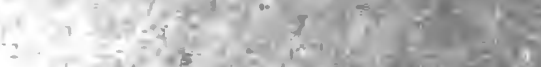

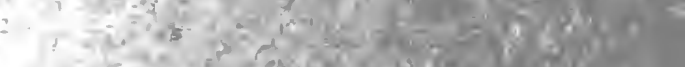

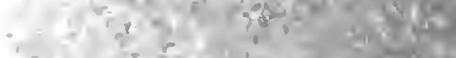

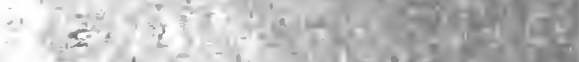

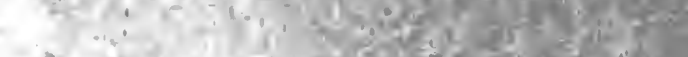

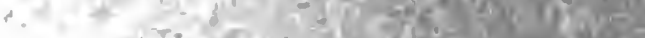

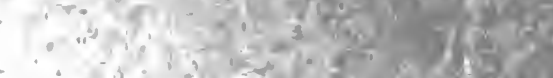

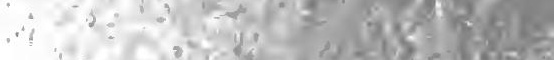
$\therefore$ 2.

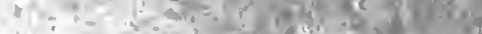

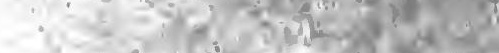

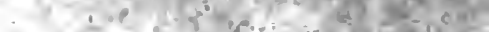

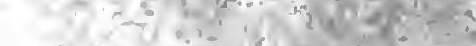

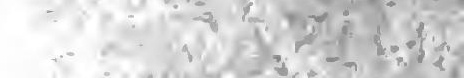

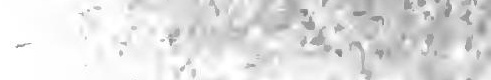

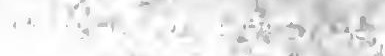

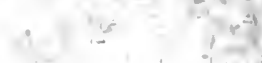

$1 \frac{p}{1}$ $+\frac{1}{2}$ 2 i. 


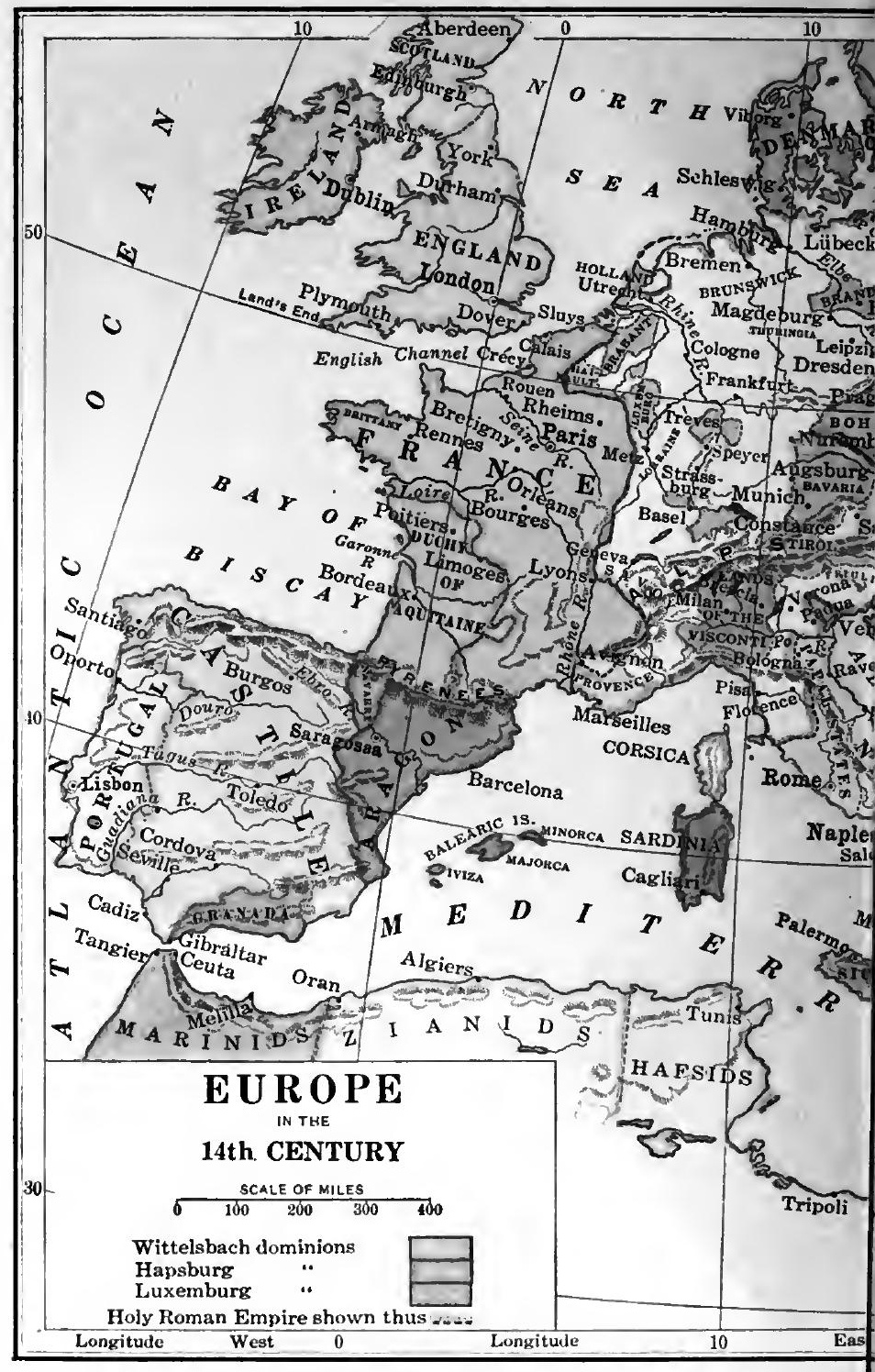




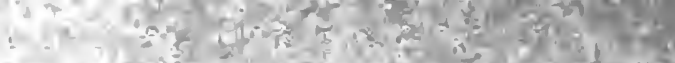

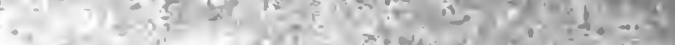

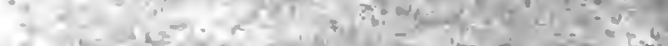

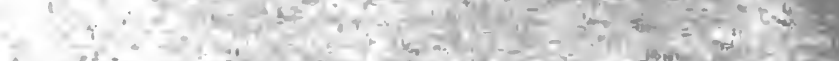

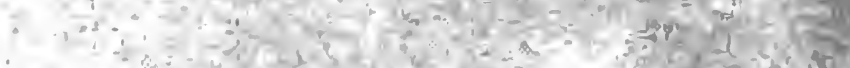

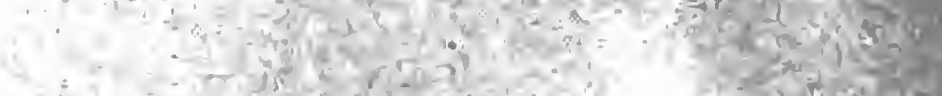

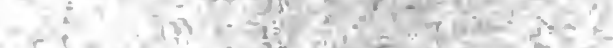

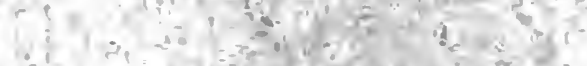
-1.

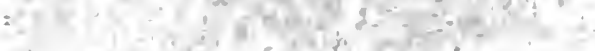

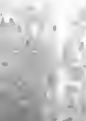

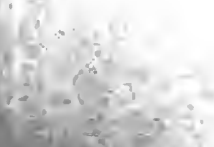

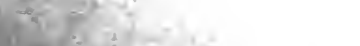

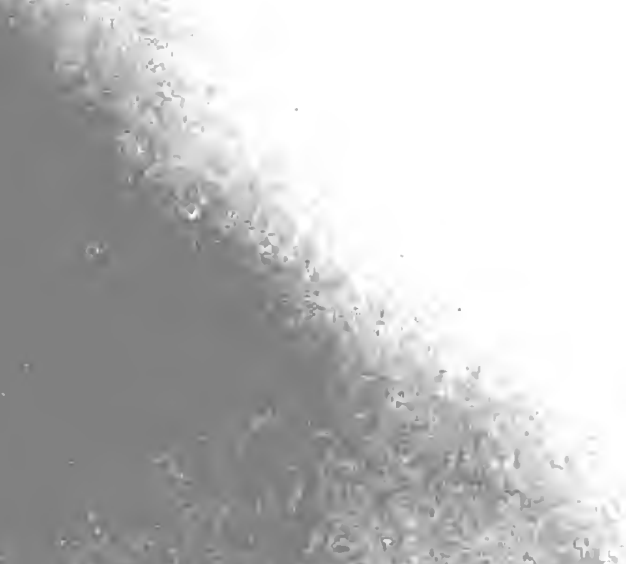

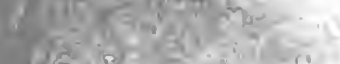

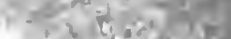

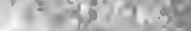

$+1$

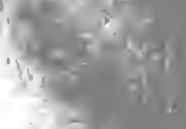

. 12

$=\frac{2}{2}$

$r_{1}+1$

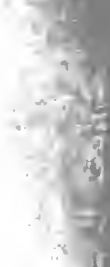

n.t.

1.13

$-\frac{1}{1}$

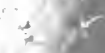

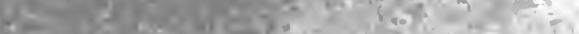
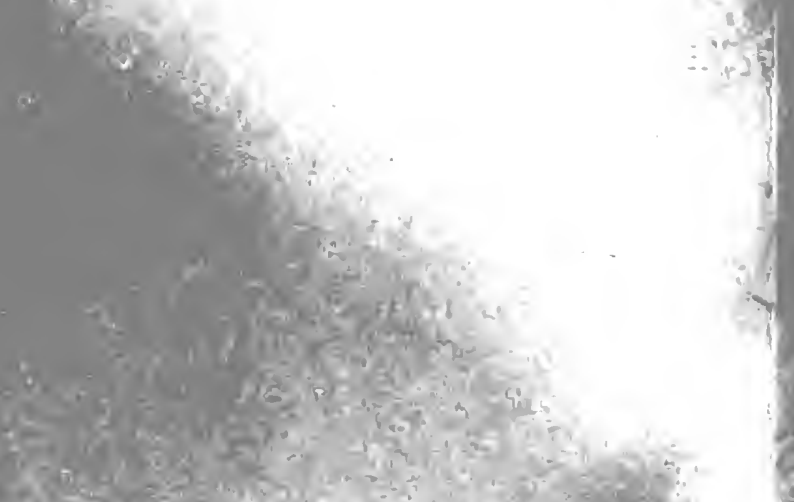

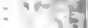

$\cdots, 43$

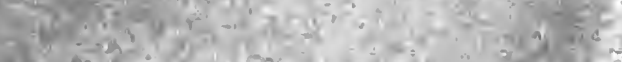

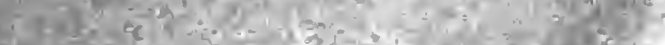

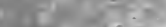

-

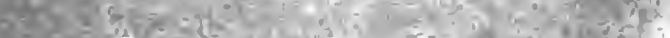

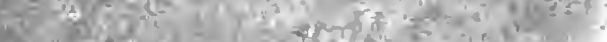

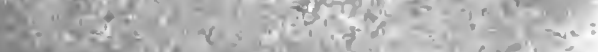

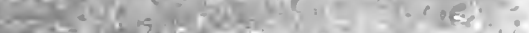

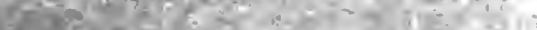

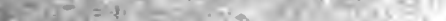

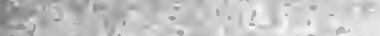

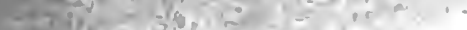


arrested and imprisoned "without irons" in the Louvre. At his trial the lord of Coucy was attended by "almost all " the principal barons of the kingdom. He demanded leave to confer apart with them, and all withdrew, leaving the king alone with his officials. After a long conference the advocate of Enguerrand, M. Jean de Thorote, declared that his client refused to plead in this case because it was one that touched his person, his honor, and his estate, but he was ready to defend himself in battle and denied that he himself had hanged the young men or ordered them to be hanged. Now the abbot and the women were there in the presence of the king and demanded justice. The king, after due deliberation, answered that in the cases of the poor or of the Church or of the helpless (miserabiles) the process by wager of battle could not be admitted, since a champion could scarcely be found who would fight for such persons against a baron of the realm. He cited the precedents of former kings, refused to listen to the prayers of the barons, ordered Enguerrand to be led back to prison, ard rose from the seat of justice, leaving the barons "abashed and confounded."

"On the same day the Count of Brittany said to the blessed king that he had no right to hear a complaint made against a baron of the realm in a matter touching his person, his honor or his estate; and the blessed king answered: 'You did not hold this opinion when the lords, your vassals, brought complaint against you before me and offered to prove their case by combat against you. You answered then before me that you were not bound to proceed in such a case by battle, but by evidence, and you said further that combat was not the way of justice."

Then they insisted that the king could not judge and punish a man who had not acknowledged his jurisdiction. And the king answered that if he knew the will of God in this case he would do full justice upon the man in spite of his noble lineage and the power of all his friends. The end of the matter was that he 
[1226-1270

condemned Enguerrand to pay a fine of 12,000 pounds of Paris in aid of the Holy Land, to hand over to the Abbey of St. Nicholas the forest in which the crime had been committed, to endow, forever three chaplaincies for the souls of the murdered youths, and to lose the right of sovereign justice in his lands. But the rumor spread that M. Jean de Thorote had said to the barons that the king might as well hang them all, and the king sent for him. "How now, Jean! Do you talk of hanging my barons? Of a truth I will not hang them, but I will punish them if they do evil." Jean managed to avoid the charge, so that the king did not hang him, as he had at first thought to do. Nor would he listen to the prayers of the highest nobles to set Enguerrand free, since they seemed to be conspiring against the honor of the crown.

In the case of Frederic II we were able to form but a very imperfect idea of the actual working of his governmental institutions, - partly, no doubt, on account of the overthrow of the Hohenstaufen power by the Angevine invaders, but partly also for lack of precise documentary evidence. In France, on the other hand, we have first a remarkable continuity of administration and then a body of documents of quite exceptional value for this purpose. These are the reports of the so-called royal inquisitors (enquêteurs $d u$ roi). The function of these officials is further indicated by their other title of "reformers" (reformatores patriae generales). They were special commissioners sent out from the royal court to inquire into the conduct of affairs by the local officers, to listen to complaints of the inhabitants against injustice or lack of justice, and even in specially insistent cases to reverse sentences and impose new ones in accordance with their own ideas of right. It is another indication of the good king's friendliness toward churchmen as such that his inquisitors were generally clerks, preferably friars of the Franciscan or the Dominican order. Their reports, covering many different parts of France and extending over many years after St. Louis, have recently been published ${ }^{1}$

1 Recueil des Historiens des Gaules et de la France, 1904, vol. xxiv. 
and furnish us with hundreds of illustrations of the early stages of the "bureaucratic state." If we overlook those instances of injustice which are easily explained by the frailty of official human nature, we can see in these often petty details a complete picture of the movement of French society towards an idea of the state in which there should be but one source of justice, the central government, and one body of citizens, all direct subjects of that central authority. That is the modern state.

These illustrations taken from the history of France and southern Italy show a tendency that was equally well marked in England; but since English history lies outside the scope of this volume we shall not concern ourselves with its contribution to this subject. As to Germany, we shall have occasion later to notice the peculiar development of its political institutions according to ideas apparently the precise opposite of those we have here been considering. It is a commonplace to remark that Germany was, until a generation ago, without a central rallying point for its national life and that, lacking this central point, the real units of government were the numerous states of which it was composed. These all accepted the shadowy Empire as an occasionally useful agency in helping to keep the peace and to hold a kind of rude balance among the local powers. Every attempt, however, on the part of the Empire to assert actual rights of sovereignty within the territories of the provincial lords was met with determined opposition, an opposition which in the famous Golden Bull of the year $135^{6}$ found its permanent constitutional expression. At the same time, within the limits of each independent German territory, the principle of the modern state, that is, the direct control of government over the citizen, was being worked out with a completeness no less remarkable than in France or England.

Much the same is true of Italy. There too the absence of a single dominating political power is the most obvious fact in Italian public life. Yet there also the several independent city states were building up a very effective bureaucratic machinery 
which was to make the hold of the local "tyrannies" over popular liberties easier and more secure. Especially as the four greater powers, Milan, Venice, Florence, and Rome, extended their control over neighboring smaller communities, the method of administration by permanent and professional officials responsible only to the head of the state becomes more and more inevitable.

It is to be noted that in this working out of the modern state under conditions varying thus widely in the several countries, the study of the ancient Roman law and its application to practical needs plays a very important part. Trained lawyers, a class of men almost unknown to the Middle Ages, become, at first in connection with clergymen and then gradually replacing them, the most efficient agents of government everywhere. It was their function to invent ways of evading the manifold contracts of the feudal period and to discover precedents for the exercise of sovereignty by the rulers who employed them. 


\section{CHAPTER II}

\section{THE NEW EMPIRE}

The most important feature of imperial politics in the Middle Ages was the working out of what is best described as the "Hohenstaufen Policy." The several elements which

The "Hohenstaufen Policy" made up this policy were as follows: (1) The Empire, in the hands of rulers of the Hohenstaufen family, was to be extended over the whole of Italy. (2) To accomplish this object, the powers of the independent Italian cities were to be treated as derived from an imperial law of which the emperor was the executor. (3) The Papacy, as the arbiter of Italian affairs and as claiming extensive rights over the Empire itself, was to be brought under imperial control. (4) The great territorial lords in Italy, that is, the great landed proprietors outside the cities, were to be dealt with as imperial vassals owing allegiance and service to the emperor and supported by him in their perpetual quarrels with the cities and with the Papacy. (5) Southern Italy and Sicily were to be united with the Empire by a permanent family union, so that with the help of the feudal lords of the North combined with this family possession in the South a pressure could always be brought to bear on the Papacy in the center which would make it the obedient servant of the Empire.

This was the working program of the Hohenstaufen Policy. It was clearly indicated by the first Hohenstaufen, Conrad III Causes of (II37-II52); it was the life work of Frederic Barbaits Failure rossa (1152-1190); it seemed to be on the point of success under his son Henry VI (I I90-II97); and it occupied his grandson Frederic II during the whole of his long reign (1215-1250). It was taken up with desperate energy and heroic 
courage by the heirs of Frederic's struggle in Italy, his son Manfred and his grandson the younger Conrad (Corradino), and the final outcome of it was complete and ignominious failure. This failure of the Hohenstaufen Policy is the natural starting point for the study of the New Empire under what we may now call by way of contrast the Habsburg Policy. The causes of the failure were briefly these :

I. The ambition to extend the power of the German ruler over Italy was in itself a fundamental mistake. It was based upon the splendid delusion that this miscalled Empire of the Middle Ages was the continuation of the ancient Roman Empire and as such had rights over Italy and especially over Rome which the Italian populations were bound to respect. In fact, the thing called the Empire was really the German kingdom, founded on German resources and maintained by German effort. Its ruler was elected by the choice of a small minority of German princes. He had power only so far as these and other German princes would permit him to have it. Italian conquest and Italian loyalty were will-o'-the-wisps luring one after another of these German kings to waste German blood and German wealth in a hopeless struggle against forces they were powerless to control.

2. It was a further delusion that the great vigorous city communities of Italy owed their origin or their rights in any sense to

Independence of the Italian Cities imperial privilege. Never in the history of the world were there better illustrations than these of independent associations of men governing themselves by their own laws, growing rich by their own industry and intelligence, keenly alive to the value of what they had and determined to defend it to the last gasp. This was the bitter lesson which Hohenstaufen kings were forced to learn on many a bloody field from Legnano ( I I 76) to Cortenuova (I 237).

3. The attempt of the Empire to control the Italian cities had roused the Papacy to a sense of its own danger. From an early period it had made common cause with them against this foreign 
aggression. To the call of "Ghibelline !" it had replied with the slogan of "Guelf!" and throughout Italy these battle cries had been the rallying points for generation after generation of partisan conflict. City against city, party against party, class against class : this hostility of Papacy and Empire had utilized them all. Again and again the Empire had seemed to be on the point of gaining permanent control over the papal administration. It had driven popes from Rome and set up others of its own choosing. It had compelled the papal government to make terms and to grant the imperial crown on conditions favorable to its further development. But in the end the combination of the papal with the communal interest had been too strong for it. At the death of Frederic II in $125^{\circ}$ the imperial claims in Italy were broken beyond hope of recovery.

4. Meanwhile the phenomenal development of Italian city life had been producing its reactions upon the feudal territorial lords, whose main reliance had hitherto been upon their landed estates held by one or another title under the overlordship of the Empire. Then, as in our own day, the attraction of the city was becoming irresistible. Even the fighting noble was finding his best advantage in the service of some fortified town where his landed property gave him a start and where the increasing refinements of life were offering him and his family a more rewarding career. The city, in other words, was gaining at the expense of the country, and with every such gain the force of the feudal tie that had bound the rural nobility to the remote and ineffective Empire was correspondingly weakened. It was only when, as happened temporarily in the north, some leader more than ordinarily strong and unscrupulous, like Ezzelino da Romano (I1941259), succeeded in getting control of the cities themselves that there was any real danger of cities being absorbed in larger territorial and feudal units. In fact the absorption was the other way. Cities became, for centuries to come, the dominant units of Italian life. 
5. The most brilliant stroke of the Hohenstaufen Policy was the marriage of Henry, son of Frederic Barbarossa, with ConThe Norman stance, heiress of the Norman kingdom of Naples and Marriage Sicily. There was a more or less clear understanding with the Papacy that this personal union was not to mean a union of territories, but probably no one was greatly deceived as to the real intention. Henry VI succeeded his father in 1190 as king in Germany and spent his short reign in an elaborate attempt to bind the feudal lordships of northern and central Italy more closely to his overlordship. In the south he pushed his rights as husband of the lawful sovereign as far as the people would bear. If he had lived, there is reason to believe that the political future of Italy would have been greatly changed. His early death in 1198 broke the force of the combinations he had so cleverly planned, but it also opened the way to new ones of equal importance. His infant son, the future Frederic II, was left as undoubted heir to the kingdom of Naples and Sicily, but presumably barred by the implied agreement at the time of his parents' marriage from ever making any claims to sovereignty in Germany. Then followed the double election to the German kingdom of Frederic's uncle Philip of Swabia and Otto of Brunswick - another outbreak of the ancient rivalry of Hohenstaufen against Guelf. Then ten years of civil war until the murder of Philip in 1 208; then seven years of struggle on the part of Otto to maintain himself against Hohenstaufen intrigue, and finally the elevation to the imperial power of the young Frederic. The Hohenstaufen party seemed to have won its most decisive victory. The unquestioned hereditary ruler of the South was now, in spite of all precautions, the elected ruler of the North as well, and the most singular thing was that he had been helped to this position by one of the cleverest men who ever sat in Peter's chair, the veteran diplomatist Innocent III. The long reign of Frederic II was one continuous illustration of the impossibility of the situation. It ended with the loss of his prestige in the north and the beginning of the ruin of 
his family in the south of Italy. What was worse, it had become clear that the temporary triumphs of Frederic in Italy had been purchased with such sacrifices of land and loyalty in Germany that henceforth the name of Hohenstaufen spelled failure to every person and every cause that tried to invoke it.

The dramatic culmination of all these complicated movements in imperial politics was the murder of Frederic's grandson, the Loss of Ger- heroic but ill-starred Corradino, on the scaffold at man Influ- Naples by the order of the French invader, Charles of ence in Italy Anjou (1268). It was the proclamation to all the world that the dominant influence of Germany in the affairs of Italy was at an end, that henceforth France was to have a voice in the decision of all Italian affairs, and that the Papacy, if it could be skillfully handled, had the chance of becoming the chief among Italian powers. We are concerned here with the reaction of this Italian crisis upon Germany and especially upon the character of the German kingdom. It is not too much to say that from this moment on that character was to be radically changed. The ruler of Germany still calls himself "King of the Romans" and "Emperor." Sometimes he thinks it worth his while to secure a coronation from a Roman source, preferably from the Papacy, but if it does not suit his convenience he gets on equally well without this decoration. Fantastic visions of world empire no longer trouble his dreams. His concern is with Germany, and his ambicions are confined to straightening out the tangled web of internal administration, to keeping the peace between his restless subjects, and, above all, to building up a family property which may secure to his descendants as strong a place as possible in the group of princes who are the real units of German political and social life.

The history of this new departure is closely bound up with an institution which better than any other illustrates the decisive movement of German politics in the second half of the thirteenth century. The German Electoral College forms a striking parallel 
to the other great electoral machine of the Middle Ages, the papal College of Cardinals. ${ }^{1}$ The two highest offices in the Christian-

Medizval Germanic state, the Empire and the Papacy, were Electoral both essentially elective. An hereditary empire was Methods

as much a contradiction in terms as an hereditary papacy. In both cases the difficulty was to fix the right of election in the hands of a well-recognized constituency. To us of the modern world nothing seems easier than to settle such a question once and forever by a constitutional law; but the Middle Ages had but slight experience in such a process. Their only way out of one set of conditions into another was the way of struggle first and lawmaking afterward.

So we find in both Empire and Papacy a long history of electoral experiment, with every variety of personal and party struggle, Electoral until at a given time each was led to define the conLaws : I, Papal ditions of its own creation. The turn of the Papacy came first, as was natural because the legal foundations of the papal government, developed out of traditions of the ancient Roman law, were more clearly defined than those of Germany or in fact of any other European country. The famous decree of Nicholas II in ro59 was intended to give at least the initiative in papal elections to a select body of Roman clergymen, the so-called "cardinals." The immediate and complete failure of this new arrangement showed that it was a case of legislation ahead of its time. It was a full century before the College of Cardinals became generally recognized as, the proper agent in the papal election, and it was long after that before it began to show itself a dangerous rival to the papal power itself. The essential qualities of the cardinalate were that it was Roman, that it was clerical, and that it was limited in numbers.

In the case of the Empire the earliest formal declarations of the right of the Electoral College to choose the future emperor come very much later, not before the early part of the fourteenth

1 See "Mediæval Europe," chap. vii. 
century. The existence of a college, however, that is, of an indefinable group of persons having a right to vote for the emperor, 2, Imperial superior to the right of all other persons, is distinctly traceable at least a century earlier. It is one of the most curious illustrations of mediæval indifference to constitutional forms that the origins of so important an institution as this, an institution which was to continue in operation for six hundred years, are lost in almost total obscurity. During the whole of the Middle Ages the principle of election in Germany had been in rivalry with that of inheritance; the reigning king had often secured the election of a successor from his own family during his own lifetime. Now and again, however, in default of a successor in the reigning family, the nation had been free to make a choice, and such an occasion always made a considerable impression upon the chroniclers of the time. Yet at no one of these occasions do we find so much as a hint at a definition of the right of suffrage. We only know what was done, and that only in meager outlines. At no two of such elections was the practice the same. For example, at the close of the direct Saxon dynasty in 1002 the succession of Henry II, a remote connection of that house, was secured by his gaining over, first, the most important clerical prince in Germany, the archbishop of Mainz, and then making terms with the leading men of the other German "stems." At the death of Lothair the Saxon in I 125 there was a regular nominating committee chosen by four of the great stems, ten from each, and the decision of this committee of forty determined the election. After the death of Conrad III in $1 \mathbf{I}^{2}$ there appears to have been what we should call a "caucus" of the princes without any definite plan, and it was their decision which determined the election of Frederic Barbarossa.

So we come down to the first clearly contested election case, that of Philip of Swabia against Otto of Brunswick in 1198 , without any further solid information than that the right of election belonged to all the principes and that some among these 
took a leading part; but who these were varied with the occasion, and in what their leadership consisted we can only guess. ${ }^{1}$

The Double

Election of I. 198

The first documentary suggestion we meet occurs in the correspondence of Innocent III with the supporters of his candidate Otto. In justifying his support the pope says that Philip was, to be sure, the choice of the larger number among the principes as a whole, but that Otto had been chosen by as many or more $e x$ his ad quos principaliter spectat imperatoris electio (of those to whom the choice of the emperor primarily belongs). There is no doubt that Innocent meant to imply that there were certain persons who were known to have a higher right in the election than others, but we get no hint as to who these persons were, and the value of papal evidence here is greatly weakened by the very plain partisan interest which set the pope naturally on the side of Otto. The phrase in question may well have been put into his mouth by the Guelf partisans.

That it was not a mere fiction, however, is shown by the next document which mentions the Electoral College. Innocent's declara-

Electoral Theory of the "Sachsenspiegel " tion was made in the year 1200 , and the "Sachsenspiegel" appeared about 1230. In the interval had occurred the death of Philip of Swabia and the general recognition of Otto IV in 1208 , and the elevation and success of Frederic II in $1213^{-12} 15$. On neither of these occasions have we the record of a definite electoral college with fixed membership and rules of procedure. The "Sachsenspiegel" was a compilation of the existing laws of Northern Germany, made by a private jurist, Eike of Repgow, for use in the courts.

1 There has hardly ever been a subject of historical controversy upon which more scientific guessing has been done than upon this. A considerable library of special treatises has already been devoted to it, and the interest is far from being exhausted. A complete solution seems as far away as ever, but a great mass of useful results has been obtained by the way, and our knowledge, especially of the proceedings at the several elections, has been greatly increased. 
It contains the earliest outline of German constitutional law, and in speaking of the emperor it says: ${ }^{1}$

"In the choice of the emperor the first shall be the bishop of Mainz, the second the bishop of Trèves, the third the bishop of Cologne. Among laymen the first in the choice is the Count Palatine of the Rhine, the steward of the Empire, the second the duke of Saxony, the marshal, the third the markgraf of Brandenburg, the chamberlain. The cupbearer of the Empire, the king of Bohemia, has no right of choice because he is not a German. Afterward all the princes of the Empire, clergymen and laymen, make their choice. Those who have been named as the first in the choosing are not to choose according to their own free will; whomsoever all the princes select as king, him they are first of all to choose by name."

This passage, interpreted by scholars in every conceivable fashion, may be made a little clearer if we compare it with the Analogy of other great electoral document of the Middle Ages, the college the papal decree of 1059. In both cases the same of Cardinals principle is evident. The ultimate electoral right of a great number of persons is recognized, but the effort is to guide this unwieldy and often turbulent mass of voters by the previous action of a smaller and carefully selected body. In neither case, probably, was there at first any idea of excluding entirely the large constituencies which had formerly produced popes and emperors. The author of the "Sachsenspiegel" goes out of his way to emphasize the rights of de vorsten alle (all the princes), and the cardinal decree of 1059 especially reserves the ancient rights of "the clergy and people of Rome." It was this sense of a wider electoral right which kept both the colleges from acting exclusively until a time came when such exclusive action was found to be a necessity if the two ancient universal 
institutions of the Middle Ages were to be adapted to the demands of a new social order. ${ }^{1}$

That time came for Germany in the second half of the thirteenth century. The interval from the death of Conrad IV in The "Inter- 1254 to. the election of Rudolf of Habsburg in 1273 regnum" is generally known as the "Interregnum." The term is misleading, for there was during all this period at least one "King of the Romans," generally two, elected with some approach to the forms of the "Sachsenspiegel" and commanding, apparently, about as much allegiance as had been given to some of their predecessors in good and regular standing. William of Holland, a German prince, was chosen in 1247 by the papal or antiHohenstaufen party and continued to hold his own after the death of Frederic II in $125^{\circ}$ and through the short reign of Frederic's son Conrad IV. He was supported, with more or less reluctance, by the northern princes, but gained no marked advantage over his rivals except by outliving them. Even the death of Conrad in 1254 did not materially strengthen his hands. At the death of William in 1256 the Empire actually went a-begging among the German princes. It was indeed a thankless undertaking to figure as the head of an institution which had lost its ancient prestige as a world power in the fight with the Papacy and had not yet come to its rights as a true national monarchy.

1 The opinion of the author of the "Sachsenspiegel" as to the basis of the electoral right seems clearly indicated by his description of the lay electors as holders of the great "ministerial" offices about the person of the king. This is emphasized by his excepting the cupbearer, the king of Bohemia, on the ground that he is not a German. That is, according to the theory of the "Sachsenspiegel," only the royal ministeriales could elect; but these must be Germans in order to qualify them for this electoral function. This opinion is further strengthened by the fact that the three clerical electors were also holders of high administrative office. The archbishops of Mainz, Cologne, and Trèves were the imperial chancellors, respectively, for Germany, Italy, and Burgundy. The principles of terri torial extent and local distribution seem to have been disregarded. 
The result was that two foreign candidates were brought forward by the fragments of the two parties which had supported

Election of

Two Non-

German

Emperors respectively the Hohenstaufen and their northern rivals. Richard of Cornwall, brother of King Henry III of England, was set up by the archbishop of Cologne and supported chiefly by the princes of the Rhine. Alfonso, king of Castile, a relative by marriage of the Hohenstaufen family, was the candidate of the southern nobles. For the first time we find the record of a regular "canvass" quite in the modern style. Better than documents to illustrate the growth of an electoral college is the fact that certain German princes were picked out by the managers of the rival candidates as those who were especially worth bribing. For the first, but not for the last, time "English gold" plays a leading part in continental politics. There was nothing whatever in the theory of the world empire which should prevent a non-German from being emperor. It only remained to be seen whether there was life enough left in this mediæval theory to hold up a non-German emperor against the general indifference of the Germans as a whole. After a year of candidating, during which unheard-of sums of money were spent in buying votes, the "princes" came together at Frankfort and, divided into two factions, elected both candidates.

If the Empire had been a thing worth fighting for, we should expect now a history of open warfare, such as had marked the True Char- rivalry of Henry IV and Rudolf of Swabia or that acter of the of Philip of Hohenstaufen and Otto of Brunswick, "Interreg- warfare which should continue until one emperor should drive the other from the field. Instead of this, Richard, after a very brilliant début in the Rhine country, went back to England, and Alfonso never appeared in Germany at all. No better proof could be given that the. Empire, in its mediæval form, was gone forever. Historians who have an eye only for politics on a grand scale are wont at this point to fall into 
melancholy descriptions of the wretchedness of Germany during the "Interregnum." Deprived of its imperial defenders, it falls a prey to anarchy within and is threatened with ruin from without. In fact, however, German life begins at precisely this time a new movement, which may be described as in all respects upward and forward. The mediæval Empire, if it had from time to time reflected a certain glory upon Germany, had won this glory at the expense of German resources. The Hohenstaufen policy had for a hundred years been draining Germany to keep up the imperial fiction in Italy. Released from this pressure of a vague ambition after the unattainable, the natural energy of the German people began to seek its own salvation.

The best illustrations of this new energy are to be found in the free associations of Germans for the purposes of public German City Leagues for Public Defence

defence. Here, as everywhere at the time, the plain necessities of commercial life gave the impulse. The cities of Germany had been going through a development altogether similar to that of their sisters in Italy and France. Beginning as the feudal property of a lord, sometimes of a territorial prince, sometimes of a bishop or even of the king himself, they had gradually got the management of their affairs into their own hands and had worked out a system of local popular government under the lead of a group of aristocratic families (Geschlechter). At the time we are now studying they were passing through a second stage of constitutional progress and were admitting the lower industrial classes, organized on the basis of trade-unions (gilds), to a larger and larger share in the city government. The very first need of these great industrial communities was peace and the security of the highways. If these could not be gained by means of a strong central administration, the next best thing was to secure them by their own action. Such is the meaning of the great Rhine confederation of the year 1254. In spite of the fact that William of Holland was still clinging to the empty title of "King of the Romans," the question 


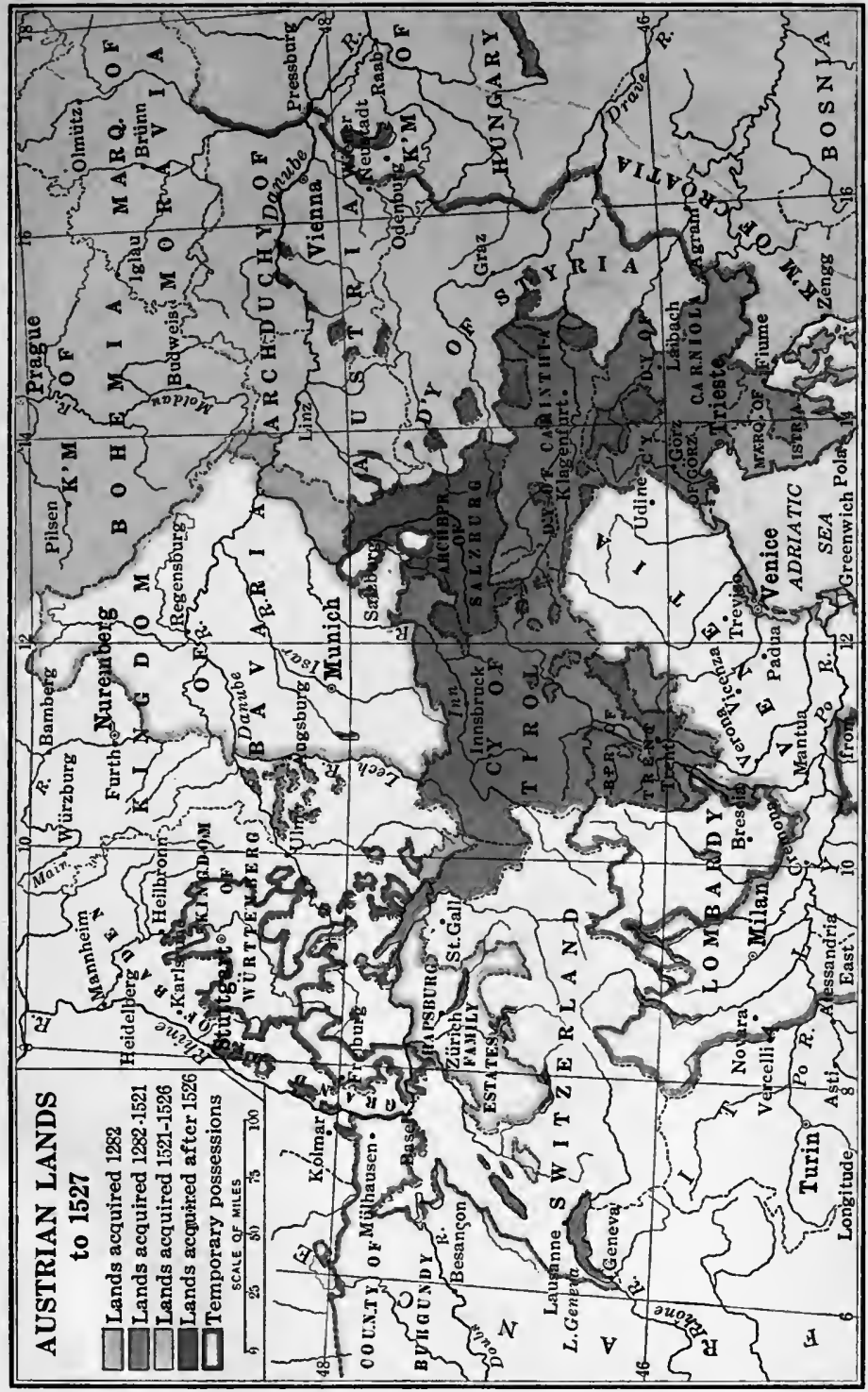




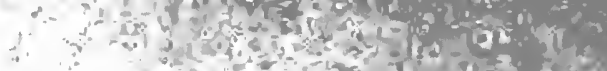

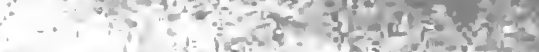

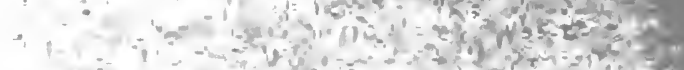

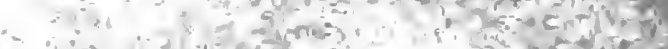

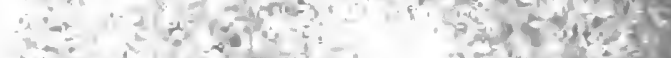

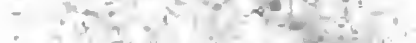

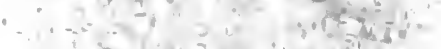

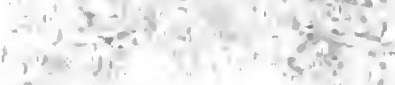

-

$\infty$

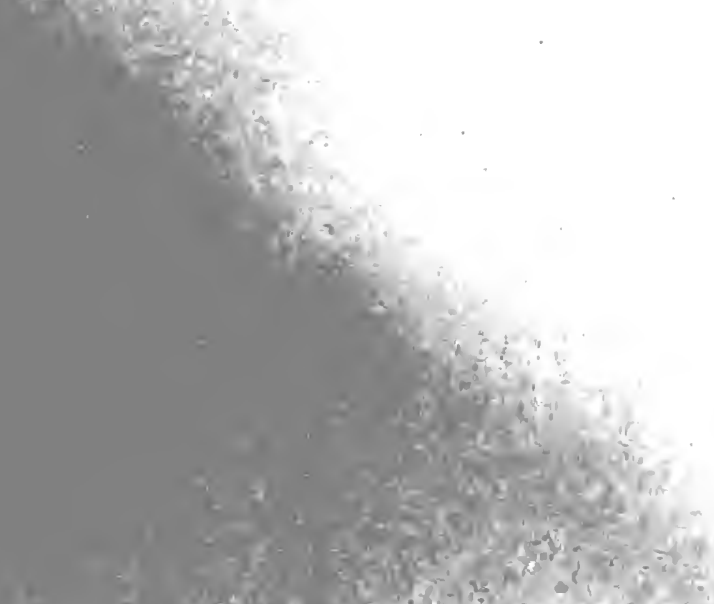

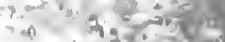

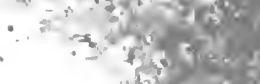

$27^{2} \quad$ in

(2)

$\operatorname{lin}^{2}=2$

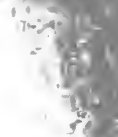

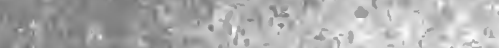

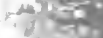

-2 ish

+98 : 1

$1+\frac{1}{2} x^{2}$

$\therefore \log ^{2}$

Tे=

$-\infty \int^{x}$

$x_{1}=$

$-12$

$+\infty \frac{9}{4}$

$5-212$

$x+\frac{1}{2}$

ip is

in:

A. 1.9

$4 \times$

.

$\frac{7}{4}$

3 ie

is

$\lim _{2}$

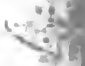

40

$\checkmark$

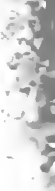

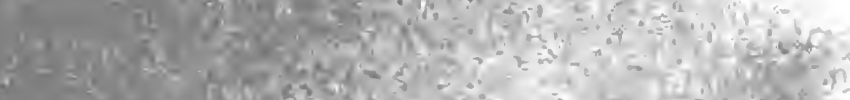

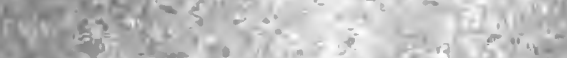

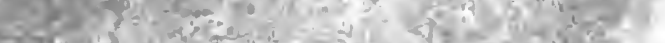

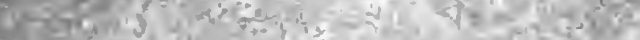

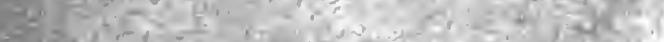

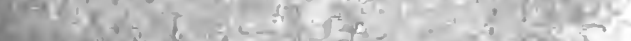

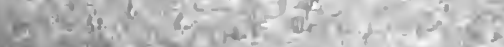

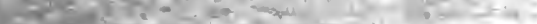
2. 
of a new election was now, by the death of Conrad IV (1254), again brought before the nation. It was of the utmost consequence to the cities that this election should result in a strong centralized administration of the public peace. The two most important cities of the middle Rhine, Mainz and Worms, entered into a union which was at once extended to Bingen and Oppenheim and then spread with such rapidity both up and down the river that in a few months more than a hundred cities had bound themselves by its terms. And not cities only; the most powerful territorial lords in the neighborhood were drawn, partly by their own advantage, partly by pressure from the towns, into the alliance.

The primary object of this Rhenish League was the Landfrieden, the security of roads, and the suppression of disorders. So far its Political purpose must commend itself to all regular authority. Aims of the King William of Holland, who had held out during Rhenish Conrad's life, was now recognized by all Germany League, ${ }^{2256^{\circ}}$ and confirmed the action of the League, even going so far as to declare that its enactments should have the force of public law, - a singular confession of imperial uselessness. At William's death in $125^{6}$ the League at once assumed the largest political functions. It laid its members under renewed obligations to defend the interests of the nation as a whole; it exhorted the principes to secure a unanimous election and declared that in case of a divided choice its members would accept neither candidate. All seemed to point towards a high and a vigorous interpretation of the imperial office. ${ }^{1}$

1 Decree of an Assembly of the League at Mainz, March 15, 1256 :

"After the death of our Most Serene Lord, William, King of the Romans, of pious memory, we have met at Mainz in the year of our Lord MCCLVI on Sunday Reminiscere and there have considered many matters of importance for the public peace.

"And since we are without a king we have agreed that each city according to its ability shall prepare for military action and shall maintain soldiers and archers, by means of whom, if occasion arise, we may instantly come to each other's aid. But to those lords, be they knights or others, 
Then began that disgraceful canvass which resulted in the choice of two foreigners. In spite of all its declarations the League Its Failure as a political agency failed entirely. The "genius of the German people," prompt to express itself in practical ways, was curiously incapable of working out a steady and persistent process of unified political development. Germans would neither tolerate a strong and efficient monarchy, nor would they learn how to combine into permanent political groupings. This political futility is the more strongly brought out by the very completeness of the constitution of the League. Its measures for taking in new members, for regular parliaments, for raising soldiers, and for dealing with outside powers are so carefully worked out that one can hardly help believing that these very clever German citizens had well studied the history of their north Italian predecessor, the Lombard League, in its century-long conflict with the house of Swabia. It might have been well for the German cities if they too had been called upon to fight for their lives against a single determined enemy. Such a conflict might well have hardened this paper compact into a band of steel. In fact the enemy they had to fight was a far more subtle one, - the interest, namely, of the great territorial princes. The question was in Germany, as it had been in Italy,

who have not joined our league, we will not give aid. So long as the kingly office is vacant we promise to defend the property and the regalian rights of the kingdom with all our might, leaving each holder in permanent possession.

"For the safety of the whole people and of the land we have agreed and promised under oath that, if the princes to whom the right of the royal election belongs shall by any chance choose more than one candidate, we will give support to neither of them by word or deed and will perform no service to them openly or in private, nor will we admit them to any of our cities or swear fidelity to them.

"But if any city shall break this covenant, it shall be treated as perjured and utterly dishonored, and we will proceed against it with all our forces and destroy it forever. If, however, the princes shall choose one lord as king, we will offer to him without delay or diminution all due service and honor." 
whether the cities were to become, not merely the chief centers of industrial and intellectual life, but the chief political units as well. They had succeeded in Italy because territorial lordship there had proved to be too feeble a force to command the allegiance of the Italian peoples, and its fate may well have been a warning to Germany. It is in this conflict of individual and class interests rather than in imperial politics that we find the true history of the Interregnum. The principle of free association, defeated as a political force in 1256, was to remain a powerful factor in German life and later, under the form of the vast trading association of the Hansa, was to show its value for political purposes as well.

That the monarchy was not thought of as suspended during the Interregnum, but only as inactive, is proved by the reluctance of End of the the princes to take any action toward making a really Interregnum, vigorous king until at least one of the royal figure2273

heads was out of the way. At the death of Richard of Cornwall in 1272, King Alfonso naturally appeared as the most promising candidate. He begged the pope to help him in securing general recognition, but the Papacy was at the moment interested in other things and quietly let him drop. The German princes, none of whom had ever shown any interest in his "claims," proceeded at once of their own motion, and under the leadership of the archbishop of Mainz, to canvass the question of a new election. From the first moment there seems to have been a conviction among them that the time had come for a new kind of German kingdom, one that should be, above all else, a national institution. None but thorough Germans were seriously considered as candidates and it early became evident that the electoral princes, into whose hands the choice was allowed to fall, were not inclined toward any one of the greater territorial princes.

The choice of Rudolf, count of Habsburg, expresses these two ideas. He was a German of the Germans and he was not one of those great landed rulers, like the duke of Bavaria or the markgraf of Brandenburg, who might bring to the kingdom the dangerous 
overweight of a too powerful feudal connection. The Habsburg lands, centering around the ancient family castle on the river Aar Rudolf of Habsburg, tended over the valleys of the Aar, Reuss, and Limmat 1273-129I to the upper Rhine. Thence down the Rhine the Habsburg power commanded both banks as far as Basel and the left bank into Alsace as far as Breisach. The Habsburgers had made rather a special business of serving as advocati (Vögte) to religious houses in their immediate neighborhood, a profession profitable in itself and easily leading to rights over land which could readily be converted into ownership. It was through one of these "advocacies," that of the Frauenmünster at Zürich, that the claims of Habsburg over the Forest Cantons arose, which were the immediate motive for the formation of the Swiss Confederation of I29I. Precisely the terms of the negotiations between the electors and the successful candidate we do not know, but it is plain that terms were made, such as the electors thought a sufficient guarantee of their own advantage. Marriages, from this time forth one of the most frequent and most powerful agencies of the Habsburg policy, were arranged between two of the count's numerous daughters and the sons of electoral families. The electors were to have their electoral expenses paid and, if we may judge by later events, they reserved some very considerable rights of consultation in important matters. Rudolf was a man of force and character. One glance at his powerful features would convince any one that in a day when men were struggling for wealth and power as never in Germany before, this man was not likely to sit still.

And, in fact, the character of a restless ambition for personal and family power is from the first moment stamped upon the The Habs- policy of the Habsburg house. The historical imporburg Policy tance of King Rudolf is that this eager striving for power is no longer directed toward those fantastic ideals which had attracted the Hohenstaufen kings. The Empire as such 
plays from first to last with him an entirely secondary part. $\mathrm{He}$ was a petty prince, but he meant to become a great prince; he saw the limitations about him and proposed to act within them rather than to waste himself in trying to break through them. $\mathrm{He}$ saw his mission as head of the German people in trying to reconcile differences, to maintain order, and to let the free development of individual powers go on rather than in trying to make an unwilling mass of subjects serve the fanciful ends of an "imperial" policy. He was a practical politician, a brave soldier, already familiar with the problems of his nation, a cool head, patient and determined.

Count Rudolf of Habsburg had long been known as one of the stanchest supporters of the Hohenstaufen party. He had Rudolf and shared in the general excommunication laid upon the Papacy Frederic II and all his partisans in 1248 , and even as late as 1267 he had joined the forlorn hope of Corradino and gone with him as far south as Verona. His election to the kingdom was, indeed, unanimous except for a vigorous protest on the part of King Ottokar of Bohemia, and relying upon this unanimity he proceeded at once to Aachen, the venerable coronation city of Charlemagne, and was crowned before he reported his election to the pope. Yet, in spite of this universal friendliness of the German princes there were still dangers lowering upon Rudolf's horizon which he must avert at all costs. In the course of the electoral campaign three rivals had been especially threatening: Ottokar of Bohemia on the east, King Philip III of France on the west, and Alfonso of Castile, already in possession of the title of "King of the Romans." The choice of Rudolf undoubtedly expressed the determination of the German princes to give themselves a national head rather than to accept any one of these "foreign" candidates. On the other hand, each of the foreigners could fairly claim that the Empire was above all nationality and could appeal to the pope to support him in maintaining the mediæval ideal of a world empire joined to a world papacy. 
There was still more than a possibility that France and Bohemia, if either could buy the support of the Papacy, might join hands across Germany and enrich themselves at its expense.

It was therefore of the first importance to Rudolf to anticipate any such combination by securing the good will of the pope without sacrificing any of the real foundations of his power. On the papal side there were also three problems of especial importance : first, to secure the papal lands in Italy from future imperial aggression; second, to block forever any attempt on the part of the Empire to annex the Norman-Hohenstaufen territories of the South, and third, to gain an emperor as head of a new crusade, the favorite, if fantastic, project of Gregory X's program. So far as Rudolf of Habsburg was concerned, therefore, the question for the pope simply was whether his kingship, already an accomplished fact, was likely to bring these results. Compact Upon receipt of the official notice of the election with Gregory invited Rudolf to meet him at Lyons in Gregory $\mathbf{X}$ France, whither he was proceeding to hold a General Council, and Rudolf responded by sending legates charged with quite extraordinary discretion in making concessions. The demands of the pope were that all the guarantees given by Otto IV and Frederic II to his predecessors, in their fullest extent and with all the vague clauses that had already given rise to endless troubles, should now be renewed by Rudolf. These demands were agreed to by the ambassadors and, upon their return, were ratified by the king. They were conditions such that, if he had had the least intention of renewing the Hohenstaufen policy in Italy, he must have broken them from the start. Especially important was the acknowledgment that henceforth Apulia and. Sicily should be independent of the Empire. It was also agreed that as soon as convenient Rudolf should come personally to Italy to receive the imperial crown at the hands of the pope and at the same time should pledge himself to undertake a crusade at the earliest possible moment. 
It appears to have been a part of Gregory's plan to return from Lyons to Rome by way of Germany, in order that he might in a still more impressive manner proclaim his right to confirm the action of the princes, but. he gave this up and chose the shorter route along the northern shore of the Lake of Geneva. There at Lausanne on October 20, 1275, he was met by Rudolf and received from him the most solemn pledges of fidelity to all the ancient privileges of the Papacy as they had been fixed and renewed from the days of Louis the Pious. The king promised to come to Italy for his imperial coronation early in the following year and with his queen, the chief nobles of Germany, and five hundred knights assumed the cross and vowed personally to go on a crusade. Gregory on his part declared that he would lead the crusade in person and that a beginning should be made very soon after the coronation. All this has a delightfully mediæval sound. Pope and emperor in peace and harmony, - the pope confirming the election of the king and graciously conferring the imperial crown, then marching at the head of a Christendom united under the military leadership of an emperor to the destruction of the infidel. The picture is complete; but what were the realities behind it? The hard-headed Habsburger was giving away only things which he did not possess and the struggle for which had been the ruin of his predecessors. In return he was securing the moral support of the Papacy against his most dangerous enemies at home. There were always good reasons why the coronation at Rome and the beginning of a crusade could be put off to a more convenient season. Meanwhile he did not fail to secure from the pope the handsome sum of I 2,000 marks and a month later 3000 more to meet the expense of the Italian journey.

Evidently Gregory X expected to make use of Rudolf for the purposes of his policy in Italian affairs, and to all appearance the newly elected king was prepared to meet these expectations halfway. He sent his legates into Italy to receive the homage of the 
northern and central powers and to make all preparations for his approaching advent. The legates were well received, the homage was easily pledged. Rudolf even went so far as to appoint his viceregents in Lombardy and the Romagna and gave repeated assurances that he would himself cross the Alps as soon as possible. Date after date was set for the journey, but there was always a reason for delay. Even these first tentative measures had aroused all the old jealousies now made more acute by the continual meddling of Charles of Anjou and Alfonso of Castile, who, opposed to each other on every other point, were one in their hostility to German influence in Italy. Added to all these difficulties was Rudolf's utter poverty. However sincere his intentions, he could do nothing but make repeated excuses, and meanwhile came one of those crises which have so often upset the balance of Italian affairs. In the midst of his many plans Pope Gregory suddenly died, January 10,1276 . The election of Innocent V was determined by the Angevine faction in the College of Cardinals, and at once a new papal policy began to make itself felt. One of Innocent's first acts was to forbid Rudolf to come to Italy until the complicated questions of his overlordship in the Romagna should be settled, and that meant that he was never to come at all. The subject of the crusade was quietly dropped, for the crusading spirit was only another expression of that universalism of the Middle Ages which culminated in the idea of Empire, and with this it died also a perfectly natural death. However unwelcome for the moment this change of the papal policy may have been to Rudolf, the sequel showed that it was the very best thing that could have happened to him. He lost the empty honor of the imperial crown, but he gained what was infinitely more valuable, the loyal support of his own German people.

At a Diet held in November, $\mathbf{2 7 4}$, at Nuremberg, we begin to see clearly outlining itself the relation of Rudolf to the Empire which was to give character to the Habsburg policy for all time. The Diet showed itself surprisingly ready to support the king 
in making himself in reality the head of a German state. It declared that the king should take possession of all imperial Rudolf and lands that had been vacated since the excommunicathe Empire, tion of Frederic II in $\mathbf{1 2 3 9}$. This was practically a 1274-1275 declaration that all acts of later kings in regard to imperial territory had been invalid, and it has gone far to fix upon the intervening period the name "Interregnum." But the scope of this act was much wider than appeared upon the surface. It gave, to the king the opportunity of making up for his lack of a great family possession by gaining, in the name of the Empire, a control over a more than princely complex of territories. The Diet proceeded to make a concrete case by summoning King Ottokar of Bohemia to appear before it in the following January, and to show cause why he should not hand over to King Rudolf the group of territories already known as the Austrian lands.

To understand the full meaning of this momentous event we must go back for a moment and review hastily the fortunes of Rudolf and these territories since the death, without male heirs, the Austrian of the last Babenberg duke of Austria in 1246. AcLands, 1275 cording to the fundamental law of the Austrian duchy the right of inheritance was shared by females, and thus conflicting claims arose through several relatives of the late duke. The einperor Frederic II was able to maintain a kind of imperial administration in the duchy, but upon his death in 1250 the field was open for the contesting claimants. While others were negotiating Ottokar, crown prince of Bohemia, with no excuse except that he was "invited" by a party within the duchy, invaded Austria and at once manufactured a "claim" by marrying the sister of the late duke. To fortify himself in all directions he took an oath of fidelity to the Papacy and also to King William of Germany. Without great difficulty Ottokar overran Austria proper, Styria (Steiermark), and in the course of the next few years succeeded in gaining Carinthia and Carniola as well. At the death of his father he became king of Bohemia and thus, by 
the acquisition of Austria, he found himself at the accession of Rudolf of Habsburg in possession of a vast territory reaching from the Bohemian mountains on the north to the Adriatic on the south. The value of this great territory in itself was greatly enhanced by the personal quality of King Ottokar. He was a man of immense energy and unbounded ambition, resourceful in politics, capable in war, and perfectly conscious of what he was aiming at. At the election of Rudolf he was the only dangerous rival, and even after the election was an accomplished fact the clever pope Gregory $\mathrm{X}$, who had secretly encouraged Ottokar, held back with his approval until he had convinced himself that it would not be worth while to push the Bohemian claim any further. But, as German politics then stood, the possession of this vast territory in one hand was a standing threat to all the princes in the neighborhood, and the promise to recover the Austrian lands as vacated imperial fiefs seems to have been one of the conditions of Rudolf's election.

The issue of the summons at Nuremberg showed the value of Rudolf's policy. Ottokar, assailed by the Empire, appealed to the

Rudolf

against

Ottokar, $1276-1278$ Papacy, but Rudolf had already gained over the papal influence by his timely concessions. Deserted by the power to which he had owed his great successes, Ottokar was thrown upon his own resources and upon whatever spirit of loyalty he might have created in the newly acquired duchies. Failing to answer the summons to Nuremberg, he was pronounced in the ban of the Empire, and all his imperial holdings, including Bohemia and Moravia, were declared forfeited. Rudolf on his side, thus supported by the Diet, was ready to push the affair to the end. All his plans were laid with the utmost cleverness and succeeded beyond expectation. Even the one ally as to whom he had been in doubt, Henry of Bavaria, came to him at the last moment and declared himself ready to join the imperial army. A plan of campaign was prepared by which five armies at once were to be marched into the 
Austrian territory. Every man did his duty. Ottokar, never a really popular ruler even in his own country, found himself threatened by treason in Bohemia and sued for peace. At Vienna in November, 1276, articles of agreement were signed by which he gave up absolutely all claim to the lands south of the Danube, received Bohemia and Moravia again as imperial fiefs, and held Austria north of the Danube as a pledge for the dowry of a Habsburg daughter, who was to marry his son, the crown prince of Bohemia.

An Austrian or Styrian chronicler, writing about a generation later, gives a thrilling description of Ottokar's reception in Bohemia by his high-spirited wife, Queen Kunigunde, on his return from this humiliating expedition. In this dramatic scene the queen upbraids the king as a coward and a traitor to the best interests of Bohemia. The "Swabian," as she calls King Rudolf, has been acting out a proverb of his country: Gesmiug ich mich, ich reck mich wohl ("I crook myself to stretch myself "). Ottokar ought to have seized the moment when Rudolf was ready to make terms, and she uses the familiar wifely argument: "If you had only had my spirit, you would not have let yourself be imposed upon." 1

A personal interview between the two kings seemed to put the seal upon this peaceful conquest; but too many causes of hos-

The Battle of the Marchfeld, 1278 tility still remained. Ottokar's humiliation reacted upon the loyalty of Bohemia; he could bear almost any injury for the sake of saving his inherited kingdom, but when Rudolf went so far as to demand amnesty for traitors within that kingdom, it was too much. We do not need the legend of a too ambitious wife, goading her husband into action, to explain Ottokar's breach of the conditions of 1276 and his invasion of Austria in 1278 . Once again Rudolf displayed his superior generalship. He allowed Ottokar to advance within a few miles of Vienna, and there, on the plain of

1 Ottokar von Horneck, Reimchronik, chap. cxxxii. 
the river March, near the village of Dürnkrut, gave battle with an overwhelming force. Ottokar made a valiant fight and long held the royal army at bay, but finally, overcome at every point, surrendered. Before he could be brought into Rudolf's presence, he was recognized and murdered by an Austrian nobleman, in revenge for some personal wrong.

The death of King Ottokar settled forever the claim of Bohemia to the Austrian territories, but it also opened up a new question Rudolf occu- of constitutional right which was full of meaning for pies Austria the future. Rudolf had gained these lands as king; would he hold them as king, or would he follow the trend of German politics at the time and use his influence as king to make them the property of his own family? If this question had come to the German princes as an abstract point of public law, they might have foreseen the dangers and sought to provide against them; but the all-important fact was that Rudolf had the lands, and to deprive him of them would have required a power of common action totally wanting among the princes of Germany. Each of those most concerned made sure of some advantage for himself and, in consideration of this, let Rudolf have his way. The direct issue was postponed for nearly four years. Rudolf spent the interval entirely in the conquered territory, providing with the utmost care for its immediate administration, making concessions here and there, winning, on the whole, the confidence of the local nobility, and then appealed to the electors for their approval of his plan to grant the lands of the former Babenberg dukes in fief to his two sons.

On this occasion we meet for the first time in an important matter this function of the electors as a body to confirm the acts The Electoral of the German king. The documents by which their Willebriefe assent was given came to be known as Willebriefe, letters of approval; better than anything else they show us that the electoral college was coming to be more and more not merely a piece of machinery for choosing the king but also a permanent 
element of the royal administration. It would be too much to say that it had rights which the king was bound to respect, but it was already true that he could not afford to go too far against its will, and for the next two generations this dependence of the king upon the electors was to grow more distinct. The College of Cardinals, always somewhat in advance, was gaining in precisely the same way upon the independence of the Papacy.

The terms of the infeudation, which took place at an Augsburg diet in 1282 , were that both the sons, Albert and Rudolf, and

Infeudation of the Habsburgers with Austria their heirs were to be invested jointly with the territories, but that Albert and his heirs alone were to rule, so long as they should survive. Only in case of failure of this line was the line of Rudolf to succeed. This principle of the joint infeudation of sons was gaining in all parts of the Empire and is an indication of the growing tendency of the princely families to fix themselves as securely as possible in their lands. The two young Habsburgers were raised to the rank of imperial princes, and the nobles of Austria were expressly released from all oaths of fidelity to the king and to the Empire. Thus, from the first moment of the Habsburg possession, the Austrian territories were directed into that attitude of separation from, or even hostility to, the interests of Germany as a whole, which has to this day so largely determined the course of German politics. The chief territories included in this first grand stroke of the Habsburg policy were Austria proper, Styria (Steiermark); and Carniola. The precise position of Carinthia is for the moment uncertain.

For the first time since the days of Frederic II Germany had now a ruler with a sense of his obligation to preserve the public Rudolf and peace and especially to protect the trading and agrithe Land- cultural classes of his people. The choice of Rudolf frieden as king had meant above all else that the best elements of German society were united in a common desire to repress unwarranted violations of the peace,-always, of course, 
provided that they were not too much restricted in their own liberty of action. The chief grievance of the industrial world, represented mainly by the cities, was the setting up of fortified toll houses at important points along the roads and rivers by members of the ruling class. Such roadside or riverside castles were nothing less than robber nests from which local barons drew a considerable revenue. The right to maintain them was supposed to rest upon royal privilege. Within limits it was a legitimate form of taxation in return for the maintenance of roads and protection against the common ruffian, which the baron was expected to afford. In fact, however, the barons, especially those of the Rhine country, had improved the absence of all central authority to increase the number of these Raubburgen beyond all reason. The result was that, although each separate contribution might be but a small percentage, in the course of a journey, say from Constance to Cologne, a stock of goods might well be taxed beyond its selling value. Obviously this meant the ruin of trade.

The problem was to cut off as many of these impediments as possible and to reduce the rate of taxation at the rest to a reasonFirst Procla- able figure. In the absence of a real kingdom the mation of Rhine cities had, as we have seen, undertaken to solve the Landfrieden, Octo- this problem by common action and had succeeded ber 26,1273 in drawing many of the neighboring barons into their League of the Public Weal. The same method had been taken up by several later voluntary associations, but nothing permanent had come of it, except that a new sense of common interest had been aroused. That was the situation when Rudolf of Habsburg became king. Two days after his coronation he issued a proclamation of Universal Peace (Landfrieden) and declared that all unauthorized tolls established since Frederic II (1250) were to be abolished. To enforce this law he appointed, also following the example of Frederic II, a royal official, to be known as the Court Judiciary (Hofrichter). To prove his sincerity he gave orders that within his own family property, the Habsburg lands, the same 
rules should be applied as elsewhere. The response seems to have been fairly prompt and general; yet within the first year Rudolf found himself obliged to step in with the strong hand against one of his most important supporters, the markgraf of Baden; who had set up a toll station at Selz on the Rhine and maintained it against all opposition from his neighbors headed by the great city of Strassburg. At first Rudolf tried the old method of commissioning Strassburg and her allies to carry out the royal execution, which they seem to have done so thoroughly that a regular feud broke out and the king himself was compelled to take a hand. Not until several of his strongholds had been destroyed could the markgraf be brought to terms, and even though the offending toll station was abandoned, Baden was permanently thrown into the camp of Rudolf's enemies. This is a typical illustration of the method to which even so vigorous and generally acceptable a ruler was compelled to resort in order to enforce a really popular law in Germany.

Rudolf's long absence in the Austrian lands gave opportunity for all the old evils to break out again; but on his return in 1281

Temporary Peace Agree- creased energy. From the remaining ten years of his ments in the reign we have a continuous series of documents showProvinces he took up this side of his royal function with ining clearly his plan and giving us the measure of his success. The significant thing is that while Rudolf holds in reserve his own royal right and his own military strength, he recognizes that the effectual enforcement of public law in Germany must after all depend upon the good will of the greater territorial lords. He begins, therefore, by persuading the princes of Bavaria, Franconia, Swabia, the Rhine lands, and later the Saxon territories to form Landfrieden compacts among the barons and with the more important cities in their several provinces for a term of years. In trying to enforce these compacts he adapted his measures to varying circumstances, but there is evident a purpose to make the royal authority felt by means of special judges or commissioners 
acting always in conjunction with the local forces. One sees here the germs of an institution which generations later was to be the most efficient means of enforcing a central jurisdiction in Germany, the division into Circles (Kreise), following in the main the ancient racial lines. Not until 1287 , after these provincial compacts had had time to show their value, did Rudolf proceed, at a diet at Würzburg, to proclaim a renewed Universal Peace for three years and cause this to be sworn to by a great number of the most powerful princes. This same compact, reaffirmed in 129 I for six years, is the final monument to King Rudolf's untiring devotion to the cause of the public welfare.

All this must seem to us a singularly crude and clumsy method of securing what we should call the most elementary conditions Crudity of of a civilized life. We have to remember that what these Methods appears to us as common robbery and cruel oppression of the non-fighting classes was only a natural means of subsistence for those other classes of society to whom work was a disgrace and landed property, no matter at whose expense, the only honorable source of income. Kings and princes might join hands with the great cities which were the strongholds of labor and coming to be more and more the true centers of culture; but there remained still the immense multitude of petty barons claiming their lands and privileges by titles ton much like those of the greater lords to be safely brought into question. Their only way to provide for their families was to seize what lay nearest to their hand under cover of ancient, immemorial privilege.

The institutions of Rudolf were an honest attempt, not to make one element of the state dominate the rest but to secure such a The Royal reasonable balance of interests that all might prosper. Domain (Reichsgut) If the kingdom were to be an efficient agent in this process, under the conditions of a mediæval, feudal state such as Germany still was, the king must have under his immediate control sufficient landed property to give him a revenue which could be applied to public purposes. And these lands must 
belong to him as king, not as head of a family, so that when he came to die his chosen successor, though from another family, should have the same rights over them which he had had. There had always been such lands, known all together as the Reichsgut, but, especially during the Interregnum (1254-1273), they had largely slipped into the hands of needy and greedy neighbors. The clearest illustration was seen in the Austrian lands, which were reclaimed by Rudolf as vacated fiefs of the kingdom; but the same situation was shown in the case of properties large and small in all parts of Germany.

To administer these royal properties Rudolf established a regular system of commissioners (Landvögte, - advocati) with larger or

Royal Commissioners (Landvögte) smaller districts. Such a Vogt was the personal representative of the king within his district. He had to oversee the management of the royal properties, collect all dues, protect the churches, see that lawful tolls were duly paid and unlawful ones abolished, maintain roads, bridges, and ferries and, in case of need, call out and command all fighting men who owed direct service to the crown. A Landvogt might also be a Landgraf, with the duty of enforcing the Landfrieden. It is obvious that we have here an attempt quite similar to those of Frederic II and Louis IX to break down the most precious rights of the feudal state and to put in their place the orderly working of a modern government. The difficulty was that the king could work only with feudal instruments.

To enforce still further the royal authority it was necessary to provide permanent fortified places in which garrisons could be kept The Reichs- and supplies stored and from which prompt action burgen could be taken in case of violence. In the language of the day, Ritterburgen must be balanced by Reichsburgen. This was no new idea. It goes back to the beginning of the feudal monarchy, but now under Rudolf it comes out into new activity. The new Habsburg royal castle is generally closely connected with a town. Sometimes the town was made over into a Burg. 
Sometimes the Burg gathered a town about its foot. Sometimes again a Burg was built inside the town wall. The service in such a royal castle was one of especial honor. The privilege of service was treated as a fief (Burglehen), was granted to a man of noble birth, and assigned a revenue of specific value, which the holder had then to collect from neighboring land, from some town foundation, or even from the tax levied upon Jews for the privilege of existence. At the head of the Burgmannen was the Burggraf, the responsible head of the whole establishment. A striking illustration was the Burggrafschaft of Nuremberg, whose chief, Burggraf Frederic of the Hohenzollern family, was the most active negotiator in securing the election of Rudolf of Habsburg and one of the stoutest supporters of his house.

How little sense of obligation to the Habsburg, or let us now say the Austrian, interests there was among the German princes Election of was shown in the clearest manner when they came Adolf of to face the question of a new election. It could not Nassau, r29y be said that the house of Austria had not a candidate fit in every sense of the word for the functions of the kingly office. Albert of Austria had shown himself in the administration of the duchy to be a man of great force and intelligence. There was no question whatever that he thought of himself as the one

The Habsburg Marriages

Albert IV m. Heilwig (Hedwig) of Kiburg

King Rudolf I m. (I) Gertrude (Anna) of Hohenberg

(I) King Albert I (d. 1308)

Elizabeth of

Tirol

(2) Matilda $\mathrm{m}$.

Ludwig of Bavaria
(3) Hedwig Otto of Brandenburg
(4) Gertrude (Agnes) m. Albert of Saxony
(5) Hartmann betrothed to Joanna of England
(6) Katherine m. Otto of Bavaria
(7) Guta (Judith) King Wenzel of Bohemia
(8) Clementia m.

King Charles III of Naples
(9) Rudolf $\mathrm{m}$. Agnes of Bohemia 
man pointed out by every consideration for the choice. Yet he was deliberately set aside by the electoral body in favor of a simple baron, much the same sort of person that Rudolf had been, a landowner of moderate extent and distinguished by no record of service or promise of usefulness. The one recommendation of Adolf of Nassau was that he seemed to meet the requirement of being a strong man, but not too strong, ready to make any amount of promises to the electors and not likely to find any special backing if he should attempt to play the king too actively.

Adolf owed his election chiefly to the clerical electors, to whom he promised large grants of privilege, but for whom he at once Failure of began to show little consideration. His one purpose Adolf's Policy seems to have been from the beginning to imitate the policy of Rudolf and to carve out for himself with his sword a piece of landed property which should secure him and his house in a position of advantage for all time to come. The Markgrafschaft of Meissen and the Landgrafschaft of Thuringia were in contention among the members of a local family, and Adolf, on the ground that a great part of the lands involved were vacated royal fiefs, undertook to take possession of them by force. He was following the example of Rudolf in the case of Austria, but the conditions were utterly different. Within the lands themselves there was no sentiment of loyalty to him, and all the neighboring princes could but feel that their interests were imperiled. His campaign in the autumn of 1294 was supported in a halfhearted fashion and served only to turn against the king the very forces which had raised him to power.

Of course all these forces found their natural center in Albert of Austria. From the first he had never given up his "claim" Austria to the kingdom. In all directions he had been workagainst Nassau ing to bring about the overthrow of Adolf. By 1298 these efforts took form in a regular conspiracy. At its head was the man who above all others had been active in Adolf's election, the archbishop and elector of Mainz. Of his own 
motion this elector summoned both Adolf and Albert, who were already in arms against each other, to submit their case to a Diet at Frankfurt. Instead of so doing, they took their chances of war, in good mediæval fashion. Albert did indeed interrupt the campaign so far as to attend a conference of princes at Mainz, at which the electors, accusing Adolf of hostility to the Church, of breaking his promises and of inciting to civil war, declared him deposed from his office. This was the first application of the electoral right to the deposition of a king. The power which could create might also destroy. Albert was at the same time elected king by the lay electors before the clerical ones could have

Battle of Göllheim, July, I298 a chance to make terms with him. Adolf, a brave and thoroughly knightly figure, preferred to fight it out and faced his enemy almost immediately after the conference, at Göllheim in Franconia. The battle, an ordinary feat of arms, bears none of the dignity of a political combat. Adolf died as he had lived, with his armor on his back and sword in hand, fighting out a great political problem in the blind pursuit of a personal ambition.

The effect of Albert's victory over his rival was so great that the electors could not refuse to confirm him in regular form, and Declaration he, on his side, did not hesitate to promise them the of Albert's same terms which had won them to Adolf. From the Policy

very first, however, it was evident that the new king was made of very different stuff from his predecessor. His reign of ten years was spent in continual pursuit of a definite aim, to make himself master of every element in Germany that was likely to interfere with his personal advantage. He was a clever politician, not overscrupulous with whom he allied himself, if only he might gain his end; a brilliant and successful fighter, prompt in action, ready to promise anything and prepared to break his promise the moment it proved inconvenient to keep it; in a word, the type of the man of power in his day and every day. At first Albert put himself into relations of closest alliance with the eager 
and ambitious King Philip IV of France, a monarch indeed, who had already touched the goal towards which the Austrian ambition Relations was reaching out, - namely, the practical control of with France the resources of his kingdom. By a marriage treaty and by important concessions in Burgundy, Albert bound himself to Philip, hoping doubtless to gain in this way a backing in his far-reaching plans in the East. France was at this moment in the midst of the conflict with Pope Boniface VIII which was soon to lead to a complete revolution in papal affairs and was glad of this chance to secure so important an ally. The reaction upon the Papacy was what might have been expected: Boniface refused and with to acknowledge the election of Albert and began at the Papacy once to stir up opposition to him within his own territories. Cause for such opposition there was enough always ready. At this moment it was an economic cause. The antagonism between the interests of the growing cities and of the local nobility had long been growing in intensity. The disorders of the open country were making the cities and the country immediately about them ever more and more attractive to all lovers of order, and these were, of course, all those who were concerned in honest industry of any sort. The cities had been willing to meet this tendency more than halfway. They had welcomed these applicants from the outside and had given them rights of citizenship under the names of Ausbiirger or Pfahlbiirger. Then the lords of the territories from which they came had complained, and kings had been persuaded to forbid by law such adoption. In spite of all prohibition, however, it had gone on, and in Albert's time it was still a fertile source of friction between town and country. King Albert now made himself the champion of the towns, and in so doing brought upon himself the enmity especially of the four Rhenish electors, the three great archbishops and the Count Palatine of the Rhine. As soon as these princes perceived that Albert was not fulfilling the promises of his election, they began to conspire against him and within two years formed a regular 
league with the avowed purpose of deposing him. Albert's answer was a decree in which he declared the abolition of the Rhine duties and confirmed the right of the cities to receive Pfahlbürger to an increased extent. At almost the same moment a petition of cities and barons was sent to the pope asking his aid against these same encroachments. Albert backed up his words with deeds; in several rapid campaigns he broke down the opposition of one after another of the Rhine electors and by the middle of 1302 found himself completely master of the situation in Germany.

From this point on to the end of his reign Albert was occupied in preparations for the grand object of his life, the extension of Albert's Plans in the Austrian family power in the eastern parts of Bohemia and occurred within a short interval opportunities for inHungary

terference on the ground of inheritance, and it so happened that in both these cases the interest of Austria coincided for the moment with that of the Papacy. Thus we find the king completely reversing the policy of his earlier years and putting himself into the closest relations with the pope. In the negotiations that followed this change of front, we find him apparently giving up everything that his predecessors, down to the time of Rudolf, had thought worth fighting for; but if we examine the nature of these concessions, we find them to be in the main on points of theory, rather than of immediate practical importance. He was willing to declare that the Empire as well as the electoral machinery by which it was kept going was the creation of the Papacy, but practically this made little difference so long as he was able to hold his own against electoral aggression and above all to increase his house property in parts of the kingdom where the hand of the electors could not reach him. He promised the pope all sorts of fine things about the land of Italy; but this was a very cheap sacrifice, since he himself had neither power nor interest in these lands and since the pope could never hope to overcome the local powers there, now firmly fixed in the hands of powerful cities. 
With the great prestige he had already gained, Albert was on the point of moving effectively against Bohemia, when, without any Death of warning whatever, he was murdered by his nephew Albert of and ward, Duke John of Swabia, who had long felt Austria, ${ }^{1308}$ himself aggrieved by personal injustice on the part of the king. With Albert what comes to be known as the "Austrian Policy" is definitely declared. Henceforth it was clear that no other family interest was likely to be so dangerous to the independence of the German princes as that of the Austrian Habsburgers.

It is not pure accident that legend should have chosen precisely this moment to place the dramatic story of William Tell and to weave it in with the history of Swiss independence. In that story, so appealing to every lover of liberty, it is this same dread of arbitrary power that moves the men of the Forest Cantons to draw the fine, but perfectly clear, distinction between Austria and the Empire which was henceforth to be the dominant note of German politics. It was becoming increasingly evident that to fight Austria did not mean to be disloyal to the Empire. On the contrary, the highest loyalty of Germans lay in continuous protest against Austrian aggression. Sometimes this protest took the form of defeating Austrian candidates for the imperial office. When that was not possible the only remedy lay in strengthening the hands of the other elements of the imperial constitution, the Diet and the Electoral College.

Once again it is this dread of the Austrian power that dictates thc action of the electors. Again it is the clerical princes of the

Election of

Rhine who take the initiative and are easily brought Henry VII of to support the half-French Henry, count of LuxemLuxemburg, burg, brother of the elector of Trèves. He was a 1308

prince rather of the older than of the later type, a man of all chivalrous and romantic ideals, to whom the practical politics of the Austrians seemed but a dull program for the successor of the Cæsars. From an early moment he fixed his eye upon Italy, not with any definite policy but rather in the spirit of 
mediæval knighthood, as the land which alone could give to the Empire the sanction its venerable tradition required.

Italy itself was at a crisis which seemed to make these imperial visions less fantastic than they really were. The Papacy had deserted its post and had become for the time hardly more than a French institution. The pope was a Frenchman and he lived in France without any immediate prospect of so much as paying a visit to the city from which in theory he derived the foundations of his power. The Ghibelline Party, strong in the scattered remnants of the feudal landed aristocracy and in certain cities, saw now for the first time since the fall of the Hohenstaufen a prospect of help from their natural head. Even before Henry's time their illustrious spokesman, the poet and patriot Dante, had turned to the Austrian Albert with a pitiful appeal for aid.

O German Albert! who abandonest

Her that is grown recalcitrant and savage,

And oughtest to bestride her saddle-bow,

May a just judgment from the stars down fall

Upon thy blood, and be it new and open,

That thy successor may have fear thereof;

Because thy father and thyself have suffered,

By greed of those transalpine lands distrained,

The garden of the empire to be waste.

Come and behold Montecchi and Cappelletti,

Monaldi and Fillippeschi, careless man!

Those sad already and these doubt-depressed!

Come, cruel one ! come and behold the oppression

Of thy nobility, and cure their wounds,

And thou shalt see how safe is Santafiore!

Come and behold thy Rome, that is lamenting,

Widowed, alone, and day and night exclaims,

"My Cæsar, why hast thou forsaken me?"

Come and behold how loving are the people;

And if for us no pity moveth thee,

Come and be made ashamed of thy renown!

DANTE, "Purgatorio" vi, 97 (Longfellow's translation) 
The summons that now went up across the Alps to Henry of Luxemburg was the genuine expression of that impulse of Italian patriotism which from the time of Otto I had seen the salvation of the land in the intervention of some foreign power.

Before starting upon his Italian journey, however, Henry had taken the first steps in the same line of policy which had carried Henry VII Rudolf to success and involved Adolf in failure and and Bohemia death. He was a petty prince in his own right, but he would utilize the royal title to gain a princely inheritance for his family. The one cause of the failure of Adolf in this ambition had been that the lands he coveted, Thuringia and Meissen, were a part of the ancient German possessions and hence involved in a multitude of local rights of inheritance that could not be overcome. Henry was spared this peculiar test by a sudden opening for his ambition in Bohemia. The kingdom there had passed by a vote of the estates, largely determined by the city interests, to Henry of Carinthia, the husband of Anna, sister of King Wenzel III and granddaughter of the great King Ottokar. He had never succeeded in overcoming a local, "national" party that found its support chiefly in the landed nobility. This party now gathered about the princess Elizabeth, a younger sister of Queen Anna, just sixteen years old, and, if we may believe the contemporary Bohemian chronicler, already showing extraordinary vigor and independence of character. She was now offered to King Henry of Germany as a suitable partic for his twelveyear-old son John, with the understanding that John should be chosen king of Bohemia. Henry, at the moment fully occupied with preparations for the Roman journey, received the Bohemian envoys with favor, and after some hesitation accepted their proposition.

With the approval of the German princes Henry of Carinthia was declared a usurper and Bohemia a vacated fief of the Empire. The envoys returned to Bohemia; Elizabeth intrusted herself to their keeping and was escorted across Germany to Speyer, where 
the marriage with her too youthful bridegroom was celebrated with great splendor. In the early autumn, while King Henry was Occupation on his way to Italy, his son, under the guidance of the of Bohemia, archbishop of Mainz, was gathering his forces at Nurem1310

berg for the occupation of Bohemia. His German following, made up of the best elements of the eastern provinces, was reënforced by a strong contingent from the disaffected Bohemian party. 'Prague, after a brief resistance, was betrayed into his hands, and thus the fate of his rival was decided. In January, $\mathbf{r}_{3}$ I I, the youthful pair were crowned king and queen of Bohemia by the hand of the German chancellor. It seemed as if this Slavonic land were definitely brought within the circle of German domination. A study of the conditions, however, upon which King John received his crown makes it clear that the party of the nobility which had supported him was above all else a "national" party and determined to secure the country against German aggressiveness. The Hussite spirit is discernible a century in advance. The young King John turned out to be a restless adventurer of the mediæval type. As the "blind king" he appeared at the battle of Crécy (1346) on the French side and met his death there in true knightly fashion. With his son, the emperor Charles IV, begins the series of new German rulers in Bohemia, who carried the country to its greatest height of power and influence but who, largely because they were thus devoted to Bohemia, proved anything but useful rulers for Germany.

The following of Henry VII in his journey over the Alps in 1310 was typical of the change in the imperial idea. The earlier Italian Expe- Italian expeditions had been great national undertakdition of ings, the expression of the highest function of the

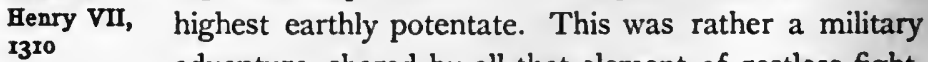

adventure, shared by all that element of restless fighting men who had no great territorial interest at stake, but who looked to such deeds of arms for their advancement in life. Henry himself was a picturesque and knightly figure. His ideas of 
Italian conditions had been gained from Ghibelline fugitives who wished to use him for their purposes and from untrained agents of his own who had seen in Italy only what they wished to see. The fact was that there was no sufficient force of real patriotic sentiment in Italy to induce any considerable number of its scattered powers to unite in a definite scheme of resistance. Each of the petty states was primarily Ghibelline or Guelf, had its own little ax to grind, and was willing to see whether this new stirring up of Italian affairs might not bring some advantage to itself. Henry came over the mountains and down into Lombardy with little or no resistance. He was met at various stages of his journey by agents of one and another of the Italian powers and proceeded to make himself very much at home. It is quite possible that Dante was one among these Ghibelline malcontents. This was very well until Henry began to talk of contributions, and then the Lombards began to think of Barbarossa and the great days of Legnano. One city after another closed its gates, and Henry found that unless he were willing to leave a hostile land behind him he must thoroughly subdue Lombardy before he could safely venture even into Tuscany, to say nothing of going on to Rome.

It was during this delay that the exiled Dante, impatient for revenge upon his townsmen in Florence, wrote an impassioned Henry VII letter to King Henry, reminding him of his high misand Florence sion as the successor of the Cæsars, whose prime duty it was to keep Italy in check. Even if he should succeed in holding his own with the Lombard towns, it would be but cutting off the branches of a tree whose roots and trunk were in Tuscany. Florence is the foul beast whose venom is infecting the whole body politic of Italy. The poet can hardly find words bad enough to express his hatred of the powers now controlling his once beloved city. Indeed, Henry's own dealings with Florence could hardly have given him much courage for the struggle in Tuscany. He addressed a summons in mild but firm language to 
the citizens of Florence, urging them to refrain from further hostilities against Arezzo and to aid him in establishing the peace of Italy. The Florentines replied that instead of telling them not to fight against Arezzo it was rather his duty to help them in restoring the Guelf exiles who had been unjustly driven from that city. As for receiving him within their walls they would see about that when he got nearer.

Meanwhile Henry found himself fully occupied with building up an imperial party in the reluctant towns of the North. At Henry in Milan, always the head and front of resistance to Lombardy German interference, he succeeded in reconciling the contending factions and in securing to himself the coronation as king of Lombardy. Nothing can better illustrate the burlesque character of this attempt to revive things that were long since dead and gone. It was a hundred years since there had been a king of Lombardy, and meanwhile the ancient iron crown of the Lombards had so completely disappeared that all Henry's efforts could find no trace of it. Still an iron crown he must have, and so a skilled workman was employed to make to order a brand-new symbol of a royalty the very essence of which lay; if anywhere, in its unbroken tradition. It was the fitting expression of a kingdom which had not a shadow of a hold upon the attachment of the people. Whoever accepted it did so for his own momentary advantage. Whoever resisted was made to feel the pressure not so much of a real sovereignty as of the jealousy of rivals, utilized by the invader for his own ends. Notably Cre: mona and Brescia suffered from what imperial historians call their rebellion, but what was really the determination to manage their own politics for themselves. They were beaten by the combination of a hostile political faction at home with a foreign invader. The hands which destroyed their walls and filled their moats for the passage of the German king were those of their fellow countrymen. All Henry's proceedings were carried on under the strict forms of ancient imperial law. At Genoa, where 
he spent the winter of $1311-1312$, he went through all the motions of a judicial sentence against the Florentines, because they had thus far resisted all his attempts to deal with them through peaceful agencies and had done all they could to help those Lombard communes which had most stoutly resisted him. The tone of this decree is that of an absolute master dealing with rebellious subjects. Florence is to lose all her rights and privileges, especially the most precious of all, - the right to appoint her own officers. All her subject communities are declared free from their allegiance to her, and she is to pay to the king an enormous fine in money. As the king could not get at the Florentines in their home he had to content himself with confiscating the property of such Florentine merchants in Genoa as could not be protected by that city.

From Genoa Henry set sail in the spring of 1312 for Pisa and passed on rapidly from there to Rome to secure his imperial Imperial Coronation, 1312, and Death, I3I3 crown, prudently leaving Florence until he should have the advantage of a support from the South. The coronation, performed by three cardinals in the permanent absence of the pope, was the result of long and anxious negotiations. It was a clear piece of trading between the contracting parties, not a recognition of rights on either side. As soon as it was accomplished the German followers of Henry began to press for an immediate withdrawal, while Henry on his part was eager to go at once to the heart of the opposition by attacking Florence. It would be idle for us to follow further the complications of Italian politics which now confronted this dreamer of imperial dreams. All the old antagonisms that had proved fatal to the greater emperors of the Middle Ages were revived once more and were even intensified by the new part played in European affairs by the vigorous and unscrupulous policy of France. Enough for us that Henry of Luxemburg, deserted by one after another of his apparent allies, strong only when he could stir up one Italian party against another, wore 
himself out in a foolish attempt to make real what had long since become a mere fiction and died in the midst of his schemes a victim of his folly. The thrilling story that he was killed by poison given him in the holy communion by a Dominican friar seems to have had no other foundation than, perhaps, some personal spite against the Dominican order. The only result of his Italian expedition was to make more acute the antagonisms already existing among the Italian states. It would be too much to say that they learned from it any permanent lesson.

For Germany the result was, if anything, to strengthen the resolution of the electors to secure for their king one who should be Double Election in Germany, I3I4

likely to identify himself with German interests, while at the same time he should leave the princes of Germany free to go on developing their individual governments as they pleased. For more than a year after the death of Henry VII the kingdom in Germany remained vacant. The most natural candidate was the Austrian prince Frederic, but more and more clearly there loomed in the distance the ever-increasing desire on the part of France to get possession of the imperial crown, and the only constitutional way to that was through an election by the German princes. Now that the Papacy was practically a French institution, it seemed far from impossible that it too might be brought to throw its weight in favor of the French ambition. Between these two parties there was, however, always the third, which, for distinctness, we may now call the German national party, and which was represented, so far as it had any representation, by the College of Electors. The only trouble was that even this body was likely to be split at any moment by the private interests of its members. The result was that the French schemes were definitely set aside, but that as between Austria and anti-Austria the electors could not agree. On the 19 th of October, 1314, Frederic of Austria was "elected" by a minority of the college, and on the 2oth Ludwig of Bavaria was "elected" by a majority. Who or what should decide? The principle of the 
majority was not established. Although each party felt the importance of papal support, neither would have been willing to accept the pope as final arbiter in German affairs. There was really no resource but war, and for the next eight years the whole south of Germany was kept in agitation by the varied fortunes of a petty civil strife, in which the larger issues of national politics were obscured by every kind of private and personal interest.

The battle of Mühldorf in $\mathbf{1 3 2 2}$ was a decisive victory for Ludwig of Bavaria. Frederic was taken prisoner and held in an

John XXII against Ludwig of Bavaria honorable confinement for several years as a pledge of peace. But no sooner had one of the parties in the imperial quarrel thus gained a real advantage than the Papacy, now in the hands of a bold and unscrupulous politician, began to show its hand. The conflict between the papal and the German imperial claims in the time of Ludwig offers to the student more of interest than any previous stage of this long controversy. Even the investiture struggle in Hildebrand's time is less instructive. There one has to do mainly with a series of dramatic events, through which the constitutional questions involved have to be studied out, often with great difficulty. In Ludwig's time the constitutional issues are put forward into the very foreground of the struggle, and we find events shaping themselves to a considerable extent in accordance with them. During the long fight between the "kings" in Germany John XXII had declined to decide between them and had busied himself chiefly in trying to drive out of Italy the "vicars" of both. That was the first and all-important condition of harmony, that during a vacancy in the Empire the pope should be recognized as the administrator of imperial rights. On the other hand is the counterclaim that he who is elected "King of the Romans" by the German Electoral College is, by that fact, adminstrator of the "Empire" as well. According to this view it is an essential quality of the "King of the Romans" that he is 
the potential emperor and that nothing is wanting to his rights but the coronation by the pope, and that this coronation is only a ceremony of confirmation, not the essential medium by which the imperial right is conferred. The "King of the Romans" is in everything except the title just as much emperor before the papal coronation as after it. We must remind ourselves that there was, technically speaking, no such person as a king of Germany or of the Germans.

The conflict was opened by John XXII in 1323 by the publication of a "process" against Ludwig as a usurper. Ludwig has

Charges and Counterdared to assume the powers of king and emperor charges, $1323-1326$ without the approval of the pope, who has a right to give such approval. He has sent vicars into Italy though the Empire is vacant. He must refrain from all acts both as king and as emperor and recall all those he has thus far performed. To this Ludwig replied in a private memorandum and then more publicly: (I) The kingdom (regnum) is not vacant, for he is king who is properly elected by the German princes. (2) The Empire (imperium) is not vacant, for as king he has the right to administer the imperium and lacks only the coronation. (3) His election had been according to immemorial tradition, but, even if it were doubtful at the time, it has been settled by the fortune of war. Here speaks out the old Gernanic principle, "he is the king who can." Of course there was nothing for the pope to do but to excommunicate Ludwig and declare him deposed from his office. It seemed as if the history of Henry IV and Hildebrand were about to be repeated, but it is clear that the German national consciousness had made great progress in the interval of two centuries and a half. A scheme to make Charles IV of France King of the Romans was rejected by all parties. Ludwig even goes so far in one of his moments of depression as to declare his willingness to abdicate in favor of Frederic of Austria, if the pope can be persuaded to consent; but the pope is bound to France. 


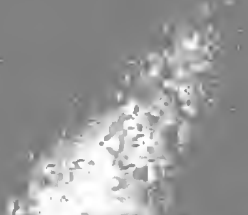

\section{f. 10,0 \\ $<,-150$}

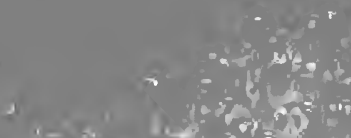

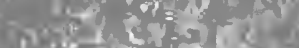

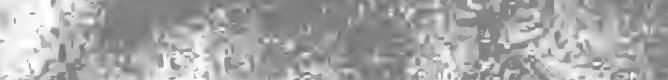

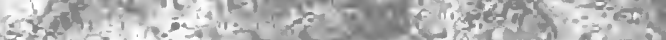

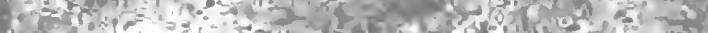

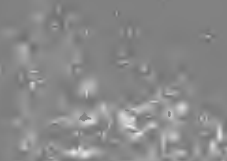

-

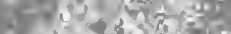

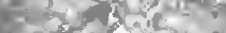

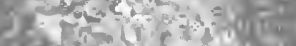
(t) (1)

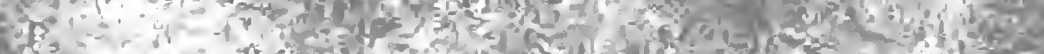

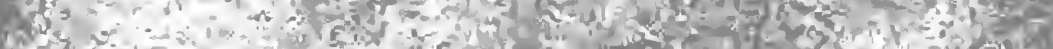
We

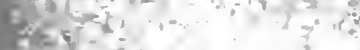

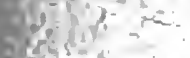
f.

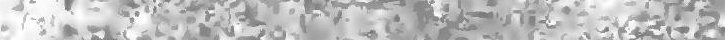

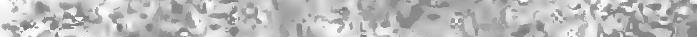

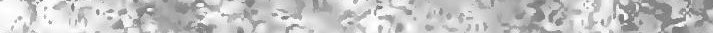

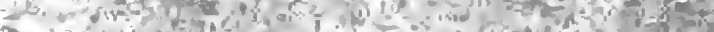

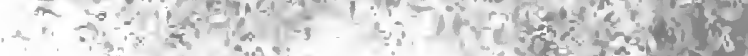

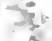

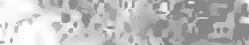




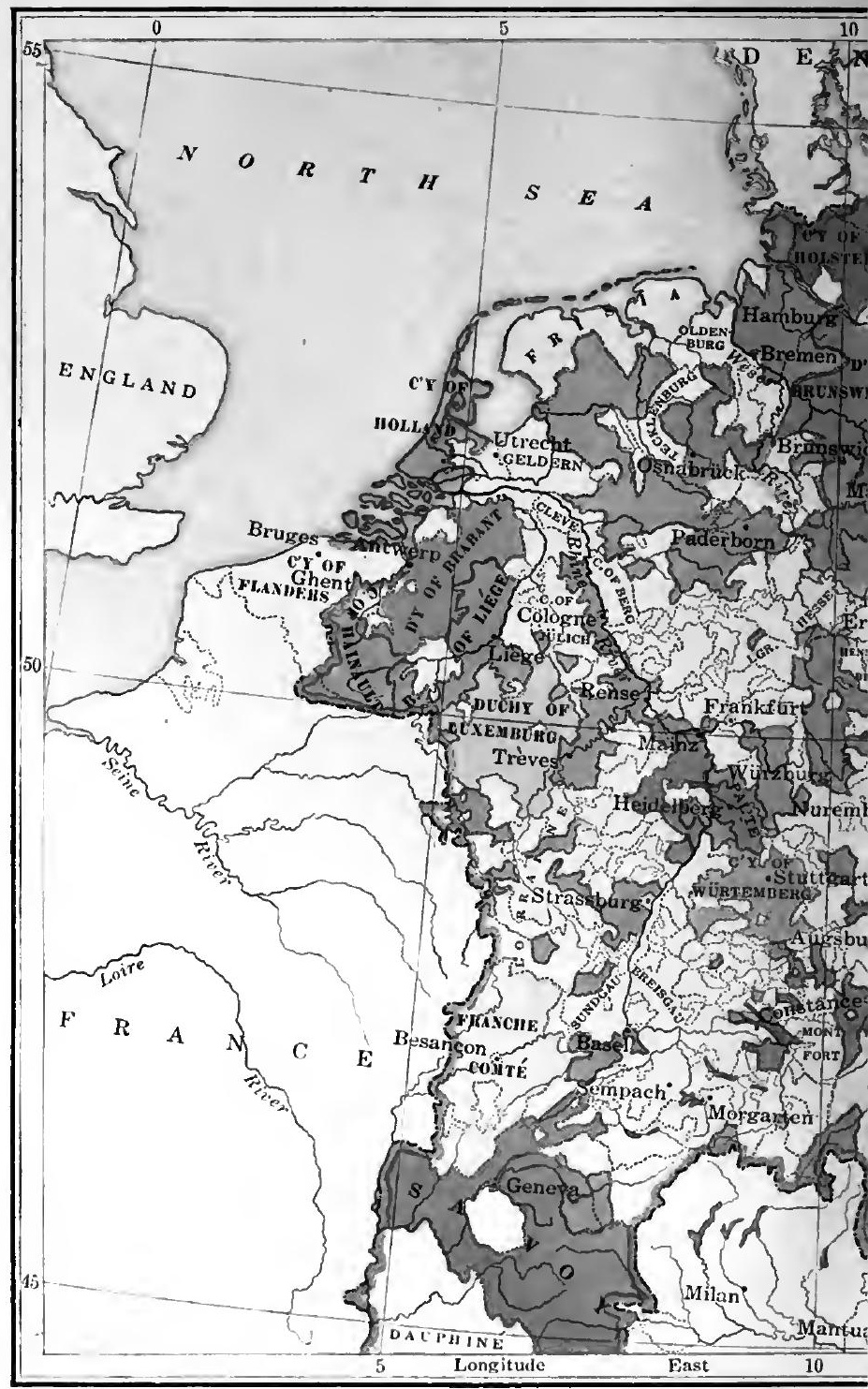




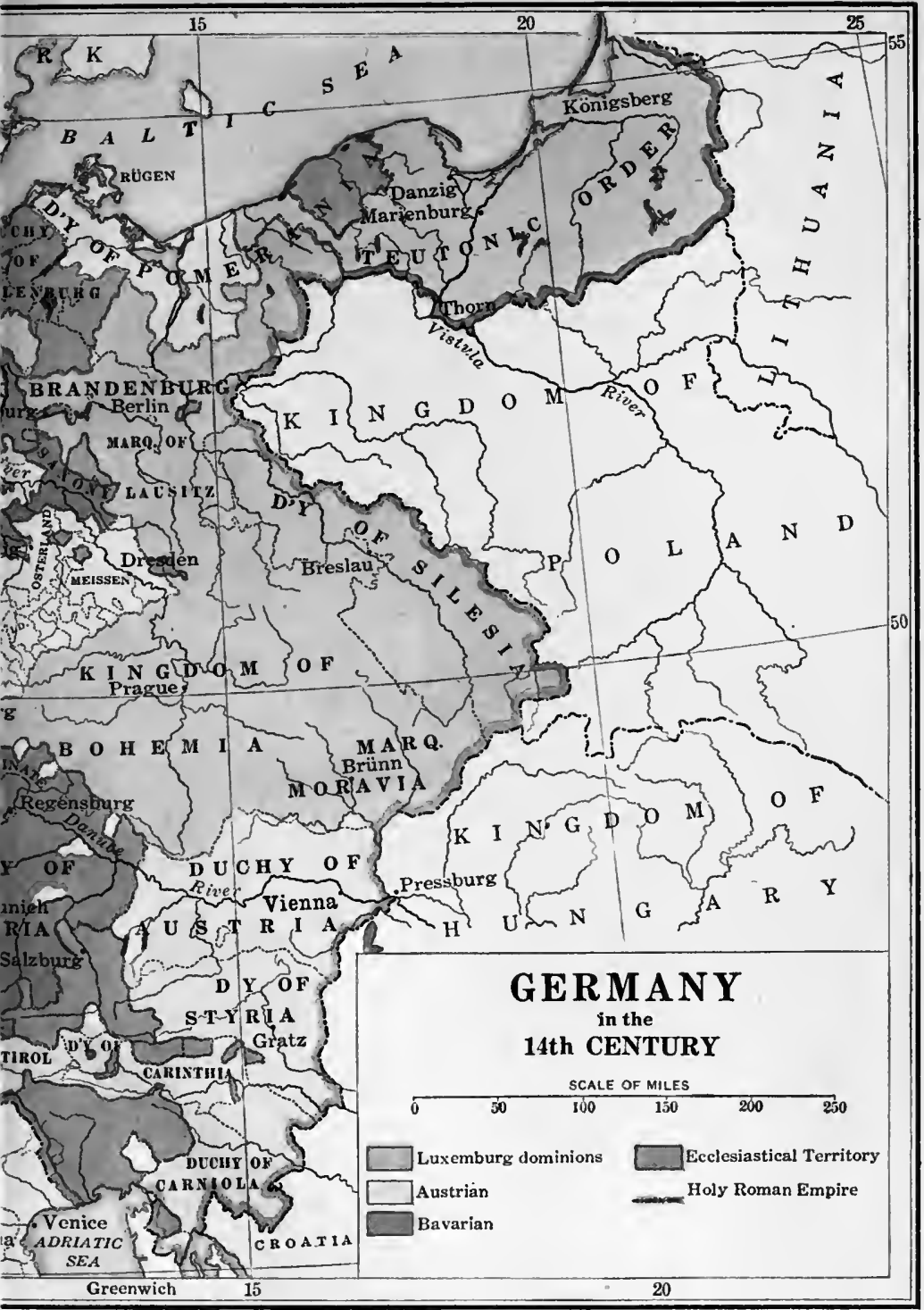




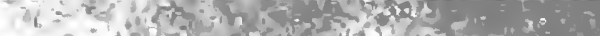

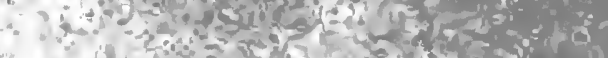

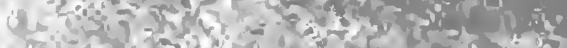

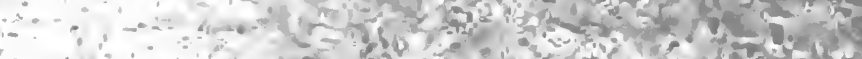

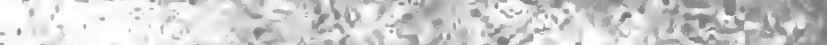

$$
\begin{aligned}
& \begin{array}{c}
2=2 y=1 \\
42
\end{array} \\
& \text { + } \Rightarrow \text { 1. }
\end{aligned}
$$

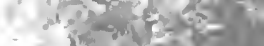

$\therefore=$

$\therefore \therefore$

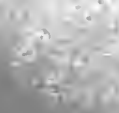

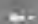
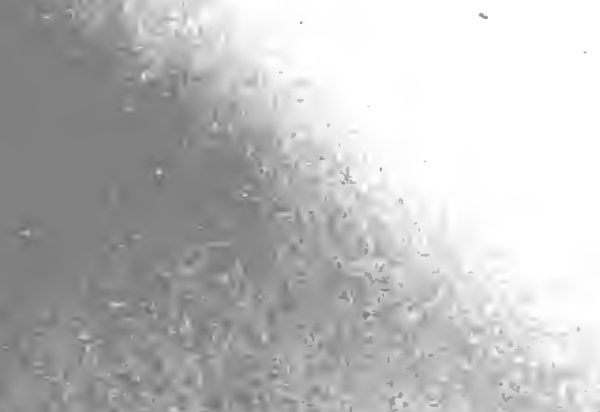

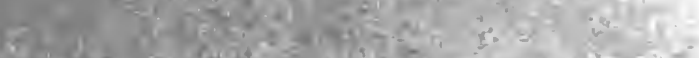

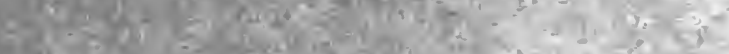

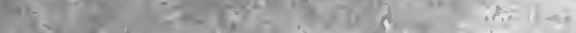
H.

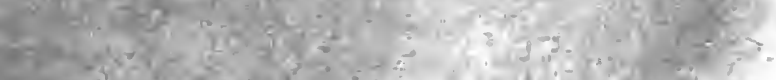

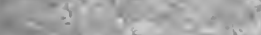

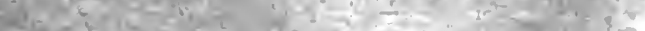

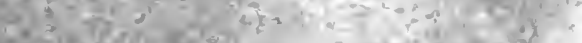

स.

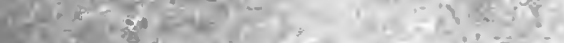

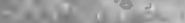


Ludwig carried out his imperial program still further by going down into Italy, strengthening the Ghibelline cause wherever he Ludwig of Bavaria in Italy, 1327-1328 could, and getting himself crowned emperor by the "People of Rome," without any reference to the pope whatever. The hand that placed the imperial crown upon his head was that of Sciarra Colonna, the same, if we could believe a later French chronicler, whose iron glove had smitten in the face the aged Boniface VIII and so proclaimed that the absolute Papacy of the Middle Ages was at an end. Ludwig's first act as crowned emperor was to depose Pope John XXII and to have a rival, a worthy Minorite, raised in his place. But here again we see how much more correct had been the political insight of Frederic Barbarossa, who had refused to receive his coronation from precisely this same Popolo Romano, and had seen clearly that a universal empire and a universal papacy were the necessary complements of each other. As soon as Ludwig had no more processions and bounties to offer to the precious popolo of Rome, they had no further use for him and did not hesitate to let him know it. His feeble antipope was glad to make terms with Avignon as cheaply as possible, and Ludwig made his way back to Germany richer only in the prestige which his courage and persistence had gained for him.

In the interval between Ludwig's Roman expedition of 1328 and his constitutional triumphs in Germany.in 1338 occurred an John of episode of peculiar interest as illustrating the possiBohemia invades Italy, 1330 bilities of Italo-German politics. King John of Bohemia, son of the emperor Henry VII, a restless schemer, always ready to take a hand in every turn of the European political game, found himself in the year $133^{\circ}$ in Tirol as chief negotiator in the marriage of his son Johann Heinrich with the famous Margareta Maultasch, daughter of that Heinrich of Carinthia who had been John's predecessor on the throne of Bohemia. While the wedding festivities were being celebrated at Trent, came messengers from Brescia in Lombardy 
to offer him the lordship of their city. In one of the perennial overturns of party warfare the Brescian Guelfs had driven out their Ghibelline fellow citizens, and these had roused their party associates in Milan, Verona, and Padua to help them to return. Now the Guelfs begged John to come to their defence, promising to accept him as their Dominus for life if only he would never let the wicked Ghibellines come back. It was just the kind of a plan to catch the imagination of a bold political adventurer. John accepted at once and began to collect troops from all over Germany.

To the emperor Ludwig's inquiries as to what he proposed to do with an army in his (Ludwig's) Italian provinces, John replied

Accepts the Lordship of Brescia that he was only going to make a pious visit to the tomb of his parents at Pisa. In fact, he led an army of perhaps ten thousand men over the Alps and on the last day of the year $133^{\circ}$ entered Brescia in triumph amid the wildest jubilation of the inhabitants. To offset his promise to the Brescian Guelfs he had on his way made another to Mastino della Scala of Verona that he would let all the Ghibelline exiles come home if Scala would kindly give up the siege of the city and let him in. Quite miraculously, as it seemed to the chroniclers, John managed to make Guelfs and Ghibellines drop their quarrels and live peacefully together for a while. As a "pacificator" he seemed to be a huge success, and this for the obvious reason that he did not, like the emperor, represent a permanent power which might be dangerous to the "liberty" of the city. Almost immediately he was invited to other Lombard cities to do the same service for them.

Within two months John had become signor of Bergamo, Crema, Pavia, Vercelli, and Novara. Even Azzo Visconti, signor of Milan,

Dominates

Central

Lombardy

and Lucca came voluntarily to offer him the signoria there on condition that he himself should be his vicar. Beyond the Po Parma, Reggio, and Modena placed themselves under the shelter of this new Protectorate, while the imperial vicars of Milan, Como, and Mantua accepted his leadership, and the Scalas, masters of Central Lombardy, 
formed a close alliance with him. Meanwhile the citizens of Lucca in Tuscany. had asked him to become their signor to help them against Florence. A word from him to the Florentines. caused them to withdraw their besieging army from "his" city of Lucca, and on the Ist of March, I33I, his lieutenant entered the city and took command in his name. It was certainly an amazing piece of political audacity. A foreigner, without a shadow of right, this adventurer had his hand on the levers of government through a region extending from the northern slope of the Alps to the Apennines and reaching well over into Tuscany. Moreover, all accounts agree that his administration of these widely different and usually warring communities was marked by singular prudence. All local animosities seemed for the moment reconciled. The curse of party warfare was at least checked. Strict orders were given that no person under his rule should call himself either Guelf or Ghibelline.

No wonder that the emperor Ludwig was alarmed. So far John had been able to assure him that whatever he had done

Lombard League rior right of the Empire; but facts were beginning to was done without any thought of invading the supeagainst King speak louder than words. The popularity of this inJohn, 133I

truder was greater than emperors had usually been able to command. On the other side the pope, bitterly hostile to the emperor, was not willing to assume responsibility for the newcomer, but was strongly suspected of having an understanding with him which might be a danger to the liberties of the Italian cities. The more efficient his government the less agreeable it was sure to be. Not an equitable administration but an everrenewed series of political shake-ups was the ideal of Italian freedom. Just five months after his triumphal entry into Brescia King John was on his way back to Germany, leaving his son Charles, a boy of fifteen, as his vicar general in Italy.

At once began the reaction. A Lombard League of quite the old-fashioned sort was formed by the southern towns backed by 
Milan and Verona, and a considerable force was put into the field. In the autumn of 1332 this army sat down to the siege of Battle of Modena. The young prince, with a somewhat inferior San Felice, force, came to the relief of the garrison and offered $\mathbf{3 3 2}$ battle to the League. His own story of the encounter, which, like most Italian battles, lasted all day, agrees substantially with other reports. It was at first a battle of knights in which the young leader took a man's part. He was unhorsed and slightly wounded, but his men set him up again - rilevati a nostris - and just then his foot soldiers rushed in and turned the fortune of the day. Quantities of prisoners were taken, but the loss of life was small " because," remarks a contemporary, "the soldiers on both sides were Germans, who had no desire to kill each other." This battle of San Felice was a personal triumph for young Charles, but of slight value for his cause. All the fireworks with which it was celebrated at Modena and Parma could not conceal the fact that the real forces of Italian politics were opposed to the permanence of a Luxemburg-Bohemian state in the peninsula.

King John himself spent the interval of twenty months between his hasty departure from Italy and his return (February 26, I333) John aban- in continuous intrigues with the northern powers, in dons Italy, which his Italian interests played an important part. 1333

He managed to patch up a peace with the emperor Ludwig which practically recognized his de facto governments in Italy, but did not give up the imperial overlordship there. In France he promised King Philip to join him in a crusade to Syria. At Avignon he tried without success to play the peacemaker between pope and emperor, and actually had the face to submit charges of bad faith against the Visconti of Milan for the pope's decision. Why King Philip should have been willing to invest one hundred thousand florins in this harum-scarum adventure is not clear; but it was this money that enabled John to raise a new army, including some of the best names of France. In the winter of 1333 he led this army across the Alps and, working in harmony 
with the papal legate, began operations at several points in Lombardy. Before Ferrara his forces met a crushing defeat, and this proved the turning point in the whole venture. At last convinced that his game was not worth the candle, and upon Charles's very sensible refusal to play any longer the part of vicar to a power that did not exist, King John sent his son home to Bohemia and prepared to evacuate Italy.

Before leaving he mortgaged his lost "claims" on Italian towns for all the money he could get, and then betook himself to Luxem-

Significance of John's Failure in Italy burg, where new adventures awaited him. The failure of his precious scheme only made it so much the clearer that the idea of a central Lombard state lying in between Milan and Venice was an impracticable dream. Ezzelino da Romano had tried it;-Verona under the Scalas and Padua under the Carraras were to try it in succession during the next two generations. In each case the really permanent centers of Italian power were ready to combine against so dangerous a breach of the fivefold settlement toward which all were moving.

If one tries to understand the movement of affairs by following the personality of Ludwig of Bavaria one is soon lost in a maze of The German inconsistencies. At one moment he appears as the deterElectoral mined champion of German national interests against Constitution, all other powers, especially the Papacy; at another he $133^{8}$

is ready to abdicate his throne and to go all lengths of personal humiliation towards Rome. These ups and downs cover the whole period of his long reign of thirty-three years, but our concern is with those moments which show great permanent tendencies and of these there are enough. The year 1338 is a crucial year in German affairs. If Germany was to have a clearly defined constitutional position, it was high time that it should make this clear to itself and to the world. Over and over again in critical times the Papacy had claimed the right to dispose of German affairs at its pleasure. France, steadily rising in power around a steadily centralizing monarchy, was likely at any moment to make 
a bold stroke for the Empire, - and if France why not England? In the course of recent schemes it had even been hinted that a strong hand might set up an emperor without regard to the sacred College of Electors. To meet all these dangers the only safe policy was a firm combination of the electoral princes. Already in March, Kurverein at 1338, under the lead of Mainz, there had been a Rense, ${ }^{338}$ gathering of bishops at Speier, and certain formulas had been adopted which seem to have been agreed to by many other princes and cities. Then in July the electors themselves met at Lahnstein on the Rhine and agreed that they would stand by each other against all other powers, to the honor and weal of the Empire. Next day, in a more formal gathering at the ancient meeting place of Rense, the electors published a declaration which made perfectly clear their determination to support the independence of the Empire from all clerical control. ${ }^{1}$ Ludwig himself was present at Lahnstein

1 The Kurverein at Rense, July 16,1338 . The assembled electoral princes declare :

"That it is established by law and the ancient custom of the Empire that when any person shall be elected King of the Romans by the electoral princes of the Empire, or by a majority of them, even though they are in disagreement, he does not require the nomination, approval, confirmation, assent or sanction of the Apostolic See with regard to his administration of the properties and rights of the Empire or as to his assuming the title of King, and that as to these matters the person so elected is not bound to consult the above-mentioned See, but, as has been held and observed from a time to the beginning of which the memory of man runneth not, they who have been elected by the electoral princes of the Empire, unanimously or in majority, as above said, have assumed the royal title and have administered the properties and rights of the Empire, and by law and custom they have been able and are able to do this lawfully, without seeking the approval or permission of the said Apostolic See in this matter.

"When all this had been thus declared and made clear, the electoral princes called upon all the subjects and vassals of the Empire present at their deliberations, one by one, according to the oaths they had sworn to the Empire, to give their opinion as to the rights and customs of the Empire as above discussed, defined and declared. And they all, each for himself, in the same or in similar words, declared and defined their opinions, and finally all agreed to what the judgment of the electoral princes had determined." 
and at Rense and probably was in full agreement with the electoral body. In further confirmation of their action he summoned a Diet The decree The decree at Frankfurt for the 6th of August and there, with
Licet juris, the approval of a great assembly of princes from all
r338
classes of the Empire, published the famous decree $133^{8}$ Licet juris, in which the independence of the imperial government from the Papacy is definitely established as imperial law. ${ }^{1}$ Whether

1 The decree Licet juris of August 6, 1338 :

"Although the witness of both the civil and the canon law plainly declares that the office and powers of the Empire have from the beginning issued directly from God alone, and that God, through the emperor and the kings of the earth, has given laws to the human race, and that the emperor is lawfully created solely by the election of those to whom the right of election belongs and does not require the approval or confirmation of any other person, since in temporal affairs he has no superior on earth, but all nations are subject to him, and our Lord Jesus Christ commanded that we should render unto Cæsar the things that are Cæsar's and unto God the things that are God's, and

"Whereas certain persons, blinded by greed and ambition, confessing their knowledge of many documents but wresting them from the way of plain common sense, are breaking forth into unjust and wicked criticism and detestable statements against the imperial power and authority and against the rights of chosen emperors and other princes and loyal subjects of the Empire, falsely and with lying words declaring that the imperial office and its powers are from the pope, and that he who is chosen emperor is not truly emperor or king unless he shall previously have been confirmed, approved and crowned by the pope or by the Apostolic See, and through such base assertions and pestilent doctrines our Ancient Enemy stirs up strife, excites controversy, begets conflicts and kindles sedition,

"Therefore, to put an end to such evils, with the advice and consent of the electors and the other princes of the Empire, we declare : - that the imperial office and its powers are directly from God alone, and that in accordance with the law and ancient custom of the Empire, it is established that, when any person is elected emperor or king by the electors of the Empire, either unanimously or by a majority of them, immediately, in virtue of this election alone, he is to be held and called true King and Emperor of the Romans, and is to be obeyed by all subjects of the Empire, and he has full power to administer the properties and the rights which belong to the lawful emperor, nor does he require the approval, the confirmation, the sanction or the consent of the pope or the Apostolic See or of any other person." 
this law made the coronation by the pope absolutely unnecessary, or whether, as others think, it obliged the pope to crown any suitable person properly elected, the outcome is the same. Henceforth notice was given to all the world that the real moving power of the German state lay in the Electoral College and in the Diet, so far as the Diet and the college could get on together. Even more than before, it was now made clear that the royal or imperial power in Germany was to exist only by the sufferance of the princely houses in which the actual political life of the nation was incorporated.

Ludwig had lent himself to this idea, expecting, unquestionably, that it would work to his advantage, but it soon became evident Ludwig as Supreme Ruler that the princes were excluding foreign influence in the German constitution, not to make their emperor strong, but to keep him weak. Now, under the influence of a school of political writers who were ready to go all lengths in demonstráting the right of the emperor to do almost anything, he went on to try to secure for his house a great territorial possession which might balance, if not overcome, the weight of the Austrian party. He had made a strong move in this direction early in his reign by securing to his son Ludwig the succession in the vacant marquisate of Brandenburg. Through his marriage he had gained expectations, never to be realized, of inheriting a large part of the Low Countries. In the settlement of the Austrian states under Rudolf there had been some reservations of rights over the southern lands of Carinthia, Carniola, and Tirol, which looked towards a division of these between Austria and Bavaria. The hopes of Bavaria in this direction had been checked by the marriage of the heiress of Tirol, the famous Margareta Maultasch, with a son of King John of Bohemia. This marriage, however, had been unfortunate, and after his return from Italy the emperor Ludwig made a plan with Margareta to marry her to his son Ludwig of Brandenburg, if she could get a divorce. A variety of charges were brought against the husband, 
but the pope, who alone of all earthly powers could grant the separation, refused to listen to any of them. In this crisis Ludwig, with the written approval of his political advisers, declared that, by virtue of his own imperial right derived from the ancient Roman emperors, he could lawfully annul the marriage and proceeded to do so.

The marriage with young Ludwig of Brandenburg was consummated, and he was invested with the Tirolese lands, but the Election of princes of Germany were far from being prepared for Charles IV, any such extravagant idea of imperial rights. A 1346

historian of the time says, "The name of Ludwig, hitherto of sweet savor, began to stink in the nostrils of the princes." "The whole country," says another, "regards this marriage as something monstrous." Those among the princes who had lately been loudest in declaring the Empire free from all foreign interference, now sought the support of the Papacy for a new candidate. The choice fell upon a member of that house which had been most affected by the fatal marriage, on Charles of Bohemia, son of King John. He was "elected" by representatives of five electoral votes in November, 1346 . If one were to follow the language of the papal documents preceding this election, one would have to think that it was the result of direct commands on the part of the pope, for never had a pope put himself forward more definitely as the creator of an emperor than did this Frenchman, Clement VI, in the election of Charles. The candidate lent himself to the papal propositions with the utmost willingness. Concessions which Ludwig, even in his greatest need, had refused to make were among the terms of the compact through which Charles secured his election. The nicknames of "king of the priests" and "the pope's errand boy" show how little popular was this half-French and halfBohemian candidate for the crown of Germany.

And yet Charles was as much of a practical statesman as Rudolf of Habsburg. $\mathrm{He}$ is not a heroic figure like his grandfather 
Henry VII, nor even like Ludwig of Bavaria at his best, but a clever, designing diplomat, whose one great interest in life, like The Golden that of Rudolf, was the increasing of the land and Bull of power of his own immediate family. "He was a Charles IV

father to Bohemia, but a stepfather to Germany" is the verdict of posterity on his long reign. Ludwig rallied his followers for a fight and had already had some successes against Charles when he was suddenly killed while hunting, October I I, 1347. His death marks the definite end of the old Empire with its sounding theories of universal sovereignty and its utter incapacity to realize these theories in permanent political institutions. The New Empire dates from the moment when Charles IV, already bound to inaction towards the Papacy, goes on to bind himself to a similar policy towards the German princes. The famous Golden Bull of ${ }_{1} 35^{6}$ has been described as the abdication document of the Holy Roman Empire, and in a very strict sense of the words it was that; but, like all great monumental documents, it only expressed a condition of things that had long been a matter of fact. The purpose of this elaborate state paper was to regulate the method of the imperial election, but also to secure to the electors the amplest possible privileges. Its principal provisions are the following:

It fixed by law the principle of the majority at the election, providing that even if three of the electors should elect a fourth, The Golden the vote of this fourth should count just as if he were Bull and not a candidate. ${ }^{1}$ After the election the very first duty the Electors of the emperor was to confirm in their fullest extent all the rights and privileges of the electors. These rights, which are declared strictly hereditary in the line of the eldest son, are so

1 Whenever a vacancy shall occur in the Holy Empire, the Archbishop of Mainz shall have authority, as from ancient times has been conceded to him, to summon by letter the other afore-mentioned princes, his colleagues in the election; and when all of them who can and will have come together, the Archbishop of Mainz, and none other, shall have the duty of 
extensive as to leave practically no room for any higher sovereignty. The electors have the ownership of all mines, of metals and of salt within their territories, the right of coinage and the right of immunity for their subjects from all other jurisdiction, saving only that of the emperor in case of a denial of justice. No privilege granted in the past or in the future to any person is to be valid if it runs counter in any way to the electoral rights. Conspiracy against an elector is treason, and the guilty person is to be punished with death and confiscation of goods and the perpetual infamy of his sons. The territories of the electors as they now exist are never to be divided. No reference is made in the Golden Bull to the papal rights of coronation or administration, but the implication throughout is that these, if not absolutely denied, are at least to be reduced to their lowest terms.

Indeed, if the emperor was to keep himself out of Italy, as Charles had promised solemnly to do, except for the mere purpose

calling upon his co-electors for their votes, one by one in the following order:- First, he shall ask the Archbishop of Trèves, to whom we declare the first vote belongs, as we find it has hitherto belonged; Second, the Archbishop of Cologne, to whom belongs the dignity and the duty of first placing the royal crown upon the head of the King of the Romans; Third, the King of Bohemia, who by law and equity holds the primacy of honor among the lay electors on account of his royal dignity; Fourth, the Count Palatine of the Rhine; Fifth, the Duke of Saxony; Sixth, the Markgraf of Brandenburg. The votes of all these, in the prescribed order, shall be called for by the Archbishop of Mainz, and when this has been done, then the aforesaid princes his colleagues shall in turn call upon him to express his intention and to declare his vote to them.

Furthermore, in the ceremony of the Imperial Court the Markgraf of Brandenburg shall present the water for washing the hands of the Emperor or the King of the Romans. The first draught of wine shall be presented by the King of Bohemia; but he shall not be bound to this service while wearing his royal crown except of his own free will, according to the privileges of his kingdom. The Count Palatine shall be bound to the service of the table, and the Duke of Saxony shall perform the office of the Groom of the Stables, as has been the custom from ancient times. - Golden Bull, chap. iv, 2, 3 
of getting himself crowned, there was no reason why the pope, on his part, should not be willing to let him alone in Germany. The Germany a Golden Bull is the Constitution of the new Germany. Federation It spoke out in plain terms what we have seen to be practically the fact since the Hohenstaufen days, - that Germany was a confederation of independent princes, who were willing to have these extraordinary rights guaranteed to the little group of the electors because they felt this to be in its turn a guarantee of their own independence. While the other states of Europe, notably France and England, were steadily placing more and more power in the hands of their kings, Germany was taking from hers almost the last vestige of power. One clause of the Golden Bull, a very innocent-sounding one, contained germs of a federal constitution, which, if they had been carefully nourished, would have anticipated by more than a century the development of German politics. This clause provided that once every year the electors should meet with the emperor at Metz to deliberate on the weal of the Empire. Such a regular assembly, if it had actually been carried out, could hardly have failed to change the very theory of the imperial executive. Charles was clever enough to let it stand without opposition and trust to the lack of unity among the princes to make it of no effect.

The coronation of Charles at Rome is another demonstration of the changed order of things. He went down into Italy, not Coronation of with an army but with a festive escort of three hunCharles IV dred knights. He let himself be crowned with the at Rome, ancient Lombard crown, on the understanding that 1355

he was to do nothing as king of Italy. The cities of Lombardy were willing to pay handsomely for peace, and even Florence was glad to give this imperial beggar a round sum to pass her by. Rome had just been recovered by the papal legate, Cardinal Albornoz, from the rule of the "Republic," which had drawn its inspiration from the passionate enthusiasm of Cola Rienzi. Charles took his crown from the hands of the cardinal 
in the presence of the prefect of the city; but, according to a previous agreement with the French pope, he stayed but one day in the eternal city and got himself back to Germany as fast as he conveniently could. He wanted his crown, but he cared nothing for the costly and useless rights of government in Italy, which had ruined his grandfather and made the reign of Ludwig a burden. Charles is the type in politics of the new order of men; who, in every relation of life, were bringing about a new era in Europe, of men who were able to distinguish substance from shadow and to aim for all the substance they could get. The historian who calls him "the merchant upon the throne" pays him the highest compliment, for he lived in a day when the merchant quality of common sense, or the just application of means to ends, was beginning to be recognized as a quality worth cultivating.

A final illustration of this quality is given by the story of Charles's second Italian journey thirteen years after the first. Second Here again he seems to have acted without any farItalian Journey of Charles IV, reaching plans of imperial policy. He was rather led into the undertaking by promises made to Pope 1368-1369. Urban V to further his plan of restoring the Papacy to Rome. The negotiations were connected with Charles's interests in the southwestern provinces of the Empire in which he needed the help of the pope. The bargain was that the pope should stand by him there, and in return Charles would lead an army into Italy, hold the enemies of the pope, especially the Visconti rulers of Milan, in check and thus make safe the pope's return to Rome.

Charles, at all events, was faithful to his promises. He imposed a special tithe on the German Church, gained the approval of the estates at a Frankfurt Diet, and sent out his call for troops. The reply was moderately favorable, so that he was able to set out for Italy in the spring of 1368 with a considerable force, in which, however, the great princes were but slightly represented. 
There was little fighting but much trading, as a result of which the Visconti were left in possession of Milan, Charles received Return of handsome sums both from them and from the more Pope Urban southern cities, and Pope Urban was enabled to $\mathrm{V}, \mathbf{1 3 6 8}$ enter Rome under the escort of a genuine popecrowned emperor. It was the first time since 1220 that the two heads of the Christian world had thus presented the mediæval ideal in concrete form before the eyes of Europe. But, after all, it was a theatrical display. Charles remained two months in Rome and then spent eight months on the journey northward. His business during that interval was chiefly bargaining with one after another of the Tuscan and Lombard towns as to the terms upon Charles IV which he would allow them to enjoy liberties of which and the he was powerless to deprive them. It is the period Italian Cities when the democratic vigor of the Italian commonwealths was beginning to decline, when business was good, money plenty, and life too enjoyable to be risked in open warfare. Claimants to power were willing to go pretty far in buying "legitimation" of their claims from the only source that still commanded a certain formal respect, and Charles on his side was too good a merchant to risk the credit of his parchment wares by military

The Luxemburg-Bohemian Royal Family

(Dates are those of nule in Bohemia)

Ottokar II (1253-1278) m. Kunigunde

Wenzel II $\left(12 \delta_{3}-1305\right) \mathrm{m}$. Judith, daughter of Rudolf of Habsburg

Elizabeth m. John (1310-1 346), son of Emperor Henry VII Wenzel III (1305-1306)

Charles I $(1346-1378) \mathrm{m} .\left\{\begin{array}{l}\text { (3) Anna of Schweidnitz } \\ (4) \text { Elizabeth of Pomerania }\end{array}\right.$

$\begin{array}{lll}\text { (3) Wenzel IV (1378-1419) } & \text { (4) Sigismund (1419[1436]-1437) } & \text { (4) Anna }\end{array}$ m. 
exploits in which he would certainly not be supported by German men or money. The result was that he came back to Germany in the summer of 1369 with his pockets full, with the Italian cities glad to be rid of him, and Pope Urban so uneasy in Rome that he again deserted it and went back to Avignon to die. Henceforth for a century to come the history of the Empire, as associated with the names of the emperors, is insignificant. Charles himself (1346-r378), his two sons, Wenzel (1378-1400) and Sigismund (1410-1437), together with Ruprecht of the Palatinate (1 400-1410), are, as emperors, not identified with any great movement of politics or society which can make it worth our while to dwell upon them here. The permanent interests of Germany were taking shape independently of them. 


\section{THE NEW PAPACY}

$$
\text { (1300-1409) }
$$

The history of the Roman Papacy consists largely in conflicts between the several elements which enter into its composition.

The Three

Powers of the Papacy We can hardly remind ourselves too often that the pope has always stood for three different things at the same time. $\mathrm{He}$ is first the bishop of Rome, second the head of a Roman state, and third the head of such part of the whole Christian world as is willing to acknowledge his leadership. But this combination of powers has always been a source of great difficulty in the papal administration. As bishop of Rome the pope properly owed his existence and was therefore in a way responsible to the clergy and people of Rome (clero et populo Romano). As head of the Roman state he was one among the temporal princes of the world, with all the political burdens and temptations naturally belonging to temporal power. As head of the Christian world again he entered into relations with all the churches of Europe and found himself, as his influence extended, the arbiter of all questions which involved - and which might not? - a religious motive.

During the Middle Ages these several sets of duties and obligations had been trying to adjust themselves. The "clergy and Localism and people of Rome" had claimed for themselves the Universalism exclusive right of choosing and of directing their own bishop, quite regardless of the fact that this bishop when elected had also the larger functions of a temporal prince and of a universal umpire to fulfill. Under this pressure the Papacy had 
frequently fallen into the hands of the local Roman political and family parties and had become worse than useless as a leader of Christian Europe. At such crises the only power that could bring it back to a sense of its universal mission was the Empire. The Empire itself was, if anything, a universal institution, owing its influence to the same kind of ideal claims that the Papacy was making. Under such men as Otto the Saxon in 962 and Henry III in 1046 the Empire had come into Italy with a strong hand and compelled the Papacy to put itself at the head of the religious affairs of Europe. For a considerable period the only way to do this had been to furnish the candidates from Germany, and this had been a serious shock to the ancient tradition of the essential Romanness of the Papacy. Then, once again on its feet through the help of the Empire, the Papacy had seen the danger of such patronage and, under the inspiration of the Hildebrandine ideas, had provided for itself a constitution, whereby its Roman character seemed to be assured to it forever.

The establishment of the College of Cardinals as the regular electoral body in the choice of a pope by the Lateran decree of The College 1059 was intended definitely to put an end to the of Cardinals division of interests we are noticing. It gave to the Papacy an electoral machinery which seemed to bind it forever to Rome, while at the same time it should not interfere with its wider function. Rome was not only to give itself a bishop and the Roman state a prince, but it was also to give the Christian world its head. So strong, however, was the force of tradition and so weak the idea of constitutionat right that it required at least a hundred years to give to this new system a practical working effect. By the year 1200 it may be said that the College of Cardinals was definitely fixed as the center of all papal politics. Not that the dissensions which had disgraced the papal administration before were now done away; rather, they had been transferred to a new field. Henceforth, all study of the Papacy must gather about the fortunes of the electoral body. 
If we compare the constitution of the College of Cardinals with that of the German Electoral College, we find, as we have

The Cardinalate and the German Electorate already shown, very striking resemblances. The purpose of both was the same; namely, to remove the election from the hands of a large and somewhat illdefined electorate to the charge of a small and compact body of persons, defined by the holding of certain definite offices. There were, however, two equally striking differences. The offices to which the cardinalate was attached were far from being as well fixed as those of the German electors. Their number was uncertain and varied from time to time. They were in no way representative of the Church as a whole. It was as if in Germany all the electors had been taken from Saxony or from Swabia. Then, the appointment of the cardinals lay with the pope himself, and thus the pope and the cardinals formed a continuous circle, the pope appointing the cardinals and the cardinals electing the pope. We may be very sure that if a similar circle had existed in Germany the Golden Bull of 1356 could never have been issued.

By the time of Innocent III (1198-1216) the Papacy, revived and reëstablished upon this new constitutional basis, may be said Climax of to have reached the highest point of its universal conPapal Power, trol. Its influence was felt in every corner of Europe c. 1215

and in every detail of the policy of the nations. It compelled the king of France to obey its orders in matters of the most intimate personal importance. It brought the king of England to its feet as its own feudal." man." It sat as arbiter in the disputes between Hohenstaufen and Guelf for the imperial crown. Hungary and the Norman kingdom in Italy were its vassal states. It was at the head of the great movement of the crusades and it had enlisted the armies of France against the heretics of Aquitaine. It had just organized in its defence the great Mendicant Orders, the most powerful militia at the service of any European state. It seemed as if the Papacy, constantly renewed by a machinery of 
which it had sole control, and master of resources such as no other power could command, were permanently fixed as the final arbiter of Europe.

But precisely this vast accumulation of power was the agency of its own destruction. The nations of Europe had desired a strong

Forces Papacy, but they were not prepared to see it absorbagainst the Papacy. ing to itself the resources of wealth and power which belonged to themselves. The thirteenth century is largely occupied with the awakening to new consciousness of two great forces, which, combined, were to hold this overgrown Papacy in check, - the monarchy and the people. The dramatic center of these conflicts is to be found in the struggle of the Hohenstaufen kings against papal claims in Italy, but there the outcome was, to say the least, of doubtful value to either party. The real gainers here were the sturdy and eager populations of the Italian cities, usually allied with the Papacy, but as far as any one from being ready to have their affairs controlled by any outside power whatever. In England the kingdom was steadily rising in harmony with the people, and the beginnings of the English Parliament at this time show better than anything else how plainly the nation was recovering from the disgrace of King John. In France the same combination of king and people was gradually taking form, only that here the royal element was to be the leading one, while in England it was rather forced to follow the lead of the popular sentiment. In France as in England a representation of the people, the Estates General, was to be the outcome of the politics of the thirteenth century. In Germany the independent princes were following in the wake of their royal brethren and building up great accumulations of territory and of privilege, which were to find their confirmation in the Golden Bull.

So, in all directions, at the close of the thirteenth century the Papacy found itself confronted by forces which were hostile to its universal claims the moment these passed the limits of strictly spiritual matters. The hostility was as yet vague, but it wanted 
only opportunity to show itself. At Rome in the last years of the thirteenth century we find something very like a repetition The Papacy of the party conflicts of the tenth and eleventh. The about 1300 names are different, but the spirit is much the same. At the head of the Roman nobility were the two great families of the Colonna and the Orsini, in deadly rivalry for the control of the civil administration and also of the papal electoral machinery. Still, as in earlier times, we find a population fiercely conscious of its ancient greatness, but unwilling to adjust itself, as the peoples of Lombardy and of Tuscany had been doing, to the changed economic conditions of the time. If "politics" was the curse of Italy, this was nowhere quite so true as at Rome. It could not be said that in the new life of industry, trade, art, and learning, which was inspiring the Italian race, Rome now or later played a leading part.

In the midst of these conflicts the papal constitution was slowly developing. The main purpose of the College of Cardinals was to

Friction

between Popes and Cardinals procure a prompt and canonical election of popes, but as the college grew in power and fixity, it began to enjoy the sweets of independent action. In the case of a vacancy there were many reasons for delaying the choice. The college, which by the middle of the thirteenth century had come to be a sort of papal cabinet, found itself in possession of the papal administration. The revenues belonging to the pope now passed through their hands, and a great share of the dignity of the papal office was now transferred to them and was increased the longer they could make their own importance felt. Like the electors in Germany, the cardinals were to be

The Bull

Ubi Periculum, $\mathbf{2 7 4}$ "approached" in every conceivable form. So great had this evil of delayed elections become that in 1274, at the council of Lyons, Pope Gregory X, whose own election had taken place after an interval of more than two years, issued the famous Conclave decree, which orders that within ten days after the death of a pope the cardinals shall assemble in the town in which the pope died and in the palace which he last 
inhabited. The civil government of the place is to be responsible for the strict observance of the following rules: The cardinals shall all be gathered in one room without partitions of any kind. They may receive no visitors or hold any communication with the outside world. Food is be handed them through an opening of such sort that a man cannot pass through it. If after three days they fail to elect, they shall receive during the five days following but one dish at dinner and supper. After that they shall be kept on bread, wine, and water until a pope is chosen. So long as the Conclave lasts the cardinals shall draw no revenues of any sort from the papal treasury or from any other source. The advantage of the conclave system in tending to hasten the choice of a pope and to remove the evils of a prolonged vacancy was obvious; but the excessive strictness of this rule of Gregory $\mathrm{X}$ brought its own destruction. Within two years it was suspended, was abolișhed by John XXI, renewed again by Celestine V, confirmed by Boniface VIII, and, though violated repeatedly in detail, the principle of the Conclave has governed all papal elections to the present day.

At the death of Nicholas IV (1292) there were eleven cardinals pretty nearly divided between the factions of the Colonna and Election of the Orsini. On one and another pretext the election Celestine V, was delayed for two years and a quarter and finally 1294

fell upon an utterly unexpected person, a pious hermit, who had passed his life in the wilderness far from the turmoil of the papal court. The whole history of Celestine $\mathrm{V}$ is involved in much obscurity. On the one hand, he enjoys the reputation of a saintly character. He was the founder and honored head of an order of hermit monks in Apulia and probably sincerely preferred the distinctions of that vocation to the interminable conflicts of the papal office. On the other hand, once in that office, he had either the firmness or the feebleness to take a distinct attitude. Having just witnessed the evil of a long vacancy in the Papacy, he at once renewed the long-suspended Conclave decree of 1274 in 
full force and thus from the start set the cardinals against him. He had accepted the election while still within the Neapolitan territory. King Charles of Naples and King Karl Martel of Hungary were his escort from his mountain hermitage to the town of Aquila near the border of the Patrimonium Petri. The cardinals besought him at least to cross the border into his own Roman territory, but the Neapolitan hold upon him was too strong, and there was nothing for the cardinals to do but to join him in Aquila, where he was crowned as pope.

Still worse was Celestine's almost immediate creation of twelve new cardinals, of whom seven were Frenchmen and three Nea-

Celestine surrenders to French Influence politans. This was the first time in the history of the cardinalate that the appointing power of the Papacy had been used to give the college a dominant nationalist partisan character. It is the first step in the process by which, under strictly constitutional forms, the Papacy was to be uprooted from its Roman traditions and transplanted to a foreign soil. Whatever good intentions Pope Celestine may have had as to settling in Rome, the fact is that he let himself be drawn deeper and deeper into the network of NeapolitanFrench intrigue. He moved to Naples, took up his residence in the Castel Nuovo, and, as far as possible, continued his hermit life, leaving the detail of the papal business to such cardinals as he thought he could trust. It seems clear that, as time went on, his conscience was somehow aroused to the impossibility of his position. It is more than probable that a faction of the cardinals led by Benedetto Gaetani, a member of one of the chief Roman families, worked upon his superstitious fears until finally he became really convinced that he ought to resign the Papacy into more capable hands. But here a scruple arose as to whether a pope once invested with the sacred office, beyond which there was no earthly appeal, could lawfully abdicate his power. To remove this scruple Gaetani, an accomplished lawyer, suggested that Celestine should first publish a decree that such abdication was 
permissible and then should act upon it. This counsel he followed. He placed his resignation in the hands of the cardinals, threw Election of aside all the insignia of his office, and left the room Boniface VIII, in the garb of a simple monk. The election which r294-1303 followed almost immediately at Naples fell upon the man who had been the champion of the college throughout its conflict with Celestine,' upon Benedetto Gaetani, who called himself Boniface VIII. Precisely the terms made between Boniface and the cardinals are uncertain, but they probably had reference to the limitation of the number of the cardinals and the approval of those existing at any time to the nomination of others; perhaps also they regulated again the share of the Cardinal College in the papal revenues. At all events, it is pretty clear that Boniface got his election by promising to be a pope of the cardinals.

In spite of this diplomatic beginning it soon became evident that nothing was further from the intention of Boniface than to His Adminis- be anybody's pope but his own. Never in the history tration of of the Papacy have its claims to universal control of the Papacy all matters, both within and without its own immediate sphere of power, been more broadly stated or more fiercely defended than by him. His administration viewed in its most favorable light was one long series of efforts to promote peace among the conflicting powers of Italy and between the rising nationalities of Europe. At first thought it would seem that there could be no higher conception of the Papacy than this of a universal peacemaker; but to carry out this mission with any hope of success the Papacy must itself have been free from all the lower ambitions and passions which were moving the princes of the earth. Only thus could it keep itself free from the suspicion of self-interest which must in the end prove fatal to its mediating efforts. Now, ever since Hildebrand the Papacy had been more and more taking its place among the temporal powers of Europe, and in all this time there had never been a pope more completely filled with all these worldly ambitions than Boniface himself. 
To begin with, he was a member of one of the great Roman families, and one of his earliest and most persistent aims was to enrich his relatives in all the numerous ways open to him who had control of the Roman revenues. It was a pious act to try to reconcile the long-standing feuds of the Colonna and the Orsini; but the exhortations to peace came with ill grace from a pope who was trying to raise his own family to equal power with the rest. Into these quarrels of the Roman nobility Boniface Boniface threw himself with passionate energy. His avowed against the purpose was the ruin of the Colonna family, and he Colonnas

pursued this aim with all the means familiar to the partisan warfare of the day. The stronghold of the Colonna was the fortified town of Palestrina, the ancient Præneste, rising with its almost impregnable castle above the level Campagna about thirty miles from Rome. Against this defence the army of the earthly Prince of Peace was led in the year 1298 with overwhelming success. Palestrina was taken, its fortifications leveled with the ground, and salt sown in its streets to signify that henceforth it should cease to be a dwelling place of men. Several of the leaders of the Colonna appeared before the pope with ropes about their necks and with every sign of contrition received his forgiveness. The victory of the pope over this personal enemy differed in no respect from that of any fighting noble over an hereditary foe. It remained to be seen whether it would bring the expected fruits. Two of the Colonna escaped to France and found at the court of Philip IV a welcome which boded ill for the future of the Papacy.

On the somewhat larger field of Italian politics the work of Boniface had much the same character. He tried to pacify conBoniface and tending powers, but it was always as an interested the Kingdom party. Do what he might, there was no concealing the of Naples

fact that he was the recognized head of the Guelf interests throughout the peninsula, and however much these interests had become local, they had still a certain common character 
which a skillful pope might use to his advantage. In the South the French house of Anjou, brought into Italy by the Papacy to drive out the hated Hohenstaufen, had so far maintained itself on the mainland, but had lost Sicily at one stroke in the uprising of the "Sicilian Vespers" in 1282 . The island had then been taken, without even a pretence of right, by the Spanish house of Aragon, and thus a new element had been introduced into Italian politics. During his whole administration Boniface was engaged in negotiations to get the Spanish out of Sicily and to hand it over again to the Anjou. Every resource of diplomacy and violence was made use of ; treaty after treaty was made, but the one factor overlooked in all these princely schemes, the wishes of the Sicilian people, finally settled the question. Sicily had come to love the Spaniard as it had hated the French, and in every crisis its king, Frederic of Aragon, had been able to count upon its persistent loyalty. One cannot see that the papal mediation had any effect whatever upon the promotion of a permanent peace, and one cannot help thinking that the reason was that in all these negotiations, from first to last, the Papacy appears as an interested party.quite as eager to gain advantage for itself as any one of the competing powers.

The same must be said of Boniface's attempts at pacifying central and northern Italy. Whatever he did the papal interest, Boniface and or what for the moment seemed to be such, appears Northern always as one, at least, among the motives of his action. Italy

For example, in the case of the rivalry between the rising commercial republics of Genoa and Venice, we find the pope mediating for peace, it is true, but clearly on the Venetian side, because Venice was at the time willing to go further than Genoa in expressions of devotion to the Holy See. Genoa, threatened with the interdict, paid not the slightest attention to these spiritual weapons, but went quietly on driving her enemy out of the western seas. It is easy for us to see, what the Papacy of 1300 could not discern, that we are dealing here with a vast upheaval of European society now reconstructing itself on a new basis, in 
which the interested dictation of a sovereign Papacy could find no place. By far the best illustration is found in the dealings of Boniface VII Boniface VIII with King Philip IV ("The Fair") of and Philip France. In this man, young, eager, unscrupulous, and the Fair determined, is typified the very spirit of the new monarchies. His long reign (1285-13r4) was animated throughout by the one principle that the resources of France in men and money. belonged in the hands of the government and nowhere else, and that all means were justified to bring and to hold them there. It would probably be going too far to say that Philip thought of war with England as a means to the unification of France, but it is certain that such was its effect. As to the immediate occasion of the war, which on one and another count was to drag itself on for more than a century, we need not here concern ourselves. The real cause is to be found in the steadily growing emphasis on the national principle in both countries. The earlier feudal ties had hopelessly confused all questions of nationality. The inhabitant of Aquitaine (Guienne) was a subject of the English king, though that king acknowledged himself the vassal of the French king for Aquitaine. If Philip was really to be king of all those lands over which he held the right of supreme lordship, this state of things could not go on. Pretexts enough for war were always on hand in any feudal country and fighting material in surplus was ready to follow the banners of both kings.

The intervention of the Papacy in such a struggle could only be thought of as a piece of superfluous meddling with what did not Outbreak of concern it. Both kings wanted to fight; their right the Quarrel to do so was clear. The papal mediation was not to protect one party from aggression; it was thought of, and rightly from the prevailing point of view, as an attempt to set up a tribunal over two independent sovereigns, neither of whom had appealed to it. Boniface took a step too far in threatening the punishments of the Church upon the disobedient kings. Philip's reply was to levy a tax on the clergy of France to meet the expenses of the 
war. Boniface, in the bull Clericis laicos, ${ }^{1}$ declared in the broadest terms that such a tax was contrary to the law of the Christian state and forbade the clergy to pay it. Philip answered by prohibiting the exportation of money from France and by taking measures to make sure that, so far as Rome was concerned, this order should be obeyed. Thus the quarrel between the Papacy and France was brought to a clear issue, and men could see precisely what the real question was.

1 " The laity have been from the most ancient times hostile to the clergy; and the experience of the present confirms this hostility in the clearest manner; for, not content with their own limitations, they are striving after what is forbidden to them and are loosing the bonds of restraint in order to gain what is unlawful for them.

"Forgetting that all power over clergymen and over the persons and property of clerical persons is forbidden to them, they are laying heavy burdens upon prelates, churches, and persons belonging to the Church, both regular and secular, are taxing them and extorting tithes of their property, tenths or twentieths or some other portion and are trying in many ways to bring them into servitude and subject them to their dictation. And, alas! not a few prelates and clerical persons, trembling where there is no occasion to tremble, and seeking peace for the moment, fearing rather to offend the temporal than the eternal majesty, have acquiesced in such abuses, not so much rashly as without reflection, not having sought the authority or the permission of the Apostolic See.

"We, therefore, desiring to put a stop to such unlawful acts, by the advice of our brethren and by our apostolic authority decree, that all prelates and clerical persons, religious or secular, of whatsoever order, condition, or rank who shall pay or promise to pay or give their consent to future payments of taxes, or imposts, tenths or twentieths or hundredths from their own revenues or properties or those of the Church to laymen . . . without the approval of the Apostolic See . . . and all emperors, kings, princes, dukes, counts, barons, governors, captains or officials or executive officers by whatsoever name they may be called of cities, fortresses or other places ; and all others of whatsoever rank, condition or station who shall impose, exact or receive such taxes, - shall incur the sentence of excommunica. tion by their very act. . . .

"From this excommunication and interdict no one shall be absolved except in articulo mortis without the special authority and permission of the Apostolic See; for we are determined that such shocking abuse of the temporal power shall not pass unnoticed." 
The war was carried on with the weapons of the new time, with proclamations, financial reprisals, and appeals to civil and The War of canon law. Boniface was a trained jurist, skilled in Documents both the civil and the canon law. Philip was sur. rounded by a group of civil lawyers who supplied him with the legal principles adapted to his needs. Not satisfied with merely keeping French money in France, he proceeded to acts of open violence against a papal commissioner and thus put himself distinctly in the wrong. The pope excommunicated the king, and the king burned the bull of excommunication. In the bull Unam Sanctam Boniface laid down the theory of the single government of the world by the successor of Peter in the most distinct terms.

The substance of this, one of the most famous of all papal utterances, stripped of its scholastic verbiage is this: There is but The Bull one Holy Catholic and Apostolic Church. The head Unam Sanctam of this Church is Christ, as the head of Christ is God. In her is one Lord, one faith, one baptism. Of this one Church there is one body and one head, not two heads as if it were a monster - namely, Christ and his vicar (Peter and Peter's successor); as the Lord said to Peter, "Feed my sheep I" "my sheep," he says in general, not "these" or "those" in particular, by which we understand that all were committed to him. If, therefore, the Greeks or any others say that they were not committed to Peter and to his successors, they inevitably confess that they are not of the fold of Christ, for the Lord says (John $\mathrm{x}$, I6) "there is one fold and onc shepherd."

We are taught in the Gospels that in the power of this Church there are two swords. Both of these are in the power of the Church, namely, the spiritual sword and the material sword; but the latter is to be used for the Church, the former by the Church, the former by the hand of the priest, the latter by the hand of kings and fighting men (milites) according to the will and the forbearance of the priest. For one sword must be under the other, and temporal authority subject to spiritual. 
If earthly power goes astray, it shall be judged by the spiritual power. If the lesser spiritual goes astray, it shall be judged by the superior; but if the supreme power goes astray, it can be judged by God alone, not by man; according to the witness of the Apostle, "the spiritual man judges all things, but is himself judged by no man" (I Cor. ii, 15). This authority, though granted to a man and exercised through a man, is not a human but rather a divine power, given to Peter by the divine lips and confirmed as a rock to him and his successors in that Christ whom he confessed, the Lord himself saying to Peter: "Whatsoever thou shalt bind on earth," etc. Finally, "We declare, proclaim, and define that subjection to the Roman pontiff is absolutely necessary to salvation for every human creature."

After that there could be no doubt in the mind of any one as to what the outcome must be. It was a war to the death. The two

Philip IV and the

French

Clergy

Colonnas, who had been driven from Rome by the pope's victory over their family, were at Philip's court ready for any desperate measure in their own interest. The French clergy, called upon to decide between their king and the pope, declared in favor of the king. It is, of course, easy to say that this was a decision under compulsion, and no one would accuse Philip of any undue gentleness in his methods. But, on the other hand, the steady growth of a national sentiment among the French clergy from this time on makes one think that their action now was on the whole the real expression of their feeling. They were coming to see that a national clergy as an honored element in the national state might have a far more desirable status than as the agents of a foreign power, always exposed to the jealousy of their fellow countrymen. The idea of the "Gallican liberty" which was to play so important a part in the whole future history of France is clearly outlined in this loyalty of the clergy under Philip IV.

Still more striking is the support received by the king from an element in the state which had hitherto been rigidly excluded from 
any share in the government. As the quarrel with Boniface grew more and more heated, Philip was led to the extreme step of The First

EstatesGeneral, I302 calling upon all the classes of the people to come together and give their consent to his royal policy. Such consultation of the clergy and the nobility had always been a part of the feudal administrative machinery, but now, for the first time, there was added to these privileged classes a representation from the "good cities" of the realm, and with this begins that reaction of the "third estate" upon the other two which is the most important element in the growth of modern governments. The same criticism has been made upon this assembly as on that of the clergy alone, that it was simply under compulsion and did as it was told. The same reply may be given: that if the Estates of 1302 had simply been driven to support the king, this attitude would surely have changed with time. Instead of this, it was destined to go on along the same lines, and this shows plainly enough that Philip was counting upon a deep-seated feeling when he ventured upon so doubtful a step. The point was that the paying classes were now to win recognition as good for something else than merely paying. Doubtless the king had his own kind of arguments, not always the most gentle, to persuade his people that his cause was just, but the fact remains that Philip in his fight with Boniface had the nation behind him.

Of Philip's final dramatic stroke, " the crime of Anagni," nothing can be said in defence. It was an outrageous violation Philip's As- of every principle of fair dealing. The king's most sault upon trusted agent, William of Nogaret, a trained lawyer Boniface VIII and reckless adventurer, went over into Italy with the banished Colonnas, put himself into communication with all the enemies of Boniface in the neighborhood of Rome, and, as soon as he felt himself strong enough, led a party of wild fellows against the pope himself. Boniface was at his summer residence at Anagni when this brutal assault was made. His guards were overpowered, his palace broken open, and he himself subjected to 
personal insult and violence. As the aged pontiff, dressed in the full robes of his office and seated upon his throne, awaited with dignity the coming of the mob, his ancient enemy, Sciarra Colonna, smote him in the face with his iron glove. It was the deathblow of the mediæval Papacy. It has been supposed that the plan of Nogaret was to capture the pope and carry him away to France. Later events give color to this idea, but the plan, if there was one, failed. The people of Anagni rallied and drove the marauders from the town. The pope, broken by the shock, died shortly afterward.

From this moment the French government never lost sight of the prospect of controlling the Papacy. At the death of Boniface Beginnings the eighteen cardinals elected almost immediately the of the French general of the Dominican order, a peaceful, worthy Papacy; Benedict xI man, who escaped the burden of the papal office after

eight months. He left a body of nineteen cardinals, hopelessly divided among themselves on the question of the relations with France. They went into conclave at Perugia almost immediately, but it was eleven months before they could agree upon a candidate and then it was upon a Frenchman, the archbishop of Bordeaux, a man high in the confidence of King Philip. We have pretty good evidence that this choice was the work of a party. among the Italian cardinals who really believed that the best hope of the Papacy lay in a close union with France. There is no reason to suppose that they thought of a removal of the papal government from Rome as among the possibilities. Indeed, the new pope, who called himself Clement V, did not at first suggest Policy of any radical change. He set out at once for Italy Clement $\mathrm{V}$, and got as far as Lyons, but was there detained by ${ }^{1305-1314}$ Philip IV, who came in person to meet him. He sent over into Italy for the cardinals to come to him and was crowned at Lyons, the king of France dutifully holding his stirrup during the coronation procession. There seems not to have been any deliberate action about residence. Clement just simply stayed 
in France, and things adjusted themselves to this fact. The most important step of Clement is the creation of new cardinals, by which the constitution of the body was radically changed. Immediately after his election he created ten and later fourteen more, all of these ultramontani and most of them Gascons, landsmen and relatives of the pope. Many of these were persons totally unfit for the office, young, gay, and reckless fellows, some of whom had not even received priestly orders. Hitherto the standard of election had been in the main high, but from this time on the Cardinal College becomes a mere worldly court, in all respects like that of a king except that in every form of luxury and riot, if we can believe contemporary critics, few royal courts could bear the comparison.

Three further transactions of Clement $\mathrm{V}$ with King Philip show how far the Papacy was willing to go in furthering the interests Clement $\mathbf{v}$ of the French crown. One of these is the posthuand the mous trial of Pope Boniface VIII, another is the ruin French Crown of the Order of the Temple, and the third is the French candidacy for the Empire. Until recently it was supposed that these concessions were part of a secret agreement made between Philip and Clement before the latter's election and as conditions of the French support. The account of the transaction given by the Florentine historian Villani has been shown to be incorrect in details; but there is still good reason to believe that Philip was at least well informed as to the deadlock in the conclave at Perugia and used his influence to break it in a way favorable to himself.

At all events he began at once to put such pressure upon Clement $\mathrm{V}$ as would force him to justify the king in his treatment Trial of Boni- of Boniface VIII. The result was an investigation face VIII in good modern style. Scores of witnesses were found to testify to the evil character of the late pope, charging him with all kinds of namable and unnamable crimes, culminating in the supreme offence of heresy. The chief agent here was naturally 
that same William of Nogaret who had engineered the "crime of Anagni" and who needed vindicating quite as much as his royal master. The interest of this trial for us is not in the question of the guilt or innocence of the accused, but in the attitude of the pope, who let himself be used by an unscrupulous king to clear the king and his agents from the reproach of violence done to the Lord's anointed.

The outcome is contained in the bull Rex gloriae, which opens with a declaration that the kingdoms of the earth are of divine April 27, foundation and that France especially is the chosen 13II nation of the new covenant as Israel was of the old, - the direct opposite, one sees, of the doctrine of the Unam Sanctam. The bull then recites the charges and the defence and declares: First, that the king and his agents acted in the matter with the highest purpose to defend the honor of the Church and of their country. Second, the unfortunate events at Anagni took place against their will; the king is therefore free from guilt in the capture of the pope and the robbery of the church treasure. Third, all papal acts against the king or his subjects since the year 1300 are annulled and the documents in the Roman archives containing them are ordered to be destroyed. As to the guilt of Boniface no definite result was reached and we are left to the conclusion that the specific charges were of little account, even to those who made them, except as giving justification for the action of the French crown, now happily exonerated.

The case against the Templars has certain similarities to that against Boniface; but the purpose seems clearer and more

Causes of Suspicion against the Templars "practical." Our starting point must be the undeniable fact that the Order of the Temple, founded in Syria after the first Crusade and bound by its constitution to poverty and the defence of the holy places, had widely departed from this high commission. In this respect it had only followed the example of every other monastic or semimonastic order, but the nature of its decline was such as to make 
it an especial offence to governments and to peoples. Invested from the first with peculiarly ample privileges by the authority of the Church, it had made use of these to acquire for itself vast accumulations of wealth in movable and in landed property. Its houses, the so-called "Temples" in all the more important European cities, were at once palaces and fortresses. Unlike other religious orders it had become an important financial institution, lending money on a great scale and acquiring in this way the same uncanny reputation which in the Middle Ages attached to Jews or other practitioners in the mysterious art of commercial credit. Whatever might be thought of the personal quality of its members, there can be no doubt that the nominal purpose of these money transactions, the promotion of the crusade and the combating of infidelity, was grossly neglected.

Neither can there be much doubt that residence in the Orient had tended to give to the knights of the Temple a wider outlook Philip IV and a more liberal judgment, which were bound to acts against make them more tolerant of what lay outside Christhe Templars tianity than the dominant opinion of Europe would approve. Added to all this was the element of mystery and secrecy surrounding the formal practices of the Order, an element always sure to be exaggerated by the public at large. Criticism on all these points had long been active, but it had not been any one's special interest to bring it to a focus. Now, the peculiar combination of a king like Philip IV and a pope who through his removal from Rome was cut off from all his natural supports brought the matter to a crisis. The initiative doubtless came from the king. He seems to have made up his mind that nothing short of the complete ruin of the Order and the confiscation of its property would satisfy him; but to justify such an appalling outrage charges must be made and proof procured.

The charges brought against the Templars are much the same as those just made against Boniface. In fact such charges are the stock in trade of mediæval persecution. They consisted mainly 
of accusations of personal vice, usually of an infamous nature, against the persons of the knights as individuals and another

Charges against Templars set against the Order as a whole. In general they are of a conventional sort, ritual acts of disrespect for the sacred things of Christianity, such as blaspheming Christ, spitting on the cross, or worshiping some obscene symbol, acts having in themselves neither sense nor value to the actors and, if they took place at all, comparable only to the inane performances of initiation into most secret societies from the Greek mysteries to the college fraternities of America.

Our concern is only with the papal subserviency which made the policy of Philip IV possible. Once again the handy knave Arrest and Nogaret appears as the king's agent in collecting eviPreliminary dence, summoning witnesses, and generally setting the Inquiry stage for the final drama. The Grand Master of the Temple, Jacques de Molay, was summoned by Pope Clement from the Holy Land to give a report of conditions there. He came apparently without suspicion, and hearing vaguely of the king's plans against himself and his brethren declared his readiness ta meet all accusations. The pope seems to have shuffled and delayed until the short patience of Philip gave out, and, without waiting for the papal sanction, he gave the word to Nogaret to go ahead. A word was enough. At the same moment throughout France all the members of the Order were arrested and its property seized by authority of the Inquisition and on suspicion of heresy, and a general trial ordered. The methods of the preliminary investigation were those familiar to the practice of the Holy Office: no counsel for the accused, no confronting with witnesses, torture applied or threatened, a formal list of questions based upon suspicion, and the usual result, confessions of everything from men otherwise of the best repute.

If the matter had been wholly in the hands of the pope it is probable that, even after this first attack of $\mathrm{r}_{307}$, the arrested Templars would have had a living chance of escape. The king, 
desiring, of course, to throw as much of the odium as he could upon the pope, agreed to a papal commission of investigation

Burning of

Templars in Paris, 1310 into the guilt of the Order. But this machinery moved all too slowly to satisfy him. For three years the inquiries proceeded with results generally favorable to the accused, when suddenly in May, 1310 , in pursuance of a diabolical distinction between the Order and its individual members, fifty-four imprisoned Templars were taken from prison and publicly burned as lapsed heretics by authority of the Metropolitan of Paris and in defiance of the papal commission.

Meanwhile in all the other countries of Europe and in the East as well the governments had been urged to take similar steps. Abolition of The prosecution was taken up with varying degrees the Order, of zeal according to the fear of danger from the 1312

Order. Its ultimate fate was decided at the Council of Vienne in 1312 . In spite of all that had appeared in its favor the Order was declared abolished by papal edict. Its property was nominally handed over to the kindred order of the Hospital or of St. John; but, so far at least as France was concerned, such enormous claims for indemnity were made by the crown that the Hospital seems not to have been greatly the gainer. There is little room for doubt that the methods of the process against the Templars were, even judged by the standards of the time, harsh and tyrannical almost beyond precedent, made possible by the infamous combination of religious and civil powers against an institution which partook of both characters. On the other hand, it is a fair question whether the mere existence of such an association after its actual reason for being had passed was not a menace which the growing state governments of Europe could not afford to tolerate. In this, as in other questions of national consolidation, France under Philip IV was taking the lead.

The third of the great negotiations between Philip IV and Clement $\mathrm{V}$ was in regard to a French candidacy for the Empire. The murder of King Albert of Habsburg (1308) opened up all 
in a moment the tangled questions of diplomacy which the two previous elections of 1291 and 1298 had started. Philip was ready Candidacy of to stake almost anything on the chance of placing a Charles of French prince on the German throne. His brother, Valois for the Charles of Valois, a typical knightly figure without Empire territorial property of his own, seemed precisely the suitable candidate. There was good reason to suppose that Clement V could be bought or coerced into compliance, and Philip pushed the affair with all his accustomed energy. It is a sordid story of bribery for the electors, especially for the clerical princes of the Rhine, of threats and cajolements toward the pope; but the outcome was failure. Clement V followed his usual shifty policy of delay. He actually did negotiate with the electors, nominally in Philip's behalf, but never once came out squarely in his support. His final plea was that the Germans should be left to settle their own problem in their own way without dictation from him. The result was the choice of Henry of Luxemburg, more of a Frenchman than a German, but inclined to look for his profit rather eastward than westward and rather southward than in any other direction. The danger of an overwhelming French influence in Italy was for the moment averted, but at the price of renewing, in form at least, the old imperial policy of Italian intervention. The Papacy now safely established at Avignon could afford to take chances in Italy.

It is the habit of papal historians to speak of the French residence of the popes as the "Babylonian Captivity," but it must be The "Baby- acknowledged that the captivity was a very willing lonian Cap- one. 'The -popes of this period were all Frenchmen, tivity," their cardinals were to a great extent their fellow 1305-1378 countrymen, and, so far as any motion of the Curia itself is concerned, there is hardly an indication of a willingness, not to say a desire, to return to the dangers and troubles of a Roman residence. The relation to France must not, however, be thought of as one of pure servility. From time to time the kingdom 
stepped in with a strong hand, as the Empire had often done, to keep the Papacy up to one or another duty, and, on the other hand, the popes not infrequently acted against the immediate interests of France. Rather, one may describe the French residence as in a way a guarantee of the liberties of the Papacy endangered by the fury of Italian party warfare. France was taking the place which Germany had left vacant.

The election which followed the death of Clement V on April 20, I 3 14, was one of the most scandalous in the long history of papal The Conclave elections. It was also one of the clearest illustrations The Conclave
at Carpentras, May- duce the result chiefly aimed at; that is, the speedy July, 1314 choice of a pope. Clement died near the little town of Carpentras in the Rhone valley, and there within a few days twenty-three out of the twenty-four living cardinals entered the conclave. Of these only seven were Italians, eleven were Gascons, and five were Frenchmen from other provinces. Sixteen votes were necessary for a choice. The Italians, hopeless of gaining an Italian pope, took the initiative by nominating a Frenchman of high character and great learning, the archbishop of Aix, who, though a creation of Clement $V$, would, they believed, be inclined to bring the Papacy back to Rome. But the return to Rome was precisely what the Gascon party did not want, and they refused to accept the candidate of the Italians.

The discussion dragged on for more than three months. Every one except the cardinals was impatient for a solution. King Overturn of Philip IV did not propose to let the control of the the Conclave, Papacy slip out of his hands. Robert of Naples

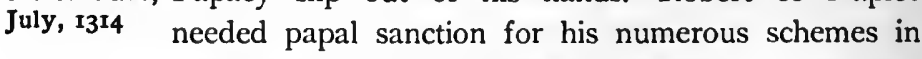
Italy. Edward II of England could use a pope in his now continuous conflicts in Flanders. The hungry partisans of the Gascon policy, led on by a nephew of Clement V, took the matter into their own hands. While the cardinals were gathered in the bishop's palace, a body of armed Gascons picked a quarrel with the followers 
of the Italian party, plundered and burned their lodgings, and from this proceeded to set fire to the palace itself amid cries of "Down with the Italians!" "Give us a pope!" The Italian cardinals, barely escaping with their lives, gathered at the town of Valence farther up the river, while the rest took up their quarters at Avignon.

Thus the body of cardinals was divided into two hostile camps, to the open scandal of all Christendom. For nine months longer Trials of Strength between the Parties, 1314-1315 Roman and the "Babylonian" factions. The Italians at first insisted that Rome should be the gathering place, but soon let that drop and agreed to come to Lyons. It is interesting to note that King Philip threatens, in case the cardinals cannot soon come to an agreement, to summon a General Council, a plan in which he feels sure the Christian princes will support him. His death, November 29, I3 I4, was the signal for a new set of complications which caused the election business to drag on for more than a year longer without any real change in the attitude of the parties.

The cardinals indeed came together at Lyons early in 1316 under the protection of Count Philip of Poitou as the representaConclave at tive of his brother, King Louis X. In order to perLyons, June- suade them to come at all, Philip had sworn a solemn July, 1316 oath that they should be absolutely free from all pressure in the performance of their holy function. The sudden death of King Louis and the candidacy of Philip for the regency of the kingdom made it more then ever impotant for him that the papal question should drag on no longer. He had sworn to protect the cardinals from violence; but was it really violence for him to assume the function of the civil magistrate so clearly indicated in the original conclave decree of 1274 ? To quiet his conscience he hastily summoned a council of theologians and then, fortified by their opinion, quietly locked the doors of the Dominican cloister in which the cardinals were gathered as usual and informed them 
that they should not leave the place until they had produced a pope. And not only this, but Count Philip, a worthy son of his father, took a hand in the election by furnishing a list of four candidates who would be acceptable to him and making it quite clear that the Conclave need waste no time in discussing others. Still the decision waited for another five weeks, the Italians making one last rally to secure the promise of a return to Rome and, perhaps only on that condition, giving the one vote needed for a two-thirds majority.

The result was the election of Cardinal Jacques Duèse, a native of Cahors, bishop of Avignon, one of Clement's creations and a Election of former chancellor of the king of Naples. When he John XXII, began his administration as Pope John XXII he was 1316

already a man of seventy. Whatever ante-election promises he may have made, the last thing he thought of was a return to Rome. He was at home in Avignon, and there he stayed. His cardinals settled themselves near him in all content and luxury, and no attention was paid to the complaints of the best minds in Italy that the Papacy had deserted its post. It must not be imagined, however, that these "exiled" popes were for a moment unmindful of their position as heads of the Christian world. Never were popes more eager in enforcing by every means their claims to universal allegiance. The trouble was that the members of the Christian family were becoming unwilling to recognize this headship except to their own advantage in a given case.

This is best seen in the changed methods of the papal finances. The proper sources of papal income were chiefly: (I) revenue New Papal from the lands which the Papacy owned outright; Financial (2) tribute from certain states, as, for example, EngSystem land and Portugal; (3) feudal dues from certain others, as Naples and Sicily; and (4) the free contributions of the faithful, especially on their visits to Rome. The removal to France acted unfavorably upon all these. There was a general feeling that what was paid to the Papacy was pretty sure to find its way, somehow or other, into the service of France. All those 
who were opposed to the French residence found herein an excuse for not paying, and the expenses of the papal court were certainly not diminished. The result was that Clement $\mathrm{V}$ began and John XXII continued a system of exactions which evaded the former direct dealings with governments and tenants and fell upon a class far less able to defend themselves; namely, upon the clergy. An organized scheme of papal taxes was wrought out in connection with the filling of vacant benefices.

In regard to the proper " canonical" method of filling clerical offices there had never been any real question. Bishops were Papal properly elected clero et populo or practically by the Taxation of clergy of the cathedral, the " chapter." Abbots were Benefices properly chosen by the brethren of the house over which they were to preside. The lower offices of the secular clergy were properly filled by appointment of the bishop, subject to many rights of nomination (presentation) by lay lords or corporations. Any departure from this general scheme was an invasion of rights on the part of some one. It could be justified only on the ground of papal privilege or of ancient custom. The most bitter controversies of the Middle Ages had turned on the attempts of lay lords, including kings, on the one hand, and the Papacy, on the other, to control all clerical appointments. The battle cry of the papal party from Hildebrand on had been "The liberty of the Church !" by which was meant its freedom from lay control; but this might mean an equally galling servitude to the Papacy itself. The most frequent charge against John XXII in his day and since is that he developed this idea of the subserviency of the Church to the Papacy into a vast money-getting scheme.

Certain technical words will help us to understand this. While the general principle of appointments remained unquestioned, the "Reserva- Papacy, in virtue of its supreme power, might make tions" exceptions. It "reserved" to itself the presentation to certain classes of benefices. If, for example, a clergyman died while at the papal court - apud sedem apostolicam - the Papacy 
claimed the right to name his successor; but this phrase proved to be a very elastic one and was presently stretched to cover all clerics in any way or in any place engaged on any specific commission from the Papacy, all who were transferred or promoted or deposed; in short, any benefice vacated in consequence of any papal action or through any relation to the Papacy might be said to be vacans apud sedem apostolicam. These are the notorious "Reservations," evidently a most clever device for the extension of papal influence, but still more, since every such case involved payment of money, a constant temptation to the papal government to create as many vacancies as possible and to set the tariff as high as possible.

Another word of evil omen in the same connection, "Expectatives," explains itself. Vacancies could be anticipated; several "Expecta- candidates were waiting; to secure the appointment tives" to one of these in return for a modest contribution to pious uses was not precisely an act of simony. If the expectation for the same vacancy were sold to several candidates, that was only one of those abuses to which all good things are liable "Annates" in human hands. "Annates" meant strictly a papal tax equivalent to one year's revenue of the benefice to which one of the higher clergy was appointed, but it was also used loosely to include many similar contributions calculated upon revenue.

All these methods of raising money through taxes upon benefices were known and practiced before; but with John XXII they

Political Value of the

Tax on Benefices are developed into a permanent system and they form one of the most striking characteristics of the New Papacy. Hitherto the policy of the papal government had generally been to check in every way the growth of the national powers in Europe, so far as these were concerned with church affairs. Henceforth it is rather to recognize the national governments and then trade with them for mutual profit. For example, John XXII begins his administration by granting 
the French "annates" for four years to King Philip V, a bargain typical of scores of others made between kings and popes during the next two hundred years. It was this aspect of mutual profit which caused the royal and princely powers to wink at these encroachments of the Papacy upon the freedom of their clergy. Popes were generally willing to appoint the royal candidates if only kings would not interrupt the flow of revenue into their treasury. Between the two, however, the clergy, especially the lower orders, were in danger of being ground to powder, and it is largely from their ranks that the loudest protests against the system are heard.

Of course the burden of this taxation fell ultimately upon the producing classes in the dioceses where it was applied, and their

Complaints against these Exactions complaints added to those of courageous and rightminded clergymen were leading straight to the great councils of the fifteenth century and through these to the Protestant Reformation. Critical observers even friendly ones - declare that at the court of Avignon one heard nothing but the most shameless traffic in offices, an incessant counting and weighing of gold pieces. These exactions were the more dangerous because there was no organized method of meeting them. If the papal theory of church life was the true one, then resistance to papal demands could easily be represented as "heresy," and heresy was crime. One of the earliest and most dangerous complaints came from an unexpected quarter. The The "Frati- order of the Franciscans, organized just a hundred celli" years before the coming of John XXII, had grown in that time to be the most popular and the most powerful clerical body in Europe. Above all things it had been a mainstay of the Papacy. Within the Franciscan body, in spite of all temptations to worldliness such as had always beset the monastic orders, there had been maintained an inner circle of spiritually minded men, whose one thought was to keep the Church up to something like the standards set by their angelic founder, Francis of blessed memory. Their rallying cry was "apostolic poverty." As Jesus and his 
followers had denied themselves all earthly wealth and ease, so in turn their followers the clergy, not merely monks, but all, ought to imitate their example. Such a thoroughgoing notion of clerical duty found, as may be supposed, very little welcome in a church which was daily growing more and more involved in the life of the great practical world of affairs. These "Fraticelli" were looked upon as fanatics by their less scrupulous brethren and soon began to be suspected by the Papacy itself. John XXII was precisely the man to put down such dreamers with a strong hand; but a little persecuting was all that was needed to stir their opposition into a consuming flame. The Fraticelli were under very able leadership and soon found supporters. Their spice of fanaticism was just what was needed to give a zest to the political hostility against the Papacy which we studied in the preceding chapter. This Franciscan or Minorite movement found its temporal rallying point at the court of the emperor Ludwig the Bavarian. The most vigorous declarations of Ludwig are the echo of the Minorite attack. "Heresy" was a handy word, and if the pope could use it against the friars, they, with the help of the emperor, could throw it back at him. Throughout this warfare John XXII is regularly described as a heretic, and certainly the Church has had men burned on less well-founded charges.

The removal to Avignon seemed to loosen the floodgates of literature on the subject of the rights of the Papacy as against Dante's "De all the other powers of the earth. The poet Dante, Monarchia" never hostile to the idea of a papacy as the religious headship of Christendom, was nevertheless convinced that it ought not to overstep the limits of religion. In his treatise on a single government of the world ("De Monarchia "), inspired probably by the coming of Henry VII to Italy, he lays down with the utmost distinctness three principles: First, that human society, like the universe as a whole, ought to be governed by one single administration; only in this way can that unity be maintained which is essential to the well-being of society. Second, the center and seat 
of this administration ought to be at Rome, the one spot clearly marked out by the divine will as best suited for the purpose. Quoting alike from Scripture and the classic literature he illustrates this point by numerous examples. As Father Aneas was sent by divine command to settle in Italy and found the Roman state, so Christ by deigning to be born under Roman rule sanctioned and confirmed it. The executive center is to be at Rome, but, in the third place, the holder of this universal office is to be not the pope but the emperor. The pope is to be merely the religious leader of a world, which, in all other respects, is to look to the divinely appointed emperor for its guidance.

Dante's dream of an effective empire was as baseless as the vision of a purely spiritual papacy, but it shows us how the papal

\section{Dante's} ideal of Innocent III and Boniface VIII was losing Criticism of its hold upon the best thought of the time. The the Papacy "exile" at Avignon called out all the poet's furious indignation. In his visit to Paradise he hears St. Peter say:

Our purpose was not, that on the right hand Of our successors should in part be seated

The Christian folk, in part upon the other;

Nor that the keys which were to me confided

Should e'er become the escutcheon on a banner,

That should wage war on those who are baptized;

Nor I be made the figure of a seal

To privileges venal and mendacious,

Whereat I often redden and flash with fire.

In garb of shepherds the rapacious wolves

Are seen from here above o'er all the pastures!

O wrath of God, why dost thou slumber still?

To drink our blood the Caorsines and Gascons

Are making ready. $\mathrm{O}$ thou good beginning,

Unto how vile an end must thou needs fall!

But the high Providence, that with Scipio

At Rome the glory of the world defended,

Will speedily bring aid, as I conceive.

DAxte, "Paradiso" xxvii, 46 (Longfellow's translation) 
Dante did not hesitate to place popes in his lurid hell for no fault but that they had perverted their office into a worldly monarchy. He finds Nicholas III of the Orsini family, who died in I 280, a man of good personal character and zealous for the success of the Papacy, plunged headfirst into a hole wriggling his burning red legs in the air. Nicholas mistakes the wandering poet for his own successor, Boniface, who was due to arrive somewhat later, and reproaches him with having first captured the "beauteous Lady," the Church, by fraud and then done her violence. Discovering his error, he says of himself :

And truly was I, son of the She-bear, (Orsini)

So eager to advance the cubs, that wealth

Above, and here myself, I pocketed.

$$
\text { "Inferno" xix, } 70
$$

Nicholas acknowledges his fault, but declares that Boniface will soon take his place and will then in his turn be relieved by the coming of Clement V, first of the French popes :

For after him shall come of fouler deed,

From tow'rds the west, a Pastor without law.

$$
\text { "Inferno" xix, } 82
$$

Soon after the death of Clement V, in $\mathrm{r}_{3} \mathrm{I}_{4}$, Dante wrote to the eight Italian cardinals then going into conclave with their sixteen "ultramontane" colleagues. Just as he had urged the emperors, so now he urges the pillars of the Papacy to come back into his beloved Italy and restore that divinely ordained balance of powers by which alone order could be brought into the apparent chaos of Italian politics. In impassioned language he describes Rome again as sitting now doubly widowed by the Tiber mourning her two proper defenders. The appeal fell upon the ears of men, Dante's Mis- who, with the best of intentions, could have done taken Ideal nothing against the overwhelming majority of the French interest. Dante, like most other Italian patriots, was calling upon powers that had abundantly proved their incapacity. The 
real remedy for Italy was in a sense of common interest, which should express itself in politics as it was already expressing itself in the manifold products of the Italian genius. Empire and Papacy were both hindrances, not helps, in developing the things for which the Italy of the fourteenth century really stands in history. Dante's great poem is one long indictment against the blind fury of partisan zeal, which he had himself shared and of which he was the most illustrious victim. His criticism of the Papacy is reëchoed by every voice worth hearing in his day.

Petrarch, the singer of human feeling, whose life covers just the period of the Avignon papacy, cannot say enough of the world: Petrarch and liness and corruption of this foreign court. He was, Cardinal it is true, himself a type of the luxurious and fastidious Orsini society he criticizes, but it is idle to deny the force of his criticism. He too proceeds from the point of view of the Roman, filled even more than Dante with the new inspiration of classic study and with pain and grief at the desertion of Rome. In his kindled imagination he sees Rome once more the mistress of the world, holding the two swords of the temporal and the spiritual powers in divine balance. The same evidence is found in a remarkable letter written in $13 \times 4$ by Cardinal Napoleone. Orsini to King Philip IV of France. Orsini was, as much as any one, during a long life the head of the Italian party among the cardinals. He had favored the election of Clement $\mathrm{V}$ in the conclave at Perugia, because he had really believed that a French pope, living as he was of course expected to live, at Rome, would be the best hope for Italian society. In this letter he describes his bitter disappointment. The residence in France, the creation of a revolutionary cardinalate for purely mercantile and political purposes, the systematic disregard of the Italian cardinals, the neglect of Rome, - all this filled the Roman Orsini with profound anxiety for the future.

The worst of it was that these abuses were only the natural working out of measures taken deliberately and after long experience. 
The strengthening of the Cardinal College was beginning to work too well. The curial party had hoped to win the right of conFrench con- firming new appointments; they had failed, and the trol of the arbitrary creations of Celestine $\mathrm{V}$ and Clement $\mathrm{V}$ in Cardinalate favor of a foreign interest were the result. But now the same point was made again. The French cardinals profited by the example of the Romans, and in the earliest preserved electoral compact of $135^{2}$ we find the right of the cardinals to confirm new creations among their number expressly guaranteed. If this right could be maintained, the permanence of the French influence seemed secure, and the Papacy was, more than ever before, to be a papacy of the cardinals and for the cardinals. Among the creations of Clement $\mathrm{V}$ were included the confessors of the kings of France and England and the vice chancellor of King Philip. A new motto, Ubi Papa, ibi Roma, showed how far men were wandering from the ancient papal law.

Meanwhile Rome, abandoned by the Papacy, was coming to feel most painfully the consequences of her long connection with The Roman it. In the other cities of Italy a free and vigorous City Govern- political life had been developed. Rome had been ment; the of importance only as the papal seat, and now it was Senator nothing. For a while Rome lived on in hope of a reaction which should bring back what it had lost, but after about 1325 it became clear that under such a body of cardinals as were now in power such a reaction was impossible. All accounts agree as to the sorry state of the city. Every active party leader grasped at what came to his hand and traded for peace with his neighbors or fought them as the case might be. The public buildings, even the great churches, began to fall into decay, and it was nobody's business to keep them up. The accidental burning of the church of St. John Lateran ( 1308 ) seemed an omen of impending ruin. The government of Rome passed practically into the hands of the democracy, with constant reference to the pope as overlord and to the heads of the aristocratic factions as indispensable agents of 
the "People." The executive power was given to an official called "senator," and sometimes this office was shared by two heads of factions, a "bipartisan" device for the sake of peace, but no more successful than similar devices have usually proved. The Colonna family, ruined by Boniface VIII, was restored to wealth and power by Clement $\mathrm{V}$ and takes its place by the side of the Orsini as the principal political force in the city. Clement received from Rome the senatorship for life with the privilege of appointing a representative, but within a very short time he gave to the citizens the right of choosing their own executive and thus frankly confessed that to the French papacy Rome was of very little account indeed.

Henceforth we find the Romans now electing their senators from among their own people and now offering the senatorship The Republic to any "savior" who for the moment seemed likely confers the to suit their purpose. By the side of the senator was Empire an elected council, usually of thirteen, and an irregular military official, the "capitano," appears in moments of especial danger with extraordinary powers. But Rome could never long rest satisfied with the practical conditions of a regular constitution, no matter how well devised. Nothing less than some grand scheme of universal sovereignty would do for that people which had once been the ruler of the world. They had got rid of the Papacy, but now came the Empire once more, with its fantastic echoes of a mighty past and with all good will to flatter the Romans for its own ends. Henry of Luxemburg was wise enough to keep on good terms with both Papacy and Rome; but Ludwig the Bavarian, carried along by his consistent theory of empire, was ready to go to the extreme length of accepting his imperial crown from the hands of the Roman Republic and even to set up a pope by virtue of the imperial character thus doubtfully gained.

One of Ludwig's first acts was to declare that henceforth the Papacy must be fixec - Rome (1328). The futility of such a decree showed perfectly how completely the papal constitution 
had been changed by the overgrowth of the Cardinal College. The moment Ludwig's back was turned the fickle folk recalled

The Republic recognizes the Papal Overlordship the banished leaders of the Guelf faction, made a Colonna and an Orsini senators in the pope's name, and declared everything Ludwig had done to be null and void. The inevitable savior was found in the person of the Angevine king, Robert of Naples, who had furnished the force needed as a backing against Ludwig and who now appears as senator, approving the other senators named by the people and generally managing a restoration of the government in the papal interest (1330). A deputation of the people made a most elaborate disavowal of any rights contrary to the advantage of the pope, - above all things disclaiming the right to elect either pope or emperor. So far nothing seemed wanting to the triumph of a papacy which was thus declared independent of any limitation except from the electoral body which was its own creation.

Pope John XXII died December 4, 1334, at the age of ninety, after a pontificate of eighteen years. He left twenty-four cardinals, Papacy of who, after a conclave of seven days, elected one of Benedict XII, their number, Jacques Fournier, a French Cistercian 1334-1342 monk, who called himself Benedict XII. It was again a case of the "papal pendulum," swinging now from an extreme of almost fanatical energy to an eight years' interval of reaction on most of the matters in which John XXII had taken especial interest. Benedict XII is chiefly memorable for the erection of an enormous and strongly fortified palace as the permanent residence of the popes at Avignon. This palace, after many vicissitudes, has now been reserved as a "historical monument" by the French government and restored as far as possible to its original condition. In his relations with the Church in general Benedict showed himself to be what his critics called "stingy"; that is, he seems to have had a conscience about the reckless granting of benefices for revenue only and a certain sense of restraint in the conduct of the Curia in general. 
Eagerly summoned to Rome, he seems really to have considered the possibility of a return, but the hold of France was

Benedict XII without

Power at

Rome too strong upon him. In naming six new cardinals he appears to have consulted the college, and of course the new members were of the same approved ultramontane kind. The Roman Republic, in dire distrust of its own capacity, offered him all the titles in its gift. He accepted them and named as his representatives leading Romans from various parties. Still the war of factions went on at Rome. There is something at once grotesque and pathetic in the picture of Romans sending to Florence in 1340 begging their fellow republicans to send them men who should instruct them in the methods of Florentine government - as if any machinery could ever replace civic virtue and a common patriotism.

There is a similar tinge of absurdity in the spectacle of the poet Petrarch seeking his coronation as world poet at the hands of this feeble remnant of ancient Roman greatness.

\section{Petrarch} crowned by Invited by several powers which were the real heirs the Republic, of republican and imperial Rome, by France, and by I34

Naples, Petrarch set all these invitations aside and declared that only at Rome, the seat of ancient culture as well as of ancient power, could he worthily receive the crown of genius. The ceremonies of the coronation at Easter, I34I, were carried out with all the splendor of decoration in which the Romans delighted. If Rome could no longer choose either popes or emperors, she might at least crown poets, and in this harmless display no one cared to disturb her.

The Conclave of 1342 lasted but two days, and out of it came the man who more than any other has given character to the Election of "Papacy of the Exile." Pierre Roger, who took the Clement VI, name of Clement VI, belonged to a noble family of 1342-1352 Limoges, had been successively archbishop of Sens and of Rouen, and had been made cardinal by Benedict XII. Under him we find the financial system of John XXII developed 
to its full consequences. Besieged with exhortations to return to Rome, he disregarded them all, acquired for the Papacy the ownership of the city of Avignon, and threw himself into the whirl of French politics as none of his predecessors had done. The evil example of Clement $\mathrm{V}$ in appointing his relatives and provincial countrymen to office was followed and exceeded. Clement VI was an accomplished courtier, a learned theologian, a patron of the Clement VI, arts, everything but a reformer of the increasing world1342-1352 liness of the Papacy. In his creation of cardinals he knew no limit of propriety. By his time the practice of treating the cardinalate as a piece of family property had become so common as hardly to attract notice; but it was a shock to learn that Clement had made his seventeen-year-old nephew a member of the highest spiritual body in the Christian world. In the ordinary course of nature such an appointment must affect the action of the whole papal institution for two generations of men. Of Clement's twenty-five creations but three were Italians. The Romans offered him the lordship of their town and he graciously accepted it, naming a Colonna and an Orsini as his representatives with the usual title of "Senator." The citizens and the new world-poet Petrarch united in urging his return, but he politely declined.

This pleasant relation lasted but a few months when Rome was again stirred to its foundations by an outbreak of the popolo Rise of Cola against the government by senators. The administradi Rienzi tion was put into the hands of a council of thirteen, reserving the papal overlordship, and an embassy was sent to Avignon to get the papal confirmation. As spokesman of this embassy there appeared a young notary named Rienzi, a man filled, even to fanaticism, with the idea of ancient Roman greatness, a fiery orator and an accomplished scholar. His political dream, nourished by the exclusive reading of the classic authors and stimulated by constant familiarity with the material remains of a forgotten past, was that of many another Roman, - the 
restoration of the former glory of Rome. As the basis for this restoration he saw neither the Empire with Dante nor the Papacy with Boniface VIII, but the Roman people. He fancied that Rome, independent of any outward aid, might rise once more to universal rule. For the moment his energy, his talent, and his courage commended him to a man of the world like Clement VI, and he was tolerated.about the papal court until his language became a little strong for the few Roman nobles who had influence there. Clement protected him awhile and then disposed of him by sending him back to Rome in the humble capacity of a papal notary (I344).

Rienzi felt himself already a man with a mission, and circumstances were shaping themselves rapidly to his need. The kingdom Conspiracy of Naples, long the firmest support of the papal power of Rienzi at Rome, had fallen into civil strife. The cities of central Italy were everywhere throwing off the control of a hereditary nobility and placing the government in the hands of the organized laboring classes. The Papacy at Avignon held barely the form of a sovereignty in the Roman territories, where regular troops of mercenary soldiers, under free captains, improved their leisure between more permanent engagements to make a living out of the almost ruined peasantry. All this was very tempting material for a demagogue. Rienzi's restless mind worked at the problem for about three years. Men enjoyed his speeches, laughed at his humor, and pointed at him in the streets as an addle-pated dreamer. By 1347 he had made himself the head of a widespread conspiracy in which even the papal vicar was included.

When all was ready Rienzi invited the people to a parlamento on the Capitoline Hill, and they came. Cola, with the papal vicar Rienzi as - by his side, addressed the great assembly, rousing them "Tribune" to frenzy by the story of their wrongs and of the former glories they had lost, but ought now to recover. Another of the conspirators read a list of laws designed to secure order, to relieve burdens, and to provide for a regular militia service. 
These reforms were carried unanimously on a great wave of popular enthusiasm. Many of the nobility fled in alarm from the city, but the approval of the Papacy had been secured from the outset. Rienzi, calling up a long-forgotten title, named himself "Tribune of the People" and tasted for a time all the joys of the wellmeaning and successful demagogue.

Rome had found another "savior" and for the moment was happy. Even the nobility, summoned to swear allegiance to the Constitutional Reforms of letters to the cities of the Roman territory, to the new constitution, obeyed. But Rienzi's view was not bounded by the walls of Rome. He sent out eloquent powers of Italy, to the emperor Ludwig, and to King Philip VI of France. The cities of Italy were invited to send representatives to a grand National Italian Parliament to be held at Rome in August (1347). The scheme of an Italian federation under the lead of Rome the City, not Rome the Papacy, is clearly outlined. In Rome itself Rienzi aimed at nothing but the strict carrying out of the existing constitution. Intrusted with the chief executive functions, he enforced justice without regard to persons. Private enmities, the most fruitful source of disorder, were reconciled by the action of a special court of the public peace. Economic reforms increased and secured the revenue without burdening the people. Messengers of Peace, clothed in white garments and bearing white wands, carried the news of this peaceful revolution throughout Italy. The replies of most of the city governments were surprisingly favorable and indicate how completely this Roman revolt was part of a general Italian movement. A new principle of Italian unity, neither Guelf nor Ghibelline, was brought into the range of possibility. Representatives of the proposed Parliament even began to gather at Rome. The poef Petrarch seemed to voice a universal sentiment when he declared Rienzi to be the inspired leader of a new Italy.

Rienzi had overcome many obstacles, but the supreme test of success was still before him. His theory of a new government 
under the nominal overlordship of the Papacy was in every way reasonable, but a steadier hand than his was needed to carry it on. collapse of The old warfare of parties, kept down for a moment, Rienzi's was ready to burst forth on the least occasion. Rienzi Government himself seems to have been intoxicated by his draft of sudden and almost unlimited power. Personal ambitions and motives began to be mingled with the pure impulses of patriotism, and the demagogue, become a tyrant, simply went to pieces. He was thrown down by the same hands that had set him up, and Rome was ready for a new experiment. This new epoch in the Roman and papal history may be described as the Age of Albornoz. Rienzi, driven from Rome, lost in a moment the great qualities which had come out in him under the pressure of his early struggle. He wandered for a time in Italy and then found himself at the court of King Charles IV at Prague, urging him, quite in the orthodox Ghibelline terms, to come down and rescue Italy from herself. Charles quietly locked him up, kept him for more than a year, and then handed him over to the pope for trial as heretic and rebel. At Avignon he was put through the forms of a trial, but was then held in an honorable imprisonment. Too many voices, it would seem, were raised in his behalf to warrant a very strict judgment.

The election of Innocent VI, a Limousin Frenchman, created cardinal by Clement VI, is of interest on account of a document, Election of the first authentic specimen of an "electoral compact" Innocent VI, (capitulatio) entered into by the cardinals before the 1352-1362 election. Undoubtedly similar compacts had been made at previous elections; but we have here the first actual text showing the continuous friction between the ideas of an absolute and a constitutionally limited papacy. It was the constant aim of the Cardinal College to keep its number small and to establish its actual control over the actions of the pope in such a way that this control should grow into a permanent right. The terms of the compact of $135^{2}$ were briefly these: ( $r$ ) The regular 
number of the college is to be twenty, and whenever it drops to sixteen, new creations are to be made with the approval of two thirds of the existing members. (2) In addition to the already The Electoral existing arrangement that the college was to dispose Compact of of one half of the papal revenues, various practices 1352 which tended to diminish these revenues are to be abolished, such, for example, as granting tithes to temporal rulers, alienating papal territory without the approval of the college, or giving high administrative offices in the Patrimonium to papal relatives (nepotes). (3) Every cardinal is to have the right to give his advice freely on all matters of papal administration. (4) The persons and property of the cardinals are guaranteed against forcible process on the part of the pope.

It is evident that these guarantees taken together formed a very considerable limitation upon the independence of the pope.

Violation of If they were to be carried out in spirit and letter, the the Electoral Papacy as the free arbiter in all human affairs accordCompact by ing to the doctrine of the Unam sanctam would cease

to exist, and its place would be taken by a privy council, appointed, it is true, by the pope but with rival interests of its own against which he was made powerless. That the danger of such a tendency was fully realized is proved by the fact that several cardinals - including the future pope - took oath to observe the compact only "if, and in so far, as it may lawfully be done." It was, therefore, pretty well a matter of course that Innocent VI immediately after his election declared that the compact was contrary to the plenitudo potestatis of the divinely ordained Papacy and that he was in consequence not bound by its terms. And, in fact, he proceeded to violate every one of its restrictions in the most thorough fashion, and it is to such violations, probably, that some of the greatest successes of his ten years' administration were due.

It was the fixed determination of Innocent VI, above all else, to bring order into the desperate condition of the Papal State. 
As his agent in this difficult matter Innocent VI selected the most capable man who had managed papal affairs for many a long day. Albornoz was a Spaniard, trained first as Restoration under a soldier, then as a churchman, and finally made Albornoz, cardinal by Clement VI. 'He went over into Italy in 1353-1367

i353, carrying in his train the former tribune, whose services he expected to make use of at Rome. Rome was taken with little effort, and Rienzi, after seven years of absence, was once more received as its executive head, not now, however, as Roman tribune, but as papal senator, holding his commission by the grace of Albornoz. For a time, again, the government of Rienzi was a blessing to the city. Of all the dangers from which Italy suffered, none was so great and so difficult to guard against as that from the roving bands of free soldiery under independent captains, who sold their services to any one who would pay them. Of these leaders the most terrible was the notorious Fra Monreale, formerly a knight of St. John, who had long been the terror of the peninsula. Rienzi had managed to persuade Monreale to help him in his wars against the Roman barons, but had then thrown him into prison and, with the applause of the people, tried him as a public enemy and put him to death. Italy was relieved from a danger, but men refused to believe in Rienzi's motives. Monreale's wealth, it was said, not his crimes, was the real cause of his destruction. It was the same story over again. Rienzi, great in times of struggle, could not meet the responsibilities of a regular administration. When the storm of revolt broke upon him he lost his head completely, and his end was unworthy of himself. He was a fantastic enthusiast, but he had in many ways pointed out to his countrymen the only true principles of a strong and permanent national life.

The outcome of the administration of Cardinal Albornoz from 1353 to 1367 was the complete restoration of the papal power in the states of the Church and at least a momentary return of the Papacy to its proper seat. Albornoz's administrative talent 
was especially seen in his moderation toward the Romans. He left the democratic constitution of the city in the main undisturbed, Revival of trying only to keep it working, so far as possible, the Temporal in the papal interest. His great aim was to encourage Power the population of the Patrimonium to renewed economic and military energy, and in fact a distinct regeneration of the Papacy as a state may be dated from his time. As Rome lost in general influence upon European affairs it gained in this, the second of its three functions. Rome from now on takes a place among the Italian powers far more effective than it had taken when it was relying upon its religious claims to superiority. A frank worldliness of policy, such as Albornoz now displayed, was really the best claim that the Papacy could put forth to a restoration of its place in Italy. ${ }^{1}$

Still the piteous appeals of Italians to the "exile at Avignon" to return to his devoted and long-suffering people kept on; but Appeals for the fact was that a permanent return of the Papacy to a Return of Rome could come about only through the same agency the Papacy which was holding it in France; namely, through the will of the College of Cardinals. Once for all the Papacy was committed to the working of this dangerously clever mechanism and could not escape from it. The election of Urban V, a French Benedictine and not a member of the sacred college, brought a momentary gleam of hope to the party of the return. His most notable action was a bull against the Free Companies, which at this moment were actually the masters of Italy and needed only skilled statesmanship to make them its "legitimate" rulers. Not that these reckless troopers cared a jot for the papal bull, but the bull was the proclamation of a decided stand among the princes and cities of Italy under papal leadership, and this did finally help.

There is little doubt that this restoration of the Patrimonium was the immediate attraction which induced Urban $\mathrm{V}$ to determine upon a return to Rome. Probably also the condition of

1 See Chapter VIII. 
Avignon, in the midst of a country hardly less desperately beset by an unruly soldiery than Italy itself, had its influence. The

Temporary

Return of Urban $\mathbf{V}$, 1367 emperor Charles IV urged the return and promised his personal escort. The Italian powers of the center and the north - always excepting Milan - were as eager for this change as for every other novelty. On the other hand, France and the cardinals raised a storm of opposition. That the days of Philip IV were past was proved by the fact that Urban V was able to carry his point and actually did set out for May 20, 1367 Italy, carrying with him eleven of his sixteen cardinals. $\mathrm{He}$ sailed from Marseilles to Genoa and Pisa and landed at Corneto. Everywhere he was received with the utmost jubilation. The aged Petrarch, who had written to urge the return, saw in this restoration the fulfillment of all his hopes for Italy. Urban remained three years at Rome, at peace in the city, but harried from without by the constant pressure of Italian politics. Then, suddenly, for reasons as mysterious as those which had drawn him from Avignon, he determined to go back, and not all the exhortations of all the patriots could change his purpose. The only visible gain for Rome was a certificate of good behavior in which Urban $\mathrm{V}$ acknowledged that he had no complaints to make against the conduct of her citizens.

The death of Urban $\mathrm{V}$ almost immediately after his return to Avignon was, of course, to the Italian party a demonstration of Election of the evident anger of God. His successor was that Gregory XI nephew of Pope Clement VI who as a boy of seventeen had been made cardinal and who had turned out to be a man of great learning and an honest desire for the welfare of the Church. The same kind of demands as before began anew to draw his attention to Rome, but more than all else the threatened loss of all the gains of the great Albornoz. A new wave of popular enthusiasm for "liberty," which meant freedom from all overlordship, swept over Middle Italy, and Florence was the source of it. An excuse was found in the misgovernment of the papal 
"rectors" in the Patrimonium, but the real motive was the ancient Florentine Guelfic hatred against any kind of permanent territorial sovereignty in Italy. Until now such sovereignties had generally been of the aristocratic Ghibelline Party, but papal-Guelf territory, under a vigorous administration, was equally dangerous to the kind of liberty of which Florence was the ancient champion.

The new pope determined, quite of his own motion, it would seem, to take an active part in Italian affairs and save the state.

Catherine of Siena, 1346-1380
His determination was strengthened by a continuous pressure from the Italian side. Catherine of Siena, a young woman of humble origin, is the central figure of what may be called the sentimental interest in the return to Rome. Whatever may be thought of her somewhat puzzling personality, whether she was chiefly saint or innocent or the tool of others more clever than herself or, perhaps, a combination of all these, she is certainly one of the most remarkable literary phenomena of all time. Without education except such as came from contact with the world of affairs, she was mistress of a literary style that appealed with singular force to her contemporaries and still has its charm for minds of a certain type. Making a profession of humility and self-effacement almost to the point of selfdestruction, she had the audacity which such abandonment of self often brings. Experience of her personal influence over men and women alike gave her increasing confidence, until there was no limit to the boldness with which she addressed the highest powers of the earth in pursuance of what she believed to be a divine commission. Like her French counterpart of the next generation, Jeanne d'Arc, she was the spiritual embodiment of the sentiment of patriotism. Italy, torn by sectional warfare, the victim of its own evil passions, appealed to her as a rebellious child turning away from its proper loyalty. Worst of all, that power which above all others was bound to work for peace and order, the Papacy itself, was recreant to its trust. Only in the return of the, 
papal government to its rightful seat and its sacred obligations was there hope for Italy. The really moving forces of Italian life, its social and economic struggles, its working out of the political problem on the lines of sectional division, these had no existence in her ecstatically simple view. The one thing needful was a new dedication of the Italian people to the following of the cross, and to this end she was prepared to devote her exuberant nervous energy. Her letters, nearly four hundred of them, addressed to every variety of person from highest to lowest, are throughout inspired by this dominant purpose.

Precisely what share in the final resolve of Gregory XI to return to Rome is to be ascribed to Catherine is wholly uncer-

Catherine's Mission to Avignon, 1376 tain. He was no doubt by nature wavering and irresolute, struggling with feeble health and generally ill suited to resist the steady pressure of all the French interests to keep him where he was. It is therefore not of itself improbable that Catherine's exhortations gave precisely the one thing needed to hold him to his resolve. To enforce her written appeals she at last went personally to Avignon with a selected group of her spiritual "family." In some sense also she represented the Florentine interests in their conflict with the Roman state. Her own belief was, so she says, that the Florentines were ready to make peace with the pope on terms favorable to the Church, a faith doomed to disappointment. Gregory XI was willing enough to receive Catherine with the honors due to her now well-established reputation for sanctity, but it was three months yet before he could arrange matters for his departure, and even at the last moment he was beset by schemes to detain him. No doubt Catherine's timely revelations gave him useful arguments against his hostile advisers. She saw him safely out of Avignon and off for Marseilles and then followed his course by land along the Riviera until she met him once again at Genoa and gave a new fillip to his halting purpose. 
It was certainly a valuable service to have aided, no matter how much or how little, in restoring the long-severed connection Catherine and between Rome and the Papacy; but, precisely as ocUrban VI, curred later in the case of Jeanne d'Arc, success in ${ }^{1379-1380}$ the main undertaking involved the innocent enthusiast in the worst political entanglements of the peninsula. She was brought to Rome in November, 1378 , by Urban VI to be used as a weapon against the French party now gathering about the rival pope, Clement VII. She was probably an asset of some value in pleading the Urbanist cause with any partisans who were to be won by sentimental appeals, but there is no evidence that she was of any use in affecting the actual political situation. She died at Rome, April 29, 1380 , in the thirty-fourth year of her age.

Gregory XI came back to Rome with a majority of his cardinals, made his peace with the city, and entered at once upon a Return and policy of violent restoration. Enough that he failed Death of Gregory XI, and papal sovereignty. His chief interest for us is and seemed only to increase the gulf between pope that he died in Rome. For the first time in seventy years an election was to be held under the pressure of the Roman people. Gregory XI foresaw the danger and just before his death issued an order that whoever should be chosen by a majority of the cardinals, at Rome or elsewhere, in conclave or not, should be acknowledged as pope.

Of twenty-three living cardinals sixteen were at Rome, and of these eleven were French, one Spanish, and four Italian. The

Preponderance of the Limousin Faction
Frenchmen were again divided into seven Limousins and four others. This latter division made it impossible for the ultramontani to work together and, in so far, favored the choice of an Italian. A glance backward at the elections of Urban V and Gregory XI will help to make clearer the meaning of the present conflict. In the conclave of 1362 , out of twenty cardinals eleven were Limousins, of 
whom three were relatives of Innocent VI and six relatives of Clement VI. In 1370 , of eighteen cardinals fourteen were French, and of these nine belonged to the Limousin faction. More than this, through the calculated nepotism of Clement VI this Limousin party was almost wholly made up of his family connections, and through their control of clerical appointments far and wide throughout Europe it had almost come to be a fact that the Papacy was a piece of family property enormously valuable and not to be given up without a desperate struggle. Gregory XI, himself a Clementine nepote, had committed what from this point of view was the fatal blunder of going back to Rome, and there can be little doubt that his decree as to the future election was inspired by the hope that an immediate choice would keep the control of affairs in the hands not merely of Frenchmen but also of his own family.

Our account of this, one of the most important of all papal elections is based almost entirely upon extremely partisan writings

\section{Election of} Urban VI, $137^{8}$ published by one side and the other after the great conflict to which it led had broken out. If we were concerned merely with questions of canon law, we should have to examine these conflicting arguments with great care; but the fact is that the legal arguments on both sides were rather excuses to explain action already taken on other and far more important grounds. There are no great differences in the formal narratives of the election. There is no doubt that feeling in Rome ran very high and that the Romans of all classes were intensely interested in keeping the Papacy at Rome by securing the election of a Roman, or at least of an Italian, pope. The cardinals were unquestionably divided by their national interests, and their negotiations were certainly prolonged beyond what seemed to the waiting populace a reasonable time. The populace no doubt showed its impatience by more or less riotous behavior in the immediate neighborhood of the conclave chamber, and the cardinals were more or less in a state of panic. At some stage of the proceedings the mob broke into the palace and the cardinals 
scattered to various places of safety; not, however, until they had elected Bartolomeo Prignano, archbishop of Bari, a Neapolitan and not a member of the college, to be pope. So far the opposing accounts are fairly in agreement. The question was whether the pressure of this popular demonstration, putting the cardinals in fear of their lives, was what determined the choice of this man. The supporters of Urban declared that such was not the fact, but rather that the ultramontane cardinals were unable to agree among themselves upon a candidate and so accepted a man whose connections were largely French, who was outside the cardinal body and hence might give reasonable hopes that they could use him for their purposes.

While it is evident that certain individuals among the cardinals were from the outset troubled by scruples as to the validity of Revolt of French Cardinals this election, it is certain that no formal protest was made for several weeks. The cardinals entered upon their usual relations with Urban VI and began to take their parts in the papal business. Very soon, however, a distinct antagonism began to show itself between the pope and the body of cardinals as a whole. He developed an unusual and most unwelcome severity in his ideas of the proper conduct of their lives. Instead of letting them have their way in disposing even of their share in the papal revenues, he ordered them to use their income in repairing their title churches and otherwise contributing to the maintenance of the church establishment. They wished to return to Avignon as soon as possible; he flatly declared that he would remain at Rome. They sought promotions for their friends; he promised the Romans that he would soon create enough Italian cardinals to break the majority of the ultramontani. They demanded to be heard on all matters of papal administration; he advised with them when he pleased, but was not in the least bound by their opinions.

The result was that two months after the election of Urban VI twelve French and one Spanish cardinal withdrew to Anagni 
to deliberate on the question whether this election had been canonically sound. After much discussion they came to the conElection of clusion that Urban was no true pope. His election Clement VII, had been defective on account of outside pressure; I378 should they remedy the defect by reëlecting him? No, because he was an "unfit" person, a fact which had not been alleged when he was before them for election. The proposition to bring him for trial before a General Council was rejected on the ground that only heresy could justify the trial of a pope, and furthermore that only a pope could call a council and give validity to its action. Two months later at Fondi the thirteen ultramontani withdrew their allegiance from Urban VI and called upon Christendom to do the same. They demanded that he should resign the Papacy and entered into relations with the states of Europe, especially with France, to secure outside support. From France they received such encouragement that in the month following they proceeded to elect one of their number, Count Robert of Geneva, as Pope Clement VII. Thus, for the first time since the Cardinal College had been in operation occurred the greatest evil possible to the papal system, the dreaded accident of schism. It was the result not of any single error in an election nor of the circumstances of any given moment. It was the inevitable consequence of the electoral method itself the moment it got into the hands of any well-defined group of men with interests they were ready to promote at all hazards. Given a French party in the cardinalate large enough to control elections, and there was no reason why the rotation of the machine should not go on forever turning out French popes, who in their turn would keep on appointing French cardinals. The evil had begun with Celestine V in $\mathbf{2 9 4}$, and now schism was the result.

If, however, from one point of view schism was the worst of evils, from another it was the greatest of blessings. It was indeed a great shock to the peoples of Christendom to see the authority to which they had been accustomed to look in spiritual things 
now hopelessly divided by the very working of its own constitution. At first it seemed as though here were merely a question of canon The Great Schism and the Nations law, and both sides did their best to show by every kind of learned argument that its claim rested upon a perfectly canonical basis. A flood of pamphlets from the ablest pens in Europe was poured out; embassies passed between the rival curiae and the courts of all the princes in Christendom. Before long Europe found itself divided into two opposing parties, each accepting the authority of one of the contending popes. These parties came to be known as the "Roman obedience" and the "French obedience." The position of the several nations was doubtless determined very largely by political conditions and especially by their respective relations to France. The French government of Charles $\mathrm{V}$ had put itself from a very early moment into communication with the seceding cardinals and had, more or less openly, encouraged their election of a new pope with French connections. There were great doubts among the French clergy, and the University of Paris, the principal authority in Europe upon all ecclesiastical questions, had long withheld its assent. The decided action of the king, however, carried all before it, and France was definitely drawn into the "obedience" of Clement VII. This attitude of France was almost necessarily decisive for both England and Germany. The "Babylonian Captivity", of the Papacy in France had been bad enough; if there was a choice between a pope at Rome and a pope in France, it was almost inconceivable that these, her most important political rivals, should not decide against the French interest. On the other hand, Scotland, still engaged in a bitter conflict with England, found its safety in the French alliance; Naples took the same side from the first, and so did the states of the Spanish peninsula - Aragon, Castile, and Portugal - after considerable hesitation. Roughly speaking, then, we may say that the Latin peoples except the Italians followed the French obedience, the Germanic peoples the Roman. 
The longer the Schism lasted, the less important became the questions as to the election of Urban VI and the justification of Plans to heal the secession of 1378 . The discussion now shifts to the Schism:

(a) Resignation the best means of breaking the Schism, which both parties, of course, deplored. Our interest in this discussion is in the revelations it makes as to the general feeling about the nature of papal authority itself. If each pope was, as he claimed to be, lawfully elected, then, strictly speaking, he had no choice but to maintain his position. He could not resign. A conceivable method would have been that one pope should refrain from appointing new cardinals, that his successor should do the same, and so, by the natural course of things, a pope would some day be without cardinals and at his death there would be no successor. This would have healed the Schism by a strictly constitutional process. Instead of this, however, both popes went on appointing cardinals quite as before, and in all other ways showed every intention of prolonging the situation indefinitely. Clement, as was natural, took up his residence in Avignon. As to other methods of healing the Schism: the favorite proposition, repeated at intervals during the thirty years from ${ }^{1} 378$ to 1408 , was that both popes should withdraw at once and that their united cardinals should then proceed to a new election. Several popes consented to this plan, provided, of course, that the rival of the moment would do the same. At the critical moment, however, something always occurred to prevent this result.

Another plan, much more interesting and far-reaching in its scope, was that of a General Council, at which the whole situation (b) General could be freely discussed and measures for relief council taken in coöperation with the nations. The difficulties in the way of a council were manifold. The popes themselves dreaded nothing more than a free and general discussion of religious matters, in which they should not play the decisive part. The clearer heads among the cardinals, too, had from the outset seen in this proposition a serious menace to their influence. Where, again, 
was the authority which could decide that a council was necessary? Who had the right to call it? Who should preside? Who would guarantee its orderly conduct? Who had the right to attend? How should its decisions be enforced? All these questions were raised and answered in different ways at many crises of the Schism, but the difficulties were so great that only in desperation could the powers of Europe, lay and clerical, be brought to action along this line.

Our interest is to notice the gradual development of the idea of a church in which the Papacy should be limited by some body Continuous with definitely prescribed constitutional powers. The Demands of cardinals of both obediences were continually trying the Cardinals to gain such limiting powers for themselves. Their demands were, as we have seen, generally formulated on these four points: first, to divide fairly with the pope the revenues of the Holy See; second, to be consulted by the pope upon all matters of papal administration; third, to have a voice in the choosing of new cardinals; and fourth, that the pope should, with all diligence and even at the sacrifice of the Papacy for himself, promote in every possible way the restoration of unity in the Church. These demands were renewed at every election. They were embodied in the agreements which were made among the cardinals before they entered into the conclave, and these agreements were sworn to with every possible solemnity, only to be broken each time by the person chosen just as soon as he found himself pope. The example had been set by Urban VI. Although he had been deserted by the cardinals most likely to make trouble for him and had appointed a new college more to his mind, he seems to have learned nothing as to the best way of getting on with them. The result was that these very cardinals of his own were soon engaged in conspiracies to defend their rights. We find them proposing to put the pope under the guardianship of a commission of cardinals as a man incapable of managing the affairs of his office. He replied by arresting and imprisoning six of them, 
and as things came to look more dangerous for himself he had five of these murdered in their prison.

Clement VII followed a different policy. He was a man of larger views and was above all else eager for the support of the The French princes of Europe. During his reign of sixteen years College he appointed thirty-six cardinals, and a majority of these were plainly chosen in deference to the wishes of political powers. Sixteen of them were lawyers, most were in the prime of life, and but few were relatives of the pope or of former cardinals. Their number was always above the traditional twenty and rose at one point to thirty-four. Clement's successor, Benedict XIII, followed this example. He kept the number high, appointed for political reasons, - as, for instance, six at the demand of the king of Aragon,- and tried, very much in the manner of Urban VI, to manage affairs without the aid of the college. As between the two obediences it may be said, perhaps, that the French represents a larger view of the constitutionally limited papacy, while the Roman clung more closely to the tradition of a college, small, mainly of Italian blood, and closely identified with the pope in the administration of affairs.

The decisive thing, however, is that in both colleges there was growing, as time went on, a stronger and stronger feeling that Outside Pres- the question of Union was the one all-important consure for sideration. This feeling was strengthened by the apUnion

pearance, from time to time, of learned treatises by recognized legal authorities, in which the question was discussed from every possible point of view and all of which were pointing more and more to the conclusion that in the cardinals, and in them alone, lay the hope of a united church. These trained scholars pointed out that there must be some lawful means for doing what every interest of the Church demanded, and this principle soon came to be put in the converse form, - that whatever process would produce this all-desirable result must be a lawful process. The principal source of these academic demands for 
union was the University of Paris, and the effect is most strikingly seen in the attitude of the French government. The two most important of these Parisian scholars were, rather significantly Conrad of in view of later developments, Germans. Conrad of Gelnhausen, Gelnhausen, of whose early life we know little except c. $1320-1390$ that he was made a Doctor of Theology in Paris about $135^{8}$ and a Doctor of Canon Law in Bologna about 1370 , was called upon by King Charles V of France in 1380 to give an expert opinion on the question, How might the Schism be healed? In his reply, under the title Epistola concordiae, he recommends the method of a general council, and, anticipating the difficulty of persuading either pope to call a council to investigate himself, he brings out especially the principle that to secure a valid council the call by the pope is not necessary. His definition of a council is interesting.

"A general council is the assembly in one place of many, or a majority (plurium), of persons properly (rite) summoned, representing or standing in the place of the various states, orders, sexes and persons of all Christendom, who desire and are able to come or send, for the purpose of discussing (ad tractandum) in regard to the common good of the universal Church."

The Church, he goes on to say, has two heads, Christ and the pope, but Christ alone is the necessary and permanent head. The Church can exist without a pope. A schismatic (and therefore heretical) pope may be judged by the whole Church in council.

Heinrich von Langenstein, a somewhat younger contemporary of Gelnhausen, vice chancellor of the University of Paris, illusHeinrich von trates the gradual progress from discussion about the Langenstein, rights and wrongs of the elections of 1378 to the 1340-1397 (?) larger questions of public policy involved in the fact of schism. He wrote, perhaps a year before the work of Gelnhausen, a treatise which he called Epistola pacis. It is a dialogue between an Urbanist and a Clementist and is largely occupied with 
the claims of the rival popes. Already, however, Langenstein is beginning to be concerned with the practical problems of union (pax-concordia). He is convinced that a council will have to decide and proposes several ways of having it called, putting them in the order of desirability: (1) by both popes; (2) by persons whom they may select ; (3) by the existing cardinals ; (4) by the clergy 'as a whole. Like Gelnhausen he finds his definition of a council in the idea of a voluntary representation by right, with the approval of the temporal powers and participation of the laity.

Two years later in another treatise, Epistola concilii pacis, Langenstein shows notable progress. He drops all reference to the origin of the Schism and brings the idea of the council into the foreground. Still more important is his declaration now that the council is a necessity not only for unity but also for Reform. It is the first time that this fateful combination of ideas appears in contemporary discussion. It was clear to every one that if a council should once come together to consider the question of the Schism, its action would never stop there. Criticism of the papal administration had been plentiful and vigorous for a hundred years. Only just now from England were coming the echoes of that battle raging about the person and the teaching of John Wycliffe. Langenstein ends his treatise with a long survey of the evils existing in the Church and demanding reform.

The resemblance of this group of ideas in general to the doctrines of Ockham and Marsiglio nearly two generations earlier is evident. The Papacy is a useful institution and is not to be given up; but it is only one of the several elements which constitute the Church. Superior to all church organisms is the voice of the Church itself, speaking through a representative assembly. Henceforth the issue was clear. The Church must free itself from the corruptions that had been fastened upon it during the French residence or it must face an open inquiry which would bring out its weakest points and might well lead to a revolt that would transform its very structure. 
The French government supported the French papacy as long as it could do so with any reasonable hope thai it would prove French Gov- itself capable of ending the Schism and so proving its

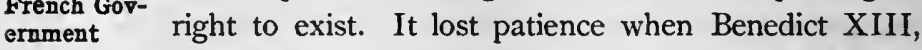
deserts afict xiI four years of shuffling, showed plainly that he had no intention whatever of carrying out his promise to work in every way for union. Supported by a five-sixths vote of the French clergy, King Charles VI in 1398 formally withdrew his allegiance. Eighteen out of Benedict's twenty-seven cardinals followed suit, withdrew from Avignon, raised an army, and shut up the pope in his palace, where they kept him in a state of siege for nearly five years. Only the ambitious schemes of the king's brother, Louis of Orleans, led to a partial reconciliation. The Roman pope Boniface IX died in $\mathrm{I}_{404}$, and his successor, Innocent VII, in 1406 , but on neither of these critical occasions did Benedict XIII take the step to which he had pledged himself by the most solemn obligations. He was ready to make advances whenever the circumstances were such that these advances were likely to lead to nothing, but he would not take the final step of giving up the fight.

Meanwhile the union sentiment had been gaining ground among the Roman cardinals, and their election of the aged Venetian, Gregory XII, Angelo Corrario, who took the name of Gregory XII, 1406-1415 seemed to be a pledge of fulfillmerit. Gregory bound himself, as his predecessors had done, but the temptations of the office proved too strong for him. Nothing was farther, apparently, from his thoughts than the idea of abdication. He began at once a career of nepotism that could mean only that he was looking to the Papacy as a means of making the fortune of his house. $\mathrm{He}$ was as ready to negotiate as was his rival, but when it came to action the balance of good intentions, if any, was in favor of Benedict. The union cardinals on both sides moved heaven and earth to bring these two obstinate old men together for a personal conference, but there was always some reason why they could 
never quite come to the point. They got within a few miles of each other in Italy, but when things began to look serious for both, Benedict sailed away for Spain, where, deserted by all his real supporters, he continued for many years to appoint cardinals and maintain the state of the papal office, without any of the reality of its power. Henceforth he ceases to be a factor in the Schism, except as a mere dead weight that must be removed.

The real representatives of the Papacy were now the union cardinals of both sides, who were at last prepared to take the Council of step they had so long been contemplating, - to call a Pisa, ${ }_{409}$ General Council of the princes and prelates of Europe and, acting in harmony with this body, to choose a new pope, who should stand, above all else, for the one essential principle of the union of the Church. With this council, which took place in Pisa from March to August of the year 1409 and which resulted in the election of Pope Alexander V, the Papacy enters upon a new chapter of its history. Henceforth it could not be an exclusively Roman or Italian institution. Europe as a whole had for the first time declared its right to exercise the kind of control over the Papacy which the old Empire had once exercised, and this right was never to be lost sight of again. The refusal of the Papacy to accept this method of limitation was, more than anything else, the cause of the Protestant Revolution a century later. 


\section{CHAPTER IV}

\section{THE RISE OF A MIDDLE CLASS}

\section{POPULAR MOVEMENTS IN THE NORTH}

What has been said of the democratic movement in Italy is truc with certain changes of emphasis, in the other countries of Europe. Rise of the Even where, as in England and France, powerful People monarchies were steadily gaining in their determined fight against feudal and clerical privilege, it is evident from early in the thirteenth century that a People is rising into view. It begins to demand rights and gets them; it organizes under leadership as able as any its enemies can put forward against it. It learns to bear arms and to use them in gaining its point. Even if it does not, as it did in Switzerland, become the actual governing power, it teaches governments that they can no longer afford to overlook it or to do without it.

We have seen that the growth of popular governments in Italy rested not upon any theories whatever as to rights of the people The "Nomi- but upon immediate and practical necessities. The nalistic" same may be said of similar movements elsewhere, Philosophy but it was not long before theoretical principles were found by which what had happened could be defended and explained. The most important basis for all such principles is to be seen in the great change which, from the beginning of the fourteenth century, began to come over the minds of men in their ways of thinking about all speculative subjects. Down to that time there had prevailed everywhere a method of thought called "Realism," which taught that so-called "general ideas" were "real" and that individual things, persons or what not, were 
only specimens of these "really" existent ideals. For example: "Empire," "Papacy," "kingdom," "Church," were the real existences "in the mind of God," and the persons who made up these institutions at any given moment were only accidentally, as it were, used to illustrate them. Opposed to this "Realism" there had early been formulated another view called "Nominalism," according to which these generalities were only "names," mere inventions to classify together actually existing individual persons or things. For example: "Empire" meant nothing but a quantity of persons organized together under the imperial government; "Church" meant only the individuals who chose to associate for religious purposes under this form; "Papacy" was only a name for a system of church government chosen or accepted by the individuals who came under it. These two schools of thought had come into collision early in the twelfth century, but Nominalism had then been utterly defeated, so completely that for two hundred years we hear no more of it. Now, however, in connection with the quarrel between the Empire of Ludwig the Bavarian (1314r347) and the Papacy of John XXII (1316-r334) we find a group of scholars at the court of Ludwig who were reviving in both speculative and practical matters the nominalistic teaching.

Chief among these were two men who, each in his own way, were to be leaders in the forward movement of political ideas for

William of Ockham and Marsiglio of Padua the next two hundred years. William of Ockham was an English Franciscan, Marsiglio of Padua an Italian layman. They were fellow teachers at the University of Paris and were doubtless personally acquainted, but it still remains a question which of them, if either, had the stronger influence upon the other. They were united in the common cause of defending the emperor Ludwig the Bavarian against the attacks of Pope John XXII, and in Ockham's case there was the additional interest in the defence of the Spiritual Franciscans. Both were moved by the same general ideas as to the nature of human society and the consequent principles of wise government. 
The distinction between them is that Ockham was primarily a philosopher trying to apply his general principles to human institutions, while Marsiglio was a trained physician and theologian without, so far as we can see, a definite philosophical system. It is of interest to note that Pope Clement VI in condemning Ockham declares that he had taught Marsiglio his worst errors.

Ockham's most important contribution to the political discussions of his time is his "Dialogus," planned on a great scale Ockham's and probably finished, but certainly not complete as "Dialogus" we have it. The conversation is between a curious scholar and his "Magister," who with much display of reluctance consents to answer the scholar's questions so far as his poor learning will allow. The main point of the demonstration consists in proving that the structure of the Church under papal government is a matter of human invention and hence not essential to a true conception of the Church. Ockham shows by historical evidence that popes and even councils have been in error. Even the whole body of the clergy may err; and what then? There is then an appeal to Christian laymen; if these fail, then to Christian women, or even to baptized children! In other words, in his intricate and fantastic fashion Ockham means to say that the essence of the Church is in all the individuals who compose it, not in any one order or institution. Any part of it may go wrong; but the Church as a whole cannot go wrong. Every individual has, therefore, his rights as. an essential part of the whole.

The most practical application of this idea is seen in Ockham's definition of a council. Admitting that under normal conditions

Ockham's

Theory of the Council the pope has the right to call a council, he declares that in the case of a heretical pope the council may assemble of its own motion, and he makes some extraordinarily modern suggestions as to how this might be done. He proposes that every parish send delegates to a diocesan convention which shall then choose deputies, both lay and clerical, to the council. Even women are not to be excluded; for, he says, in 
matters of faith there is no difference between lay and clerical; male and female. We see here how the thought of Ockham proceeds always from below upward, from the individual to the class or the institution. That is the nominalistic process wherever we find it, and one sees readily how destructive it must be to all claims of authority which are not based upon the idea of a voluntary representation of the great body of individuals.

Marsiglio of Padua did not, so far as we know, profess the nominalistic philosophy in any formal way, but his whole attitude Marsiglio toward the public questions of his day is in complete of Padua harmony with that mode of thought. He illustrates how this change in the way of looking at the world and life was affecting men's views of particular questions in the fourteenth century, precisely as the doctrine of development has been affecting the views of the generation just past upon similar questions of social, religious, and political import. If Marsiglio, like Ockham, appears as the "hired man" of the emperor Ludwig, employed to defend him against the papal assault, it is quite certain that his opinions were his own, formed long before and placed at the service of the emperor because they were what he needed at the moment.

These opinions are expressed in-Marsiglio's principal work, the "Defensor Pacis," written probably about the year 1324-1325. It The "Defen- is hardly too much to say that this is the most remarksor Pacis," able and, in its consequences, the most important lit1324-1325 erary product of the early modern period. Though written still in the ponderous and intricate style of mediæval scholastic authorship, its course of argument is singularly direct and simple. As compared with Ockham it is almost readable. The modernness of its conclusions is at times startling and explains why this book was regarded with the utmost hostility by the conservative and used as a continuous source of inspiration by every advocate of human liberty from Wycliffe to Luther. Its peculiar title, "The Defender of the Peace," is explained by the author as indicating his main purpose. He wishes to show the 
real cause of the confusions from which the world is suffering. Peace is the normal condition of society. Ancient writers have sufficiently shown the ordinary motives that lead to disturbances of the peace; but now a new element unknown to the ancients has come in as the chief cause of social confusion, and that is the Church. He proceeds then to analyze in great and often wearisome detail the nature and functions of organized society, its division under civil and religious governments, and the relations of these to each other.

In his definition of the state Marsiglio follows mainly the formulas of Aristotle. The state is a natural organism growing out Definition of of the family. The several classes of society correthe State spond to the several needs of production, defence, and spiritual guidance. "Law" is such regulation of society as has a praeceptum coactivum behind it. Government is for the purpose of exercising this power of coercion. But now - and here is Marsiglio's main point - the source of law is the people. Government derives its authority from the consent of the governed. Every man, however dull, has a right to his opinion. The best way to make laws is to have them proposed by wise and experienced men, discussed by all, then returned to the wise men as representatives of all, to be reconsidered and worked out into practicable form. Marsiglio's favorite word for the people is legislator, the "lawmaker." The best form of government is the monarchy, not hereditary, since heredity gives only physical continuity, but elective, for election secures a continuity of character. And yet Marsiglio distinctly repudiates the mediæval ideal of a single monarchy for the whole Christian world as but lately presented in Dante's "De Monarchia." On the contrary, he thinks that differences of race, climate, and custom may well require diversity of government. In other words, Marsiglio is prepared to champion the principle of the modern, independent national state, the essence of which is a body of citizens in willing subjection to a government of their choice. 
In much the same way the "Defensor Pacis" analyzes the nature and function of the Church. The Church is the community of Definition of believers, and in this sense all believing Christians may the Church be called viri ecclesiastici. Here is the Reformation principle of the "priesthood of the Christian man." There can be nothing higher than the Christian character; whatever goes beyond this is a matter of function, not of character. The priesthood, including the Papacy, exists only to teach religion and to administer the sacraments, and for nothing else. The priest is the claviger of God and gives absolution only as the turnkey of an earthly judge carries out a judicial sentence. Even heresy is to be judged by the Church only as to the fact; its punishment belongs to the state and even this only in so far as it is an offence against the secular law. Priests themselves are subject to the civil law, and punishments for them ought to be the more severe because they are better informed. All clergymen, secular as well as regular, are subject to the rule of "evangelical poverty," and should be forbidden to hold property except in so far as is necessary for their maintenance. As to papal supremacy, Marsiglio denies every stage of the Petrine argument. The Papacy rests upon historical facts and has grown gradually to its present portentous pretensions. The papal office is useful, but it should be restricted to certain presidential functions. The pope is to notify the "lawmaker" or its representative, the emperor, of the need for a council, over which he may preside; he may make propositions to it, may publish its decrees and punish offenders against these with spiritual penalties only. The actual call for a council may proceed only from the Christian, temporal "lawmaker" or its representative, who may define membership in the council, watch over its procedure, and punish violations of its decrees. If now we place all these ideas together, we see in Marsiglio of Padua the clearest outline of what are commonly considered purely modern notions of society. Sovereignty of the people expressed through representative rulers; separation of Church and state; evangelical poverty as the rule 
for all clergymen; supremacy of the state in all human affairs; and finally, so far as could be expressed in mediæval terms, freedom of individual thought. We can readily understand that Marsiglio and his book were equally unwelcome to established powers, especially to the Church. He was personally protected by Ludwig, who found him useful, but his book was repeatedly condemned as a most pestilent breeder of heresies. Marsiglio, as a citizen of Padua, had learned to believe in the doctrine of the right of the people through seeing its practical working in the Italian democracies. The question was whether this doctrine could be made to work in other countries where the conditions were essentially different from those of Italy. As to France or England it was too late for a democratic revolution, but elsewhere there was still a chance. Wherever there was no strong central power, wherever there was room for the people to act, they acted and, to a greater or less extent, succeeded.

\section{SwitzerLaND}

What is now Switzerland was at the close of the thirteenth century a group of feudal dependencies lying between France, Italy, Switzerland and Germany and generally forming, without any. in $\mathbf{3 0 0}$ common name, a part of the imperial territory. It was a land chiefly of peasants living according to long-inherited feudal traditions under local lords who were mainly of common blood with their subjects and who owed an easy allegiance to the remote and always necessitous Empire. Cities were few, but Basel, Berne, Lucerne, and Zürich were already important markets and centers of a considerable industry. Politically the land was without unity, but already a sturdy race quality was developed, which wanted only an outward impulse to bring it at once to self-consciousness and rouse it to determined political action.

This impulse came from an attempt on the part of one of the most important Swiss landholders, the count of Habsburg, to compel the Forest Cantons, Uri, Schwyz, and Unterwalden, to 


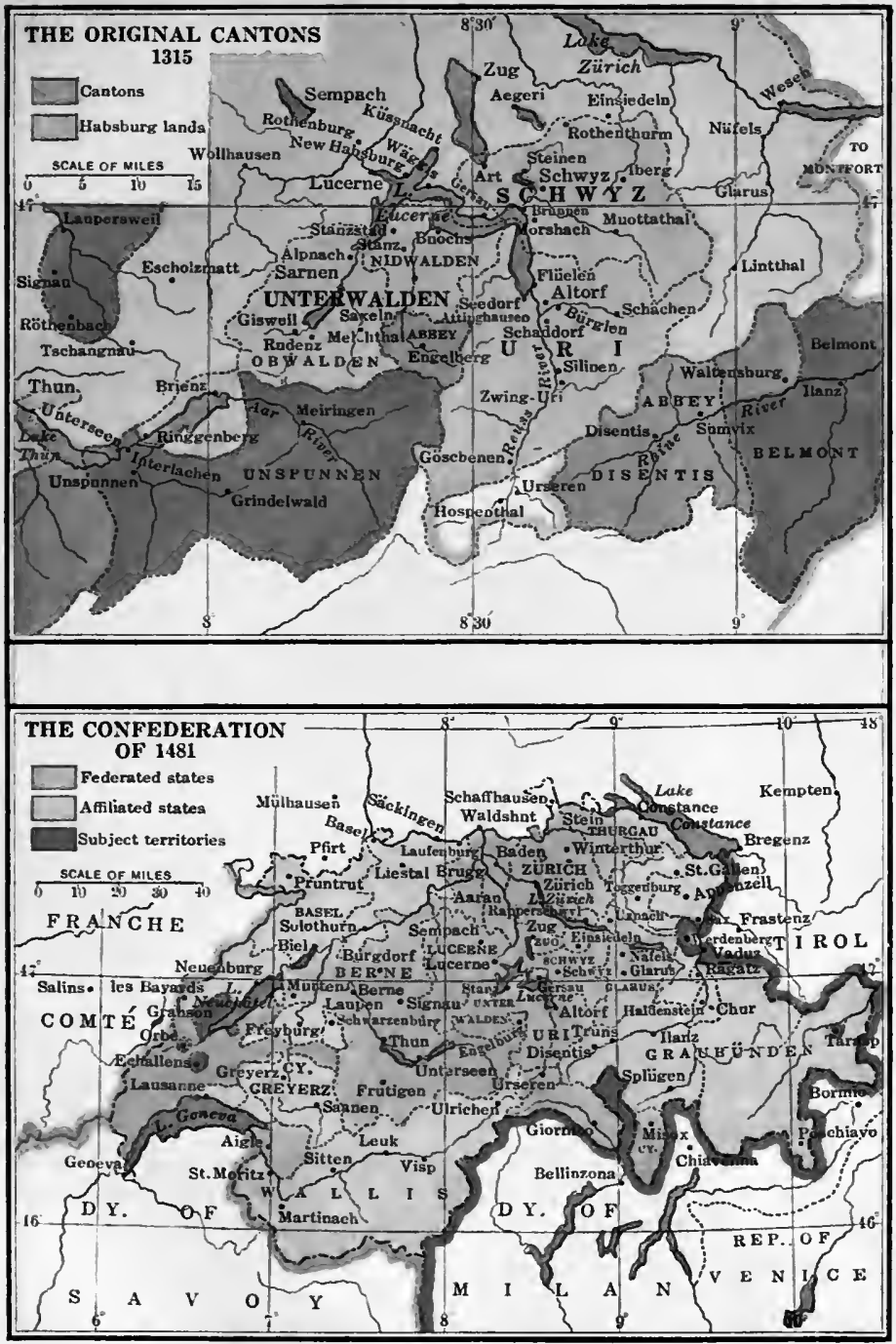

THE SWISS CONFEDERATION 


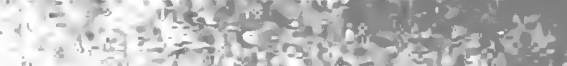
I.

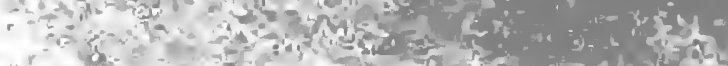

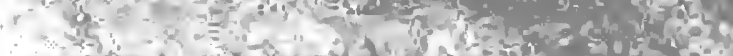

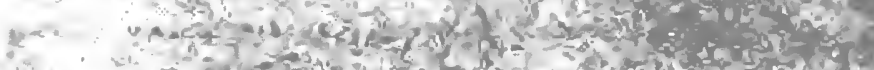

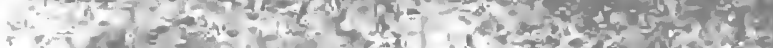

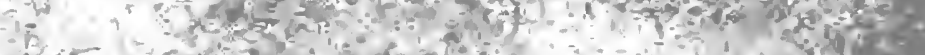

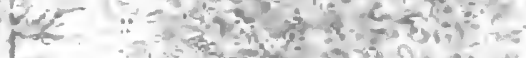

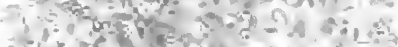

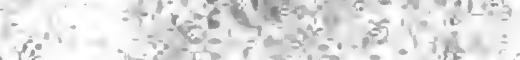

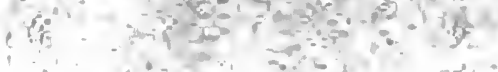


acknowledge his overlordship as a territorial prince. The claim of the Cantons in their long and desperate struggle for liberty The Habs- was that whatever "mediate" rights might once have burg Claim existed over them had been abolished by a charter of to the Forest the emperor Frederic II of the year I $240,{ }^{1}$ whereby
Cantons

they had been declared reichsunmittelbar, that is, subject only to the emperor. They were to be ruled by imperial governors (Vögte), but were to be free from every other jurisdiction. This privilege was a blow aimed especially at the counts of Habsburg, who, on various pretexts, were claiming rights of sovereignty over the "valleys." The complication became greater when the count of Habsburg became also emperor. Rudolf of Habsburg (1273-129I) was a prudent and capable ruler, chiefly occupied in extending his power over the Austrian lands. For a generation before his election he had been contented to respect the independence of the valleys and even to serve the Empire there as imperial Vogt. Now, as king, he took no direct action towards establishing a hereditary lordship there, but it was evident that such a combination of feudal and royal (imperial) powers was a menace to the valleys by the very nature of the charter of Frederic II which bound them to the Empire. For who should say at any given moment whether rights of government were really exercised in virtue of imperial or of local, hereditary sanction? Were given rights $\mathrm{Habsburg}$ rights or imperial rights? If they were Habsburg rights, then they passed by inheritance from one Habsburger to another. If they were imperial rights, then they

1 The essential part of the decree of Frederic II is as follows :

"Since, therefore, you have of your own free will chosen the lordship of ourselves and the Empire, we embrace your loyalty with open arms and repay your sincere affection with our entire favor and good will, receiving you under the special protection of ourselves and the Empire; so that at no time will we permit you to be alienated or withdrawn from the sovereignty or the possession of ourselves and of the Empire, granting to you security and such full enjoyment of our gracious favor as a kind sovereign should pour out upon his faithful subjects." 
passed away from Habsburg hands whenever the emperor was not a Habsburger. That was the political question out of which the Swiss Confederation with its glorious history was born.

Within a fortnight after the death of Rudolf (I29r) the Three Cantons bound themselves by an eternal compact, wherein, "conThe "Per- sidering the dangers of the times," they agreed to petual Com- stand together in peace and war. Every man shall pact" of obey his lawful master in all lawful ways, but they r291

will admit no ruler who has bought his place or who is not of their own country. In case of disputes among themselves "the most prudent among the confederates" shall give judgment, and the rest shall enforce it. We see here, though in crude and prinitive fashion, the determination to found a state, without, it is true, cutting loose from the ancient formal relation to the Empire - even the Italian republics did not do that - but with every consciousness of the solemn meaning of what they were doing. It is the same spirit which three hundred years later animated that little band of state-builders in the cabin of the Mayflower.

Events proved at once how very real the danger was. The election of Adolf of Nassau was a direct blow at the Habsburg The Cantons interests. The Cantons, true to their declarations, against stood by the elected emperor, and in I 297 gained Habsburg, 1298-1308 from him a new confirmation of their "immediacy." $\mathrm{He}$ addresses the men of Uri as "free men, who are bound to respect no authority but ourselves and the Empire." "Freedom" meant, we understand, not absolute independence, but Reichsunmittelbarkeit; that is, freedom from all "mediate" control, a direct relation to the Empire. Within a few months Adolf was killed in battle, fighting for his crown against Albert of Habsburg-Austria, and the victor was recognized by the Empire as its head. Once more the Cantons were put to the test. According to their own charters the emperor had the right to appoint as Vögte whomever he might choose. Constitutionally 
there was no check upon him; but it was precisely against this danger that the Cantons had provided in their perpetual compact.

It is difficult at this point for the historian to hold the balance between the accounts of Swiss patriotic writers on the one hand Causes of and the witness of documents as to the working out Swiss Revolt of strict feudal law on the other. The early Swiss historians naturally tried to show that the revolt against Austria was occasioned by oppression and justified on general principles of human liberty. A more careful study of documents has led more recent writers to doubt whether there was much, if any, such oppression and to seek other motives for what undoubtedly happened. It can be reasonably well proved that during at least the first half of King Albert's reign the valleys were governed by native officials, whose names are a sufficient guarantee of their loyalty to Swiss interests. After that the case is not quite so clear, but we may fairly accept the situation dramatized in the splendid story of William Tell as representing what the Swiss patriots of the first decade of the fourteenth century really felt. The American colonies were not oppressed by England beyond what they could easily have borne; but they improved every new demonstration of English authority to justify them in doing what they had long since made up their minds to do; namely, to become a state by themselves. So the Swiss cantons, determined to govern themselves, watched their opportunity, themselves struck the blows that made them free, and then justified their action by the injustice of their former rulers. The alleged tyranny of the Austrian Vögte is the companion-piece to our Stamp Act and the "penny a pound upon tea." These were the occasions, but the cause in both cases was the same: the unconquerable spirit of free men united not to destroy but to build up a social order of their own.

To find the conventional form of the story of Swiss emancipation from Austrian rule, we need go back no further than to the 
patriotic Chronicle of Agidius Tschudi, who in 1570 collected with pious care the scattered bits of legend and historical record already Origins of existing and wove them into the compelling narrathe Confed- tive which until quite recently was generally accepted eration as the true account of the origins of the Confederation. Tschudi's recital was the more convincing because he knew how to conceal all the difficulties of his problem. He worked out a rational chronology, he had no doubts about the personalities involved, and was quite sure of the motives of the leading actors. His account has been riddled at every point by modern criticism, but the essential elements of it still remain as a faithful picture of the political situation in the Cantons just before and just after the turn of the century. The whole history of the Habsburg policy makes it beyond question that the valleys could expect nothing from Austria but gradual absorption into its territorial complex. The little description of the "Rütli Council" in the "White Book of Sarnen" (1470) gives us the clearest picture of how this peasant conspiracy against the might of Austria was conducted.

"And so the three came together, the Stauffacher from Schwyz and one of the Fürsts from Uri and one from Melchi in Unterwalden, and each made his complaint to the others, and they took counsel and swore an oath together. And when the three had sworn their oaths, they sought and found one from the Niederwald who swore with them, and they found now and again in secret others whom they added to themselves and bound by an oath to faith and loyalty and to pledge life and property to defend themselves against the lords. And when they had anything to plan or to execute they came at night by water to the foot of the Mythenstein to a place called 'Rütli.' There they held council and each brought trusty men with him, and this they did for a long while and always in secret, and at that time they met in no other place, but only at Rütli." 
The result of these long-continued preparations was, no doubt, an uprising of the people of the valleys around the Lake of the The Swiss Four Forest Cantons, the breaking of some of the and Albert Habsburg castles, and the driving out of such of of Habsburg the Austrian governors as were still there. It is altogether probable that these events were associated with the death of King Albert in 1308. He was murdered by his nephew, John of Swabia, in a purely private quarrel regarding certain lands in Bohemia which the young man believed were unjustly withheld from him. There is no reason whatever to suppose that the Swiss were in any way implicated in this crime, but it was impossible that they should not benefit by it. The ten years of Albert's reign were filled with attempts to utilize his position as emperor to strengthen his hold upon the widely scattered Habsburg possessions. In the case of the valleys he had steadily refused to confirm the charter of Frederic II and its reaffirmation by King Adolf in 1297 , and this is the most tangible proof we have of his fixed opposition to the idea of Swiss independence.

It was, therefore, a matter of vital importance to the Swiss that a new turn in imperial affairs carried the Empire once more away Henry VII from Austria. The election of Henry of Luxemburg and the (1308-1313) opened up new possibilities of imperial Cantons support against Habsburg aggression. Within six months Henry gave to the Forest Cantons a formal renewal of all their former privileges and added a charter of exemption from all foreign jurisdiction except that of the emperor. The federated Cantons were thus definitely constituted as an estate of the Empire. An imperial Vogt was sent into the country to administer imperial law, as far as that went, and to protect the Cantons against possible violence from the side of Habsburg. On the other hand, it soon became evident that Henry's interests were to be in Italy rather than in the North. To safeguard himself at home while he launched out into his ill-fated Italian policy, he was forced to stand well with Austria, and plans were well 
under way for a legal adjustment of Austrian rights in Switzerland which might have turned out unfavorably to the claims of the Cantons, when suddenly the news of King Henry's death in Italy ( 1313$)$ threw the whole matter into confusion again.

Once more the problem of an imperial election brought out all the old Austrian and anti-Austrian antagonisms. In the divided

The Swiss support Ludwig the Bavarian election of 1314 the Cantons were naturally drawn to the side of Ludwig the Bavarian. Frederic of Austria, the candidate of the minority, did not accept the result of the election and for eight years kept up an intermittent warfare precisely as his father Albert had done against Adolf of Nassau. Ludwig on his side sought at once the support of the Cantons. He sent them a friendly letter in the early spring of 1315, announcing a Diet at Nuremberg for the approaching Whitsuntide, "to curb the restless arrogance of the dukes of Austria, who on every hand are disturbing the public peace and prosperity." It would, however, be wrong to think of the struggle between the Swiss valleys and Austria as only an incident in the larger conflict for the Empire. Even before the recent election it had become increasingly evident that these sturdy mountaineers were taking the aggressive in many ways of doubtful legality. For example, there had been a long history of friction between the canton Schwyz and the neighboring monastery of Einsiedeln, which was claimed as an Austrian possession. A long series of nagging raids into the property of the monastery answered by blows of the spiritual weapons on the part of the worthy monks culminated, in the winter of 1314 , in an attack of more than usual violence by the Schwyzers, in which the church of the brethren was violated and several of the monks carried off to Schwyz, put through a sham trial, and set free. The monastery succeeded in persuading the bishop of Constance to excommunicate the men of Schwyz, and Frederic of Austria, in his capacity as minority emperor, laid them under the ban of the Empire as well. It seems clear that neither the one nor the other ban mattered greatly to the Schwyzers, and 
they were speedily set free from both by the all-sufficient Ludwig. Still it is evident also that this aggressive attitude of Schwyz turned the sympathies of many of its Swiss neighbors to the side of Austria and seriously affected the course of events.

A crisis was approaching, and the Cantons were preparing to resist an attack which they had certainly done everything to pro-

Bostilities

voke. The war of documents and proclamations was with Frederic at an end. On both sides we feel that the last resort of Austria of force was inevitable. The battle of Morgarten was the explosion that followed all this gathering of inflammable material. The Schwyzers had already begun important defensive works in the passes leading from Austria through the mountains, and Duke Leopold, acting in place of his brother Frederic, had been getting together a considerable force, mainly of knights and men-at-arms, fifteen or twenty thousand of them. Recruits joined him from all the surrounding country. Even such cities as were afterward to be the sturdiest supporters of the Confederation Zürich, Winterthur, Zug, Sempach - lent their aid in this attempt to check what seemed to be the revolutionary proceedings of the Forest Cantons. The men of the valleys alone, sustained only by an unconquerable love of freedom and relying solely upon the God of Battles, went into this unequal combat. The army of Leopold, on the other hand, advanced as if on a pleasure trip, certain of victory and simply counting the plunder they were sure to find beyond the mountain wall.

The story of the battle of Morgarten, a worthy companion piece to those of Thermopyla and Lexington, is told by the monk John

Battle of of Winterthur, whose father was in the Austrian army Morgarten, and who, as a schoolboy, saw Duke Leopold with his November 15, broken columns returning, gloomy and silent, from the 1315

fatal pass. The Swiss, four hundred from Uri, three hundred from Unterwalden, and six to eight hundred from Schwyz, were well informed as to the point, just southward from the Lake of Egeri, where the main body of the Austrians were to enter the 
canton Schwyz. They held themselves concealed in the woods above the pass until the gay company of knights and city-soldiery, unused to mountain roads and already wearied with heavy climbing, had come out into a narrow defile on the border of the lake. Then on a sudden they hurled a shower of rocks and tree trunks into their midst and followed it up by a furious charge from above. It was rather a slaughter than a battle. The hardy mountaineers, armed with their terrible battle-axes and wearing iron spikes to keep their footing, simply cut the helpless knights to pieces or drove them into the lake. Some, driven to terror by the sudden assault, threw themselves into the water. The number of the killed is moderately estimated as equal to the whole number of the Confederates. Leopold himself led the retreat, and men said that from that day he never smiled again.

The day at Morgarten decided much more than the liberty of the Forest Cantons. It was a terrible lesson to every enemy Development of Switzerland, and it was the definite blow to all of the Swiss attempts to establish permanent feudal lordships in Confederation the mountain country. Henceforth, out of these crude to $\mathbf{1 3 3 3}$ and unpromising beginnings, a nation begins to develop. The spirit of courage and devotion that made Morgarten possible was a new augury for liberty in Europe. The immediate consequence was the renewal at Brunnen (1315) of the Perpetual Compact of $129 \mathrm{r}$, with certain slight additions emphasizing still more the common obligations and showing more distinctly the germs of an actual state. In a treaty with Austria signed three years later (1318) the Cantons appear as one independent power over against another. In repeated renewals of this treaty during the next five years no mention whatever is made of any sovereign rights of Austria over the Cantons, and a year later (1324) a charter of King Ludwig, renewed in $133 \mathrm{I}$, declared all property rights of the Austrian house within the valleys forfeited to the Empire. The result was an immense gain in uniformity of legal conditions and in a sense of common nationality. 
The further enlargement of the Swiss Confederation proceeds from the Forest Cantons as a nucleus. By 1353 five more mem. Battle of bers had been added: Lucerne in 1332 , Zürich in Laupen, 1339 1351, Zug and Glarus in 1352, and Berne in 1353. Each member preserved its local government and its peculiar institutions, but surrendered a part of its independent action in its outward relations in return for the support of its allies. Splendid proofs of loyalty and practical political sense showed how solid were the foundations of this slowly developing state. In i 339 Berne, threatened by a coalition of neighboring noblemen, called upon the Forest Cantons, who responded with a solemn sense of obligation: "Dear friends! A friend in need is a friend indeed; if you are now in need you shall find us your friends." They begged only that in the coming fight they might be placed over against the enemy's cavalry, — " they had learned about that at Morgarten!" The victory of Laupen (1339) secured forever the dominating influence of Berne in western Switzerland. In Austria the lesson of Morgarten had not been fully learned. At every point she lent her aid to the enemies of the Confederation and never lost an opportunity to revive the old antagonism of the noble against both citizen and peasant.

The accession of Berne settled also the question of political union between the eastern and the western parts of what we Union of

East and may now begin to call Switzerland. The battle of West Switzerland

Laupen was the expression of a common interest

between the free communities of the East and the West over against the feudal claims of a hereditary nobility, which in turn found its support in the larger territorial units, - such, for example, as Austria, Bavaria, Baden, or any of the Rhine principalities. Austria, with its manifold relations to the feudal sovereignties bordering upon Switzerland or even penetrating into the interior of the mountain state, was the natural nucleus for all the political combinations which in the generation between Laupen (1339) and Sempach (1386) form an unbroken 
series of trials of strength for the confederated Cantons. Every accession to the Confederation was a new menace to the vested rights of its feudal neighbors, and there can be no doubt that the temper of these allied towns and peasant communities, never very conciliatory, was growing less and less so with every increase of strength. It is an idle waste of time to search for "blame" or "provocation" when we are dealing with a profound social antagonism bound to break out from time to time into open conflict.

As the interest of Morgarten centers around the Forest Cantons and that of Laupen about Berne, so the interest of Sempach

Alliances with South German Cities gathers primarily about Zürich, the most important industrial and commercial city of northeastern Switzerland. This primarily commercial character of Zürich had brought her into close relations with the imperial free cities of the upper Rhine and Danube. In many ways their interests were the same. The aim of these German cities was, on the one hand, to protect themselves against aggression from the Empire and, on the other, to secure themselves also against the ever-active political machinations of the neighboring territorial lords who were generally supported by the restless intrigues of the Austrian policy. The situation became more intense when the management of the western Habsburg territories came, in 1379 , into the hands of Duke Leopold III, grandson of the Morgarten Leopold and a worthy successor of King Rudolf himself. By every device known to the diplomacy of the time Leopold gathered into the Austrian administration place after place along the Rhine valley, reaching westward well toward Burgundy and Alsace and including, for example, such critical points as Freiburg in the Breisgau and Basel. The German city leagues took the alarm and in 1384 sought the alliance of Basel as a federated member with themselves, thus depriving Austria of one of her most strategic points in the West. Next they began negotiations with the Confederation. The Forest Cantons were at first lukewarm, but Berne and Zürich responded promptly and entered 
into a compact for nine years with the Swabian and the Rhine leagues, and Lucerne agreed to stand by Zürich. In the elaborate deed of agreement between the cities south and north of the Rhine ( $1_{3}{ }_{5}$ ) every provision is made against attack from without, and it is clear that the expected aggressor could be none other than Austria.

Meanwhile the fortunes of Duke Leopold had suffered a serious reverse. The emperor Wenzel, of the house "of Luxemburg-

Provocations against Austria
Bohemia, for reasons quite foreign to the Swiss question, had turned against him, had deprived him of his place as imperial Vogt in Swabia, and declared him an enemy of the Church on account of his support of the French pope, Clement VII. This was, therefore, obviously the moment of all others favorable for the final decision of the Austro-Swiss struggle. The occasion was given by the continuous efforts of Lucerne to widen her citizenship and increase her territory at the cost. of Austria. Zug and Zürich followed suit, and once again there was nothing left for Austria but to fight. At first it seemed as if the German cities would stand by their agreements and join forces with their Swiss allies; but soon that lack of political sense we have elsewhere noted as characteristic of these German city leagues made itself felt. They were keen enough in defending their local commercial interests, but state-building lay quite outside their range of vision. They allowed the Austrian to argue them into inactivity and left the Cantons to fight it out alone as before. The most they would do was to attempt negotiations for a peace when there was no peace. Not for the last time were these South German communities to refuse to follow the lead of Switzerland into liberty and light.

The preliminaries of Sempach were in all respects a repetition of those of Morgarten, - fortification of mountain passes, destruction of scattered fortresses, and the formation of fighting troops on the side of the Confederates, and on the side of Austria a general summons for recruits from the feudal territories injured 
or likely to be injured by the expansion of Swiss democracy. The response to the call of Leopold III was widespread and Battle of enthusiastic. Especially from all through Upper GerSempach, many the fighting nobility flocked to his banner, glad July $9,3^{86}$ of the chance to strike'a blow at the upstart peasants and citizens of the mountain state. Leopold himself, a young, knightly figure, trained in all the exercises of the feudal gentleman, was the perfect embodiment of the spirit of mediæval chivalry. The decisive shock took place on the field of Sempach, ten miles northwest of Lucerne, where the odds of position were far more nearly equal than at Morgarten. The Austrian commander, not wholly incapable of learning by the experience of others, dismounted a part of his cavalry and stationed them, still with their heavy armor, in the front of the attack. From early in the morning until noon of a hot July day the battle raged around this impenetrable phalanx with apparent gain for the Austrians, when quite suddenly the fortune of the battle began to change. The knights worn out with heat and fatigue wilted under their weight of armor and began to waver. Duke Leopold, who with the rest of his mounted troops had held himself in reserve, came into the thick of the fight and performed prodigies of valor; but it was too late. Once again the superiority of light-armed infantry over cavalry or heavy-armed foot soldiers was amply proved. The gallant leader, true to his character of perfect knight, chose death upon the field rather than flight or surrender. The remnant of his army, without discipline or coherence, scattered in every direction, leaving weapons and equipment to the victors.

The day of Sempach marks for the Swiss patriot the highest point of his splendid tradition. Curiously incomplete in the conLegendary temporary record of details, it has been woven about Decoration with a wealth of half-legendary decoration. The fateful moment of wavering and recovery has been personified in the noble figure of Arnold of Winkelried, who threw himself upon the lances of the enemy, bore them to the ground, and thus 
"made way for liberty and died.". If, with William Tell, he must be consigned to the limbo of mythical characters, he represents none the less accurately a true historical situation.

The effect of the decisive victory of Sempach was twofold. On the one hand, it gave immense and immediate stimulus to Effect of all the hesitating elements of the mountain country. Sempach Berne, which since Laupen (1339) had shown little aggressive enthusiasm for the Swiss idea, now began vigorously to extend its power over neighboring feudal territories. In the East the canton Glarus, till then rather outside the movement of Swiss politics, became a new center of intrigue for the democratic as well as the princely parties. On the other hand, the enemies of Swiss liberty were roused to new activity. How far was this virus of democracy going to spread? That was the question pressing with especial force upon the German communities beyond the Rhine. They had been willing, up to a certain point, to recognize that the cause of the Swiss was their cause also. They too were trying out the principle of federation for the common weal. They too found their natural enemies in the territorial princes who surrounded them. Would they join hands across the Rhine in some permanent form of union with the rural and city communities which now for the third time and in decisive fashion had given proof of their capacity to act together as one civil organism, a democratic, federated state? Such a political union of the South German with the Swiss cities was, at the close of the fourteenth century, by no means an idle dream. The material elements, the common interests, were all present. It only remained to be seen whether the civic spirit in the two regions was the same, and the years $13^{8} 7^{-1} 3^{88}$ gave the final answer to that question.

For the moment the Rhine cities were ready, as before, only to act the part of peace negotiators, but the truce of four months which they brought about in October, 1386 , showed the direction in which affairs were bound to move. It was agreed that the confederates should hold during the truce " all the towns, fortresses, 
valleys, land and people" which they had taken from Austria during the Sempach war. The prolongation of this truce for

Battle of

Näfels, April 9, 1388 another year made it still more evident that the Confederation had no intention of giving up anything it

had once laid its hands on. The test came in the case of the canton Glarus, which, until recently under Austrian control, had come by the truce under the protection of the Confederation. The moment the truce expired (February, 1388) Duke Albert III, brother of the late Duke Leopold and now the head of the Austrian house, fell upon the town of Wesen in Glarus by night and slaughtered the confederate garrison in their beds. The Glarus folk called upon their Swiss allies, but for some unexplained reason no help came, while a considerable Austrian force poured into their country, driving all before it. The little company of foot soldiers, perhaps one tenth the number of the invaders, drew up with their backs against a mountain wall near the village of Näfels and awaited the attack. As the Austrians advanced in loose order and without plan, the little troop received them first with a shower of stoncs which threw the horses into confusion, and then fell upon them with their cruel halberds and broke their order completely. It was the story of Morgarten over again. The terrorstricken horsemen trampled down their own footmen in their wild retreat. Behind them was a river crossed by a rickety bridge which gave way under them. The furious peasants drove the remnant before them until the flight became a rout, then turned back to the first battlefield, slaughtered all the wounded, plundered their bodies, and hung their trophies in the church at Glarus. From that day to this the annual "Näfels Procession" recalls to the Swiss patriot this fourth great military triumph of democracy over the forces of a feudal, aristocratic society - the fourth, and so far as Austria was concerned, the last. Glarus had made her fight alone, but after the victory the remaining cantons sent their contingents to the siege of Rapperschwyl, while in the West, Berne held the whole Swiss line against the allies of Austria on that side. 
For about a year after the battle of Näfels a state of irregular warfare continued until, in April, 1389 , through the mediation of Seven Years' the South German cities, a seven years' truce with Truce Austria was brought about. The conditions of this truce give us the basis upon which the permanent status of the Confederation was to be established. The former provision that "All castles, towns, fortresses, valleys, land, and people" taken from Austria are to be held by the confederates is renewed. On the other hand, they bind themselves to admit no more Austrian subjects as Pfahlbürger and to make no further encroachments upon Austrian territory. Austria promises to make no demands upon the territories annexed by the Swiss.

While this seven years' truce was still in force occurred one of the most significant acts in the development of the Confederation The Sempach into a true state, - the so-called Sempach Compact Compact (Sempacher Brief). In this agreement the eight cantons declare first a permanent Swiss Landfrieden; that is, a prohibition of private warfare among the inhabitants of the Cantons both in times of peace and of national war. Those who have enlisted under a banner shall stand by it and each other "as men of honor, after the manner of our forefathers." Whoever violates this or any other rule here laid down shall be tried by the court where he belongs and punished according to the law of his place, "and therewith shall the other confederate be satisfied." Very curious is the provision, inspired by the mistake made at Sempach, that in any future battle, when the enemy is put to flight he shall be pursued without any thought of booty until he is thoroughly routed and there is no further danger. Then only, and only with permission of the captains, may the plundering begin; but all the booty must be delivered to the captains, who will then divide it equitably among the combatants. Churches, monasteries, and chapels shall not be attacked or even entered unless men or goods of the enemy may be within. "For the sake of Our Blessed Lady we order that no one shall injure wife or 
maid, unless she make too great an outcry which might give the enemy an advantage, or join in the fight against us."

Already, nearly a quarter of a century before the Sempach Compact, another significant agreement had been adopted which The Compact shows how clearly the Swiss were facing the same of Clergy, problems of the national state that had met the gov1370 ernments of England, France, and Italy on a larger scale. All the records show in Switzerland a profound and simple piety expressing itself in all public actions. On the other hand, these humble state-builders were perfectly conscious of the overgrown powers of clerical establishments, bishoprics, chapters, monasteries or what not, and they did not propose to let these clerical rights interfere with the claims of personal liberty. In the year $137^{\circ}$ the confederated states, then six in number, entered into what has come to be known as the "Compact of Clergy" (Pfaffenbrief). This rather elaborate document shows plainly that to the Swiss citizen the clerical court was a foreign court and that this, and not any antireligious feeling, was the basis of his hostility to it. The provisions against clerical jurisdiction are so closely mingled with measures against foreign, especially Austrian, aggression that they can hardly be distinguished from them. The first article is a distinct proclamation of what Swiss citizenship was to mean.

"Whoever, being under oath to the dukes of Austria wishes to live within the limits of the Confederation, must take oath also to support the honor and the welfare of the confederated states, and this oath shall have precedence of all others whether earlier or later. This applies to clergymen as well as laymen, to nobles as well as commoners."

Foreign clergymen living within the Confederation shall not summon any of its subjects before any foreign court, be it clerical or civil, except in purely spiritual cases. If a clergyman violate this law, he shall be absolutely boycotted and outlawed until he gives 


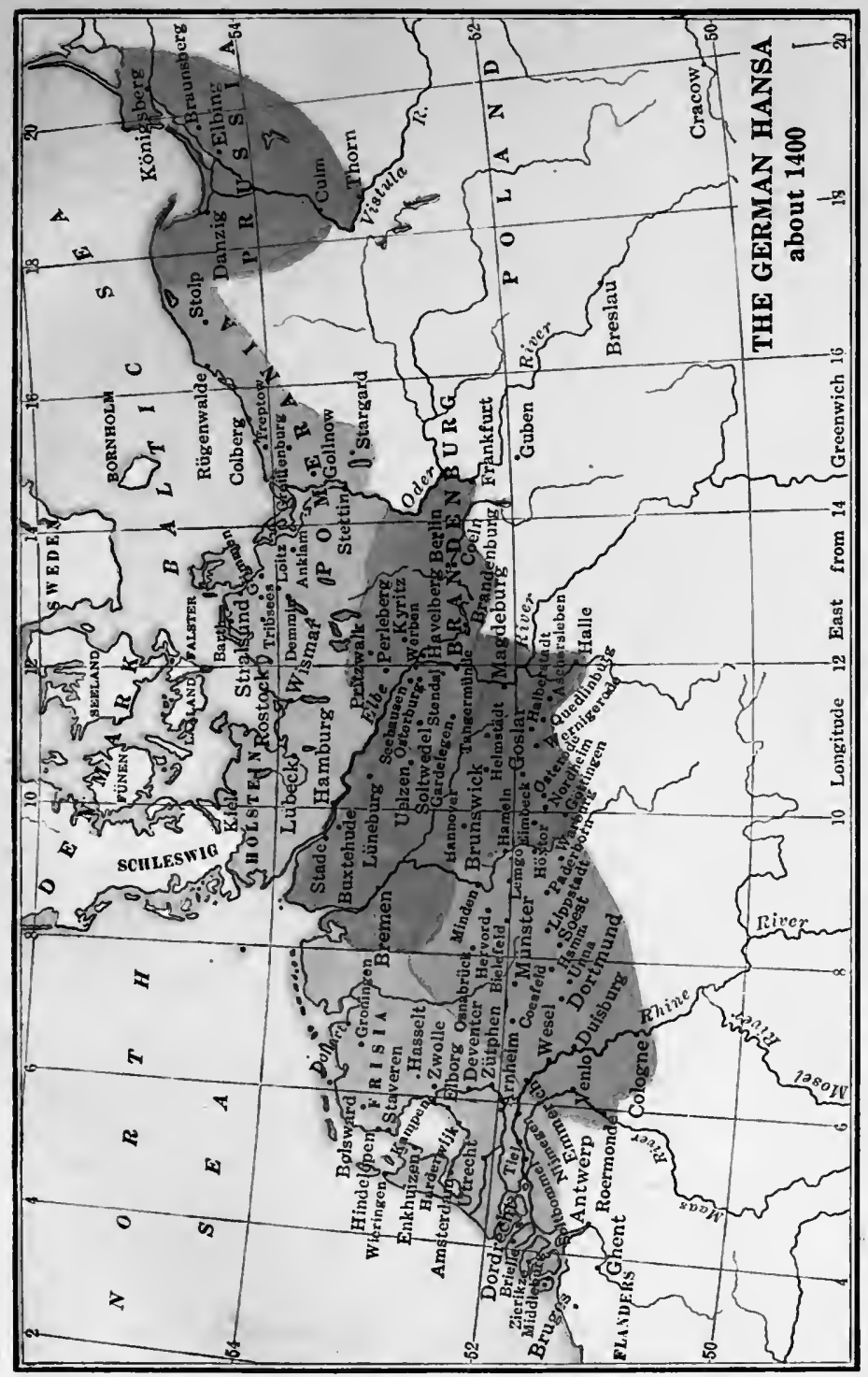


up the foreign court and pays damages to the injured person. It is the same spirit which at the same moment in England was bringing out the famous defence by John Wycliffe against the encroachments of the clerical system and causing the reënforcement of the statute of praemunire against appeals to Rome.

From about the year 1400, therefore, we may regard the Swiss Confederation of the Eight Cantons, Uri, Schwyz, Unterwalden, Final Emancipation of Zürich, Zug, Lucerne, Berne, and Glarus, as complete. Switzerland It was a definite unit in the larger complex of the mediæval Empire and was nominally so to remain until the Peace of Westphalia in I648. Practically, however, the connection of the Confederacy with the Empire grew steadily looser and looser as the bonds between the Cantons themselves tightened. In the Peace of Basel (1 499), Switzerland, long since acting as an independent state, was frankly recognized as such by the Empire itself. From that time on the relation to the imperial crown was much the same as that of the stronger Italian states. It made use of emperors as convenient donors of privileges they did not possess and were powerless to withhold or to enforce, but it was wholly exempt from the imperial jurisdiction and from every obligation of service.

\section{Germany}

The same impulse of local independence which in Switzerland produced effective organization and a new, vigorous national life The Demois to be seen also in other parts of the German Emcratic Spirit pire. We read in all the books that the lamentable in Germany weakness of the imperial power during the thirteenth century compelled, as it were, princes and cities to be strong and to unite for all purposes of an organized society. But why was the Empire allowed to become weak? Simply because the real life of the German people lay, as it has always lain, not in its centralized, but in its local, traditions. They got on very well without a strong central government, and the same spirit which 
enabled them to go on developing their own country and their own institutions made them jealous of every attempt to exercise a strong government over them. It is this spirit which we have seen in opposition to the house of Habsburg, setting up emperor after emperor against the Austrian candidate and postponing until far into the fifteenth century the evil day when Austria and all that it represented fastened itself permanently upon Germany.

The natural centers of this new impulse were the cities, which during the early thirteenth century had been gaining an importance

Expansion of German Trade in German life quite unknown in earlier times. Some, as, for instance, Ulm, Augsburg, Regensburg in the Danube region, Constance, Basel, Strassburg, Mainz, Cologne in the Rhine valley, were ancient Roman seats of industry and civilization. Others, like Bremen, Hamburg, Osnabrück, Magdeburg in the north, and Frankfurt, Bamberg, Nuremberg in the center, went back to a very early period in the Christianizing and Latinizing of the Germanic peoples. Others again, and these chiefly in the Northeast, such as Frankfurt on the Oder, Lübeck, Danzig, with the Vistula towns Thorn and Elbing, represent the new Germanic activity of the twelfth and thirteenth centuries. This activity had shown itself, above all else, in a rapid and vigorous expansion of German industry and trade over the whole vast region lying eastward from the Elbe and occupied up to this time by sparsely settled and, especially in the more eastern parts, persistently heathen Slavonic peoples. The German merchant was the most intelligent and the most active agent of civilization throughout all this wide domain. His value was demonstrated by his success, and governments, whether of kings or princes, were not slow in granting him privileges and permitting him to organize. Our interest is in the fact that this eastward expansion is on the whole a great popular movement, furthered, it is true, by sagacious princes, but essentially depending upon individual energy and capacity for independent organization. 
This is clearly shown in the relations of the great northern trading communities with foreign countries. From an early date The German Merchant their citizens had begun to trade with England and Abroad had naturally associated themselves in London for purposes of defence and mutual advantage into a kind of community, occupying permanent quarters near the river and governing itself by a rude form of law. Among these traders those from Cologne took the lead and were the first to deal with the English government in gaining permanent recognition and extensive trading privileges. Gradually other cities joined with Cologne in measures for furthering the interests of their citizens in London. The kind of protection which modern traders in foreign countries expect from their home governments could here be furnished only by such a voluntary combination of interested municipalities. The same situation in other foreign places led to the same results. In the Baltic Sea, on the island of Gothland, lying between the shores of Sweden, Denmark, Germany, and Russia, was the little town of Wisby. Its situation made it a natural point of exchange for the goods of all these countries, and German traders were quick to perceive this advantage. They formed there a community with its churches, its defences, its permanent as well as its shifting population, and for generations preserved it as a bulwark of northern civilization. In Russia, at a point where the river-ways to the Baltic join with those to the Black Sea, had grown up the free market place of Novgorod, where twice in every year a great fair was held and the products of the North of Europe were exchanged for those of Russia itself and even of the far Orient. This trade was for a long time dominated by German influence. In Flanders, at this time the most densely populated land of Europe, the old town of Bruges had become the point of exchange for the trade of the Mediterranean and that of the northern seas. There too an association, the "German Countinghouse," maintained the privileges of German traders. In Norway a similar organization grew up at Bergen. 
There can be no doubt that the common life of these trading communities, regulated as it was by codes of an almost monastic Origins of strictness, was a valuable training in the sense of a the German common nationality and in the processes of associaHansa tion for common ends. The lessons of forbearance and coöperation learned abroad, reacting upon the home community, taught them the same capacity for organization and common action which their Swiss brethren had learned in resistance to foreign oppression. It is in this sense of a corporate interest and the right to pursue it that we find the origin of the most powerful voluntary organization in European history, the German Hansa. Originally intended to promote only the mercantile interests of its members, without further political purpose, it grew to be by far the most important combination of power in Germany. Its precise origins are lost in obscurity, but we may safely say that about I 250 there is already some recognized coöperation among the principal northern towns in regard to certain special interests. For example, in $124 \mathrm{I}$ there is a compact between Hamburg representing the North Sea and Lübeck representing the Baltic to join in the expense of driving out pirates from these waters and to protect each other's citizens from injury. From $125^{6}$ on there is preserved a series of decrees called " Recesses," passed at assemblics of representatives held as occasion required, and dealing with the widest range of subjects. Beginning with a few simple prescriptions of a strictly business character, they soon become more frequent and include the most important economic regulations, and these could not fail to lead still further to political complications. As in the Italian leagues, so here we see the sense of common advantage continually struggling against the selfish interest of the individual community but gradually getting the better of it.

The first great demonstration of the power of the League was in $128_{3}$, when a group of cities under the lead of Lübeck, which bore one quarter of the expense, declared war on Norway for violation of privileges against German merchants. Denmark 
joined the League while England held with Norway, but the pressure of the combination of cities was too great and in 1285 Political Activity of ests. While the history of the Empire as such is the Hansa chiefly that of one power after another, - Habsburg, Nassau, Luxemburg, Bavaria, Bohemia, - using the imperial name only to gain land and influence for itself, we find among these trading communities a profound sense of nationality. It was the "associated German merchant" (gemeiner deutscher Kaufmann) in whose name and in whose interest they were ready to sacrifice blood and treasure. As in Switzerland, so here temporary alliances between certain smaller groups of cities were the preliminary step to a larger and a more complete union. Cologne is a leader among the western, Lübeck among the more eastern, towns. Even from a very early date alliances of this local sort provided for mutual exclusion of criminals, for equal enjoyment of legal rights, for reciprocity in customs, even for certain regulations as to marriage. It is evident that the sense of belonging together is the strongest political instinct of these cities, - much stronger than their sense of duty to the Empire or to any territorial prince. In connection with measures relating to trade and special privileges we find also groups of cities joining in a Landfrieden; that is, a sworn association to preserve the peace and to enforce it against all violators, a function expressing one of the highest duties of an actual state.

In the course of the fourteenth century the number of towns which found it for their interest to go into a formal union was The Han- more than eighty. In 1347 the German merchants at seatic Consti- Bruges appear definitely divided into three groups: tution

(r) "those from Lübeck and the Wendish cities and the Saxons and all that belong with them; (2) those from Westphalia and from Prussia and those who belong with them; (3) those from Gothland and Livland and Sweden and those who belong with them." This clear division of the Germans at Bruges corresponds 
to a division of the towns themselves. The natural head of the first group was Lübeck, of the second Cologne, and of the third Wisby; but it is evident at this time that Lübeck was leading in the great struggle to open up all the northern waters on equal terms to all Germans, and her success in this effort placed her finally at the head of the whole association. The name "Hansa," originally applied to any one of the groups of German merchants in a foreign city, was later transferred to the confederation of towns itself. The organization of the Hansa was always of the loosest possible description. It never had a formally recognized head, regular magistrates, an army, a fleet, or a treasury. Each member was free to act as it chose within the limits of the common interest. If it violated that interest, it took the consequences. The firmness of the union during two centuries depended wholly upon the principle of mutual advantage. The only regular penalty for a violation of agreements was that of "unhansing" (verhansung), a penalty which like that of excommunication by the Church was feared in proportion to the practical ills it might bring with it. During this heroic period of the League an "unhansed" city was like a man shut out from the protection of society, - it could not live.

There is one striking difference between the fortunes of the Hansa and those of the Swiss Confederation. The Hansa had not War against to contend against oppression from above, but from Denmark, the beginning took the upper hand in all its deal1361 ings with its neighbors. This comes out especially in the great fight with Denmark. Under its king, Waldemar IV (1340-1375), Denmark had greatly increased in strength and above all had recovered its lost possessions in Schonen, the southern extremity of Sweden. Wisby, on Gothland, where according to the legend "the swine fed from silver troughs and the women span with golden spindles," was a tempting prey. In 136 I Waldemar led against it a powerful army and completely defeated the devoted citizens who had rashly ventured out against him in open 
fight. From Sweden, to which it belonged, Wisby had received no help, but the Hansa would not endure this outrage. Under the lead of Lübeck and the Wendish towns they at once negotiated with Norway and Sweden and agreed to supply ships and men to join them in an attack on Helsingborg in Schonen. They declared an embargo against Denmark and threatened to punish its violation with death and confiscation. The promises of the Hansa were strictly kept. They fitted out a powerful fleet and for twelve weeks besieged Helsingborg without a sign of help from the northern kings. Then Waldemar attacked the fleet and captured twelve of their largest ships laden with food and weapons and carried off many prisoners. The Hansa was forced into a truce, and trade with Denmark was restored. It reminds one of Italy to read that the luckless commander of the fleet, the Lübeck Bürgermeister Johann Wittenberg, was thrown into prison and a year later beheaded, a scapegoat for the treachery of the faithless kings.

In 1368 a new declaration of war against the kings of Denmark and Norway was made at Cologne by allied groups of towns exWar against Denmark and Norway, 1368 tending from Holland to the Vistula, and any Hansa town failing to support them was excluded from trade for ten years. Waldemar, at the first news of this combination, fled the country and took refuge in Germany. The allied fleet in the Baltic attacked and destroyed Copenhagen and with the Swedes occupied Schonen, capturing Helsingborg after a long winter's siege. The Netherlanders on their side attacked Norway, captured Bergen, and forced the king to sue for peace. Waldemar, still in exile, to save his country and his crown, agreed (May 24, 1370) to a solemn compact with thirty-seven Hansa towns whereby he granted them all former privileges, agreed to pay a large war indemnity, and promised that if he should die or abdicate no successor should be chosen without the approval of the cities and the fullest confirmation of their liberties. The "German merchant" was dictating the policy of three kingdoms. 
It is at this point that we might expect to find a permanent northern political state growing out of these purely commercial Greatness relations. No such thing happens. The cities remain, and Decline like other members of the Empire, independent in of the Hansa local matters but exert themselves politically only when some practical end calls for such action. The "Calmar Union" of I397, whereby Denmark, Sweden, and Norway were for a long time to become united under the Danish crown, endangered again the supremacy of the cities in the northern seas, but not until trade was diverted into new channels and greater skill in seafaring made longer direct voyages possible was the great power of the Hansa seriously diminished. The absence of a formal constitution was probably an element rather of strength than of weakness, since it allowed each member to keep up its own political connections and thus avoided many occasions for hostility. As the Hansa had no definite beginning, so it had no definite end. Its formal existence continued down into the seventeenth century, but its power declined in proportion as it deserted its original commercial purpose and tried to play a political rôle. It was inevitable that powers so great as these should lead to tyranny. The Hansa at times violated its own principles by interfering in the domestic politics of its members. It was always looked upon with a certain jealousy by its neighbors. The result was that from the latter part of the fifteenth century one after another of its members found it for its interest either to enter into some one of the larger political units of Germany or to stand for itself as an altogether separate fraction of the Empire.

The Hansa was a union of cities only. It dealt on equal terms with kings and princes, but it did not admit them to its membership. Its wisdom in this respect was proved by the experience of other associations in other parts of Germany. We have already noticed the brief but brilliant career of the Rhine Confederation of $1254 .^{1}$ This was an association of cities deliberately ${ }^{1}$ See pp. 58 ff. 
formed for permanent political purposes. It declared itself to be a confederatio, conjuratio, consortium sanctae pacis; that is, a

The Rhine Confederation, 1254 league, a confederacy, and an association for upholding the public peace. It was to have regular quarterly meetings at fixed places. Representatives were to have power to bind their cities. Mainz and Cologne were the permanent heads of the league. Unfaithful members were not merely to be excluded; they were to be outlawed and destroyed. An executive force, made up of a fixed contingent from each member, was to be kept always in readiness to suppress disorder or enforce the policy of the league. An immensely more efficient organization, one would say, than that of the Hansa; but in practice this very completeness proved fatal to its influence. It was thus brought at once into conflict with powers already existing for the very purposes it was trying to carry out. It succeeded in bringing a certain pressure to bear upon the election of emperors and in temporarily securing public order; but its members were without that keen sense of common interest which held the Hansa together. The Rhine Confederation thus speedily fell apart into many smaller and ever-shifting groups which lasted only so long as they seemed useful for momentary ends.

For example, in 1273 the Rhine cities, Mainz, Worms, and Oppenheim, united with the towns of the Wetterau, Frankfurt at the head, to secure a unanimous election to the Empire, and all through the fourteenth century we find these cities in frequently renewed alliances for similar purposes. So also we find separate groups of the Hansa towns forming alliances of this kind with more southern groups. So in r33r a great Swabian League appears and leads to unprecedented results. It will not seem strange to us that the idea of the Empire as a confederation should have found supporters at this time. The Golden Bull of $135^{6}$ is itself a declaration of the federative principle, but the units of federation here were not the cities but the territorial princes. The Golden Bull is distinctly hostile to the city leagues. 
In 1376 fourteen Swabian free cities, that is, cities directly under the Empire, made a new and permanent alliance, offensive and The Swabian defensive. Within three years this Swabian League League, numbered thirty-four members. In $\mathrm{I}_{3} 8 \mathrm{I}$ it formed r38I-r388 with other cities on the Rhine, in the Wetterau, Franconia, and Bavaria, a general league directed against the princes and nobles, who also by this time were united into well-organized associations to oppose the growing demands of the towns. For a while collision was averted, and it seemed as if the two orders might even unite for the common weal of the Empire. Here, however, came in the reaction of events in Switzerland. In 1388 , two years after the battle of Sempach, war broke out between the cities of Upper Germany and the princes. It is the story of Sempach over again, but with a totally different result. The army of the cities, largely made up of contingents of hungry noblemen hired for the occasion, was attacked at Döffingen by Eberhard of Würtemberg, the bitterest enemy of all city liberties, and completely defeated. Other lesser conflicts fell out in the same way. It was evident that the spirit of the Hansa and of the Swiss which had inspired the best men to risk life and treasure in a common cause was sadly lacking in these mercenary brawls. The war dragged on for a year, but in ${ }^{1} 389$ the Reichstag at Eger, under King Wenzel's lead, declared a general Landfrieden with explicit prohibition of all other forms of association. The cities were ordered to accept this "peace," and within a few months most of them complied.

Thus at the moment when the German cities, both in the North and in the South, seemed to have the political future in Conflict be- their hands quite as completely as did those of Italy, tween Cities we find them failing to fulfill this mission. The exand Princes planation is to be found in their different relation to the territorial lordships and to the rural populations about them. We noted in Italy especially the persistent attraction of the city as against the country. The same thing is to be seen in Germany. 
One of the bitterest contentions there between a city and its neighboring lordships was that about the Pfahlbürger, or adopted citizens. These.were residents outside the regular city territory, The Pfahl- who found it to their advantage to gain a limited right bïrger of citizenship. To this extent they were, of course, lost to the lord to whom they had owed allegiance, and this lord found, therefore, in this arrangement one more grievance to keep alive his traditional enmity with the town. In Italy he would have been drawn or forced into actual residence within the walls; in Germany he remained outside, nursed his wrongs, and was ready on the first occasion to join his kind in open conflict against the city. Again Germany, unlike Italy, had always a considerable number of large territorial political units, and their effort was always to "mediatize" the cities; that is, to bring them under their own control instead of leaving them under the "immediate" rule of the Empire, which meant no control at all. The smaller cities were saved from this absorption by alliance with the larger; but after the great defeat of 1388 we find all the towns rapidly falling into two classes: those which simply became parts of territories and those which were definitely declared to be "imperial" or "free" cities. The former class has ever since been gaining on the latter, and at present there are only three cities in Germany - Hamburg, Bremen, and Lübeck - which do not belong under some higher mediate sovereignty.

As to the internal affairs of the cities, we find marked differences between those of Germany and of Italy. All pass through The Gilds much the same stages: emancipation from a resias Political dent feudal lord, government by the higher classes, Units and gradual encroachment of an organized democracy. In both countries this democratic organization rests upon the gilds, and among the gilds there is the same division into the higher, or merchant, gilds and the lower, or craft, gilds. The ordinary form of popular representation in Germany is the Council (Rath), with the Bürgermeister at its head, and the usual story of 
democratic progress is that the gilds strive against the aristocratic families (Geschlechter) to gain for themselves places in the Rath. Socially also the course of things up to a certain point is similar to that in Italy. The new aristocracy of wealth becomes easily ennobled and unites itself with the old landed aristocracy of blood; but the tendency is then for this new mixture of families to leave the city rather than to move into it, and thus the cleft between the two is continually widened and the democratizing of the nation effectually prevented. Between the centralizing efforts of the Empire, on the one hand, and the city democracies, on the other, the territorial princes, relying on the principles of the Golden Bull, held their own and thus gave a permanent federative character to the constitution of Germany.

The leagues of city democracies succeeded in so far as they took the place of a well-ordered general government. A similar

The Vehmgericht; its Value and its Dangers phenomenon is to be noticed in Germany in the field of law and justice. The Empire was as incapable of administering justice as it was of governing the country in other ways. Nor was the local jurisdiction of princes or of cities much more effective. The people were, therefore, driven to help themselves in some way, and out of this need grew the very famous and curious institution of the Vehmgericht, the "Holy Fehme" or the "Free Courts." We shall not be very far wrong if we describe this as a kind of organized Lynch Law. The region of its greatest prevalence was Westphalia, the "Land of the Red Earth," and the time of its best success was the early part of the fifteenth century. The "Fehme" was an association of citizens, nobles, and even peasants, who formed themselves into a vigilance committee under the lead of a "Free Count" who was supposed to hold a commission from the emperor. The members were called "free jurymen" (Freischöffen) or "initiated" (zeissende). The theory was that only such cases were brought before the "free courts" as could not be satisfactorily settled in the regular courts. The process was not 
essentially different and the law was supposed to be the same with a leaning towards "equity," at the discretion of the judge. What gave to these irregular tribunals at once their usefulness and their danger was the element of mystery and arbitrariness that surrounded them. True, they are now known to have been intended to be open, public resorts for the oppressed; but the temptation to secrecy and terrorism was too great, and with the gradual strengthening of the whole system of government during the fifteenth century they came rightly to be regarded as public nuisances demanding forcible suppression. During their useful period membership in the free courts was regarded very much as membership in one of the fraternal orders would be nowadays, as a kind of insurance against the vague evils of a society in which the strong and the clever were but too ready to take advantage of the weak and simple.

\section{Flanders}

The democratic movement in Flanders, beginning in the latter part of the thirteenth and reaching its climax in the middle of the The Flemish fourteenth century under James and Philip van ArtaCommunes velde, has also many similarities with that in Italy and Germany. Here too we find a group of manufacturing and trading communities, governing themselves under elected magistrates, and occupied chiefly in maintaining such economic conditions as would secure them in their pursuit of wealth. Bruges was the most important port of entry and exchange of goods in all the northern seas, only to be surpassed at a later stage by its neighbor, Antwerp. Ghent and Ypres were the chief centers of the wool industry, depending upon England for their raw material and looking to Italy for a large share of their export trade. As elsewhere, the control of the city governments had passed, in the fourteenth century, into the hands of an aristocracy of mingled wealth and blood, which filled the offices, dictated the policy of 
the town and naturally aimed to get all it could out of the artisan population it despised. The artisans in their turn were organized in their trade gilds and, as their organization strengthened, were growing continually more alive to their rights and less patient under the control of the upper classes. It is the popolo grasso and the popolo minuto, the Geschlechter and the Zünfte, over again.

But with these similarities came also certain marked differences. The greater part of Flanders was a fief of the French crown,

Political

Problem of held by a count who was one among the very highest Flemish Democracy nobles of France. Closely connected with all the economic and political fortunes of Flanders were the duchy of Brabant, with Brussels as its most important city, and the county of Hainault (Hennegau), both of which were states of the Empire. The relations with England made another very serious complication, since every approach in that direction was sure to rouse the jealousy of France. Democracy in Flanders was, therefore, from the first involved in much larger external interests than elsewhere. Especially was this true on the side of France, since the French kingdom under Louis IX (1226-1270), Philip III (1270-1285), and Philip IV (1285-1314) had done all it could to break down every form of power, feudal, ecclesiastical, municipal, which might seem to diminish that of the crown. The existing parties in Flanders about 1300 were: (I) the French crown; (2) the dominant aristocracy in the cities; (3) the count; (4) the artisan populations. In the conflicts which followed, the first two were generally allied against the last two. The permanent ambition of France was to absorb the county of Flanders into the royal domain; this provoked the hostility of the counts. The permanent desire of the city aristocracy was to maintain control of the cities as against both the counts and the artisans, and it was willing to go halfway to meet the king's plans if it could gain his support in this policy. This ambition of the city patriciate corresponded to that of the German, Swiss, and Italian 
towns for the Reichsunmittelbarkeit; that is, for independence of every one but the emperor. The great and decisive difference was that whereas the Empire was a remote, shifting, and feeble power, incapable of effective government, the kingdom of France was now a firm and vigorous hereditary monarchy, master of a great territory, and fiercely conscious of its policy. To come under its "immediate" control meant, sooner or later, to part with every vestige of individual liberty. It is in the great artisan and trading population that we are to seek the real vigor of the Flemish resistance to absorption in France, the real expression of Flemish nationality.

We need go no farther back than the year I 280, when the longgathering hatred of the artisans broke out against the oppressive

Uprising of the Lesser Gilds rule of the monopolistic aristocracy precisely as it did almost at the same moment in Florence and on quite the same grounds. The "families" were not only controlling the larger mercantile interests; they were charged with perverting the forms of the constitution to fix all power in their own class. The same complaints were made as in Florence: the daughter of an artisan was not safe against the lustful protégé of a noble; new taxes were imposed without the consent of the artisans; liberal measures toward foreigners, which were the life of trade, were selfishly blocked by this narrow-minded aristocratic "ring"; the magistrates would give no account of their stewardship, and so were charged with embezzlement. The revolt broke out at nearly the same time throughout Flanders. Furious mobs led by capable leaders went through an orgy of destruction and plunder and then called in the count, Guy de Dampierre, to mediate. They begged him to abolish the inheritance of places in the magistracy, to open certain of these places to artisans, and to reinstate his "bailiff" - a foreign executive similar to the Italian podesta. It is instructive to note also a demand for removal of the import monopolies of the gilds, so that any man might freely buy wool, the indispensable material of Flemish industry. 
The count saw his great advantage, - he was compelled to punish the riotous artisans for taking the law into their own hands; The Appeal but, on the other hand, he had them to thank for this to France chance to take a leaf out of the book of French monarchical policy. In granting the petition of the artisans he aimed to put himself in the place of the hated aristocracy. We may well compare him to the temporary executive tyrants who mark the progress of Italian democracy. His policy was to conciliate both elements of his city populations, but to both he was equally offensive. The dominant aristocracies began to look beyond him to his overlord, the king of France, and from 1285 that king was Philip the Fair, a man filled as no one of his predecessors had been with ambition for the greatness of the monarchy. $\mathrm{He}$ jumped at the chance to interfere in Flanders and thereby opened the eyes of every Flemish patriot to the inevitable result of weakening the count by appealing to the king. It could only be that the fair cities of Flanders would be drawn into the politics and the taxation system of the relentless monarchy of France. We are little concerned with the personality of this and the succeeding counts of Flanders. They play a rather pitiful part between the social parties at home and the continuous struggle of England and France abroad. They turned to England to get help against France and tried to conciliate the artisans to make head against the governing aristocrats.

Here as elsewhere the real interest is in the feeling and action of the people. They, the workers, the producers of wealth, would Flanders bear no policy that seemed to endanger their prosdeclared a perity. They would not stand an embargo on EngFrench Prov- lish wool; they would not use the debased coinage ince, $\mathbf{1 2 9 6}$ of France; they would not pay fines for disobeying French laws. It was not their affair that their local lord, the count, was by some ancient feudal contract a subject of the French king. So Philip, shrewd as he was masterful, tried conciliation, - favors in France for Flemish industry, - anything to 
keep Flanders from going over to England. In 1296 Count Guy, summoned before the parlement de Paris, the supreme court of France, was declared to have forfeited Flanders to the French crown. It was, to be sure, delivered back to him again in fief with the reservation of Ghent as a crown property; but it was clear that no device of feudalism could longer conceal the hard fact that France proposed to treat Flanders as a royal domain. The count had no resource but to throw himself upon his "good towns" and upon England. In I 297 King Edward I signed a treaty wherein he promised to aid Flanders with men and money, and the count declared war on France. Philip's reply was to overrun Flanders with great rapidity, to cut off all sources of help for the count, and then to make first a truce and then a treaty with England. In January, I300, on the expiration of the truce, Philip moved another army into the county. With hardly a blow in his defence the aged count surrendered himself, and Flanders was formally declared a royal province. In May, r 30 r, came Philip the Fair himself, in all the splendor of a royal progress, to take possession of the country. A royal governor was installed, and everything pointed to a complete annexation of the Low Countries.

This revolution had been made possible primarily by the narrow class feeling of the ruling aristocracy, but it would seem obvious

Revolt against France that French rule could maintain itself only by giving every consideration to the city populations as a whole. That so clever a politician as Philip the Fair failed to grasp this idea is to be understood as a part of that same general failure to give due value to the "common man" which we have noted elsewhere. France began at once to treat Flanders as a conquered country existing only to be plundered by the conqueror. The result was to rouse the artisans to fury and to gain for them the sympathy of many of their aristocratic neighbors. The storm burst in Bruges. The royal bailli was driven out, and the citizens, led by one Peter Koninck, a weaver, declared open rebellion against the provincial governor. Ghent followed in a few weeks 
and the revolt became general. The rebels - or patriots - called to their command William of Juliers, a grandson of the old Count Guy, and prepared for war. The French governor succeeded in gaining a peaceful entry into Bruges, but before he could proceed to action his followers were murdered in cold blood and he barely escaped with his life. A sudden impulse of local patriotism, of which hatred against France was the immediate cause, seized upon the whole population of western Flanders.

A great army of citizens and peasants, led by William of Juliers and his uncle, Guy of Namur, gathered in the neighborBattle of hood of Courtrai and awaited the French attack. The Courtrai, ${ }^{302}$ French force, commanded by Count Robert of Artois, was a typical knightly army, strengthened by a force of Genoese crossbowmen and German mercenaries. The Flemings were almost exclusively foot soldiers armed with their peculiar weapon the pike, called in jest "Good-day!" The plan of Count Robert was to let the bowmen gain the first advantage, but his young Hotspurs remonstrated, "These rascals will do such service that there will be no sport for us." "Charge, then!" said the count, and they charged, only to find themselves thrown back again and again from the impenetrable wall of Flemish pikes. The inconsiderate burghers, quite regardless of the "courtesies of war," killed their man where they could. The knights in utter confusion were slaughtered in such numbers that their golden spurs made a considerable spoil and gave to this day of Courtrai the name of "The Battle of the Spurs." Count Robert was slain in the thick of the fight. We must place Courtrai in the long line of victories of infantry over greatly superior cavalry which were needed to teach the privileged classes their inferiority, even in their own special field of military prowess, to the new social force that was slowly changing the face of Europe. The Treaty of Athis in 1305 restored Robert, the son of Count Guy, to his honors, but laid such heavy terms upon the cities that it was only a question of time when they would lose patience again. 
The time came in 1336 when, after a generation of friction under Count Louis "de Crécy," the same antagonisms broke out Jacques van with renewed energy. The count was a firm friend of $\Delta$ rtavelde, France and an implacable enemy of the towns. To I336

show his zeal for France he ordered the arrest of all English merchants in Flanders. England replied by forbidding all export of wool. This meant ruin for Flanders, - sans laine on ne peut pas draper. Soon came idleness and then hunger; the towns of Flanders united with those of Brabant and Hainault for the common defence. Some slight concessions by king and count made no change in the situation; but quite suddenly, so far as our knowledge goes, a new element comes in with a new leader, the famous Jacques van Artavelde, a citizen of Ghent. We know little of him except that he was a member of the gild of weavers, that he had enlarged his outlook by travel, and was looked up to as a man of judgment and character. Called upon by his distressed fellow citizens, he laid before them a program of action. Above all things he counseled neutrality between the two great powers, neither of whom would allow the other to break this neutrality. Meanwhile they were to strengthen their forces, preserve order, and restore business.

Negotiations with England at once procured a supply of wool, and prosperity began to revive. The picturesque narrative of Alliance with Froissart throws out into relief all the prominent perEngland sonalities, but we can readily see beneath it all the working of a proud and self-conscious citizen body, tired of oppression and strong in its sense of common interest. Attempts to capture or murder their leader only brought out more completely the communal spirit. The chief interest of the moment lies in the separation of the towns from the political entanglements of the county. The count might be loyal to his overlord, the French king; the towns, of course, should not be disloyal to their lord, the count; but all this did not mean that the towns were bound to play the king's game against another foreign power with whom 
all their practical interests demanded that they should be at peace. That is the modernness of the situation. Set neutral Belgium in place of Flanders, expanding Germany in place of France, King Albert in place of any count of Flanders, the modern trade-union in place of the mediæval gild, leave England as she was, and we have material for a comparison between 1914 and 1314 that is full of pregnant interest.

It is clear that the tendency of things was rather toward England than toward France, and it was obviously a case of "whipping

Triumph of the Lesser Gilds the devil round the stump" when the towns agreed to recognize Edward III as their lord provided he would take the title of "King of France" and thereby save them from the charge of disloyalty to the French crown, - a truly medireval scheme! Edward III accepted the proposition and made with the towns most advantageous commercial treaties. The influence of Artavelde seems to have been steadily in this direction, so that his murder in 1345 , though probably directly caused by gild hostilities, was naturally defended by charging him with treason to Flemish liberty and to the French allegiance. It was even said that he had formed a plan to invest the Prince of Wales with the county of Flanders. Artavelde's rise to power marks also the same crisis in city government we have elsewhere noted. It was the triumph of the organized gilds over the patrician rule. The form of government adopted was that of a triple representation, the weavers, the fullers, and the lesser gilds forming the three units of the magistracy, to the complete or partial exclusion of the patrician elements.

It was a dramatic incident in these many-sided conflicts that while King Edward III had left his queen Philippa to the hospi-

Philip van Artavelde, 1382 tality of the good citizens of Ghent in $134^{\circ}$ she bore him a son, the famous John of Gaunt (Ghent), and served also as godmother to a son of Jacques van Artavelde, to whom was given the name of Philip. This son grew up, so the chronicles say, in retirement, without holding office or 
showing any marked talent; but when, a generation later, in $\mathbf{1}_{3}^{82}$, similar conditions seemed to call for action similar to that of $133^{6}$, the popular party called upon him to take his father's place as chief captain of the city. For a short time the stout spirit of the ancient communes made way against the monarchist reaction that since the murder of Jacques had taken possession of the country, but it proved to be a last rally. The resources of Count Louis Battle of were too great for the divided interests of the towns. Roosebeeke, It came to an open conflict on the fatal field of Roose1382

beeke, where the second Artavelde was slain under the feet of his own troops while trying to check them in a panic flight. His few months of leadership had not in any way affected the real problem. Henceforth Flanders was to give up the dream of government by a league of independent towns and submit to the ever more and more centralized rule of powerful territorial lords, whose model was naturally the aggressive monarchy of France. At the death of Count Louis in $1_{3} 8_{3}$ the county passed by inheritance to his son-in-law, Philip the Bold of Burgundy, the first in the line of princes through whom the Low Countries were drawn into the politics of France, the Empire, and Spain. The cities, still great and powerful, enjoying very wide privileges, were to be only incidents in the larger political relations of the country.

\section{France}

In Flanders we have had to note the continual reaction of French politics and French institutions, an influence steadily hosEarly French tile to democratic ideas. We have now to remind Communes ourselves, however, that France during the fourteenth century had its own democracy and that there were moments when it seemed not impossible that this element of the state might gain a permanent voice in its affairs. The French communes, both in the North and in the South, had had their history of feudal lordships, revolt of the citizens and "charters" from 
the kings which recognized the rights they had already gained by' their own sense and courage. Kings had early seen here a chance for an alliance with the great new industrial element against the claims of the feudal aristocracy, but they had also been keen to discern the danger of allowing these cities to become independent in the sense of the Italian or German towns. From the earliest stages of the steady monarchical development beginning with Philip Augustus (1 189-1223) a measure of direct control of the king over the cities had been insisted upon. The institutions of St. Louis $(1226-1270)$ had carried out this principle in detail. By the side of every local magistrate was ever present the king's bailli to represent the royal rights of justice and taxation. As a consequence we have to look, in France, not for great leagues of cities united by common interests in opposition to established institutions but rather for a growing sense of importance in the burgher class and for attempts to gain for this class as such a share in the administration of public affairs. In France as elsewhere the new power of the people was demanding to be heard, but on the whole this demand aimed to clothe itself in constitutional forms.

The earliest demonstration of this new power is seen in the same year ( 1302 ) in which Philip the Fair was fighting the First Estates- Flemish towns and receiving his first costly lesson in General, $\mathbf{1 3 0 2}^{02}$ the battle of Courtrai. Philip was in a position which called for every possible resource. His death struggle with the Papacy of Boniface VIII was already declared; he was preparing for the campaign in Flanders, and at any moment the everthreatening hostility with England might break out anew. It was this situation which forced Philip, the most strenuous defender of royal prerogative, to call together for the first time representatives of all three orders or "Estates" of the French people the clergy, the nobility, and the commons - under the name of the Estates-General. It was not strictly a "representation" in the American sense. The nobles and clergy came in person by right of 
holding certain specified positions; only the burghers of the "good towns" could be said to be represented, and the process of electing their deputies was at first ill-defined and irregular. As often as not they chose a noble or a clergyman to speak for them. The three orders met and deliberated separately and communicated the result to the king each for itself by means of an orator chosen from its own members. In one common session in the church of Notre Dame in Paris the king appeared before the Estates, stated the case of the nation as against the Papacy, and demanded their support. It is hardly necessary to say that the responses were such as he desired. Philip was too clever to confess his dependence upon any doubtful loyalty; but, once admitted to a share in the public councils, the French bourgeoisie was not likely to let itself be quite neglècted in future.

It would be a gross exaggeration to describe the Commons, or Third Estate, of France as forming, for a long time to come, a The Estates very important part of the political machinery. Their to 1355 function was to support, not to originate, measures of policy. Above all else they were called upon to approve the schemes of taxation which the increasing needs of the monarchy and the pressure of continual warfare made ever more and more necessary. Thus at the Estates of Tours in 1308 the king sought and gained the support of the nation in his assault upon the Order of Templars. In $\mathrm{I}_{3} \mathrm{I}_{4}$ he called the Estates together once more at Paris and simply demanded of the Third Estate, in the presence of the other two, whether they would approve a special tax for the war in Flanders, without any details as to the amount of the tax, the method of imposition, or any other particulars. From I 314 to 355 the Estates were doubtless called several times, but historians differ as to place, time, business, and even as to whether several reported meetings were really Estates-General at all. One thing, however, is clear, - that no essential advance was made during this half-century in independence or initiative of the Commons. 
The change came quite suddenly in the wretched times of the "good" King John (1350-1364). The progress of the war with Estates-Gen- England had been uniformly unfavorable to France. eral of 1355 The battle of Crécy in 1346 had thinned the ranks of the French nobility without rousing the country to any adequate sense of national honor or energy. The government, playing fast and loose with every obligation, debasing coinage, ruining industry by a taxation which bore no fruits, had forfeited all claim to an unquestioning loyalty. So the people began to question. In 1355, as the English under the Black Prince renewed the war in Aquitaine with fresh energy, the king summoned the Estates of the North, the Langue d'oill, at Paris to devise measures of relief. The president of the nobles was that Walter of Brienne, "Duke of Athens," whom we meet elsewhere as signor of the Republic of Florence. The leader of the Third Estate was Etienne Marcel, prévot des marchands of Paris, a companion figure to the Artaveldes and reminding us of many a capitano del popolo in Italy. It is evident that from the start the leadership is in the hands of the bourgeoisie, the only element of the state fitted by its habits and its interests to understand the simple principles of public honesty and fair dealing.

After due deliberation the Estates declared themselves ready to approve for one year a tax sufficient to equip an army of 30,000 men, but - and here is the importance of the situation - this only upon conditions: (I) that the tax shall fall equally upon all classes of citizens from king to peasant, - including the clergy; (2) that the Estates shall themselves collect and expend the tax; (3) that all votes of the Estates shall be approved by all three orders; (4) that the Estates may set their own dates of assembling. Such rights as these were almost equivalent to a democratic revolution. A parliament that could meet at will, impose taxes, and see that they were properly spent was unknown in the great states of Europe. Even in England, where this same principle of a fair exchange between money for the king and 
privilege for the people had long been in operation, no such opportunity as this had as yet declared itself. King John, at his wits' end to meet the danger of the moment, gave his consent. The tax was imposed, not without serious resistance in several places, and the army took the field.

But no experience seemed to avail to teach the mad chivalry of France the simplest lessons of military prudence. In the fatal Estates-Gen- day of Poitiers (1356) the little army of the Black exal of ${ }^{235^{\circ}}$ Prince, perhaps one quarter as large as its opponent. repeated on a larger scale the slaughter of Crécy. The excellent John was taken prisoner and carried off to a merry captivity in England. His son, an unpromising youth, who later was to be known as Charles the Wise, fled with a few followers from the field where the best blood of France had been thrown away in vain. The government was without a head; the enemy was at the doors; where were men to look for defence and reorganization? The answer came from the democracy of Paris under the clever and intrepid leadership of Marcel. In the Estates of 1356 at Paris, in a total of eight hundred members four hundred were of the Third Estate. Robert Lecocq, bishop of Laon, a fiery orator, was a worthy co-worker with the prévôt des marchands. A committee of eighty from all the orders drew up a plan which they submitted to the Dauphin. They demanded the punishment of eight crown officers as evil counselors for the king, the appointment by the Estates of a Royal Council from the three orders, and a reunion within a few weeks to examine into the use of the ample subsidy which on these terms they agreed to furnish. The Dauphin hesitated, quibbled, delayed, and finally dissolved the Estates-General, hoping for a cheaper bargain with the provincial Estates, especially of the South. The irritation of the deputies reflected that of their constituents. The Dauphin in despair resorted once again to a debasement of the coinage; the people of Paris by Marcel's advice refused to receive the debased coin. It was Marcel who undertook the direction of the fortifications 
which were to secure Paris against the enemy, and who controlled the only forces visible for the defence of the kingdom. Each party was making its appeal by popular harangues and promises of great things to the people.

The Estates of 1357 , summoned reluctantly by the Dauphin, are the most important in the series we are studying and mark The Estates the highest point of democratic hopes and opportunigovern ties in France. Their first act was to reëdit the comFrance, 1357 plaints of the Committee of Eighty and send them throughout the country for formal ratification by the provincial estates. The response showed that the nation, in the only form in which it could express itself, was united in demanding changes and was likely to support radical measures to accomplish them. The propositions of the Estates were therefore even more sweeping than in the year before. They named twenty-two royal officers for especial prosecution and suspended the whole body of royal officials pending an examination by the Estates. They demanded a Royal Council of thirty-four, one half to be of the Third Estate. They proposed to meet three times within the coming year. The Dauphin, without resources, agreed to everything and signed an ordinance whereby the whole constitution of the state was to be completely revised. The Council was to be an effectual check on the action of the king; the Estates were to assemble whenever and wherever it should seem good to them, and the deputies were declared under the special protection of the law. They were to lay, collect, and spend the taxes, and for one year to control the coinage. The Estates were given extensive powers over the army and were to provide for something very like the modern universal military service. Important restrictions were provided against abuses of power by the governing classes.

The ideas contained in this ordinance of 1357 are sound and practical in the extreme. Taken together, they amount almost to a declaration of the Republic. It remained to be seen whether the democratic sentiment in France was able to get beyond the stage 
of making attractive programs. The Dauphin had signed the ordinance; the king forbade the payment of taxes imposed by Murder of the Estates. The Dauphin withdrew the king's prohiRoyal Coun- bition, but many places took advantage of it to refuse cilors, $\mathbf{3 5 7}$ payment. The first enthusiasm vanished before the masterly inactivity of the Dauphin and the stolid resistance of the governing classes. Only at Paris, which was now beginning to show itself the real center of French ideas, were the principles of the ordinance vigorously upheld. The work of fortification went steadily on; Marcel was the idol of the people and was always rousing them to greater fury against the evil advisers of the king, to whom they were ready to ascribe all the ills of the country. When all other means failed he marched at the head of three thousand citizens wearing the red and blue cap of the Parisian commune to the palace of the Dauphin and, admitted to his presence, made a last formal demand for the defence of the kingdom. The Dauphin pleaded his lack of resources and thereupon, at a signal from Marcel, the crowd rushed upon the hated counselors and murdered two of them, the marshals of Normandy and of Champagne, at his very feet. To the terrified boy Marcel said, setting upon his royal head the cap of the people: "You have naught to fear." Then, later, "Do not be troubled; what has been done was done by the will of the People."

This was revolution! The Dauphin escaped from Paris, rallied the nobility, and laid siege to the town. He even succeeded in Fall of turning the weapons of the enemy to his own advanEtienne Mar- tage by calling the Estates to meet him at Compiègne. cel, $135^{8}$ They came in much diminished numbers, renewed many of their former demands, but were ready to help in reducing the capital. Within the walls the tide was turning against Marcel. Raised by the people to an irresponsible power, he fell by the people, a martyr in the cause of popular liberty (July $3 \mathbf{I}$, $\left.135^{8}\right){ }^{1}$ It is interesting to note that a month before his death 1 See p. 278. 
Marcel wrote to the communes of Flanders, calling upon them to make common cause with the burghers of Paris in freeing the land from the ills that were oppressing it. The history of the Estates-General after $135^{8}$ is that of a semipopular body, called only at the will of the king and only under the pressure of necessity. It is called in order to gain money. It has the right to add complaints to its grants of money, but it has neither the right nor the desire to make these grants conditional upon an increase in its own share in the government. Herein lies the difference between it and the Parliament in England. The Parliament had the same fight to make, but it made it, generation after generation, with a clear consciousness of purpose which allowed no advantage once gained ever quite to slip from its grasp. 


\section{CHAPTER V}

\section{THE ITALIAN REPUBLICS TO 1300}

The greatest achievements of the Middle Ages were the product of that ancient Frankish stock which had its home in what

Italy the

Leader of

Europe is now the north and east of France. It is there that we must look for the origins of organized feudal society, for the highest intellectual culture, for the splendid energy which found expression in the Crusades, and for the marvelous sense of beauty and constructive skill displayed in the Gothic building of the late twelfth and the early thirteenth century. In the period we are now studying, this leadership in the thought and in the productive capacity of Europe passes from France to Italy. Henceforth, during a period of three hundred years, the Italian genius gives direction and example to every form of human energy. Only in one aspect of Italian life do we of the modern world seem to see nothing but weakness and incapacity; that is, in its perpetual party conflicts and its failure to develop any principle of outward political unity. It will be part of our problem to make clear the real elements of Italian unity, rather than to dwell upon the features of disorder and disunion. Nationality, which in France and England was expressing itself in highly centralized political structures, was none the less marked in Italy. It is only that this principle of unity found other ways of showing itself and did not feel the need so strongly felt elsewhere of a compact political organization. Indeed, we may well doubt whether, if Italy at the close of the twelfth century had gone straight onward to any conceivable form of political unity, it would ever have made the wonderful record of individual achievement which is its greatest glory. 
To understand the political situation of Italy in the thirteenth century, we need go back only to the splendid performance of the City Life against Lombard cities in the great fight against the Empire Country Life, Peace of Constance in 1183 . These events fixed the II83-1250

conditions of public life in Italy for a long time to come. They made it clear that henceforth the real problem was to be the maintenance of that free, independent city life out of which the resistance to the imperial Hohenstaufen policy had grown. Politically speaking, we may divide the population of Italy into two great classes. First, there were the cities, tracing their origin generally to ancient Roman times and cherishing still a proud consciousness that, in spite of all the "barbarian" storms that had swept over and around them, they had never quite lost the glorious traditions of culture and the power of material production which were essentially the Roman heritage. Over against this city population there was, throughout the mediæval period, another, an essentially rural element, living in the open country under the rule of a widely spread landed aristocracy. This territorial nobility represented not a Roman but a German tradition. It traced its ancestry by preference to the days of the Lombard occupation, and all its institutions were those of the typical northern feudal society. And yet Italian feudalism had never become so entirely the dominating principle of society as that of the City Life North. In the long period of social reconstruction prevails following the break-up of the Carolingian power, the cities had, it is true, generally fallen into the power of some feudal lord, very often a bishop, who was likely to be a member of some noble house. But by the close of the eleventh century these feudal lordships in cities had been pretty generally overthrown, and in their place had come independent municipal governments under elected magistrates, usually called consuls. In the course of these conflicts the feudal lords, together with many of their noble followers, were usually driven from the city and compelled for a 
longer or shorter time to live on their rural estates. Then, however, happened a thing especially fortunate and especially characteristic of -Italian politics. The citizens had no hatred for nobility as such, but only as a threat to their liberties. If the nobles would join with them in maintaining the "commune," they were welcome to return and live at least a part of the year in the city, lending their arms in its quarrels with its neighbors and their superior intelligence and experience in the management of its affairs.

So it came about in the generation after Legnano that in the Italian cities there were to be found two classes of citizens, - the Rise of the "old" burghers and the "new" nobles (nobili or Podesta grandi). The burghers were the more numerous and were again divided into two classes: the burghers properly so called, who had well-defined civic rights, including especially the right to bear arms; and the great mass of the lower working classes, who had rights only in times of trouble, and then only to confirm or to protest in a somewhat tumultuous fashion against the action of the ruling classes. This period also - the late twelfth and the early thirteenth century - saw the rise of a very peculiar magistracy, devised with much skill to counteract the friction sure to result from these marked distinctions of class. Under the fitful administration of the German emperors the cities had become accustomed to the presence of an executive officer who should be quite independent, as he was quite outside, of the party conflicts of the town over which he ruled.

This imperial officer had been called podestà, a name which did not connect him with any tradition, Roman, Frank, or Lombard, Powers of and which was, therefore, specially well suited to the the Podestd aims of the Hohenstaufen policy. It seems a curious paradox that Italian citizens after having made a fight for generations against any form of foreign government should have chosen for their chief executive officer this same title. Yet it indicates very clearly their sound political sense. They believed that the peace and order of their communities would be better preserved 
by the administration of a foreigner, provided only that they might choose him for themselves and hold him to a strict accountability to their own laws. It is precisely as if the city of New York, tired of the desperate struggle to keep its government free from local partisan interests, should call its mayor from Boston or Chicago and so hedge him about with restrictions that he should find it worth his while not to enter into any of the combinations of New York politics. The striking difference is that the cities of Italy were also states, with foreign relations continually reacting upon their local problems. The result was that the podesta was from the first a half civil, half military official. By the beginning of the thirteenth century we find him in almost all the more important cities of northern and central Italy. He must, ordinarily, be a foreigner, - that is, a citizen of some other Italian city, - of noble birth, belonging to the dominant party, and of tried capacity in public affairs. He was paid a handsome salary; he was surrounded by a good deal of splendor, lodged in a fine palace, and given very large powers of administration. On the other hand, he was subject to many burdensome restrictions. He might not bring his wife, his son, or any relative with him. He might not enter into any personal relations with the citizens; he could not even accept an invitation to dinner, nor give a dinner party himself. He was bound to administer the laws as he found them, and at the close of his year of office he must lay down his power and stand ready to give an account of his stewardship and to pay any damages resulting from his error or his fault. His functions were those of a military leader and of a criminal judge, a combination quite familiar to the men of the Middle Ages but destined soon to arouse antagonism. So universal and so honorable was this office that service as podestà became a regular profession followed by many of the most capable Italian gentlemen during the whole period of the republics.

The bringing of the nobles into the city was not, however, an unmixed blessing. Formerly, scattered about on their estates over 
a widely extended suburban territory, they were likely to be united only when some outside impulse - as, for example, the coming Double Popu- of an emperor into their region - drew them together; lation in the but now, in the closer contact of city life, they develCities oped rapidly a more acute class feeling. Instead of their ruined castles in the country they now built themselves great city palaces, hardly less strongly fortified, and as much more effective as they were nearer together. This is the age of the "towers," of which but few have survived the fury of civic hatred, but which, so long as they were suffered to stand, formed the natural rallying points of family feud and party broil. Naturally, relatives and friends of a rich family built their towers in the immediate vicinity of its chief palace, so that by a judicious arrangement of chains and barricades their quarter of the city could be completely shut off from approach and defended almost indefinitely. But this tower-building was not all on one side. There were rich and powerful burghers as well as nobles, and they soon had their towers and palaces, equally strong and equally well grouped for defence. In ordinary times circulation was free through the narrow streets, and the regular business of manufacture and commerce went on around these city fortresses with an ever-increasing vigor and intensity. The masses of the common people (popolo minuto), in whose hands rested ultimately the prosperity of the commonwealth, were rather more likely to side with the "new" nobles than with their more natural allies of the burgher class (popolo grasso). This was probably, as the sequel showed, because the nobles, when in control of affairs, were more likely to help them in winning concessions from the already highly privileged burghers.

These were the elements of the population which during the thirteenth century fought out the furious party conflicts that fill the records of the Italian chroniclers and appear as the dark background to the poetic descriptions of Dante. If these had been nothing but party struggles, they would not be worth our 
notice; but they were complicated at every stage by larger interests, which give them meaning and value for the student. First, Larger the civil strife of the cities was, almost from the Meanings of. start, inseparably connected with the struggles of the Party Conflicts : $x$. Empire against imperial power, in the hands of the successors of Cities Barbarossa, to maintain in Italy a regularly organized imperial administration. Wherever the party of the nobility, new or old, had the upper hand, there was always a center for imperial intrigue. Wherever the burgher party was in the ascendant, there imperial aggression was sure to find a desperate resistance. In spite of the Peace of Constance ( $118_{3}$ ) the same attempts at imperial rule in Italy went on during the whole of the reign of Frederic II (1215-1250). If only the same power of alliance for a common cause which had broken the power of Barbarossa could have been maintained, the solution would have been easier. As it was, the work that had been done in the twelfth century by such great combinations of cities as the Lombard League and the Tuscan League had to be done in the thirteenth by a widespread partisan organization, extending throughout all the cities of Italy and gaining its point only at the price of civil discord within the walls of every one.

This organization was the Guelf Party. It owed its origin primarily to the opposition of the common people to the government 2. Empire of the nobility. Its growth was stimulated by the aid against Papacy given to it by the Papacy, because the enemy of the commonwealth was also the enemy of the papal interests. It even borrowed its name from this papal connection, and thus we are led to the second great public question involved in the civil strife of the cities, - the long struggle of Empire and Papacy. One easily gains the impression, even from contemporary chroniclers, that the cities as such took part in this greater fight, according as their sympathies led them to side with one or the other party concerned. In fact, however, the cities took but little interest in the abstract question of emperor versus pope. 
To say that a city, as, for instance, Pisa, was an imperial or Ghibelline city meant that the faction of the nobles there was more powerful than the burgher faction and looked to the Empire to help it maintain itself in power. To say that Florence was a Guelf city meant that on the whole the popular party there was the stronger and might generally count upon the support of the Papacy as a makeweight against imperial claims.

Not only was the party feeling powerful within the limits of a single commonwealth, but the cities were arrayed one against 3. City the other by animosities going back often through against City many generations and having their origin in economic conflicts or merely in local political rivalry. These interurban jealousies were now greatly intensified by the partisan division we are describing. Florence and Pisa, for instance, were long-time enemies in trade. Florence desired to gain the use of Pisa as a port of entry for her goods, but Pisa feared injury to her own commerce. Now, in case of a demonstration by the Florentine Guelfs against their Ghibelline townsmen, it was quite certain that the latter would find a refuge at Pisa, and by uniting with their partisans there might hope to win their way back into Florence by force of arms. Such banishments and consequent conspiracies against the mother city form a large part of the history of every Italian commonwealth in this period. The singular thing is that actual treason against the home city is very unusual. The exile might turn his arms against the party that had driven him forth, but it was the party, not the city, upon which he made war. This intense local patriotism is the good side of the narrow jealousy which set these communities, so similar in character and real interests, over against each other through generations of conflict. These several interests - Empire against Papacy, Empire against the towns, town against town, and party against party - were thus so closely interlaced that it is impossible at any given moment to be quite certain as to causes and effects. Historians and poets have naturally united to throw the personal element always into 
the foreground. For instance, at Florence in 1215 a young Buondelmonte, who had broken his troth plighted to a daughter of the house of Amidei, was murdered in the open street by relatives of the slighted girl. The feud was taken up and drew into it all branches of the two families most concerned. Villani the historian speaks of this as the first entry into Florence of the Guelf and Ghibelline conflicts, but in fact the Buondelmontes had long been the champions of the popular party and the Ubertis, near relatives of the Amidei, were the leaders of the nobility. This incident was only one of the characteristic outbursts in which long-concealed hatreds and rivalries found their expression.

Such was the situation of Italian politics about the year $\mathbf{2} 200$. The death of the emperor Henry VI in 1198 , the divided election Frederic II resulting in the choice of the Hohenstaufen Philip and the Democracies and the Guelf Otto IV, and the accession in the same year of the great pope Innocent III, all tended to give to the cities free scope for the development of their own institutions. Milan in the North and Florence in 'Tuscany became the natural centers of democratic movements that carried all before them. With Frederic II (1215-1250) comes a new series of attempts to reduce these scattered and numerous centers of power under one effective imperial administration. But even here the change in conditions is marked. Frederic Barbarossa had tried to control the cities by placing his own administrative officers (podestìs) over them and thus making them merely parts of a general imperial government. Frederic II tricd rather to use the local powers which he found ready to his hand and to win the cities by gaining the loyalty of their local rulers. If, for example, he could succeed in binding to himself the podestis of a great number of cities, he might hope that these cities would come to find their profit in regarding themselves as parts of his empire. This ambition of the emperor was met halfway by the progress of the office of podestà itself. Gradually the limits set by the jealousy of the early democracies to the power of their executive officers were 
removed. It became possible for an ambitious and powerful nobleman to become podestà of several neighboring cities at the same time. It no longer seemed necessary to limit terms of office quite so closely. A podestà was now often chosen for several years or even for life. His powers, too, were frequently enlarged, so that he was given more discretion in carrying out the laws. Sometimes, in moments of especial danger, he was given extraordinary powers, an arbitrium, - that is, free hand, - or an absolutio, that is, release from the checks of ordinary law, arrangements obviously borrowed from the old Roman dictatorship.

We see here very clearly the temptation to utilize the forms of popular liberties to overthrow these very liberties themselves. Only Ezzelino da at the price of eternal vigilance could they be preRomano as served. The best illustration of such attempts is the Tyrant in the Veronese career of Ezzelino da Romano. Ezzelino was the deMarch

scendant of a line of feudal nobles in the neighborhood of Verona. His fathers had distinguished themselves in the local fights of the time of Barbarossa, but, like other nobles, had come to see that their best hope of power was in taking their part in the life of the city communities near them. This Ezzelino, born in the same year with Frederic II, added to his program the policy of keeping on the side of the emperor in his attempts at Italian rule. During the whole long struggle of Frederic with the allied forces of the cities and the Church, Ezzelino steadily made his way to power by first gaining the government in one and another city and then using this advantage as agent of the emperor. The center of his influence was Verona, and from this point of vantage he managed to extend his control, partly by violence, but always under the forms of law, over the whole of the Veronese March; that is, pretty nearly the whole eastern half of Lombardy, up to the borders of the Venetian territory. In the cities of this region he appears as podesta, either actually governing or deputing his authority to some one else. The means by which Ezzelino strengthened his hold upon these subject cities were of such a 
violent and outrageous description that his name has stood for all time as the type of the very worst sort of tyrant known to human history.

Yet it must be remembered that he commended himself to his following as a centralizing and unifying force. Had he prevailed, The Second there might have grown out of his tyrannis a milder Lombard and stronger government for eastern Lombardy that League, 1226 would, conceivably, have served as a nucleus for a united Italy. Ezzelino failed, happily, because he had against him the democratic instincts not yet corrupted by too great success and by the laxity that followed it. The story of the great Lombard League of 1176 is repeated in the second Lombard League of 1226 . The emperor, encouraged by some successes, had called a Diet at Cremona to settle the destinies of Italy. Only a few territorial lords and the out-and-out Ghibelline cities responded to his call, while the Guelf cities, such as Milan, Bologna, Verona, Brescia, Padua, Ferrara, and many others formed a League of offence and defence for twenty-five years. Ezzelino acting, though without title, as the emperor's vicar in Italy did everything possible to undermine the loyalty of these cities to their allies, with the result that in 1237 the emperor could venture to attack the League Cortenuova, in open conflict. In the battle of Cortenuova he re1237

versed the fortunes of Legnano. The allied towns, Milan as usual in the front, were defeated with great loss. Yet the consequences were hardly less disastrous for the emperor than those of Legnano had been for his grandfather. His success aroused anew all the opposition that had been allowed to slumber. The Papacy, now led by the indomitable veteran Gregory IX, moved heaven and earth to bring out against him every resource of republican zeal. Frederic on his side employed every weapon of force and diplomacy. The pope excommunicated him; he stirred up revolt in Rome against the pope. The pope proposed to crown as rival emperor the brother of King Louis IX of France; Louis, saint though he was, promptly declined the proposition, for 
the fate of the emperor seemed to be bound up with that of all other sovereigns. The pope called a council at Rome (124I); Frederic, aided by the stanchly Ghibelline Pisa, attacked the fleet which was conveying the prelates from Genoa, totally defeated it, and carried the reverend fathers, together with representatives of the Lombard cities, captive to Pisa. While the pope appears everywhere as the champion of Italian liberties, the emperor goes on step by step building up a group of regular sovereignties in Italy which might easily in the future be united into one imperial subject state. He gives a daughter to Ezzelino in the north. His son Enzio marries the heiress of Sardinia and is made king of that country. His son Manfred, the beloved hero of later wars, governs for him in his own hereditary dominions in the south and fights his battles in the center of Italy. His lawyers, men skilled in every device of the old Roman imperial law, invent claims for him as fast as new emergencies arise. A permanent military force, largely composed of Saracens, makes it possible for him to dispense with the loyalty of the Italians. The wealth of Sicily and Apulia furnishes him the means to carry on his campaigns.

At the death of Gregory IX (124I), it seemed as if Italy must fall completely into the hands of the Hohenstaufen. The vision The Democra- of Barbarossa when he married his son Henry to cies reject Constance the heiress of the Normans in southern the Empire, Italy and Sicily seemed about to be realized. That $1241-1250$

this did not happen was due to the deep-rooted democratic spirit in the communes of the north and center of the peninsula, backed up by the unconquerable energy of the Papacy. After an interregnum of nearly two years and the short rule of Celestine IV, the Genoese Innocent IV continued with even greater determination and with much greater success the policy of Gregory IX. Our interest is only in the part played in this final stage of the Hohenstaufen tragedy by the Italian towns. The successes of Ezzelino must not be thought of primarily as imperial 
triumphs. In so far as they showed gains for the Italian Ghibellines, they have a real meaning for Italian history; in so far as they opened a way for imperial control they roused antagonism even in the Ghibelline party itself. Especially was this the case when the desperate cruelties of the tyrant began to show what the land had to expect if it should put its fortunes into the hands of any one executive power. Especially after the death of Frederic (1250) had cut him off from imperial support, the real nature of Ezzelino's control became increasingly evident. Only by continuous terrorizing of the subject populations could he hope to maintain Downfall of his hold upon them, and terror showed itself here, as Ezzelino, always, the most fatal source of political weakness. 1259 The terrorized peoples needed only the opportunity to turn against their tyrant, and the opportunity came when Ezzelino, feeling secure in eastern Lombardy, tried to become master in the west as well. He utilized the party quarrels in Milan to put himself in connection with the exiles driven out by Martino della Torre, undertaking to restore them at the price of the lordship of Milan for himself. It was an enterprise worthy of his talents, but it was to be his last. He succeeded in getting together a considerable army and advanced without resistance as far as the river Adda at Cassano. There the Milanese forces under command of Martino blocked his way, and he was compelled to give battle. Then was shown the real weakness of his position, the natural result of his tyrannous treatment of his subjects. The troops on which he had counted deserted him one by one, and he was left with a small troop to fight his last fight alone. Wounded and overpowered, he was made prisoner and decently cared for, but, if we may trust the contemporary accounts, died after a few days, tearing off his bandages, cursing his enemies, and blaspheming God, - the fitting end of a man who, during a long life of furious activity, had known no law but that of his own success. The March of Verona was once again "free"; that is, its cities were at liberty, each to govern itself by its own constitution. 
The year $125^{\circ}$ may be taken as marking the highest point of Italian democracy. It had already suffered many assaults, Rise of the but it had so far overcome them all: It had shown its Signoria ability to organize governments, to form leagues, to defend its rights with military force, and to develop within the limits of its several communities a vigorous industrial and intellectual life. It was proud of its achievements, restless in its ambitions; and looking forward to still greater things. The very violence of its local and partisan conflicts illustrates a common quality which we cannot otherwise describe than as "Italian." Underneath all this turmoil and apparent confusion of purposes and feelings there lay, after all, a perfectly well-developed national character. The furious individualism that was working itself out in these incessant conflicts was precisely the quality that was giving to this Italian character its capacities for individual production in every field of accomplishment. The question was, in the middle of the thirteenth century, how this tremendous democratic energy was to find guidance, direction, and order. Left to itself, it seemed as if it would wear itself out in violence and discord. The answer to this question is found in the history of the rise, throughout the peninsula, of the institution of the Signoria. This word, perhaps the most frequent of all the numerous terms descriptive of Italian political power, means the government of a city by some recognized single headship. This headship need not necessarily be vested in one individual. It might be held by several individuals or by a board of persons legally constituted. In general, however, it may be said that from the earliest moment the tendency was to concentrate the powers of a signoria in the hands of one person, the signor par excellence. Yet it belonged also to the essence of the Signoria that up to its very last stage it always denoted a deputed power, an authority lent for a specified time and under clearly defined statutory or, as we should say, "constitutional" conditions. The source of power was always and everywhere clearly understood to be the people itself. 
Down to about 1200 this "people" had, as we have seen, consisted of two classes, the well-to-do burghers and the noble fam-

Growth of ilies who had found it best worth their while to join the Organized Popolo fortunes with their fellow citizens of humbler origin. These two classes, with all their jealousies and frequent frictions, had come constantly nearer each other by the development of burghers into nobles and by the identification of nobles with commercial interests. Meanwhile a third element had been rising into prominence and power. The great mass of selfrespecting manufacturers and traders, the popolo minuto of the records, had fully shared with the higher classes the general advance of Italian civilization. They had organized themselves according to occupations into gilds, similar in many respects to the tradeunions of modern times, and they were coming more and more to a consciousness of their class interests and to a capacity for enforcing them. About 1200 we find taking shape in most of the Italian cities an organization of the popolo minuto, with organs of expression quite similar to those of the other classes. While the regular,-constitutional city organization was known as the "Commune," this new body appears by its side as the Popolo. Like the commune, the popolo has its statutes, its governing councils, and its chief officer, who is sometimes called, like that of the commune, podestì, sometimes anziano, but more frequently capitano.

In describing the limitations on the powers of the podestd we have already indicated the dread of excessive power felt by these Alliance of democratic communities, and the care with which the Popolo these limits are defined shows us that the danger was with the Higher Nobility a real one. The very prohibitions of the statutes indicate to us the steps by which a podestà might rise to be the tyrant of the community he governed. It is therefore a somewhat singular fact that in all the cities in which a signoria grew up, there is but one notable case of such a signorate being developed out of the office of podesta. In by far the greater number of cases the more or less arbitrary, aristocratic rule of the 
signor is the outgrowth of the purely democratic popolo and its head, the capitano del popolo. The explanation is not difficult. The great mass of the democracy, struggling for its political rights, found itself strengthened by an alliance with some powerful noble, who would take its part against the claims of the higher burgher class already in control of the commune. Such a noble, on the other hand, found in this democracy a solid support for any ambitious plans he and his friends might cherish to gain power and wealth for themselves. In the incessant 'strife of interests we have been outlining, there was obviously no lack of opportunities for such apparently unnatural alliances. It was generally by taking advantage of such opportunities that the most illustrious names of Italian history came first into prominence.

We shall, perhaps, best understand this process by taking as an example the course of events in Milan from about 1200 to the The Signoria definite establishment of the signoria in the family of in Milan; the Torre Family

the Visconti. Within the commonwealth of Milan, organized on the general plan we have just sketched, we find shortly before 1200 an organization of the popolo called the Credenza di San Ambrogio, from the name of the patron saint of Milan. In course of time the head of this organization comes to be called the podesta del popolo. Sometimes in the struggles that follow this official appears to be abolished, but the organization survives and keeps gaining little by little upon its rivals. In 1259 appears as podestà del popolo the noble Martino della Torre, and he continues to be chosen every year until his death in 1263 . Then his brother Philippo is chosen for life. We notice here two new ideas: succession in a family and life tenure of office, both ideas which had been specially obnoxious to the old democratic spirit. Philippo died in two years and was followed by his nephew Napoleone della Torre as podestà del popolo for life. This Torre family represents the strong Guelf reaction which took place everywhere after the death of Frederic II (1250). Napoleone held his place for eight years, but was driven out in 
1277 by a rival family, the Visconti, who represent henceforth the Ghibelline interest. Otto Visconti, the first of his line to hold the office of podestd del popolo, was also archbishop of the city. For a long time he seems to have held no political title whatever, but to have appointed the city officers and managed the city business without official position. That is the precise definition of the figure in American politics familiar to us as the "Boss," the most subtle enemy of popular government, since he can always shelter himself behind the laws, which he abuses but does not violate.

After ten years of unofficial "bossism" this ecclesiastical politician makes his nephew Matteo Visconti capitano del popolo for The Visconti one year, then for another, then for five years. In 1294 another idea takes shape. Matteo Visconti gets himself made "imperial vicar" by the emperor Adolf of Nassau, and this title is confirmed to him by Albert of Habsburg and by Henry of Luxemburg. In other words, the people of Milan, who had fought to the death against the claim of the Hohenstaufen emperors to exercise actual authority over them, make no opposition to the "legitimation" of a popular tyrant by emperors who were under all kinds of bonds not to assert imperial sovereignty in Italy. The imperial name was made a cat's-paw to strengthen ideas of "legitimacy" which had no place whatever in the traditions of the Milanese democracy. The principle of family succession was again strengthened in 1301 by the appointment of Matteo Visconti's son Galeazzo as capitano del popolo with his father for one year and then for another. A revolution in favor of the Torre family brings in a series of capitani of that name, but makes no change in the tendency of affairs towards a permanent signoria. With the return of Matteo Visconti to power

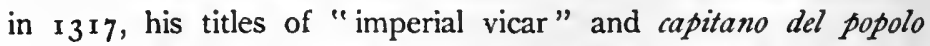
disappear and he is now known as dominus generalis; that is, in plain language, lord of Milan. The constitution was as yet unchanged, but in 1349 Archbishop Giovanni Visconti is definitely proclaimed dominus on the ground of heredity, and it is 
constitutionally provided that the lordship of Milan shall pass by inheritance in the direct line of legitimate male descendants of Matteo Visconti: Thus we see clearly illustrated in Milan the three stages of development of the Italian Signoria: first, the domination of the community by a family, then the "boss-rule" of an individual of this family while the structure of the government remains unchanged, and finally the "legitimation" of one of these individuals by an imperial charter. It must be remembered, however, that this was by no means a restoration of actual imperial power in Italy. Rather, it marked an intensification of the Italian spirit, with which the Empire found it profitable to deal on fairly equal terms.

A similar and almost parallel development goes on in the other cities of northern Italy. This apparent abandonment of democracy Expansion of must not be thought of as showing conscious distrust the Larger of the democratic principle, but rather as the only Signories practical means of overcoming the fury of partisan conflict which is its shadow side. The rapid growth of commerce and industry demanded above all things peace and safety, and men were ready to accept almost any form of native government that could assure them these. The same explanation must be given of the other most interesting phenomenon of the fourteenth century, the gradual expansion of the larger lordships by taking in the smaller. By about $135^{\circ}$ the number of the North Italian city-states had been reduced to six, and by about 1400 it had again shrunk to four. The methods of this expansion of power illustrate the same qualities of the Italian people we have already studied. The constitutions of the smaller commonwealths were not at first disturbed. The lord of the larger city was simply "chosen" as the chief magistrate of the smaller. He administered its affairs either himself or by some deputy of his choice, and this arrangement, at first temporary, easily became permanent. Or; a person already dominus of a smaller city might sell his signoria as a piece of personal property to the dominus of a larger one, receiving in 
turn either a handsome sum of money or certain permanent privileges in the appointment of officials, or, perhaps, certain castles or other landed property within the general sphere of influence of the greater lord. Or, again, an actual conquest by force might be necessary to "round out the frontiers" of the growing state, and the consequence would of course be that the victorious lord took the lordship of the conquered place. And then, finally, in a later stage, generations after the Empire had ceased to have any actual sovereignty in Italy, the successful tyrant found his most effectual guarantee of power in a "legitimation" by charter from an emperor, whereby he became a hereditary prince of an empire which had practically ceased to be. There could be no greater error than to think of these great Italian princes of the fifteenth and sixteenth centuries as having any relation whatever to the Empire except in name.

The six chief North Italian states were Milan, Verona, Padua, Mantua, Ferrara, and Venice. Down into the fifteenth century the The Great development of Venice was so little connected with the Lordships : movement of Italian affairs that we reserve all account r. Milan of it for another place. Venetian life and politics faced rather eastward than westward. We must mention also the largest of the remaining feudal, territorial sovereignties of the northwest, the counties of Savoy and of Montferrat, which were in continual dealings of diplomacy or of war with their democratic neighbors. In Milan we have already traced the rise to power of the Visconti family. For a long time its influence in Lombardy

2. Verona was seriously threatened by the similar growth of the Scalas or Scaligers in Verona. At one time it seemed likely that there would be a permanent Veronese state, holding a balance between the power of Milan at the west and that of Venice at the east of Lombardy. The immense growth of Milan in the second half of the fourteenth century, however, narrowed constantly the influence of the Scaligers and in 1387 completely destroyed it. Under this great expanding impulse there was again 
a prospect that Milan might control the politics of all Italy. At one time or another, her influence was supreme in Genoa, in Bologna, in Pisa and Siena in the west, and in Perugia and Assisi in the east. Only the steady opposition of Florence, the bulwark of democracy in Tuscany, averted this impending danger.

At Padua the family of the Carrara rose during the fourteenth century to the lordship of the city and surrounding country. Their

3. Padua

nearness to Venice, however, was a constant threat and, after passing temporarily under the control of Milan, Padua fell in 1405 definitely into Venetian hands and 4. Mantua

remained henceforth a part of the Republic. In Mantua the house of Gonzaga gained control early in the fourteenth century and let itself be "legitimated" by successive emperors. It held out against Milan and contrived to maintain its own existence and the integrity of the Mantuan territory under the name of a marquisate and later of a duchy during the 5. Ferrara whole of our period. In Ferrara we have almost precisely the same development as in Mantua, substituting the house of Este for that of Gonzaga and the Papacy for the Empire. Ferrara was the stanch defender of Guelf interests in the northeast, and its tyrants found the Papacy as good a source of legitimation as the Empire was for others. Among these 6. Venice four city-states, with Venice and the feudal territories of the northwest, there existed a relation altogether similar to that among the larger states of Europe. They were in almost continual warfare upon questions of expansion, but after all they came in time to recognize a certain principle of balance of power, and underneath all their conflict there was a vivid sense of common nationality, expressing itself, not in political union, but in a common interest in the things for which the Italy of this period especially stands.

In the south of Italy the French monarchy of the Anjou, which had replaced the German monarchy of the Hohenstaufen, had fixed itself upon the country and had done its utmost to repress 
the spirit of independence that had been working itself out in the north. The transfer of Sicily to the house of Aragon in the The Kingdom overwhelming catastrophe of the "Sicilian Vespers" of Naples (1282) brought in a Spanish influence to complicate still further the politics of the peninsula. Throughout our period the Angevine princes share in the life of Italy by maintaining a splendid court where every form of talent found ready recognition and by joining from time to time in political combinations such as we have just been describing. The kingdom of Naples, the largest, and in many ways the strongest, of the Italian states, could not, however, under any circumstances give any permanent promise of Italian unity. After all, it was a state dominated by foreign influences, founded by Norman Frenchmen, given its final form by a German legislator, threatened by the Spanish in Sicily, and now again more French than Italian in its real political interests.

As to the papal state, we have elsewhere ${ }^{1}$ outlined its peculiar character and problems. Though it had, like the states of the The Papal north, grown from a municipality, from that city State which could, without exaggeration, describe itself as "The City," the process of its growth had been totally different from thcirs. Like the authority of the Roman bishopric itself, its claims to a territorial possession went back to a semidivine source rather than to any natural process of growth. Two bodies of territory, the one on the west, the other on the east, of the Apennines, with a narrow connecting strip formed the ever-shifting limits of Rome's temporal power. The genius of Innocent III at the beginning of the thirteenth century had laid anew the foundations of the papal control in these territories, but the continual struggles with the Hohenstaufen and with the rival municipalities in the thirteenth century, and the absence of the popes at Avignon during the fourteenth, reduced the papal control to hardly more than the shadow of a name. The energy and military talent of Cardinal 
Albornoz (d. $13^{67}$ ), assisted for a time by the popularity of Cola di Rienzi (1313-r354), served to bring these papal lands once more into some semblance of regular submission to papal taxation, but it was not until well into the fifteenth century that the rule of the popes here could at all be compared with that of the half-popular, half-despotic governments of the northern republics. While in these latter the city elements were distinctly superior to the territorial or feudal, here in the papal state the power was chiefly in the hands of a turbulent nobility, active only in mutual rivalries, not in honest efforts to further the welfare of the land.

There remains to be noticed the vast central plain of Tuscany, lying on the western and southern slopes of the Apennines, in the fertile valleys of the Amo and the upper Tiber. Here,

The Florentine Population after 1250 favored by situation and by the fortunes of politics, had grown up to splendor and power the great ruling democracy of Florence and with her her scarcely less powerful rivals, Pisa, Siena, and Lucca. The striking difference in the development of Florence, as compared with that of the northern communes, is in the greater persistency of the democratic instinct. The earlier stages of its history correspond very closely to those we have been studying in the north, but whereas there the middle of the thirteenth century found most of the cities well along on the road towards a tyranny, the death of Frederic II in $125^{\circ}$ was the signal for a democratic revival in Florence which was to give character to her history for two centuries to come. The outline of parties here was essentially the same as elsewhere, but circumstances had combined to throw the strength of the Florentine people into the industrial and trading classes. From an early day, it is true, the hereditary nobility of the neighborhood had come to share in the life within the walls. Sometimes voluntarily, sometimes under compulsion, they had come to live a great part of the year in strong city houses, which had largely taken the place for them of the rural castles where the jealousy of the citizens no longer permitted them undisputed sway over the 
surrounding country. Many of them had gone into business and were growing rich by the same processes as their city neighbors. Once for all it was settled by this time that there was to be no territorial split between the city and the country. City life was to prevail; but still the more difficult question remained, how these two divisions of the people were to get on together. Chroniclers have dwelt chiefly upon the political aspects of this question. For them it is enough to say that Guelf and Ghibelline were always flying at each other's throats and forgetting the real interests of the city in bloody feuds. Poets, Dante above all, have naturally emphasized the personal element. We must, however, bear in

The First mind chiefly the economic motive. If Florence was to Popular Gov- develop a great industrial civilization, it was a matter of ernment, ${ }^{225^{\circ}}$ life and death that she should command the highways of Tuscany, should have a seaport on the west coast, and should be secure against unexpected attacks from her powerful neighbors. This is the policy, dictated by the commercial chiefs of the city and followed out with extraordinary consistency and success, which carried Florence to the very highest place among the Italian communities of the Renaissance period. The deliverance from Hohenstaufen control in $125^{\circ}$ was followed by an immediate popular uprising. The Guelf Party, now definitely forming into a close organization, put forward a Committee of Public Safety, consisting of thirty-six commoners, six from each ward of the city, as the basis of a new government. The podestì was still retained as the official head of the state, with his two councils of ninety and three hundred, but coördinate with him was also a capitano del popolo, now given chiefly military powers and distinctly representing the popular interests. He also had his two councils of eighty and two hundred and twenty. As a central executive body appears now a board of elders (anziani), composed of two commoners (popolani) from each ward, and, under varying forms, this board remains as the nearest approach to a permanent signoria. Under this first distinctively popular constitution Florence goes forward with its 
policy of control in Tuscany. It was a confessedly Guelf government. Ghibellines were banished, their property devoted to the interests of the Guelf Party, their names covered with infamy. Naturally these exiles (fuorusciti) sought to redeem themselves by alliance with the enemies of Florence. They found these in the neighboring cities, especially in Siena and Pisa and in the Hohenstaufen remnants which, under Manfred and then under the ill-starred Conradin, were making a desperate effort to resist the interests at once of the Papacy and of the communes.

For a while the Guelf government had moderate success, but in 1260 , in the fatal battle of Montaperti, it was utterly defeated by

Ghibelline a combination of the Sienese with Germans and GhibGovernment elline exiles, and the flower of the fighting men of and Failure, Florence perished. There was talk of wiping Florence 1260-1266

from the face of the earth as, just a hundred years before, Milan had been razed to the ground by the Ghibellines among her jealous neighbors. It was a splendid exhibition of Florentine patriotism rising above partisan hatred when Farinata degli Uberti, the most violent of all the Ghibellines, declared that he would defend the existence of his native city with his sword, if need were, alone against all her foes. Not to destroy Florence, but to rule it, was the purpose of their apparent disloyalty. That saved the day, but Florence passed for the time under a Ghibelline government as harsh and unjust as that of the Guelfs had been and, unlike theirs, without any clear program for the future greatness of the city. An orgy of exile and confiscation succeeded. So desperate did the situation become that in 1266 two outsiders, members of a semireligious order (Frati Gaudenti), a Guelf and a Ghibelline, were sent for to take the lordship of the city, a singular confession of momentary impotence. This bipartisan measure failed. A temporary council of thirty-six commoners, made up of Guelfs and Ghibellines, did not help matters. Bipartisan government was only a temporizing with antagonisms that had a deeper meaning than appeared on the surface. 
Just at this juncture appeared in Florence Charles of Anjou, brother of the French king, invited into Italy by the Papacy to

Signoria of Charles of Anjou, I266I276 take possession of the South and to end forever the claims of the hated Hohenstaufen. His aims were, for the moment, coincident with those of the Florentines, and they offered him for ten years the lordship of their city. We must not, however, fancy that this step corresponded at all to such grants of the signoria as we have seen in the northern cities. The democracy of Florence knew very well what it was doing. Charles needed it as much as it needed him. $\mathrm{He}$ had soldiers to spare, and Florence saw fighting ahead. He was the friend of the Papacy, and the papal interest was that of the Guelf Party. They would take their chances of his power becoming too great. The signoria of Charles of Anjou in Florence must be regarded not as a grant of real power but as an alliance for temporary purposes. Charles passed on southward to that series of military victories which completely crushed the Hohenstaufen party and brought the sovereignty of Naples permanently under French influence.

Meanwhile in Florence the real democratic forces were also taking on their permanent form. The names "Guelf" and "GhibOrganization elline" signify nothing but the party of the organof the Gilds ized commercial element over against the party of the "great ones," who were showing themselves less and less in sympathy with the dominant policy of the democracy. The problem was to render them incapable of an effective opposition. The program of the democracy was peace within and expansion without. The grandi were lawless within, and as to foreign relations were more inclined to futile partisan conflicts than to any wellconsidered scheme of national progress. Step by step, almost year by year, we can see the steady movement of the great trading and laboring population toward better organization and greater consciousness of power. The actual units of life had long since come to be the Merchant and Craft Gilds, and now "these 
were to become the units of power as well. The most important of them were classed together as the Greater Gilds (artes majores), The Mer- at first seven in number, but afterward increased to chant Gilds twelve. The rest, making up a total of twenty-one, were classed as the Lesser Gilds (artes minores). By far the most important were the two gilds of the wool merchants, that of the manufacturers, and that of the finishers, the famous "Calimala." It was this art of wool-finishing that gave especial reputation to Florentine industry. Cloths made in Flanders or in France from English wool could be bought more cheaply abroad than they could be made at home, and then, when they had been dyed, clipped, and finished as only Florentines knew how, they could be sold at a great profit. The art of silk-weaving came next, and closely related was that of the druggists, spice dealers, and physicians. The money changers, the furriers, and the notaries completed the first group. It will be seen that, with the exception of the notaries, all these were merchants in the grand style. They were all concerned with foreign affairs. They must travel constantly to secure markets for their goods, to regulate the purchase of raw material, to secure favorable conditions for their agents abroad. They must know how to deal with foreign governments, and could never forget that their native city was a state equal in dignity to any other. They must be men of education, of large views, of farseeing policy. It is they, and not the bearers of ancient names, who are to produce the proudest records of Florentine culture.

The gild was a miniature state. It had its consuls and its councils, its treasurer and its representative, the notary, who Florentine enforced its statutes and punished offenders. It unCommercial dertook to guarantee absolutely the quantity and Supremacy - quality of every piece of goods sent out under its stamp. An offender against its requirements was first punished by fines and then excluded from its membership, and that meant ruin. The consequence of this strictness was that Florentine goods and Florentine commercial honor had the highest respect 
of all Europe. It was the Florentines who had developed the system of bills of exchange, whereby commercial intercourse was incredibly furthered. While the currencies of Europe were in a hopeless state of confusion, the gold florin was becoming the model for gold coinage elsewhere. Florentine bankers were welcomed in every city, and their houses were coming to enjoy the confidence which made them eventually the creditors of half the princes of Europe. From an early day the Merchant Gilds had united into a general organization with a board of government, the Capitudini delle Arti, and later with an official, the proconsulo, who was in many ways the most important person in the state. Over against the grandi on the one hand and the craftgilds on the other, they formed the solid upper middle class that by the last quarter of the thirteenth century was prepared to take the burden of the state upon its shoulders.

Early in the year 1282 the Guelf Party, tired of bipartisanship, entered into combination with their fellow Guelfs throughout TusGovernment cany and secured commercial agreements that promised by the Mer- good things for a long time to come. Then followed chant Gilds ; the Priors, 1282 almost immediately the crushing overturn of the Sicilian Vespers, whereby the power of Charles of Anjou was lost in Sicily and seriously threatened in Naples. Florence had nothing to fear or to hope from that side and was free to act as seemed best to the party in power. In the month of June three heads of gilds, taken from the Calimala, the money changers, and the wool merchants, were declared to be chiefs of the state, under the name of "Priors." Two months later three others from the druggists, the furriers, and the silk merchants were added, and thus was constituted the magistracy of the Priori, generally called simply the Signoria, which was to remain the chief executive branch of the Florentine government as long as the Republic lasted. The Priori were to be chosen, one from each of the six wards of the city, were to serve two months, and then to have the chief voice in naming their successors. They must be Guelfs 
and active members of their respective gilds. With characteristic conservatism the rest of the municipal machinery, the podest $\grave{a}$ and capitano with their councils, was not disturbed. The new magistracy must prove its fitness by gradually overshadowing all others.

Still the animosity of parties was not overcome. The especial grievance of the commons was the illegal formation of the grandi The "Ordiinto family associations (consorterie), which made it nances of Justice," 1293 almost impossible to bring noble offenders against popolani to justice. Complaints were daily heard of commoners drawn into the houses of the nobles, tried by illegal tribunals, tortured, and made away with. Redress by the ordinary processes of law was impossible. Extraordinary circumstances demanded extraordinary measures. This was the provocation to the passing of the famous "Ordinances of Justice" of I 293. This, in every sense, extraordinary piece of legislation was due probably to the initiative of a man belonging to the very class against which it was especially aimed. Giano della Bella was a noble of great wealth and influence among the dominant Guelf families. Of course the historians of the time could explain his action only as the result of a personal affront at the hands of a rival noble, but it is evident that the measures against the class of nobles now set in motion by him were only the expression, on the one hand, of an intense class feeling and, on the other, of an ardent patriotism which was prepared to use exceptional means to meet exceptional dangers to the state.

The Ordinances of Justice were not intended to change in any way the constitution of the Republic, but only to provide Collective Re- additional safeguards for its effective administration. sponsibility They were what we call special or class legislation in of Nobles its most pronounced and offensive form. They did not, like the laws of the early French Revolution, try to abolish nobility, but rather to make it such a burden to its possessor that he would be glad to get rid of it. In fact, at first sight certain of the new laws seemed to strengthen rather than to weaken the 
prestige of the aristocracy. Just as on the one side the individual popolano was restrained in his action by his membership in a gild, so, on the other side, the grande was to be made to feel himself responsible for the actions of all the members of his consorteria. For every offence against a commoner the family or clan was to be held responsible, and this responsibility was defined to the most minute detail, - father for son, son for father, brother for brother, uncle for nephew, and so on. A popolano injured by a grande was bound under severe penalty to give information to the authorities. Two boxes were to be placed, one "in the palace of the podesta under the loggia lately constructed," the other in the palace of the Defensor (capitano) in a public place, to receive complaints.

For the more efficient administration of the hew laws a new magistracy was created. The gonfaloniere di giustizia was to be The Gonfa- the executive head of the commune in all matters loniere di arising out of the new situation. He was to be chosen Giustizia for a term of two months and from each of the six wards of the city in turn. He was to carry a banner of white divided by a red cross. He must be a member of one of the greater gilds and not of noble family, a sincere lover of peace and good order. He was to have under his orders a special force of a thousand foot soldiers, soon increased to two, and later to four, thousand. With this armed force it was his duty to proceed at once against any noble violator of the peace to the injury of a commoner and enforce the penalties of death, mutilation or destruction of property minutely prescribed by the Ordinances.

The form of procedure, as described in the sixth chapter of the Ordinances, is characteristic of the whole system. It is ordered

Summary Process of the Ordinances that if any noble of the city or the suburbs of Florence shall commit or cause to be committed any mortal injury against the person of a commoner, the podestd shall be bound by his oath immediately, without delay, and in conference with the gonfaloniere di giustizia to sound the alarm and proclaim throughout the city that the thousand foot. 
soldiers shall rush to arms and hasten to the house of the gonfaloniere, and at once the gonfaloniere with the foot soldiers and the Banner of Justice shall go to the house of the podestà. Then the podesta shall order one or more of the judges or knights with their followers to proceed with the gonfaloniere and the foot soldiers in full force against the houses and goods of the malefactor and completely destroy them to the foundations. And always, when the gonfaloniere, together with the familia of the podest $a$ and the foot soldiers, shall go to destroy the said property, the standard bearers of all the aforementioned gilds shall stand ready armed and equipped to go in full force to the capitano and put themselves under his command to do as seems best to him.

One sees that this is summary proceeding without the regular safeguards of trial and conviction, but at the same time one sees "Nobility" also how carefully the new measures are to be coma Disgrace bined with the normal working of the constitutional governing boards. So far as the repression of violence by the stronger against the weaker was concerned, this class legislation may be defended, but it did not stop here. The very fact of "nobility" itself was declared to be a stain upon the honor of the Florentine citizen. The word grande was now so carefully defined that there could be no misunderstanding it. The number of families thus branded was at first thirty-three, but this number was rapidly increased by the practice of counting as grandi any special family which might become offensive to the all-powerful Signoria. Even a popolano, if he married into a noble family or was guilty of the kind of offences against his class provided for by the Ordinances, could be punished by being degraded to the rank of noble. The only way by which a noble could become eligible to public office was by enrolling himself in the list of some gild and thus actually becoming a popolano. The most singular thing is that this monstrous system by which the traditionally " best" were excluded from the service of the state really worked. The Ordinances of Justice, increased in number, modified by 
circumstances, and adjusted to the fluctuations of party government, remained as the basis of Florentine political life so long as the Republic lasted. It can surprise no reader of Florentine history to learn that their reputed author, Giano della Bella, after playing for about two years the part of a Tribune of the People, fell a victim to the system he had helped to create and died an exile in France. Crude and inadequate as such measures must seem to us, they were the expression of a determination on the part of the industrious and forward-looking elements of the community that the idle and dissolute fraction, noble or not noble, should not obstruct the regular working of the machinery of the people's life. As compared with the readiness of the northern communes to surrender their liberties into the hands of noble tyrants only to escape the burden of that eternal vigilance which is ever the price of liberty, we cannot refuse them our admiration.

One of the greatest triumphs of the régime of the Priors was the ultimate victory over Pisa. The ambition of the Florentines Political to secure a seaport had always been foiled by the Control over persistent refusal of Pisa to let them pass through Pisa, 1284 its territory. Florence alone was unable to overcome this opposition, but she cleverly fomented the natural jealousy of Pisa's hereditary enemy on the sea, the rival republic of Genoa. While Florence kept Pisa busy on the land, Genoa gathered a fleet against her, which in the fatal battle of Meloria in 1284 completely destroyed her maritime prestige. So many prisoners were taken that the saying ran: "If you would see Pisa you must go to Genoa." It was the policy of Florence not to destroy Pisa, but to control her, and she pleaded her cause so successfully with the conqueror of Meloria that she maintained the integrity of Pisa and at the same time acquired a complete control of her future policy.

The same general policy dictated her arrangements with the other Tuscan towns. Siena, Arezzo, and Lucca, one by one, found it for their interest to fall into line with her politics and her 
industrial advancement. The best proof of the wisdom of this policy is seen in the rapid progress of the Republic in wealth and Florence con- culture. Down beyond the times of Dante (d. I32 I) trols all the Florentines and the Tuscans in general were noted Tuscany for simplicity and frugality of life. The wealth they were creating was devoted to the further extension of their trade and to the adornment of their cities in all the ways that most tended to real progress and cultivation. The very first action of the democracy after the death of Frederic II in $125^{\circ}$ was to order the reduction of the fortified towers within the city from one hundred and eighty to seventy-five feet in height, and with the material thus obtained to extend the city walls around the southern suburb of Oltrarno. In 1255 the splendid palace of the podestà, the later "Bargello," was begun. The streets, many of which were already paved with the great irregular slabs still surviving, were widened and leveled; bridges were added as necessity required. The great cathedral of Santa Maria dei Fiori was planned by Arnolfo di Cambio in the very last years of the thirteenth century. The same architect was intrusted with the magnificent Palace of the Signoria, the worthy home of this triumphant democracy. He was given much liberty of action, but with the express limitation that no part of the building should stand upon ground once covered by the houses of the Uberti, "Ghibellines and rebels against Florence." "To Arnolfo belongs also the church of Santa Croce, the Pantheon of Florence's illustrious dead. Santa Maria Novella dates from 1278 , San Marco from 1299 , the final outward decoration of the Baptistery from 1293. The wonder of Giotto's bell tower, lifting its dainty stem from the Piazza of Saint Mary of the Flowers, was the fitting symbol of these first fruits of popular liberty working itself out through fierce internal conflicts into lasting monuments of human genius.

The period of the "Ordinances" may be described also as "The Age of Dante." That name of itself brings before us the wonderful group of poets, artists, builders, chroniclers, who mark this 
glorious dawn of Italian culture. We think of Cimabue and his greater pupil Giotto, the leaders in the new school of painting which was to carry over the ancient tradition of Byzantine formalism into the naturalness and vigor of the Renaissance masters. We find the Italian tongue emerging from the medley of dialects which had grown out of the disappearing Latin, and taking form not merely in the verse of Dante but in the crisp and vivid prose of the historians Villani and Dino Compagni and even in the formal text of the "Ordinances" themselvès.

Down into the thirteenth century the history of Venice is singularly independent of that of the Italian peninsula. During all this

Origins of early period the outlook of Venice is toward the East the Venetian rather than toward the West. Its situation upon a State, $697-$ II72 group of islands, remote from all continental influence, had served to turn the interests of its inhabitants primarily to the sea as their chief source of occupation and of wealth. This remoteness had saved it from all those political complications in which the other cities of Italy had been involved through the conquests of northern invaders. The feudal system had passed it by, and the ecclesiastical system of the Middle Ages had adapted itself to Venetian conditions without great difficulty. The political instincts of the Venetians show from the first rather an oriental Byzantine, than a western feudal, cast. The peculiar political institutions under which the little state was to live during more than a thousand years begin to take shape in the year 697 , when the scattered inhabitants of the lagoons first perceived the necessity of union and joined in electing a duke (doge) to be their leader in government and in war. Though chosen for life and limited by no defined constitution, the doge was always a semipopular official. Every attempt to make his power absolute or hereditary was met by a determined opposition from the people, who declared that they had not come out into the lagoons to become the property of a lord. The same independence marked their dealings with their neighbors. The attempt of the Frankish government under 
Charlemagne to bring them under the general administration of the north of Italy was utterly defeated by the bravery of the Venetians and the advantage of their position. Though nominally subject to the Empire at Constantinople, they were in practice equally free from Byzantine control.

The history of Venetian development down to the year $\operatorname{II}_{72}$ is one of continual increase in actual popular rights without any forEstablishmal changes of constitution. That, it will be seen, is ment of the the time of great constitutional struggles on the mainGreat Council land, and these could not fail to have their reaction upon Venice. By this time there had been developed by perfectly natural processes what is commonly called the class of nobles; but it must be noted that Venetian nobility rested upon a basis altogether different from that of other Italian nobilities. It was an aristocracy of fact, not of creation or of sentiment. This group of leading native Venetian families led because they had shown the power to lead and had acquired the wealth which was the legitimate result of the same qualities of leadership. The establishment of the Great Council in 1172 was only the formal recognition of a fact, - that the actual managers of the Republic were to be found in its great families. The process was characteristic. Twelve deputies were elected from the six city wards, and each of these twelve was commissioned to choose forty persons from his own ward to form the council. This seems like a most democratic measure, but its aristocratic spirit is shown by the provision that at the end of the year this Great Council was to choose the twelve deputies who should select the members for the year following. This was a "ring" indeed, with no visible break at which "new" elements might be brought into the government. The council was to name six counselors for the doge instead of two as heretofore. Measures were taken to increase the formal honors and privileges of the doge, but it was clear that the whole scheme was devised to provide efficient checks upon his action. A few years later a Supreme Court of forty members was chosen to direct the civil 
and criminal justice, and this court was later invested with important economic and political functions as well.

This process of limiting the power of the doge goes steadily on during the period of the Republic's greatest activity in both Limitations upon the Doge internal and foreign affairs. Together with it moves on also at equal pace another process, the exclusion of the people. In 1229 a system of investigating the administration of a deceased doge by a special commission, and then preparing a form of coronation oath for his successor based upon this investigation, served to define the ducal policy in advance and wholly in accordance with the will of the council. The year following saw the establishment of a new council of pregadi (invited persons), later, under the name of the "senate," to be the principal executive body of the state. The temper of the controlling aristocracy is well shown in the extraordinary method of selecting the doge, perfected in 1268 . Though Venice was practically free from the factional wars of Guelf and Ghibelline, partisan spirit ran high, and the passions evolved in the ducal election seem to have

Process of the Ducal Election become fiercer as the importance of the office declined. The electoral scheme of 1268 displays the ingenuity we have elsewhere remarked by combining in an election the three several processes of election of a smaller body by a larger, selection of a larger by a smaller, and the lot. The Great Council chose by lot thirty of its members; from these nine were drawn by lot; these nine selected forty (seven votes necessary to a choice); from these forty, twelve were picked by lot; these twelve selected twenty-five (nine necessary for a choice); from these twenty-five, nine were picked by lot; these nine voted for fortyfive (seven necessary for a choice); from the forty-five, eleven were picked by lot; the eleven voted for forty-one (nine necessary for a choice), and these forty-one voted for the doge (twenty-five necessary for a choice). The object of this complicated process was of course to prevent electioneering, but it was a process eminently adapted to government by a "ring." 
It is instructive to compare this elective machinery in Venice with the two other permanent elective mechanisms of the middle

Comparison with Papal and Imperial Elections period, the imperial and the papal. In both of these the electoral body was small and was perpetuated, in the one case by appointment through the executive official whose successors it was to choose, in the other partly by inheritance in certain fixed princely families, partly by the election of certain cathedral chapters. In the case of Venice the electoral body was large; in comparison with the size of the community, very large. It may, therefore, be considered as, in a very real sense, acting in place of the community itself, a body of manageable size acting for a body too unwieldy to manage its own affairs. The difference in method of action too is characteristic. Instead of the simple process of direct election by equal suffrage, it employed a complicated system involving the principles of election, selection, and the lot. The coronation oath of the newly elected doge defining the policy he was to follow may well be compared with the electoral compacts both of the cardinals and of the imperial electors. By these compacts the future pope or the future emperor was bound to do certain things. We have seen with what ease the papal agreements were violated on the ground of papal superiority to all restraints. Imperial compacts were hardly better observed, but in Venice the smaller theater of action and the more acute jealousy of rivals made rebuke of bad faith more prompt and effective.

The next and final step in the organization of the aristocratic government took place in 1297 . The Great Council had by this

Closing of the Great Council time shrunk to a membership of two hundred and ten instead of the original four hundred and eighty. If it were to be the real managing power of the state, it must be enlarged and more precisely defined. Under the lead of the doge Pietro Gradenigo a law was made that the Supreme Court should ballot upon the names of all those who had sat in the council during the four years just passed, and that all those 
who received twelve votes out of the forty should be permanent members of the Great Council. At the same time a committee of three was appointed to propose new candidates with the approval of the doge. The question was upon what principle such candidates should be selected, and the answer to this question determined once for all the character of the Venetian government. The committee decided to present the names of those only who could prove that a paternal ancestor had been a member of the council at some time since $1 I 76$. This is the very famous measure known as the "Closing of the Great Council." It commended itself at once to all those who were interested in fixing forever the aristocracy of leading commercial families as the real "people" of Venice. How close this aristocracy had already become may be judged from the fact that in the year 1293 the council numbered eighteen Contarini, eleven Morosini, and ten Foscari. In a sense, therefore, the "Closing" was only the legal expression of what was already happening; but it was also, strange as this may sound, in another sense a popular measure. This is seen at once in the fact that the number of members in the council increased in fourteen years from 210 to 1017 and in forty-three years to 1212. In 1437 it had grown to 1300 , in 1490 to 1570 , and in 1510 to $167 \mathrm{I}$.

This steady growth of the council was due, of course, to the slow but continuous admission of "new" men by the choice of Membership their fellows. Such admission was based, at least in in the Great theory, upon distinguished service to the state and Council

provided, therefore, a needed counterpoise to the weakening effect of hereditary power. The Venetian aristocracy probably came as near as any aristocracy has ever come to being really a government by the "best." The Closing of the Great Council, usually dated at 1297 , was subject to repeated revision and modification. In the year 1315 a book was opened in which were to be inscribed the names of all persons reaching the age of eighteen who were eligible for admission to the council. This 
eligible list was then revised from time to time, and various devices were adopted to secure a fair selection from it. A law of 1319 The "Golden shows us again how the ultra-democratic principle of Book" the lot was trusted here. A number of counters equal to the number of names on the eligible list were placed in an urn. Of these counters a number equal to the number of vacancies were gilded. A child was then made to draw the counters from the urn, and the names were called in the order of their registration. Those whose names corresponded to the gilded counters were declared elected, - but if any one reached the age of twentyfive without being drawn, he had the right to enter the council with no further delay. Great care was taken to secure legitimacy of birth and social equality in marriages. The final seal was put upon this system in 1506 by opening the famous registry of births and marriages known as the "Golden Book."

Thus at almost the same moment the citizens of Florence were declaring nobility to be an absolute bar to the public service, and Nature of those of Venice were making it the indispensable conthe Council dition even of full citizenship. The Great Council must be thought of not as a representation of the Venetian people but as a substitute for them. In place of a vast, unwieldy mass of citizens was set a body much smaller, but still large enough to seem in a sense popular. It was very much as if the citizens of a New England town which had outgrown the stage of the town meeting should select one tenth of their number and hand over to them the administration of the affairs of the community. The business might be done better; it could hardly be done worse. The best proof of the value of the Venetian system for Venice is its permanence. With some modifications it lasted through the whole heroic period of Venetian history and lingered on until the destruction of the Republic by Napoleon Bonaparte. 


\section{CHAPTER VI}

\section{THE HONDRED YEARS' WAR}

\section{(1328-1453)}

The long conflict between France and England, to which histo. rians have given the name of "The Hundred Years' War," interests Character of us chiefly as an illustration on a great scale of the the Struggle transition from the mediæval, feudal order of society to the modern, national idea of political organization. Its nearer causcs were largely feudal, and its methods were still, to a great cxtent, those of the earlier period. Its remoter causes, however, and the motives that kept it alive are to be sought on both sides in a steadily growing sense of national unity and national honor. Under the feudal régime it may fairly be said that it mattered little to the landholding aristocracy whether it were under the sovereignty of one king or another. The thing it really cared about was whether its privileges were such as it had a right to expect, and whether these privileges were likely to be fully and honorably maintained. So long as this was the case the barons found their profit and their glory in standing by their king in those undertakings which had a certain national character. But if their rights were tampered with, or if another sovereign offered equal guaranties of privilege, they easily took advantage of the flexible feudal arrangements to shift their allegiance.

While this is true of both the countries engaged in this desperate struggle, there is evident by the close of the thirteenth century a very marked difference between them. English feudalism had always differed from that of France in its relation to the overlord. The impulse given to the royal power by William the 
Conqueror had never been quite lost. The rights of the crown had been steadily enforced, and what might have seemed a great disThe Royal advantage, namely, the absence of a large and compact Power in domaine which might become the nucleus of a monEngland archical state, had really proved an element of strength. For if the monarchy in England were to be maintained at all, it could only be through the willingness of its subjects to support it. Doubtless there were many times when this loyalty had been strained almost to the breaking point, but the necessity under which the English king was put of appealing to all his people instead of relying upon the resources of a great domaine had proved a powerful educating force in bringing about, on the whole, a harmonious working together of the several elements in the English state. On the other hand, it is clear that a rich family property overseas in France was a very tempting prize to an ambitious king in England. It offered him a chance, similar to that which his French rival enjoyed, of disciplining troublesome barons or obstinate parliaments by means of resources not dependent upon their good will. From this point of view, therefore, we can quite understand the energy with which the English kings of the eleventh and twelfth centuries pursued this ambition, to hold and to increase the lands in France which had come to them by way of feudal inheritance. Yet it remains true that while these lands, one after another, fell away from them by the chances of feudal succession, the monarchy was gaining slowly but surely in its hold on the people of England. Further, the smaller extent of English territory, its comparative isolation, and the relatively greater uniformity of its population made it more easily possible for its kings to assert themselves as against the rival interests of barons or of commons. The definite establishment of Parliament toward the close of the thirteenth century offered a point of application for all measures looking towards a wider extension of the royal power as the price of a more firmly founded popular liberty. 
In a word, by the year 1300 English nationality was no mere dream of the future. It was finding its expression in a popular The Royal Power in France monarchy and in a vigorous, self-conscious national life. In France a similar effort at concentration of royal power had been proceeding on different lines and had led to different results. We have already ${ }^{1}$ examined some of the processes by which the French kings of the thirteenth century had succeeded in enforcing their judicial authority outside their own domaine, while at the same time they were widening as far as possible the extent of the domaine itself. In both these ways the gain had been very great, so that when, in the early years of the fourteenth century, King Philip IV had called upon the nation to support him in his trial of strength with Pope Boniface VIII, the response had been, on the whole, surprisingly prompt and complete. Yet in all the measures of all the kings from Philip Augustus to Philip IV the essentially feudal structure of the French state had not seriously been called in question. The king could never forget that he was himself a feudal prince, a landbaron like the rest, and the aim of his policy was always not to crush his feudal rivals but to substitute himself for them. When a principality of France became domaine, the king succeeded to the rights of the former lord. For the moment nothing was changed in the land except its headship. Its "customs" - that is, the legal status of its inhabitants - were not essentially altered; the same contributions of men and money that had formerly been paid to the lord were now due to the king. Even before such annexation to the crown, it had been possible, certainly from the time of Philip Augustus, for the kings to maintain in the feudal territories royal officials with more or less extensive rights of jurisdiction and of taxation. After annexation the scope of action of these royal officials was simply increased, and they came to replace the similar officials formerly employed by the lesser lords. It is thus almost literally true that during our period the French kings 1 See Chapter I. 
were conquering France not often by the sword but gradually by the slower weapons of purchase, mortgage, forfeiture, gift, or inheritance.

The Hundred Years' War found France in the midst of this slow and difficult transformation. It is, of course, true that the Weakness of farther the strengthening of the monarchy went, the the Valois greater momentum it gained toward overcoming Monarchy the resistance of feudalism; but the peculiar character of the war, its long duration, the French reverses, and the dissensions among the leaders in French affairs are all to be understood only in the light of this conflict of political ideas. The monarchy at its best, as under Charles V, was too weak to control perfectly the resources it needed for the deliverance of the country. At its worst, as under John "the Good," it was itself too hopelessly feudal to be a real leader in the national cause it failed so utterly to understand.

As between the two powers, then, at the opening of the Hundred Years' War, the advantage appeared to be on the side of EngContrast in National Spirit land, - a small, compact, fairly homogeneous people under a popular and energetic monarchy over against a people widely extended, made up of many distinct racial elements, and divided against itself by strongly opposed class interests. The war was, on the whole, popular in England, while the French went into it for the first generation rather languidly and without any just sense of the great national issues involved. The armies and navies of England were almost entirely made up of Englishmen; the French, both on land and sea, fought with the aid of large contingents of hired foreigners. The English notion of fighting was to get the better of the enemy and to kill him off as fast as possible. The French leaders were still governed by the lofty but fantastic ideas of mediæval chivalry, which treated war rather as a game, to be played according to certain rules of honor, than as a desperate struggle of peoples bent on carrying their quarrel to the last extremity. It was only by the long training 
of the war itself that these notions were gradually dispelled and the French people taught that national unity was the indispensable condition of national honor.

'The immediate occasion of the Hundred Years' War was a dynastic one. A glance at the table of the Valois family shows The Dynastic at once the question at issue. When King Philip IV Quarrel died in 1314 he left three sons who followed him in regular succession upon the throne, and this in spite of the fact that the first two had each left daughters who might have succeeded them. The daughters had been set aside in pursuance of what was called the "Salic Law," and thus a precedent had been established for all future time. The last of the three brothers, Charles IV, dying in 1328 , left his queen in near expectation of an heir. Should this child prove to be a daughter, it was evident that the same question would arise once more and would be so much the more troublesome as the men likely to appear as claimants were more remote from the main Capetian line. In any case there would have to be a regency, and the choice of a regent was felt to involve the whole question of the succession. The male person nearest to the three late kings was their cousin, Philip of Valois, whose claim descended in the male line from Philip III. Philip's claim to the regency was at once disputed by King Edward III of England, who was the son of a daughter of Philip IV and hence, like Philip of Valois, a descendant of Philip III. He based his claim on the fact of his descent through an elder, though a female, line and maintained that even if the Salic Law debarred a woman from the succession, it could not prevent her from transmitting to her descendants a right she could not herself exercise.

If both claimants had been Frenchmen the decision might have been difficult; as it was, the national spirit was strong enough to settle the matter. Philip of Valois was chosen regent by the barons of France and two months later, on the birth of a daughter to the widow of Charles IV, he was proclaimed king. Then 


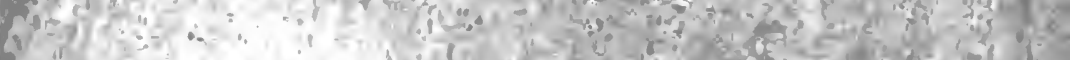

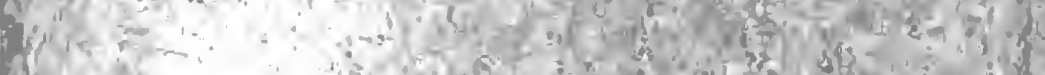

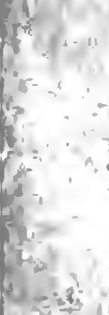

its

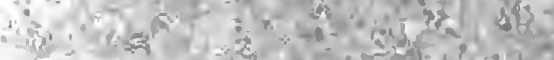

(1)

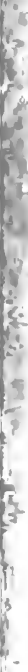

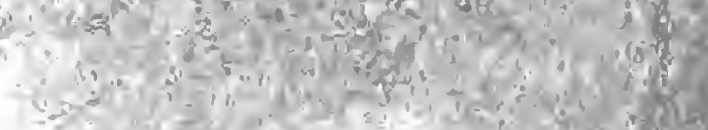

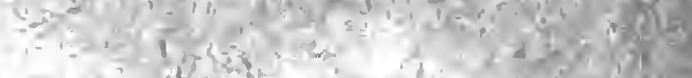

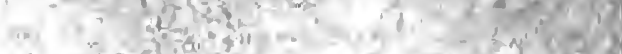

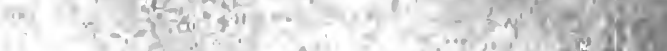
- -1
Bu.

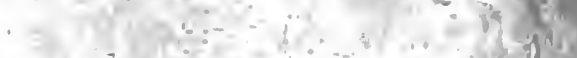

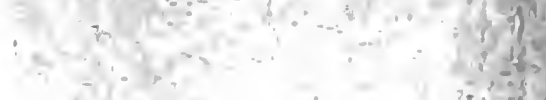

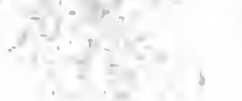

Tilitis -1 is $+f^{\prime}=10$ $+1$ 


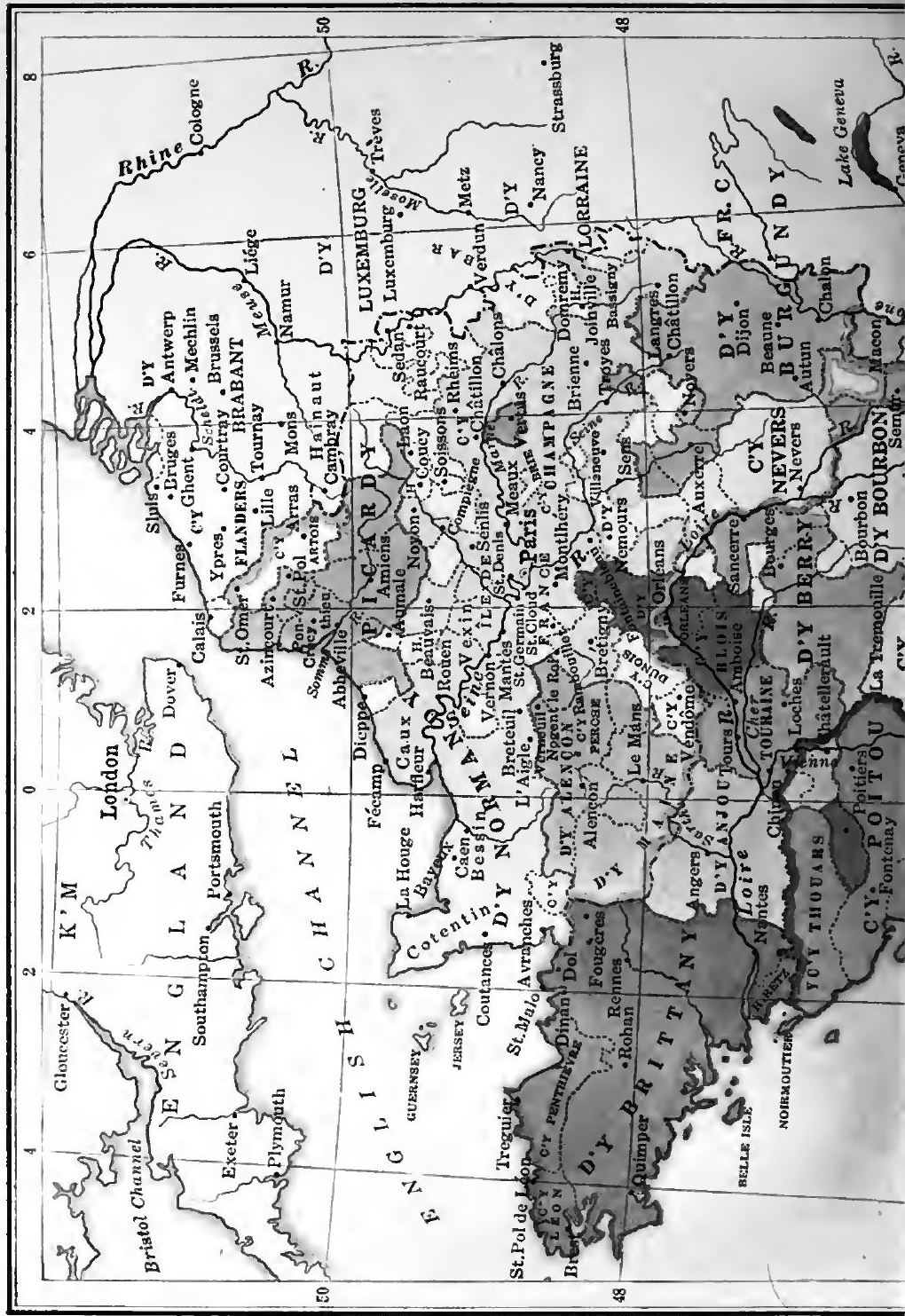




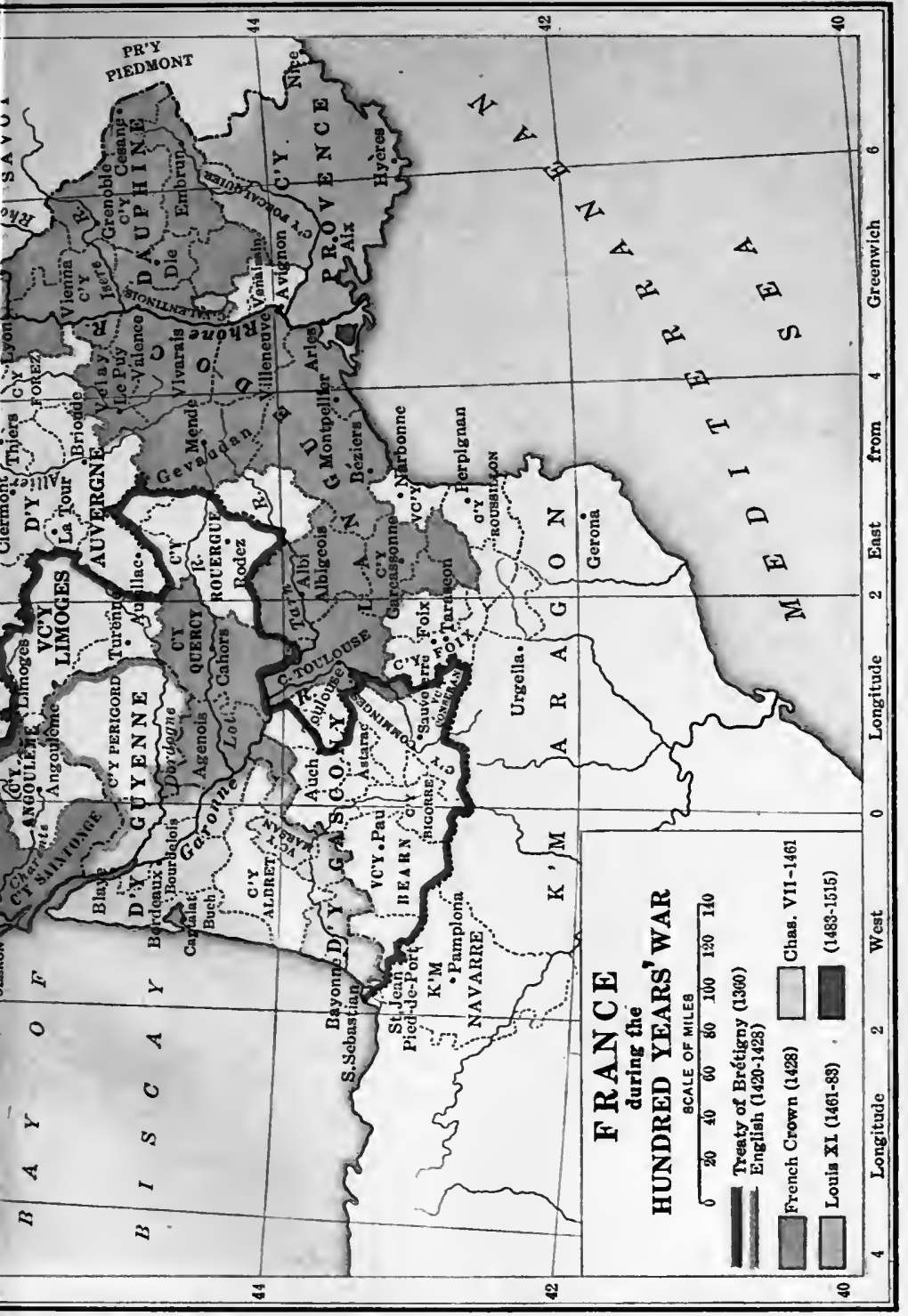


came the test question, - whether King Edward would accept the situation and do homage to King Philip for the lands which succession of he held in France. Under earlier feudal conditions Philip of homage paid by one king to another had not seemed Valois, 1328 to involve any sacrifice of honor. The relation was a personal one and did not carry with it any reflection on the vassal king's duty to his own people. Now, however, under the new impulses of the national spirit, King Edward could but hesitate. Homage to the French king seemed to be, in a way, a stain upon the honor of the English people. Summoned by Philip VI to do homage in person, he failed to appear, and Philip made preparations to seize the revenues of his lands. In response to a second summons Edward came over to Amiens and there, in a personal interview, agreed to pay homage "by mouth and word," but refused to place his hands in those of Philip and swear to be his liege man. ${ }^{1}$ It is significant that the reason he gave for his refusal was that he must refer the question to his Parliament and do as it would have him. Edward's conference with his advisers, the pressure of Philip's agents in Guienne, and the perpetual danger of war on the Scottish border resulted three years later (1331) in a formal declaration on his part that the homage at Amiens should be held to be liege homage, but only for those lands actually in the English possession.

The dynastic question seemed thus to be settled once for all, and so it might have remained but for a series of events not dynastic The Question and not feudal in their nature, but rather political and of Flanders economic. These were the affairs of Flanders, which we have treated more fully elsewhere. Politically, Flanders was to England what Scotland was to France, a country bound to her rival by ancient feudal ties, but stirred by the new spirit of national independence and seeking for a pretext to break. or to weaken

1 This is the statement in Froissart, I, 96. The "Grandes Chroniques de France," V, 326, say that Edward placed his hands in those of Philip and kissed him on the mouth. 
those earlier bonds. Economically the bond of Flanders with England was stronger than with France. The chief industry of the great Flemish cities, the manufacture of woolen cloths, was entirely dependent upon the ready importation of English wool, whereas the business dealings of Flanders with France were by comparison unimportant. The rich and powerful citizens of Ghent and Bruges were little inclined to bear the burdens of feudal service in order to maintain their lord, the count of Flanders, in his normal feudal relation to the French king. Especially was this the case when the feudal loyalty of their count to King Philip VI was met by Edward III with an embargo on English wool. "No wool, - no work !" was an appeal stronger than any sentiment of loyalty to prince or king. When the pinch of distress began to be felt, they listened eagerly to able leaders who were ready to show them a way out. Alliance with England was the obvious remedy, and to that policy Jacques van Artavelde, the ablest citizen of Flanders, was prepared to commit them. It was a glaring illustration of how far the old feudal spirit had given way to the demands of the new national states, that Edward III should relieve the scruples October 7 , of the Flemish on the point of their loyalty to the 1337 king of France by again declaring himself to be that person. Loyalty to him was thus in fact loyalty to France. It was a quibble unworthy of the great days of chivalry, but quite in harmony with the "practical" demands of modern politics.

This open violation of the dynastic settlement of $\mathrm{r} 33 \mathrm{I}$ was a challenge which Philip VI could not refuse, and both sides pressed Preparations their preparations for war. Indeed, for months past for War these preparations had been going on. King Edward had succeeded in bringing together a formidable group of allies. At a conference held at Valenciennes in May representatives of the count of Hainault, the dukes of Brabant and Geldern and several others of the lower Rhine princes, the Count Palatine of the Rhine, and the emperor Ludwig the Bavarian declared themselves in Edward's favor. Immediately afterward (May 24) Philip 
summoned the Council of Peers at Paris and with their approval declared that Edward had forfeited all fiefs held by him of the French crown. In a sense this was a declaration of war, but it is idle to attempt to throw the blame of what followed upon either party. Both were bent upon a trial of strength, and it was only a question of opportunity. That opportunity was offered by the situation in Flanders.

By far the most important ally of Edward III seemed to be the emperor Ludwig the Bavarian, whose long quarrel with the French English Support in Germany popes we have treated in connection with imperial history. The outbreak of hostilities between France and England coincided with the extraordinary series of political declarations in Germany by which the emperor and the electoral college proclaimed their independence of papal interference in the regular working of the imperial electoral machinery. ${ }^{2}$ The residence of the popes in France and their close relation to French politics seemed to throw Ludwig naturally on the English side. In the summer of 1338 King Edward left the Low Countries, where he had been strengthening his alliance with the local princes and set out on a journey up the Rhine. The emperor, after the great day at Rense, met him at Coblenz. All the electors of the Empire except King John of Bohemia, who was at the court of Philip VI, were present and gave their sanction to what followed. With every circumstance of solemnity the emperor made a public declaration that King Philip had forfeited his claim to the crown of France and proceeded to invest Edward III as imperial vicar. The preEdward III cise meaning of this transaction is not clear. Edward as Imperial names himself in documents: Vicarius generalis per Vicar

totam Alemanniam et Germaniam, but it seems unlikely that anything more than the lower Rhine country, especially on the left bank, can have been intended. The fact is that Edward was warmly received both going and coming by the princes of

1 The Electoral Compact at Rense and the imperial decree Licet juris of 1338, pp. 96-97. 
that region. All followed the lead of the emperor in promising their aid in the impending war, and all were only too glad to take the handsome sums of money which Edward distributed 'right and left. A few trifling acts of authority in the name of his imperial master were not resisted; but further than this the loudly heralded imperial alliance did not go. In the desultory campaigning of the next few months the German allies made but a sorry showing. Ludwig the Bavarian, a shifty politician here as always, did nothing whatever to support his grand promises, and Edward, fortunately for his cause, found himself thrown back upon the only true sources of his strength, upon English loyalty and English courage.

While diplomacy between the German, the French, the papal, and the English courts was doing its utmost to avert the conflict Battle of or to line up the adversaries to the best advantage, Sluys, Edward gathered his English forces for, a decisive June 24, $134^{\circ}$ blow. It had been Philip's intention to carry the war into England, and with this in view he had taken elaborate measures to strengthen the French power at sea. A naval station was established at Rouen, agreements were made with Italian sea captains, notably with Genoese, to furnish contingents of ships and men, and a new administration of naval affairs was planned. The names of Doria, Grimaldi, and Fieschi, famous in the naval wars of the Mediterranean, reappear here in the service of France. The earliest ordinance regulating the movement of the French fleet dates from this time. During the years 1338 and 1339 repeated descents were made upon the English coast; towns were attacked, some small outlying places burned and considerable shipping destroyed, but so sturdy was the resistance of the English whenever a landing was effected that the French fleet was withdrawn and the attitude of offence changed to that of defence.

It was still a matter of uncertainty whether Edward would decide to strike the first blow in the North or in Guienne, but in 
either case it was of the utmost importance for him to have control of the English Channel. The account of this, the first great naval encounter in English history, as given by Froissart, shows the English to have been as clever in manipulating their fleet as they were brave in fighting, whereas the French, equally brave, were led into the fight without any well-considered plan. The ships on both sides, not materially different in build from ordinary merchantmen, carried from one to two hundred fighting men, and the object of all maneuvering was to pair them off against the ships of the enemy, so that the conditions of the fight might be brought as near as possible to those of a combat on land. The English seem to have come quite suddenly upon the French not far from the mouth of the Scheldt, near the village of Sluys, from which the battle takes its name. The French ships, about two hundred in number, had all been crowded together into a bend of the shore, so that the Genoese captain urged the admiral, Behuchet, to order them out into the open sea, lest the English should fall upon them as they were and destroy them at will. The admiral refused. The English in about equal force bore down upon them, but as they came near quite suddenly veered and seemed to be in full retreat. Then the French set sail in pursuit, but the English turning once more had now the advantage of sun, wind, and tide. In perfect order, a ship with men-at-arms flanked in every case by two others carrying archers, they met the French, and the fight, quite like a battle on land, broke up into a series of encounters, the object of which was to bring two ships to close quarters and hold them fast by grappling irons until one side or the other should gain the advantage in a handto-hand mêlée. King Edward was there in person, and the presence of many English ladies who were on their way to join the queen in Flanders and who had to be protected by a special detachment of the fleet, seems to indicate that this expedition had been intended rather to transport troops for land service than to join battle at sea. 
The event proved, however, that this use of both men at arms and archers was the best that could have been made. The terValue of the rible English longbow, a weapon far superior to the Victory at mechanical crossbow, won here for the first time the Sluys fame which it was to sustain throughout the Hundred Years' War. Under cover of its deadly arrows the heavier ships with the men at arms were enabled to grapple with the enemy, and in spite of a desperate resistance, which prolonged the fight throughout the long June day, English valor finally prevailed. Of perhaps twenty thousand men on the French fleet barely five thousand escaped under cover of the dusk, and of these many were overtaken and destroyed on the following day. The English loss also was heavy, but the prestige of the victory at Sluys was of enormous value. It was a revelation at once of the power of the English people and of the quality of their young king. In a very strict sense of the word this was a national achievement. Henceforth the command of the sea was in English hands, the fear of invasion was banished, and the way was opened to carry the war into the enemy's country. It would seem to have been quite possible for King Edward to press straight on through the friendly Flanders and, using that country as a base, to dictate terms to Philip at Paris. But that was not the method of romantic warfare. To take too great advantage of an enemy's unpreparedness seemed to violate the rules of the great and honorable game of war. It was more in kceping with the code to sit down before the border fortress of Tournay and spend fruitless months in a vain attempt to take a prize that after all was hardly worth the cost. It was quite in harmony too with the chivalrous notions of the time that Edward and Philip should have made a personal issue of their quarrel and tried to arrange a single combat. which should settle their rivalry once for all. The trouble with this scheme was that Edward would put down as his stake only his claim on the kingdom of France, while Philip insisted on staking kingdom against kingdom, and so nothing came of it. 
The interval between the campaign of Sluys and that of Crécy (r340-1346) is mainly occupied with the early stages of the war

The War of Succession in Brittany of succession in Brittany, a long-drawn conflict which forms the background to many of the incidents of the greater national struggle. The outward pretext of the Breton war was the question of a successor to Duke John III, who died in 134I leaving no heir. The claimants were his brother, John of Montfort, and Charles of Blois, husband of Duke John's niece and himself a nephew of King Philip. The same point was made as in the case of the succession to the kingdom, that a woman could not inherit; but the futility of this pretext was shown by the fact that Philip in supporting the claim of Charles of Blois had to champion the very principle which would have excluded him from the throne. The truth was that Brittany included two regions very distinct as to population, an upper section bordering on lands of the French crown and a lower filled by a people of Celtic origin, furiously tenacious of their local right and owning but the slightest loyalty to the French king. Upper, or French, Brittany supported the claim of Charles of Blois, backed by his uncle King Philip, while John of Montfort found his support among the true Bretons and in the alliance of King Edward. It was on a smaller scale a national question, and its value to Edward III in offering him another entrance into French politics is evident. The history of this secondary conflict is one of heroic feats of arms, of useless sacrifice of brave men and devoted women, but it concerns us only as it was utilized for larger purposes. Philip VI, treating the Bretons as traitors to his crown, permitted himself acts of violent repression that could not fail to arouse anew the spirit of revolt and throw the province only the more decidedly into the arms of England. MeanWar in the while in the south the policy of Philip was to encroach South, r345 continually, little by little, upon the now comparatively narrow strip of territory left to England along the western coast. Taking advantage of the situation in Brittany, Edward declared 
war anew, and this time he chose Guienne as his point of attack. The summer of $\times 345$ found the earl of Derby in the field at the head of a considerable force, and in a few months the hold of England in the south was restored and considerably extended without any very serious fighting. The following spring (r346) hostilities were reopened in the face of a greatly increased French army. The English leader threw himself into the very strong fortress of Aiguillon on the Garonne, where he was besieged in form by the whole French force under John of Normandy, afterward King John "the Good."

While the choicest troops in France were thus engaged in the south, King Edward improved the opportunity to land with a The Cam- powerful army at La Hogue. Without resistance, paign of under the best of conditions, through a country teemCrécy, ${ }^{334}$ ing with abundant harvests, he moved in leisurely fashion through Lower Normandy toward the left or southern bank of the Seine. At Caen he halted long enough to take and pillage the town, but was not tempted into a siege of its fortress. It appears to have been his plan to cross to the right bank of the river and make for his own territory of Ponthieu, but everywhere he found the bridges destroyed and was thus led on, up to the very gates of Paris. Evidently he did not trust himself to enter upon the chances of a siege, but repaired the bridge at Poissy and began a rapid march northward. It was a marvel at the time that Philip, who was all this while at Paris, whence he could sec the smoke of his own burning villages, made not the slightest attempt to prevent the repairing of the Poissy bridge. He allowed the English to cross and to get well on their way northward before he set out with a large army to follow them. This famous race to Crécy was, on the English side, in the nature of a retreat. Edward III was driven, the more as he advanced, into a dangerous position between the sea, the lower course of the Somme in the neighborhood of Abbeville, and the line of the French army. Again he was anxious to cross a river, again he 
1346]

found the bridges and fords defended by the loyalty of the inhabitants, and again he pulled himself through by the superior steadiness and discipline of his troops. Above all things he insisted upon close order, - no straggling and no hurrying.

The French on the other hand, now eager for a fight, pressed on by forced marches and came almost in touch with the retreatThe Ford at ing English. King Edward was apparently in a desBlanchetaque perate strait, when suddenly he learned of a tidal ford below Abbeville. He waited for the fall of the tide, and then, pushing his men with all haste, got them across just as the advance of the French army came up. Meanwhile a French detachment had crossed above and hurried on to dispute the passage of the ford. They were, however, easily disposed of by the English archers, under cover of whose deadly fire the men at arms made their way across and secured the passage of the rest: King Edward's first move on finding himself in safety was to make a rapid detour westward, destroying everything in his way, until he came to his own land of Ponthieu. There he vowed he would stay and fight "if the king of France would come on, though he had ten times as strong a force as himself." And he ordered all his host to go to rest and to pray God to give them an honorable and a happy issue out of the affair.

The French army is represented as having spent a long time in getting itself into formation after crossing the river at Abbeville. In place of a compact and well-ordered host

Battle of

Crécy, August 25, the usual jumble of feudal contingents, each under its 1346 own leader and each eager to prove itself better than the rest by some signal feat of daring. The king was advised to hold his army in check, to give them food and rest, and not to fight until the following day. The chronicler, Jean le Bel, says that this advice pleased the king and that he gave orders to withdraw the banners; but it was already too late. The barons pressing on, each fearing that some one.might get into the fight 
before him, came in full sight of the English drawn up in fair order near the village of Crécy. This was too much for them. When they heard the king's order to draw back "no one of the lords was willing to give way unless those in the advance would turn back first, and those in the advance would not turn back for shame, but held their place without moving." Thus the knights were more and more crowded together in "pride and rivalry but without order." Then the troops of light foot soldiery, the Genoese crossbowmen, and the Spanish bidaux armed with darts, pike, and dagger, worn out as they were by the forced march from Abbeville, were brought by their captains in front of the knights and crowded forward by these until they were so near that the English archers began to shoot them down and drive them back upon the French horsemen. According to all rule the horsemen ought to have opened a way for the bowmen to pass through their ranks and re-form for a new attack, but as the king saw his archers give way, he and those about him cried out: "Down with this rabble! They are crowding upon us and getting in our way to no purpose." So these valiant knights charged upon their own foot soldiers and thus found themselves in a hopeless tangle of men and horses under the pitiless fire of the English longbowmen. It was rather a slaughter than a battle. Every arrow told on man or horse. The English men at arms, dismounted from their horses, awaited the assault. The first attack was upon the "battle" of young Edward, Prince of Wales, who won his spurs in a desperate encounter. The French army broke up into its feudal units and fought with infinite bravery but without leadership or plan. The episode of the blind king, John of Bohemia, whose place was at the other end of Europe, but who was here with a group of knightly followers enjoying the game of war, is characteristic of the time. When he heard that the fight was on and going badly, he begged his attendants to lead him forward far enough so that he might strike one good blow at the English. So they drew up about him, bound the bridles of their horses 
together with his, and charged pell-mell into the English ranks. The old king, true type of the mediæeval fighting ruler, had his desire. Not one blow only but three or four he had the joy of striking before he was himself stricken down, he and all his troop but two squires, who lived to tell the tale to Jean Froissart, who has told it to us.

From late afternoon until far into the dusk of the August day similar charges of French horse were hurled against the English The English line only to be thrown back with cruel loss. All Victory through the fight the English never moved from their position. Their action was directed from one point by the king in person. As night fell they were ordered to rest where they had fought, and only when the morning broke was the extent of their victory known. The French army was literally cut to pieces. It had engaged without waiting for the communal troops from the "good cities" to come up, and these were found next day in camp, ignorant of what had happened, and were scattered with heavy loss. King Philip, whose horse had been shot under him, riding through the night, was brought to a place of safety. The French loss, as given by Froissart from reports of actual count, was eleven great lords of the realm, eighty-three barons, and twelve hundred knights, besides thirty thousand foot! The English were said to have lost not a single knight, but this is highly improbable. Their victory was a triumph of steadiness and discipline over undisciplined and disorganized bravery. Behind it lay the spirit of English nationality, giving order and unity to every action.

The immediate sequel to the battle of Crécy was the siege of Calais, by far the most important point on the northern coast of

Siege of

Calais, 1346-1347
France and indispensable to England if her claims to French territory were to be maintained. The defence of Calais is one of the most heroic incidents of the war, or indeed of all wars. It shows a spirit strikingly in contrast with that of the French government, and helps us to understand why the great national struggle was so long-drawn-out. So far 
King Edward had avoided the costly delays of a siege, but now, as soon as his army at Crécy could be moved, he led it before Calais and began the investment of the place in regular form. The situation of Calais made all thought of an assault impossible. Close to the sea, at the mouth of a small river, surrounded by a double tide-moat, and protected on the land side by the shifting sands, it. could have repulsed any attack possible to the art of war of that day. Nothing remained for Edward, therefore, but to starve it out. He had command of the sea and counted upon the depression of the French to secure him by land. In this latter hope he was not disappointed. The English army settled into winter quarters, built a regular town with an open market twice a week, and by ranging pretty widely was able to keep open its communication with Flanders and to draw subsistence from a wide extent of country. On the sea there was more difficulty. It is true the English had no regular French fleet to fear, but the hardy sailors of Normandy and Picardy were able to elude them and during the first six months of the siege were continually slipping through their rather loose blockade and supplying the brave citizens with food. Meanwhile many a doughty deed of arms was performed between the city and the invading host, but no change came in the situation, except that King Edward was drawing tighter and tighter the lines of the blockade. The final link in the chain of investment was formed by a great wooden tower built close to the harbor entrance and equipped with canons, d'espringalles et darchiers, so that nothing could enter or leave without being destroyed. This may have been the first case of the use of cannon in warfare, though the missiles used may have Inaction of been only combustibles, not stones. Meanwhile King Philip VI Philip, in safety at Amiens, was doing nothing. Not until the early summer of 1347 was he so far aroused by the piteous appeals of the starving men of Calais as to send out his summons for an army to go to their relief. The response seems to have been surprisingly prompt. If we may believe Froissart, two 
hundred thousand men joined the royal banner and moved in the month of July direct toward Calais, arriving on the 27 th at Sandgate, a slight eminence two leagues from the beleaguered city. The citizens could see them from the walls and believed that their relief had come. Edward had made his preparations by fortifying the surrounding downs and guarding the one bridge by which the French could approach. On the other side, toward the north, a great force of Flemish had responded to his call and had advanced as far as Gravelines. Philip had not recovered from the bitter lesson of Crécy. He sent messengers to Edward with this highsounding challenge :

"The King of France sends us to you to say that he has come hither and is waiting at Sandgate Hill to fight with you, but can find no way to come at you. He greatly desires to relieve his good city of Calais and so has had his people inquire and see how he may come to you; but it is an impossible thing. He would be glad if you would appoint commissioners to meet with his and set a place where we may fight. And this he charges us to say and demand."

The king of England, when he had heard these words, was straightway counseled and advised to reply as follows:

"Sirs I I have well heard all that you demand of me from my adversary, who wrongfully keeps from me my heritage. Tell him from me, if you will, that I am here, where I have been for nearly a year. He has known this all the time, and might have come sooner if he had chosen; but he has let me stay here so long that it has cost me dear, and now I believe I shall soon be master of the town and castle of Calais. I have no intention of suiting his convenience and his ease and giving up what I believe I have conquered after so long desiring it. Tell him if he and his cannot come by this road they may look about till they find one." - 
Legates from Pope Clement VI, passing back and forth between the camps, were able to secure a truce of only three days, which King Edward characteristically improved by strengthening his intrenchments. Then the anxious watchers on the walls, saw the French banners scattering and the great army breaking up in all directions without striking a blow.

The fate of Calais was sealed. Summoned to surrender at discretion, the citizens begged of King Edward terms suited to their Fall of courage and their misfortunes. $\mathrm{He}$ at first refused to Calais, $\mathbf{3 4 7}$ treat with them, but was persuaded to accept six of their number to be dealt with as he pleased, the rest to be spared. Six noble citizens were found, who volunteered for this desperate service. They were led before the king barefooted, bareheaded, clad only in their shirts, and with ropes about their necks. The young king made as if nothing could turn him from his purpose to have their lives as part payment for all the losses of that costly year. 'The barons begged him to be merciful, but he held firm until his queen, Philippa of Hainault, threw herself at his feet and said: "Ah! My dear lord! Since I crossed the sea, in great peril as you know, I have never asked a favor of you. Now I beg and pray you humbly as a gift to me, by the blessed Mary's son and for love of me, that you have mercy on these six men." The king waited a little space before he answered and looked upon the good lady his wife, who was great with child and was weeping piteously before him on her knees, and his heart was softened, for he was loath to cross her in her condition, and when he spoke he said: "Ha! Lady! I would you were somewhere else than here! You beg so that I dare not withhold the gift you ask, and, loath though I am to do it - there! I give them to you. Do with them as you will." The six pledges were saved and sent on into France where they were provided for by the government. The inhabitants of Calais were driven out wholesale and replaced by English settlers. Calais thus became, and for two hundred years remained, an English town, a thorn in the side of France and a continual reminder 
to England of claims that with every generation, as the national sentiment strengthened, were growing less worth the having.

The eight years between the campaign of Crécy-Calais and the campaign of Poitiers were occupied by both France and England

An Interval of Truce, 1347-1355 in preparations for a conflict which both felt to be inevitable. Truces were made and from time to time extended; but they were little observed. The war in Brittany was hardly interrupted, and in the south the continual attempts of the French crown to assert rights over lands claimed by England were an endless source of bitterness. The internal policy of Philip VI, his persistent determination to enforce the rights of the crown against clerical and feudal privilege, his heavy taxation, all tended to weaken his government as against a determined foreign enemy. The monarchy was indeed gaining, but Philip of Valois was not the man to utilize for great national ends the vast resources of the country. At his death in $135^{\circ}$ the allimportant question of the English war was as far from settlement as ever.

The accession of John, the eldest son of Philip VI, confirmed the Valois dynasty, but changed nothing for the better. John's surname, le Bon, expresses his character. He was emphatically the "good fellow," popular in the sense of making himself well liked when he would, but without persistence of purpose; "honorable" in the feudal meaning of the word, but insensible to the obligations of business honesty; brave in his own person, but incapable of leadership at a crisis when the one thing most needed was to concentrate the whole strength of the state upon the national defence; hopelessly lacking in largeness of view and in command of himself. Over against this "good" king appears the "bad" Charles, king of Navarre, count of Evreux and lord of other wide estates in Normandy, a direct descendant in two lines from St. Louis and distinctly the ablest politician in France. His restless ambition aimed at nothing less than the French crown, and he became the center of a series of conspiracies, 
chiefly in the north, which fully occupied the opening years of King John's reign. The succession of blackguardly murders and royal reprisals reads more like the story of "an Italian tyrannis than like the record of a well-ordered state. Our interest in it lies only in the reaction upon the English question. The renewal of the great war was the direct consequence of the action of King John against Charles of Navarre, who called in Edward III of England to his aid in Normandy.

As in the campaign of 1346 , so now it was not clear until the last moment whether the decisive action was to be in the north or The Raiding in the south. The defence of Guienne was intrusted of Langue- to Edward, the "Black" Prince of Wales, who had doc, 1355 won his spurs at Crécy and now, as a youth of twentysix, was displaying exceptional military capacity. The campaign of 1355 was little more than one continuous raid through the fertile lands of Languedoc. Its object was simply destruction, in order that the resources of the country might not be used against the English in the following year. It was in all respects parallel to the raiding of King Edward through Normandy in 1346 , and it was equally successful. When the Black Prince went into winter quarters at Bordeaux he left behind him a desolated country, worth little to his enemies, but far from being won to the English cause. It was good warfare, but bad statesmanship.

Meanwhile King John, at his wits' end for resources to meet the coming attack, was suffering the pains of negotiating for sup-

King John and the EstatesGeneral port with his bourgeois subjects. The Estates-General of the North, the Languedoil, which now for more than a generation had been gaining in consciousness of their power, were willing to help the king, but only upon terms that must have seemed to him derogatory to his royal right. More and more clearly comes out the distinction between the monarchy and the nation. The Estates were loyal to France, but profoundly and with right distrusted the king. They were willing to approve a general tax, provided they could be assured 
that it would be honestly collected from all classes of the people and applied directly to its purpose; namely, the maintenance of an army for the national defence. To this end the Estates constituted themselves a permanent financial check upon the king, with their own officials to superintend the collection of the tax and its application to the purpose intended. They provided for regular future meetings and for the probable outbreak of new wars. They were really nothing less than a Committee of the National Defence, made necessary by the imminence of the danger and the incapacity of the king to adjust himself to the demands of a new time.

For the moment there was nothing for the king but to yield. $\mathrm{He}$ accepted everything, relying doubtless on his expected success in

\section{Normandy} and Charles of Navarre war and the imperfect organization of the "constitutionalist" party to clear himself of all unpleasant restraints. In the early spring of $135^{6}$ similar measures, displaying the same distrust of the king, were passed by the Estates of Languedoc. In neither case, however, were the Estates well supported by the country. The mediæval view of taxation as something imposed from above by a superior power rather than as a pledge of citizenship was not to be overcome for many a long day yet. King John was indeed in a hard place. If he could have turned without reserve to face the danger in the south, he might have captured or beaten the small force at the disposal of Prince Edward. He chose rather to meet what doubtless seemed the worse evil, the revolt of Normandy under the lead, open or secret, of Charles of Navarre. Instead of paying their dues to the officials of the Estates for the support of a national army, several Norman leaders broke openly with the king. John was not lacking in personal bravery. At Rouen, where his son, the Dauphin Charles, had invited Charles of Navarre to dine, he presented himself at the table with a following strong enough to arrest the chiefs of the conspiracy and to take the heads of several before any resistance could be made. The spectacle of the king of France shaking his royal brother of Navarre about the room by 
the hair, while a Navarrese squire strikes him in the breast with a dagger, is not an edifying one, but it was the kind of feat that, in lack of the deeper sentiments of loyalty, might decide the fate of kingdoms. Lower Normandy was thrown upon the English side, and English troops ravaged the province again as far as the town of Verneuil.

King John stood in Upper Normandy with an army of perhaps fifty thousand men, when news came that the Black Prince had

The Campaign of Poitiers, I356 left Bordeaux (July, 1356 ) and was on his way northward to join the English forces in Normandy. From Bordeaux the young prince moved in a direct line towards Orléans on the Loire, spending more than a month on the way and crossing at least a dozen water courses without opposition or loss. When nearly at Orléans he learned that King John with a very strong force was coming southward from Chartres; and, turning westward, he struck the Loire near Tours. He did not cross the river, but turned southward again and began a rapid march back to his "own" country. It was the story of the march to Crécy over again; only that this time the French won the race and succeeded in turning the English position, so that the prince found himself near Poitiers, well placed indeed, if fight he must, but little desiring to fight. His army was not above eight thousand men. That of the French may have been four or five times as large. At the last moment, after two cardinals in the name of the pope had exhausted every means to bring about a trucc, young F.dward had determined to retreat and had already moved two of his three "battles" across a stream, when the third under the earl of Salisbury was attacked by the French advance. Seeing that it was now too late to retreat, the prince called back his men, and so admirable was the English discipline that they re-formed and arrived in time to meet the French assault.

On the French side the same causes produced the same results as at Crécy. Horsemen wcre sent forward within range of the 
English bowmen, horses became unmanageable, and heavily armed men were sacrificed without a chance to show what they could Battle of do. Then, following the English example, men at Poitiers, arms dismounted and came into the fight on foot 1356

but unprotected by archers, and the English, taking advantage of this moment, mounted and charged. Prodigies of valor were performed on both sides, and the loss was far more evenly divided than at Crécy. King John holding in reserve his "battle," more numerous, it was said, than the whole English host, at last brought it into the fray, but in vain. Nothing could break the steady discipline of the English, and as, one after another, his chief followers fell around him or deserted the field, there was no escape but death or surrender. Again it had been demonstrated that the heart of the French people was not yet in this war.

The captivity of King John, his transportation to England, and the negotiations for his release are of importance to the national The Estates- cause only as giving to the sole remaining element of General of unity in the state, the Estates-General, its opportunity 1356-1357 to show what it could do. As before, they were called upon to provide first of all for the national defence, and that meant first money, but also it meant leadership. The history of the Estates of $135^{6-1} 357$ is one of the most important chapters in the story not merely of the French nation but of government by the people throughout Europe. Nowhere in the early records of parliamentary government is there a more impressive picture of a popular representation coming together with entire comprehension of what needed to be done and apparently with the amplest resources and the best intentions to do it. Nowhere is there a more dismal record of failure to grasp the real nature of the problem, to see that what gives security to any government must be some solid element of the people willing to stand by it and work with it. Such an element the feudal monarchy - as far as it went - had found in the great military and landed aristocracy. The 
question in France in $135^{6-1} 357$ was whether the new financial state was going to find a similar support in the rising power of the industrial and trading classes. Would those classes take their place as loyal supporters of the Valois monarchy and help it to drive the foreigner from their shores?

The answer seemed at first likely to be favorable. Under the lead of a remarkable man, Etienne Marcel, prévôt des marchands, Leadership of the chief of the Parisian bourgeoisie, the Estates rose Etienne for the moment to the height of their great opporMarcel

tunity. In a series of notable enactments they provided for a new levy of troops and for money to pay them. They began negotiations with the Dauphin and with Charles of Navarre on the basis of a permanent share in the administration of government to be given the Estates. Regular meetings with well-defined powers seemed to promise them a leadership in national affairs distinctly more effective than that of the Parliament in England. It was, however, precisely on the administrative side that the weakness of the Estates was most pronounced. As a check on the monarchy they might prove its salvation. As a substitute for it they were limited by an entire lack of traditions and by the pressure of a social order as far as possible from sympathizing with The Estates them. From an early moment in their brief career it and the became evident to their leaders that they could accomCrown

plish results only with the help of the monarchy, and the visible representative of the monarchy was the young Charles, later to be known as Charles the Clever (le Sige). The first aim of the Estates was to force him to take the head of affairs with advisers of their choosing. Their method was rude but, for the moment, effective. Marcel, at the head of an ever-ready Parisian mob, burst into the Dauphin's palace and murdered before his eyes the two counselors on whose advice he was relying. Then, acting in harmony with Charles of Navarre, who was looking for his own profit in the distress of the Valois, they persuaded the Dauphin to take the title of Regent and thus to give royal 
sanction to their acts. For about a month the clever youth allowed himself to remain under the tutelage of the bourgeoisie, then slipped quietly out of Paris and began that appeal to French loyalty which was to become the keynote of the regeneration of the monarchy and the making of the nation.

One is vividly reminded of the French Revolution and the Paris Commune as one reads of the Dauphin's dread of Paris and his Alliance of summons to the Estates to meet him at Compiène. Bourgeoisie It was a very meager gathering, quite without the and Jacquerie glowing enthusiasm of the former meetings, but it came halfway to meet the Dauphin's plans. Meanwhile occurred that frightful outbreak of the peasantry of the Île de France known in history as the "Jacquerie," from the word "Jacques," the ordinary nickname of the peasant. For a time it seemed as if the Parisian bourgeoisie acting with the Jacquerie might effect a practical overturn of society in the whole region of which Paris is the natural center, but the result, inevitable when the forces of social disorder are let loose without a definite constructive program, was not long delayed. The forces of order rallied and with reprisals no less savage than the outrages which had called them forth wiped out the stain upon the honor of their class with the blood of their fellow countrymen. In this reaction Marcel also met his fate. His nominal position was that of defender of Paris in the name of the Dauphin, but to strengthen himself he had entered into a fatal alliance with Charles of Navarre, the evil genius of every cause he touched, ambitious only to advance his own interests and never forgetting his "claim" on the throne of France. In June, $135^{8}$, Charles was made captain general of Paris and admitted troops of English soldiers into the city. It seems hardly doubtful that he had in mind the chance of capturing the Dauphin and, supported by Paris and the English, of proclaiming himself king. The Dauphin gathered a considerable force outside the city, prepared for a siege, and probably had his emissaries within the walls working quietly to gain adherents. This was the situation 
when Marcel, making the round of the gates at night, was set upon by a troop evidently well prepared and was murdered, a victim, Murder of Étienne like Artavelde, of a force he had set in motion but Marcel, July 31, $235^{8}$ was powerless to control. Like every leader of revolution he was expected to show in a moment results that need generations of training to accomplish. In the scheme of French politics as they were in 1357 there was no room for such a man except as the counselor of a monarchy wise enough to employ him, and such a monarchy did not exist.

While France was thus being torn in pieces by friend and foe alike, the excellent John Valois was enjoying his captivity in Royal London as became a gentleman and a prince. There compact at is little to indicate that he was anything but delighted London, 1359 to be out of the wretched snarl into which his own incapacity had helped to bring the government of his country. His attitude, if he had one, is well shown by the disgraceful treaty to which he agreed in March, I359, and which was sent over into France to be ratified by the Dauphin and the barons. According to this treaty King Edward was to receive in full sovereignty most of the ancient possessions of the English crown in France, both north and south of the Loire, amounting to about one half of the French territory, besides Calais and the surrounding country and the overlordship of Brittany. An enormous money indemnity was to repay England for the expenses of the war. It is to the eternal honor of all concerned that the Dauphin, the Estates, and even Charles of Navarre, who saw himself likely to fall between two stools, united in repudiating so shameful an abandonment of the French cause. It was far too high a price to pay for getting back their worthless king.

Edward, on his side, had his preparations made, and, hearing that the treaty had failed, "he cried out, so that all could hear, English Raid that before winter he would come into the kingdom

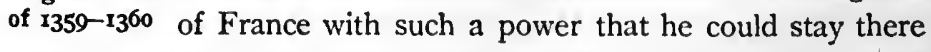
until he should either make an end of the war or bring about a 
peace to his own honor." He was as good as his word. The army which in October, 1359 , gathered about him at Calais was the most formidable host as yet brought over. It was not merely a fighting army, but was provided with every resource for a prolonged winter campaign. The first objective point was the strong city of Rheims, but on a show of resistance all attempt to take the place was abandoned, and the English army, unmolested by any enemy, passed on towards Upper Burgundy. The winter was spent there, and in the spring, after making most advantageous terms with the duke of Burgundy, the king turned to the northwest again and moved his army into the neighborhood of Paris. It was now past the middle of April. The English force had made another of the great marches which, no less than the battles it had won, had given proof of its quality; but it had made no permanent gains of any sort. The government at Paris had let it wear itself out in this heart-breaking fashion without stirring hand or foot, and even now, with the enemy at the gates, refused to come out and fight. The news from England was disquieting; a siege of Paris was out of the question; envoys of the Church were unceasing in their efforts to make peace, - Edward III decided to negotiate.

The outcome of these negotiations was the Treaty of Bretigny, one of the landmarks in this long national struggle. Its terms Treaty of Bretigny, 1360 were a considerable modification of the London agreement between the two kings, but secured a great extension of the actual English holdings in France. King Edward was to hold practically all the land along the western coast from the Loire to the border of Navarre and stretching eastward about halfway across the country. Many feudal lordships bordering on these territories were transferred in their allegiance from France to England. In the far north Ponthieu and Calais were secured to England in perpetuity. King John was to be released at once in return for an indemnity of three million gold crowns. King Edward renounced all claim on the ancient territories of the house of Anjou north of the Loire. France was to 
give up her alliance with Scotland, and England was to renounce her agreements with Flanders. The first generation of the Hundred Years' War had thus resulted in the bitter humiliation of France, a result directly traceable to her lack of unity and sense of national honor. Even the hard terms of the Peace of Bretigny were received at Paris with extravagant joy, so utterly was the country's power of resistance broken down. Here and there sparks of a true national feeling blazed up in revolt against this surrender to a foreign power, and naturally there was long delay in bringing together the first installments of the ransom money and in collecting the hostages who were to be left in England as pledges of the fulfillment of the treaty. King John had been brought over to Calais, where the two kings passed a jovial fortnight while the main terms of the treaty were being ratified, many 'details as to renunciations, however, being left for further elaboration within the year. The actual occupation of the surrendered territories showed the folly of the policy by which the English had gained them. The cruel raids throughout the south had left in the inhabitants, notably in those of the cities, a bitter resentment against the foreigner. Demands for the surrender of their keys were met in many cases with obstinate delay and even here and there with a show of resistance. It was not until four years later, and then after a vigorous demonstration in the country by the Prince of Wales, that the feudatories of Guienne could be brought to acknowledge the English sovereignty.

In all this we may see, if we will, the signs of a national sentiment stronger in disaster than in prosperity. This sentiment, The King's however, was far from attaching itself to the fortunes Ransom of the released but not yet ransomed king. In fact this incident of the Treaty of Bretigny was of importance only as adding another burden to the exhausted country. In vain were the people called upon to redeem the engagements of their useless sovereign. The money for the ransom came in but slowly, and, what was worse, instead of paying his debt of honor, this 
"good" king so frittered away what did come in that by the beginning of 1364 he was a million crowns in arrears with no prospect of making up the deficit. Fortunately, alike for himself and the country, a pretext was offered for relieving France of its worst encumbrance. The four princes of the blood who were serving as his hostages in England had grown more and more impatient at the slow progress of events. After about two years they made arrangements with King Edward by which they were to receive their liberty in return for still further concessions and were allowed to return as far as Calais, where they were left on parole with considerable freedom of movement. One of the king's sons, that same Louis of Anjou whom we meet in many adventures in southern Italy, broke his parole and escaped. The noble king, feeling that his son "had greatly stained the honor of the king and of his lineage," made the one sensible decision of his life, handed over the government to his other son, the clever Charles, and went back merrily to his English "prison." There he died three months later with all the obligations of his April, 1364 life still unfulfilled. The problem for France was whether her governing classes could unite upon a policy which would frankly recognize that the old feudal order of society was changing and would build up a new structure to take its place.

The answer to this problem is found in the policy of Charles $\mathrm{V}$ $\left(13^{6} 4^{-1} 3^{80}\right)$, and the person who more than any other typifies Policy of the spirit and the needs of the new time is Bertrand Charles v du Guesclin. Above all things it was necessary that the material resources of the country, its men and its money, should be brought into the service of the government. This meant heavy taxation, but it had been abundantly shown that France, in spite of all exhaustion, had money enough if only it could be honestly applied to her crying needs, and men enough if only they could be made to work together for a common end. These were the lines along which the rehabilitation of France was 
to be undertaken. First, the necessities of the country were plainly perceived by a clear-sighted monarch, and then men and measures were found to relieve them. It is plain from the outset that the government of Charles $\mathrm{V}$ had no intention whatever of observing the terms of the Treaty of Bretigny any further than was absolutely necessary, and there were loopholes enough left in that document to give them ready means of escape. Especially was this true in regard to the so-called "renunciations" of sovereignty in the surrendered territories. Even an actual occupation by an armed force under an English governor did not suffice so long as the legal title to the land was wanting in this particular form of guaranty. At any moment the people of a district might declare themselves to be unlawfully in English hands and unite in favor of France. In fact, this is just what happened in many cases. Charles $\mathrm{V}$ was a master in apparent inaction. He liked above all the policy of letting things go until they should right themselves, meanwhile, however, watching every opportunity to strengthen his hold on the allegiance of his subjects. Compared with his father and his grandfather, he is the very model of a modern as contrasted with a mediæeval king. Not a soldier, - he had according to all accounts run away, or at least "retired," from the battle at Poitiers, - he knew how to employ soldiers to the best advantage. Instead of relying, as his predecessors had done, upon a rabble of knightly adventurers more eager to perform "feats of arms" than to win battles, he began from the first to make use of the mass of fighting material which, under the form of the "Free Companies," had settled itself upon France.

The first great relief came with the settlement of the succession in Brittany. In the first year of Charles's reign, after twenty-three Settlement years of struggle, the extreme Breton party of the in Brittany, Montforts gained a decisive victory over the French 1365

party of the Blois at Aurai. It was a victory of the English sympathizers, and it was won largely with English arms; but the result was wholly favorable to France. Negotiation secured 
what war had failed to gain, and Jean de Montfort became not only duke of Brittany but also a vassal of the king of France.

The disposal of the Free Companies was a matter of great difficulty. Fortunately affairs in Spain shaped themselves so that Alliances of King Charles $V$. was naturally led to take part in Charles $\mathbf{v}$ them, and he improved the occasion to charge Du Guesclin with the task of enlisting an army from the Companies. The relief was, however, but temporary. A first success was followed by later reverses, Du Guesclin was made prisoner by the English allies of Pedro of Castile, and all the evils of an uncertain peace were let loose upon the South. Events were moving rapidly towards a rupture of the Treaty of Bretigny. One of Charles's first cares was to secure himself by a series of important alliances. King Edward had by the treaty formally renounced his close union with Flanders, which had been of such decisive service to England during the first stage of the war. He had, however, succeeded in arranging a marriage between his son Edmund, Earl of Cambridge, and his cousin Margaret, daughter of Count Louis of Flanders. The necessary dispensations had been obtained from the pope, and the marriage arrangements were approaching completion, when Charles $\mathrm{V}$ put in a demand for the hand of Margaret for his own brother, Philip of Burgundy. The complaisant pope, Urban V, was persuaded to revoke his dispensations, the engaged pair were released from their engagement, and, in spite of an obstinate resistance on the part of Count Louis of Flanders, this FlemishBurgundian marriage, one of the most momentous in its consequences in all European history, was celebrated at Ghent (June 19, 1369). The Valois monarchy had won a momentary diplomatic victory only to raise up against itself in the house of Burgundy the most implacable of enemies.

On the south the internal conflict in Castile brought about a valuable alliance between Charles $\mathrm{V}$ and the successful claimant, Henry of Trastamare, who also drew in King Ferdinand of Portugal as a third party in the union. This gave Charles a constant 
support in the rear of the English in Guienne, especially valuable along the seacoast, where naval operations were likely to play an

Support in Spain and in Germany important part in the approaching struggle. In Germany Charles $\mathrm{V}$ secured himself by a treaty with the Luxemburg-Bohemian emperor Charles IV, thus reversing the situation as it had been at the first outbreak of the war. Finally, Charles $\mathrm{V}$ showed his superiority over his predecessors by raising to the post of Constable of France that is, to the chief military command - the one man who had shown himself worthy of the honor, the rough Breton gentleman, Bertrand du Guesclin.

The formal declaration of war was justified by a purely national pretext. During the year 1368 many barons of Gascony, tired of Renewal of their relations with England, formally applied to King the war Charles to receive them into his allegiance. Charles bided his time until he felt sure of his support and then cited the Prince of Wales to appear before him at Paris in May, 1369, as his vassal, on the ground that King John had not renounced the sovereignty in Guienne but had only left it in abeyance for further discussion. This was the question of the "renunciations" on a great scale. When Prince Edward had read the citation, he cried out: "Gladly will I come to Paris, since the king of France commands it; but I will come with helmet on my head and sixty thousand men at my back!" It was an idle boast, for from the very outset the fortune of war was with the French. The recovery of the South and West was as rapid as had been their loss. Within a few months town after town had changed hands, and by the end of 1370 the Prince of Wales, instead of dictating terms in Paris, was sailing home, broken in health and spirit, to his early death.

North of the Loire things went somewhat better for the English cause. The raiding policy of the previous stage of the war was renewed, but without permanent result. By the king's order the French shut themselves up in the strong places and let the raid go by until it wore itself out. Even such doughty blades as 
Du Guesclin and Clisson approved this policy: "Better a country pillaged than a country lost !" Only from time to time and under favorable circumstances did the cautious cabinet of Charles V venture upon some bolder demonstration. Thus year after year the war, now become, as it seemed, a permanent incident of French Ruin of life, dragged itself on. The old antagonisms revived. Charles of Charles of Navarre continued to play his old game of Navarre, $\mathbf{r}^{800}$ treasonable intrigue until finally, after the failure of a plot to poison the king, his lands in Normandy were declared confiscated to the crown and definitely occupied by the French government. Navarre itself was mortgaged to the king of Castile to pay the cost of Charles's numerous wars. He died in 1387 , infamous to all time, the most extreme type of the great landed prince of the transition period, no longer content with the limitations of the heroic days of the feudal state and not yet adjusted to the duties and responsibilities of modern nationalism.

Still more significant were the events in Brittany. Here too an intense local patriotism had yielded only with great reluctance Nominal Re- to the terms of the Treaty of Bretigny. The land covery of was a continual entrance way for England into the Brittany, heart of France. Late in 1378 Duke John of MontI379

fort was cited before king and Parlement, duly tried and convicted of felony, and his lands declared forfeited to the crown of France. It was one thing, however, to decree and another thing to execute. The men to whom the king had to intrust the process of execution, Du Guesclin at their head, were mainly Bretons and, even without suspicion of disloyalty to him, were slow to attack the Breton forces which rallied about their beloved duke. Nothing decisive could be done, and it was to be generations yet before Brittany could be effectively united to the crown of France.

The "sage" king had not long to enjoy the fruits of his prudent policy. He died in 1380 without bringing the English question to any definite solution. He had succeeded in bringing 
most of the territory of France back into nominal allegiance to the crown, but this was only a first step toward making it actuBeginnings ally subject to French government. The king's death of Charles VI, raised a new set of problems which were to occupy 1380 the governing classes in France for a generation to come. The heir to the throne was a boy of twelve, a pitiful little figure, doomed from the start to a life of physical and mental misery. He stood for a monarchy that was really in the hands of a group of royal princes united only in the one purpose of making all the capital they could out of their commission as regents of the kingdom. The best security for the integrity of the French territory was the hardly less distracted state of England. King Edward III had died three years before (1377) and was succeeded by his grandson Richard II, a boy of eleven, whose uncertain hold upon the throne was an effectual bar to any vigorous foreign policy. In both countries the most imminent peril was civil war. In France the guardianship of the king was in the hands, first of his uncle, Louis of Anjou, and then of his two uncles, Philip of Burgundy and the duke of Bourbon, his mother's brother. The third brother of the late king, the duke of Berry, was given the administration of Languedoc and Guienne. A Council of Twelve, including the four uncles, was to have the direct administration of the business of the crown. The first years of the reign of Charles VI were a time of popular disturbance in many directions. In England occurred the great industrial uprising of 1381 under the lead of John Ball and Wat Tyler, and Internal Dif- similar disturbances broke out in the following year ficulties in France and England throughout France, both north and south. Doubtless profound cconomic changes were at the root of this widespread discontent, but the reaction upon political life was none the less evident and prompt. The remedy in every case was sought in a strengthening of the royal power and an increasing emphasis on the national interest. For a considerable period each of the great parties to the Hundred Years' War was too 
much occupied with these internal problems to give much thought to the larger question of national rivalry. Only after the suppression by the harshest measures of these popular demonstrations was it possible to return once more to the idea of a foreign war.

This time it was France that took the aggressive. Under the lead of the king's uncle, Philip the Bold, duke of Burgundy and Attempted now, since the death of his father-in-law in 1384 , Invasion of count of Flanders, by far the most important attempt England, $\mathbf{r}^{86}$ ever made at an invasion of England was set in motion during the year I386. From every quarter of France, even from the far south, contingents of mer and supplies of money poured into Flanders during the autumn. A fleet said to have numbered sixteen hundred sail was gathered at the port of Sluys and provided with every kind of apparatus, even to a sort of portable wooden town for winter quarters. The young king came in person, full of spirit, apparently looking forward with joy to the expedition, and the young princes of the blood could hardly contain their eagerness to be the first to touch the shore of England. Only the duke of Berry failed. In response to continued appeals he finally left the South and journeyed in leisurely fashion by way of Paris, arriving at Sluys just as the bad weather of the early winter set in. Meanwhile a foolish attempt had been made by the Constable of France with a fleet of sixty-two ships to make a landing at the mouth of the Thames. Heavy winds scattered the fleet, drove some vessels into the river, where they were captured by the English, and others on the coast of Zeeland, while only a broken remnant wandered back to Sluys. It is a curious story of mingled energy and timidity. The duke of Berry, upon his arrival, began to represent to the king the great dangers of even a successful landing in England. It was a hard and barren country, of which they, the French, were totally ignorant. A small force of Englishmen on their own soil could repel a much stronger invading army. It would be better to give up now than to risk all this splendid armament. On the other hand, the duke of 
Burgundy declared it would be a mortal disgrace to France to withdraw now after such great preparations; but his counsels were not heard and, in short, nothing was done. The several contingents were allowed to return home to add to the dangerous fighting material with which France was already overburdened, and another failure was added to the long list of French aggressive Failure of undertakings. A renewed effort in the following spring Invasion was defeated by the internal conflicts of Brittany. At every point it was growing more and more evident that the divided leadership under which France was suffering would prevent effective action in any direction. Especially it was becoming clear that Growth of the a deep-seated antagonism was developing between Burgundian the new Burgundian power and the other branches Power of the Valois family. Already the lands of Burgundy extended in an almost unbroken curve from the valley of the Rhône to the mouths of the Rhine and the Scheldt. A daughter of Duke Philip the Bold was married to an Austrian prince whose lands in western Switzerland bordered upon the Burgundian territory. Another daughter and a son were married $\left(13^{8} 5\right)$ to a son and a daughter of the Bavarian house of Wittelsbach, whose territories lay along the lower Meuse and Rhine. It was only natural that the ancient dream of a middle state between France and Germany, connecting the Mediterranean with the North Sea, touching England at one end and Italy at the other, should revive once more under the lead of a family of princes strong enough to hold the balance between the Great Powers.

A check seemed to be put to these and other rival ambitions, when, rather suddenly, on the completion of his twentieth year,

Charles VI

Sole Ruler in France, 1388 the young King Charles summoned his court to Rheims and there, with all formality, having duly thanked his loving uncles for their care of the kingdom, declared that henceforth he would govern for himself. In vain the princes protested and sought at least compensation in lands for their recent heavy outlays. They were 
allowed to retire to their estates, and Charles VI proceeded to reform the administration on the lines followed by his father. Especially he sought to fill the offices of the kingdom with "new men" of talent, a type which came to be known in derision as "Marmousets." In the course of two years important steps were taken toward securing a unified and capable management of the crown finances and judicial administration. The personal hold of the king on the provinces was demonstrated in a series of royal progresses. His young brother, Louis of Orléans, was betrothed to Valentina Visconti, daughter of Gian Galeazzo Visconti, lord of Milan, while the momentary success of Louis of Anjou in southern Italy, acting in harmony with the French pope, Clement, seemed to open up an indefinite prospect of French expansion in the peninsula. The national spirit was once more rallying about a governMadness of ment that was seeking to deserve its loyalty, when, Charles VI, with hardly a warning, the fatality of those who put 1392 their trust in princes overtook the peoples of France. In the year 1392 the young king, it is uncertain from what cause, fell a victim to a violent form of epileptic madness. It was the misfortune of France that this malady was not continuous enough to justify a permanent regency, which might have fixed upon a settled policy. It was to be thirty years yet before death was to put an end to the alternations of sanity and madness which opened the way for continual vacillations of policy and, what was worse yet, for the unbounded ambitions of a troop of rival princes, the scourge of France. "Woe to the land whose king is a child!" but worse yet is the fate of that land whose king is a fool. It was especially sad for France that in the multitude of her councilors the king in his lucid intervals was the only one who seemed to be actuated by a true sentiment of national honor. In those brief moments, growing unhappily less and less frequent, the cause of order and justice could at least be heard. At other times the only point on which the princes who stood for government were united was that the people were to be ground down to the last penny, 
in order that they, the princes, might enjoy life. It is a period of surface brilliancy, when splendid castles were built and a life of luxury was lived with every adornment of taste and refinement, such as only the Italian city-states could parallel.

The period of French history from 1392 to 1413 is best described as that of the Burgundian-Orleans rivalry, or, as it is more Burgundian- generally called, the Burgundian-Armagnac contest for Armagnac the control of the government. At the head of the Conflict

Orléans party was the king's brother Louis, husband of the Italian Valentina Visconti, intimate friend of the queen Isabella, the Bavarian woman upon whose head Frenchmen have united in visiting the evils they were powerless to prevent. This Louis of Orléans was the type of the gay cavalier and courtier, without a larger thought than his own political advantage. Over against him stood, since the death of Duke Philip the Bold of Burgundy in 1404, this Philip's son, John the Fearless, a rough, determined fighting man, lord of a great territory and ready to utilize France for the ends of Burgundian aggrandizement." As between these two dominant factions it is hard to see any distinction that means very much. Neither had any real support in any permanent element of the state. If either, perhaps the Burgundian party was the more generally popular at Paris, which was now coming to be more than ever before the center of French political life. We discern certain furious personal hatreds, and here and there class interests of one sort and another break out and play a momentary part in the larger movement of affairs; but until the English question once more reappears, there is no central point on which the historian can fix his attention.

Naturally the chroniclers of the time are most concerned with the dramatic incidents of this civil strife. No matter what question of public interest arose, the parties of Burgundy and Orléans were sure to take opposite sides. On the question of England the Orléanists were inclined to keep up the national hatred and to make political capital out of it, while Burgundy, anxious to save 
its Flemish lands from the certain danger of an English war, was equally active for peace. The leaders were constantly brought together in the royal council, and so long as Duke Philip lived, they were able to keep up a decent show of harmony. After his death in 1404 matters moved rapidly to a crisis, and it was the English war that gave occasion for the outbreak. Louis of Orléans was bent upon its renewal. John of Burgundy, though opposed to this policy, could do no less than support the war'when it was once declared ( 1407 ), but in the north, the field of action intrusted to him, he did nothing, while the campaigning of Louis of Orléans in the south was equally barren of results. The leaders came together for the winter in Paris, and had entered upon the usual course of alternate bickerings and festivities when suddenly Louis Murder of of Orléans, returning unarmed with a small guard from Louis of Orléans, November 23, 1407 a visit to the queen, was attacked in the street by a band of ruffians and brutally murdered. Suspicion fell upon Duke John, and after some days of pretended grief he frankly avowed the fact and left the city. A few weeks later he appeared again in Paris before the chief princes of the realm and through his advocate, the famous theologian Jean Petit, delivered a four-hours-long justification of his act as the lawful "removal" of a tyrant who had abused his power to oppress the people. Whatever may have been the value of this ex post facto argument, it is certain that the government - if we can speak of a government - did nothing, and that on the whole public sentiment in Paris approved the deed and was glad to be rid of an oppressor.

The civil war was on. The nominal head of the Orléans party was now Charles, son of the murdered Louis, a youth of eighteen, Outbreak of but the real leader was Charles's father-in-law, Bernard Civil War of Armagnac, from whom the party now takes its name. Territorially the Armagnacs became the party of the south and west, against the Burgundians in the north and east. The lesser barons ranged themselves under one or the other banner, and an 
irregular warfare, destructive to life and property but leading to no clear result, began. The utter lack of national feeling is shown by the zeal of both parties in bargaining with England. The "usurping " king, Henry IV of Lancaster, was only too glad to listen to overtures from any source that might seem to promise a recovery of the English lands in France and thus a gain in his prestige at home. At first Burgundy had the advantage and, with the help of English troops, succeeded in gaining Paris. Then an Armagnac coalition promised to restore to England the duchy of Guienne with many royal fortresses if Henry IV would send troops to August 12, aid them against Burgundy. Then again, within a 1412 few months, the rival chiefs were entertaining and embracing each other at Auxerre and mutually promising to disavow their foreign alliances.

For a time the center of interest shifts to Paris, the financial heart of the nation and at critical moments the spokesman of the "Ordonnance hard-working and tax-paying classes. Once again, in Cabochienne,"the face of the English peril, the government calls 1413 upon the Estates of the North, the Languedoil, to help it out, and again this call is the signal for a new activity of the organized gilds. This time it is the butchers of Paris who take the lead in city affairs, deal as a political unit with John of Burgundy, and undertake to dictate terms to the government. Under the lead of one Simon Caboche they constitute a formidable rival to the constitutional Estates. Their demands were chiefly two: reform of the public administration and war with England; but, as generally happens, this demonstration by the lowest grade of society was only an opportunity for better-trained and more responsible reformers. Everything that happened at Paris between 1413 and 1416 is roughly called "Cabochien," from the name of the butchers' leader, but the really valuable things done were the work not of the Cabochiens themselves but of royal officials, jurists, and theologians, representing especially the University and the corporate government of the city. Such is, 
for example, the famous "Ordonnance Cabochienne" of May 26, 14I3. The calling of the Estates was the signal for a flood of "grievances," poured in from the provinces, from the University, and from the trades, in which the demand of the government for more money was met by counter demands for administrative reforms. There was money enough, it was declared; the only trouble was that the people who had it - the princes, officials, and all their tribe of followers - were not called upon to disgorge. Violent scenes, recalling the days of Etienne Marcel (1357) and reminding us of the "Terror" of 1793 and the "Commune" of $187 \mathrm{I}$, led to the formation of the Ordonnance and its acceptance by the panic-stricken figment of a government. It interests us as showing what were the evils of administration most keenly felt and what measures were demanded for their remedy. It is a ponderous indictment of the mechanism of government, but it is in no sense a revolutionary document. Like so many similar efforts in the history of the Italian states, it was directed solely to securing a better administration of the constitution as it was. Its main purpose was to avoid the evils of personal appointment of officials by the king or by those who at any given moment stood for him. In place of such personal appointment with all its train of favoritism and corruption was to be substituted a system of elections, - not by any means popular elections, but rather selections of the necessary officials through the established councils of state, such as the Parlement and the Chamber of Accounts. Even the members of these great councils were to be created by election; so that if this scheme had ever worked, it would have resulted in a vast rotary, bureaucratic mechanism no less dangerous to liberty than the method of personal appointment. Every act of the crown was to be referred to its appropriate council, which was thus to serve as a check upon arbitrary abuse of power.

The Cabochian Ordinance was a fine specimen of that nice logical sense so characteristic of the French mind. Its weak point 
was the absence of any permanent roots in the French people at large. Without substantial power to enforce it the Ordinance was September 5, only so much paper, and when the popular demonstraI413 tion that had called it forth was crushed by an Orléanist revival at Paris it vanished. On the flimsy ground that it had not been regularly approved by the king, it was declared annulled and a copy of it was torn in pieces by the hangman in the presence of the king and the princes. Once more an alliance of "the people" with well-meaning doctrinaires had failed to save France from herself. Civil war broke out again and raged with intermittent fury until the one thing happened that could really touch the sense of national honor, - the renewal of the English peril. Accession of The death of Henry IV of Lancaster brought to the Henry V of English throne his son, Henry V, the "wild prince," England, March 20, still in the full flower of adventurous youth, but 1413 sobered by the responsibility of power. The disorders of France, the absence of any real government there, added to the active persuasions of John of Burgundy, were enough to determine him to renew the claims of England upon the French crown and to make his success at least highly probable. Scarcely a year after his accession he boldly demanded of Charles VI to hand the crown over to him and to seal the union by giving him his daughter in marriage. It is characteristic of the condition of affairs in France that the de facto government thought it worth while to pay England the doubtful compliment of proposing to send over an embassy of six hundred persons to offer him the princess together with substantial grants of land, but then, when this generous offer was rejected, informed Henry that he was not even rightful king of England. Naturally the business failed, and Henry pushed forward with energy and skill his preparations for an invasion of France.

His objective point was Harfleur, in the mouth of the Seine, where he might hope to establish an English station for the west that would serve the same purpose which Calais was already serving 
in the east. Although the nominal center of the French naval power was at Rouen, farther up the Seine, not a step was taken Invasion of to meet the oncoming of the English. An army variFrance, 1415 ously estimated at from ten to thirty thousand men, with a full equipment of material for a siege and for marching, was landed without accident, and in a month Harfleur was in its hands. From this moment on the history of the campaign of Agincourt is almost a repetition of that of Crécy two generations before. It would seem that Henry V, like Edward III, had no other object than to make a safe military demonstration and get back to a secure place with as little loss as possible. Having now Harfleur, he set out with only eight days' provision to march direct to Calais. Meanwhile a French army had been forming at Rouen, but it was fully two months after the English landing before this disorderly rabble of knightly contingents was ready to move. The old spirit of reckless adventure marked the gathering of this force, too large for management, without capable leadership, and with only slight attention to either strategy or tactics. Henry had planned to cross the Somme near its mouth by the same tidal ford by which Edward III had reached the field of Crécy. His march thither was unobstructed, but he found the ford well defended and turned to follow up the river until he should find a place to cross. As before, all bridges were destroyed by the neighboring people, and it was not until he had passed Amiens and got as far as Nesle that he heard of a place where the river spread out over marshes in such a way that a corduroy road could be thrown across it.

The French had already passed to the north of the English and were moving on a line nearly parallel with them, apparently The March seeking a favorable point to intercept their northward to Agincourt march and compel them to fight. As usual it was the French who were spoiling for the fray. The young nobles were tumbling over each other in their eagerness to get at the enemy. As usual also they had the advantage of numbers, and this time 
they reached the field of battle in better condition. The English army was suffering badly from lack of food, but in spite of everything it was held in that strict order which had marked the earlier campaigns. Even at the last moment, according to some authorities, King Henry made overtures to the French, offering to give up Harfleur and pay an indemnity for all damage done if he might be permitted to go on to Calais. Crossing a little stream near the village of Agincourt, the English found the whole French army barring the way and had no resource but to fight.

The battle of Agincourt forms the third in a series of which Crécy and Poitiers are the first two. It is one more demonstraBattle of tion of the superiority of the English arms and EngAgincourt, lish discipline. The attack was begun by their archers, 1415 who are reported as lightening their clothing to the last degree and advancing in the heavy mud to a point where they could plant their stakes in firm ground and from behind this temporary shelter could pour in a perfect hail of arrows upon the enemy. The French center was composed entirely of men at arms on foot flanked by two mounted squadrons. The center moved forward upon the English archers, who gave way a few paces. Then the French riders came up, closing in upon the archers, but by the same movement crowding also upon their own comrades of the center. The horses were no sooner within reach of the English arrows than they were driven wild, reared, and turned upon the French foot soldiers. The archers took advantage of the confusion to rush in between the ranks of the men at arms and ply their daggers with cruel effect; while the regular "battle" of the English knights charged into the mêlée and carried all before them. It was another victory of discipline, steadiness, and good sense over disorganized bravery and boastful contempt of every form of service except the heavy-armed chivalry of the medixval past. The slaughter of French knights was terrible, and so many prisoners were made that at one moment of the fight, as the fortune of battle seemed turning against him, King Henry gave orders to 
murder every man of them. Like Charlemagne and Napoleon under similar circumstances, this modern captain was sacrificing no practical advantage to humane sentiment. Seven thousand Frenchmen of noble rank were killed as against an English loss of four or five hundred. Fifteen hundred prisoners were taken, including the dukes of Orléans and Bourbon.

The crushing defeat of Agincourt should have been a revelation to France of the inevitable consequence of national discord. DurEnglish- ing the whole period of preparation for the English Burgundian invasion Duke John of Burgundy, by far the most Alliance, ${ }^{1416}$ powerful vassal of France, had not only held aloof himself but had ordered his immediate dependents in the north not to answer the king's summons to war. His failure to appear was doubtless one element in the disaster; but worse yet was his attitude of open preference for an English rather than a Valois government for France. Immediately after his victory at Agincourt King Henry pushed on to Calais and embarked for England, having been only three months on French soil. At Paris the first effect was a vigorous Orléans-Armagnac reaction under the lead of Bernard d'Armagnac, father-in-law of the young duke of Orléans and now made Constable of France. It was clear that the real enemy of the government was not England but Burgundy, and every preparation was made to resist an expected attack from Duke John. So complete in fact was this preparation that John found it impossible to reach the city and entered into closer and closer relations with England. In the autumn of 1416 the two rulers had a prolonged interview at Calais which resulted in some kind of understanding whereby Henry was to be left free to reconquer his land of France, while John of Burgundy was to engage the enemies of England in other directions. That slippery diplomat, the emperor Sigismund, under pretence of mediation, allied himself formally with England and Burgundy, and France was thus isolated. If we are inclined to accuse John the Fearless of a shameless act of treason, we must remember that feudal loyalty 
was a matter of give and take and that it would be idle to expect any good thing from loyalty to such a feeble thing as this Valois monarchy. Burgundy was as good a name as France, and in the movement of the peoples there was nothing extravagant in the notion of a Burgundian monarchy that might divide the Gallic lands with England and hold the balance of power on the Continent.

Thus carefully prepared, King Henry V came over again in 1417, landed at the mouth of the Seine, and began a systematic Subjection of reduction of Normandy. This time it was not a raid, Normandy but a conquest, that was planned. While Burgundians and Armagnacs were tearing each other in pieces at Paris, the English in several divisions were bringing one town after another into subjection and order. The central point of resistance was Rouen, whose heroic defence of six months is the companion piece to the noble story of Calais. Such episodes as these are the real revelations of the French spirit, crushed and crowded out of sight by the mad egotism of the governing classes. As at Calais, so here no effective attempt was made to relieve the distress of the starving citizens, and the surrender of Rouen meant the loss of all Normandy. Within the captured city Henry V proclaimed himself king of France and received the homage of the Norman barons. If now England and Burgundy could work together, it seemed as if the dismemberment of France were only a matter of a short time. It was openly discussed in the council of King Charles VI, represented for the moment by the wretched Queen Isabella the Bavarian, whether it were not best to treat with England on the basis of the Treaty of Bretigny ( 1360 ) and accept in addition the loss of Normandy !

It is at this point that we begin dimly to discern the rise of a new political party destined before long to be the rallying point of Rise of the national regeneration, - the party of the Dauphin Charles the Charles, the third son of Charles VI to bear this title. Dauphin, ${ }^{1418}$ This Charles, now a lad of seventeen, had gained his first experience in government as the head of the Orléans-Armagnac faction, and as such he commanded a considerable following in the 
center and south of France. At the close of the year 1418 he assumed the title of Regent and came into open competition with the court party and with Burgundy. Fortunately for him his entrance into affairs came at a moment when John of Burgundy, not getting out of his English alliance quite all he had hoped, foresaw his profit in adding a second string to his bow and making a treaty with the Dauphin looking toward the expulsion of the English now pressing on nearer and nearer to Paris. The final negotiations were set for September ro at Montereau but under circumstances of great suspicion and mutual distrust. The interview, held in an inclosed space on the middle of a bridge across the Yonne, was a stormy one, and, though the details are obscure, it seems hardly possible to free the party of the Dauphin from Murder of Jean sans Peur the charge of premeditated violence. The discussion soon turned into mutual recrimination, and it would have been more than human if hands had not been as ready with the sword as tongues were with insults. A general mélée seems to have taken place, in the midst of which the duke of Burgundy was murdered. There can be no doubt that the murder of Louis of Orléans twelve years before had left bitter resentments which had with difficulty been kept in check until now, and certainly the recent conduct of Jean sans Peur, his dealings with England, and his double-dealing with France had filled full the measure of a distrust for which murder was only the natural fifteenth-century expression.

In the negotiations that preceded the interview at Montereau John of Burgundy had continually insisted that the Dauphin had Treaty of no authority to make terms. While on the fatal bridge Troyes, he had demanded that the lad should go to the king May 20, 1420 his father at Troyes, and the Dauphin had replied with spirit that he would go to the king when he pleased and not at the duke's orders. In these words we may find at once the gist of the situation and the promise of the future. The party of the Dauphin was a new force, trying to work itself free of the influences that 
had surrounded the unhappy king. It was largely composed of "new men" similar in type to those who had made the fortune of Charles V. The class of citizens and scholars, despised by the futile chivalry of the princely houses, was to be the instrument by which the monarchy was to be reinvigorated and France redeemed. For the moment things seemed all io be going the other way. The new duke of Burgundy, Philip the Good, entered at once into close relations with Henry $\mathrm{V}$ of England and joined with him in securing from the government of Charles VI the signature of the Treaty of Troyes. By this document King Charles was made to recognize Henry $\mathrm{V}$ as heir to the crown of France to the exclusion of the Dauphin, who is expressly declared an enemy of the state. Henry is at once to enter upon the government of France, according to established principles, and is to marry Catherine, daughter of Charles VI. It remained only to conquer the lands south of the Seine which so far continued loyal to the Dauphin. Henry's entry into Paris was made in the winter of $\mathbf{1 4 2 0}$, amid the uproarious joy of the population. As between English and Armagnacs, Paris preferred the English, an expression of that inveterate distrust of the North toward the South which has never been quite absent from French politics.

In the following year, 1 421, King Henry crossed again to France and began a vigorous campaign in the country between the Seine

Death of Henry $\mathrm{V}$ and Dauphin into Aquitaine. Henry wintered in France and Charles VI, was preparing to renew the war in the spring when he 1422

was seized with a fatal illness. His heir was an infant of ten months, the future Henry VI. Two months later died also the pitiful object who for thirty years had served as the tool, now of one and now of the other, of the great political parties, but whose name had never served to rally to his service the national sentiment which alone could save France from herself. At the close of the funeral ceremonies for Charles VI the heralds proclaimed "Long life to Henry, our sovereign lord, King of France and England!". 
The seven years following the death of the two kings mark apparently the lowest point of the national feeling in France. Her government was divided between the "Roi de Paris," represented by the English regent, the duke of Bedford, and the "Roi de Bourges," the disinherited son of Charles VI, disavowed by every recognizable authority, by Parlement, by the Estates, and by the chief feudatories of the North. The momentary energy of the royal party, which had expressed itself in the murder of John of Burgundy, gave way almost immediately to an almost incredible egoism and indifference to the common weal. This fifth Valois seemed to be the worst of a very poor lot. He gave himself up to evil counselors, who for their own advantage encouraged his vices of idleness and pleasure seeking. Nothing could rouse him from his slothful self-indulgence, and his resources, considerable at first, melted away until the most degrading tales of his poverty were circulated and believed. Meanwhile the English, fortified in the Île de France, were pushing their conquests into the valley of the Loire. Their administration of the conquered country was strict but equitable. If taxes were heavy, at least the people were protected. The reputation for good order and discipline which had accompanied the English forces from the very beginning of the war continued now. So far as practical advantages were concerned, the inhabitants of Normandy, Picardy, and the Île de France were better off than they had been before. Still it is evident that an important fraction of the people always felt the rule of the English as an "occupation" rather than a permanent conquest. Many voices in prose and verse were heard lamenting the loss of the national honor. The sentiment of French unity was not dead, but only disarmed, scattered, wasted in fruitless appeals to a governing class that had worn itself out in senseless partisan conflicts. What was needed was some impulse, some shock that should bring the best elements of the people to the front and unite them, first against the foreigner and then against the still worse enemies at home. 
This new motive was to be found in the inspiration of a singlehearted and surprisingly gifted girl. This is not the place to The Mission rehearse again the familiar story of Jeanne d'Arc. of Jeanne D'Arc Stripped of all its unhistorical decorations, there is nothing in the story which violates our sense of the probable in human affairs. Her childhood passed in the midst of the furious raids of Burgundians and Armagnacs had caused her mind, already peculiarly sensitive to ideal impressions, to divell upon the miseries of life and to embody her own thoughts in the form of visions of saints and angels, the current coin of a devout fifteenth-century imagination. With the clear eyes of childhood she saw only the simple elements of the situation, - a nation without a king and the foreigner on the soil. To restore the king and to oust the English - this was the simple program revealed to her by her spirit-counselors and proclaimed by her to all who would hear as the gospel of regeneration for France. And she was right. It seemed a mad venture, but there were those in the Dauphin's council who discerned in this semidivine phenomenon a weapon more serviceable than all the persuasions of patriotism or of reason. Presented to the "Roi de Bourges," she disarmed all criticism by the simplicity of her manner and her unshakable faith in her divine mission. Her demand for troops to relieve the siege of Orléans, heard at first with a natural derision, was granted, and at once a new spirit of enthusiasm seized upon the entire Relief of French army. Orléans was invested by the English orleans forces in a manner not approached by them in any former land siege. A circle of fortresses (bastilles) was built around the city on both sides of the river, and a complete blockade was thus secured. The English themselves were supplied by a line of communication resting upon Paris, so that the fall of Orléans seemed to be only a question of time. The only possible method of relief was by breaking the blockade and gradually capturing the fortresses, and to this task the new energy of the French was now directed. The same sense of a superhuman aid 
which was inspiring them with new courage was also disheartening their enemies. Skirmish after skirmish resulted in their favor. A firm belief in the invincibility of their virgin leader carried them over every obstacle, and within a few days the gates of Orléans were opened, the victorious Maid had entered at the head of her devoted troops, and the systematic recovery of the surrounding country could begin.

So far the useless princeling in whose name this great feat of arms was accomplished had not stirred; but now the second stage of the program of redemption was proclaimed. The king must be crowned, and nowhere else must this be done but at Rheims, the ancient coronation city of the French kings from Clovis down. It required much persuasion to move the Dauphin even to such a joyous progress as this, but it was done. With a little army of twelve Coronation of hundred men the king and the Maid set out from Charles VII, Orléans, going by way of Troyes, which received them I429 after a brief resistance, and on the 16 th of July, 1429 , entered Rheims. The moral effect of the coronation of Charles VII was immediate and decisive. It was as if a ban had suddenly been lifted from the cities of the north and east. Many hastened to send their keys to King Charles; others were occupied without resistance. It would have needed only a decided action to bring Paris into his hands. It was the urgent advice of Jeanne d'Arc to march straight upon the capital; but counsels of diplomacy prevailed. Above all things Burgundy must be conciliated, and precious time was wasted in idle negotiations. Meanwhile the fighting spirit could not be quite restrained. Jeanne lead an assault on one of the very gates of Paris, and it was perhaps only a wound of hers that saved the city from capture. One feels at this point that her peculiar mission was ended, but, as with other prophets, her inspirations grew with what they fed on. Her "voices," that so far had confined themselves to general suggestions, became specific, and that is always fatal to prophecy. This girl would have been more than human if the constant repetition 
of her praises from far and near had not confirmed her in a sort of fatalistic confidence in herself. Without orders from the king she led in several little skirmishes that had no special purpose or result, and in one of these, at Compiègne, she fell by accident Capture and into the hands of a Burgundian troop. Like any other Death of piece of captured property she was then for sale to Jeanne d'Arc the highest bidder. The infamy of Charles VII begins here, - that he made no move to ransom the best asset his bankrupt monarchy had found and allowed the unhappy Maid to pass into the pitiless hands of the. English. From that moment her doom was sealed. It is a pity for the credit of her captors that she was not quietly put out of the way, as so many another troublesome person was. The long imprisonment, the weary trials, the devilish ingenuity that turned her story of rather conventional spiritual manifestations into confessions of heresy, - all these only serve to bring out into brighter relief the essentially simple motive of the young enthusiast. During these long months many a voice was raised in doubt or open criticism, but never a word came from the one source that might have helped.

It is quite probable that Charles VII, having been carried so far on the rising wave of popular sentiment, was beginning to dread its too insistent force. And, on the other hand, it is more than probable that Jeanne, if she had been spared, might have become the center of intrigues difficult to control. It was cheaper to let her go, and this Valois monarchy had never hesitated at any baseness. The pathetic figure of Jeanne d'Arc, lost for a moment in a frightful calamity, rises henceforth in dignity and sweetness as the type of that national unity she had helped to save. For, after all, her unclouded instinct had been right. The hold of England upon the conquered districts was not strong. Only a determined leadership was needed to gather together all the scattered elements of resistance and fling them in one concerted effort against the invader. For the present there was no visible sign of such leadership. The seven years following the death 
of Jeanne d'Arc $(1429-1436)$ are as unpromising as any in the whole history of the war. Private enmities breaking out in petty conflicts exhausted the resources of the country in all directions. Only an irregular guerrilla warfare served to keep alive the really great issue, but without decisive result on either side. The first real turning point is seen in the changed attitude of Philip of Burgundy. As time had passed, his relations with England had grown less and less cordial, while it had become more and more evident that his permanent interests lay on the side of France. Treaty of That is the meaning of the Treaty of Arras made beArras, 1435 tween Charles VII and Duke Philip in 1435. It was definitely intended to be a repudiation of the Treaty of Troyes (1420), but it was hardly less humiliating to the pride of France. King Charles promised to prosecute the murderers of Duke John and to hand over to Philip important territories, especially a line of cities along the river Somme adjacent to the Burgundian lands lying along the Meuse and Scheldt, thus forming a notable increase to the already vast dominion of Philip. Further, both these and the old Burgundian lands were to be held during Philip's life free from the obligations of homage and from all financial dues to the French crown. In short, the way seemed to be paved for that rounding out of a future Burgundian monarchy toward which the policy of the dukes had been steadily tending. The price of these ignominious concessions was to be the breaking of the Anglo-Burgundian alliance and the formal renunciation of all enmity on the score of the murder of Duke John. France was to save one portion of her territory by placing another portion in hardly less imminent danger.

The final expulsion of the English was aided by political dissensions in England which prevented a vigorous and consistent policy Reconquest toward France. Charles VII, now a man of thirty, of Normandy, began, though slowly, to realize some of the respon1450

sibilities of power and to surround himself with wiser counselors and more effective military commanders. Throughout the northwest repeated local plots against the English rule were 
utilized as centers of action, and finally, in 1436 , it was possible for the French army under the count of Richemont to make its entry into Paris. In I 444 a truce of twenty-two months was made on the basis of the status quo and was prolonged until 1449. In that year the war broke out again, at once in Normandy and in Guienne. In Normandy the French success was so rapid and decisive that by the close of $145^{\circ}$ the whole province was in French hands. In the south the fortune of the war turned largely upon the fate of Bordeaux, the great rich city of the western coast, industrially by far the most important possession of the English on the Continent. The English in Guienne had of late adopted the very liberal policy of letting things go pretty much as suited the local interests, and the inhabitants, not through any English sentiment but only in dread of a more exacting governReconquest ment, were little inclined to meet the French advances of Guienne, halfway. It required four years of campaigning by 1453 land and sea before the English domination in the south could be broken. In this last stage of the great war the parts of the adversaries appear changed. It is here the French who represent stern discipline and a grim determination to push the national struggle to the end. The surrender of Bordeaux in I 453 marks the final absorption of Guienne into the royal administration of France. It was the dramatic culmination of the national upbuilding, just as the loss of Calais, one hundred and six years before, had marked the beginning of the national disintegration.

It would be a great exaggeration to suppose that the lesson of the Hundred Years' War had been thoroughly learned. It is easy Effects of enough now to perceive that the ills of France had the War in come largely from the failure of her governing classes France to grasp the responsibilities of government; but, looking at things as they were in 1453 , it is hard to perceive any very great change in this respect. If England had been in position to turn all her energies to the maintenance of her French conquests, to winning the affection of her subjects there by wise economic 
measures, and to a sound development of the country, one can see no good reason why she might not be there yet. Certainly it was no love for their Valois rulers that held the people of France finally to their French allegiance. In certain definite respects, however, we can note improvements destined to be the germs of a permanent progress. The campaigns of the great war had been fought, on the French side, with armies still organized under mainly feudal conditions. True, the old feudal service had changed largely into that of professional, mercenary bands, but the traditional weakness of the king had continued. Where formerly he had been unable to hold permanently the service of his greater barons, now he was not able to find the money to pay hired troops under his own orders. Still, as before, he had been compelled to bargain with the provincial nobility to get soldiers, and we have seen how utterly untrustworthy such a system was. Not that there was not enough fighting material in France. One of the chief anxieties of the government was the superabundance of armed men roughly organized in "Companies," who were getting their living off the common people in all parts of the country, plundering merchants and making life unsafe for honest men and women. Again and again attempts had been made, as in the time of Du Guesclin, to get rid of these troublesome servants by employing or transporting them, but always, in every lull of actual warfare, they had reappeared to plague the land anew.

The truce of I 444 was the moment taken by Charles VII to remedy this primary evil by a systematic reorganization of the Military Reform of taking were almost ludicrously modest. A maximum Charles VII, of two thousand "lances" was set as the nucleus of I444

what was to become the royal army. A "lance" consisted of one fully armed fighting man with a squire, a coutillier, a valet de guerre, and two archers, all mounted. The army. would thus number twelve thousand mounted men divided into twenty companies of one hundred "lances" each. A company: 
was to be under the command of a captain, a professional soldier selected from the numerous unemployed bands that had been terrorizing the country, but now to be utilized against them. These captains were chosen with great care and bound by oath to the permanent service of the king. They were to pick their own men and were to hold them to a strict account as to conduct. Still more striking is the provision for a service of foot soldiers. The most important lesson of the Hundred Years' War was the superiority of a well-managed infantry over even a well-armed and courageous cavalry, but down to this time the governing classes had not been willing to learn the lesson. There had always, howEmployment ever, been a considerable communal militia maintained of Communal in the larger towns, armed mainly with the crossbow Infantry

and organized into fraternities of the usual mediæval type. Again and again they had offered their services in time of active warfare, but had either been rejected or if actually employed had been destroyed in action by the foolish military pride of the governing classes. Where foot soldiery had been utilized at all, it had generally been in the form of hired foreign companies without interest in the national cause and certain to prove a scourge of the land when active campaigning ceased. These communal troops were now to be set in honor as an integral part of the military strength of the nation. Their fraternities were recognized by royal ordinance, their privileges confirmed and increased, and measures taken to encourage them in practice with their peculiar weapon. A still further encouragement was given to the military spirit by the institution of the "Free Archers." In every parish one archer, the best that could be found, was to be enlisted as the The "Free king's especial soldier, — not a professional, but bound Archers" to appear fully equipped upon the royal summons. In return he was exempted from all taxation, as well by the crown as by the local authorities. The number of such "free" bowmen was at first about eight thousand, but rose in a few years to double that figure. The effect of these military reforms was naturally 
to free the crown from its former dependence upon the good will of the great feudatories. It must not be supposed that they could be made fully effective at once, but they mark a change in the whole national attitude. It was already a victory for the crown that they could be undertaken at all, and the spirit that underlies them is seen in the decisive actions of 1449 to 1453 .

The same general principles are to be seen in the dealings of Charles VII with the other elements of the monarchy. Building Administra- upon the old administrative framework, he made use tive Reforms of every opportunity to strengthen his hold upon the of Charles VII provinces by supporting the royal officials in their attempts to administer justice and to collect the revenues of the crown. The success of these experiments depended entirely upon the extent to which the king could make it worth while for his officials to be loyal to him. In loyalty to the king was to be found the only practical expression of national patriotism. This object was secured by a continuous process of advancing men of capacity in the royal service and maintaining them in honor by sufficient grants of power and income. It was a part of the modern process of substituting for the domination of a small party of great nobles the influence of an army of interested officials drawn mainly from the lower nobility or from the bourgeoisie. Naturally this process was resisted by the great territorial lords and by those princes of the blood who, during the pitiful times of Charles VI and the youth of Charles VII, had been the actual rulers of the country. So long as the English had been in the land it had always been possible to bring pressure upon the king by conspiring with the foreign enemy; but when the English were gone the most fruitful source of treasonable intrigue was removed. There remained Burgundy, and the last years of Charles VII were embittered and his work of reconstruction crippled by the persistent encouragement given by this his most powerful vassal to the open or half-concealed rebellion of his son Louis, afterward the redoubtable King Louis XI. 
If we try to sum up the results of the Hundred Years' War, we are met by the same curious paradoxes as in the Italy of the same period.

\section{Results of}

The records of the time are filled with pitiful accounts of the Hundred desolation and misery. The almost continual campaignYears' War ing on a larger or a smaller scale would seem hardly to have left time for the industries of the people to go on. Yet France in this interval had made solid gainsin all that goes to make up a civilized existence. It is a period of great advance in all the arts. Literature had progressed at once along the lines of the common tongue and the serious Latin of the schools. History, pursued as a branch of literature, produced some of its most splendid monuments. Legal science, developed at the schools of Montpellier and Orléans, was continually called into service in building up that vast structure of rights on which the future monarchy was to rest, in expounding the ancient customs that formed the basis of local resistance, or in furnishing weapons to both parties in the never-ending conflict of church and state.

It was an age of luxury in living. Satirists and moralists alike complain of reckless expenditure as the commonest of vices. The dress of the time shows us fashions far from simple. The customs of the landed gentry with their hunting and hawking, their games and jousts, their exaggerated sentiments of courtesy, were imitated by the newly created nobility of money and by the fat citizens of the bonnes villes. The decline of morals kept pace with the increasing luxury. All the complaints familiar to periods of great material prosperity reappear in the midst of this society that at times seemed to be on the verge of dissolution. The fact is that the period, in France as elsewhere, was big with the new constructive ideas that were making the modern as distinguished from the mediæval world. In spite of the drain of continuous warfare the productive power of the country was undiminished. The great cities were growing to be the mainstay of the national principle. Again and again during the war they had checked the flood of invasion, had furnished the means for raising new armies, and had contributed their own citizens freely in the national cause. 


\section{CHAPTER VII}

\section{THE AGE OF THE COUNCILS}

The death of the Italian pope, Innocent VII, November 6, I 406, opened up once more the possibility of ending the Great Schism Renewed either by the retirement (cessio) of his rival, Benedict Efforts to XIII, or by the voluntary acceptance of Benedict by Unity of the the Italian cardinals. If any one was still optimist Church, 1406 enough to expect any such display of self-sacrifice, he was promptly undeceived. Benedict had broken so many promises that his refusal to abdicate can hardly have surprised his best friends, and the Italian cardinals, zealous as some of them had shown themselves for union, were ready to unite only in their own way. They came together at Rome immediately after the death of Innocent and agreed upon a plan of union which committed the newly elected pope to every possible measure likely to secure this supreme good. Each cardinal bound himself by the most terrible oaths to carry out this agreement if he should be elected and to use his whole influence upon any other elected pope, whether he were a member of the Sacred College or not, to the same end. A contemporary historian, himself a member of the papal household, says that the most active person in drawing up this ironclad agreement (capitulatio) was the aged Cardinal Angelo Correr (Corrario), a Venetian nobleman.

It may have been for this reason that Correr was chosen to carry out the plans of the Italian cardinals. Immediately upon his election he solemnly renewed the oaths he had taken as cardinal and then proceeded to break them all with a consistent energy not surpassed by that of any of his predecessors. If his advanced age had seemed to the cardinals to promise easy 
submission to their will, it was for him only another reason for making his hay while the sun shone. Never yet had a pope, even Gregory XII in the worst days at Avignon, shown such activity in opposes putting his relatives and friends into places of honor and Union

profit. His nephews, Antonio Correr and Gabriel Condulmier, afterward Pope Eugenius IV, both young and active politicians, were made cardinals and became the center of a Venetian party ready to exploit the Papacy to their own advantage and certainly never likely to favor the resignation of a pope to whom they owed everything they were or were to become. Meanwhile this pope, who took the name of Gregory XII, published to all the world his readiness to end the Schism in any honorable fashion and especially notified Benedict XIII to this effect. Negotiations between the rivals were opened at once and proposition after proposition was made by one side and the other. If either side deserves the more credit for sincerity, it is that of Benedict. He too was in the direst need of support. A large party among his cardinals was earnest for union and had brought every pressure to bear upon him to bring him to the point. Attempts were made to bring about a meeting of the rivals, and Benedict at least went so far as actually to make the journey to Italy and to await the coming of Gregory for some time at Porto Venere on the west coast. Gregory's cardinals - not, of course, his nepotes kept urging him to the conference, but on one or another pretext he steadily refused, until finally Benedict XIII, in disgust or in relief that now at least he was free from further obligation, set off for Spain and henceforth practically disappears from the game except in the character of a persistent obstacle.

It had become clear that all hope of ending the Schism by any voluntary action of the rival popes was mere delusion. All parties interested in union were now concerned to find a sanction on which they could base their action. In former cases of division in the Papacy there had always been in reserve the authority of the Empire, and it had been used promptly and with effect. 
Now, however, schism had come about through the working of the papal constitution itself, and the question was up to this point

Universal

Demand for

a General

Council

whether there was virtue enough in this constitution to heal its own disease. Now that question seemed, so far as the papal office itself was concerned, to be answered in the negative. Where then was the Church to look for an authority that should give a final judgment and have power to enforce it? Already for a hundred years men had been discussing these questions of authority. Since Marsiglio of Padua there had never been wanting men who would carry the final appeal back to its ultimate source, the voice of the Church as a whole, expressed through a General Council. Sometimes this opinion had been coupled with other views of more doubtful orthodoxy and so had been condemned as heretical, but ever since the beginning of the Schism it had been put forth by scholars of undoubted soundness, and now that a crisis seemed to be at hand, it came out again more distinctly and with more energy than ever before. Indeed, as to the ultimate authority of a council there never was any serious difference of opinion. Even the more strict papal disputants had to admit this final appeal; they only insisted that a pope was the sole judge as to when a council must be called and had the sole right to call it. A council called in any other way was not a council at all. A council acting in opposition to a pope was inconceivable, for without him it had no legal existence.

By the year 1408 the patience of Europe was well-nigh exhausted. Governments everywhere were tired of maintaining at Schemes for ruinous expense a papacy which could not command calling a Council the allegiance of more than a fraction even of western Christendom and which was violating every solemn obligation to make sacrifices for the common good. From every quarter came demands for a council. Opinions were given by the foremost doctors of the canon law, and the drift of them all was that somehow or other there must be law enough in the Church, as in every other human institution, to enable it to save its own 
life when its regular governors failed to do their duty. Some thought the council ought to be called by the cardinals; some by a convention of princes; some by the emperor; but the main thing was that all were agreed that a council there must be.

The Council of Pisa was thus made possible by the implied consent of all parties except the contending popes. The initiative The Calling was taken by seven of the cardinals of Gregory XII. of the Council In defiance of his express orders they went to Leghorn and there entered into a conference with several like-minded cardinals of Benedict XIII, the result of which was a call for a council by these "union" cardinals. Not even yet, however, did they venture to act as a single body having rights of its own. The call was sent out by each "obedience" separately, so that the theory of an authority derived from papal appointment might be preserved. Each call was also addressed separately, first to the higher clergy, then to princes, universities, and cities, and finally to the rival popes. In the call both obediences justify themselves by the pressing necessity of the case, the Italians going also into the legal aspects of the situation in detail. The eight months between the date of the call and the meeting of the council were spent in untiring efforts on the part of the cardinals to gain the support of all possible authorities for their undertaking.

Of the twenty-six living cardinals twenty-four took part in the council. A distinct advance in the union sentiment is seen in the Council of fact that the council from the beginning met and acted Pisa, March 25 to August 7, 1409 as a unit, not, as had at first been proposed, in two separate sections. On the knotty question of a presiding officer the council cleverly avoided offence by not choosing any official president, but simply intrusting the general conduct of business to the senior cardinal. The response of Europe to the call of the cardinals was the best justification of their action. An imposing representation of the higher secular clergy and of the great monastic orders, ambassadors from Germany, England, France, Sicily, Poland, scholars from all the great 
universities, scores of doctors of theology and law, were present to lend their countenance in the pious work of ending the deplorable schism. As soon as the council was organized it proceeded to summon the two rival popes to appear before it. This was done on three successive days, and then the popes were declared to be contumacious. The leading place in the action of the council was henceforth taken, with admirable caution and good judgment, by the cardinals. They were exceedingly careful not to put forth any claims that might have roused antagonism or proved embarrassing in the future, but they quietly took the lead in matters in which their experience in the business of the Papacy gave them an unquestioned superiority. While certain questions affecting the right of the council were being discussed, while lawyers were arguing, while ambassadors from Spain, from King Ruprecht in Germany, and King Ladislaus in Naples were protesting, the cardinals went steadily ahead in preparing a great indictment against the contending popes. A liberal shower of excommunications from Benedict XIII and of protests from Gregory XII only made more clear the folly of further negotiations.

On the $25^{\text {th }}$ of April this indictment was read to the assembled council. It reviewed the history of the Schism in great detail and Deposition of in such a way as to throw all the blame for its conBenedict XIII tinuance upon the popes. Their failure to remove this, and of Gregory XII, the greatest evil possible in the Church, was a violation June 5,1409 of one of the most important dogmas, the doctrine of unity, and hence was fairly to be classed as "heresy." A heretical pope must be deposed; in fact, heresy was the only charge that could justify deposition. The judgment of the assembled doctors of law and of the universities was given in support of the indictment, and the council declared the popes deposed. The voice of the Church as a whole had spoken in unmistakable terms. Europe was tired of schism and desired unity in the Church; but this was not all. The next and far more important question was how far Europe was willing to go in guarding itself against similar evils in 
the future. Whither was all this discussion tending? Were men on the eve of a revolution against the whole papal system, or were they going to be satisfied with simply getting over the present difficulties?

So far as the cardinals were concerned, they were certainly not likely to take any very radical ground. They were glad to have Plan of Papal the help of a council in getting rid of a situation they Election at and their predecessors had themselves created, but if Pisa

the council should take too much upon itself the cardinals might find themselves permanently sidetracked. The power that had deposed popes might well feel some desire to take at least a part in creating a new one. It is another evidence of the wonderful tenacity of the papal tradition that at Pisa the council did not go so far as this. Some proposition of the sort seems to have been made by some of the French members in order to meet the danger of an Italian majority in the Cardinal College, but it was promptly rejected by the council. The whole matter of choosing a new pope was left in the hands of the cardinals and was managed by them with great cleverness. Above all things they wished to avoid any possible appearance of being in any sense a new or irregular corporation. To maintain the principle of apostolic succession the new pope must be made to appear as the successor to each of the deposed popes. Although the cardinals had withdrawn their allegiance from their respective chiefs, they still owed their appointments to them or to their schismatic predecessors. Only one cardinal in the whole combined college dated his appointment from before the beginning of the Schism. They arranged, therefore, that the election should be not only by the usual two-thirds majority of the whole united college, but by two thirds of each obedience. This plan would also tend to prevent the Italian majority from overwhelming the French minority. Only certain scholars of the Paris University continued to urge that the council ought to take part in the election in order to give it greater authority, and they succeeded in getting a clause accepted by 
which the council declared that it "committed the election to the cardinals in place of the council." The great importance of this idea becomes clear as we come to the history of the later councils. It was by no means forgotten at Paris.

For the cardinals the all-important consideration was to provide against any possible questioning of the election. They tried to conElection of ciliate all parties. They severally promised if elected Alexander V, to recognize the deposed Wenzel as King of the 1409-1410 Romans. They agreed to keep the council in session after the election until a thoroughgoing reform of the Church should have been accomplished. The Italian cardinals had already sworn to do what they could to maintain Ladislaus as king of Naples. Thus the papal conclave was made a central factor in general European politics. All previous experience that promises made by any man as cardinal were released when he became pope seemed to be forgotten. The choice of the cardinals fell, after eleven days of discussion, upon one of their own number, neither a Frenchman nor an Italian, but a Greek, Peter Philargi, archbishop of Milan, who took the name of Alexander V. Alexander was an altogether suitable candidate, a Franciscan, a trained theologian, a man grown old in the business of the Curia. His wide acquaintance with European politics gained as papal legate at various courts seemed to commend him as likely to harmonize conflicting interests to the advantage of Rome. Enough to say that the short pontificate of Alexander $\mathrm{V}$ was a complete failure. The College of Cardinals, now united and free from all dread of competition, renewed all its extended claims to the control of papal affairs. The promises of reform vanished into thin air. The council lingered on for a few weeks, but showed no zeal in following up the plans of reform put forward by some of its members.

It is, however, worth our while to note what these much-desired reforms were, since they sound, not for the first time, the note of complaint against the papal system which was to grow louder and more imperative until it should burst forth in the great protest 
of the Reformation. It is of the highest significance that these complaints were drawn up by representatives of the "Nations"

Reforms as such. They deal primarily with invasions by the demanded at papal power of the local rights of both governments and Pisa

clergy. They attack especially the financial schemes by which, since the beginning of the French residence, the Papacy had been thrusting itself into the place of all other church authorities. These involved the abuses known as "reservations," "expectatives," "translations," "annates," exemptions from episcopal powers, and unlimited appeals to Rome, - all for money and all without foundation in the original conception and the early practice of the Christian Church.

It is needless to remark that the two rival popes did not accept either the Council of Pisa or its pope. When Alexander V died Election of Pope John XXIII, r410 (May 4, I 410) the claims of these rivals were put forward again, and it was chiefly owing to the clever management of one cardinal, the Neapolitan Baldassare Cossa, that the college was held together and enabled to proceed to a new election. The cardinals resolutely refused to consider any propositions from the papal pretenders and in a short conclave of three days chose Cossa himself to continue the Pisan succession. John XXIII, as he now called himself, has been so overwhelmed by charges of personal infamy that we may easily overlook his real character as pope. He came of a family of some distinction in the occupation of seafaring, a trade which then resembled piracy as captaincy on land resembled freebooting. The future pope served his time at this somewhat doubtful profession until he saw better promise in the line of clerical promotion. He entered the papal chancery of Boniface IX, studied some law at Bologna, was made archdeacon and then cardinal without ever having taken priestly orders. The charge that he bought his way to the top of the clerical profession may be true. Until he became pope he was resident legate at Bologna, one of the most important political posts in the papal service. 
John XXIII, unscrupulous politician as he was, was a fairly typical Italian man of affairs. His successes up to this point Failure of made it reasonably probable that he would steer the John XXII as Pope, 1410 to 1415

Papacy through its troubled waters with equal cleverness. That he failed to do this probably explains the unanimous abuse of him in later times. Every other fault in a pope could be forgiven, only not failure. In one respect John began well. He strengthened the Cardinal College by many new. appointments and chose men who had been identified with the cause of union. Several were of the highest character and capacity, such as the Frenchmen D'Ailly and Fillastre, the Italians Zabarella and Adimari, and the Englishmen Thomas Langley and Robert Hallam. The whole history of the conciliar period is largely dictated by these excellent appointees of one of the worst of popes. It is chiefly through their energy and good judgment that the papal idea was able to hold its own through the storms of the councils, after it had been abandoned by the luckless adventurer who was its divinely chosen head. The real question was whether western Christendom could be persuaded to regard the Council of Pisa as having ended the Schism and John XXIII, therefore, as sole lawful pope. Against this position there was now developed, the longer he ruled, the more vigorous opposition. He made enemies in every direction. Nepotism was the least of his vices. In Italy the center of this opposition was Carlo Malatesta, lord of Rimini, the stanchest supporter of Gregory XII and of the claims of King Ladislaus in Naples. Malatesta's aim in the long negotiations with John, with the emperor Sigismund, and with various other powers was to persuade or compel John to agree to abdicate if the other claimants would do the same, - in other words, to go back of the Council of Pisa and clear the field so, that a new election might be held. The evil character of John gave color to this demand, and as time went on he commended himself less and less even to the "Pisan" party, which had created him. 
By the year I4II it had become evident that instead of a simple schism there was now a triple schism. More than ever

John XXIII recognized by the

Empire, I4II

Christian Europe must be scandalized by the condition of its religious headship. But where was the voice of Europe to be found? Not in the Empire, for there too were at the same moment three rival claimants for the imperial crown, Wenzel, son of Charles IV, who had been deposed by the Diet in I 400 , Jobst of Moravia, elected by one fraction, and Sigismund of Hungary, Wenzel's brother, elected by another fraction, of the Electoral College. Happily for the cause of unity Jobst died within a few months, Wenzel made terms with his brother, and Sigismund, a man of real force and capacity, was July 2x, 24xi finally acknowledged as sole king. The effect on the Papacy was that John XXIII was recognized by the Empire as the one pope on whom rested the rights but also the responsibilities of the papal government. If he would hold his place, he must fill it successfully. Sigismund now makes himself the mouthpiece of what we may henceforth fairly call the public opinion of Europe on the papal question. All parties were united in demanding a general council, and John XXIII was quite willing to comply, if only he might dictate where it should be held and might be free to control its action. That was, however, precisely the one point on which all Northerners were agreed. The The Call to council should not be held in Italy and John should the Council not be allowed to take the leading part in it. For of Constance, a time he succeeded in holding his position. He 1413 went so far as to summon a council at Rome, which actually came together on February I0, 1413, but in such small numbers that it amounted to nothing. The only result was that John, more or less seriously, agreed to call another council in some fitting place for the following December (I4I3). Meanwhile his fortunes in Italy were going from bad to worse. At first he was able, working with Louis of Anjou, cousin of the French king Charles VI, to gain some advantage over King Ladislaus 
of Naples, but this advantage was soon lost ; Ladislaus occupied Rome, and John was driven to the last extremity. No resource was left him but to come to Sigismund's terms and agree to a council to be held the following year at the free imperial city of Constance. It seemed for the moment as if the old mediæval system of Empire and Church were to be revived; but a moment's thought will convince us that the situation was wholly new, modern in the true sense of the word.

The Council of Constance, called by a pope on the compulsion of an emperor who was acting in obedience to the best opinion objects of of Christian Europe, was something more than an the Council assembly of the Church. To understand it we must of Constance compare it rather to that series of great European congresses beginning at Münster in 1648 and extending at intervals down to our own day. It was the first expression of the common interests of the new family of European states. That clerical questions were the excuse for its existence shows only that in these questions were found the subjects of most immediate importance to all the nations. From the first moment it became clear that the European powers were determined upon certain changes in the ecclesiastical system not so much for the sake of that system itself as for the advantage they expected to gain for their own national institutions, both political and religious. So far as the formal business of the council was concerned, all parties were agreed upon three main objects: (I) to end the Schism in some way that would satisfy the demands at once of the canon law and of the awakened conscience of the Church at large; (2) to do away with the doctrinal heresies which now for two generations had been threatening the very existence of the papal system and had seriously shaken the faith of Christendom on many points of the accepted doctrine ; (3) to reform the Church "in head and members." So far there was agreement; but precisely how any one of these objects was to be reached was clear to no one. 
On one point, the second, the council was relieved of much embarrassment by the splendid courage and self-sacrifice of John Hus,

Trial and the leader of church reform in Bohemia, who of his Execution of own free will and relying upon the safe-conduct of John Hus, November, the emperor Sigismund, put himself into its hands. 14r4, to July, He asked only for a hearing, an examination of his 1415

views by competent learned authority, and a judgment based upon an appeal to the "Law of Christ" as above all law of man's devising. He was allowed to come to Constance under promise of an imperial safe-conduct, was arrested by the agents of the wretch Cossa, who was himself on trial, was foully betrayed by Sigismund, and after months of cruel imprisonment was burned at the stake. His history does not belong here. It is a part of the long story of the Protestant Reformation. So far as the council was concerned, the trial and execution of Hus and of his countryman Jerome of Prague, a year later, gave it a standing with all the conservative forces of Europe which was doubtless an aid in enforcing its authority on other points. It was a fair notice to the world that, however radical it might be on matters of administration, the question of the faith was safe in its hands.

As regarded the other two objects of the council, the reform and the Schism, the all-important question was which should come Order of first. The moment discussion began it became clear Business at that if the council were to lay down distinct principles Constance of reform, any pope whom it might then put forward would be at least morally bound by them. If, on the other hand, it should proceed at once to secure a new pope, on what principles should he be selected, and when he should be elected what security was there that he would carry out any reforms at all? It was obvious that the strictly Roman, curial party would favor the early choice of a pope and trust to the momentum of the papal tradition to hold its own against any checks the reform party might try to place upon it. The reform party, on the other hand, was eager to define first and with great distinctness its views of 
principles, and hoped that a papal candidate might then be found who would carry out these principles into action. Each party was determined, but neither was well enough organized to force the council into action with any promptness. The discussions dragged on month after month and year after year, each party trying its strength on minor questions, but always coming sooner or later to the fundamental opposition we have just outlined.

The historical importance of the Council of Constance consists in certain great declarations made from time to time and in cerJohn XXIII tain precedents for future action. It was obviously as Papal Representative at Constance the cue of John XXIII to take the upper hand from the start. He had prepared his plan with much cleverness, and presented it in due form to the council, November 16, 1414. He first laid down the principle that this council was an adjournment of that of Pisa in accordance with the promises of Alexander $\mathrm{V}$ and that its function was to investigate heresy and bring the Church back to peace and necessary reforms. For support in this position he naturally reckoned on the Pisan cardinals who had created him and upon the post-Pisan cardinals whom he had himself created. Herein he was totally disappointed. The revolt began with the Frenchmen D'Ailly and Fillastre, who within a few days put forth a series of propositions destined completely to overthrow John's position. D'Ailly declared that the council was superior to the pope, a declaration going to the very root of the whole situation, and especially welcome to all the radical elements of the council itself. Fillastre was the first to suggest the deposition of John XXIII together with his rivals. It was chiefly owing to these men that the council determined upon the method of voting by "nations" instead of by polls, a decision of the utmost importance. It secured the council against the danger of being "packed" in the interest of any one party, especially against the dreaded preponderance of the Italian members. It expressed in the most practical fashion the new national interest in religious affairs. Now was the chance for John XXIII to 
put himself really at the head of a movement that meant something, to meet this new spirit halfway, and eventually to utilize it in the interest of a reformed papacy. That would have been statesmanship, but John was not equal to anything more than "politics." He lost courage completely and in the midst of the discussion threw up his case by escaping in disguise from Constance and summoning the cardinals to join him at the neighboring town of Schaffhausen, March 21 , 1415.

The flight of the pope left the cardinals at Constance in a singularly difficult position. On the one hand, they were naturally The Cardi- suspected of standing in close relations with their nals as Representatives of the Papacy pope, while in fact they were as completely surprised as any one by his defection. Their primary duty was to the pope; for, after all, cardinals were only the creatures of the Papacy, but here comes out the result of the development we have studied in a former chapter. The College of Cardinals had long been something more than a mere appendage to the person of a pope. By steady insistence upon one right after another it had come to be something very near a permanent Council of Regency for the Papacy. Popes died, but the college lived on and thus came to express in itself the idea of papal continuity. That was now the guide for its action. The emperor demanded at once what attitude the cardinals proposed to take, and they replied that they would stand by the pope only on condition that he would agree to place himself on a level with the other two claimants and to resign with them. Negotiations with John XXIII soon made it quite clear that no such promise from him could be depended upon, and the college unanimously decided to throw him over and trust themselves to the council.

Meanwhile within the "nations" the most extreme opinions were heard; so that the cardinals found themselves in danger of being left out in the cold by both pope and council. The superiority of the council to the pope, not only in matters of faith and unity but also in matters of reform, was formally voted in spite 
of the opposition of the cardinals, April 6, 14I5. Charges of the most violent nature were made against them, - men who could Isolation of elect a John XXIII were unworthy of any confidence ; the Cardinal they ought to be excluded from the council; their College proposition to be treated as a "nation" by themselves was rejected with contempt. There was danger that even the office of cardinal might be abolished. It is worth noting that on the whole the most extreme anticurial propositions came from Germans. In this trying position the Cardinal College, with many internal differences, carried itself on the whole with remarkable prudence and sagacity. It held together; it did not sulk; it kept itself always as far to the front as it dared and improved every occasion to show that its experience and its traditions were valuable factors in any practical policy.

Especially was this the case in the negotiations leading to the trial and deposition of John XXIII. The nations were enthusi-

Trial and astically unanimous in their determination to go to the Deposition of very bottom of the whole affair. When John from his John XXIII retirement, first at Schaffhausen and then at Freiburg, refused to answer their summons to return to Constance and stand his trial, they declared him contumacious and proceeded to draw up against him a portentous indictment. In this he was accused of every conceivable form of vice and crime, from his earliest youth to the present day, and on the strength of these charges he was declared unfit for the papal office and deposed. It will be observed that John's deposition was not based upon any defects in his election. It was not because he represented the Pisan succession, but because he was a bad man that the Council of Constance would have none of him. And yet personal wickedness was not in itself a disqualification for the Papacy. A pope ought, of course, to be good, but a wicked pope was none the less pope. The only charge on which a pope could technically be deposed was the very elastic one of heresy, and even the fictitious heresy of schism was no more proved against John than 
against every pope since 1378 who had sworn to end the Schism and failed to do so. It is hard to kindle even a spark of sympathy for a man of this type, but it is clear that he was sacrificed not to his crimes but to the grim determination of the nations to clear the board and start over new. John's acceptance of the decree of the council and his own resignation (cessio) removed the last doubt as to his case, May 31,1415 .

With regard to the other two popes the way had become easier. Gregory XII, now a very old man, having done all he could for Abdication of his relatives and being assured by the council of an Gregory XII honorable provision, sent Carlo Malatesta as his proctor to Constance and voluntarily resigned his claim - not, however, into the hands of the council as then constituted. He carefully summoned the bishops present to a council of his own in which were also included the remnants of his own "obedience," and thus having secured the fiction of a papal continuity he abdicated in due form (July 4, 1415). Thus, according to the strict Roman theory, the papal See was now for the first time vacant and steps towards a new election might properly and canonically be taken. In fact, the awakened conscience of Europe cared little about canonicity and was only too glad to have this troublesome claim of the Italian pope disposed of on any terms.

The other claimant, Benedict XIII, himself a Spaniard, had so far succeeded in holding the allegiance of the Spanish governDeposition of ments and in preventing them from taking any part Benedict XIII, in the council. Now it became essential to dispose July 26, ${ }^{417}$ of him too, and this was undertaken by the emperor Sigismund in person. He left Constance, sought an interview with Ferdinand of Aragon at Perpignan, and easily came to terms with him. Benedict, however, had also his ideas about canonical succession. He would abdicate, but only on such terms as would recognize him to be the only lawful pope and would annul all the acts of Pisa and Constance. Meanwhile his "obedience" was rapidly becoming a disobedience. His cardinals entered into the 
plans of Ferdinand and Sigismund, and a scheme was arranged which removed the scruples of both sides. The council and the obedience of Benedict each summoned the other to join in a General Council at Constance, and each obeyed. The result was that Spain now entered as a fifth "nation" into the work of the council, and Benedict's support was drawn out from beneath him. In spite of promises he still remained obstinate, and there was nothing left but for the council to depose him. It was just two years from the time when Sigismund had set forth on his errand of pacification that the sentence of deposition was finally passed. It was based upon the ever-useful charge of "heresy," since the unity of the Church was an article of faith, and Benedict was proved to have done what he could to prevent unity.

The delay in finally disposing of all three existing popes arose from the conflict within the council between the forces of reform The Parties of Reform and of Union and the forces of union. It was felt that the moment the pretenders were out of the way a decision would have to be made, and so every shade of opinion and of interest was concerned to get itself represented in the council before it was too late. On the papal or Roman, or curial, side the chief interest centered in the cardinalate. Opinions about this institution ranged, as we have seen, from one extreme view which would gladly have seen the cardinals abolished altogether to another equally extreme, which made them the authorized expression of.church unity. On the onc hand, men had come to identify them with the greed, the cunning, and the oppression of the Papacy; on the other hand, there were those who saw in the cardinals their chief protectors against precisely these evils. The former critics were inclined, therefore, to get rid of the cardinalate as being itself one of the evils they were trying to eradicate. The latter thought it safer to keep the cardinalate but to influence appointments within it and so make it a real represeritation of the universal Church. The former, if they must have 
a cardinalate at all, would restrict its powers as much as possible; the latter would even be inclined to enlarge its powers as a makeweight against the exclusive right of the pope. In this contention we see very plainly reflected the parliamentary struggles that were going on at the same time all over Europe. Everywhere the Changes in the Papal feudal monarchies were being gradually transformed Constitution into more or less clearly defined absolutisms. In the process, however, parliamentary checks were being devised, and this, we may be sure, was one of the causes of the attempts at Constance to place constitutional checks upon the world monarchy of the Papacy. The other cause was the greatly strengthened sense of nationality which led many of the more daring speculators of the day to think of the papal system as a kind of federation of national churches with the council for a parliament and the Cardinal College as a federal executive council. In all such schemes the essentially Roman character of the Papacy was forced ever more and more into the background. The problem for the cardinals themselves was to which side they should lend the weight of their experience and their traditions. If they adopted an out-and-out Roman, curial policy, they were sure to offend the council ; if they fell in with the demands of the " nations," they were cutting themselves off from the very source of their own existence, breaking with the canon law, and embarking upon a troubled sea of political experiments, the farther shore of which no man could discern.

On the whole they succeeded remarkably well in steering their course between these two dangers. The question of reforms was The First intrusted to a commission which began its labors in Reform Com- July, 1 $_{4}$ I $_{5}$, immediately after the council had disposed mission, 1415 of John Hus and Sigismund had set out on his journey to Spain. This commission, which was made up of eight members from each of the four nations, together with three cardinals, took fifteen months to prepare its report. The interval was spent chiefly in a comparison of views and in seeing how far it was 
possible to go in limiting the obvious evils of the ecclesiastical body without actually cutting off the resources by which the papal establishment was maintained. Every proposition of the more advanced reformers was met by some quibble of the canon law or some private political interest. The result, therefore, was as might have been expected, rather a meager showing. The commission reported a long series of articles touching the chief complaints of the nations, most of them referring to financial abuses or encroachments upon the rights of local powers in church matters. It was far from being a violent document, but even so it was not at

Second

Reform once accepted by the council. A new reform comCommission mission of five from each nation, including now the Spanish, was appointed, and after it had again revised the propositions, these were embodied in a Decree, which may be regarded as the final and official utterance of the council on this side of its activity.

(I) The first and most important article of this reform decree provided for regular General Councils, the next to be five years Reform Propositions, October 9, I477 after the present one, the second seven years after that, and then one every ten years unless called by the pope after a shorter interval. The place must be announced by the pope a month before the end of the previous council and confirmed by the council itself. The Church would thus always have a council either in action or pending. (2) In case of schism the council is to come together within a year without any call: "prelates, emperor, kings and princes personally or by deputy, hurrying to the meeting like men running to a fire." (3) No "translations," that is, transferences of prelates from one see to another are to be made against their will. (4) The numerous exactions of money by the Papacy from prelates of all grades and in all places are to cease. Especially the well-named "rights of spoil" (spolia) claimed by the Papacy over the property of clergymen dying at Rome or while in some special relation to the Papacy are to be restored to their proper possessors. 
"When these decrees had been read the Council or Synod of Constance unanimously, without a dissenting voice by the mouth of Lord John, Cardinal Bishop of Ostia, ... answering for the time in the name of the whole council, gave its approval by the word: Placet!"

Meanwhile the question of a new papal election had been coming more and more to the front. The position of the College of Preparations for a Papal Cardinals as representing papal unity had gradually Election

grown stronger. Its members had been wise enough to sink personal differences and, on the whole, came out now, toward the close of the council, as a fairly united body over against the national and personal dissensions of the rest. The question was whether the council should go on to define more fully its plans for reform, so that any pope now elected would be bound to carry them out, or whether it should proceed at once to elect a pope and take its chances for reform. The cardinals steadily threw their weight on the side of a speedy election, and this view prevailed. The council contented itself with drawing up a memorandum of eighteen points on which " reforms were to be made by the pope together with the council before its adjournment " and decided to proceed at once to the election.

Then came discussion as to who should do the actual voting. There was, of course, but one constitutional, that is, canonical,

Election of

Pope

Martin V, 14I7-143I body proper for this task, and that was the College of Cardinals; but the nations had not yet recovered suffcient confidence in them to intrust them entirely with the electoral function. Even at Pisa the cardinals had been allowed to do the voting only as agents of the council. At Constance there were some who favored excluding them entirely from the election, but a more moderate view prevailed, and they were allowed to act as electors in conjunction with thirty members of the council, six taken from each nation and representing also the several orders of the clergy and the class of jurists. This made 


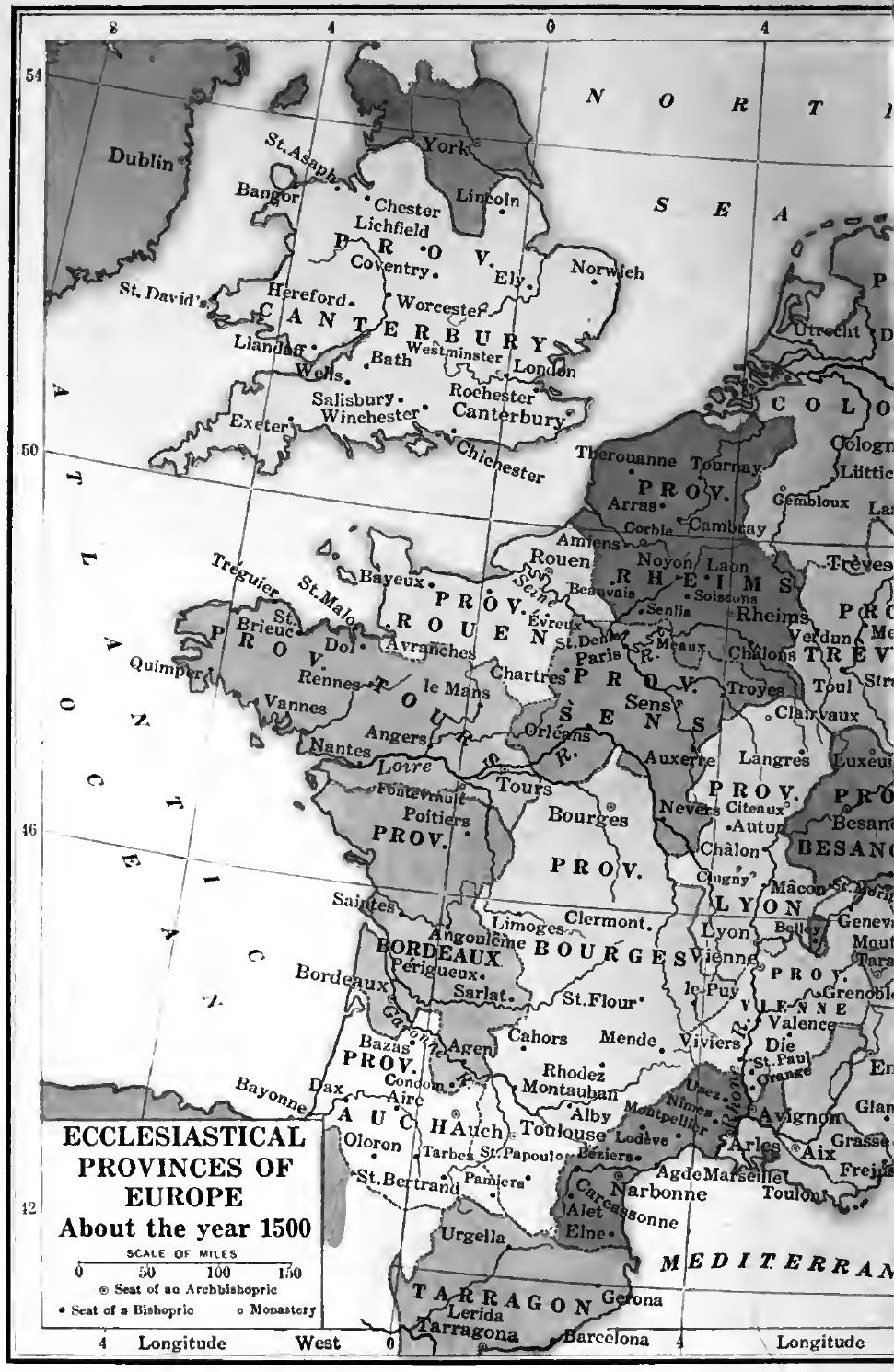




\section{0 \\ $x^{2}+\frac{3}{x}$

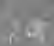

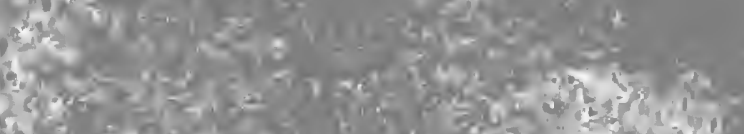

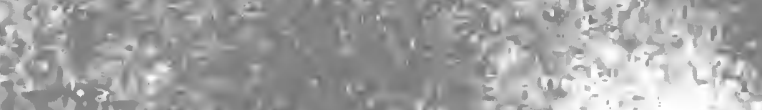

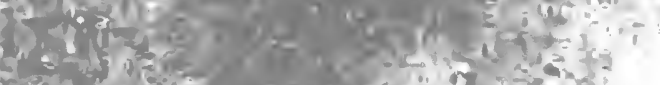

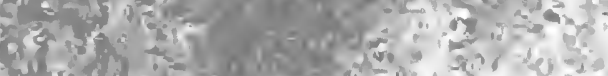

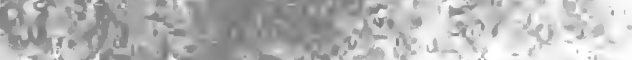

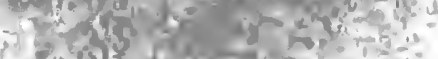

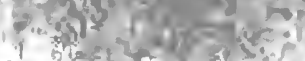

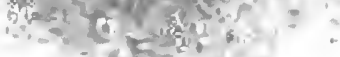

is

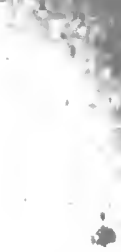

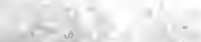

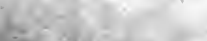

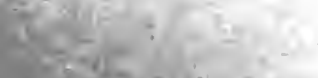

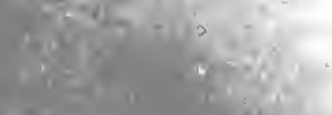

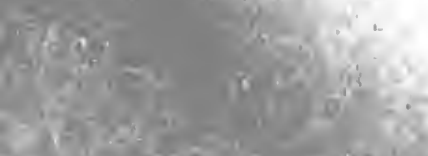

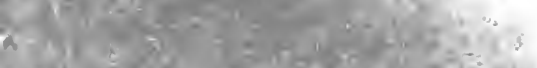

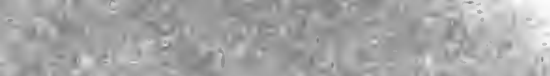

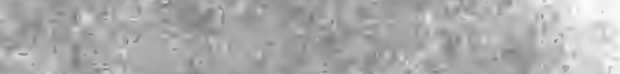

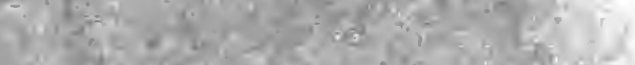

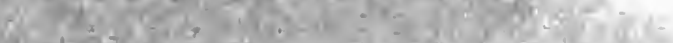

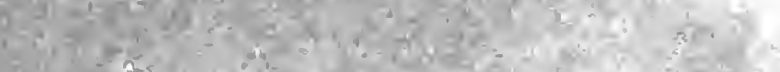

I)

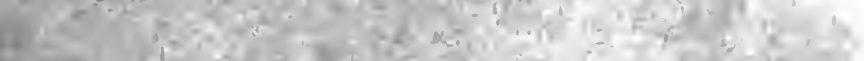

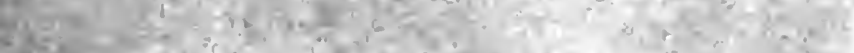

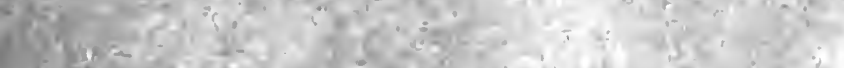

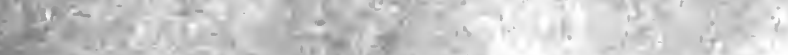

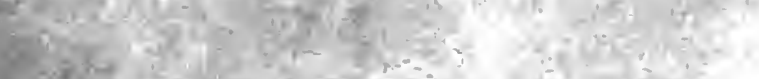

c.

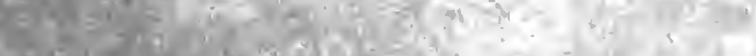

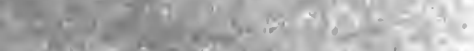

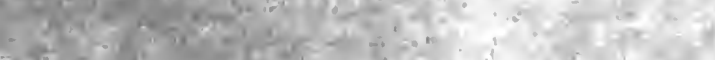

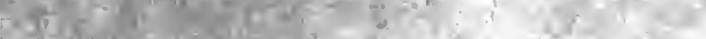

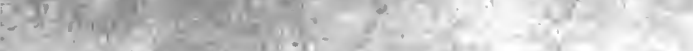

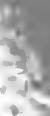

$\therefore y$

, 2

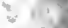

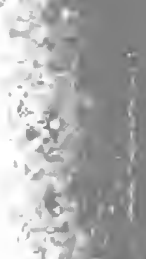

$7.7=$

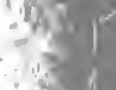

$-21$

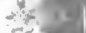

aid 0

if $\mathrm{H}^{2}$

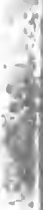

9

. 
an electoral college of fifty-three. They must elect by a two-thirds majority both of the cardinals and of the conciliar members. Their choice fell, after a conclave of three days, upon Cardinal Otto Colonna, who took the name of Martin V. This choice meant several things: Colonna was in the prime of life, a member of one of the two most important Roman families, a cardinal, of unquestioned character, of fair ability, well versed in the papal business bu: not specially active in any of the discussions at the council. In other words, he was a papal candidate of the best old-fashioned Italian type, all of his antecedents pointing to a moderate, perhaps even to a reactionary, administration.

At last Ghristendom had a pope. Schism, the most dreaded of all evils, was at an end; the Church universal rejoiced or appeared

Martin V and the

Papal Chancery

to rejoice at the beginning of a new era of unity, peace, and recovery. The very first act of Pope Martin, on the day following his election, was to confirm in their fullest extent the rules of the papal chancery or business office as they had been formulated by Pope John XXII in the most infamous days of the Avignon residence. They contained the whole system of papal finances based upon control of the clerical machinery all over Europe, which had been the chief source of complaint by the "nations" and the chief reason for the display of reforming zeal at both councils. In giving to Christendom an undoubted pope the Council of Constance had thrown away its own weapons. It had expressed pious wishes for a thoroughgoing reform, but it had been obliged to commit the actual work of reform to its elected pope. It had been working on a theory of a papacy that would represent the Church. In a moment it found itself face to face with a pope who proposed to rule the Church.

As to reforms, Pope Martin followed the excellent rule of giving the reforming parties all the rope they wanted and letting them hang themselves. - He professed readiness to consider propositions on which the council could be unanimous, well knowing that 
unanimity on details was impossible, and that every day's delay was as sure to divide the parties more and more as it was to give new The Fate of force to the magic of the papal name. A new Reform "Reform" Commission was appointed, but it was evident that the at Constance spirit was gone out of the reforming leaders. Only the Germans, in a separate statement, showed something of the earlier zeal. The basis of what action was taken were the eighteen articles of October 30,1417 . Some unimportant details were granted by the pope, and the rest were left to be settled with each nation separately by a series of national concordats, which were approved by the council subject to their later acceptance by the nations themselves. It was clear that the council had done its work, and it could now go home. Let us note the result of these four long years of discussion. (I) There had been discussion. A full opportunity had been given for individuals and corporate interests to express themselves, so long as nothing of a doctrinal nature was involved. The habit of open criticism once acquired was not likely to be wholly unlearned again. (2) The nations as church units had taken a position they were never again to lose. The Papacy by adopting the system of concordats had recognized this position and was adjusting itself to it. (3) The papal government by taking cardinals and officials of the Curia more and more from the nations was, in spite of itself, taking on an increasingly international character. (4) Many of the reforms granted, however grudgingly, by the Papacy tended to strengthen the whole episcopal body as against papal encroachments, and this was a great gain. (5) The idea of the council as a permanent factor in church government, superior even to the Papacy, had been expressed and carried out into action with unmistakable distinctness. In short, it is a great mistake simply because the Council of Constance did not at once bring about the Protestant Reformation to describe it as a failure. It was a highly important step in that vast process of education by which the modern world of Europe was being created. 
The immense importance of Constance is seen still more clearly when we come to study it in its relation to the next great demonThe Conciliar stration of the universal Church, the Council of Basel Movement, (1431-1448). Pope Martin V found himself fully oc1419-143X cupied during the five years' interval until, according to the decree of Constance a new council should assemble, in settling the distracted politics of Rome, especially in providing for the fortunes of his own family, the Colonna. At the end of the five years he summoned the council to meet at Pavia, - not, it is quite clear, from any interest in the conciliar idea, for he was known as a determined hater of it, but rather in order to conciliate its northern adherents and because he had every reason to believe that very few prelates would care to take the trouble to come to Italy to attend a council under the direct control of the Curia. He would save his credit by carrying out the decree of Constance and trust to the hopelessly involved politics of the northern nations to keep them at home. The council met on April 24, 1423, with a very slim attendance, and almost immediately, on account of an outbreak of the plague, was removed to Siena. There it was organized by nations and was prepared to do business, but never came to questions of real importance. The papal representatives did what they could to foment the natural jealousies of the nations, and finally, after about nine months of squabbling over petty matters, they declared the council adjourned (March, 1 424). At the same time Pope Martin declared his readiness to call another council after seven years and at Basel. Indeed, what might not happen in seven years! A few more paper concessions published in 1424 served to pacify for the moment some criticisms of papal and curial extravagance.

Now appeared the immense value of the Constance decree in regard to regular councils. It was no longer possible for a pope to defy the will of the Church by refusing to call it together to reform evils of which he might be the chief. Once more Martin V was forced to meet halfway the eager demand for an 
impartial assembly to be held at such place and time as would be likely to secure a representative attendance. The most he could Preliminaries do was to prevent the appointed date from being of Basel anticipated, to appoint as his legate a man of first-rate character and ability, Cardinal Giuliano Cesarini, and trust to him to give the meeting as far as possible a papal coloring. If reforms must be made it was at least better to appear to lead them rather than have them forced upon the Church by any other power. Cesarini was empowered to preside at Basel, but also in case of danger to dissolve or remove the council. Martin V died February 24,1431 , just before the opening of the council, and his more or less conciliatory theory of the pope's relation to it was promptly repudiated by his successor.

The election of Eugenius IV must be regarded as a reaction against the strict policy of Martin V toward his cardinals. Martin Election of had done his best to make them feel his superiority, Eugenius IV, but they could not forget the years in which they, I43 I -1447 not any pope, had stood for the unity of the Church. Before the new election they bound the future pope by an electoral compact (capitulatio) like those of the French period and the Schism, to respect and confirm all the previous rights and privileges whereby the college had taken its place as an essential element in the church government, a positive check upon the pope's freedom of action. The choice fell upon Cardinal Gabriel Condulmier, a Venetian, ncphew and creature of Gregory XII. He was a man of personally upright character, profoundly convinced of the papal theory of church life, and absolutely distrustful of all popular notions as to reform. During his long reign of sixteen years he steadily opposed the council and all that belonged to it, seeming to give way only now and again in order to gain some advantage for his side.

The Council of Basel came together under circumstances greatly changed from those of Constance. By far the most important of these changed conditions was brought about by the surprising 
conflict of the Bohemian people against the combined forces of the Empire. The execution of John Hus and Jerome of Prague The Religious at Constance, the only action in which the council had War in Bohemia, 1419-1434 been altogether unanimous, had called forth a furious storm in Bohemia, the like of which had not been seen in Europe before. The only comparison with it is to be found in the resistance of the people of southern France in the early thirteenth century to the pressure of Church and state combined in the long misery of the Albigensian wars. The Bohemian people, already aroused to a fierce consciousness of their national unity, had taken the action of the council as an assault upon their national honor. Hus and Jerome became martyrs of the Bohemian nation. If they were heretics, so were a great majority of the Bohemian people. They saw in the whole affair only another instance of the hated German interference in their local interests. With Germany they included the Roman church system too in their bitter feeling as equally responsible for the catastrophe at Constance. The whole country was aflame with revolt. When in August, r419, King Wenzel of Bohemia died and the throne was claimed by his brother the emperor Sigismund, organized rebellion began. Popular leaders, the most successful of whom was the gifted John Ziska, were developed with marvelous rapidity and drew to their standards the best fighting strength of the country.

Against this national resistance Sigismund raised the war cry of the "crusade." The Bohemian campaign was proclaimed as a

The Bohemian Campaign of IpI holy war, and papal legates, in the name of the Vicar of Christ, gave the sanction of Rome to this assault upon a Christian people fighting for national life, national honor, and the right to celebrate the supper of the Lord in the way they believed He had taught. The "crusading " army, eighty thousand strong, entered Bohemia from the Silesian frontier and moved upon Prague. They were met by a small but compact body, largely of peasants, under Ziska, armed with rude weapons but inspired by a wild enthusiasm, and were 
completely routed. Sigismund's army, bound to him by no ties of real interest in the cause, melted away, and he was driven from the country. His cause, however, was taken up with unusual energy by the German princes. Again the crusading cry went forth, and within a few months a new army of two hundred thousand men was in the field. Time was wasted in unimportant sieges, and the men suffered severely from the advancing winter. Ziska meanwhile had developed a new system of warfare depending largely upon the use of heavy wagons as a means both of attack and of defence. When all was ready he hurled the whole mass of his peasant warriors against the center of the German army under Sigismund himself at Kuttenberg and broke it completely. A panic fear fell upon the crusaders, and Ziska was master of Bohemia. His death in October, $\mathbf{1 4 2 4}$, made way for a successor of equal capacity but more uncompromising zeal, the priest-captain Procopius the Great. In the summer of 1426 Procopius led an army of twenty-five thousand against seventy thousand Saxons, drove them into confusion, and slaughtered ten thousand of them. There seemed to be no limit to what a united Bohemia might accomplish. In 1427 Cardinal Henry Beaufort, bishop of Winchester in England, headed the crusade, but with the same result. His great army broke and fled at the mere sight of the terrible Bohemians. Not satisfied with merely repelling invasion Procopius was beginning to make successful raids into the surrounding German territories. It had become clear that as long as the Bohemians held together all attempts to deal with them on the footing of heretics and rebels would go for naught. Crusading under papal leadership had proved worse than failure. Thus to all other causes of eagerness for a council was now added the hope that it might accomplish what the Papacy and the Empire united had failed to do and rid Europe of the threatening danger of a triumphant heresy. On the other hand, the Hussites, like their great leader, asked nothing better than the privilege of laying before a fair tribunal a frank confession of their faith. Worse than all, the 
Hussite doctrines had been sifting their way in through all the peoples of the West. Europe was honeycombed with "heresy," and men were asking whether, after all, the lines between truth and error had not been too sharply drawn. At all events men of serious thought were anxious to have the religious interests of Europe brought once more to full and frank discussion.

Such were the circumstances which drew men to the Council at Basel. The very situation of the place seemed a guarantee of

Opening of the Council of Basel, June 25, I43I freedom and fairness. Basel was a free city of the Empire, in intimate relations with the Swiss Confederation, grown rich by the commerce of the Rhine, and well able to protect the persons of the members of a council. Cardinal Cesarini was confirmed as papal legate and authorized the opening of the council, coming thither himself as soon as he could leave the fatal business of crusading in Bohemia. $\mathrm{He}$, like his chief assistants John of Ragusa and Nicholas of Cusa, was earnestly convinced of the need of reforms and ready to work heartily for them even in conjunction with a council. It was a significant sign of the determined attitude of the deputies that at the very first session they declared this to be a continuation of the Council of Constance and announced that the "Reform of the Church in Head and Members" was to be their chief purpose. To secure the freest and most impartial discussion the organization by "nations," which had caused so many delays and dissensions at Constance, was abandoned. Instead of this the members were each assigned to one of four "deputations," or sections, called respectively those of "faith," "peace," "reform," and "other business." Within the deputations the members were to represent as equally as possible the several nationalities and also the several grades of the clergy. Every four months the membership was to be readjusted, so that each member of the council would take his turn in each deputation. Every question was first discussed in its proper section, and when this section had come to a decision it was reported to the others and there discussed anew. It is interesting 
to notice that if unanimity in a section could not be reached the minority had the same right to state its case as the majority. Finally, the matter came before a general session and was decided by a majority of the deputations. This apparently very clumsy procedure had the effect of securing the most thorough discussion and gave to every individual and every group abundant chance to be heard; but it was obviously not calculated to promote the rapid dispatch of business. Its historical value is in the emphasis thus laid upon the essential unity of the council. It was not a representation of national churches as such, nor of separate church institutions, as, for example, cardinals, monastic orders, grades of clerical dignity, or what not. It was the Church itself in its representative capacity. Its decrees were published as conciliar bulls under the seal of the council as an independent legislative body. The emperor Sigismund recognized it by appointing the duke of Bavaria as the special protector of the council and declaring the imperial safe-conduct for all its members throughout the Empire.

It is precisely this unity, this claim to stand for the whole Church, that gives importance to the action of Bascl. Pope EugeCesarini as nius felt at once the new tone of confident determinaChampion of tion in all these arrangements and promptly ordered the Council his legate to dissolve the council, inviting it, however, to adjourn to the following year and to some place in Italy. When Cesarini received this message, "he laid his hand upon his breast and swore that though he should receive many bulls and commands of our lord the pope on this matter, he would not obey them, for he plainly believed it would be the ruin of the faith and that other scandals and dangers would follow. And he said to more than one of the members of the council that if he should procure a dissolution of this sort he should feel that he was sacrificing to the Devil." It was Cesarini's first thought to resign his legation, but the council prevailed upon him to remain, and he wrote to the pope defending both himself and it. The Hussites had already been summoned to Basel. If now the council should 
remove to Italy, would not the world say: "Behold! the armies have so often fled before them; now the Church is running away from them !" After all these fruitless efforts at reform would they not say: "It is all a mockery before God and man? And would not the laity, like the Hussites, rise up against us - as indeed there is already much talk of this? If -I should act in this matter against the will of the fathers here they would stone me as a heretic or tear me in pieces with their teeth. If my death is wanted, well and good! Send me to Prague or against the Turks. There I shall at least die a Catholic. I am ready and I know how to die for the faith but not to the injury of the whole church."

These are noble words for a cardinal legate standing between his papal master and the Church they were both sworn to serve.

Eugenius IV recognizes the Council, 1433

Again the emperor Sigismund showed himself the firm friend of the council. Early in I 433 he made an expedition to Italy mainly to secure for himself the papal coronation. Eugenius IV used every device to make the crown dependent upon Sigismund's desertion of the council, but without success. On the contrary the council took the upper hand with both, declared the pope in contempt and the emperor under its protection, so that all papal acts against him should be invalid from the start. Under this pressure the pope recalled his bull of dissolution (February, 1433) and gave Sigismund his crown. To make their position more secure the Basel fathers passed a series of decrees fixing the regular succession of councils, renewing and reënforcing the decrees of Constance, and even requiring cardinals to include these decrees in the electoral compact before each papal election. Not only was the council inclined to defend itself as an essential part of the church constitution; it proceeded to take independent action in many affairs as if there were no other constitutional organ of the Church. For example, it took upon itself to deal directly with the Hussites of Bohemia, - invited them to send representatives to Basel with assurance of safe-conduct coming, staying, and going. 
This again aroused Eugenius IV. He seemed to see all authority quietly slipping away from his grasp, and again he ordered the council to disperse. This time Cesarini reminded him that in denying the validity of Basel he was questioning also the legality of Constance, and that this was throwing doubts upon the election of Martin V and so upon his own election. The attitude of Cesarini is the more striking when we consider that the attendance at the council was as yet but small and made up chiefly of Italians and Spaniards. The significant thing is that the more bitter the controversy with the pope became, the more sympathy and interest were developed for the council, and the clearer became the issue Summer in the mind of the council itself. In a series of notable of $\mathbf{1 4 3 2}$ resolutions it defined still more precisely its superiority to the Papacy. It went so far as to declare that in case of the pope's death the election must take place within the council. Popes have erred, but the Church speaking through a council cannot err. If a pope fails to call a regular council according to the decrees of Constance, the clerical members may issue the call, and if the pope tries to hinder the council he is ipso factu sủspended. Eugenius IV was duly summoned to Basel, declared in contempt, and given a fixed time in which to obey.

The claims of the council were no doubt extravagant and revolutionary. To have carried them out logically would have Apparent been to destroy the historic Papacy as a Roman, Reconcilia- monarchical institution and put in its place an ecclesi-
tion of the Council and astical republic. No pope could accept these terms the Pope, 1434 without confessing himself to be not pope but president of a parliamentary democracy. Sigismund went as far as he could in using the council to get terms for himself from the pope, but he kept urging it to moderation, and it was probably owing to this that the formal deposition of Eugenius was so long delayed. When he had got all he needed at Rome Sigismund came in person to Basel, but could not succeed in moving the council from its position. Eugenius, seeing at last that he stood 
practically alone in his resistance, finally withdrew his bull of dissolution and recognized the council as legally in session without committing himself to the principles it had laid down (January 30 , 1434). His humiliation has its tragi-comic side, for the Romans treated him as a traitor to their interests and, led by the family of Martin V, the Colonna, they pelted him with stones out of the city, so that he sought refuge in Florence and from there sent to Basel to beg the council to take him under its protection and intercede for him with his own rebellious subjects !

It cannot be said that this formal recognition of the council by the pope made any difference whatever in the movement of The council events. The council kept right on with its action and the Bus- as an independent body. The Hussite ambassadors sites, $\mathbf{1 4 3 3}$ reached Basel in January, 1433. They represented all shades of Bohemian opinion and were empowered to make terms binding upon the whole nation. Their journey across Germany had been something like an ovation, and they entered Basel not at all in the attitude of suppliants but with the self-confidence born of their long series of victories in the field. They were received by the council with the utmost respect, were allowed the free exercise of their religion, and were given every opportunity to present their case. They made four demands, which interest us as showing on what points the popular discontent with the church government, not only in Bohemia but elsewhere as well, chiefly expressed itself. They demanded (I) that the use of the wine in the Eucharist should be permitted to the laity as well as to the clergy ; (2) that the temporal powers of the clergy should be taken from them; (3) that every person should be free to preach the Word of God; (4) that open sin should on no account be allowed to go on. These "Four Articles of Prague" were the basis of all later discussion of the Bohemian question. They were defended in long orations by chosen orators and answered in similar fashion by learned doctors of the council. This went on for three months, and then the council in its turn dispatched an 
embassy to Prague and, after hearing its report, still another. Finally, the Bohemian Diet agreed upon terms which seemed on the surface to cover pretty fully the demands of the Four Articles. In fact, however, the council had been following again the clever policy of delay and had trusted hopefully to the natural working of the well-known dissensions within the Bohemian nation. The agreement was carried by the more conservative elements, while the advanced radical party was for the moment brought into line, - but only for the moment. The envoys of the council had hardly set out for Prague when the question of applying the terms of the compact brought out anew the causes of dissension. The religious question had become a social and a political one. On Conservative the side of religious conservatism were ranged, as victory in was natural, the forces of landed wealth and inherited Bohemia, $\mathbf{1} 434$ power. The barons of Bohemia and Moravia leagued together with the purpose of making their peace with the Church. Over against them were the men of the towns and the peasantry, radicals in religion and furiously national and democratic in politics. The League of Nobles, now supported by the council, took the aggressive in 1434 and forced the matter to a decision by arms. In the battle of Lipan the army of the extreme radical, or "Taborite," party under the great popular leader Procopius was completely cut to pieces, its captain was slain, and its cause was lost forever. Henceforth the fate of Bohemia was in the hands of men who, still strong in the Hussite faith, were inclined to compromise on points that did not seem to them essential.

The council had thus done what long years of war by Empire and Papacy combined had failed to do. Heresy in Europe was, Union of the at least partially, brought to terms. Another even Greek and Latin Churches more alluring task was offered it in the prospect of uniting under one control the eastern, or Greek, and the western, or Latin, churches. This union was a dream that for centuries had at intervals served to kindle the imagination of the West. It had been one of the inspirations of 
the crusades; it had seemed almost realized when through most of the thirteenth century a "Latin" emperor had held the throne of Constantinople, and now once more, as the terror of the Turk was pressing closer and closer upon the doomed Empire' of the East, it seemed as if the time had come. Pope Eugenius IV had taken up the question of union with great zeal and was already in the midst of negotiations with the Greek imperial government when the Council of Basel undertook the same business on its own account. The position of the Greeks was desperate. They desired to negotiate with the Church of the West; but where was that church? Was it at Rome or at Basel? As might have been ex? pected, the all too clever Greeks were ready to find the Church wherever they saw their chance of getting help against the Turks on the easiest terms. In all former negotiations the worst stumblingblock had been the demand that they should acknowledge the papal supremacy. Now it almost seemed as if that supremacy were being lost even in its own field, and so the offers of the council were listened to with eagerness. With the detail of the negotiations we are not greatly concerned. It may well be doubted whether there was much sincerity on either side. Certainly the Greeks had no serious intention of buying their safety from the Turk at the price of any permanent union under Rome, and Rome in turn was far less concerned in the deliverance of the Christian East than in widening the rule of St. Peter.

Our interest in the whole Greek question is in the trial of strength between the pope and the council as to which was the Negotiations true representative of western Christendom. The first for a General point of conflict was on the place for a conference of Conference with the Greeks the two churches. The council arranged for a meeting at Basel or some other suitable place in the West and promised to do everything to bring over the Greek emperor and the Patriarch of Constantinople at its own expense. Eugenius tried to defeat this move by arranging a conference at Constantinople whither he would send legates and thus, of course, monopolize the 
whole expression of western opinion as in the good old days of the fifth century. Failing in this, Eugenius in 1437 proposed a meeting at the town of Ferrara in Italy, a place under Venetian protection and easily accessible to delegates from the East. Both parties sent legates to Constantinople, who fought out the question there before the puzzled emperor, until finally the arguments of the papal delegates seemed the more promising and decided him against the Baselers. Eugenius then summoned a general council at Ferrara and ordered the members at Basel to present themselves there. The council not only refused to let itself be captured in this way, but declared the pope suspended from his office (January, 1438). The most serious result of this new breach between pope and council was the loss of Cardinal Cesarini, who felt it his duty to stand by a council with a pope rather than a council without a pope. His place as president was taken by the Cardinal of Arles, a more zealous friend of reform, but a man far less likely to work for harmony with Rome.

Meanwhile at Ferrara and later at Florence the work of "Union" with the Greeks was going on. Dramatically considered, this was Union Council one of the very greatest moments in the history of the at Ferrara Papacy. The Greek emperor, John IV Palæologus, and Florence, the Patriarch of Constantinople, and many other lead1438-1439 ing prelates of the East came over and sat in council with the pope. If there had been here a united representation of the western church, it might well be said that this was the first truly ecumenical council since the days of the early church. In fact it was not a true representation of anything except the desperate straits both of the Greeks and of the pope. Their bargain was a fair one. The pope promised to help Constantinople with men, money, and ships, and in return the Greeks agreed to recognize the bishop of Kome as "sovereign pontiff, vicegerent and vicar of Christ, shepherd and teacher of all Christians, ruler of the Church of God, saving the privileges and rights of the patriarchs of the East" (July 5, I 439). A large majority of them, after long and involved discussion, agreed also upon a form of statement 
of the doctrine of the "procession of the Holy Spirit" (filioque) which sounded enough like an acceptance of the Roman doctrine to make it acceptable to the Papacy. The Greeks had got what they came for and had expressed their willingness to pay the price, but when it came to handing over this price the ambassadors found themselves wholly unable to redeem their pledges. On their return they were roundly denounced as traitors to their religion. The only hero among them was the bishop Marcus of Ephesus, who had refused to sign the agreement. Absolutely nothing was ever done to ratify the action taken at Florence, and the Empire of the East moved steadily towards its inevitable doom.

The only real result of the Council of Florence was to demonstrate that for the moment the pope had scored a point against The Nations the council at Basel. Men of moderate views, like and the Cesarini, had been drawn away from the extreme party Council

of the council and thus had left it in the hands of the more violent reformers. Sympathy with the ultimate principles of Basel cannot blind us to the rash extravagance of the Basel program. Nor, on the other hand, can it be denied that the attitude of the leading European states gave encouragement to the strife. None of the states took decided ground as between pope and council. Many of the Basel decrees were heartily welcome to the governments, and their cue was to keep the council in session long enough to gain its support for their own ends without going into the abstract question of its rights as against the Papacy. The most notable instance of this policy is seen in the so-called Prag-

Pragmatic

Sanction of Bourges, July $7, \mathbf{1 4 3 8}$ matic Sanction of Bourges in the year 1 438. King Charles VII called together the clergy of France at Bourges, inviting also legates from the council and from the pope. The king undertook to hold the balance between the two, but sanctioned the establishment of certain Basel decrees as law of the land. These decrees had reference to the well-known invasions of the Papacy into the rights of "patronage" and of clerical taxation in France. They included a recognition of 
the authority of Basel and of the principle of regular councils every ten years. This Pragmatic Sanction was an effective declaration of the "Gallican Liberties"; that is, the sufficiency of the Church in France to manage its own business affairs, reserving the right of the Papacy in all final questions of faith and discipline.

Similar action was taken by the German Diet at Mainz, when Albert II of Austria was chosen emperor to succeed SigisGermany mund (d. December 9, 1437). Here too legates of adopts Basel the council were heard, and the case of the pope
Decrees, March 26, 1439 was presented by Cardinal Nicholas of Cusa, formerly a warm adherent of the council but carried over to Eugenius IV with Cesarini and other moderates. The result was that the principal reform decrees of Basel were made law for Germany in so far as a general law could accomplish anything in a country where the final authority rested after all in the several states. In the case of both Germany and France the new laws were laid before the council for its approval, and thus its continuous authority was recognized. The other states of Europe showed little interest in the main question, but were willing to keep the council in session for ends of their own. In fact the year 1438 may be taken as marking a distinct turning point in the history and influence of Basel. Up to that time it had stood for a principle which had gained for it the sympathy even of men close to the papal Curia, - the principle, namely, that the Church ought to be represented by a parliamentary body similar to those that had come to be essential parts of the government in most European states. But when the council undertook to take the place of the Papacy and to act for the Church without its coöperation, then it began to forfeit the respect of governments, each of which was permanently threatened by parliamentary rebellion in its own affairs. Gradually, too, the make-up of the council had changed. By the year 1439 it had got into the hands of Savoyards, Spaniards, and others who saw in Eugenius IV an obstacle to private or national aims. The council had gone so far that it must either go farther 
or give up the fight. The leading spirits were determined to push matters to the uttermost and began openly to demand the depoDeposition of sition of the pope. The lesson how to get rid of a Eugenius IV, pope had been learned only too well at Constance. It June 25, I439 was only necessary to concoct a charge of "heresy," and the Papacy itself had shown men long since how to do that. The proposition laid before the council was that since it was an article of the Catholic faith that a council was above the pope and could not be dissolved or removed by him without its own consent, therefore Eugenius IV, who has obstinately opposed this article, is a heretic. Moreover, since he has once recognized his error and again taken it up, he is a lapsed heretic, which is several degrees worse than a simple heretic. The debate was long and excited. The council seemed at times to degenerate into a mere political caucus, but finally, in a solemn session, with large attendance, the articles of condemnation were accepted and Eugenius IV was declared deposed from his office.

But one step remained in the rash course taken by the council. It had deposed a pope on the ground that he had refused to Election of acknowledge its supremacy. It must now assert that the Basel supremacy by creating a pope of its own. In this act Pope, Felix $V$ we see most clearly the advance within one generation of the parliamentary idea in the Church. At Pisa in 1409 the Church had had its say in the business of choosing a pope, but it had left the actual work of selection in the hands of the Cardinal College. At Constance in $\mathrm{I}_{4} \mathrm{I} 7$ it had gone a step further and had produced a pope by the joint action of a committee of the council and the cardinalate. Now at Basel in 1439 the cardinals do not enter into the election at all. Instead, the council chose three universally respected men whose duty it was to select thirtytwo others as electors, having regard to nationality, learning, and character, and these electors were to choose the pope. The novelty of the process was equaled by the unusual quality of the man chosen. Amadeus, duke of Savoy, was a layman, a widower 
with grown-up children, who some years before had given up his government and was living a life of semimonastic religious retirement. He was not a theologian nor even a scholar in any field, but merely a prince of good reputation and supposedly with a knowledge of the world. His negative qualities combined doubtless with his satisfactory revenues commended him to the electors, and he was chosen with little hesitation. He took the highly inappropriate name of Felix V.

Thus through the action of the body which stood above all else for the unity of the Church a new schism had come about, and General Distrust of the Council of Basel the question was whether western Christendom was ready to accept this new theory of church government. Here was a "papacy" without any Roman element whatever, the creature of a council, dependent upon it for support and responsible to it for its action. It was a conceivable form of church government, but it was not the Papacy. The Papacy demanded the allegiance of men because it was the bishopric of Rome, the See of Peter; but here was a church sovereign to whom Rome was only a place on the map: That was the real question for Europe to decide, - whether it was prepared for a parliamentary church system into which Rome should enter as a set of traditions, honorable and venerable indeed, but not in any way essential to the actual life of the Church. The answer could not be doubtful. This meant revolution, and Europe was not ready for revolution. Reforms it certainly demanded and had already secured, each nation for itself, in accordance with the recommendations of the council; but to accept the supremacy of a pope who should be only the executive officer of a council was not a promising alternative.

Once more the Papacy profited by that wonderful mechanism which had carricd it so long. For a while several important countries, notably Germany, seemed inclined to support Felix V, but soon inevitable differences of opinion between him and his council appeared. The same old questions of money and privilege that 
had brought scandal upon the Roman Papacy threatened to work the ruin also of this papacy of the council. Meanwhile at Rome

Mediation of Eneas Silvius Piccolomini

Eugenius IV was enjoying the advantage of an evident reaction. The typical man of this period is Eneas Silvius Piccolomini, to whose spirited pen we owe the most effective descriptions of the Council of Basel. An Italian, a citizen of Siena, trained in the humanistic learning, a clever writer, a shifty politician, Eneas Silvius had been at the council as a free lance, lending his facile Latin to the service of any patron. His first preferment was a benefice at Milan given to him, a layman, by authority of this reforming council. He was made use of by the council on various embassies, was one of the masters of ceremonies at the election of Felix $\mathrm{V}$ and accepted a place under him as papal secretary. Incidentally he was crowned "Poet" by the emperor Frederic III, and as service under Felix began to be a doubtful policy, he was glad of a chance to become secretary to the emperor. This opened up the way for his gradual.approach to Eugenius IV, to whom as an ambassador of Frederic III bent on conciliation he could only be welcome in spite of the genial abuse he had poured upon the pope in his Basel-days. Largely through this mission of Eneas Silvius the relations between the emperor and Eugenius were placed upon a satisfactory footing. The whole question of principle was sacrificed, and a treaty was made giving to Frederic rights over Austrian churches every whit as dangerous to real liberty and quite as much in violation of all decency as were the papal claims against which the reforming party everywhere was protesting. In other words, the pope and the emperor divided the spoils of the Austrian churches, and the pope kept the lion's share.

But Austria was not Germany, and Frederic could not at once carry the Empire with him. The Electoral College, standing firm between the rival popes, was finally brought to promise that it would recognize Eugenius if he would substantially approve the decrees of Constance as confirmed at Basel. Eneas Silvius was 
the soul of these negotiations, now at Rome, now at the Diet in Frankfurt. The old trick of promising a future council was worked

Eugenius wins Germany, 1446-1447 again for its full value, individual electors were played upon by every possible device, "divide and conquer" proved again a winning policy; the electoral agreement was broken down and Germany was practically gained for the pope at Rome. Herewith fell the last support of the Council of Basel. It had done its great work - overdone it in fact - and now found itself with a superfluous pope on its hands and no organized support anywhere. The death of Eugenius IV (February 23, 1447) made no real change in the situation. An obvious way to end the schism would have been for the cardinals of Eugenius to elect Felix V, but no one seems to have thought of that.

On the other hand, the Baselers would rather prolong the schism -than drop the pope of their choice. The eighteen cardinals Election of who entered the conclave at Rome, March 4, 1447, Nicholas V, were not divided by any clearly marked line of cleav1447-1455 age. The first ballots were in favor of men who had been decided opponents of Eugenius IV, but the final choice fell after two days upon one of his creations, Cardinal Tommaso Parentucelli, bishop of Bologna, who took the name of Nicholas V. It was distinctly a personal triumph, not that of any party. The new pope was universally respected as a man of great erudition, of moderate but decided character, of sincere piety, and especially as a champion of the New Learning. He is the first in the long series of popes under whom the long-deserted and often dishonored capital of western Christendom was to take its place as a center of literary and artistic appreciation second to none.

The immediate problem of Nicholas $\mathrm{V}$ was to reëstablish in the eyes of Europe the sadly damaged prestige of the Papacy. The council and its pope were still in action, and their partisans formed still a respectable minority among the European powers. If Nicholas were to follow the example of Eugenius IV and begin 
a policy of violent denunciation of everything belonging to the conciliar system, there was still reason to fear that he would His Policy toward the Council simply rouse once more the dread specter of Reform. That might well mean prolonged schism and endless political complication. He chose, therefore, the wiser method of conciliation and readjustment. His first care was to secure the alliance of the power which, at least in theory, was the guarantor of the council. The emperor Frederic III of Habsburg desired the imperial coronation and the moral support of the Papacy against the ever-threatening danger of the Turk. $\mathrm{He}$ undertook the thankless task of disposing of the council by withdrawing his protection and ordering the city government of Basel to turn the hundred or so surviving members out of their town. The good citizens of Basel objected to losing their most profitable guests, but finally complied, and the council, still protesting, adjourned to Lausanne, where it was under the immediate protection of Pope-Duke Felix-Amadeus.

Then began a series of courteous negotiations between Rome and Lausanne. The chief desire of the council now was to "save Negotiations its face" and to let down its unfortunate but still active with the Anti-Pope, Felix V

pope as easily as possible. On'these terms it was prepared to make almost any concessions. And on his side Nicholas V was far more concerned with the realities of power than with any overfine distinctions between papal and conciliar right. The actual work of mediation, not-without a considerable mixture of pressure, was undertaken by a conference representing France, England, Castile, and Provence under the lead of France. The result was seen in two bulls issued in August, 1448, by which Nicholas agreed, if Felix V would abdicate, to create him Cardinal-Bishop of Sabina, to give him the highest place in the Sacred College, to assign him a monthly allowance of 500 florins for life, and to give him an unlimited dispensation from the rule against plurality of benefices. He agreed also to confirm all the grants of benefices made by Felix or the council. 
Felix V held out for some months longer, but finally, as he saw that his support was gone and that the fate even of his own family Abdication property in Savoy was in danger, he consented to of Felix $\mathrm{V}$, surrender his papal office into the hands that had April 7, ${ }^{449}$ given it to him, to the council at Lausanne, reaffirming at the same time the supreme authority of councils as declared at Constance and Basel and expressing the hope that in future this principle would be acknowledged by all faithful sons of the Church. The council accepted the resignation and named Amadeus as Cardinal-Bishop of Sabina and perpetual legate of the Holy See for the estates of Savoy. Not to be outdone in courtesy or canonical correctness the council then proceeded to annul all its decrees against popes or their adherents and finally elected as pope Tommaso Parentucelli, otherwise known as Nicholas V, with the understanding that he accepted the doctrine of the supremacy of the council as laid down at Constance and Basel. The council then adjourned April 25, 1449, with a final reminder to the world that a vote at Basel had fixed a date three years hence for a new council at Lyons.

The Age of the Councils, which had covered the forty years between 1408 and 1448, was at an end. What had it accomEnd of the plished? If we try to answer this question by pointConciliar ing to specific reforms in the Church, the result seems Apparent to be chiefly failure. Not one of the radical proposiFailure tions which had been carried with such enthusiasm at Constance and reaffirmed with such decision at Basel had passed into legislation so generally accepted that it could be considered a part of the law of western Christendom. The superiority of the council over the pope, which had given the keynote for the most vigorous declarations of the whole period, had not in fact been maintained. In the person of the excellent Nicholas $\mathrm{V}$ all antagonisms seemed to be reconciled, and the papal system seemed to be entering upon a new period of unquestioning acceptance. And, in fact, until the Council of Trent $\left(1543^{-1} 5^{6} 3\right)$ the experiment 
of a General Council was not to be tried again. The monarchical principle seemed to have scored as decisive a victory in the Church as it had in all the leading countries of Europe.

If, on the other hand, we count the permanent gains of the conciliar period, we find the result to be anything but failure. (I) It

Permanent

Gains of the had produced a great literature in defence of the prinConciliar Period ciples of democracy in religion.

(2) It had carried these principles into action by bringing together on three great occasions representatives of every element of the universal Church, both lay and clerical. (3) These assemblies had come together not only without the papal initiative but in each case flatly against the papal will. (4) Their discussions had been carried on with the utmost freedom, and their decisions had been published by their own authority, in defiance of papal prohibition, and had been received by civil governments without regard to the papal disapproval. (5) It had been demonstrated that resistance to the mediæval system did not mean hostility to any real doctrines of the Christian faith. If the papal government could invent "constructive heresy" to defeat its opponents, these in their turn had bettered their instruction in finding constructive heresies to throw back at offending popes. (6) Once for all, the nations of Europe had forced their recognition as units of church government and thus prepared the way for the final break with Rome. (7) This national interest had fixed itself in the papal constitution through the widening of the cardinalate to include representatives of all the nations as such. If the nations were to support the Papacy they must have a voice in its management. (8) The notion of the Papacy as the divinely appointed arbiter among the nations on the basis of the Unam sanctam was definitely abandoned. These were great gains. Their permanence depended upon the degree to which they should be followed up by the several parties in interest. For the next two generations they were to he obscured by the more insistent demands of national existence. But then, when that struggle had pretty well spent 
itself and the word of liberation had been spoken, it was once more these same principles of the Age of the Councils that were to form the solid basis of the Protestant Revolution.

There followed what may fairly be called the Age of the Concordats. Instead of a general assembly representing, no matter

The Age

of the

Concordats, I448-I5I7 how clumsily, the voice of Europe as a whole, we have now a series of special agreements, "deals," "trades," or by whatever more fitting name we may call them, between the monarchical Church and the several monarchically developed or developing states. The type of all these negotiations is seen in the Concordat of Vienna (February, 1448). The way to this typical document was prepared by the activity of the emperor Frederic III in persuading the several leaders of the opposition among the German princes to withdraw their objections and unite in recognizing Nicholas $\mathrm{V}$ as sole and lawful pope. The

Concordat of Vienna, 1448

Concordat itself was based upon agreements made by Pope Martin V with the German nation thirty years before. It guaranteed to the pope all the varieties of control over clerical appointments which had been fixed by John XXII and Benedict XII a century earlier. It added the extraordinary scheme of allowing the pope to "provide" to all benefices falling vacant in the odd months of the year, leaving to the regular patrons those vacated in the even months! New tariffs were to be fixed for payments in all cases of vacancy in cathedral churches and monasteries, while the already existing "annates" were to be maintained.

It is evident that such an agreement was nothing less than a return to the very evils against which the conciliar movement Gradual Ac- had been directed, and we can understand that the ceptance of several local powers, especially in Germany, were loath Concordats to accept it. It was only after they had been labored with individually by a papal commission under the lead of Cardinal Nicholas of Cusa, whom we last met as a stout advocate of reform in the early days at Basel, that anything like a general acceptance 
of the Concordat of Vienna could be reached. Even then the conflict of principles remained. In defence of the papal claims it was and is said: (I) The Papacy must live, and in some form the whole community must be taxed for its maintenance. (2) If the pope did not control appointments in the Church, kings, princes, and town governments would control them, and as between the two it was better that the clergy should be fleeced by the pope than by the lay lords. In the end the people paid.

Two events of dramatic interest marked the climax of this papal restoration : the Roman Jubilee of $145^{\circ}$ and the imperial coronaThe Papal tion of Frederic III in $145^{2}$. The Jubilee was the Jubilee of fifth of these celebrations designed to bring out with 450

especial clearness the hold of the papal system upon the allegiance of western Europe. The first was in 1300 and was invented by Boniface VIII as a part of his general scheme of papal absolutism. Its central idea was to emphasize the value of the pilgrimage to Rome as a means of obtaining those spiritual advantages included under the general term "indulgences." The practice of such pilgrimages was then already well established. The Jubilee was to be only a special reënforcement of the idea underlying them, the idea of Rome as the fountain head of those spiritual graces of which the Church was the acknowledged medium. The original intention was, probably, to make these occasions extremely rare, to occur only once in a century; but the immense success of the experiment in 1300 led the French pope Clement VI to authorize a repetition in $135^{\circ}$, the year immediately following the awful scourge of the Black Death. Thereafter various shorter intervals were proposed, always on the ground that every good Christian ought to have a chance at least once in his life to acquire such extraordinary privileges. The vast contributions of money poured by the pilgrims into the papal treasury were a by-product not without its value.

The Jubilee of $145^{\circ}$ was rightly accepted by the faithful in all countries as the symbol of the monarchical restoration within the 
Church. The accounts given by contemporaries describe in great detail the enormous crowds that filled all the ways leading to the Mecca of Christian devotion. They record the enthusiasm of these crowds as they were shown the precious relics, the heads of the martyred apostles Peter and Paul, and the handkerchief of Saint Veronica with its authentic portrait of the Christ, and received the assurances of penitential remission which were the answer to their faith. There can be no doubt that the demonstration of loyalty to the now united Church and its apostolic head was a sincere expression of the relief of Europe at the definite end of the conciliar struggle.

The imperial coronation of Frederic III is of interest chiefly as one more illustration of the changed conditions of the papal-

Previous

Coronations

at Rome, I $25^{\circ}-145^{\circ}$ imperial relation. Of the fourteen rulers who, since the death of Frederic II in $125^{\circ}$, had borne the rather foolish title of "King of the Romans" only four had added that of "Emperor," and of these not one had been of the Habsburg line. Three had been of the LuxemburgBohemian house, and of these Sigismund alone had received his crown from the hands of a pope in person (Eugenius IV, 1433). Henry VII and Charles IV had been crowned by papal representatives during the absence of the popes at Avignon. Ludwig the Bavarian had accepted his dignity from the "Roman People." Nor can it be said that the formal addition of the imperial name had made any real difference in the claims or in the actual effectiveness of the rulers who had taken it. It was in every case a question of power, and the realities of power in Italy were in the hands of political organizations quite well able to take care of themselves.

With Albert II, the father of Frederic III, the crown had passed anew to the house of Habsburg, never but once to leave it until the final catastrophe under Napoleon Bonaparte (1806). Frederic's eager desire to be crowned emperor by the pope and at Rome was no doubt explained by the uncertainties of his position in 
Germany. Pope Nicholas V, on his side, was at first little inclined to meet him halfway, because of the complications that Coronation of might thus be brought into Italian politics; but upon Frederic III, Frederic's insistence he accepted the situation and did 1452 all he could to add splendor to the occasion. Frederic's following into Italy was not large, perhaps two thousand in all, and was sent on in detachments lest it might seem to threaten the liberties of any Italian state. At Siena the young king was met by his bride, the princess Eleanor of Portugal, who accompanied him to Rome. Their marriage by the pope was the first in the series of grand festivities carried out with all the elaborate display of the Italian Renaissance. The coronation of the emperor and empress followed three days later in Saint Peter's with the use of the imperial insignia brought from Nuremberg for the occasion. Frederic spent two months longer in Italy, visiting the court of Alfonso of Naples and returning by way of Venice early in June. He was everywhere received with jubilant hospitality, for the reason, doubtless, that he carefully refrained from all acts of an "imperial" character. The only notable exception was that in Ferrara he created the marquis of Este duke of Modena and Reggio, a typical illustration of the only kind of use the Italians were henceforth to make of their historical relation to the Holy Roman Empire. Nor was any future emperor to receive his crown at Rome. The mediæval world had passed, and the modern world had begun. 


\section{CHAPTER VIII}

\section{THE AGE OF THE DESPOTS IN ITALY}

\section{FLORENCE}

With the establishment of the "Ordinances of Justice" in I 293 Florence entered upon the most serious trial of the democratic The Floren- principle as yet attempted by an Italian state. Nobility tine Political of birth had been declared a disqualification for public Problem in the Fourteenth engaged in the trade and manufacture by which FlorCentury ence had grown rich and powerful were entitled to a share in governing the Commonwealth. It was a program marvelously attractive to the democratic mind, but the test was to come. The very life of the Florentine community depended not only upon its power to maintain itself in the midst of jealous neighbors, each aiming at an independent commercial and political life of its own, but also upon its power to control these neighboring communities and lead them into some kind of conformity with its own policy. In other words, the Florentine problem of the fourteenth century was to build up a great central Italian, Tuscan state which should be able to hold its own against the more distant units of power at Milan, Venice, Rome, and Naples.

The Florentine writers follow naturally the lines of local, partisan politics, but we have to try to read through these rather pitiful Split in the records of street brawls, cowardly murders, impotent Guelf Party military displays, and far too clever negotiations the story of a real political growth. The old party cries of "Guelf" and "Ghibelline" had lost their large significance since King Rudolf, the Habsburger, in 1273 , had definitely promised to leave Italy to 
itself provided the Papacy would keep its hands off the politics of Germany. They were retained as a handy classification but. were replaced in practice by new terms to indicate new phases of the old social antagonisms. In Florence the Ghibelline Party as such had disappeared. The Guelfs had triumphed with the triumph of the local, democratic principle over the feudal, imperial, aristocratic principle. But hardly had this victory been declared in the Ordinances of Justice when a split in the Guelf ranks grouped the local interests on much the same lines as before. The Neri (Blacks) became the conservative, upper-class party over against the Bianchi (Whites) as the party of the lower gilds. This phase of party strife has been dignified to later times by the part taken in it by the poet Dante, who was a passionate Bianco and was finally driven out of Florence in a general banishment of his party in 1302; but the genius of Dante only brings out into higher relief the pettiness of the motives that seem to have governed most of the actors in this political drama.

The victory of the Neri would have had little meaning if it had not been accompanied by a new development of wide significance Charles of for Italian affairs. Their success was largely due to Valois as the aid of a French prince called into Italy by Boni-

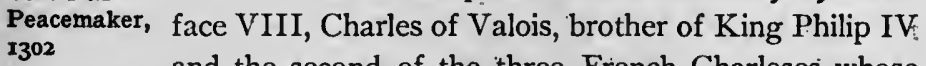
and the second of the three French Charleses whose advent in Italy marks three of the most important crises in the history of the peninsula. The modern student feels himself in the region of fable or of comic opera when he suddenly finds this sternly democratic community, where nobility was a crime under the constitution, and where the most democratic elements had but just gained the upper hand, admitting this foreign prince with his armed followers into their city, giving him a sumptuous lodging, and inviting him to do for them what they could not or would not do for themselves, - make peace between the factions of their own fellow citizens. To that end they granted him full power (signoria) in the city, and were then surprised and grieved to find him using 
his power to set up again, if this were possible, the banished party of the Bianchil Charles himself, quite indifferent one way or the other to the local squabbles of the Florentines, as soon as he had got out of them all the ready money in sight went on his way southward.

The episode of his momentary rule interests us only as showing how badly the carefully wrought scheme of Florentine democracy

Danger of

Foreign

Executives worked in any moment of trial. It was a system devised by a community of merchants to prevent any one person or any small group of persons from gaining permanent power over the rest. It assumed that every full citizen was as capable as every other to do the business of the state. It dreaded expert capacity in governing just as the Florentine gild system dreaded any expertness in industry when not regulated by the laws of the gild. And yet, the moment any extraordinary emergency arose, such expert capacity was precisely the thing needed. Every one was afraid of giving power to any of his fellow citizens, and so they all welcomed an outsider, in full confidence that Florentine patriotism would unite them all in preventing such a foreign master from going too far in getting power for himself. And the singular thing is that, on the whole, they were right. Helter-skelter policy as this must seem to us, the fact remains that the Florentine city-state bungled along under it for more than a hundred years in a continual up-and-down of democracy and hired tyranny, growing all the time in wealth and power, a light and a leader in all the things that go to make up an advancing civilization.

Charles of Valois left Florence in April, 1302, and for more than two years the city was occupied in warding off attack by the Captaincy of Bianchi exiles, who rallied at Pistoia and kept up a Robert of Calabria, r304-1306 continual attempt to win their way back into their beloved patria by force of arms. The next experiment was to hire Robert of Calabria, son of Charles II the Angevine king of Naples, to command the Florentine military forces and to bring with him a considerable body of fighting men. With 
this help, not only were the Bianchi beaten, but Pistoia was destroyed after a frightful siege (April 10, 1306) and its territory divided between Florence and Lucca, her momentary ally. No great harm came from this Robert, who soon, by the death of his father, became king of Naples and found in Florence his best ally against the threatened assault of the emperor Henry VII, the Luxemburger.

This futile expedition of Henry VII affected Florence only by drawing together all the enemies of her existing government, in-

Castruccio

Castracani,

Lord of

Lucca cluding many of her own exiled citizens, into an opposition that might have become dangerous but for the timely death of the emperor and the consequent scattering of the Ghibelline forces (1 313$)$. Florence was the center of resistance to Henry's imperialistic plans, as Pisa was the center of what power he had in central Italy. Thus the ancient quarrel between the two most important Tuscan cities was renewed, and Lucca, lying between them, was for a time the most active agent in furthering the conflict. This is to be explained by the rise to power in Lucca of a man of first-rate capacity in his kind. Castruccio Castracani, who seemed to Machiavelli two hundred years later worthy of a biography, is one of the earliest examples of a type soon to become fatally familiar in every Italian community. It is the type of the strongly individualized citizen, impatient of the restraints of the local constitution and quick to find ways of setting himself above them. The citizens of Lucca often followed Florence in the dangerous game of employing foreign executive officers, but on this occasion went far ahead of her in readiness to surrender themselves to a tyrant of their own creating. Castruccio offered them a fighting chance of keeping themselves independent of both Florence and Pisa and even, if they could make suitable alliances, of controlling the valley of the Arno. He readily became the ally of the Visconti in Milan, who were watching the growth of Florence with everincreasing jealousy, and by the year ${ }^{1} 3^{2} 5$ he was able to put into the field a large army of native and hired soldiers. 
Castruccio's policy was to avoid a fight until he should be in a position to hit hard, but when the moment came he showed him-

Defeat at self the ablest general of his time. The army of the Altopascio, Florentines, caught at a disadvantage, was completely 1325 routed at Altopascio, and the whole country up to the very walls of the city was laid waste. For nearly a year this shameful situation lasted. While party quarrels and divided counsels crippled all effective action in Florence, the energy of Castruccio held the surrounding country in terror and raised the name of the little commonwealth of Lucca to the highest point. The result was that Florence was driven along one step further on the road toward a tyranny. To offset the influence of Milan she bargained with Naples and hired Duke Charles of Calabria,

Signory of Charles of Calabria son of King Robert, to come and govern her for ten years. He was to have the signoria of the city, but promised not to change the Florentine constitution in any particular. In return for a very handsome salary he was to maintain a considerable force of transalpine soldiers both in peace and war and engaged either to reside personally in Florence or to keep there one representative to command the army and one to administer justice. In short, the Florentine democracy was already convinced that it lacked the executive force necessary for prompt and effective action, but was afraid to do what Venice had just done, to intrust any one or any body of its own citizens with such power. Pending his own arrival, the duke of Calabria sent his French cousin, Walter of Brienne, "duke of Athens," to begin the necessary work of restoration.

This new experiment brought no relief. The duke seems to have regarded the whole affair very much as a pleasant and profitable September comedy. He bled the worthy Florentines as much as 23, $\mathbf{1 3}^{28}$ they would stand, but saw no reason why he should waste good fighting material in defending people who could not defend themselves. Castruccio met every movement of the Florentine forces with his usual promptness and was in full possession of 
every advantage, with a fair prospect of making himself master of a united Tuscany, when he suddenly died. Within two months Charles of Calabria died also, and Florence was thus relieved at once of her most dangerous enemy and a still more dangerous friend.

There follow fifteen years of constitution-tinkering, bargains with every power in Italy, fitful and disastrous campaigning under Signory of incompetent hired generals, all with the one great Walter of object of getting possession of Lucca and breaking Brienne, ${ }^{1342}$ forever the power of Pisa. Even with the emperor Ludwig the Bavarian secret negotiations were carried on, but the price demanded by the emperor, the acceptance of an imperial vicar in Florence, was too high, and Florence turned once more to the device of a foreign lordship of her own choosing. In spite of their experience with him fifteen years before as lieutenant of Charles of Calabria, the citizens were innocent enough to intrust their fortunes to Walter of Brienne. This French nobleman, who had little to do with France, nothing whatever with Athens, and still less with Florence, a typical fourteenth-century free lance out of a job, was hired as "Captain of the People." Employed to execute the constitution, he almost at once took measures to place himself above it. Examples, like those of Castruccio and the northern Lombard tyrants, were not wanting. The constitution gave large scope for executive action, and party hatreds furnished support against almost any dreaded citizen. The duke began a strenuous policy of "justice," which soon showed him in his true colors as a servant of the commonwealth only that he might become its master. He had been hired to lead Florence in gaining possession of Lucca and humiliating Pisa. Instead, he made a peace with Pisa which guaranteed her the lordship of Lucca for fifteen years. In a few months he had offended every element of the Florentine population, including that of the popolani by which he had hoped to rise. A furious reaction against him set in, and in fourteen months from the day of his arrival he was driven from the city with every circumstance of tumult and infamy. 
The experiment with Duke Walter was the last of the kind which the Florentines were to try for many years to come. The

Florence under the was the dominant passion of the Florentine democracy latent dread of a tyranny, - regno d'un solo, — which Parte Guelfa, was greatly increased by the series of costly experi-
1343-1378

ences we have been noting. From 1343 to 1378 is a period of comparative peace, in which we can clearly discern two parallel tendencies, - one the intensifying of the democratic spirit and the other the gradual building up of a "ring" of noble families that were in time to break down democracy. We have The Black also to note in this period two scourges of Italy, both Death, $\mathrm{x}_{348}$ of which fell with full force upon Florence. One of these was the terrible pestilence, the "Black Death" of 1348 and I 349, of which Boccaccio has left us such a graphic and appalling picture in the introduction to the "Decamerone." Politically this visitation could affect the community only by reducing the numbers of the lower orders and thus throwing the balance of power on the side of the aristocratic party. The other infliction was the incursion of the "Free Companies." For this evil Italy had only The "Free itself to thank. War being an honorable occupation, Companies" it was but natural in an age when science of every kind was coming to be appreciated that the science of war also should be studied and carried out in practice as a fine art. War was a tradc, and the Italian trader, absorbed in his profession of money-getting, found it quite in order to spend the money he gained in paying for professional service of this as well as of other kinds. Life to him was too pleasant a thing to be risked when he could hire some one to take the risks for him. But, on the other hand, the professional captain, like any other merchant, was bound to reduce the risks of his business to a minimum. He was not called upon to waste good fighting material when it could be saved to fight another day. If having been hired by one party he could sell out to the other at a profit, he saved his men, was able to pay them better and so keep them loyal 
to him, and he gained also a new customer for his wares. In the intervals of his "engagements" he held his men together in the joys of camp life and could now and again take a hand in politics on his own account. Florence had her full share of dealings with these gentry. Especially with the English captain, John Hawkwood, - Giovanni Acuto, - one of the most decent of his kind, she had a long series of negotiations and succeeded on the whole in holding him to a fair degree of fidelity to her interests.

During this generation down to the outbreak of the Ciompi in I378 the general progress of Florentine life was greater than ever The Tumult before, and this in spite of the fact that her pet of the ambition, the control of the Arno valley through the Ciompi, ${ }^{378}$ subjugation of Pisa, had not yet been realized. The uprising of the lower orders under the name of the Ciompi does not indicate any serious discontent with the principles of the government, but only a restless desire to change the elements of the population through which the government was to be carried on. It was a furious and brutal demonstration of power by the democracy, but it proved also the utter incapacity of this democracy to use its power in the steady administration of a state. Its only means to carry out its wishes was through the leadership of strong, rich, and determined individuals, and here we begin to see, shaping itself more and more definitely, the group of "new" families among whom the real conflict for power was about to take place. The most useful person in calming the passions of the lower orders through an understanding of their wishes and an attempt to meet them reasonably was Salvestro dei Medici, a prosperous merchant, carried by the rotation of office into the signoria and implicated from the start in the designs of the lower gilds. He carried himself through the storm, trusted on the whole by the masses and too important to be crushed in the general reprisals that of course followed the inevitable collapse of their blind protest. With him appear on the popular side a Strozzi and an Alberti, names full of meaning for the future. The close of 
the century is marked by a long struggle with the Visconti of Milan, who, in alliance with Pisa, were trying to break the power Fall of of Florence in central Italy. It is a rather weariPisa, 1406 some story of continuous intrigue, now with Venice, now with Genoa; of bargainings with the free captains, of money poured out in rivers and of precious little real fighting. The climax seemed to be reached when, in 1399 , Pisa was actually sold out to Milan by her own tyrant, Gherardo d'Appiano, and thus the schemes of Florence seemed forever blocked. The death of Gian Galeazzo Visconti, the most implacable enemy of Florence, in 1402 , opened up a new prospect of success in this direction. Again took place a long series of negotiations, ending finally in a contract with Gabriele Maria Visconti, son of Gian Galeazzo, by which he undertook to sell the lordship of Pisa to Florence. The sale was completed, but the delivery of the prize was delayed by an unusual display of energy on the part of the Pisans, who had meanwhile taken possession of themselves and refused to give themselves up. It required a siege of several months, accompanied by brutal atrocities, to bring them to terms, one of many indications of the capacity for resistance in these Italian commonwealths, whenever their citizens could unite for common action. Starvation finally accomplished what generations of diplomacy and warfare had failed to gain, and Pisa, the key to the Arno and the chief representative of Ghibellinism in Italy, passed without redemption under the power of Florence, the type of Guelfism and all that it stood for.

What Florence meant to Italy had never been so clear as now. Her control of 'Tuscany after the Pisan conquest was continually Florence and strengthened and widened by the voluntary submission the Tuscan of one after another of the remaining feudal lordships Communes which had been keeping alive what was left of the Ghibelline spirit. Such an arrangement was described by a word borrowed from the old feudal practice of "commendation." The territorial lords were called raccommandati, and they entered into 
a contract for a longer or a shorter period to serve the great commonwealth as her citizens. The analogy of this arrangement with that of the Pfahlbürger of the German cities is obvious. It was an expensive luxury, but the necessity of some such compact to make possible the growth of Florence from a city to a state is clear. The importance of this question is well illustrated by the case of Forli, a little lordship in Romagna, whose chief had "recommended" himself to Florence and, before his death in 1423, had counseled his widow to maintain this relation. The duke of Milan, however, could not afford to let such an opportunity slip and urged the countess of Forlì to enter instead into an alliance with Milan. To one or another of the greater cityThe Case states the little principality must turn. It was a test of Forll case, for the loss of Forli would have carried with it that of Imola and many another Romagnol territory. More clearly than ever before we see now the growth of the greater states into which Italy was grouping. The real question was whether Florence was prepared to face the issue squarely and block the southward progress of Milan on the east as she had already blocked it in the Pisan war toward the west. In the negotiations that followed it is interesting to note, on the one hand, the implied understanding that Italy was to be divided among her five greater powers, but, on the other hand, the failure to fix definitely and once for all the lines along which such division should take place. That division_was finally to be determined by just such accidental tests as this of the Forll inheritance.

The first move in the game was made by the Duke Filippo Maria Visconti, who promptly occupied Forlì and began negotiaAlliance with tions with this advantage on his side. The ring of Venice against Milan aristocrats who now for two generations had been ruling Florence hesitated, negotiated in every direction, and finally decided to fight - of course with hired soldiers under hired captains. Again the fortunes of war were disastrous for Florence. Four times in two years (1 424-1 426) 
her armies were beaten in the field, and it was only the dread among the other powers of too great success on the part of Milan that saved her from utter humiliation. From the first moment of this Milanese trouble Florence had been in negotiation with Venice, trying to persuade the City of the Islands to make common cause with her against the overgrowth of Milan. The first ambassador to Venice had been Giovanni dei Medici, the first of that family to appear in public life since the complication of Salvestro with the Ciompi in 1378 . His plea for aid had been rejected on the ground that Milan had so far done nothing to violate the treaties by which Venice was bound to peace with her. Now, however, as it began to appear that Milan was growing too fast, Venice changed her policy also and entered into a treaty with Florence by which the whole political situation in Italy was at once altered. Not only did Venice enter heartily into the war on the eastern frontier of the Milanese territory, but many of the smaller lordships were thus led to forsake Milan and range themselves on the side of Florence. The loss of Brescia, the humiliating peace signed by the Milanese envoys, - though immediately repudiated by the duke, - and the crushing defeat at Cremona are the chief incidents in this most important struggle. The end was a new peace giving to Venice Brescia and a large increase of territory and securing to Florence, so long as the peace should last, a firmer hold on the whole of central Italy.

This great result had been brought about under the lead of a narrow group of rich trading families. They had gained such conRise of the trol over the resources of the commonwealth that they Medici had not hesitated to incur enormous indebtedness to Family ; Giovanni, d. 1429 bring about the desired end, the freedom and security of the Florentine state. This indebtedness, however, was to their own fellow citizens, imposed by a system of forced loans so arranged that the burden of them fell upon the mass of the people, while the richest families, bearing proportionately less of the money burden, were able to keep their capital continually employed to profit in the great commercial undertakings by which 
the city as a whole grew and prospered. The Milanese war had immensely increased this burden on the lower classes and with this had increased also the demand for a revision of the method of imposition of taxes, so that the share of the rich should be greatly increased and the mass of the citizens proportionately relieved. It is here that we begin to see clearly the policy whereby the family of the Medici, perhaps the richest of them all, took the position of leadership which it was to maintain for many generations. Giovanni dei Medici, already known as a busy champion of the lower orders, put himself at the head of a movement for The Catasto tax revision under the name of the Catasto, whereby the extraordinary expenses of the late war were to be shifted upon the Grandi. It was a peaceful revolution, but none the less a revolution. Designed as a relief from special taxation, it opened the way for all that sentiment of the duty of the richer toward the poorer which has so often been the motive power of a tyranny. Our interest in it arises chiefly from this glimpse it affords us of the first important Medici who rose to wide influence in Florence and who from the start outlined the policy by which his successors of the same name were to control the state.

Giovanni dei Medici died in 1429 , the most distinguished citizen of the community which he had served during a long life in every cosimo dei public capacity. Machiavelli, who greatly admired him, Medici says that he was constantly urged to make himself the head of a new, popular party in avowed opposition to the still dominant aristocracy under the lead of Rinaldo degli Albizzi. This proposal he had steadily refused, preferring the reality of influence to the forms of power. His son Cosimo, however, the actual founder of the political party of the Medici, had no such scruples. $\mathrm{He}$ began almost at once to emphasize antagonisms which his father had tried to soften, and especially to dispute with the clan of the Albizzi the leadership of the state. There is danger at this point that we may slip into the language of monarchy before its time. We must bear in mind that the form of the Florentine 
constitution was not essentially different from what it had been at the time of the Ordinances of Justice (1293). The units of public life were still the trade and merchant gilds with their Priors, from whom were taken by a regular process of selection the members of the signoria, the body nominally responsible for the government.

The actual business of the state, however, was intrusted in all special emergencies to special commissions, and this "government Government by commission," as we should call it, had the great by com- advantage that it enabled the state to employ expert mission capacity without limiting it by the curiously jealous restrictions of the constitution itself. One gets completely bewildered by the maze of "Tens of War," "Tens of Peace," "Tens of the Sea," councils of this number and councils of that number, balias without end, which seem to appear and disappear without rule or reason, until one learns that these extraordinary powers were all a part of the system. The game of politics in Florence consisted, as under similar circumstances we may be quite sure it always will consist, in the efforts of party leaders to manipulate the commissions so as to do the business of the state and at the same time to win party capital for themselves. It was "boss rule" pure and simple, and the remarkable thing about it is that it goes on for about two hundred years, through the heroic period of the Florentine state, before the "bosses" think it worth while to follow the example of their Northern fellows and get themselves converted into "legitimate" rulers. The process was long, but the steps are as evident to us as they were to those who watched and recorded them.

The Medici faction begins its history as the impelling force of the popular party under Cosimo by driving the government into Cosimo in a war for the conquest of Lucca, a war of disasters Exile and in and with no results except the increased unpopularity Power of the aristocratic party which had to carry it on and bear its burdens. To defend itself against the popular indignation the government procured from the citizens a balia ; that is, a special 
authorization, which enabled it to arrest Cosimo as a danger to the state. No charge could be found against him sufficient to justify his legal execution, and several attempts to hire assassins to remove him more quietly failed. There was nothing left but to banish him from Florence and send him first to Padua, then to Venice. No better fortune for an ambitious leader of a popular party could have been desired. At one stroke Cosimo became a martyr to his cause at home and an object of the greatest interest to his "hosts" abroad. At Venice he was received with every honor; he was splendidly lodged at the expense of the state, and the government at Florence was warned to respect his property as that of a Venetian citizen. Within a few months Cosimo was back again in Florence, hailed with tumultuous joy as Pater Patriae! Needless to say, his rivals, the Albizzi and their followers of the aristocratic party, were exiled in shoals, thus, as Machiavelli says, "depriving Florence not only of many worthy citizens, but of much wealth and industry." In fact, every such exile became at once a center of hostility, not indeed to Florence but to the governing party there. No more foolish policy was ever followed, but it was inevitable in a community where party spirit was the dominant passion and politics a game even more exciting than making money. It would seem to have been quite easy. for Cosimo to do what so many others had done in other cities, declare himself duke of Florence, buy or beg a title from pope or emperor, and defy any one to question its validity.

Instead of this, Cosimo chose the far wiser policy of making himself master of the constitution as it was and working it to his Cosimo dei advantage. By means of a very simple little deyice he Medici, Head so arranged things that the magistrates who had charge Florentine of putting into the bags (borse) the names from which State the incoming signoria was to be drawn by lot should see to it that only the names of those favorable to him should go in: Thus, as long as this device would work, there would always be a Medicean signoria, and Cosimo took excellent care that his 
new machinery should be started right by clearing the board of all who were so much as suspected of conniving with his rivals. The time had come when the same instinct which had led the Florentine democrats to throw over their democracy and welcome a series of foreign lordships was now to make them, on the whole, quite contented with a lord of their own. It was only necessary that such a lord should be a wise, a prudent, and a kindly ruler to make them blind to the obvious fact that they were letting go liberties which they could never recover. $U p$ to this time civic liberty had been a thing worth having and worth defending for its own sake; but now Florentines were too much concerned with the good things of life, with commercial prosperity, with learning and art and science and all the charm of a highly cultivated society, to care very much how these fine things were to be maintained. The result was that when, the balia of ten years, under which the boss rule of Cosimo dei Medici had come about, expired in 1444 it was an easy matter for him to secure a new balia, which quietly clinched the Medicean system by putting the choice of the signoria directly into the hands of a ring made up of tried friends of the benevolent despot. It was precisely as if the citizens of New York should formally invest Tammany Hall with the power of permanently creating all city officials.

Cosimo lived for twenty years longer, admired, respected, and feared by his fellow citizens, the actual ruler of a commonwealth The Tyranny which still prided itself on its democracy and its of Cosimo "liberty," by comparison with those other city-states dei Medici which had definitely parted with their own independence. He himself hardly ever held office, but he succeeded, by skillfully putting every one under obligations to him, in steering the policy of Florence so that she was able to hold her own against the powerful rivals who were pressing her on every side. The rule of Cosimo rested upon his cleverness in maintaining the theory of a democratic state, while at the same time guiding its fortunes in his own way. It would probably be unjust to speak 
of the Medicean rule as dictated by the personal greed of the rulers. On the contrary, the wealth of Cosimo and his successors was not the plunder of office but rather the means by which their control of the offices was gained and held. Nor does this mean that the Medicean power was wholly bought by direct methods of bribery and corruption. These methods were employed, it is true, but they were less important than the indirect ways in which the Medici commended themselves by a policy that actually satisfied the demands of the peculiar people they at once managed and served. The most popular cry in Florence, as always in a mercantile community, was "Prosperity!" The Medici, beginning with Cosimo, knew how to keep this captivating idea continually Foreign before the people. For example, in his foreign policy Policy Cosimo perceived that whoever held Milan was likely to have his hands full with complications that did not touch Florence, and hence he chose to favor with great supplies of money the military adventurer Francesco Sforza, who was trying to gain power in Milan, rather than to promote the cause of a momentary republican revival there. He was under great personal obligations to Venice, but he saw clearly that it was for the advantage of Florence that two great powers should divide the north of Italy pretty evenly between them rather than that Venice should spread too far westward. Helping Sforza, therefore, meant to check Venice in the north and thus to give Florence free hand in the center of the peninsula. So in the south he promoted an understanding with the hereditary enemies of Florence, the Aragonese rulers of Naples. Both Milan and Naples were in continual dread of French aggression, and through this Triple Alliance with the Tuscan capital both found themselves strengthened in their most vital interests, while Florence was freed from her worst anxieties and thus enabled to follow her natural policy of commercial expansion. In making these important connections Cosimo did not always command the immediate approval of his fellow citizens, but with time they came to see how just his estimate of the 
situation had been. Though with many fluctuations, this form of the balance of power in Italy - Milan, Florence, and Naples united against Venice and with a hand over the Papacy - remains for a long time to come the scheme of Italian politics most significant for the modern student. Personally Cosimo dei Medici had much Personality of the quality of the typical solid citizen of the "good of cosimo old times." His aim was to create and hold for himself and his party as much of the reality and as little of the appearance of power as possible. He built himself a plain but ample house in the midst of the city. He was accessible to all comers, a generous patron to every form of talent, the type of the cultivated merchant prince of whom the Florence of a generation or two later was to show so many examples. When he died, in 1464 , his fellow citizens could find no more fitting words to describe his relation to themselves than those with which, thirty years earlier, they had hailed his return from exile, - Pater Patriae.

The hold of the Medici upon Florence was demonstrated by the ease with which Cosimo's son Piero, a man of no marked Elements of quality and in feeble health, was able to maintain until the Medicean his early death in 1469 the prestige of his house and Power hand it on to his two sons, Lorenzo and Giuliano. With these brilliant youths we come to a stage in the development of the Florentine tyranny where we can see very plainly the breach with the old democratic tradition. True, the brothers, acting in apparent harmony, made for the present no changes in the constitutional forms of the Republic. They kept themselvès out of office, only seeing to it that the machinery of state was so manipulated that the important functions should be held by men favorable to them. The Florentine rage for office-holding was satisfied with the abundant spoils of a system by which every office changed hands every few months, and men were thus comparatively indifferent to the slow and silent growth of a power destined to enslave them all. To the foreign observer the Medici were already rulers of Florence in a sense quite similar to that in which other men 
were princes and kings. Embassies, nominally directed to the signoria, really did their business with these permanent though untitled sovereigns, who entertained them in their palaces, negotiated their loans with the great banking houses, and prepared marriage alliances with the children of the princes whom they represented. And why not? A signoria with which business was begun went out of office before it was well underway. A commission intrusted with power to make a treaty could be repudiated by another set of officials, but here at the center, alert and cautious, with a definite policy and the means to carry it out, was the expert ring of the Medici followers. Every one saw the approach of a tyrannis, but no onc really felt strongly enough the evil of the situation to make effective resistance. The plausible appeal that there must be some one to "do things" without waiting for the slow processes of constitutional action had its usual weight, and the Republic slipped into the spirit of monarchy without alarm and almost without protest.

A brief sketch of the famous "Conspiracy of the Pazzi" will serve to show the curious variety of interests involved in the fixing Conspiracy of the Pazzi, $147^{8}$ of the Medicean power. The parties in this conspiracy of 1478 were Girolamo Riario, favorite nephew of Pope Sixtus IV (della Rovere), the pope himself, several members of the great Florentine banking family of the Pazzi, and Francesco Salviati, archbishop of Pisa. The interests of these several parties were quite diverse, but they all converged upon the one motive of hostility to the Medici. The conflict with the papal party turned upon the question of controlling the region in central Italy known as the Romagna. This territory was the natural field for expansion of Florentine influence, but it was also the region where the militant Papacy of the later fifteenth century was planning to carve out subject principalities for its numerous dependents. The immediate quarrel raged about the little municipality of Imola. Here a local family, the Manfredi, had gained control, but had fallen into a decline and had put up their princedom for sale. 
Pope Sixtus was eager to buy it for his nephew Riario, who was to marry the illegitimate daughter of the Milanese Duke Sforza, the afterward famous Caterina. To buy Imola, however, the pope had need of Florentine money, and the Medici were prepared to block every attempt at raising money for this purpose in Florence and especially to prevent the Pazzi, their chief rivals in business, from negotiating the loan. The enmity of Salviati arose from quite different causes. He had been appointed to the archbishopric of Pisa four years before, but had been kept out of his see for three years by the machinations of Florentine policy and had thus come to a bitter hatred of the Medici brothers. It appears that Riario was the active agent in the conspiracy, that he first approached the Pazzi, that they then drew in the willing Salviati and finally laid the matter before the pope. Sixtus was quite ready to bless their undertaking, insisting only on the pious stipulation that there should be no shedding of blood. His point was, and it may have been honestly made, that the Medici were to be ousted by one of those revolutions so familiar to Italian politics, and to this end all discontents were to be fomented and brought to a head. This was enough. The more active spirits, Riario, Jacopo and Francesco Pazzi, and Salviati, went on with their plans, confident that the pope could not afford to disavow them in case of their success.

The arrangements were made with great cleverness and on a scale so large that it is wonderful that the secret could have Murder of been kept. Every known malcontent in Florence was Giuliano dei enlisted. Bands of hired soldiers were posted at many Medici

points in the neighborhood ready at the given signal to march into the town. The actual work of assassination was put into the hands of trusty bravos, and nothing seemed lacking but the right moment to strike the two brothers at once. The time finally selected was the visit in Florence of the young Cardinal Rafaello Riario, nephew of Girolamo Riario, the archconspirator. This young dignitary of the Church, a lad of sixteen, was kept in utter ignorance of the plot, and so far the game was well played. 
The Medici brothers, totally unsuspicious, were planning a series of festivities to entertain their guests, and the conspirators had fixed upon a grand banquet as the occasion of all others suited for their double blow. Everything was prepared, when Giuliano suddenly gave out word that on account of illness he would be unable to be present at the festivities, but that nothing should prevent him from attending Mass in the cathedral the following morning. Again the conspiracy was in danger. The ruffians to whom the slaughter of Lorenzo had been committed declared they would not kill a man in a church, and so their place was taken by priests. Enough; the murderers, of high and low degree, divided into two gangs, each keeping watch upon one of the victims. At the signal agreed upon, the elevation of the Host, one of the scoundrels assigned to Giuliano felled him with a dagger thrust, and Francesco Pazzi hacked him to death as he lay on the pavement in front of the high altar. Lorenzo, in another part of the church, was struck by one of his priestly assassins, who, unskilled in murder, failed in his blow. The dagger glanced off, leaving only a slight wound; friends rushed to his assistance and he was hurried into the sacristy, in ignorance alike of his brother's fate and of the extent of the conspiracy.

The calculations of the conspirators were based wholly upon: the instant death of both the brothers and upon the reaction

Failure of the Pazzi Conspiracy against the Medici which long experience in Florentine affairs made at least probable. The first condition had failed; Lorenzo was alive and in the hands of devoted friends. His position for the moment was indeed alarming, but almost immediately it appeared that the second condition of success was also lacking. As the conspirators rushed into the streets proclaiming the "liberty" of the city and its deliverance from its tyrants, they were met everywhere with shouts of Palle! Palle! - the rallying cry of the Medici. The machinery of government, lubricated so carefully for more than a generation with Medicean oil, worked well. Archbishop Salviati hastened to the palace of 
the signoria and asked for a conference with the gonfaloniere di giustizia on certain business of state. His confusion of manner betrayed him; the wary official caused the doors of the palace to be locked and held the archbishop prisoner. Francesco Pazzi, wounded by his own weapon, was caught by the furious mob and dragged more dead than alive to the signoria. Within a few hours this precious pair were hanging from a window of the palace, the teeth of the archbishop fixed in the jaw of the banker in the agony of death. The lesser conspirators, the tools of the ringleaders, were caught in various hiding places and promptly lynched or dragged to the signoria for judicial sentence. The attacks of the armed companies posted on the frontiers were repulsed with success by the Medicean troops, and Lorenzo was more than ever the hero and the darling of the people. ${ }^{1}$

The Pazzi conspiracy marks the definite establishment of the Medicean tyranny by a title which Lorenzo himself declared to be Lorenzo's the best possible one for any ruler, - namely, that the "Tyranny" people could not do without him. It was to be a long established time yet before the forms of a "legitimate" sovereignty were to be fixed upon Florence, but already little except the form was lacking. The conspiracy had sought to justify itself with the pope on the ground of a prevalent discontent with the Medicean policy in Florence. Its failure only strengthened the hands of Lorenzo in his effort to prevent the warlike Sixtus IV from blocking the expansion of Florentine influence in the Romagna. The story of these conflicts would lead us too far into the detail of Italian mercenary warfare, which we are as far as possible avoiding. Far more important was a change in the constitution made possible by Lorenzo's success in fighting the pope and in negotiating with Naples. The continual shifting of the city officeholders was in many ways a security for the power of the tyrant;

1 The story of the Pazzi conspiracy is told in Latin by the famous humanist Angelo Poliziano, who was an eyewitness, in his "De Pactiana Conjuratione," contained in "Angeli Politiani Opera Omnia." Basel, 1553. 
but, on the other hand, it was plainly a weak point in the Florentine constitution that there was no one solid and permanent body, like the Great Council of Venice, which could secure a certain continuity of policy. In 1480 Lorenzo believed the time was come for a change in this direction. He first secured from the several The Council governing boards a balia, which meant in this case a of Seventy, Reform Commission, and, for the first time, this exI480

traordinary power was granted without even the form of calling the people together in parlamento. As had often happened before, this commission was made large and given quite sweeping powers to readjust the governing boards on a new system. Its most important work was the creation of a permanent Council of Seventy representing at least forty "families," each member to be at least forty years of age and three fourths of them to be taken from the greater gilds. The members were to be chosen for life, and vacancies were to be filled by the votes of the surviving members, thus securing to this new institution a permanence never before even attempted in any Florentine constitutional experiment. The chief duty of the Seventy was to present the names of candidates for the signoria, from which the requisite number were to be drawn by lot every two months, so that if the Seventy were politically "sound," the signoria was bound to be safe. Further, the Seventy chose two subcommittees, one of eight (Otto di Pratica), which had supervision over all important matters of foreign policy, and one of twelve, which controlled the affairs of finance and commerce. Membership in these subcommittees was limited to six months without the privilege of reappointment. This Council of Seventy, either as a whole or through its subcommittees, was given the right of revision in the case of every public act. All the former mechanism of government was retained, but it was the obvious purpose of the Medici party to deprive all other branches of their initiative and to make them finally responsible to the Seventy, which was under the immediate control of the party leaders. There can be little doubt that the new scheme was a vast 
improvement in the direction of executive efficiency. It put real power into the hands of experienced men, fairly united in opinion and working under a sense of responsibility. But it was a step toward personal government, since whoever could manage the Seventy could control the state.

Thus definitely and consciously fixed in supreme control, the Medici were free to carry on that policy of clever diplomacy abroad The Public and development of talent at home which has made Policy of the age of Lorenzo the symbol of all that was best in Lorenzo

Renaissance Italy and has caused it to be compared with the Augustan age of Rome and with the generation of Pericles at Athens. The literary and artistic side of this subject will be treated elsewhere; we are concerned here only with its political aspect. Lorenzo's consistent policy was to maintain the balance of power among the five great Italian states, not in any way to work for the unification of Italy. It was this that gave to his foreign policy a character of continuous opportunism; that is, he was prepared to take advantage of any turn in the political game which seemed to promise at once security for Florence and restraint upon the expansionist tendencies of any one of her neighbors. What he did for Florence will appear more clearly when we have followed the history of some of the other powers down to the close of the fifteenth century.

\section{VENICE}

We left the history of Venice at the point where, by the "Closing of the Great Council," the government was definitely placed in Beginnings of the hands of a limited group of aristocratic families. ${ }^{1}$ Continental It appears, however, not to have been the purpose of Expansion this arrangement to limit the powers of government to any specific persons or even families, but rather to fix once for all the class of citizens who should henceforth be responsible for the conduct of public affairs. Within the limits of this class there 1 See pp. 249 ff. 
was room for a continuous increase of membership through the addition of new councilors. Starting in 1297 with a membership of 210 , the Great Council increased in the first fourteen years to 1017. By the year 1340 it had risen to 1212 , and in 1464 it numbered 1634 , nearly eight times its original number. The most rapid increase, it will be seen, was in the early years after the "Closing," and it was also in those years that the evils of the system began to show themselves. So large an executive body was sure to be slow and clumsy in action, and hence arose the necessity of continually deputing executive power to smaller bodies. Of these the most famous is the notorious "Council of Ten," organized in 1310 after several hard experiences had shown the necessity of some such tribunal. Twice in the interval of thirteen years dangerous conspiracies had tried the strength of the new system, and a foreign war had tested its efficiency abroad.

This so-called "war" interests us as the first step in that expansion southward which was to bring Venice into conflict with The War of the two great powers of central Italy, - Florence and Ferrara, the Papacy. The city of Ferrara had passed under the 1308-1310 signoria of the Este family, whose representative, Azzo d' Este, died in 1308 , leaving his claim to sovereignty to his grandson Fulco. Fulco's claim was disputed by his uncle Francesco, who was supported by the Papacy, which claimed the overlordship of Ferrara. He, therefore, sought the alliance of Venice, and the real issue of the struggle was thus transferred to a conflict between Venice and the Papacy for the control of a territory lying attractively near the frontiers of each. The situation became more acute when the Este family actually resigned to the Republic all their claims on Ferrara, as if the place were merely a piece of property to be handed about from one owner to another. A proposal from Rome - or rather from Ferrara - that Venice should accept Ferrara as a papal fief was promptly rejected. Feudal claims were no longer popular in Italy except as excuses for actual ownership. Still there were differences of opinion. A conservative 
party opposed the whole policy of territorial expansion of the Venetian state and dreaded especially any conflict with the head of the Christian world. The pope, using spiritual weapons for temporal ends, excommunicated the Venetian leaders, laid the Republic under an interdict, and, what was of more importance, forbade all good Christians to engage in any commerce whatsoever with the Venetians. The troops of the Republic held the castle of Ferrara, while the papal forces, occupying the rest of the city, laid siege to the fortress and finally took it. Thus the first attempt of Venice to expand southward failed, and this failure was justly ascribed to divided councils at home.

While the Republic was thus struggling to assert itself abroad, the democratic elements of the state had been roused by clever Conspiracy leaders to a final outbreak against the doge Gradenigo, of Tiepolo, to whom the above-mentioned changes in the constiI310 tution were rightly attributed. The conspiracy, planned on a great scale and headed by Bajamonte Tiepolo, a typical aristocratic demagogue, was defeated by the treachery of one of its members, and an ample revenge was taken by the victorious Gradenigo. Still the fact remained that Venice had lost her hold on Ferrara and had come into collision with that Italian power with which she must stand well if her policy of expansion were not to be given up forever.

It was to remedy the defect of a too complicated executive machinery that Gradenigo now proposed and carried out the The Council establishment of an executive council which, under the of Ten, r3ro name of "The Ten," became for generations the very symbol of prompt and even tyrannous exercise of power. As was usual in Italy, "The 'Ten" was at first presented to the people as a temporary expedient. It was chosen by and from the Great Council, and it might contain only one member of a "family" at a time. At the expiration of its term it was renewed and again and again renewed until finally, in 1335 , it was declared permanent. The Council of 'Ten is distinctly the most remarkable of all the 
mechanisms whereby the Italian states kept up the show of democracy while they were steadily and even consciously losing its spirit. Nominally the creature of the Great Council, that is, of the full citizens of Venice, it succeeded in making itself their master. Created as a temporary committee of public safety, it became a permanent criminal court, before which came all matters involving the welfare of the state. Intended from the beginning as an extraconstitutional aid to the regular constitutional machinery it always, at least formally, retained that character. Technically it did not form a part of the Venetian governmental system; practically it watched and regulated the action of every part. It was, like other institutions in Italy, provided with abundant checks against a tyrannous exercise of power, and on this ground modern apologists have tried to defend it against the frequent charges of cruelty and tyranny. One quality, however, has made this defence of no avail, - its secrecy. No human tribunal has ever been able to withstand the temptations of secrecy and a lack of direct responsibility to the people it serves, and we may be sure that much of the infamous reputation of the Venetian Dieci was richly deserved. If we compare it with the personal or family tyrannies in other Italian cities, we see at once its great superiority in that it avoided that jealousy of individual power which elsewhere made life a burden to the tyrant. It was idle to conspire against a shifting, elusive, and yet permanent body protected as it was by powerful interests and able to act with phenomenal promptness and energy.

Thus equipped, the Venetian aristocracy goes on with the career of expansion on the mainland of Italy that had been The Venetian for the moment checked at Ferrara. Expansion was Political Problem, 1329 for Venice not merely the outlet of patriotic ambition; it was an economic necessity. Venice was a trading and manufacturing community. Seated on her island throne, she had come to command the carrying trade of the western world and had secured meanwhile a world market for her own manufactures. Venetian ships carried English wool to Flemish 
looms and Flemish cloths to Florentine dyehouses, Eastern spices and fine textiles to Italy, Russian furs to Flanders and England. Wealth and population had rapidly increased, and all this time Venice had enjoyed the unique privilege of having no land frontier to defend. The analogy with modern England is evident. This privilege, however, was bought at the price of constant danger of starvation if at any time the agricultural products of northern Italy and Dalmatia should be witheld from her markets. The larger her population the greater this peril. There were three principal sources from which danger might be expected: (I) the land-hunger of her neighbors in Lombardy; (2) the commercial rivalry of Genoa; (3) the ever-increasing pressure of the Turk on all the countries east of the Adriatic. The policy of landward expansion was fiercely debated. All the dangers were clearly foreseen, especially that arising from the fatal necessity of hiring mercenary troops, since Venice was practically without a land army of her own.

The critical moment came in the year 1329 . Ever since I $_{3}$ ro eastern Lombardy had been going through a transformation under The War the energetic and capable tyrants of Verona, the family against the of the Scala, or Scaliger. Beginning with the territory Scala of Verona, 1336-1339 immediately about Verona, they had succeeded gradually in bringing under their control pretty nearly the whole country up to the very wharves of Venice. Padua, hitherto under the lordship of the Carrara family, was first absorbed, and from here the Scala conquest passed on eastward and around to the north of Venice as far as the eastern Alpine passes. Treviso, the last conquest of the great Can Grande della Scala, fell in 1329 , and almost immediately his successors declared a tariff war on Venice. It was idle for the island state to retaliate in kind. She needed these neighboring lands not only as a market for her goods but also as a source of supply for the food she must have, and it seems to have been this argument that finally decided the question of war. The sudden greatness of Verona was a threat to all her neighbors, and Florence, from whom the Scala had 
taken Lucca, was quick to perceive the advantage that might come to her from meeting Venice halfway in some plan of alliance. With these two as leaders a league against the Scala was formed, in which Venice bore a third of the cost, Florence a third, and the lesser powers of Lombardy the rest. Florence was to have Lucca for her reward, and the other states their independence. Without at first formally joining the league the Visconti in Milan were ready to aid it by attacking Brescia and other western territories of the Scala. Negotiations went on for several years; but when, in 1336 , the league was signed and war declared, the fate of the Scala dominion was sealed.

The war of $133^{6-1} 33^{8}$ was of the typical Italian sort, - a large armament, much marching to and fro, an occasional siege, infinite Treaty of negotiation, frequent treachery, and very little bloodI339 shed. The result was that the hastily acquired empire of the Scala resolved itself into its elements and that these were again recast into the threefold form which the affairs of northern and central Italy were assuming. Milan acquired Brescia and some neighboring territory, Florence failed to get Lucca but was guaranteed other lands within her own "sphere of influence," while Verona and its immediate neighborhood alone remained under the lordship of the Scala. The gain to Venice was decisive. Padua was allowed a nominal independence under the Carrara lordship but with the clear understanding that she was subject to Venetian interests and was to serve the Republic as a "buffer state" toward the west. Treviso was definitely incorporated with Venice, the first acquisition of the island state on the mainland. This war against the Scala is important as the first occasion on which the great permanent divisions of land and power into which Italy was to fall clearly appear as real political units. The mediæval form of an imperial suzerainty over a multitude of little states without coherence or sense of common political interest is gone forever. In its place we see a new scheme of five great independent powers outlining itself with perfect distinctness. Milan, Venice, 
Florence, Rome, and Naples are henceforth to be the units of Italian political development. It required no great insight to perceive that the real struggle of Venice in the north was to be not against Verona but against Milan.

It was, however, to be a long and roundabout road that was to bring the Republic face to face with the Duchy. For the moment

Commercial

Rivalry with The mistaken view of foreign trade then prevailing Genoa

led to the fatal delusion that the prosperity of one of these greatest of commercial cities meant the ruin of the other. An enmity such as had formerly existed between Pisa and Genoa now drove these new rivals into a conflict which admitted of no end but the destruction of one of them. Hostilities began in the East, where both parties had enjoyed great trading privileges, sometimes, as at Kaffa in the Crimea, in common. Frequent collisions led in $135^{2}$ to an outbreak in the Bosporus under the very walls of Constantinople. The two fleets engaged in considerable force, with much loss but without decided advantage to either side. The Venetians now made an alliance with King Pedro of Aragon, in order to have his protection in the western seas, and within seven months were able to meet the Genoese off Cagliari in Sardinia with a strong fleet of their own supported by an Aragonese contingent. 'The fortune of war was this time with Venice, and the Genoese defeat was so complete that the fate of Genoa itself was for the moment in doubt. To defend themselves against this threatening disaster the Genoese voluntarily offered the lordship of their city to the Visconti of Milan on the understanding that Milan would take up their quarrel with Venice. Thus, without any direct cause of enmity whatever, the Republic found itself compelled to face the most powerful rival in all Italy and that too in a land warfare in which she must necessarily be at a disadvantage.

For the moment danger was averted by a coalition of all the Lombard powers against Milan, but henceforth, throughout her 
long and bitter conflict with Genoa, Venice was forced to safeguard herself toward the west and thus was seriously hampered in Naval Defeat all her movements. The Genoese, heartened by this at Sapienza, Milanese alliance, took the sea in $\mathrm{r} 354$ and went in 1354 search of the Venetian fleet. They discovered it in the harbor of Sapienza at the southwestern extremity of the Greek peninsula wholly unprepared for an attack. Their admiral, the famous Paganino Doria, taking advantage of the situation, was able to slip into the harbor and, without striking a blow, to capture the entire Venetian squadron. If Genoa and Milan had been able to work together and push their advantage, it seems as if the newly won land empire of Venice might have been swept away at one stroke. Such farseeing policy, however, was not to be expected of Italian statesmanship in that generation. The war was a commercial one, and an advantageous peace with favorable terms for trade was far preferable to a wasting war. Genoa was for the present satisfied, and a treaty, negotiated by Milan, was signed by the rival cities in 1355 . The basis of this treaty was an agreement on the part of each power not to trade in the waters of the other and that both should keep out of the Sea of Azov for three years.

In the very midst of this struggle for supremacy on the seas the strength of the new Venetian constitution was put to the Conspiracy severest test by the famous conspiracy of the doge of Marino Marino Faliero. The concentration of power in the Faliero, 1354 hands of the Ten had reduced the office of the doge to little more than an executive agency for the dominant aristocracy. The outward splendor of his position was indeed increased and he was put forward on all public occasions even more prominently than before; but his ability to influence a party among the people was practically checked. It was probably this sense of political insignificance that drove Faliero to revolt. He was a citizen of the highest repute, seventy-eight years of age, with an honorable record of public service in many fields, but also well 
known for his testy and violent disposition. The story of his crime brings out, of course, the personal motives of Faliero into high relief. He was offended by a personal insult for which the Ten refused to give him what he thought sufficient reparation. He was forcibly reminded that there was but one law in Venice for doge and artisan alike, and again this same point was forced upon him when an official of the dockyards, outraged by a patrician, brought the case before him only to be informed that he, the doge, was powerless to help. Here, as so often in history, we find the extremes of a social order meeting in opposition to an overpowerful aristocracy. Faliero let himself be drawn into an attempt to overturn the constitution and to put in its place a princely rule similar, perhaps, to that already existing in Milan and elsewhere in Lombardy. The plot called for nothing less than a wholesale slaughter of aristocrats. It was well laid and seems to have been widely spread, but it was betrayed by an overscrupulous knave who later made a very good thing out of his double treason. The action of the government machinery was swift and decisive. The lesser conspirators were arrested, tried, and executed with exemplary promptness. Faliero, arrested and confronted with the proofs of his guilt, made a full confession and met his fate with the dignity and composure of his class. He was beheaded on the stairway of the ducal palace, April 17, 1354. This was the last effort to destroy the extraordinary system of government under which Venice was to go on to new triumphs.

Not, however, without continual struggle. The expansionist policy of Venice had already gained for her a vigorous crop of The Circle enemies, whose bitterness was quite in proportion to of Enemies the largeness of her aims and the dread of her power. On the west the Carrara at Padua, who owed their very existence to her generosity, watched every turn of the game with a persistent determination to check her advance in that direction. On the north the dukes of Austria were prepared to drive her out of her new territory in the March of Treviso. In Dalmatia she was 
threatened by Hungary, which aimed at acquiring a sea power in this quarter, and back of all these lay always the danger of Genoa backed by the permanent hostility of Milan. The history of Venice from $135^{\circ}$ to $145^{\circ}$ is mainly occupied with this unequal contest. That the Republic was not annihilated is the best proof of the extraordinary vigor of her people and the excellent working quality of her constitution. On this latter point the tendency was steadily to diminish still more the power of the doge and to strengthen and limit the oligarchy which really ruled the state. In 1361 it was provided that a doge must abdicate at once on a request from all six of the "ducal councilors" and a majority of the Great Council, while on the other hand he was not free to abdicate of his own will.

The revolt of Candia (Crete) in ${ }^{1} 364$ illustrates difficulties peculiar to Venice among Italian states. Candia was one of the most

The Revolt of Candia, $1364-1366$ important of the Eastern possessions that had come to the Republic after the capture of Constantinople in I 204. It had been feudalized under a duke dependent upon Venice, and many young Venetian nobles had settled there for purposes of commerce. For generations these Candiote Venetians had been satisfied with their colonial position; but now they pressed a claim for recognition as full citizens of Venice. It was a test question whether the Republic would be large-minded and farseeing enough to incorporate these outlying territories under her own constitution or whether she would make the same mistake that England made with her American colonies four hundred years later and treat them as property, not as fellow members in her own body politic. The revolt of ${ }_{1} 3_{4}$ was the result of an attempt to secure for Candia a representation in the home government. The demand was for a board of twenty prudent men ( $\operatorname{saggi})$ to represent the interests of Candia at Venice. The reply of the government, "We did not know there were twenty prudent men in Candia," struck the keynote of the whole matter and drove the Candiotes into open rebellion. The situation was the more serious because the local difficulties were aggravated by 
a race hostility - Greek against Latin - and by a religious hostility - Greek Orthodoxy against Roman Catholicism. Fortunately for Venice no one of her other numerous enemies made use of this occasion as a pretext for war. All promised neutrality, and thus aided the Republic was able to postpone for a while yet the beginning of the end of her power in the East. Venice was too useful as a guardian of Mediterranean commerce to be put out of action unless some other naval power, as, for instance, Genoa, could be found to do the same service.

On the Austrian side the bone of contention was Trieste, which had long been a tributary of Venice without actual incorporation

War and

Peace with

Austria, r368-r370 into the Venetian state. On one and another pretext the payment of further tribute was refused in 1368 , and Austria took up the case, sending a considerable force to support the revolting city. The Venetians blockaded Trieste and kept up a half-hearted skirmishing for several months until in November, 1369 , they thoroughly defeated the Austrians in a pitched battle and recovered all their former rights over Trieste. A peace with Austria signed the following year secured to Venice perpetual control over the peninsula of Istria, by far the most important land guaranty she had yet acquired.

Meanwhile Francesco Carrara, lord of Padua, had been strengthening himself in every way for the conflict with Venice which he

Defeat of Padua and was doubtless anxious to provoke. He had built several fortresses on the frontier, had kept up continual negotiaHungary, tions with King Louis of Hungary, and had even gone so far as to lay a plot of truly Italian fourteenthcentury devilishness for the murder of several Venetian nobles known for their hostility to Padua. The discovery of this plot threw Venice into a very pretty panic, but only for a moment. It really served to strengthen her determination to act once for all against her restless neighbor. An army was got together and, according to the custom of Venice on land, a captain was hired, the best in the market, but, as it proved, not of first-rate capacity. 
The Republic, which regularly intrusted her fleets to her own citizens, was obliged on land to take the doubtful chances of mercenary leaders. The only check upon these more than shady characters was in the form of commissioners (proveditori), who accompanied the army, had charge of the pay chest, and sometimes aided, sometimes embarrassed, the action of the general. Venice had hoped that her recent compact with Austria would secure her against the passage of Hungarian troops through the Austrian passes, but Carrara was able to offer Austria substantial territorial rewards for the free passage of his Hungarian allies. The troops of King Louis reached Italian soil and were successful in a first encounter, but later were beaten, their leader was taken prisoner, and, after due negotiation, they were withdrawn. Carrara, deserted by his allies, accepted peace on terms personally humiliating to himself and politically most advantageous to Venice.

Thus in three directions, in the eastern Mediterranean, around the headwaters of the Adriatic, and on the western mainland of The War of Italy, Venice had maintained herself with honor. All Chioggia, these enmities, however, and more were soon combined 1378-1380

in the most serious attempt yet made upon the life of the Republic. The so-called "IVar of Chioggia" was actively begun by Genoa. The diplomacy leading up to it reaches out into the farthest East. Venice had begun to trade on the fear of the Turk, which had now become the dominant motive in every action of the feeble and degenerate Empire of Constantinople. Using the threat of an alliance with the Sultan, she forced the emperor, John Palæologus, to cede to her the island of Tenedos near the mouth of the Dardanelles, and this was at once taken as a deadly affront by Genoa, whose commercial interests in the East were thus again threatened. A foolish row at Cyprus between Venetians and Genoese, ending with the discomfiture of the latter, roused anew the enmities of former years. At the court of Constantinople the Genoese were for the moment all-powerful, and they improved the occasion of a palace revolution to place on the throne John's 
son Andronicus, who promised to give Tenedos to them instead of to the Venetians. The governor of the surrendered island, however, refused to give it up, the Venetian admiral, Giustiniani, promptly took possession of it for the Republic, and Genoa immediately declared war. Francesco Carrara of Padua and King Louis of Hungary joined hands with her, and Venice was in desperate straits.

The fleet of the Republic under command of Vettore Pisani had some success in Genoese waters, but was badly beaten off Pola Siege and Capture of Chioggia, 1379 in Istria by the Genoese under Luciano Doria in May, 1379. The enemy pursued their advantage by entering the Lagoon and taking possession of Chioggia at one of the mouths of the harbor. This was done, however, in the name of Francesco Carrara of Padua, who had a large force on the mainland near by. Carrara's plan was to move at once on the city of Venice, but the Genoese admiral, now Pietro Doria, refused his aid and prepared for a blockade. The Venetians were roused but not panic-stricken. Pisani, who had suffered imprisonment for his defeat at Pola, was recalled to the command, and every resource of the rich and powerful community was strained to the utmost to provide men and money. It was decided to reply to the blockade of Venice by blockading Chioggia. All three of the entrances to the Lagoon were barricaded by sunken ships, and the war became one long struggle on the part of the Genoese, aided by Carrara, to break out into the open sea, and on the Venetian side to prevent their escape and cut them off from receiving supplies. Months passed in this equal conflict, until finally Pisani, June, 1380 reënforced by a fleet under Carlo Zeno, effected a landing and succeeded in cutting off the convoy of supplies sent by Carrara. This decided the fate of Chioggia. The Genoese army surrendered at discretion and were carried prisoners to Venice.

The War of Chioggia was the deathblow to Genoese power in the Mediterranean. Henceforth Venice was free to extend her influence on the sea as far as the wealth of her merchants and the courage of her rulers would carry her. Within a few years she 
acquired Corfu and from there as a stepping-stone advanced into Albania and Epirus, where her strongholds were Durazzo and Milan gains Scutari, then into the Peloponnesus, where she held all Lombardy, Nauplia and Argos. Our interest lies, however, mainly $13^{88}$

in the expansion of Venice on the mainland of Italy. Francesco Carrara, balked of success in his alliance with Genoa, continued the campaign and set in motion all the machinery of intrigue and conspiracy of which he was master to rouse new hostility against the Republic. His best hope lay with Austria, from which he regained the March of Treviso and the command of the northern Alpine passes. It seemed for the moment as if Venice were to be reduced again to the limits of the lagoons; but a power beyond the immediate circle of frontier disputes was to give the decision. Milan too was expanding, and it is clear now, as it could not have been then, that the future of Lombardy was to be settled between these two great powers to the exclusion of all lesser ones. The question was - and in the year $13^{87}$ it was a very real question - whether the eastern half were to be permanently held by Padua or by Venice. At the moment all chances seemed to favor Padua. Carrara was a very able and energetic prince. He held Venice within a circle of fortifications extending from the eastern Alps around to the lower reaches of the Po. Toward the west he touched upon the borders of the remaining Scala territories, and these were an apple ripe to the falling. The duchy of Milan, bordering on the Scala lands still farther west; was readily brought into a treaty for the partition of the Veronese territory. Milan was to have Verona, and Carrara was to take Vicenza. This meant a notable increase of the Paduan lordship, but it forced upon the Carraras more plainly than before the absolute necessity of destroying Venice if they were to maintain themselves against Milan. The conquest of the Scala lands was not completed before Milan made it clear that she was not going to be contented with her half of the spoil. Her armies went straight on to occupy the Paduan half as well, and Carrara, far from being 
stronger against Venice, was forced to beg for her aid against his too powerful ally. He even went so far as to promise to abdicate in favor of his son, Francesco Novello, if only Venice would save the freedom of Padua. The same argument that had so far kept the Scala lands as a buffer between Milan and Padua now suggested that Padua under Venetian protection might be kept as a buffer state 1388 between Milan and Venice. But for the present this plan was impossible. Milan took Padua outright, and Venice was obliged to be content with recovering the March of Treviso and thus maintaining her routes of commerce to the north. The armies of Gian Galeazzo Visconti now held the whole of Lombardy, and if he had been content to consolidate his lordship Padua under Milanese permanently excluded from the mainland. It was just there, it seems probable that Venice might have been Overlordship, at this point, however, that Milan entered upon that 1392-1402

career of expansion southward which brought her into conflict with Florence, the Papacy, and all the lesser powers of central Italy. While her armies were thus employed, Francesco Novello, after long and romantic wanderings, was able to make a descent from Germany into the Paduan territory in 1390 and by a sudden attack to recover his capital. Visconti was in no position to meet this bold stroke with the necessary promptness. $\mathrm{He}$ found it cheaper to enter into the Treaty of Genoa in 1392, whereby he gave up Padua but retained all his other conquests in Lombardy. Padua, with the approval of Venice, was given to Francesco Novello on condition of an annual tribute for fifty years to Milan. Obviously Gian Galeazzo was aiming at the sovereignty of northern Italy, and only the alliance of Venice, Padua, Bologna, and Florence availed to keep the Italian balance of power unbroken.

The death of Gian Galeazzo in 1402 was the signal for a general revolt against the conditions of the Treaty of Genoa. The Visconti inheritance passed to three sons under the regency of the duchess of Milan, the mother of two of them. The Carraras saw a chance to reassert their "claims" on Verona and Vicenza, 


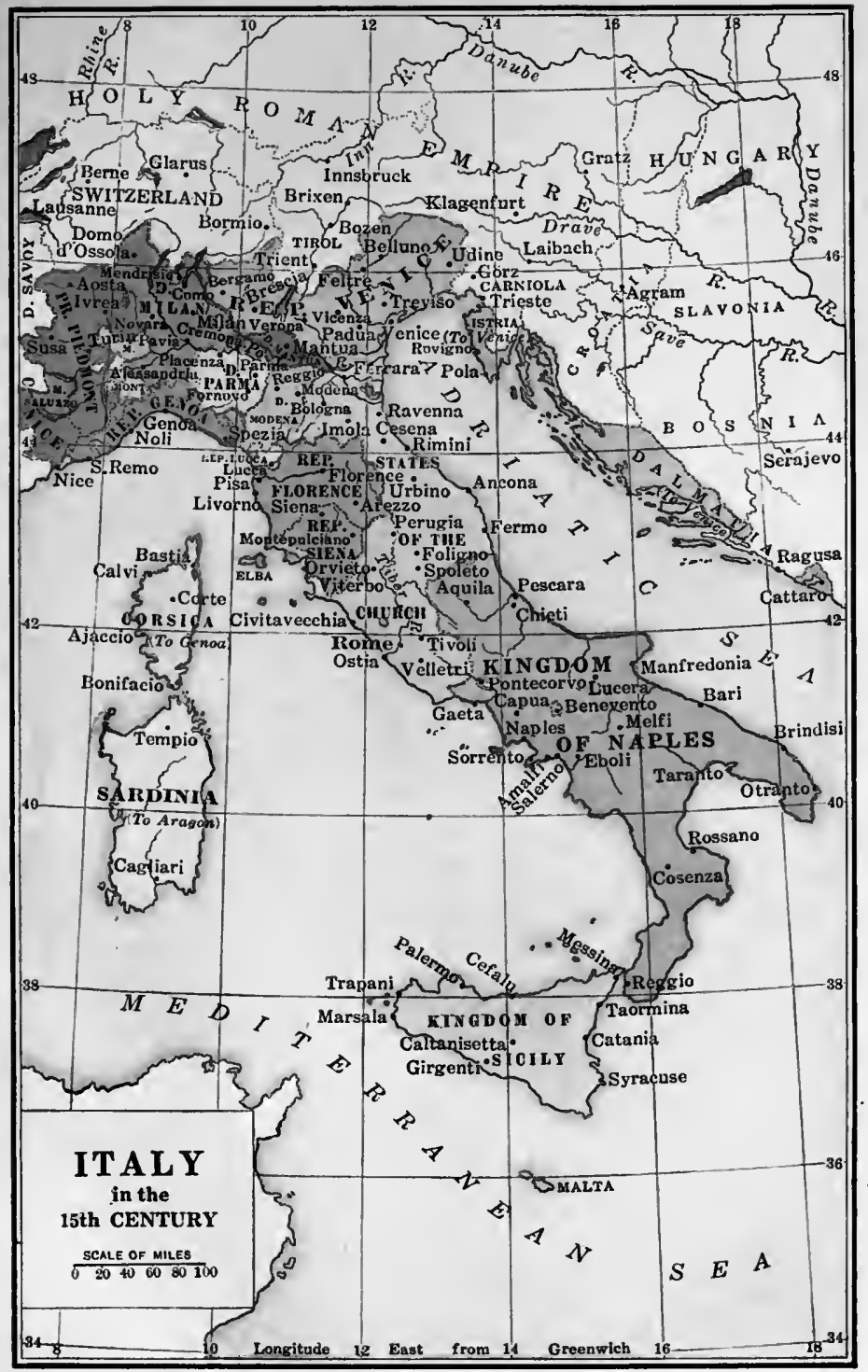


$4 x=3=0-7$

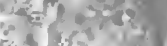

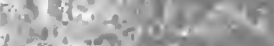

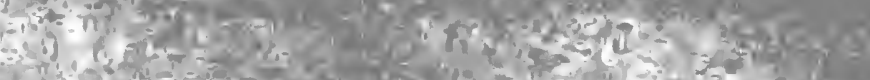

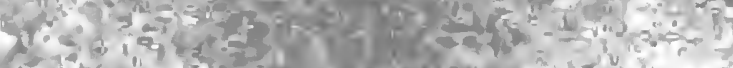

$5 \frac{x^{2}}{10}, 11,2^{2}=1$

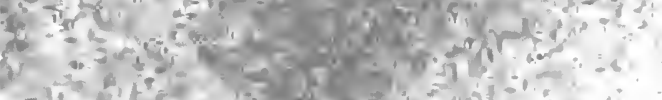

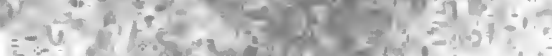

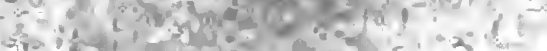

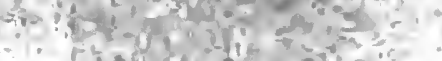

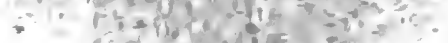

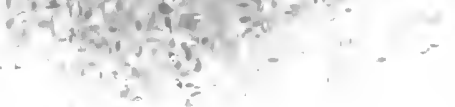

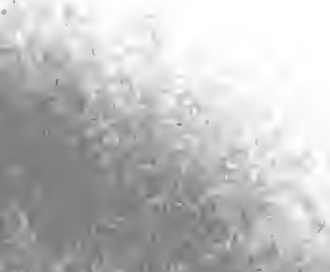

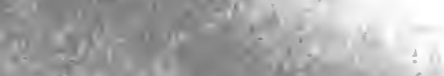

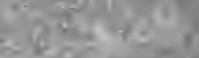

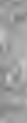

2.

\section{(4)}

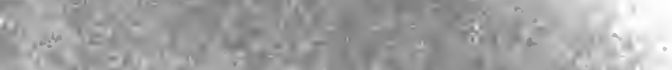

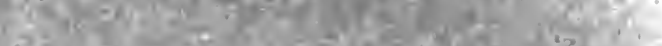

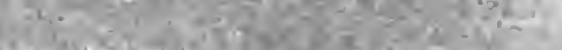

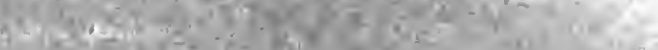

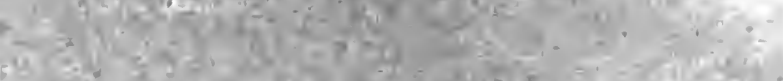

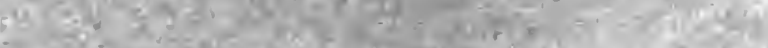

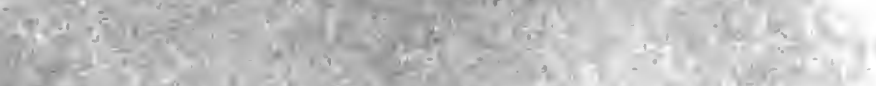

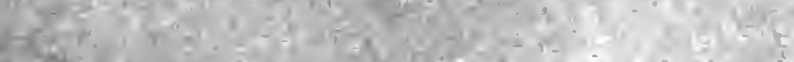

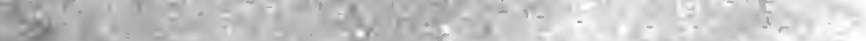

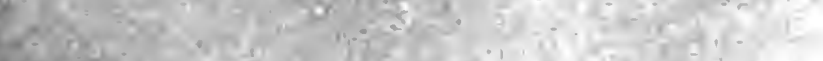

$\therefore 4$

. 30

$-13$.

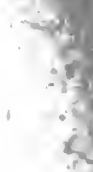

$\rightarrow 18=$

$\therefore \quad+5=$

:1.

$\lim _{2}^{3}$

$=\frac{5}{4}$

$i^{2}-\frac{1}{2}$

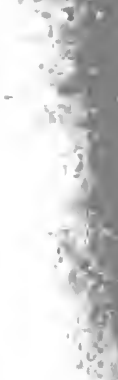

34:

18

i.

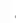

-

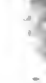

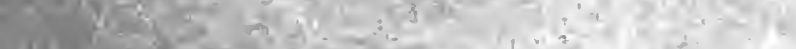

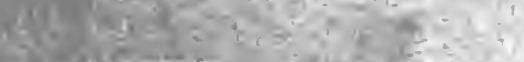
$x=1$ 
but by a singular display of independence the citizens of those towns declared their preference for the lordship of Venice, and at Downfall of the same moment the duchess was calling upon the the Carraras, Republic to aid her against the Carraras. The time had 1405 come for a long-delayed reckoning with these troublesome neighbors. Venice was fighting her own battle as well as that of Milan when she declared war upon Padua. It was a hard fight, for the Carraras showed to the end the same qualities which for three generations had kept them in the forefront of Italian politics. The city fell, and Francesco Novello with his son Jacopo was taken prisoner to Venice. There it appeared that they had been the center of a widespread conspiracy against the Venetian government, and on due proof they were condemned to be strangled in prison. The contemporary picture of Francesco beating off his executioners with his prison stool to the last moment is perfectly characteristic of the furious spirit of the Italian despot.

The downfall of the Carraras of Padua marks the final establishment of the state of Venice as a member of the Italian political War with Milan, family. The westward movement of her frontier made 1425-1432; Venice into the regular employment of the mercenary Carmagnola troops which had already become almost the sole reliance of the other Italian powers. Her greatly extended territories, to be sure, furnished her with a limited number of what might be called native troops, but fighting for the fatherland was no longer popular in Italy. If Italians were furnishing the best-trained and the most scientifically officered troops in Europe, it was because they were pursuing the art of war as they followed all the other arts, in the professional spirit, not as a patriotic service. The first experience of Venice with the new warfare on a large scale was in the years 1425 to 1432 . Their general, Carmagnola, was perhaps the most famous of the Italian condottieri. He had served the Visconti in the wars of Padua but had now transferred his services for higher pay to the Republic. Everything seemed so 
favorable to his success that his employers even negotiated with him as to the terms on which he would contract to deliver the city of Milan into their hands. Yet during all the eight years of Carmagnola's service the only gains to make up for a ruinous outlay were Brescia and Bergamo, valuable indeed, but hardly enough to make it worth while. The government at Venice, not accustomed to this manner of doing business, continually protested and urged a more vigorous policy, but Carmagnola simply kept on demanding higher pay and greater honors, negotiating meanwhile openly with the enemy. At last, with truly Venetian energy and secrecy, the government invited their general to come to Venice "to a conference," arrested him, gave him a fortnight's trial, condemned him, and the same day beheaded him. This was public notice that henceforth Venetian warfare was to be business, and that not for the general but for the state.

In her government of subject territories Venice pursued a policy of mingled strictness and liberality. The communities The Venetian brought under her rule were made to feel that they State, were "affiliated" rather than conquered. Their local 1405-1437 customs were as far as possible left undisturbed, the only requirement being that they were to be faithful to Venetian interests and were to contribute handsomely to the expenses of her government. On these foundations the state of Venice, as it enters into the family of European nations, was to be built. One other fashion of the time still remained to be followed. Every Italian tyranny, founded no matter how securely on the bases of actual power and the consent of its people, found it worth while sooner or later to seek for itself a "legitimate" title. The feudal notions of the Middle Ages still clung with ludicrous tenacity. A power that would not for its life have allowed pope or emperor to perform one act of sovereignty within its borders was willing to go on its knees to either of them in order to gain a title which added not one particle to its actual strength or dignity. Empire or Papacy was ready to grant rights which it did not possess to 
governments which had no need for such rights. Milan, the ancient champion of Lombard democracy against imperial aggression, had long since (1395) become a duchy by virtue of an imperial grant, and many others of the lesser states were enjoying dignities similarly gained. Of all Italian powers it would seem as if Venice had least need of any such fictitious decorations. She had never been included in the mediæval scheme of German-Italian empire. Her constitution was her own, the natural growth of centuries

Investiture of the Doge by the Emperor of energetic action. Her territory was hers by right of conquest and the consent of her subjects, - yet, in spite of all this, nothing would do but a formal investiture with these lands by an emperor who had never lifted a finger in their behalf. It is a striking incident that the person sent up to Prague in Bohemia in 1437 to receive this grant from the emperor Sigismund was a Dandolo, a member of that family under whose leadership Venice, more than two centuries before, had been the chief agent in driving the Roman emperor from the throne of Constantinople. The doge of Venice now becomes duke of Treviso, Padua, Brescia, and half a dozen other places in the wide territory from the Adda to the Julian Alps. For this grant Venice did homage to the emperor and exposed herself to all the chances of the feudal obligation without any of the protection which that obligation had once implied.

The end of Carmagnola was by no means the end of the Milanese war. Indeed, war with Milan may fairly be said to have

Rise of been a permanent condition of Venetian public life Francesco Sforza for more than a century after the destruction of the Carraras in 1405 . It was largely a border warfare turning on the possession of frontier places like Brescia and Bergamo on the Venetian side or Lodi and Piacenza on the Milanese. The excellence of the Venetian government was well proved by the loyalty with which her subject cities stood by her in distress; notably in the case of Brescia which withstood the horrors of a siege for many months rather than fall into the power of 
Milan. Yet this Milanese war cannot be described as a popular conflict. It was rather a military game between hired captains with hired troops. It is an interesting chapter in the history 1440 of the art of war, full of daring "feats of arms" but with little to stir the sentiment of patriotism or to enlighten us as to the real issues of Italian life. Certain famous names, like those of Piccinnino for Milan and Gattamelata for Venice, stand out as names of artists in warfare, but the results of their campaigning, year in and year out, were little more than a temporary shifting of the frontier. The first change came with the rise of the great captain, Francesco Sforza, a rough soldier with no other claim to distinction than success in arms. Sforza had served many masters with a fair degree of fidelity and had married a natural daughter of Filippo Maria Visconti, duke of Milan. This alliance had by no means secured his devotion to the house of Visconti, but, on the death of Filippo Maria in 1447 , it furnished him a wclcome pretext to make a bold push for political advancement. The situation in this year 1447 is highly characteristic of Italian conditions in the fifteenth century. Filippo Maria, who died withWar and out legitimate children, left his dukedom by will, like Negotiations a piece of private property, to Alfonso of Aragon, with Sforza who was also king of Naples and Sicily. Such an arrangement would obviously have upset the Italian balance of power, and to prevent this calamity Venice proceeded at once to aid and abet an attempt to set up a republic at Milan - not, however, without a sharp cye to her own advantage. As the price of her support she demanded the cession of several important towns, and this price was more than the Milanese republicans were inclined to pay. Upon their refusal to come to her terms Venice approached Charles of Orléans, son of the murdered Louis of Orléans, with offers of assistance to him if he would enforce his "claim" to Milan based upon the rights of his mother, the famous Valentina Visconti. Meanwhile the excellent Captain Sforza, nominally still in the service of Venice against the state of his late 
Visconti father-in-law, was the one man who was on hand with a force sufficient to strike an immediate blow. Some first successes led Vehice to offer to support Sforza in the lordship of Milan if he would guarantee Cremona to her as the price of her neutrality. Sforza, however, confident in his own resources, declined to negotiate and went straight on adding town after town to his conquests. Venice, prepared to fight, renewed her offers and dropped her support of the republican movement in Milan. Republic or monarchy meant nothing to her in comparison to the solid advantage of adding to her possessions in the West. Then, all of a sudden, the wheel of diplomacy took a new turn. Naples was ready to fight Venice rather than to see Sforza in Milan; a very strong party in the city of Milan itself was bitterly opposed to him, and so an agreement was reached whereby a new deal was to be made. Milan and Venice were each to receive certain territories, and a separate principality for Sforza was to be carved out of former Milanese lands. Sforza agreed to this arrangement and promised to evacuate the immediate territory of Milan which he had occupied. This, of course, he failed to do. The inhabitants of the city, driven to distraction by hunger and panic, were soon only March 26, too glad to come to terms with the only strong man in I450

sight. Sforza, on his side, was again, of course, ready to sign every kind of guaranties and, on the strength of these, was admitted into the city and proclaimed prince and duke of Milan.

The first effect of Sforza's rise to power in Milan was to set against him all parties who had any "claims" upon the Milanese

Venice, Milan, and Florence to 1494 territory. Especially Venice and Alfonso of Aragon and Naples were aggrieved by this threatening access of power in the hands of a man who was exceeding likely to use it. They allied themselves for action and both set armies in the field; but very soon afterward Venice made terms with Sforza and with Florence, entering with them into a defensive alliance for twenty-five years on the basis of their existing territories (1455). Doubtless Venice was greatly influenced in 
coming to this agreement by the fall of Constantinople into Turkish hands in 1453 . The Republic had been able to do but little in delaying the inevitable loss of this bulwark of Christianity in the East, but evidently a clear definition of the balance of Italian powers would be a vast help to her in defending what was left to her of her Eastern possessions. This year of 1453 marks the point of her greatest strength as a territorial state, but also the beginning of her decline as a commercial power. If Venice could be content with her Lombard possessions, we may fairly say that her future as an Italian state was secure. All authorities agree as to the extraordinary excellence of her rule in Lombardy and the affection of her subjects there. In all the long conflict with Milan this best of guaranties for the future had been displayed at every crisis, but now the passion for expansion destroyed all this great advantage. Even while Venice was straining every nerve to hold together the fragments of her power in the East she was reaching out toward the south after territory that could never become really identified with her interests and, on the other hand, was sure to involve her in conflicts with the powers of central and southern Italy. Ravenna was already in Venetian hands, and Ferrara gave the pretext for war $\left(\mathrm{r}_{481}\right)$. It is the same old story over again, - some early successes and then the fear of all parties that the balance of power might be disturbed. Pope Sixtus IV, Naples, and Milan united against the Republic and drove her to a step which marks a new stage in Italian affairs. She used the favorite device of Italian politicians and invited King Charles VIII of France to take the kingdom of Naples, renewing also her proposal to Charles of Orléans to assert his "claim" on the duchy of Milan (1484). These alluring invitations were not at the time accepted, but they opened the way for negotiations which led to a renewal of the invitation to Charles VIII ten years later by Ludovico Sforza of Milan (1494) and to that famous expedition which may rightly be taken as marking the end of one epoch and the beginning of another in the history of the peninsula 


\section{MILAN}

In the course of our studies of Florentine and Venetian history in the fourteenth and early fifteenth centuries we have had conPolicy of the tinually to refer to the politics of Milan as reacting on Italian States events and institutions in Tuscany and eastern Lombardy. Milanese ambition is the dark shadow overhanging every attempt to establish anywhere in the peninsula a firm and lasting sovereignty. There can be no doubt that the Visconti rulers of Milan were aiming, in a sense quite different from any other Italian power, to build up a true Italian kingdom. Once before Lombardy had given law to Italy and, as the long event proved, Italian unity was to be attained along precisely this road, - the extension of the rule of the North over the South. In Florence and Venice political ambition was governed and limited by primarily commercial and economic motives. For each of them it was necessary to control a large extent of country in order that their own development as centers of human life might go on in security. It would be hard to find in either case much indication of a spirit of conquest for its own sake. In each we have noted that the treatment of the subordinate towns was on the whole liberal. They were regarded rather as affiliated than as subject. So long as they remained faithful to Florentine or to Venetian interests and supplied money and troops for the defence of the common territory, they were fairly free to govern themselves. In the long run these subject communities came to see that their interests lay in living in harmony with a great power rather than in complete independence.

Not so with Milan. There from the definite establishment of the signory under Matteo Visconti in 1317 we can readily perceive the plan to gain territory for the sake of making a great and united political state. In a sense this makes the history of Milan simpler and more easily understood. It is one long story of expansion. - the capture of a town here, the forming of an alliance 
there; now an act of open violence, now a piece of infamous treachery; a wearisome repetition of petty details elevated to Archbishop interest only by the persistency with which they are all Giovanni Visconti, 1349-1359 directed to the one single end of power. Speaking generally, we may say that Milan usually stands for the Ghibelline Party in opposition to Florence, which is usually Guelf ; but we have to remember that in our present period these party names are growing less and less significant. The most important figure in the early history of Milanese expansion is that of the archbishop Giovanni Visconti. He came into power first in $\mathbf{I} 339$ as the colleague of his brother Lucchino, but on Lucchino's death, in 1349, became at once the spiritual and political head of Milan. His plan of campaign was directed southward and eastward, and his ambitions were no doubt furthered by the terrible depression of Italy resulting from the Great Plague of 1348 . On the south his objective point was Bologna, at that time under the nominal overlordship of the pope at Avignon, but actually ruled by the family of the Pepoli. Pope Clement VI, dreading the overgrown power of the Pepoli, sent his governor in the Romagna against them (1350), and they replied by selling out to Milan. The archMilanese bishop-signor was hailed by "the people" as lord of Expansion in Bologna, and thus was accomplished by far the most Romagna dangerous step yet taken in the direction of Milanese control of central Italy. Of course the pope excommunicated the Visconti and laid his lands under an interdict, but the archbishop was churchman enough himself to snap his fingers at spiritual penalties. He knew how much stronger were trustworthy mercenaries and well-filled purses. While he held Bologna with a firm hand, he sent envoys to Avignon and with such success that the pope recognized him as "papal vicar" in Bologna in return for a handsome tribute in money. Summoned to Avignon to receive his investiture, he replied that he would be happy to come and would bring with him 12,000 foot soldiers and 6000 horsemen. The invitation was withdrawn (1352). 
It was just at this crisis that the power of Milan again received a notable increase through the appeal of Genoa for protection Genoa united against Venice. Henceforth the politics of Genoa were with Milan essentially intertwined with those of Milan, and the Visconti rulers were provided with an effective "buffer" towards the west, in case of attack from that quarter; while at the same time they secured an ally who might occupy the Venetians at sea if at any time they should be at war with them on land. Masters of Milan, Genoa, and Bologna, it seemed as if the Visconti were destined to bring about that unity of Italy towards which the dreams of poets and the ambitions of statesmen were always pointing. The poet Petrarch, the noblest exponent of these hopes, was a frequent guest at the court of Milan and an ardent admirer of the genius of Giovanni Visconti. Too great power, however, produced the usual effect. A league of the states most directly threatened was formed against Milan, and in the midst of preparations to resist it the great archbishop died (1354).

The Visconti power was now divided among three nephews of Giovanni in such a way that Matteo held the southern, Bernabò Charles Iv the eastern, and Galeazzo the western sections, while in Italy, r355 Milan and Genoa were held in common. Matteo died in a few months, leaving his share of the government to his two brothers. Their first problem was to defend themselves against the League, in which Venice, Padua under the Carraras, Verona under the Scalas, Vicenza, Mantua, Ferrara, and most of the other northern cities took part. Florence, threatened by the Milanese power in Bologna, was in open sympathy with the League, though in continual negotiations with the Visconti. The usual touch of comedy is not wanting. While every power was at odds with every other, each was ready to jump at the chance that a foreigner might stir up things in such a way that it could gain some personal advantage. The rumor that King Charles IV of Germany would like to be crowned king of Italy and emperor set them all agog with expectation. Negotiations for this excursion occupied nearly four 
years. All parties - the Papacy, Milan, the League against Milan, Florence - vied with each other in offering money and in begging favors, yet each was alarmed lest their imperial guest might favor some one else at his expense. So long as Giovanni Visconti lived, there seemed to be some excuse for this interest in the emperor as a makeweight against him, but his death relieved the tension and lessened the need of currying favor with Charles. He came in 1355 , was received with much splendor at Milan, was crowned there with the iron crown of Lombardy, and was handed on, after a week of festivities, to a most chilling reception in Tuscany. At Pisa, to be sure, a local party was ready to welcome him in order to use him against another party, and the same was the case at Siena, but Florence sent him handsome speeches and let him go by. He was crowned emperor at Rome on Easter Sunday, at once set out on his return, and was back again in Germany in June. His six months in Italy were absolutely without result and only showed once more that while Italians were but too ready to deal with any foreigner for a momentary advantage against each other, they would not allow him any rights whatever that might curtail their precious privilege of doing as they pleased. For Milan the only visible trace of the imperial visit was the investiture of the brothers Visconti with the title of "Imperial Vicars in Lombardy," whatever that might be worth.

For ten years after the death of the archbishop (1354-1364) the two Visconti brothers were engaged in one continuous conflict Galeazzo and with their neighbors on all sides, but with no other Bernabd result than the loss of Bologna and the deepest hatred Visconti, on the part of their subjects. Their combined tyranny 1354-1385

became the type of a furious and arbitrary personal rule unchecked by constitutional restraints and maintained only by their control of blindly obedient servants whose advancement in life depended wholly on the good will of the despot. Galeazzo and Bernabò sought, each in his own way, to build a throne upon a foundation of blood and terror. Yet these men, hardly more 
than beasts when their lust of power was roused, were aiming also at a permanent place among the rulers of the world. Galeazzo married his son Gian Galeazzo to Isabella of Valois, daughter of King John of France, and his daughter Violante to Lionel, duke of Clarence, third son of Edward III of England. The numerous daughters of Bernabo were accepted in marriage by princes of Austria, Bavaria, Thuringia, and others. Taxes to equip these foreign brides were laid upon the people of the Milanese territory with inhuman severity. The two branches of the Visconti sought also to cover their mutual hatred by local marriage alliances. Bernabò gave a daughter as second wife to Gian Galeazzo, and himself married a daughter of his next neighbor on the east, the Scala of Verona. It seemed as if two Visconti lines, one growing toward the west and one toward the east, were about to divide the Milanese lands between them. This result was averted by the growing jealousy of the two. Galeazzo, who died in 1378 , had for several years given up the actual business of ruling to his son Gian Galeazzo, a mild, gentle-mannered youth, much given to study and to religion. Bernabò, in the same way, as he grew older divided the rule among his five sons, himself retaining a sort of family supervision over them. It was obviously a situation that could not last. The gentle Gian Galeazzo, made imperial vicar for Lombardy in 1380 , regarded by the family in general as dull and cowardly, spent five quiet years in preparing for a coup d'etat. When all was ready he wrote to his uncle Bernabò ( $13^{8} 5$ ) that he expected to pass by Milan on a pious pilgrimage and would be glad to pay his respects if Bernabò would come out to meet him near the city. The uncle, though warned, came but did not return. $\mathrm{He}$ and two of his sons were seized and thrown into prison, while Gian Galeazzo entered Milan amidst the jubilations of the people always ready to take their chances with a new tyrant to escape the burden of an old one. The Milanese Council proclaimed him lord of Milan, Bernabò's palace was ransacked, all memorials of his rule were destroyed, and, what was more to the purpose, 
within a month all the outlying landed possessions of the Milanese were in the hands of Gian Galeazzo. The unity of Milan was restored and apparently on a firmer basis than ever.

Under Gian Galeazzo's vigorous rule takes place that great extension of Milanese power which we have already noted in conGian Gale- nection with the history of Venice. The partition azzo Visconti, of the Scala territories with the Carraras of Padua 1385-1402

( 1387 ) carried the Milanese frontier eastward to include Verona and Vicenza and thus brought nearer the inevitable struggle with the Republic. At the same time the lord of Milan married his only daughter, Valentina Visconti, to Louis of Orléans, brother of King Charles VI of France, and gave as her dower all his Piedmontese territory with the town of Asti. This marriage opened up the fateful "claims" of France on the Milanese lands, that were to be enforced a hundred years later by King Louis XII, grandson of this Valentina. Foreign marriages, planned as defences of Italian tyrannies, were to prove a potent weapon for their overthrow. That the great powers of Europe were more than willing, however, to accept such alliances is a proof of the extraordinary development of these Italian commonwealths. They were taking rank with the ancient kingdoms of the north, and we have to compare them, so far as public policy is concerned, with these and not with the lesser principalities or city communities which they seem at first glance more closely to resemble.

Once more the pet ambition of the Visconti, to get possession of Bologna and thus to control Tuscany and all central Italy, leads The Visconti to a new struggle. Florence as before takes the lead in Tuscany, and not only puts into the field a strong force under I399

the famous English captain, John Hawkwood, but makes alliance with a troop of French mercenaries under the count of Armagnac, who were to make a diversion in the northwest. Here enters also the younger Carrara, Francesco Novello, in a last desperate struggle to maintain himself in the Paduan territories. The combination was too strong, and Gian Galeazzo 
was content to sign the treaty of Genoa in $139^{2}$, whereby it was agreed that henceforth Milan should keep out of Tuscan affairs and that Florence should leave the Milanese in peace. Of course this engagement was no sooner made than broken, and for the next eight years the outward history of northern Italy is little more than a new series of plots and counterplots of which the central motive is the Tuscan ambition of Gian Galeazzo. His goal seemed to be reached when, in 1399, he succeeded in buying from the momentary signor of Pisa the lordship of that town and in actually planting a garrison there by which he hoped not only to control Pisa but, what was of far more importance, to block the activities of Florence at a most vital point. Siena, the ancient enemy of Florence, was gained by similar means, and Perugia and Assisi were persuaded to receive Milanese governors by the vague hope of a milder rule than they had previously enjoyed.

Thus Florence, deserted by her natural allies, found herself at the center of a ring of Milanese fortified towns and in imminent Emperor danger of ruin. A diversion from the north held Ruprecht Gian Galeazzo for the moment in check. The emperor in Italy, ${ }^{1401}$ Wenzel (1378-r 400), son of Charles IV, had proved himself a totally useless person, a drunkard and ne'er-do-well. It needed only a slight impulse from the Roman pope, Boniface IX, to persuade a majority of the German Electoral College to depose him and to choose in his place the elector Ruprecht of the Palatinate. All the enemies of the Milanese now combined to urge Ruprecht to come down into Italy as his predecessors had done and make one more attempt to bring order out of the Italian chaos. Ruprecht was willing and actually went so far as to raise a considerable force and come over into Italy. In the region around Brescia he was met by troops of Gian Galeazzo and beaten in several skirmishes. His army melted away in the fashion of the time, and he got himself back into Germany as he could without having accomplished anything whatever. Again it was demonstrated that the idea of imperial control in Italy had no heart in it. 
Freed from this danger in the north, Gian Galeazzo pushed forward with all his energy the recapture of Bologna. The method

Gian

Galeazzo, was the usual one. A party within hostile to the rulDuke of Milan, 1395 ing signor, a Bentivoglio, was glad to open the gates to the Milanese and to hail him as lord of Bologna. The Milanese tyrant had now reached the summit of his greatness. Down to seven years before 1395 he had been merely the partisan chief of a republic, a tyrannos in the strict sense, a ruler without a title, who was permitted to manage the business of state because there was no better visible way for the citizens to enjoy the good things of life and to share in the national glory which his ambition guaranteed to them. His only personal title was that of count of Vertus, derived from the French property of his first wife. He had, it is true, the empty decoration of imperial vicar for Lombardy, but this was not enough. In 1395 he had made it worth while for the Emperor Wenzel to grant him the investiture as duke of Milan, a "legitimate " sovereignty which he might transmit to his children." The deposition of Wenzel and the election of Ruprecht did not affect his hold upon this the first great hereditary power established in Italy on the ruins of the liberty of the Italian people. The obvious fact that the emperor, himself utterly powerless in Italy, was giving away rights which he did not possess was lost sight of in the brilliancy of a title which seemed to place the first citizen of a republic on a level with the hereditary princes of the earth.

The capture of Bologna made the subjugation of Florence appear certain. It was reported that Galeazzo had begun negotiations looking toward his recognition as king of Italy and was actually making preparations for a royal entry into Florence, which

1 The text of this grant is given in the "Annales Mediolanenses," published in Muratori, "Scriptores Rerum Italicarum," XVI, 824, Ist ed. The festivities at Milan on the day of the investiture are described at great length. A second charter of the year following, Muratori, XVI, 827, enumerates the several territories over which the dukedom of Gian Galeazzo was to extend and regulates the right of succession by the law of male primogeniture. 
he proposed to make his capital city, when this dread was suddenly removed by his death (1402). Gian Galeazzo represents the Character of Gian most marked type of the Italian city-despot and statesGaleazzo Visconti man. Naturally a man of quiet and reserved character, sincerely devoted to learning and the arts, without military skill or personal courage, he rose to absolute power over a great state by an extraordinary combination of cleverness and mental activity. Seldom taking part in military expeditions, he kept his armies in incessant motion in every direction. The tangled web of his diplomacy reached into the remotest parts of Europe, and he held its threads in his own hand, never losing sight of the one object of Milanese aggrandizement. His methods of enforcing control over his people were harsh and exhausting to the tax-paying strength of the country, yet his death left Milan rich and prosperous as never before. The splendid cathedral, the only really great Gothic church in Italy, and the marvelous Certosa of Pavia are the chief existing monuments to his grandeur of conception and his command of material resources.

The death of Gian Galeazzo Visconti in 1402 brought to Milan again the dangers of a division complicated this time by those of a collapse of regency. His three sons, all under age, divided the terMilanese Rule in Tuscany, 1402 ritory under the nominal guardianship of the duchess. Gian Maria received the ducal title, Filippo Maria was called count of Pavia, and Gabriele Maria, a legitimated bastard, was given the lordship of Pisa. As was to have been expected, the withdrawal of the hand that had held the widespread lands of northern and central Italy together was the signal for a general uprising. The old party cries of "Guelf" and "Ghibelline" were raised again to give point to the new conflict. Florence and the Papacy, ever the centers of Guelf Italy, make common cause once more against the northern peril. On every side the collapse of Greater Milan goes on apace. Bologna, the key to Tuscany, was naturally the first object of the Florentine-papal 
alliance. The Florentines went honorably to work and placed an army in the field; but the papal legate, the wily ex-mariner and future pope, Cardinal Baldassare Cossa, began treating over their heads with the Milanese regency for the surrender of Bologna into papal hands. With Bologna were included also Perugia and all the other towns taken from the Church by Gian Galeazzo, but no mention was made of the Tuscan towns whose recovery was the main interest of Florence. It seemed her misfortune, but was really her gain, that she was now compelled to take the lead in a restoration of her Tuscan influence. In Siena she was met halfway by a popular movement, old scores were wiped out, and a treaty of lasting peace was framed whereby the welfare of 'Tuscany seemed permanently guaranteed. Pisa, where Gabriele Maria Visconti was ruling after the manner of his house, following her ancient policy of hostility to Florence, allowed her tyrant to enter into an arrangement with the French Marshal Boucicault, at that moment signor of Genoa, whereby Gabriele was to be recognized as a vassal of France. The marshal put the screws on Florence by arresting all the Florentine merchants at Genoa and thus compelled her to enter into a four years' truce with Pisa. In the rest of Tuscany the Milanese rule disappeared.

In Lombardy itself the years from I 402 to 1406 are occupied with the closing drama of the house of Carrara at Padua, which Milan we have described in connection with the history of against Venice. Padua was the agent in stripping away from Venice, Milan her eastern territories, Verona and Vicenza, 1402-1406 only in turn to fall a victim to the growing power and the political necessities of the Republic. The end of the Carraras in 1405 brought nearer to each other the frontiers of the two great states whose manifest destiny it was to divide Lombardy between them. The murder of Gian Maria Visconti in 1412 by a group of disaffected Milanese nobles has no special meaning except as an illustration of brutal tyranny bringing its own revenge. The succession of his young brother Filippo Maria is. important 
only as confirming the force of the hereditary dukedom and showing how far Milan had departed from any republican spirit. The farce of an imperial right in Lombardy was sustained for a moment by the emperor Sigismund's appointment of the marquis of Montferrat, a long-time opponent of the Visconti, as his vicar general there, but the real interest of Lombard affairs centers about the long struggle for supremacy between Milan and Venice. The central figure of that conflict for a long time is the condottiere Carmagnola, whose first great reputation as a captain was won in the service of Milan. It is idle to search here for any principles whatever that can explain the movement of events. Carmagnola was simply a dealer in warfare as other men dealt in other wares. His aim was his own personal advancement in wealth and power. So long as he found these at Milan, just so long he was a faithful servant of the Visconti. When his vast property and his obvious ambition for territorial lordship roused the jealousy of his employers he deserted them and sought service with their enemies. We have already seen how the game of war as played by Carmagnola for his own advantage was blocked by the determined action of Venice. In the skilled tradesmen of the Adriatic the condottiere found more clever judges of the value of their investment in him than he had reckoned upon. He lost at once his fortune and his head, but the issues of the struggle were not seriously changed. Venice held her own, and Milan rather lost than gained through the growing pressure upon her of the lands toward the west, of that Piedmontese country from which the long-delayed unity of Italy was after more than four centuries finally to come.

The five Visconti rulers, Galeazzo, Bernabò, Gian Galeazzo, Gian Maria, and Filippo Maria were all men of similar type. Not Tyranny of one had made even a pretence of military courage or the Visconti, capacity. All were of that dark and sinister quality 1354-1450 which suits with the name of despot. Withdrawn from the frank and open association with their fellow citizens which marks the early Medici in Florence, they had spun the subtle web 
of their diplomacy and planned the campaigns they never shared. Their ambition to extend their rule had not, as in the case of Florence or Venice, the solid basis of reason in the necessity of maintaining their commerce. It was simply the greed of power for what they, the rulers, could make out of it. Their rule over subject provinces was harsh and cruel, directed solely to straining their tax-paying powers to the utmost. Without assigning any too lofty motives to any of the other Italian governments, it is safe to say that the restless determination of the Milanese Visconti to go as far as they could disturbed the peace of Italy more than any other one cause. If they had been content with their boundaries as fixed by the partition of the Scala lands in 1387 , it seems probable that the fivefold balance of power in Italy might have been upheld with far less expenditure of energy than it actually required. The truth is, however, that Italy did not want peace. Activity, a restless movement of body as well as of mind, was rather the ideal of Italian life, and these incessant skirmishes and combinations dignified by the name of wars and alliances were simply one of the natural expressions of this quality.

The change from the rule of the Visconti to that of the Sforza was at least a variation in tyranny, and the type of ruler was in The Republic so far an improvement as Francesco Sforza was a man of Saint who had risen from obscurity to power by the force Ambrose of personal talent. His way to rule was opened by the death of Filippo Maria without legitimate heirs (1447). In spite of the long submission to tyranny the old republican spirit, the temper of Legnano, was not altogether dead in Milan. While partisans of Alfonso of Naples, of the duke of Savoy, and even of Venice were calling upon the people to accept some one of these several outside governments, a group of leading nobles proclaimed "The Republic of Saint Ambrose." A wave of lofty enthusiasm swept for a moment over the Milanese people and carried all before it. The dangerous captains of soldiery in the city were easily bought over, and a government on the lines of the ancient 
commune was set in operation. That would do very well for the city; but it soon became apparent that to give up despotic government meant to give up also the hold of the city over her outlying possessions. After a fashion her rule over these had been justified by her character as a legitimate monarchy. If she, Milan, could go back to republican days, why not also Cremona, Crema, Lodi, and all the rest, whose names also had rung out in the old fights against imperial pretensions? In all directions the lesser towns of Lombardy fell away from Milan. This was the opportunity of Francesco Sforza. He had been the most successful of the Milanese captains, so successful that Filippo Maria had gone so far as to give him one of his superfluous daughters in marriage. The Republic retained him as its general in chief, but the opportunity to fight his own battle as well as that of his employers was too tempting. His first care was to see to it that the subject towns were not at once swallowed up by the ever-vigilant Venice. He took one after another of them and held them, nominally for Milan; but it seemed quite in order that he should pay himself by making himself lord of Pavia by the way and should quietly annex one and another good town to this stronghold as the chance came. The war with Venice went on, but with everincreasing difficulty for Milan, since her former sources of revenue were now running dry and in consequence her captains were deserting her daily. Sforza remained nominally faithful, but meanwhile was negotiating on the one hand with Venice and on the other with his Ghibelline partisans in Milan. The wildest party conflicts raged in the city, and the outcome was a peace with Venice in which Sforza was left out. This absolved him from all sense of duty to Milan, and he went into negotiations with Venice Francesco on his own account. In the midst of these, however, Sforza, Duke a new turn of affairs in Milan led to a proposition of Milan, $145^{\circ}$ that Sforza should be invited to take the lordship of the city. At first brought forward cautiously, the suggestion offered a way out of many complications, and Sforza's own talent did the 
rest. He first turned his whole attention to securing the eastern frontier against the Venetians and, when this was done, celebrated with all pomp his installation as duke of Milan, without saying "by your leave" to the emperor. His son, Galeazzo Maria Sforza, was at the same time invested with the lordship of Pavia (1450).

With the coming of a new governing house the issues of Milanese politics were not essentially changed. The Visconti

Galeazzo ambition to control the affairs of the northern half of Maria Sforza, the peninsula became the inheritance of the Sforza. Growth of The only notable variation is seen in the increasing imFrench Influence portance of French influence. The French monarchy of Louis XI, still in its mortal struggle with Charles of Burgundy, was ready to listen to almost any propositions looking towards a strengthening of its alliances on that side. The immediate cause of French negotiations was the county of Savoy, Milan's next and most dangerous neighbor on the west. Through French influence Francesco Sforza betrothed his son Galeazzo Maria to Bona of Savoy, who had been educated at the French court and who was guaranteed by the French king in the possession of all the lands which, formerly belonging to the Visconti, were now held by her brothers the counts of Savoy. Galeazzo Maria himself had been largely educated in France and, if we may trust the Italian chroniclers, had there acquired the taste for extravagant display which was to be his ruin. Certain it is that when he succeeded his father in 1466 as duke of Milan and had gained his Savoyard bride, he began a series of enormously costly entertainments at home and journeys abroad, for which the overtaxed people of Milan had to pay. His father had been able to bring order into the administration of affairs, but the son's insensate folly and greed rapidly turned the attachment of the people into a furious hate. The worst days of the worst Visconti were revived by this monster of cruelty. He became for all time the type of the prince who inherits power without having to earn it by any quality whatever. The catalogue of his infamies reads like a Newgate Calendar. 
Yet the fact remains that when in 1476 he paid the penalty of his crimes at the hands of assassins, the mechanism of government worked so well that no serious changes took place. Not only were his murderers promptly dispatched but the most severe test of any monarchy, the succession of a child, was withstood for the time with surprising success.

The Duchess Bona of Savoy became regent, and through the cleverness of her adviser, Simonetta, was able to maintain her

Ludovico

Sforza (II infant son Gian Galeazzo Sforza, against the machinaMoro), Regent made possible by the banishment of all five of them
of Milan, $\mathbf{x}_{480}$

from the Milanese territory. The most active, the afterward famous Ludovico Sforza (Il Moro), entered at once into dealings with all possible enemies of the regency and within a year was able to bring such pressure to bear on the duchess that she deposed the faithful Simonetta and in his place set Ludovico himself as chief adviser and military head of Milan. It required only a few more strokes to compel the duchess-regent to abdicate and to bring the young duke to recognize his uncle Ludovico as his guardian and regent in her place ( 1480 ). The twelve years following, to 1492 , are a time of great development of the Milanese power under the direction of a man capable of all the arts of the political school of Machiavelli. He allied his state to Naples by marrying his nephew to Isabella, granddaughter of King Ferdinand, but soon after he himself married the famous Beatrice d'Este of Ferrara, whose brother married the sister of the young duke of Milan. The jealousies arising out of these family alliances were an excuse to Ludovico to take upon himself continually more and more of the actual powers of government, so that by the year 1492 he was practically the ruler of Milan.

In this great year of $\mathrm{r}_{492}$, when Lorenzo the Magnificent was dying at Florence, when Roderigo Borgia was elected pope as Alexander VI, and when the Italian Columbus was discovering America, begin those negoțations of Ludovico Moro which 
were to bring into Italy two outside powers that were never again to leave it entirely to its own devices. Germany was just passing Ludovico under the rule of the Austrian Maximilian I, and to Moro, Duke him Ludovico offered his niece Bianca Sforza and a of Milan

handsome sum of money in return for his own investiture as duke of Milan. Neither Francesco Sforza nor his son had been regularly invested by an emperor, a proof, if proof were needed, how unnecessary such a sanction was to the actual power of any prince who chose to neglect it. Ludovico kept his investiture a secret until his time should come. Meanwhile he entered into negotiations with the young King Charles VIII of France to secure his alliance in return for his own help in securing to Charles the crown of Naples. This meant, to be sure, driving the Aragonese out of the south of Italy, but that was only a part of the game long since prepared for when the marriage of the nominal duke of Milan, Ludovico's nephew, with a princess of the Neapolitan house had seemed to threaten to unite the duchy of Milan more intimately to the fortunes of Naples and thus to check the ambitions of Ludovico. The expedition of Charles VIII in 1494 is a turning point in the affairs of all Italy. $\mathrm{He}$ was received with enthusiasm by Ludovico and escorted by him through the Milanese territory without the formality of a call upon the rightful duke, Gian Galeazzo, who was meanwhile living at Pavia, the victim of a lingering disease ascribed by some to his early excesses but by others to a systematic course of poison administered by his farseeing uncle. The king and the regent were on their journey southward when suddenly the news arrived that the young duke was dead. Ludovico hurried back to Milan, met there the complaisant "Senate". which he had himself created, and yielded to their entreaties that he would save the state by allowing himself to be proclaimed duke of Milan. To satisfy all cavil he now produced the imperial investiture of a year previous, and his "legitimacy" was proved beyond a doubt. 


\section{NAPLES AND SICILY}

The history of Naples and Sicily rests upon foundations entirely different from those which underlie the course of events in

Peculiar the other parts of the peninsula. Elsewhere we have Character of found the chief interest of our study in the free deNeapolitan velopment of the Italian people. The institutions of
Bistory

Florence, of Venice, in a less degree those of Milan and Rome, have been shown as resulting from a truly Italian quality, often obscured, often distrustful of itself, but even while it was losing its ancient vigor still fiercely conscious of its right and ready to make sacrifices to uphold it. Tyranny in the north seems always an invasion upon a spirit of popular liberty. In the south there was, in the first place, a population which, even to the present day, has been markedly different from that of the north and center. It is only with reluctance and with a kind of repulsion that the northern Italian brings himself to admit that the southerner is an Italian at all. At the close of the thirteenth century this antagonism of race was accentuated by political differences. The kingdom in Naples and Sicily had existed for generations, while the rest of Italy had been spending its best energies in resisting every form of imperial or royal control. When an Italian said il regno - the kingdom - he meant Naples. Furthermore, this kingdom had from the beginning been a vassal state of the Papacy, a relation which no other leading Italian state admitted. Again, the last holder of the early Norman Neapolitan kingdom had been of that hated Hohenstaufen race, whose policy for a century had been to subject Italians to a foreign and a royal supremacy. And finally, city life had played a far less prominent part in the south. Instead of being the natural units of political life, cities were rather incidents in the general constitution of the country, dependent upon the central government for their rights and compelled to pay taxes for its support.

After the death of Frederic II in $125^{\circ}$ and of his son Conrad in 1254 the kingdom was claimed by Pope Innocent IV as overlord, 
and a considerable part of it came actually into his possession, only to be lost again when Frederic's illegitimate son Manfred overComing of ran Apulia and with little resistance occupied Naples.' Charles I of Constance, a daughter of Manfred, was married to the Anjou, 1268 eldest son of the king of Aragon, and to offset this Hohenstaufen-Aragonese alliance the French pope, Clement IV, opened negotiations for a French succession in Naples. The result was a compact between the Papacy and Charles of Anjou, brother of King Louis IX of France, who was to have the kingdom of Naples and Sicily in return for certain concessions to the papal power. Charles agreed that the kingdom should be held as a unit under the feudal lordship of the pope, on condition of an annual tribute besides a large semiannual contribution. He guaranteed that he would never be a candidate for the Empire nor for the lordship of Lombardy or of Tuscany; but if by any chance he should be elected emperor, he would renounce the kingdom. $\mathrm{He}$ promised to restore to the Church in his kingdom all the rights of which Frederic II had deprived it and to maintain a force of threc hundred horse in the service of the Papacy.

We see thus indicated the political situation in the south as it was to be during the kaleidoscopic changes of the next two The Situation hundred years. From Charles of Anjou in 1268 to of Parties Charles VIII in 1494 we can generally untangle the snarl of Neapolitan politics sufficiently to perceive a few permanent ideas: ( 1 ) the overlordship of the Papacy, which seemed to justify popes in taking a somewhat more active interest in Neapolitan affairs than in those of the rest of Italy; (2) the Angevine or French interest, generally supported by the Papacy and always opposed to (3) the Aragonese or Spanish claims; (4) the influence of local families, which had always to be conciliated by the contending parties; and (5) a certain national sentiment in the island of Sicily, which often proved a check upon the despotic rule of any government. As a rule this sentiment favored Spain as against France. 
The reign of Charles of Anjou is marked chiefly by the development of the city of Naples as the worthy capital of a great kingReign of dom and the actual center of a government which Charles I of until then had had rather the character of the NormanAnjou, 1268-1284 Hohenstaufen feudalism. There is little doubt that Charles, a capable and ambitious prince, had farreaching plans of empire in the eastern Mediterranean. He made a successful expedition against the Moors of Tunis, where his brother, King Louis IX, was just at the point of death, saved the remnant of the French army, and secured tribute from the Moors for himself. The way seemed opened for indefinite expansion eastward, when quite suddenly, in I 282, the revolt of the "Sicilian Vespers" gave the first indication of that unquenchable hatred of The "Sicil- the Sicilians for everything French which was to be ian Vespers," 1282 one of the principal checks upon the Angevine rule in Italy. The pretext for this revolt was the harshness of the French administration in the island. The chief agent was a gentleman of Palermo, John of Procida, who had been injured in his property rights and who devoted three years of strenuous activity to enlisting in the Sicilian cause the aid of King Pedro of Aragon, Manfred's son-in-law, of Pope Nicholas III, and of the emperor at Constantinople. Pedro embarked a considerable army on a fleet nominally intended to fight the Moors, and lay off and on, waiting for a signal from Palermo. The conspiracy was very widely spread, but the secret was kept with uncommon success, and at the concerted moment, on Easter Monday, 1282, all Sicily rose as one man against the foreigner. Eight thousand Frenchmen of all classes were said to have fallen victims at the first blow. Charles with great promptness threw a large force across the strait, laid siege to Messina, and was on the point of taking the town when Pedro of Aragon appeared with his fleet, destroyed part of the Neapolitan ships, and landed a greatly superior force for the relief of Messina. All Sicily accepted him as their king, and thus begins the separate history of Sicily under Aragonese rule. 
It well characterizes the personal nature of sovereignty in the south that Charles's first impulse was to challenge Pedro to single combat and thus to settle their "claims" independently of the wishes of their subjects. All the preliminaries for this absurd performance were duly arranged. The king of England was invited to be referee in the duel, which was to take place at his town of Bordeaux in France. Charles was on the spot at the appointed time, but Pedro, alleging distrust of his opponent's honor, spent only a few hours at Bordeaux and slipped away to Spain. There was a deal of bluster on both sides, but the course of events was not seriously affected either way by this piece of romantic folly. Far more important was it that Pope Martin IV, as zealous for Charles as Nicholas III had been against him, now excommunicated King Pedro, deposed him from his lordships of Aragon and Valencia, granted these to Charles of Valois, the second son of King Philip III of France, and sent a legate to France to preach a "crusade" against Aragon.

While Charles was wasting his time on the point of honor in France, his son Charles, prince of Salerno, acting as his vicarius Constitutions in Naples, had fortified the Angevine dynasty by a of the Prince series of laws known as the "Constitutions of the of Salerno Prince of Salerno." These were directly intended to conciliate the Papacy, the Neapolitan clergy, the barons, and the people by removing many of the limitations imposed by Frederic II, and especially to avoid the harsh measures by which Sicily had already been lost to the Angevine rule. The prince here promised in the name of his father all due tithes to the clergy, that clergymen should not be brought before the lay courts, that churches should have the right of asylum, that clerical elections should be free from lay interference, and that the clergy should be exempt from many forms of taxation. As to the barons, the king bound himself that in future they should be relieved from gratuitous service at the court, should have the right to collect moderate "aids" from their vassals without special permit, and that' their 
causes should be tried and settled by a court of peers, relieving them in this way from the burden of interference by the royal officials. A comparison of these and subsequent Angevine regulations with the "Constitutions of Frederic II" 1 shows at a glance that the antagonism of France-Anjou and Hohenstaufen-Aragon went much deeper than the merely political ambitions of rulers or the rivalries of nations. It was the expression of permanently different ideas as to the function of the state.

The war between the mainland and the island went on, chiefly at sea, each party trying to effect a landing on the coasts of the Naval defeat off Naples, tions. The fleets of both powers were largely com$\mathbf{1 2 8 3}$ other and thus to gain a foothold for further operaposed of hired galleys, just as the armies on land were coming more and more to consist of mercenary troops. The most famous admiral of the period was Roger di Loria, a Genoese who for many years proved himself the saithful servant of the Aragonese party. In the year I $283_{3}$ he captured the island of Malta after a sea fight with a Provençal fleet in the service of Charles of Anjou, and then with forty-five galleys appeared before Naples. His plan was to draw out the Neapolitan fleet by attacks along the coast near by, and in this he succeeded so well that the young prince Charles, no longer able to contain himself and against the advice of the papal legate, got together what ships he could and set sail in pursuit of Di Loria, who pretended to flee before him. As soon as the chase reached the open sea the clever sailor turned his ships and gave battle. It was a desperate fight, worthy of the issue at stake. The superior numbers and greater skill of the Sicilians won the day, the Neapolitan ships gradually dropping out of the fight until the flagship of the prince was left to bear the brunt alone. His men vowed to die rather than surrender, but the Sicilian admiral sent down divers who bored holes below the water line of the flagship so that she began to sink, and there was no way but to yield. Prince Charles was taken prisoner and 
carried first to Naples, where Di Loria's first care was to set free the princess Beatrice, daughter of Manfred, who had been for fifteen years a prisoner in the Castel del Uovo. For a moment it seemed likely that the Angevine power in Naples would be lost. Some popular demonstrations against it were made but were promptly suppressed by the steadier elements of the people, and Di Loria was content to sail away with his royal prisoner without having entered the city. Throughout the island of Sicily the temper of the Sicilian Vespers was still hot, and a unanimous demand was made that the murder of Corradino (1 268) should now be avenged by the death of this Angevine victim. Queen Constance, however, daughter of Manfred and heiress of the Hohenstaufen traditions as she was, refused her consent and sent the prince on at once to Spain, where he was held a close prisoner for several years at Barcelona. The fortune of the war went steadily against Charles of Anjou. One defeat after another in Calabria delayed him in his plan for a grand assault upon Sicily, and in the midst of these misfortunes he suddenly died, January $7, \mathbf{2 8} 5$.

Within a few months died also the other principal actors in the Neapolitan drama: Philip III of France, Pope Martin IV, and Treaty of Pedro of Aragon. The imprisoned prince, now King Olexon, 1288 Charles II, became the center of all the negotiations set on foot to settle the Sicilian question. The price demanded for his liberty was a guarantee of a separate Aragonese government for the island, and this meant the permanent loss to the Angevine power of its finest possession. Furthermore, the claims of Charles of Valois, brother of King Philip IV, upon Aragon and Valencia were to be withdrawn. The very existence of the Angevine power was at stake. So important did these negotiations seem that King Edward I of England went in person to meet Alfonso, the son and successor of Pedro of Aragon, at the town of Oléron in Béarn to mediate between the contending parties. Alfonso was ready to deliver up his prisoner on the conditions named, but the new pope, Nicholas IV, refused his consent, and only the renewed persuasion 
of King Edward finally prevailed upon Alfonso to strike out of the Treaty of Oléron all mention of Sicily. King Charles promised on his side, on his honor as a gentleman, that if the conditions were not observed he would voluntarily return to his imprison: ment. It would appear that Charles did his best to persuade King Philip IV of France to observe his part of the Treaty of Oléron, but he did this only with the greatest difficulty, after he had actually threatened to surrender himself to Alfonso and had given up to Charles of Valois the county of Anjou. Charles II was crowned at Rieti by Pope Nicholas IV in May, 1289, as king of both Sicilies, though at the same time James of Aragon was maintaining himself as ruler of the island. The settlement of Oleron was soon overturned by the death of Alfonso of Aragon, whose brother James of Sicily succeeded him. It was not a part of James's plan to hold Sicily, and he quite willingly gave it up to Charles II in exchange for a daughter of Charles as his wife and the islands of Sardinia and Corsica as Aragonese territory. Once more the spirit of the Sicilian people asserted itself in a determined refusal to be made the sport of foreign diplomacy. They positively declined to pass under the Angevine dominion and proclaimed a third Aragonese brother, Federigo, as their king.

This Federigo represents more fully than any of his predecessors the determination of Sicily to stand alone. He was deserted by Reign of Don all those powers to whom he would most naturally Federigo in have looked for support. His admiral, Roger di Loria, Sicily

hitherto the most loyal servant of the Aragonese, now abandoned him and entered the service of Charles II of Naples. His brother James made common cause with the Papacy and the Angevines against him, and even his mother, Constance, daughter of Manfred, and his sister Violante, who was betrothed to Robert, son of Charles II, withdrew their support. In 1298 the united forces of Aragon, Naples, and the Papacy landed in Sicily and laid siege to Syracuse, but so determined was the resistance of the city and so vigorous the attack of Federigo's relieving army that one 
after another the attacking forces were compelled to withdraw. The campaign reopened in the summer of 1300 with a naval defeat for Sicily which seemed likely to settle the whole question. The French Charles of Valois, being in Italy on his way to undertake a new conquest of Constantinople, was persuaded by the new pope, Boniface VIII, to lend his troops for an attack on Sicily in common with those under Charles II. Federigo, still relying on native Sicilian loyalty and courage, met this new assault with such success that without actually fighting, merely by harassing the enemy and cutting off his supplies, he compelled the signing of a new treaty in 1302 . This treaty guaranteed to him the title "King of Trinacria" for life, the sovereignty to pass, after his death, to Charles II of Naples.

The reign of Charles II (1289-1309) is specially notable for the successful establishment of the Angevine power in southern

Reign of Charles II in Naples, 1289-1309 Italy upon a basis of adjustment with the local customs and with the demands of the papal overlord. In other words, the "Ghibelline" character that had been fixed on the south by the Hohenstaufen rule was changed to a "Guelf" attitude, and thus a new stability was given to the balance of power in Italy as a whole. Charles II himself was a man of peace. and left his mark rather in institutions than in the expansion of his territories. He caused the customs of Naples, Bari, and other cities to be reduced to writing, adorned his capital with many buildings, improved the streets, strengthened the university by new privileges and by calling distinguished professors with ample salaries. The same general policy was followed by his son Robert, under whom the kingdom of Naples reached the height of its splendor. King Robert lived to see two attempts to revive the imperial power in Italy, that of Henry VII of Luxemburg (1310-I3I3) and that of Ludwig the Bavarian ( 1328 ). As head of the Guelf interest he became, next to the pope and in alliance with Florence, the most important agent in defeating these Ghibelline attempts. On the side of 
Sicily he was less fortunate. King Federigo lived until $\mathrm{I} 337$ and during his long reign was able to repel every attempt to dislodge him. He kept in close touch with every Ghibelline movement in the north, taking advantage of these diversions to make attacks upon the coasts of Naples. His last campaign was in defence of Sicilian soil against a renewed assault of King Robert. On Federigo's death his claim on Sicily should, according to the treaty of 1302, have passed to King Robert; but times had changed. Federigo's son Pedro declared that he was not bound by his father's promises, nor could Robert, in spite of every effort, gain for himself the kind of support in France and the Papacy that had won the point for Naples a generation before. Don Pedro continued the stubborn policy of his father, and the six remaining years of Robert's life were mainly occupied in futile attempts to break the Aragonese power in the island. Pedro's worst enemies were a group of malcontent Sicilian families, which gained possession of large parts of the country and on the death of Pedro in 1343 sent to offer the crown to King Robert. The offer reached the aged king on his death bed, too late to realize in this peaceful fashion the hopes of a half century of warfare.

Both kingdoms now entered on the sorry heritage of dynastic monarchies. Of the many attempts to unite Anjou and Aragon,

Origin of the Hungarian Party in Naples Naples and Sicily, by marriage ties none had succeeded. True, the infant son of Don Pedro was a great-grandson of Charles II of Anjou,as well as of Pedro of Aragon, and he would have seemed a fitting heir to both kingdoms. Robert of Naples, however, being without male heirs, had betrothed his young granddaughter, Joanna, to her cousin Andreas of Hungary and had brought that young savage, as the Italians represent him, to be educated at the Neapolitan court. At his death in 1343 he left this girl of sixteen sole heiress of all his titles and claims, under an express agreement with the barons of the realm that they should pay their allegiance to her alone, while Andreas should be merely the royal consort. Thus a 
new foreign interest enters here into Italian politics, destined to be a fruitful source of complications throughout the peninsula for generations to come. Hungary was distinctly a rising power, ambitious to take its place among the nations and especially anxious to expand in the direction of the Adriatic, where it already held important places on the eastern coast. The opportunity to set up a "claim" in Naples was, therefore, not to be lost, and Robert, clever politician though he was, made the fatal mistake of binding his descendants to this Hungarian rather than to the Sicilian alliance which would have been infinitely more valuable.

The accession of Queen Joanna in $\mathbf{r} 343$ was marked by the almost immediate predominance of the Hungarian directors of

Murder of Andreas of Hungary, 1345 the young Prince Andreas and the withdrawal of the local Neapolitan barons to their estates. The aim of the Hungarian party was to secure from the pope the coronation of Andreas as king, partly on the ground of his marriage, but also because he, equally with Joanna, was a great-grandchild of King Charles II. They succeeded, but their success on this point did not seriously affect the course of events, while it did distinctly increase the tension between the Hungarian and the native parties. To keep the balance Joanna relied upon a Neapolitan noble, Charles of Durazzo, the husband of her sister Maria. Within two years of her accession to the kingdom a conspiracy was formed against Andreas to which he fell a victim under circumstances of peculiar atrocity. Joanna did her best to prove her own ignorance of the plot, but little confidence was placed in her protestations. The papal overlord set in motion a bloody persecution of the murderers; but what was far worse, the murdered youth's brother, King Louis of Hungary, laid claim to the crown of Naples. In the year $\times 348$ he came down into Italy with a strong force, occupied Naples without striking a blow, and exacted summary vengeance for his brother's death. Joanna had meanwhile gone to Provence to get from the pope, who, it must be remembered was all this time living in France, a 
certificate of her innocence, and had taken to herself a second husband, Ludovico of Taranto. The first Hungarian occupation of Naples lasted but a few months, and Joanna found herself again in possession. Pope Clement VI had refused to accept Louis of Hungary as king of Naples, but was willing to give this title to Ludovico, and the young pair were received by the degenerate people of Naples with every sign of joy, as if the merry days of the jovial King Robert were come again. The recovery of most of the Neapolitan territory was comparatively easy, and a good stand was made even against King Louis himself, who came a second time into Apulia with a larger army. Through the mediation of papal envoys peace was finally made between the rival claimants.

Still the same antagonisms we have been trying to follow continue. The politics of the Regno are henceforth for a hundred

Queen

Joanna's

Schemes of

Succession years little more than a three-cornered fight between Hungarians, Angevines, and Aragonese, with the Papacy continually used by one party or another to gain some momentary advantage. Queen Joanna I married four husbands, the last a German adventurer with the historic name of Otto of Brunswick. Like her former consorts he was carefully excluded from the functions of government. Childless at last, she adopted as her heir Louis of Anjou, brother of King Charles V of France and, after the outbreak of the papal schism in 1378 , clung to the fortunes of the French pope. The head of the Hungarian party was Charles of Durazzo, who set up his own "claim" against that of Louis of Anjou and made war on the queen. A prisoner in his hands she still refused to give up her plan of a French succession and was strangled in prison by Hungarian mercenaries (1382). The murder of Andreas of Hungary was avenged.

This Charles of Durazzo, now in possession of the government of Naples as King Charles III, gained also for a moment the crown of Hungary as well, and after his murder there, his son 
Ladislaus was proclaimed king of Naples. Thus two children, Louis II of Anjou and Ladislaus, each under the regency of an

Reign of active and ambitious mother and favored, the one by Ladislaus, the pope at Avignon and the other by the pope at 1400-14I4 Rome, became the champions respectively of the French and the Hungarian factions. Both grew up in these conflicts, neither giving way until finally, after years of petty warfare, Ladislaus gained the upper hand and won over to his side almost all the partisans of Louis, who now abandoned the Angevine cause and returned to France. Ladislaus, on the whole the most capable figure in the affairs of southern Italy since King Robert, lived fourteen years longer. His most important activities were in connection with the triple schism in the Church caused by the Council of Pisa. He espoused vigorously the cause of the Italian pope, Gregory XII, even after the death of the "Pisan pope," Alexander V, had made way for John XXIII. The natural answer to this attitude was a renewed attempt to restore the Angevine succession in Naples. Louis of Anjou, summoned by Alexander $\mathrm{V}$ and again by John XXIII, came once more into Italy with a strong mercenary army and this time gained a complete victory over Ladislaus in the battle of Roccasecca, near the borders of the papal state. If only he could have kept his hold on his hired troops he might have appealed successfully to the Angevine sympathies of the Neapolitan nobility, but, as continually happened elsewhere, the troops paid once by him were only too glad to be paid again by his enemy, and Ladislaus was able with their help to carry fire and sword throughout the states of the Church. His victorious career, threatening the Italian balance of power from the south as Milan had so often done from the north, was stopped by a sudden illness which carried him off at Naples while still in the vigor of manhood.

Ladislaus was followed on the throne of Naples by his sister, Joanna II, and a new chapter in the miserable history of 
government by women and children begins. As usual, the nominal rulers were only the tools of private and party ambition. Queen Joanna It seemed a reconciliation of the rival interests of II, I4I4-I435 France and Hungary-Durazzo when the queen gave her hand to the French Jacques de Bourbon, count de la Marche, but his active rule soon set him in opposition to Joanna and led to his imprisonment and her deliverance from the restraints at once of her husband and of all laws of decency. Paramours took the place of generals and councilors. The luckless husband, after an imprisonment of three years, went back into France and years afterward died there as a member of the Order of St. Francis.

The only change in the situation of parties worthy of our attention is the substitution of the house of Aragon for the Renewal of house of Hungary as a makeweight against the the Arago- Angevine interest in Naples. By a series of events nese Claims which we need not follow, the kingdom of Sicily had fallen into the hands of Alfonso the Magnanimous of Aragon. A third Louis of Anjou had been persuaded to try his fortunes in Italy, and to escape this danger Queen Joanna II, being childless, adopted Alfonso as her heir, with the promise of immediate possession of large estates in Calabria. Both candidates appeared in the country with considerable armies, and so complete was the success of Alfonso that Joanna in new alarm revoked her decree of succession and adopted Louis III. All this might be passed over as the mere burlesque of politics were it not that "claims" founded on these desperate freaks of a half-mad woman were destined later seriously to affect the fortunes of Italy and of Europe. For the present the action of the queen had no effect on the political situation. Louis III kept up the fight intermittently as long as he lived; and dying in 1434 left his "claim" to his brother René of Anjou. The will of Queen Joanna, who died in the year following, recognized René as her successor, but Alfonso of Aragon renewed the war and after eight years of 
fighting and diplomacy finally drove René from the country. The first Angevine dynasty in Naples was at an end, and now for the first time since the death of King Robert a hundred years before, the south of Italy and Sicily came together into the hands of a really strong and capable man.

Alfonso was already master of Aragon, Valencia, Catalonia, Majorca, Sicily, and Sardinia, and it might naturally have been Reign of feared that he would regard this latest and most Alfonso the remote of his possessions as a mere appendage to Magnanimous, ${ }^{1443-145^{8}}$ all the rest, made it his residence and the object of his especial care. He was the first to adopt the title of "King of the Two Sicilies," as he was the first since Norman times really to bring the two countries under one effective and freely acknowledged administration. Alfonso's first care was to secure the succession in Naples for his favorite but illegitimate son Ferdinand. The barons of the Regno readily consented in spite of the opposition of Pope Eugenius IV. The fall of the Angevine power had been most unwelcome to this sturdy champion of papal rights, for the Angevines had never been allowed to forget that they were in a sense the creatures of the Papacy, while the Spaniards in Italy had usually been opposed by the Holy See. Indeed, already on the death of Joanna II (1435) Eugenius IV had declared the Regno to be a lapsed fief of the Church which could not be assumed by any one without his approval, and that meanwhile he, the pope, had a right to administer the government through a regency of his own appointment. That scheme had failed, but now a new opportunity had arisen. Alfonso met the opposition of Eugenius by at once entering into negotiations with Felix V, the pope of the Council of Bascl, ${ }^{1}$ and playing off one pope against the other until within a few months Eugenius IV was persuaded to come to terms. Alfonso was recognized as king by right of adoption; his son Ferdinand was declared legitimate

1 See pp. 347 ff. 
and approved as his successor in the Regno. It is probable that Sicily was not included either in the investiture of Alfonso or in the promise of succession to Ferdinand. In this whole matter it is quite clear that the claim of Aragon to Naples rested in reality on the solid fact of power and on its acceptance by the Neapolitan barons and that the papal approval was only a useful form of legitimation as against future claimants. It is the same relation as that of Milan to the Empire, useful upon occasion, but easily disregarded when it was not required. In fact Alfonso was king in his own right and, during his long and peaceful reign (i $443^{-1} 45^{8}$ ), used his power for the advantage of the state as the standards of the time approved.

Alfonso was in many ways the ideal type of the Renaissance prince. Whether the power of such a man rested upon hereditary

Character and Policy of Alfonso of Naples

claims as here, or upon commercial success, as in the case of Cosimo dei Medici, or upon military prowess, as with Francesco Sforza, the type is much the same. Alfonso is described ${ }^{1}$ as a man of the noblest qualities, devoted to religion, an ardent admirer of the classic learning and a generous patron of scholars, splendid in his manner of living, a terror to his enemies and faithful to his friends. His greatest service was in maintaining, as far as he could, the peace of Italy. His chief reliance in the peninsula was upon Milan, whose interests, especially in regard to France, seemed to fall in with his own. In 1455 a double marriage alliance was planned between the house of Naples and the new Sforza dynasty, a grandson and a granddaughter of Alfonso being betrothed to a daughter and a son of the duke of Milan. This family connection was later of great importance in the negotiations preceding the descent of Charles VIII in 1494. It was obviously unwelcome to the Papacy, since its consequences might be that union of the North and the South which, from the days of Frederic Barbarossa to the year 1870 , was the thing most dreaded by the papal policy.

${ }^{3}$ Vespasiano da Bisticci, I, 695-98. 
Alfonso did much for Italy but nearly ruined it all by his failure to keep Sicily and Naples united under one government. The fatal practice of treating the lesser countries as pieces of family property led him to give Sicily to his brother, Juan of Navarre, rather than to his son, Ferdinand of Naples. At his death, in 1 $45^{8}$, he is reported to have warned this Ferdinand to follow three rules: (I) to dismiss all his own Spanish councilors and to govern by means of Italians; (2) to reduce taxes to their "ancient" figure; (3) to keep the peace with the Church and with all other powers.

In spite of these sage counsels the reign of Ferdinand, which lasted until the very eve of the expedition of Charles VIII, was

Reign of Ferdinand of nearly every power in Italy, especially the Church. Naples, 1458-1494 Underneath all lay the ancient enmity of France, one long series of conspiracies and wars involving represented by the claims of the house of Anjou. It was always possible to find enough discontented barons to form a conspiracy, and the first resort of the conspirators was sure to be the Angevine claimant and the second the Papacy, which could generally be counted upon to support any French party in Italy as against any Spanish interest. A notable instance of this latter point is the entire change of front of Pope Calixtus III, who as the Spaniard, Alfonso Borgia, had been the most faithful servant of Alfonso I, but, once become pope, devoted all his energies to checking the plans of the Aragonese dynasty in Naples. The new activity of the Angevine claim was first shown in 1459, when Jean of Anjou, son of René I, answered the call of a Neapolitan conspiracy by coming into Italy with a considerable force, overrunning a large part of the Neapolitan territory and holding it for more than two years. He was driven out again with the help of Milan and the Papacy, now in the hands of Aneas Silvius (Pius II). How little the people, who had to pay, entered into the question is well shown by the contemporary story that Jean of Anjou made this expedition not so much to please himself as to 
give his Neapolitan tutor, who during nineteen years of exile had been devoted to his fortunes, a chance to revisit the scenes of his youth !

An interval of peace gave opportunity to Ferdinand to follow his father's example in carrying out many reforms in the governAn Angevine ment, notably in the judicial system, in encouraging Revival industries, and in furthering the progress of learning. defeated, ${ }^{1486}$ Still he was personally disliked, and this enmity extended in full measure to his son, afterward King Alfonso II, to whom during the last ten years of his life $\left(14^{8} 4^{-1} 494\right)$ he handed over in great part the business of government. In 1484 a new conspiracy revived once again the Angevine peril. The conspirators applied as usual to the pope, now Innocent VIII, and he willingly undertook to bring over René of Anjou, duke of Lorraine, grandson of the first René. Before this new claimant could arrive, however, the rebellion broke out, and a proposal was made to Ferdinand's more popular second son, Frederic, to place him on the throne in his father's stead. He promptly declined, and the king, striking at his real enemy, carried the war at once into the papal state and thus enforced a peace, giving to the rebellious barons every guarantee of safety. Within a few months on two occasions he made wholesale arrests of these same barons and slaughtered them all with only the merest forms of a trial.

The year 1492 made important changes in the fortunes of all Italy. Lorenzo dei Medici died at Florence; Alexander VI (Roderigo The Year Borgia) became pope ; and Ludovico Sforza of Milan 1492 began the series of negotiations with Charles VIII of France which encouraged the latter to undertake his expedition to gain the crown of Naples. So far as Naples itself was concerned, the way was prepared by the furious hatred of the people for their Aragonese rulers. The coming of Charles VIII begins for them a new period of foreign rule. 
Of the five great powers in the Italian peninsula the one which in several respects had an apparent advantage over all the others Peculiarities was the State of the Church. No other had so favorof the able a position or so long a history or so definite a Patrimonium policy. It held the city which above all others seemed the predestined capital of a united Italy. It represented as did no other the ancient Roman tradition as against the Germanic elements of the north and the mingled Greek, Arabic, and Norman populations of the south. From a very early date its rulers had secured themselves by a long series of charters against foreign aggression, and in fact its territories had never, since the Lombard times, suffered from any foreign occupation. Its capital city, Rome, often violated by war from many sides, had never fallen for any considerable time into alien hands.

The name Patrimonium Petri gives us the clue to some of the puzzles of this singular history. As in the case of no other soverThe Religious eignty there was here an inseparable mingling of the Sanction human and the superhuman. The right of the Papacy to govern this vast territory, reaching from Terracina on the frontier of the Regno on the south to Ravenna in the north, touching both seas and including the rough fastnesses of the Apennines and the wide plains of Umbria and the Roman Campagna, rested not only upon the usual sanctions of earthly power but upon the higher one of a divine commission. To maintain the See of Peter in a dignity worthy of its origin and its mission, there must be a basis of temporal power. From this it was to draw its necessary revenue and the military force needed to defend its integrity.

As in other parts of Italy, so here prosperous cities, Ravenna, Rimini, Faenza, Forli, Cesena, Viterbo, and, above all, Bologna, had become the natural centers of public life. A fierce individualism had held these cities in jealous isolation, one from the other. Nor was there among them any one such dominating force as Florence 
in Tuscany, or Milan in western, or Venice in eastern, Lombardy. Rome as a political power never, in spite of her double claim to Rome and authority, quite succeeded in binding these Romagnol her Subject republics to her interests as her three rivals in the north Cities

had held their neighbors. Indeed, it may be safe to say that, just because of her division of interests between this world and the next, she could offer her subjects terms of less practical value than Florence or Milan or Venice could offer to theirs.

To understand the nature of the Roman sovereignty in the Romagna we need go back no farther than the year 1278 , when The Habs- the papal power had come into the hands of a man burg Compact of first-rate quality. Gian Gaetano Orsini, as Pope of 1278

Nicholas III, a Roman of the Romans, began his administration just at the moment when King Rudolf of Habsburg was needing every possible support in his effort to establish the rule of his house in the Austrian lands. ${ }^{2}$ A part of the price which the king was willing to pay for the papal backing was the formal surrender of all imperial rights in the cities of the Romagna. In the negotiations for this bargain the papal lawyers brought out all the ancient charters of former emperors back to Carolingian times, and the guaranties now given were expressly recognized as the confirmation of those earlier claims. It was a clear victory of the Roman as opposed to the Germanic tradition in Italy. From this act of 1278 may be dated the formal organization of the State of the Church.

The local lordships throughout the Patrimonium were largely of German-Lombard origin. The effect of the new arrangement Papal Nepo- was not to destroy them, but to bring them definitely tism in the under papal overlordship. Nor was this suzerainty to Romagna

be, for a long time to come, of a very vigorous or: oppressive sort. The papal administration was intrusted to officials (rectores) whose function was to preserve the peace if possible, to see that the local government was regularly carried on, and

1 See pp. $67 \mathrm{ff}$. 
to collect such dues as were collectable. Nicholas III filled these offices with his relatives among the Roman nobility, the first instance of that papal "nepotism" which was to become so fatal a source of corruption within and of hostility without. The frequent shiftings of the papal power tended, of course, to weaken continually the central control and in proportion to strengthen the independence of the local chieftains. Within a generation after Nicholas III the removal of the Papacy to Avignon and the consequent Frenchification of papal officialdom brought about an almost complete demoralization of government in the Romagna. There is no doubt that this situation in turn made the idea of a Roman residence increasingly unattractive to the French popes and their French court.

Another effect of the lack of unity among the Romagnol towns was to expose them to the continual intrigues of the greater Italian Intrigues of powers. Thus we see Ferrara drawn into the political the Greater schemes of Venice, Bologna occupied for a time by the Powers

Milanese, Forli, and Imola under steady pressure from Florence. Yet on the whole it is remarkable with what persistency this group of towns cling to their nominal relation with the Church. This relation meant for them the nearest approach to that entire independence which was the ideal of the Italian community as it was of the Italian man and the Italian woman of the Renaissance.

That was the situation at the coming of Cardinal Albornoz in 1353. His policy, directed to the single end of restoring the papal Government of Cardinal Albornoz, 1353 sovereignty in the Patrimonium, was one of mingled firmness and compromise. Former attempts of the kind had aimed to control the authority of the local tyrants by that of the papal envoys, and thus had kept up a continual friction which the papal administration could not overcome. Albornoz tried the plan of winning over certain of the tyrants by creating them Vicars of the Papacy and then using them against others who refused to accept the same terms. The most striking illustration of this policy was given at the very outset in Rome itself. There the good will of the people was 
conciliated by the restoration of Cola di Rienzi, after seven years of absence, to be the administrative head of the city in the name of the sovereign pope. Through this judicious compromise Albornoz succeeded in tranquilizing the Roman Campagna, repressing the local factions, and doing away for the time with the danger of the Free Companies. Then, after two years, he was able to turn his attention to the Romagna.

There he first received the homage of Gentile da Mogliano, tyrant of Fermo, confirmed him in his power as vassal of the

Compact with the Malatesta of Rimini
Holy See, and made him gonfaloniere of the army of the Church. With this help he captured the town of Recanati from the Malatesta of Rimini and declared it under the protection of the Church. This first success had for its result the formation of a League of the Romagnol tyrants under the lead of the Malatesta and the Ordelaffi of Forli, soon joined by Mogliano, who repented of his treason to the local cause. The prestige of Albornoz, however, upheld by the greater part of the Patrimonium, was too great to be thus overcome. In a rapid series of victories he broke the power of the Malatesta and compelled them to sue for peace. The result was a compact by which the Malatesta were given the government of Rimini and several neighboring communes as papal vicars, engaging to pay a large annual tribute to the pope and acknowledging his sovereignty over all their territories.

Having thus gained the most redoubtable chieftains of the Romagna, Albornoz proceeded against the Manfredi of Faenza,

The Manfredi of Faenza using here first the most unfair advantage of the threat of papal excommunication and interdict. When the Manfredi refused to be alarmed by these spiritual terrors he declared them to be heretics and proclaimed a "crusade" against them as enemies of Holy Church. Whoever took the cross in this pious cause should receive the same indulgences as if he were enlisted against the Turks. In spite of these handicaps 'Faenza held out for seven months against the "crusaders," 
until it was compelled by starvation to capitulate on honorable terms. The "heretic" chief, Manfredi, was gladly accepted as an ally by the prudent cardinal in the next stage of his conquest.

There remained a group of towns, of which Forli and Cesena were the most important, under the rule of the Ordelaffi family, The Ordelaffi represented at this time by Francesco Ordelaffi, a most of Forli

typical specimen of the Italian tyrant. A contemporary describes him as "a faithless dog of a Paterino. For thirty years he was excommunicate and his lands under an interdict without the singing of a Mass. He was a desperate character, a mortal enemy of priests on account of bad treatment by a former papal legate, a faithless and obstinate tyrant." Yet the same writer has to admit that he was "tenderly loved by the people of Forll; he gave proof of devoted charity; he gave dowries to orphan girls, found places for young women and cherished the poor in affectionate memory."

From the year 1333, when he had made himself tyrant of Forll, the story of this man is one of the most singular tragi-comedies of

Francesco Ordelaffi, Tyrant of Forli the Renaissance period. Excommunicated in 1336 after he had captured the archbishop of Ravenna, stripped him, beaten him, and carried him off to prison in Forll, he had gathered so powerful a party that the pope had made terms with him, withdrawn the excommunication, and made him Vicar of Holy Church in Forll and Cesena, in return for an annual tribute and the obligation to furnish troops for the defence of the Patrimonium. Of course he failed to pay and was again excommunicated, but gained only so much the more advantage.

Finally in Albornoz Ordelaffi met his match. At first, when the cardinal summoned him as a reputed heretic he made no reply,

Albornoz

against Francesco Ordelaffi was condemned, and the crusade declared against him. The contemporary biographer of Rienzi writes: "When this Francesco heard the bells ringing for his excommunication he set some other bells ringing and excommunicated the pope and the cardinals, and, what was worse, had them burned in effigy in the public square." This was pretty bad, 
but partisan malice seems to have gone further and blackened the record of this singular being with a long list of unproved cruelties.

There follows the thrilling story of the defence of Cesena by Francesco's heroic wife, Marzia, to whom he had committed the

Marzia Ordelaffi defends Cesena task while he held the town and fortress of Forll. Even after the citizens of Cesena had turned against her, this modern type of ancient Roman valor shut herself up with a handful of followers in the citadel and for weeks held out against a furious bombardment accompanied by undermining of the towers. Her father, serving in the papal army, came to beg her to surrender. "Nol" answered the intrepid Marzia, "when you gave me in marriage to my lord, did you not tell me to obey him at all costs? Now he has intrusted this fortress to me and I will defend it to the death." Only when it became evident that the main tower must fall and crush a quantity of citizens of doubtful loyalty whom she had imprisoned there did she consent to negotiate. The legate with his usual wisdom gave her garrison free exit from the place and received her into honorable imprisonment at Ancona. In fact, when the cardinal offered her liberty she declined, "fearing the suddenness of her husband."

Summoned to surrender Forli in return for the liberation of his wife, his son, and his nephews, Francesco replied: "Tell the Surrender Legate that I had supposed him to be a sensible man; of Forl but now I call him a silly beast (bestia pazza). If I had had him in prison I would have hanged him by the neck three days ago." For two years the siege of Forli went on. Francesco's German mercenaries were bought off at double price by the prudent cardinal. Again and again the call to the "crusade" brought recruits to the papal army anxious to save their souls by a not too dangerous risk of their bodies. All through this desperJuly 4, 1359 ate resistance runs the thread of Italian diplomacy. July 4, 1359 Francesco had been promised aid from Milan, and not until this definitely failed did he finally make up his mind to surrender. The cardinal made a decent show of righteous wrath, but 
soon decided not even in this case to make an exception to his usual policy. He granted this most hardened sinner complete absolution, withdrew all proceedings against him, restored to him his knightly honor, and created him papal vicai in Forlimpopoli and Castrocaro. Francesco's restless spirit, however, drove him into new conflicts, but always against the Church. He fought under the banner of the Visconti at Milan and ended his days at Venice, where he had served as Captain General of the Republic.

The elimination of Francesco Ordelaffi was the last act in the preparation of the papal state for its reorganization under CardiValue of the nal Albornoz. It was a service of immense value to Services of the Papacy, so great indeed that it seems to have Albornoz

aroused a natural jealousy at Avignon lest the great cardinal might be aiming at a princely power for himself. In $1360^{\circ}$ he was summoned to give an account of his stewardship and appeared at the papal palace with a wagon loaded with the keys of the towns and castles which he had recovered from their rebellious lords. "This," he said, "was the best account he could render," and he proceeded to present the keys one by one with an account of the place to which each belonged, until the patience of the pope was exhausted and he was ready to admit that the cardinal's administration was fully justified.

The crown of Albornoz's achievement in the Romagna was the book of laws preserved as the Constitutiones Egidianae, so called The Consti- from the given name of their author, Egidius (Gil, tutiones Egidianae, 1357

Giles). Published in 1357 immediately after the first pacification of the Romagna, this code was retained as the basis of government in the papal state at least as late as 1816 . It aims to define the rights and duties of the papal officials, to fix the powers of courts, to prescribe the penalties for crimes, and generally to secure the control of the papal government over the restless communities with which it had to deal. The burden of a great part of its enactments is the right of the papal rector to give his approval in the last instance to the acts 
of the local authorities of whatever sort. The work is, however, animated throughout by the same spirit of compromise which had marked the action of Albornoz in his subjection of the Romagnol barons and which had brought him success where others had failed.

The somewhat wearisome details give interesting glimpses into the social and political problems which were continually threatening Control of the Papacy over all Local Powers the integrity of this motley state. Especially that fury of party spirit which had been the text of Dante's bitterest denunciations, and which flashes out at every page of Villani's sober narrative, was to be repressed in every possible way. It was a desperate undertaking, but what could be done by legislation the great cardinal was determined to do.

"Whoever comes to the court of the apostolic legate or the rector of the province or to any city where they are in residence, shall immediately go to the house or inn where he expects, to lodge and shall there deposit his arms and shall not carry them about the city openly or secretly" (iv, 46).

"Since party divisions (partialitates) between persons, towns and provinces have led to murder and destruction of property, with great peril to souls and bodies and daily menace to the peace and quiet of those places, we decree that no person, of whatsoever rank or station, shall dare by way of insult to call out the name of the Guelf or the Ghibelline party or use or invent any other party name which could lead to the forming of factions. Nor shall any one cry 'Hurrah !' for any party or community or person save only, "Hurrah for the Church and her officials!'" (iv, 45).

"We decree that treaties of peace and reconciliations between cities, fortified places, towns or districts of any sort made, or, under God's providence, to be made by authority of the rector, shall be maintained and preserved inviolate by all cities, communes or persons whomsoever, and let no one, be it city, commune, baron, knight, noble or individual, dare to violate or break or disturb, 
directly or indirectly, these contracts or their effects. Such a person shall be regarded by all as a traitor and rebel to the Holy Roman Church. His house and all his goods shall, in perpetual memory of his deed, be utterly destroyed, broken up and confiscated to the treasury of the Roman Church" (iv, 44).

This regard for combinations to preserve the peace did not, however, diminish the hostility of the legate towards all other Jealousy of kinds of political association.

\section{Combinations}

"We decree that no city, community or individual shall dare, presume or attempt to enter into, contract or negotiate, dictate or consent to any association, league, obligation, confederation, compact or guaranty or anything of similar import, the object of which is to establish unlawful gatherings or to choose, ordain or create any captain, rector, governor, councillor, or by whatever other name he may be called" (iv, 22).

There are curious illustrations of the principle, so foreign to our practice, but deep-seated in Italian political theory, that no citizen Executive could safely be intrusted with executive power over

Officers to be his fellow citizens.
Foreigners

"We decree that no one, of whatever rank or station, shall have the right to accept, to exercise or to hold the office of podesta, capitano, gonfaloniere, conservator, defensor, protector, or however else it. may be called, through which he can claim any superiority of power or preëminence over his fellow citizens. Nor shall any city, or other community elect any one to an office of this kind" (iv, 23).

Further, in the chapter defining the qualifications and functions of the rector it is said:

"His officials (familiares) shall not be natives of the province nor regular inhabitants thereof, for it is not seemly that under pretext of this familiar service they should acquire favor and thus oppress their fellow citizens" (ii, 4). 
Evidently, if any oppressing was to be done, it were better done by a stranger than by a native.

It was natural that while the cardinal accepted the tyrannis in the form of a papal vicariate as a necessary evil, he should restrict Regulation of the Tyrannis it as far as possible.

"We decree that no one shall seize lands of the Church by violence against the will of the inhabitants or any part of them and hold them per tyrannidem or help others to do so or expel from them any party or individuals."

In the same way no community may take another under its protection (recommendatio) without permission of the rector.

- The following illustrates the continual dread lest subjects of the Church should shift their allegiance to some other suzerain. It Prohibition shows how the modern spirit of benevolent monarchy of Foreign was crowding out the feudal principle of personal Rulers as Executives loyalty.

"We decree that henceforth in the provinces and lands of the Church or in any one of them no emperor, king, prince, marquis, duke, count or baron, or any brother, son or nephew of them shall be named, elected or accepted as rector, podesta, capitano, defensor, conservator, custos or official of whatsoever name or title or function without a special permit of the Apostolic See conferred in writing by the See itself for this especial purpose" (iv, 17).

An interesting light is thrown upon previous practice by the provisions concerning private warfare:

"We decree that no city, town or territory, baron, count or any other person whosoever shall presume to grant a license for reprisals against persons, places or property of the same province or against any others whatsoever; and no one shall carry on a reprisal of any sort without a special license from the rector" (iv, 2I). 
It was a natural consequence of the French residence that the rectors of the Patrimonium should soon come to be Frenchmen,

The "False

Shepherds" in the Patrimonium

nepotes of the popes or not, but in any case foreigners in a sense quite different from that in which the word was ordinarily applied in Italy to any person from outside a given commune. Italian nationality, that subtle but powerful agent in the life of the peninsula, was offended by the very presence of these clerical adventurers. The warmest friends of the Papacy, of whom Catherine of Siena was the type and the mouthpiece, were most scandalized by their shameful abuse of power. All the too familiar complaints of feudal tyranny are heard again in the fierce denunciations of their misrule. In every district was built a special fortress as a residence and stronghold for the licensed despot who was the civil representative of the sacred authority of the Church. In this fortress were gathered the hired ruffians who at his command drained the people of their substance, who blocked the course of justice, and before whom no man or woman was safe. These are the persons who appear in the literature of the time as the pastores ecclesiae. It is against these false shepherds that Catherine of Siena sent out her most fiery declamations, and we have to note the dominant motive of nationality to which she appeals. These are cruel wrongs done in the name of him who sits in the seat of the Apostle; but the blame is not to be put upon the apostolic seat itself. It is because evil men are holding that seat in a base captivity in a foreign land that these wrongs have crept in. If only the supreme Shepherd will take pity upon his flock and come back, all will be well. Italy calls and he must obey.

That is the religious and sentimental side. The more clearly political aspect of the situation was taken up by a group of cities under the lead of Florence. It is an obvious reversal of the historic attitude of the great Tuscan commonwealth. For generations Florence had stood as the chief reliance of all that was Guelf in Italy, the bulwark of the Papacy in every trial of strength 
with the Ghibelline elements of the north and center. It is, therefore, of especial significance that it is Florence to whom the The Floren- oppressed communes of the Romagna now turn for tine League against the relief. This reaction begins from about 1370. Even Papal State, 1375

Milan, the arch-enemy of the Florentine policy, joins with her and eighty other cities, including Pisa, Siena, and Lucca, to break the power of the wicked "shepherds." Eloquent and flattering appeals were sent to the "Romans" to join this national uprising and cast out the foreigners from amongst them. It seemed for the moment as if with the foreigner the Papacy itself might be driven from Italy and its lands formed into an independent Roman state or divided among their greedy neighbors.

That this did not happen was due to the force of that tradition which, for good and evil, bound the idea of the Papacy to the The Roman Commune soil of Rome. The Romans would go to almost any lengths in asserting themselves against papal aggresloyal to the sion, but when it came to the point they never failed Papacy, $\mathbf{1 3 7 6}$

to cling with a desperate resolve to the fateful alliance of their commune with their bishopric. Once already they had brought a pope back to Rome, but had not been able to hold him there. Now, under this new pressure, began that series of negotiations which ended with the return of Gregory XI in 1376 .

As a preliminary move the pope made use of his religious character to lay, not only upon Florence but upon all individual

Gregory XI excommunicates the Florentines

Florentines, whoever and wherever they might be, the curse of Rome. Whoever anywhere chose to lay hands upon the person or the property of a Florentine would, so far as the Church was concerned, be held blameless. It was a weapon before which even the sturdy commonwealth by the Arno found it worth while to give way. Negotiations, intrusted partly to Catherine herself, were opened, and Gregory's return put new heart into what was left of Roman loyalty to the papal government. The keynote of the new order was struck by the frightful slaughter of four thousand citizens of 
Cesena, where Cardinal Robert of Geneva, afterward the antipope, Clement VII, was in command. Their offence was that they had risen in despair against the brutalities of the Breton hirelings Restoration kept there in garrison by the papal governor. The of the terror of this example combined with other causes to Patrimonium make one after another of the allies of Florence break their compact and made it possible for Gregory XI to get the better, at least for the time, of the threatening republican spirit in Rome.

Then came the death of Gregory, the disputed election of Urban VI, the Great Schism, and the desperate struggle of Urban to carry out the principle of papal supremacy to its logical end. The singular thing is that through all the storms of the Schism, the incessant intrigues of the French party, and the boundless greed of its more powerful neighbors, the integrity of the papal state was curiously well preserved. The hold of the popes themselves over their nominal dominions was indeed of the slightest. The several communes, as in the days before Albornoz, came under the control of petty local tyrants or bungled along under more or less republican forms; but the constructive work of the great cardinal was never quite undone. The sense of belonging under the "Chiesa" was never quite lost even when men refused to let their liberty of action be greatly restrained by it. If they would not submit to the pope, at least they would not go permanently under any other allegiance.

So it came about that when, after the long ordeal of the Schism and the first two councils $(1378-1418)$, there was again a pope Martin $\mathrm{V}$, of unquestioned authority, a member once more of a Founder of great and honored Roman family, personally respectthe Papal Monarchy, 1419-1431 able and of more than ordinary ability, this Colonna, Martin V, was able without great expenditure of resources to win back the formal allegiance of all the more important cities of the Patrimonium. Even Bologna, the most precious as it was the most troublesome possession of the Papacy, fell into line and was henceforth, though with many vicissitudes, 
to be the northern bulwark of the papal territories. As Albornoz may be called the founder of the civil constitution of the Papacy, so Martin V may be described as the founder of the monarchical form under which that constitution was to be administered. From his time on, although the papal state continues to be involved in the interminable political conflicts of the peninsula, its integrity as a state is not seriously questioned.

The long pontificate of Eugenius IV (1431-1447), with its continuous struggle against the claims of the council at Basel, brought Final Pacif- frequent crises in which it seemed as if the papal cation under sovereignty itself were in danger; but the outcome Nicholas $\mathbf{V}$, showed that on the whole the European powers pre2477-1455

ferred to guarantee that sovereignty, both on its religious and its political side, rather than to lose it as a convenient tribunal in their differences with each other or with their subjects. The general restoration of papal prestige after the collapse of the council at Basel and the accession of Nicholas V (1447-1455) is seen also in the affairs of the papal state. The policy of Nicholas here was the same as that which governed him in all other relations. He sought to bring all the elements of the state under his overlordship and, in return, was willing to allow the several communities their own rights of administration. The one condition on which he insisted before all others was that peace and order should be maintained, - a Utopian dream for his Italy, to be sure, but at least measurably realized under his wise direction.

If now we compare the three epochs we have here touched upon, those of Albornoz, of Martin V, and of Nicholas V, cover-

Comparison of the Three Epochs of Restoration ing just about a century, we find a striking continuity of aim in the midst of apparently hopeless confusion. As one reads the narrative of perpetual warfare, of beastly decadence in character, of devastation in city and country by the bands of hired soldiery which found their most profitable trade in this border region, one wonders how any semblance of civilization could have survived. Yet this is precisely 
the period of the greatest splendor of the petty courts and the communal governments which were the centers of every form of human activity. The accounts of the frequent festivities, the visits of ambassadors, the weddings of princes, the conferring of feudal rights, the coronation of "poets," the granting of titles of nobility, all indicate a high degree of material prosperity such as we associate only with periods of peace and social order. Beneath the confusions of political rights there was going on continually all that wonderful activity of the mind and the hand which produced the splendid achievements of the Italian Renaissance. The highest refinements of art and literature and manners were often the accompaniments of the most dissolute morals, the most hideouis egotism, and the most demonstrative piety. Nowhere were these violent contrasts of human life more crudely displayed than precisely here in the lands subject to the mild sway of the vicegerent of Christ on earth.

\section{THE ITALIAN EXPEDITION OF CHARLES VIII}

The Italian expedition of King Charles VIII of France in the year $1494^{-1} 495$ has usually been treated as marking a decisive Precedents for the Expedition of Charles VIII epoch in the history not only of Italy but of Europe as a whole. In reality it is only one in the long series of transalpine undertakings beginning with Pepin the Frank and continuing through the whole period of the Germanic Empire. Though King Rudolf the Habsburger formally gave up all claim to interfere in Italian affairs, he could not break the tradition of centuries, and we have seen how it was taken up again by the emperors Henry VII and Ludwig the Bavarian, and how even the Luxemburger Charles IV and the Habsburger Frederic III had kept up the fiction of imperial rights in Italy. Meanwhile, as we have also seen, a new series of "claims". had been put forth by France, claims fostered by the unceasing hostility of the Papacy to every advance of German imperial 
power in the peninsula. The establishment of the French house of Anjou upon the ruins of the Hohenstaufen rule in Naples and Sicily had given a pretext for endless conflicts, and these conflicts had been still further complicated by Spanish interests founded on family alliances with the Hohenstaufen remnants in the south.

There was, therefore, nothing novel in the idea of foreign intervention in Italian affairs. It must be taken as one of the understood things in Italian history that some outside power must always be claiming rights over the native self-governing states. And what is still more striking and more puzzling is that these Italian communities themselves were always turning to outside powers for help in the political problems they could not, or would not, solve for themselves. Both sides of this curious political phenomenon continued to appear until, in the great year, 1870 , the last blow in the long struggle for Italian unity was struck in the final expulsion of the French troops, who were the sole dependence of the papal rule in Rome.

In the latter half of the fifteenth century the Italian problem was further complicated by the greatly increased strength of the Dynastic notion of hereditary power everywhere in Europe. in France, Dynastic marriages in all directions, criss-crossing in Germany, and Italy every conceivable way, were more and more giving rise to "claims" over territories which had been formed under the influence of popular institutions modified by "signorial" control. By the close of the century it was becoming clear that both Germany and France were likely to put their rival "claims" in Italy to the test of armed intervention. In France King Louis XI (d. I 483), a clever politician, had limited his efforts to concentrating the royal power within the kingdom and to breaking down the threatening overweight of Burgundy under Duke Charles the Bold. In Germany King Frederic III (d. I 493) had doggedly followed the Habsburg policy of family aggrandizement without much concern for the affairs of Italy. Both were succeeded at almost the same time by sons, as different one from 
the other as well could be, but alike in the one quality of active political imagination. Charles VIII, a boy of thirteen at the death of Louis XI, began really to reign in 1489 . Maximilian I, accepted as co-regent with his father in 1486 , began his independent rule in 1493 . The first trial of strength between the two was in an affair of marriage politics. Charles VIII had been betrothed in childhood to the daughter of Maximilian by his first wife, the famous Mary of Burgundy, daughter of Charles the Bold and heiress of the Low Countries, while Maximilian himself was well along in negotiations for the hand of the Duchess Anne of Brittany as his second wife. It was something more than a political stroke when Charles in 1492 repudiated his contract with Maximilian's daughter and, in spite of certain canonical obstacles, married the Duchess Anne himself. It was clearly a counterstroke when Maximilian in the year following married Bianca Sforza, niece of Ludovico (Il Moro), regent of Milan for his nephew, Bianca's brother, Gian Galeazzo Sforza, an invalid not long for this world. The price of this marriage was to be the investiture of Ludovico with the duchy of Milan as a vassal state of the Empire. Apparently satisfied with this double play of marriage diplomacy, the emperor signed with King Charles the Treaty of Senlis (1493), in which he received substantial portions of French territory and promised peace for the immediate future.

These were some of the preliminaries to the Italian expedition of Charles VIII. It remained to secure the consent of the French

Sources

for the

Expedition

Estates and the acquiescence of the Italian governments of the north and center of the peninsula. The great importance attached by later tradition to this promenade of the French king through the Italian peninsula arises, partly at least, from the nature of the materials for its history. On the French side we have the narrative of the competent observer Philippe de Comines, who accompanied the king and served him continuously in important negotiations. On the Italian side we have the accounts of the Florentine Guicciardini and the 
Venetian Marino Sanuto besides a host of lesser chroniclers. We meet also the impressive figure of the Dominican Savonarola as the mouthpiece of all that great body of Italian sentiment which imagined it saw in the coming of the French king a divine instrument for the pacification of Italy and the punishment of her national sins, - a last echo of that strain of mystical prophecy which. had accompanied the Italian expeditions of emperors from the Saxon Ottos to Ludwig the Bavarian and which had more recently found expression in such prophetic voices as those of Dante and Petrarch, Catherine of Siena, and Cola Rienzi. It is the same old piteous cry to the foreigner to come down and deliver Italy from herself.

It is, therefore, idle to discuss whether Charles VIII's Italian expedition was primarily an answer to this call of Italy or rather French Sanc- the fulfillment of his own political ambitions. It was tion for Charles's Ondertaking both, and the proportions of each element cannot be precisely defined. His main object, proclaimed in all his official utterances, was to take possession of "his" kingdom of Naples and Sicily, which he pretended to claim in virtue of the Angevine inheritance; but there is no doubt that his motive was far from single. It would have been possible, of course, to reach southern Italy by water directly from French ports; but against this plan there was the difficulty of protecting ships from attack by possible enemies, - perhaps Pisans or Genoese, whereas the land journey offered opportunity for dealing, one by one, with the several Italian powers and thus securing incalculable advantages for the more remote future. In France there was no very great enthusiasm for what appeared to many prudent councilors the dream of a very young and not very well-balanced ruler. At an assembly of all three Estates held at Lyons in March, 1494, Charles did his best to represent his Neapolitan ambitions as merely preliminary to a future "crusade," and such a fantastic notion may well have had its part in his own thoughts of the vast possibilities opening out before him. 
The army, numbering perhaps twenty thousand men, with which Charles crossed the Alps in September, 1494, was comNegotiations posed mainly of hired soldiers, and among these the with Ludo- chief dependence, as the result showed, was to be vico Moro placed on Swiss mercenaries already famous as the best fighting material in Europe. The years from 1492 to 1494 had been occupied in continuous negotiations with the Italian states. Each of these had its own ends to gain and hoped to make use of a French intervention for its own purposes. Anything remotely resembling an Italian national sentiment is hard to discover in any of these intricate plots and counterplots. The decisive stroke appears to have been the agreement made with Ludovico Moro, regent of Milan, by which Charles was assured of an entrance into Italy and of at least neutrality in his rear when he should have got well started on his journey south. So important, in fact, was this alliance that the whole expedition has often been made to appear as the result of an "invitation" by Ludovico in order that he might gain support in case he should wish to dispose of his poor little nephew Duke Gian Galeazzo before his time. The wife of the nephew was a daughter of King Alfonso of Naples, and, as things were going in Italy, any attack on the husband might be a cause of danger from the relatives of the wife. Up to the last moment Ludovico had tried to pose as the protector of Italian interests against France, but after his first interview with Charles, on September 9, he threw off all disguise and openly claimed credit for bringing in the "Pacificator" of Italy. Meanwhile this clever diplomat, to keep himself right with Germany while apparently playing the game of France, had secured from the emperor Maximilian his charter of investiture as duke of Milan, but was holding it secret until Charles should be well on his way to Tuscany. The opportune death of the young duke (October 2 I), giving rise, of course, to unfounded suspicions of poisoning, made further concealment unnecessary and weakened also, by so much, the bonds which bound Ludovico to Charles VIII. 
Of all the Italian negotiations the most interesting are those with Florence, the ancient citadel of Guelfism ; in other words, of resistFiorentine ance to foreign control in Italy. The special form of Preliminaries foreign intervention against which Florence had always opposed a stubborn resistance had, of course, been that of Germany. The question was now whether the same spirit would dictate resistance to French aggression. During the two years following the death of Lorenzo dei Medici the Florentine ambassadors in France had kept up a continuous discussion of the proposed expedition. The influence of the anti-Medici party, represented on its idealistic side by the followers of the Dominican "prophet" and social reformer Girolamo Savonarola, was strongly in favor of the French plan. In rather vague fashion they imagined that a French intervention would somehow or other unite the elements of Florentine democracy against the Medicean "tyranny." Under the battle cry of "Liberty!" they were ready to throw their country into the hands of a foreign prince, if only they could secure themselves by paper assurances against any far-reaching plans of conquest on his part. Up to a late date the Florentine ambassadors were, or pretended to be, in doubt as to Charles's sincerity, and held back with their guaranties of free passage through the Florentine territory.

As Charles VIII approached the frontier of Florence, coming by way of Lucca and Pisa, the hostility against the Medici, who

Charles VII in Florence;

Piero Capponi were now represented by Piero, the rather feeble son of Lorenzo, broke out into open revolt, and Piero chose to throw himself into the hands of Charles rather than to face the domestic situation. The French king thus found himself the arbiter of Florentine politics and played the two parties against each other with considerable skill. Through Piero's connivance he was able to take possession of important fortresses and was assured of the money loans needed to keep up his army. On the other hand, the Florentines, relying upon secret assurances from Milan and Venice, were willing to receive him within their 
walls and to pass him on southward, taking the risks of what he might do when once inside. The reception was of the usual Italian type, - splendid decorations, magnificent banquets, glowing orations, but underneath a deep current of well-founded suspicion. The king and his immediate following were quartered on the inhabitants quite in the manner of a conquering army. Troubles between the citizens and the soldiers, especially the Swiss, naturally arose. The good old Florentine sport of stone throwing was not forgotten. There were even murmurs of a possible Sicilian Vespers. Negotiations between the king and a special commission of citizens seemed to be growing farther and farther from a settlement, when the firmness and courage of Piero Capponi, as told by Guicciardini, gave the final decision.

"But at this crisis the feeling on both sides had become embittered; for the king would not abate his last demands, and the Florentines would not bind themselves to pay an intolerable sum of money or agree to any form of jurisdiction or overlordship in their commonwealth. These troubles, which it seemed impossible to settle without an appeal to arms, were solved by the noble courage (virtii) of Piero Capponi, one of the four citizens deputed to confer with the king, a man of talent and of high spirit and greatly esteemed in Florence for these qualities and for his honorable ancestry, since he was descended from men who had rendered great services to the Republic. Being one day with his colleagues in the presence of the king, as the royal secretary was reading the unreasonable articles proposed on their side, he snatched the docunient from the secretary's hand with a violent gesture and tore it in pieces before the king's eyes, and cried out with a loud voice :'If you make such dishonorable demands as these, sound your trumpets and we will ring our bells,' meaning to make it quite clear that their differences should be decided by force of arms. And thereupon with the same violent action he burst from the room followed by his colleagues." 
What might have happened if King Charles had insisted upon all his demands we cannot say. Certainly the terms of the final agreement with the Florentines were favorable enough for him. He was to hold Pisa and several other important Tuscan towns during his Neapolitan trip. Two French commissioners with a royal lieutenant were to arbitrate all cases between Frenchmen and inhabitants. The French army was to have free passage going and returning through Florentine territory with the right to buy provisions. Florence was to pay a subsidy, large enough, indeed, but smaller than had at first been demanded. Piero dei Medici and his brothers were to be freed from outlawry and confiscation, but were to be exiled beyond the hundred-mile limit from the Florentine frontiers. On the other hand, the Florentines were assured of all the trading rights they had ever enjoyed in France and Naples and were to be treated by the king in every way as his own subjects.

As to the Papacy, much the same story has to be told. Alexander Borgia was notoriously concerned rather with the aggran-

Entry into

Rome ;

Popular

Enthusiasm

dizement of his own family than with any really papal interests. He was dangerous only because he could add the weapons of the Church to the ordinary resources of a secular state. As feudal overlord of the Neapolitan kingdom he was at first opposed to the plans of Charles VIII, refused him passage through the papal territory, and received Neapolitan troops into the city. Then occurred what was almost sure to happen in Rome. The "People," that amazing Popolo Romano, always distrustful of its papal rulers, compelled a change of policy and welcomed the foreigner with joyous enthusiasm. The pope was forced to give way, the Neapolitan troops were sent home, and Charles was received into the Eternal City. He showed his gratitude by healing five hundred persons of the scrofula through his royal touch and his common sense by refusing to back up a party among the cardinals who proposed to depose their scandalous chief. 
From the Neapolitan frontier the march to Naples was uninterrupted. King Alfonso abdicated, and his successor, Ferdinand $\mathbf{H}$, Charles viII sailed away to Ischia, leaving Charles in undisputed occupies possession. So far this mad project of an adventurous Naples youth had moved according to program; not a drop of blood had been wasted, not an enemy had appeared. Judging by the result Charles might well have believed that all Italy was united in welcoming him as its savior. In his leisurely promenade of five months from the Alps to the Strait of Messina his diplomacy had apparently succeeded in playing off one Italian power against another so completely that no one of them need cause him any further anxiety. Then happened what ought to have been done long before. Under the lead of Venice these same Italian powers, roused at last by a sense of common danger, united in a league for mutual defence. With the one exception of Florence the whole north and center of the peninsula, with the emperor Maximilian and the Spanish "kings" Ferdinand and Isabella, bound themselves together against further aggression on the part of France. So carefully was the secret guarded that the news came to Charles VIII as a complete surprise. On the 12 th of May, I 495, he assumed the crown of Naples without the papal investiture, and a week later began his return march to France. As before, a long series of negotiations accompanied his journey. Whatever of heartiness there had been in his previous receptions along the way had pretty well disappeared. If the League had really meant what it seemed to mean, especially if Florence had given it her cordial support, there is little doubt that the army of Charles VIII could have been wiped out before it had passed the Tuscan frontier. Even as it was, though Florence refused to join the League, it refused also to go into any new compact with France. Pisa, as before, received the king as its deliverer from the Florentine yoke and saw him safely by on the way to the western passes of the Apennines.

Certainly from this point on, if not earlier, we may describe the march of the French army as a retreat. The League had from 
the beginning provided for the formation of an army, though only in case of an attack by the French. Now, however, as the common Formation of enemy seemed likely to give them the slip they pushed the League their preparations with renewed zeal, and it began of Venice, to be evident that Charles would not be allowed to 1495 escape without a fight. The obvious point to trap him was at the passes of the Apennines. A few determined foot soldiers there could have held the pass against the French army, wearied as it was with long marching, encumbered by heavy baggage and the ponderous artillery, which on the southern journey had been sent by water but now was being drawn painfully by horses or, when these gave out, by great gangs of men. The number of the French, never very large, had been diminished by a considerable contingent sent along the coast to Genoa, so that it was with a force of perhaps ten thousand fighting men that Charles VIII, now apparently fully awake to the seriousness of his position, entered the mountain defiles above the little town of Pontremoli.

Meanwhile the army of the League, made up of contingents from Milan, Venice, and the Romagna, numbering in all perhaps thirty Passage thousand, had gathered in the valley of the Taro, a of the Apennines southern tributary of the Po, near the town of Fornovo. The direction of it, so far as there was any, was in the hands of Venice, but suffered from diversity of interests and the absence of any well-considered plan. The motive of the fighting men - a large part of whom were the light horsemen, known as "Stradiots," recruited by Venice in the Balkan country - was the plunder of the vast wealth which the French were reported to be carrying in their train. We need not ascribe any greatly superior motives to the medley of Swiss, Italian, and Gallic mercenaries which made up the "French" army; but they were in a trap, and their problem was a simple one : to hew their way out and secure a.line of communication into Piedmont and so to come into touch with friendly support and regain the Alpine route to France. 
From the lively account of Comines, who represented the king in the negotiations preliminary to the battle of Fornovo, we gain Battle of a very clear idea of the situation. Charles did not Fornovo, want to fight, and his messengers were instructed to July 6, 1495 find out on what terms the Allies would allow him to go his way in peace. The Allies on their side had no specific cause of quarrel with France, but they were concerned to prevent her from gaining a foothold in the northwest of Italy as she had already done in the south. Their league was a defensive, not an offensive, one. The parleys, undertaken without great heartiness on either side, were in fact only a means to gain time; as Comines remarked to the king when taking his instructions, "I never saw two great armies as near each other as these without a fight." The night of the $5^{\text {th }}$ to the 6 th of July, 1495 , was spent by the French in preparations for crossing the river Taro, swollen by a furious thunderstorm, and in the early morning their army in good order, without interference from the enemy, was safely on the west bank. The superiority of the French leadership was shown in the success with which the army, although divided into a main "battle" with separate vanguard and rearguard, was held together. By noon the Allies had crossed in pursuit and forced the French to turn and fight. The brunt of the attack fell upon the center, where the king, surrounded by two thousand men at arms, supported by artillery posted on the neighboring hills, was prepared to make a desperate stand. Several writers describe in detail his

Victory claimed by the French magnificent equipment and his superhuman performance. "To tell the truth," says the author of the Vergier d'Honneur, "he deserved that day to be called a true son of Mars, successor of Cæsar, the peer of Pompey, bold as Hector, knightly as Alexander, like to Charlemagne, brave as Hannibal, valorous as Augustus, fortunate as Octavian, chivalrous as Oliver and prudent as Roland." French writers, of course, make much of the bad condition of their troops after the long and exhausting march, the lack of food for men and horses, and the loss of sleep. 
"For, according to human judgment, the enemy ought to have beaten ten times as many men as the king had. And the victory was not by the might of the men who fought, but it was God who fought for them, so that by his divine grace and his will to guard and save the Very Christian King, the pillar of the Catholic faith, his subjects and his friends, the enemy was beaten, killed, slaughtered and trampled under foot by the valorous French."

And this, the pious author thinks, was proved by the fact that "as long as the slaughter, the pursuit and the skirmishing lasted, it never ceased to blow and rain, thunder and lighten as if all the devils were on the field." Comines, who had the best opportunity to know how very ticklish the French situation was, describes the issue of the short, but terrific, encounter as a French victory, but cannot conceal the anxiety of the king and his councilors for the immediate future. The day following was occupied in renewed parleyings, but that night, without sound of trumpets, leaving their fires burning and banners flying, the French slipped out of their encampment and began a regular but orderly retreat. "We had no need of guides," says Comines, "for God had led us thither, and, as Friar Jerome (Savonarola) had said, He would carry us back again."

On the Italian side the day at Fornovo was equally counted a victory. There can be no doubt that the allied army had suffered

Loss of great loss, but at all events it held its camp and was French Gains able to send out pursuing parties to harass the rein the North treating French. Marino Sanuto, the Venetian diarist, speaks of the whole affair as a display of Italian patriotism, by which the terrible danger of a foreign rule was, once for all, averted. At Venice and in the other allied cities the "victory" was celebrated with processions, thanksgiving services, and the ringing of bells. Later historians, having in mind the fatal example set by this first great French national invasion of Italy, have been 
inclined to magnify the French advantage, such as it was. Arrived at Asti, in Piedmont, the king felt comparatively safe and made his, way at a more leisurely pace back to Lyons, where he arrived November 7 , four months after the battle of Fornovo and less than six months after his departure from Naples. In that interval the gains of his Italian exploit were almost entirely lost. In the north the expedition against Genoa by land and sea failed completely. A French garrison at Novara under command of Louis of Orléans, the king's brother-in-law, was besieged by troops of Milan and Venice and surrendered after frightful suffering (September 26).

In the south, almost from the moment of the king's departure; a violent reaction against the French rule had begun. One after Results of another the strong places held by French troops dethe Italian clared for their Aragonese sovereigns, and within less Expedition of than two years not one of Charles's Italian conquests
Charles VII

remained in his possession. In spite of his repeated declarations nothing was done to reënforce the preposterous "claims" on which he had pretended to base his Italian ambitions. Italy had abundantly demonstrated that if her several rulers would stand together, their vast resources in men and money could secure them against any foreign aggression. Instead; however, of learning this obvious lesson they continued to pursue the mad policy of inviting the foreigner to come and help himself to their territory. To balance the danger from France they called in Germany, and Maximilian, in the full tide of his personal popularity at home, was only too ready to answer the call. Northern Italy, which should have been, as it was in the days of Barbarossa, the bulwark against the foreigner, became henceforth at once the battleground and the prize for the warring nations from beyond the Alps. With this begins a new stage in the history of the European peoples. 


\section{CHAPTER IX}

\section{THE RENAISSANCE IN ITALY}

If we compare the movements in European society which we have thus far studied, we shall easily perceive that they have one characteristic in common. Whether we consider the politics of Germany resulting in the practical destruction of the mediæval Empire, or the progress of feeling within the Church which brought the mediæval Papacy to a point where men were seriously questioning its claims upon their allegiance, or the vast movement of trade and industry by which a wholly new element in society had come to have rights and know how to enforce them, we are equally impressed with the growth of individualism in thought and action. In-distinction from the all-important traditions that had regulated the life of the Middle Ages we find in every sphere a new importance given to ideas because they seem to be practical, adapted to new conditions, and not the less worth attention because they have-no tradition behind them.

This new individualism finds its highest expression in the movement of thought to which we give the names of "Renaissance,"

The Mediaval and the Modern Spirit

"Revival of Learning," or "Humanism" according to the point of view we may have in mind. No one of these terms quite sufficiently expresses the whole character of the intellectual enthusiasm which from about the middle of the fourteenth to the middle of the sixteenth century gives new life and purpose to the thought of Europe. We -must: employ them all, sometimes in connection, sometimes in contrast, if we are to avoid a narrow and one-sided understanding of a great historical phenomenon. We gain our most instructive spoint of view, perhaps; if we begin with some brief comparison of 
this essentially modern spirit with that of the mediæval period. It is not difficult to convince oneself that the instinct of the Middle Ages was unfavorable to the development of marked individuals. By this is not meant that there were not in the mediæval period men of as great personal powers as at any other time. Charlemagne, Scotus Erigena, Gregory VII, Anselm of Canterbury, Frederic Barbarossa, Bernard of Clairvaux, Innocent III, Thomas Aquinas, the nameless builders of the Gothic architecture, all these were men of singular personal endowment, fairly to be compared with the great names of any period. If, however, we consider what they did, we shall find that it was in each case the working out into more effective form of a something already existing as a tradition or an institution. It is hardly too much to say that the typical man of the Middle Ages was he who most completely effaced his own personality in order that the something greater than himself, church, empire, monastic order, system of thought, artistic principle or what not, might be the more perfectly realized. It would have been the greatest pain to such a man as Bernard of Clairvaux if he had been praised for what he did, as if it were his work and not rather that of the divine worker through him.

We have already noted how this suppression of the individual was expressed in the system of thought, the "Realistic Philosophy" The Medi- of the Middle Ages, according to which the general xval Idea of idea was everything and the particular phenomenon Literature nothing. We applied this principle to political things and saw how in the present period men were coming to disregard it and were forming new political and religious combinations in defiance of it. The same application may be made in the subject of learning. Throughout the Middle Ages men were content with the meager inheritance that had come down to them from the last days of Roman culture, without caring to go back of this to the great original material of the Greek and Latin classic writers. The study of Greek had almost disappeared from the West. Greek authors were known only in Latin translations. It is true that the 
Latin language was still studied; indeed, we may almost say that it was the only thing scientifically studied; but it was thought of only as an instrument, indispensable indeed, but not in itself worth. considering. The contents of this literature were, as far as possible, to be ignored by those who studied them. Joy in literature was classed with all the other forbidden joys of the world of sense. To have taste was as much of a sin in the Middle Ages as to have what we call "common sense"; both seemed to imply a wicked self-assertion, to be repressed by conforming self to a something higher and larger than self, a something mysterious which could be made useful to the individual man only through. the agency of authority in some form. The authority of greatest value and greatest certainty was the Church.

One of the most singular illustrations of this doctrine of selfrepression is seen in the ideas of language as an expression of The Vulgar thought. Whatever was natural being in some sense Tongues wrong, it followed that the common speech of the people was somehow discredited as a vehicle of serious thought. It is almost true to say that for five hundred years there is an impassable gulf between the "vulgar tongues" and the Latin, the clerkly speech, which alone was deemed worthy of conveying important ideas from man to man. Such bits of literature as found their way among the people in their own tongues, songs of local heroes, scraps of translation from the Psalms or the Gospels, were looked down upon by the man of clerkly education as fit for the sport or the edification of the vulgar, but unworthy of his enjoyment or imitation. Thus in that earlier period the intellectual life was hampered by a twofold limitation: on the one hand, an indifference to the real meaning of the classical literatures, and on the other, a contempt for the newly developed common tongues which prevented them for a long time from playing their part in the culture of the nations.

This twofold limitation of mediæval learning gives us the outline of a corresponding twofold awakening in our period. On the 
one hand, we have to study the revival of an interest in the classical languages for the sake of the culture they might bring, and on: Meaning of the other, the splendid beginnings of modern litera"Renais- ture as expressed in the tongues in which men sance" really felt, thought, loved, hated, and aspired: The word "Renaissance" expresses the former aspect of our subject; for the latter there is no word. By "Renaissance" we mean the new. birth throughout the regions of Latin civilization of an interest in classical study, no longer merely as a means to the end of a better understanding of the Christian writers or as a preparation to become a clergyman but as a means of personal culture. The thirteenth century offers, indeed, many illustrations of this "modern" temper, but they are sporadic and not characteristic of the time. The evil repute of the emperor Frederic II, for example, as a searcher after forbidden knowledge, illustrates at once his "modern" character and the dominant restrictive spirit of his age. Study for the sake of study, with only so much of the "practical". as could eventually make it self-supporting, study in order to satisfy the instinct of curiosity as to the something beyond what was already known, study as an incentive to new and original production, - all this which seems to us so natural was in the fourteenth century like a divine revelation to the men who gave themselves up to it. To others, both then and since, to whom these impulses seemed dangerous to the peace of human souls, it has appeared rather as the inspiration of an evil demon driving men on to sinful inquiry into mysteries that were never intended to be revealed. We shall have no difficuly in recognizing here the modern "scientific spirit" which does not fear to push its researches as far as the mind of to-day can carry them, confident that a universe which could not bear investigation would not be worthy of respect.

One other word we must define here. "Humanism" suggests to us that aspect of the Renaissance which is concerned primarily with the thing we call "culture" and which the Romans called 
humanitas. It reminds us that men were no longer content to think of mankind as a lost and struggling mass of material out Meaning of of which some few individuals might be found worthy "Human-. of a higher life, but rather as essentially a part of a ism" creation which was on the whole good. At all events, men were tired of the ascetic ideal of life and were ready to try something the very opposite of it, the life of active concern with things that interested them now and here. If man were indeed a worthy part of a good universe, then it could hardly be a sin for him to make the most possible of himself and to find out all he could about that universe of which he was not merely a part but the most important part, the part which had rights and powers over all the rest. Thus it has been possible for a modern writer to describe our whole period as that of the "discovery of the world and of man," by which he meant that in this period, for the first time since the civilization of Greece and Rome, men were eager to know themselves and the world about them. Humanism meant the concern of man with himself; whatever related to man, his history, his forms of speech, his thought as this had fixed itself in literature, his powers to produce objects of beauty and things of use, the earth on which he has to live, the means by which all his power of production could be increased and his products exchanged, all these things are, properly considered, to be brought under this one comprehensive term. Ordinarily, however, when we call a man a "humanist" we mean that he was primarily devoted to the study of the ancient classic languages and literatures (litterae humaniores). The reason for this is that men found, or fancied they found, in this ancient literature, as soon as they came to study it with open minds, a key to all the mysteries of thought and life.

It is obvious that this meant a turning away from the sources of mediæval inspiration; in other words, it meant that men were no longer to be governed primarily by religious ideas. The Jewish and the Christian scriptures were made to feel the rivalry of the heathen authors, and it could not fail to happen that questions 
of authority should begin to rise in many of these eager minds: The singular thing is that these questionings did not take on a The Laifica- serious form until other forces working with them led tion of Cul- to the vast upheaval of the Reformation. There is ture

not one among the leaders of Italian Humanism who could be called a declared enemy of the church traditions. Plenty there were to whom these traditions had become a matter of indifference; but this indifference was so widespread, even in the highest circles of the Church itself, that it did not easily turn into effective opposition. The Church adapted itself to this new phase of society as it had adapted itself to so many others and was to adapt itself to so many others still. An enthusiasm for the classics which as late as the early days of the fourteenth century was looked upon askance as likely to prove a danger to existing institutions, 'became by the middle of the fifteenth a recommendation for a man in almost every walk of life, - even in the Papacy itself.

One distinction greatly emphasized of late may be noticed here: that between a "true" and a "false" Renaissance, as if there had "True" and been two separate movements, parallel in time but "False" essentially contradictory to each other. By the "true" Renaissance Renaissance is meant that use of the classic models which would give greater value to all learning, improve literary style, and arouse a prudent curiosity as to the meaning of ancient life. By the "false" Renaissance is meant that exaggeration of the importance of the classic world which made it appear as superior to all that had existed since, but especially superior to the world of the Middle Ages in that, as Marsiglio of Padua had said, it had been free from the domination of an all-powerful Church. An effect of this delusion was undoubtedly to make men indifferent to the restraints of the society in which they lived, to overstimulate their sense of individual right, and free them from responsibility to any authority.

This distinction, however, valuable as it is, must be carefully guarded. There were not two separate movements, but one. Like every other movement for the emancipation of the human mind it 
had its dangers, and many men fell into them. Especially was there this danger of overvaluation. The good which men saw was so very good that it seemed there could not be too much of it. The principle of the new freedom was so sound that men of the highest character were sometimes blinded to the risks they ran in following it. When, then, men of a lower type became skilled in the technique of learning it was inevitable that they should lose their sense of proportion and often be swept away from their moorings entirely. It must needs be that the old sanctions should be largely done away; the question was whether the new spirit would provide new sanctions, and that question was slow in finding an answer. Meanwhile there was confusion of many sorts, above all a confusion of standards, so that no one could say just how far it was right or safe to go. There was no practical test to determine whether a man or a community was at a given moment in the course of a "true" or a "false" Renaissance. The true and the false were hopelessly mixed in the conscience of the time.

It is impossible to fix upon any point of time as the beginning of the humanistic movement. Liberally interpreted, it may be Origin and Place of Bumanism discovered wherever from the twelf th to the fourteenth century we find individuals who seem to be moved by the impulse of artistic creation in the Latin or the vernacular tongues. In some sense it may be found in that curious literature, perhaps of the twelfth century, which is ascribed to the so-called "Wandering Scholars" (scholares vagantes), but it would be grotesque to describe by the serious name of "humanist" these merry fellows who wrote in Latin of a sort about the joys of a purely human life. There would be rather more fitness in giving this name to Dante; but that too would be to ignore the essentially mediæval character of his thought and method. Nor could we with any more propriety use it of the Troubadours, in spite of the purely human feeling reflected in their literature. But if we are in doubt as to the precise point of time, we can have no hesitation as to the place to which we must turn for the earliest manifestation 
of the true humanistic spirit. As in other things, so in this, Italy is leading the world. That splendid individual energy which had been showing itself in the fight against the Empire and against the rule of local territorial lords, and in the development of Italian industry to be the model for all Europe, had not failed to show itself in the things of the intellect and in the world of rsthetic production as well.

The colossal figure of Dante, with his vast indictment against every evil and folly of his time, has overshadowed the multitude of lesser talents that had gone before him or were contemporary with him. Yet it is in his generation that we must seek the germs of culture which in the age following were to ripen into the marvelously stimulating activity of Petrarch and his school. Dante died in 1321 . Seventeen years before, in the company of his fellow exiles from Florence, he may have met at Arezzo or at Pisa the Francesco father of the infant Francesco Petrarca. The younger Petrarca, poet says that once in his edrliest childhood he saw 1304-1374 Dante, and, so far as we know, this is the nearest approach to an intimacy between these two greatest lights of Italian literature. The child grew up at Avignon, where the father found occupation at the papal court. His taste for literature developed early, but was viewed with distrust by his father as showing an idle pleasure in a thing unworthy the serious pursuit of a youth who had his living to earn. He was put to the study of the law, first at Montpellier in France and then at the great school of Bologna. A legend of the relations of father and son is worth repeating for the light it throws upon the conditions of classical study at the time. The father, suspecting that "books" were drawing the youth too much away from the law, descended upon him and found him idling away his days in the company of the classic authors. In a fury at this waste of expensive time he threw the whole mass of trash into the fire, but was moved by the tears of the boy to pull out a Cicero and a Virgil, with the remark that Cicero might be useful in the law and that Virgil might serve as a proper diversion for an idle hour. The incident expresses the 
fact that scholarship, pure and simple, had as yet no place among the regular occupations, even of educated men. Petrarch persisted, and his love of literature grew with his knowledge of it.

Petrarch's definition of himself is also the most serviceable for us. He was above all else the "Poet," that is, the creator of a something that had not existed before. He would not be classified by any other term. He knew the law, but he was not a lawyer; he held various clerical offices, but he was no priest; he taught a multitude of younger men the best things they ever learned, but he was no teacher; he had the charge of collecting books for one and another rich patron, but he was not a librarian; he copied manuscripts, but he was not a copyist. Just as the great poet Dante had set himself up as the judge of human society on its moral side, so the poet Petrarch liked to be thought of as the great authority in the intellectual world. There is no subject in

Petrarch as the Restorer of Latin Culture the whole range of human thought upon which he did not at one time or another express himself and find a hearing. In Petrarch we find the first illustration of that singular dual life which marks most of the men of the Renaissance. His genius expressed itself naturally and easily in the language of his people, and thus he became the master of Italian lyric poetry. Yet his whole intellectual interestseemed to be absorbed in the revival of the Latin tongue and in gaining the utmost possible skill in its use. These two sides of his activity may be called his Italian and his Latin sides, or, perhaps more instructively, his unconscious and his conscious intellectual life. His own valuation of these two sides of his life was pathetically out of proportion to the value which the world since has put upon them. In regard to his Latin side, he was a victim to that oftentimes absurd self-appreciation which marks the Renaissance man. He really believed that he was commissioned to bring the world back to the.language and the thought of Cicero and Virgil. All his serious prose writing, on a vast variety of subjects, was in Latin. He wrote voluminous letters to his literary 
friends, in which he discussed minute questions of grammar, of philosophy, and of morals. He undertook to rewrite, from original sources, the lives of the most eminent men of antiquity.

Above all, he desired and expected to live in the memory of men by a great epic poem on the plan and scale of the Aneid. $\mathrm{He}$ The "Africa" labored over his task through several of the best years of his life; friends to whom he read bits of the great work pronounced it worthy of the best days of literature. It was never completed, and within a generation it had almost disappeared from the thoughts of the world. Yet the "Africa" has its value as a document to show how completely throughout his life Petrarch was filled with the one dominant idea of the greatness of Rome. And this Rome was neither the Rome of the Papacy nor the Rome of the Empire but the Rome of the "Roman People." Petrarch was at no time the enemy of either Empire or Papacy. On the contrary, he was upon occasion the champion of both. He had inherited from his father the quality of a Bianco, a White Guelf, but he had not like Dante been carried quite over into the Ghibelline camp. For him both Papacy and Empire had value in 'so far as they helped to make real to the modern world the sacred majesty of Rome. In choosing the Second Punic War and its hero, Scipio Africanus, as the subject of his supreme literary effort he believed himself to be bringing that ancient world back into the consciousness of his fellow Italians.

The temporary fame of the "Africa" and its rapid decline in popular interest are both to be explained by this appeal to the Its Imitative ancient ideal. For the moment that ideal was upperCharacter most in men's minds. It is shown in the meteoric career of Cola di Rienzi. It flashes up in the feverish enthusiasm for Ludwig the Bavarian, emperor "by the grace of the Roman People." It glows through all the passionate appeals to the popes of the "Captivity" to come back to their faithful Romans. But when that object had been accomplished and once again, two years 
after Petrarch's death, the Papacy had taken its place where it belonged, then it was seen how remote and antiquated after all this ideal had become. Neither Empire nor Papacy nor the Rome they tried to express could recover its hold upon this modern world. The fate of the "Africa," forgotten by the generations immediately following and printed after centuries as a literary curiosity, showed how purely imitative it was both in its art and in its substance.

It was this sentiment for the ancient Roman greatness that governed Petrarch also in one of the most dramatic moments of

\section{Petrarch's} his life, the coronation at Rome as "Poet" in the Coronation as year 1341. Such coronations were just coming into "Poet" fashion as a part of the newly awakened interest in the ancient Latin culture. They correspond fairly to our modern granting of honorary degrees to men of letters by universities and were liable to similar abuses. In after life Petrarch affected to despise this and all like honors as having no real value and serving only to rouse the envy and malice of his critics. It seems, however, altogether probable that he pulled the wires pretty skillfully to secure for himself the coveted distinction. The love of fame was one of his ruling passions and, little known as he was at the time, this was an obvious means of increasing his reputation.

And yet, when three alternatives were offered him, to "take his degree" from the University of Paris, the center of the learned

The Ceremonies at Naples and Rome world, or from King Robert of Naples, the most brilliant representative of the courtly culture of the day, or from that shadowy thing the "Roman People," he, with only a decent show of hesitation, chose the last. The majesty of Rome even in her decline seemed to him far to surpass the greatest of modern dignities. For his "preliminary examination" he went to Naples, where King Robert gave him a three days' quiz in history, science, and geography, while Petrarch on his side discoursed eloquently to the king on the subject of "poetry." Thence he went on to Rome, where amid splendid festivities arranged by the civil government the Senator in the 
name of the people placed the laurel crown upon his head. The poet in response read a sonnet and delivered an oration in praise of poetry. Then he proceeded to Saint Peter's and laid the crown upon the altar of the saint as a testimony to his own Christian character. The gift of Roman citizenship conferred on Petrarch as a part of the coronation ceremonies completed his adoption into the ancient tradition.

The fate of the "Africa" was pretty nearly that of the rest of Petrarch's Latin writings. They have never entered vitally into the world's great literary movement. Of his Italian

Petrarch as

Master of

Italian

Poetry work Petrarch thought -- or wished to seem to think - but very slightingly. He says that at one time he was tempted to burn the whole mass of it as unworthy the restorer of classical antiquity I This Italian poetry deals with the primal emotions of human life, especially as interpreted to the poet through the dominant emotion of love. The inspiration of it all was a lady, with whom, after the fashion of the troubadours, he stood in some relation altogether removed from the idea of possession. This Laura stood for him as the object of his poetic adoration; he celebrated her in over three hundred sonnets, about half of them written after her early death. Extravagant as this fictitious feeling must appear to the modern world, the fact remains that the literature it inspired has held its place through all the ages to the present day as one among the world's great expressions of human sentiment. It was undoubtedly a work of art; but it was a genuine art, not an imitated one. It supplemented the work of Dante in giving to Italian poetry its permanent form.

But it was not through his writings only that Petrarch influenced the thought of his day. He was the earliest modern man to call Petrarch as attention sharply to the importance of securing the best collector of possible texts of the Latin classics, in order that men Manuscripts might be sure that they were really reading what the masters had written. To this end he began the systematic search for old manuscripts which has gone on to the present day with 
increasing energy, though with diminishing returns. Through his frequent journeys and his wide circle of learned correspondents he was able to set in motion a fruitful activity which soon resulted in a continuous stream of material, poured from all quarters of Europe into Italy as the great publishing house of the early Renaissance. What we call the science of literary criticism was then not even in existence. Standards by which to judge the value of one manuscript as compared with others were almost wholly wanting, and under these circumstances men turned to the autocrat among scholars as to the only trustworthy source. Doubtless his knowledge and his judgment were immensely overestimated by himself and his admirers, but the beginning was made, and it only remained for others, men of far greater technical learning, though of infinitely less genius, to carry the work to completion. Probably there has never since been a time when there has been such an eager enthusiasm for the treasures of antiquity as in these first years, when every discovery was a revelation of something more to be expected, and men were rejoicing in a new spirit of inquiry and progress.

It all seemed so simple when once the way had been opened. What more natural, when a reference in an oration of Cicero Petrarch as pointed to some other work of his, as yet unknown, Archæologist than to hunt for this hidden treasure until it was found? And yet this was a positively new idea in the world. What more inspiring to one looking upon the tops of ancient columns reaching up out of the deserted quarters of ancient Rome than the thought that a few strokes of a spade might bring to light some marvel of classic art? Yet these simple devices had never occurred to centuries of men who professed to draw their civilization from precisely these sources. Thirty feet of earth covered the pavement of the Roman Forum, and in the libraries of monasteries and churches all over Europe were moldering the precious manuscripts needed to complete the record of the ancient classic world. It was one of Petrarch's chief merits that he began to collect not only books but every other form of monument of the 
past. The great libraries of Italy, the Vatican at Rome, and the Saint Mark's at Venice owe to him their earliest impulse. His own little collection of gems and fragments of ancient sculpture was the primitive model from which the splendid museums of Europe have grown. His zeal spread to every one with whom he came into relation and thus became fruitful for all Italy.

We are learning, as we come to know more of the Middle Ages, that even through those comparatively unæsthetic centuries Petrarch and the ineradicable love of beauty which is one of the the Love of marks of our human nature had not quite disapNature peared. It was only that, under the dominant religious motive of mediæval life, beauty had not seemed worth the serious attention of the "best minds." Throughout purely mediæval literature we find few references to the beauties of nature; the beauty of the human form had only a sinful suggestion, and the beautiful in art, produced chiefly to meet the practical demands of building, found little appreciative expression in language. Here again Petrarch marks an epoch. His sense of the beauty of nature was quick and keen. Wherever he lived he surrounded himself with beautiful things. His gardens, his groves, the views of mountain and stream from his modest house, all find their reflection in his writing. His love of the country drew him continually away from the life of cities and courts and to personal communion with outward nature.

It means a great deal when we say that Petrarch was the first of modern men to climb a mountain for the sake of the view and The Ascent for the joy of the climb. In the month of April, 1 336, of Mont occurred this momentous event, the report of which, Ventoux written the same evening by the poet in a letter to a friend, illustrates beautifully the singular contrasts and conflicts of the period. For years, says the youthful poet, he had been gazing at the peak of Mont Ventoux - the Windy Hill — and longing to stand upon its summit, but only on the day before, as he was reading in his Livy how King Philip of Macedon had climbed Mt. Hæmus 
in Thessaly, did this vague longing change to sudden resolve. The desire for the climb pure and simple he declares to have been his sole motive. He selects a companion with as much care as if he were going on an arctic expedition. His choice falls upon his own younger brother, and each takes a servant with him. Spending the night at the foot, they begin the ascent in the early morning. Part way up they meet an ancient shepherd who warns them against the perilous undertaking. He had tried it fifty years before, but since then no one had been rash enough to attempt it. He indicates however a practicable path, and the writer speaks several times afterward of paths good and bad. He proved to be a very poor climber, always wandering, he says, from the direct way. up; but finally they reach the top and enjoy the glorious view. They stay until the sun gets low and reach their starting point in the early evening, - evidently not a very heavy day's work for a vigorous youth of thirty-two.

The extraordinary thing is that he should have done it at all, and the instructive thing for us is the way the poet takes it. As Petrarch's always, he is here first of all the poet. After his sevInterpreta- eral wanderings from the path and while his comrades tion of Nature are laughing at his wrong-headed clumsiness he reflects that this is only a picture of life. The great things lie above us, but we neglect the direct way up to them and wear ourselves out in headstrong wanderings. First come to him the suggestions of the classic literature. Now he knows what it meant that Hannibal crossed the Alps to attack his own beloved Italy, - dearer than ever to him as he reflects upon how she threw back the Punic invader. Now he realizes the meaning of Athos and Olympus. Then, with that extraordinary mingling of the modern - that is, the ancient spirit with the temper of mediæval Christianity, he pulls out his little copy of the "Confessions" of Augustine, the inseparable companion, he says, of his travels, opens it - so he calls God and his companions to witness - at random, and behold the words : "And men go about to admire the heights of mountains, the 
mighty waves of the sea, the broad courses of rivers, the compass of the ocean and the revolutions of the stars, but themselves they consider not." At once he turns from the outward to the inward, and all the way down, he says, he is so filled with the thought of his own sinfulness and the slight importance of all this outer world as compared with the elevation of his own soul that he never notices the difficulties of the way. Once safely down, he still has energy left to set himself to the writing of this long Latin epistle. The really important thing is that the momentary impulse of ascetic self-reproach does not last. He had been on the heights, and henceforth the world was a bigger and a better place.

This tendency to turn the thought even of outward nature in upon one's own soul is eminently characteristic of this age of Petrarch's transition. Dante had really felt like a mediæval Melancholy man; Petrarch was pursued by the sense that he ought so to feel, but could not, and it is probably from this conflict that he drew that tinge of gentle melancholy which marks so much of his serious work. How far this was genuine and how far it was a literary pose is not quite clear. In any case we may fairly connect it with his dominant individualism. It pleased his poetic fancy to think of himself as a victim of the world struggle between good and evil. His reading of Augustine strengthened this fancy. He liked to believe himself important enough to be an object of concern to the powers that rule the world. If he had let himself be governed by this sense of an irresistible fate, this acedia, or what the Germans of a later day called Weltschmerz, it would have been a sign of hopeless weakness. Petrarch did not so give way, but pursued his chosen course in life with uncommon diligence and persistence. If the character of repentant sinner pleased him, he took excellent care not to give up any of the good things that had come his way in the pursuit of what he cared most about.

Petrarch's individualism showed itself most strongly in his attitude toward the learning of his day. If his principle of free personal judgment were right, then the mediæval principle of blind 
acceptance of tradition must be wrong, and Petrarch did not hesitate to apply this reasoning. He takes up one after another the

Petrarch's several branches of existing learning and proceeds to Criticism of show that they are all founded on false methods. Mediaval Learning Of course it was the subject of classical philology that chiefly interested him, but the law, medicine, theology, and the very respectable science of astrology each received a criticism such as no one as yet had ventured to make. His summing up of the false logic of astrology is characteristic. He does not try to explain the movement of the heavenly bodies; that was not his affair. What he does know is that "God is above us and above the stars, and there is no such thing as a blind Fate." So far as he was concerned that settled it, and it was a brave position in an age when astrology was as much believed in as were the daily miracles of the Church.

Against the prevailing practice of medicine he seems to have had an especial grudge. He was willing to admit that there might Petrarch and be such a thing as a science of medicine, but he demedicine clares that up to the present time it had not appeared. Neither in the ancient nor the modern world had men advaneed beyond guesswork, idle traditions, foolish superstitions, and appeals to fear. He boasted of his own superiority to physicians and his ability to regulate his life by reason; but when he was alarmed about himself he did not fail to call in the doctor. All this would be unworthy of notice were it not that back of his rather loose criticism we discern a certain sound principle. It was something to have made clear that medical knowledge was chiefly ignorance and that only a radical change of method could improve existing conditions. That change, vaguely as Petrarch could define it, was to be along the path of actual experiment, of scientific observation, and the free use of reason in drawing conclusions, - in short, the path of modern science.

In much the same way he pays his compliments to those who might have been his colleagues, the practitioners of the law. His 
own legal studies seem to have made little impression upon him save that of a profound disgust for the petty detail which he The Law chose to consider the chief part of the prevailing legal practice. The law in itself was indeed worthy of all respect as one of the products of that Roman world which to him embodied all that was best in human history, but that men should spend years in acquiring knowledge of this noble subject and then employ it to make money, this he affected to regard as a degradation of the sacred cause of sound scholarship, and this is the reproach he continually makes against the lawyers, as he had similarly made it against the doctors.

Still more violent was Petrarch's judgment of the whole system of mediæval thought as expressed in the degenerate scholasticism of Scholasticism his day. The really vital conflict of the time, the war of Nominalism and Realism with its far-reaching consequences for the intellectual life of Europe, seems not to have interested him. And yet the individualism of his thought was, as far as it went, one of the clearest expressions of the nominalistic attitude.

Already with Petrarch we come to the problem which was to be the most difficult of the whole Renaissance period: how to Petrarch and keep the balance between the ever-increasing indethe Church pendence of the human spirit and the unquestioned authority of the established Church. If a man had a right to his own thoughts, then it would seem to follow inevitably that no authority whatever could compel him to accept any system of doctrine. Petrarch himself seems to have felt the peril of this dilemma, and critics were not lacking who pressed it upon his attention and his conscience. He was an ordained clerk, priest, and archdeacon and showed an average human willingness to beg for and to hold various church benefices, drawing the revenues and never making even a pretence of doing any of the duties they implied. His warmest friends throughout life were clergymen, some of them, for instance, Cardinal Giovanni and Bishop Giacomo Colonna, among the highest dignitaries of the Church and of Roman society. 
In his dealings with these churchmen he used the greatest freedom of speech, criticizing the outward evils of the Avignon papacy Eis Double with entire frankness. Between these outside things, Standard of however, and the doctrinal side of religion he draws Faith

a clear practical distinction. For the teaching of the Church he professes the most profound and complete respect. His contempt is reserved for the so-called philosophers who darken the-simple counsels of religion with their foolish dialectics. In him we see that curious double standard which enabled the clearest thinkers and the most advanced individualists of the Italian Renaissance to build, as it were, a wall between their mental processes in dealing with formal religion and with all other subjects. What the Church taught they were willing to accept as coming to them through sanctions quite different from those they demanded for their other beliefs. It would be going too far to call this conscious hypocrisy; but it could not fail with practice to beget an indifference to authority which must eventually lead somewhere to revolt.

Petrarch's life from 1304 to 1374 was in itself an illustration of the dominant passion for individual freedom of thought and His Indi- action. He never had a home, but spent the greater vidualism part of his mature life at the court of one or the other of the Italian tyrants, who were beginning to add the patronage of art and learning to their other devices of popular government. When he tired of this, or found himself more deeply involved in some regular occupation than seemed useful to his art, he withdrew to the solitude of Vaucluse, in the neighborhood of Avignon, where he had a little country place. Here lived the faithful housekeeper who was the mother of his children. Here, in the land of the troubadours, he gave himself up to the inspiration of his Muse, to the thought of Laura, and to dreams of fame.

One grief pursued him through life, - he never knew Greek; but in the regret at his lack there lay the evidence that he knew how to value it and the promise that his followers would not be content to go without it. The mediæval ignorance of Greek 
in Italy is the more surprising when we consider that the whole southeastern part of the peninsula was inhabited by Greeks, His Ignorance who still preserved a practical knowledge of the lanof Greek guage, though they too seem to have lost interest in their ancient literature. Doubtless it was but another illustration of the general indifference to the suggestions of antiquity we have just been remarking. Petrarch's mind was fully alive to the importance of getting at all literature by first-hand processes, but he felt himself too old and too occupied with other things to attempt the learning of a new language. He died amid the unbounded admiration of his day, enjoying to the full in his own life the fame which he was the first among moderns to declare a worthy object of human desire.

Giovanni Boccaccio (1 $\left.3^{1} 3^{-1} 375\right)$ was a Florentine with, perhaps, a French mother; at all events brought up in Paris, where Giovanni his father was in business. He too had to go through Boccaccio a period of parental opposition to his pursuit of learn. ing for its own sake, but found means to break away and seek his fortune as a man of letters at the court of King Robert of Naples. Boccaccio was one of the earliest admirers of Petrarch as the apostle of a new literary gospel, but unlike his master he was eminently a man of the world. In Petrarch we cannot fail to recognize the idealist ; in Boccaccio we feel ourselves dealing with a modern "realist," a man content with the world as it was, getting vast amusement out of it, and ready to do his day's work in pursuit of the things that interested him. In him too we have to take account of the Renaissance dualism, the joyous creation of masterpieces in his native Italian and at the same time the laborious production of useful work in Latin and in the elements of Greek.

Boccaccio must stand for all time as the master of Italian prose. He wrote poetry, but it has not stood the test of time. His special genius lay in the telling of stories, not usually original with him, but taken largely from already existing tales and 
worked over by him into such form as appealed powerfully to the awakened sense of human happiness. In his principal work, The "De- the "Decamerone," he represents a party of Florencamerone" tine ladies and gentlemen, driven from the city by the plague of 1348 , gathered at a country house and beguiling the time by the recital of merry tales of such a character as would divert their minds from the horrors they had left behind them. Usually the interest of these stories turns upon some trick played by one or more of the characters upon some figure which serves as the butt of their more or less refined wit. It could not be said that their purpose is moral, but on the other hand it is not immoral. The wit is often coarse, the situations anything but nice; yet the impression is not offensive. They leave with one the sense of having been among the people of the fourteenth century as they were, and that after all these were very much like the people of all times, only rather more frank about it. The style is charmingly simple, free, and natural, a model of narrative prose.

This Italian activity of Boccaccio occupied the earlier half of his life, during which we find him a frequenter of courts, the Boccaccio as favorite of highborn ladies, openly celebrating the a Classical charms of a mistress who was believed to be the natuScholar ral daughter of King Robert of Naples. Yet, even at this time, he was under the spell of the reviving spirit of classical study. He had learned to admire and reverence the genius of Petrarch, and when he was still in early middle life formed with him a personal friendship which was to last as long as both should live. It is one of the many paradoxes of the Renaissance that this man, the gay retailer of slippery anecdotes, the darling of Florentine "Society," should have been at the same time the most patient of plodders in the field of classical philology on its most repellent side. He did not, like Petrarch, aspire to be a "poet," a creator of new and great things; he was content to busy himself with the dull detail of word study, in the 
laudable purpose of clearing the way for others. His greatest achievement, by which he hoped to live in the memory of the after-world, was the making of two classical dictionaries - one of mythology, which he called the "Genealogy of the Gods," and one of geography, under the title "Mountains, Woods, Springs, Lakes, etc." And in fact these laborious and crude collections of classical passages, jumbled together without any of the assistance of modern philological science, did for two hundred years perform the service their author had intended.

Further, Boccaccio claims for himself the merit of being the first of Italians to study Greek. He did this by taking into his His Knowl- house a wandering teacher, of whose ignorance and edge of Greek incapacity he gives a deplorable picture. It is not clear that he made great progress, but a beginning was made and a fashion set which must needs result in an entirely new. inspiration for Western culture. Henceforth no scholar could venture to be satisfied without going to the original sources of Greek as well as of Latin literature, and the means for meeting this requirement were not long in presenting themselves. Our special interest is in noting that the impulse to Greek study begins early and in the West and is not the result of any accident, but the natural development from the more accurate and careful study of the Latin. Two methods were open to the ambitious Western scholar: either to import a teacher from the East or to go there himself and study the Greek at the fountainhead. Both methods now began to be employed, but of the two the latter was in the long run the more effective and the more permanent. Everything contributed to this new enlargement of the literary horizon. The commerce of the Italian cities was at its height and offered the natural channels for the transportation. and the personal introduction of the traveling scholar. 'The wealth of these trading republics was unstintedly placed at the service of collectors of manuscripts or used to support the learning. gained by foreign travel and study. 
In the three great names of the early revival of learning we note a steady change which indicates at once a decline and a prog-

Dante,

Petrarch,

Boccaccio

ress. Dante seems a being apart from his time. He sets himself over against it as a judge; his work is almost purely a work of the imagination; his guide is Virgil, not merely as a literary model but as the embodied spirit of poetry and prophecy; the woman who inspires him is a pure creation of his fancy, only dimly suggested by an actual personality. Petrarch is more human. His poetry deals with a human affection, yet idealized almost to the point of unreality; he teaches men how to approach the problems of the intellectual life; his feminine counterpart is an actual woman, but his relation to her is as fictitious as his passion. He becomes an immediate influence upon the thought and movement of his time. Boccaccio is a purely human figure. He sings of human joy in a very human fashion; he seeks his inspiration in a liaison of the conventional sort and reproduces in his writing the emotions he has really felt; he labors not for the idealizing of learning but to popularize it. The intellectual life which in Dante still shows the mediæval loftiness and apartness becomes fashionable with Petrarch and popular with Boccaccio. "We marvel at Dante; we praise Petrarch ; we read Boccaccio."

The most striking quality of the intellectual movement in the time of Petrarch and Boccaccio is its striving after freedom, inFree Liter- dependence of tradition, liberty of thought within the ary Associa- limits of the Christian faith. Even a certain readiness tions

to stretch these limits as far as they would bear is early to be perceived. These men were above all else individuals, making their place in the world by virtue of their own personal qualities and not dependent upon their membership in any class whatever. It is evident, however, that the society in which their work was to be done was in many ways prepared to receive it. The proof of this is seen in the eagerness of the response which came from bright young men in many walks of life. To Petrarch or even to Boccaccio anything like the organization of learning 
would have been repellent; it would have seemed like a limitation upon their free activities. But even before they had passed off the stage the natural human instinct to seek fellowship in effort began to make itself felt - at first in the freest possible forms.

The earliest type of such organization is seen in the so-called Academy of Santo Spirito in Florence. The center of this group The Academy was Luigi Marsigli, a Florentine of good family, a of Santo friar of the Augustinian Order, and a theologian of Spirito

repute. In the quiet cloisters of Santo Spirito he received the choice spirits of the new humanistic generation and led them in discussions upon all the novel and thrilling subjects of the day. We have no record of these conversations, but it is clear that they were anything but "scholastic" in the old sense. They appear to have been the free comparison of views by independently thinking men under the direction of a highly gifted and thoroughly. respected leader. A similar picture of a free intellectual circle is given in the famous Paradiso degli Alberti, a description of the gatherings which took place in the gardens of the Alberti villa outside Florence. The participants in these several literary reunions were largely the same persons. They include those we have now to consider and many others of less note and of widely different interests, but all united in a common love of liberal studies.

If we are impressed with the decline of moral and spiritual force during the half century preceding the death of Boccaccio, we can-

Coluccio

Salutato, Florentine Secretary not fail to notice on the other hand a vast progress in the direction of popularizing learning and in making it practically useful. The scholar by profession, for whom there seemed to be no place in the youth of Petrarch, is now a widely recognized, almost indispensable person in many relations of life in which he had previously been unknown or distrusted. A few illustrations will show this under widely differing conditions. Coluccio Salutato was a Tuscan of good family who early fell under the spell of the new culture and set himself to work to acquire the facility in Latin composition which 
was the first necessary step on the road to humanistic fame. He was a man without genius, but of good parts, capable of learning all the technical points of a good Latin style and desirous of applying his skill in the service of the Commonwealth. In him we have the earliest instance of the humanist in politics. Salutato, who was a younger contemporary of Petrarch and Boccaccio, began his career as a public official at a time when diplomacy was beginning to play a part in politics quite unknown before. The five great powers of Italy were engaging in the long conflict which was to end only with the definite partition of the peninsula into "legitimated " principalities. Warfare between them was always in order, but it was usually a kind of mimic warfare, preceded and followed by long negotiations, not popular with the Italian people themselves but fought out chiefly by hired mercenaries, who were as likely to be on one side as the other, - if indeed they did not find themselves on both sides more than once during the progress of the campaign.

Under these circumstances it was quite natural that the art of political correspondence should rapidly attain the dignity of a the Public Secretary
Function of branch of literature. Formerly diplomatic negotiations were wholly conducted by special ambassadors, and the training acquired in such embassies had been one of the most valuable parts of the education of the Italian citizen. There is hardly one of the better-known names of the fourteenth century that is not found on more than one occasion on the lists of the envoys of this or that city. At a later day this function was to be placed in the hands of resident ministers. Between these two stages came the period of literary diplomacy. Salutato held, during the greater part of his active life, the honorable and difficult post of secretary to the Florentine state. It was his function as such to prepare the documents in which the still vigorous democracy declared its terms to its rivals, made its bargains with the captains of mercenaries, concluded treaties, congratulated young princes on their accession to power, welcomed visitors to its hospitality, or adjusted some outstanding economic difference. In expressing the 
intentions of the state, however, the classically educated secretary went far beyond the actual needs of the case. His state papers were essays of literary brilliancy, decorated with classical allusions, in which his princely correspondents were compared to the heroes of antiquity, the emergencies of the present with the political crises of the classic past.

Nor was this a mere amusement of the writer, at all comparable, for example, to his pleasure in a fine handwriting. All this Value of Salutato's letter of Salutato was worth a thousand men. His Work

persuasions or threats or promises really decided things, and he was kept at the head of the Florentine chancery during so many years because his services as a literary man were appreciated at their full worth. In his case and in an increasing number of similar cases it was not that the office was merely a support for a needy scholar; the man honored the office and elevated the public business a little above the dead level of hard fact into a certain atmosphere of idealism. This public correspondence was Salutato's chief title to fame. His letters were published as literary monuments, after they had served their purpose in diplomacy. Besides these he wrote essays on a variety of philological and speculative subjects in the manner of Petrarch, whom he honored as the chief of scholars. It was his highest ambition to be allowed to edit the "Africa" after its author's death. His fellow citizens celebrated him as one of their greatest adornments.

A very similar career was that of a man somewhat better known to later time, Poggio Bracciolini. He spent his life as a secretary Poggio Brac- to the Papacy during the troublous times of the Great ciolini, Papal Schism and the controversies that followed it. With Secretary Poggio we begin to get glimpses of that aspect of the Renaissance which has brought most discredit upon it; namely, its too frequent divorcement of literary capacity from moral quality. Probably there was no worse school for errant genius than precisely the papal court. Poggio, brilliant, reckless, filled with the 
conceit of the scholar, but without high ideas of the scholar's mission, stands for all time as the type of the self-glorification, the petty joy in trifling bits of learned acquisition, the small triumph over a rival scholar, the pleasure in doubtful witticisms, which so often obscured the real greatness of the Renaissance men and have so often since been a cause of reproach to philological scholarship. Without discussion, to be sure, there could be no fruitful intellectual life; but under the conditions of the early fifteenth century discussion too readily took on the form of controversy, the object of which was less the search for truth than the discomfiture of an opponent. It is hardly unfair to compare this kind of literary controversy with some form of sport, and the spirit of the circle in Italy, notably in Florence, within which these subjects were pursued is not unlike that in which men pursue any enthusiasm of the moment. The sport was dignified in this case by the seriousness of the subject and the indication it gave of a sound intellectual life underneath it. Poggio was no less useful as a papal secretary because he was the author of slippery stories, the Facetiae, and of scandalous assaults upon the personal characters of his fellow scholars. These things were read and admired for the literary skill they displayed, and surely our generation ought to find nothing strange in this. As the companion of Pope John XXIII at Constance, Poggio had a rare opportunity to explore the region about the lake and investigate the literary treasures of the monasteries that in earlier times had been among the principal seats of northern culture. His search was rewarded by some of the most remarkable "finds" in the whole history of the recovery of manuscripts. In one respect we must distinguish the career of Poggio from that of Salutato and others. In his case we have to admit that the office appears pretty completely as a bread-and-butter affair, useful only as a means of keeping the man while he pursued his own literary aims.

Niccolo Niccoli interests us in quite another way. He is the earliest type of the book lover by profession. A man of good parts but without even exceptional literary talent, he became one of the 
most useful members of the Florentine humanistic group through his skill in all that pertained to the outward aspects of literary proNiccold duction. The modern publisher and bookseller was as Niccoli, yet unknown. The readiest way to publish an essay Book Lover was to send it as a letter to a friend, with entire certainty that he would pass it on. If it commended itself to general interest, the next thing was to have it copied by a professional hand, and additional copies would be made to the order of any who chose to pay for them. A new edition of an ancient author was best placed by being dedicated to some rich patron, who would presumably make a present to the editor and then pay for copies for his friends. Niccoli, himself without means, knew how to interest men of wealth in the new enthusiasm and thus made himself a center of the Florentine collecting and publishing business. His special cleverness was in the judgment of manuscripts as to their genuineness. Already within the first generation of humanists fraud had begun to creep in, and speculation in manuscripts, as in any other highly desirable wares, was active. It is not clear that Niccoli kept a shop or even an "office," but we learn from the letters of many of his contemporaries how large a part he played in their learned undertakings. Florence early became the central point for the humanistic interests of Italy, and that meant, for the present, of all Europe. Manuscripts discovered anywhere were most likely to be sent there for identification and correction. It appears that it was Niccoli rather than any one more distinctly gifted as a writer to whom they were apt to come first, and it was he who could place them in the hands where they would command the best price. Allusions to his personality show him to have been of a somewhat peppery temper, a fussy little man, to whom the mechanical details of bookmaking were a congenial occupation, yet with a keen instinct for the best in literature, an ideal description for a publisher in any age. His house appears as a kind of headquarters for literary interchange, suggesting already the great offices of Aldus at Venice and Froben at Basel after the invention of printing. 
Still within the Florentine circle we find a type of the conflict and reconciliation of learning with religion in the person of Ambrogio Ambrogio Traversari, a monk of the order of CamalTraversari, doli and early raised to the important post of General a Humanistic of the order. A truly learned monk, in the sense of
Monk

the New Learning, seems to imply a contradiction of terms. We cannot forget the long line of Franciscan and Dominican scholars who had given distinction to the thirteenth and fourteenth centuries; but nothing could be further from the spirit of their scholarship, devoted as it was almost exclusively to maintaining the doctrines of the Church, than this new interest in the heathen books, the Greek language, the history and institutions of the ancient world. Traversari had the cruel fortune to be a man of taste. The fame of Petrarch, a little dimmed to be sure by the small criticism of the second humanistic generation, seemed to him more worthy of imitation than even the virtues of the early fathers or the pious compilers of catechisms in the generation just passing away. He allowed himself the sinful joy of studying Greek, of collating classic manuscripts, of writing an occasional dissertation on points of grammar, or even of editing a new oration of Cicero. He loved the company of these light-hearted explorers in the new field of classic thought. They were not all, as we have seen, men capable of getting the highest and best out Conflict of of the ancients. If we take them at their own word, Learning and they were easily interested and amused by things that Religion

a more refined taste would have passed over in silence. Their conversation cannot have been such as Saint Bernard would have recommended to the chief person in a great monastic order. All this Traversari knew, and we have in his letters the clearest evidence of the struggle it cost him. He might assure himself, as thousands have done since, that to the pure all things are pure and that the teachings of the ancient to the modern world were worth all the risks - there came times when he would vow never again to let these worldly charms draw him from the study and 
contemplation of divine things. Then for a while the text he was editing would lie idle and his friends in the Florentine circle would know him no more. But again, after a little, the argument would take on a new phase, and he would venture back into the delightful club at Niccoli's and take up his editing anew. On the whole, he succeeded remarkably well in maintaining the balance between these two sides of his nature. He escaped ecclesiastical discipline on the one hand and he learned to use the classics without abusing them.

This experience of the monk Traversari would not be worth our attention were it not so exact a reproduction in the life of one Change of man of what was going on in the whole greater world Intellectual of European society. All the standards of judgment Standard that had served the mediæval world so long and so well seemed in danger of being reversed. Men saw them going and were alarmed at first; but then they saw a new thing coming, a new kind of standard, taken from the life of a world, out of which after all, as they were beginning to learn, had come most of the good things they were then enjoying. It was a dangerous game, but men were ready to play it and take the consequences. Whence, for instance, could come any effective criticism of such a man as Traversari? Surely not from any recognized authority in Church or state. The Papacy was on trial for its life. Any false step on its part would have been the highest gaudium for the assembled fathers at Basel. It could exist only by putting itself into harmony with obvious tendencies of the day, provided only that these tendencies did not touch the foundations of its own power. And as to the states, - the new governments of Italy, with their sham democracy, were only too glad to encourage this occupation with things of the past, provided only that men would avoid the subject of the proper treatment of tyrants. The power in Church or state which should have attempted to discipline Traversari would have had against it the most terrible weapon known to the modern world - the laughter of its brightest minds. 
All these scholars were and prided themselves on being essentially self-taught men. In this fact doubtless we find the explana-

The New

Classical

Training tion of the vigor and freshness of their enthusiasm, for it is only the culture that comes from the original, individual impulse that truly cultivates. The mechanism of so-called education was, so far as their needs were concerned, almost totally lacking. The great universities were either schools of the old scholastic learning or were training-grounds for the professions of law, medicine, or theology. Their spirit, as we might naturally expect, was in the last degree conservative. They had no room for such unsystematic processes as these of the early humanists. It is not until the second generation was well on its way through life that we see the universities beginning to take part in the competition for capable and trained teachers of the classics. The course of preparation for such a position included by this time a residence in Greece, with study under some of the teachers there who were now beginning to make their profit out of the fresh zeal of these Western youths. A continuous stream of young scholars now begins to set toward Constantinople and even toward Athens, where some remnants of ancient culture still survived. The training they received does not appear to have been always of the best, but it answered. It gave them, at all events, a first-hand acquaintance with the seats of that civilization which Eastern they believed to represent all that was best in their own Influence inheritance and a chance to gather for themselves in Italy some of the material from which they were to gain their linguistic and grammatical knowledge. The process may well be compared in all its details with what has been going on in our own development during the last generation. Our own country has been through the same process of commercial expansion which has given the means to ever-larger numbers to seek in Europe a culture they fancied they could not reach at home. There has been the same stage of eager profiting by whatever was profitable in the older mechanisms of education, the same 
exaggerated views of what this profitable thing might be, the same appropriation at home of what was valuable, - frequently also of what was not, - and the same disillusionment when it was found that, after all, the true process of culture must begin and end with the indwelling capacity for culture in the individual himself. The comparison may be carried still further. Not only did the scholars of the East profit by the chance to teach the youth of the West; they soon began to see a golden future for themselves in this same half-barbarous Italy. Men quite commonplace in their home loomed up large when they came to present themselves before the patrons of Western culture as candidates for places in the universities or as adornments to the mushroom courts of successful bankers like the Medici in Florence or of victorious brigands like the Sforza in Milan. Not infrequently such wandering teachers were men not greatly missed in their own communities but gladly welcomed in Italy for the wares they brought, without too much curious inquiry into their personal histories.

It was the stage of a genial optimism in all things. All sorts of universalistic notions, born of a rampant individualism, were in The Enthu- the air. The world was going to be saved once more siasm of by culture. East and West were, after all, heirs of the Culture same great inheritance and must make it good together. In 1439 the Council of Florence came "within an iota" of uniting the Greek and Latin churches. If only the obstinate Greeks would have said "and the Son" in their creed and would have acknowledged, ever so imperfectly, the supremacy of the pope, the Christian world would - so men dreamed - have become one in faith and action. Pope Pius II, the genial humanist Eneas Silvius Piccolomini, died in 1464 in the midst of preparations on a vast sçale for taking up the work of the crusades where Saint Louis had laid it down! As in our own day, the world was in a ferment of generous impulses with no manner of idea what to do with them. The earliest of the Greek teachers in Italy was Manuel Chrysoloras, a man of solid personal character; who had 
begun by receiving pupils into his house in Constantinople and had then come over on some commission from the Byzantine govemment and found himself so well off that he had remained. He became the teacher of several of the best-known Italian scholars of the years just before and just after 1400 and left with them an impression of sound learning and real culture. He died at Constance in the early days of the Council (1415). Others of this class made an altogether different impression upon their pupils. They seem to have been regarded as a necessary evil, to be tolerated for the service they could render as assistants in getting at the Greek language in spite of their personal filthiness of body and mind. It seems to have been clear to all these scholars that there is no such thing as teaching a language; that the student must acquire the language by using it; and that another person can only help one over certain difficulties as they present themselves. The teacher was therefore properly kept in the relation of a servant and valued in proportion to his actual service. The method of learning appears to have consisted largely in committing to memory and in copying whole codices of the ancient writers. The study of grammar by itself was an altogether secondary part of the process. All the great scholars from Petrarch down were copyists and prided themselves on copying more or less of what they read, though, of course, as the volume of texts increased this work had to be left chiefly to professional hands.

Far more important is the class of teachers who went over to Greece and came home ready to hand on what they had acquired. The type of such a man was Francesco Filelfo, a

Francesco

Filelfo, Classical Teacher
Florentine, who came back from his studies in the

East just in time to catch the first wave of popular demand. He was undoubtedly a man of good parts, but set upon himself a value wholly out of proportion to his actual merits. It was not altogether his fault, for he found himself at once an object of competition among various patrons and naturally advanced his price to correspond. Humility was never the 
vice of the Renaissance scholar, but the demands of this favorite of fortune were beyond all reason. He is perhaps the best illustration of the scholar who feels himself elevated by his mere learning to a place above the common. It was not his creative production that was to give him fame; only the possession of a something not shared by very many and having therefore some occult value.

Like others of his class Filelfo was not regularly installed as a university teacher but was engaged by the year. This plainly Literature indicates that classical teaching was still thought of as of the Invective something quite outside the necessary equipment of a university supported by public funds. There seems to have been no question as to Filelfo's learning and capacity to teach, but unhappily he was, or imagined himself to be, an object of jealousy to the dominant power in Florence, the all-powerful Cosimo dei Medici. He defended himself with his own weapons, and there was no one who could strike harder and more wicked blows. In a series of biting satires he attacked the Medici and the group of Florentine scholars who were patronized by them. Language cannot go beyond the abuse which he heaped upon their unoffending heads. The Florentines stood manfully together, but the result was a branch of literature that has given to the Italian humanists their most unsavory reputation, - the literature of the "invective." Starting with some real question in dispute, Filelfo's attacks were repaid in kind. When he accused poor Niccoli of every kind of vice the ready Poggio rushed to the defence and riddled the character of Filelfo with equally foul abuse. Filelfo replied and dragged in other friends of Niccoli ; they, nothing loath, contributed their contingent of blackguardism, and so it went. As between scholars this sort of thing might be thought of as a kind of literary game; but when it came to politics, that was another matter. Filelfo was banished from the city he had abused and spent the greater part of his life elsewhere, returning at the call of the Republic in his eighty-third year to take a professorship, which, however, he never lived to fill (148I). 
With Filelfo we may regard the first period of the Italian humanism, its period of fresh enthusiasm, of creative energy, as Tommaso complete. The precious treasure of ancient learning Parentucelli, could no longer be kept as the exclusive possession of las V, 14471455 a few individuals, but had become the common property of the educated world and was ready to do its work of enlightenment in clearing away from men's minds a vast amount of accumulated intellectual rubbish. This adjustment of learning to the common needs of the world of thinking men is best shown in its relation to the Papacy. Strictly speaking, nothing could be more hostile to the papal institution than the spirit of this new scholarship. Above all else it tended to magnify the individual, and the only safety for a universal institution is in the surrender of the individual to its superior claims. The very essence of humanism was the spirit of inquiry, and inquiry is the most fatal thing to an institution that rests upon assumptions which lie within the reach of human investigation. Without being specifcally hostile to Christian ideas of religion and morality, humanism was playing with the very foundations of both. While its leading men were still living the invention of the printing press was just about to begin its marvelous work of beneficent revolution. Yet at this very moment we see the Papacy, the bulwark of ancient traditions, apparently in entire harmony with this new enthusiasm. A humanistic pope seems the most complete contradiction of terms, yet if we seek the reasons why Tommaso Parentucelli was elected pope in 1447 it is hard to find any more important than his lifelong interest in the New Learning. Born poor, working his way up from the lowest to the highest places in the Church, he had commended himself to one and another patron by his zeal for classical study. His dream of life had been to rise to a position where he could command such an income as would enable him in turn to become the patron of learning and of art on a great scale. As bishop of Bologna he had done what he could; but when he found himself with the papal revenues in his hands, the opportunity 
was come indeed. With him Rome begins for the first time to rival the other Italian communities in its regard for the higher

Decline of

Rome the

City

things of life. In the middle of the fifteenth century

Rome was still a mediæval town. The great buildings of antiquity had for generations served as stone quarries from which the Roman barons had plundered the material for their city houses, and their ruins had been converted into strongholds in the furious faction fights which had become the regular accompaniment of every political change. Whatever other reasons may have determined the decision of the popes of the fourteenth century to keep out of Italy, the fact is that Rome was not a safe or dignified or comfortable residence for a ruler. It was not comparable with any of the other great centers of Italian life. And what was true of its material was true also of its intellectual condition. Rome was not a normal community. The prestige which came to it as the seat of the Papacy had always a certain foreign character. If Rome gave the Papacy to the world, this world quality was, after all, what made the Papacy worth having, and of late the Christian world had been showing that it could get on very well without Rome. In its reliance upon this prestige the Roman community had lost the elements which had made the greatness of the other Italian commonwealths. While Florence, Milan, Venice, Bologna, and the rest had been developing a wonderful civilization based upon the energy and civic devotion of a singularly gifted industrial and commercial population, Rome had contributed strangely little to the common stock. Not one of the leading ideas of the new time is traceable to a Roman origin. Not one of the names most famous in this splendid creative activity of the human spirit belongs to a man of true Roman stock. It is only another illustration of what has been shown over and over again - that the mission of Rome had never been to create, but rather always to order, to systematize, and to make practical what came to it from outside. And yet never, as we have been seeing, was there lacking some voice to remind the Romans of their 
marvelous heritage. The sense that in spite of all that had come between they were still heirs of the ancient Roman greatness was the one sentiment to which every Roman patriot could always appeal and be sure of a certain response.

The problem of Nicholas $\mathrm{V}$ was how to restore to Rome the leadership it ought to have. He was the first pope since

Building

Plans of

Nicholas $\mathbf{V}$

Boniface VIII, that is, for nearly five generations, who had held undisputed possession of his own city. His policy here is marked by the same spirit of compromise which he showed in dealing with the wider questions of European politics. The moving force of the resistance to papal control in Rome had always been the appeal to antiquity. Nicholas. undertook to forestall this resistance by making himself the champion of precisely the same ideas. The eight years of his pontificate were crowded with plans for the restoration of the city in every sense of the word. The first need of the restored Papacy was security. To insure this Nicholas planned a double system of defence, - first a complete restoration of the city walls with towers at suitable intervals; then a smaller inner ring of walls about the "Leonine City" north of the Tiber, inclosing St. Peter's, the Vatican, and the "Borgo" with the castle of St. Angelo. This gave to the Papacy a city within the city, secure against any force likely to be brought against it.

Then, within this inclosure, Nicholas $\mathrm{V}$ planned a complete new building to take the place of the old basilica of St. Peter, a plan St. Peter's so gigantic that his biographer declares that if it had been carried out the result would have surpassed all the wonders of the world. In connection with this and in recollection, doubtless, of the papal palace and castle at Avignon, he The Vatican proposed to enlarge and beautify the Vatican so as to make it the most splendid governmental residence in existence. His scheme of apartments, courtyards, gardens, lakes, and groves, all united by appropriate architectural forms and all secured to the papal rulers forever, shows a grandeur of conception possible only to one whose constructive imagination 
had been kindled by a study at first hand of Roman imperial splendor and who believed that unlimited resources were going to be at the disposal of like-minded successors.

This primary purpose of defence is seen also in Nicholas's farreaching plans for building towers and castles in many of the cities Collection of of the Patrimonium, in the restoration of the Milvian Manuscripts bridge, the fortification of the Ponte St. Angelo, and many other similar schemes. It hardly needs to be said that the short eight years of his pontificate could suffice for little more than a beginning of such comprehensive city planning as he had in mind, but the effects of his work were stimulating in the extreme, and some of them are visible to this day. To accomplish his purpose Nicholas began at once to call about him a multitude of workers in every field of the new activities. His impulse came from books, and books were, next perhaps to building, the first object of his intellectual interest. By his time the discovery and collection of manuscripts had gone so far that single copies of almost every known work of antiquity were already in the hands of scholars. The labor of collating and copying was well advanced; but in all these directions Nicholas displayed a feverish enthusiasm. He employed regular agents to ransack the storehouses of Europe and to get possession of the coveted manuscripts by hook or by crook. At first the value of these treasures was not known, and they could be begged as gifts or purchased for a song; but already the era of fancy prices was beginning. It required a peculiar talent to drive suitable bargains or find devices for successful appropriation of the prize. Professional scribes in shoals were hired to increase the number of copies and, if these copies were not to increase hopelessly the chances of error in reading, the scribe must be a man of more than ordinary education and culture.

Then, especially in Nicholas's time, came the enormous labor of translation from the Greek into Latin. Nothing less than the rendering of the whole mass of Greek literature into the more familiar idiom was the goal of this undertaking, and such were the energy 
and enthusiasm put into it by many of the very best scholars of the time that this goal was very nearly reached. Such translation Transiations may fairly be called a conscious popularizing of learnfrom the ing. The man who could not read Latin could hardly Greek

be thought of as wishing to know the literature of the Greeks, but by this time the knowledge of Latin was widely enough spread to insure for the translation a really popular circulation.

This activity in translation means, of course, that great progress had been made in the study of Greek by the two methods we George of have described: by the employment of Greek teachers Trebizond in Italy and by study at the source in Constantinople or Athens. Nicholas $\mathrm{V}$ made use both of Italian scholars trained by one or the other of these methods and also of native Greeks who had made themselves masters of literary Latin. An illustration of the latter type is the Greek George of Trebizond. A quite ordinary person at home, he became in Italy a phenomenon of learning. With that "certain condescension in foreigners" not unknown to our own day and country, he let himself be flattered and rewarded by the simpler-minded Italians as one of the chief interpreters to them of a superior culture. Beginning at Venice as a teacher of Greek, he was invited by Eugenius IV to assist in his prolonged dealings with the Greeks, in the business of Christian union. To qualify for this service he mastered Latin and changed his theology enough to make himself acceptable at the papal court. These qualities of ready acquisition and quick adaptability were just what would commend him for immediate use, and in spite of his personal vanity, ill-breeding, boasting, and quarrelsomeness he soon found himself honorably placed at Rome as a papal secretary and professor of rhetoric at the university. Indeed, we may almost believe that his unlovely traits were viewed by the contemporary Italians only as so many proofs of his individual force of character. The accession of Nicholas $\mathrm{V}$ was George's golden opportunity. As a Greek it was more or less taken for granted that he knew all about his native literature, while his command of Latin made him 
just the man for the pope's vast schemes of translation. Relieved of his teaching duties, he was given ample means to devote his His Trans- entire time to this work. The first texts intrusted to lations him were those of certain early Christian writers, but from these he passed to works of Aristotle and other heathen classics. His rapid work and confident interpretation commended him to his eager patron, but more careful scholars soon began to point out all manner of carelessness and inaccuracy in his product. Their criticisms drew the fire of his scorn, and scandalous controversies were the result. Probably because he had no friends, certainly not because he was so much worse than the rest, poor George was ordered out of Rome by the scandalized pope. A year later he was allowed to come back but was not again received into favor. With many ups and downs of fortune, sometimes in the papal service, sometimes eking out a precarious living by teaching and translating, he lived to extreme old age and died in Rome in 1484 .

Similar in outline but different in detail is the story of another Greek wanderer, Theodore Gaza. He too came to Italy ignorant Theodore of Latin, but learned it rapidly and became so profiGaza cient in it that his contemporaries declared he could write it without a trace of Græcism. He too was set to work by Nicholas $\mathrm{V}$ and produced a quantity of useful translations. Unlike his rival, however, he was a man of gentle, modest, self-respecting nature, not ambitious for place, and naturally in a circle where push and servility were the passports to success he was allowed to slip out of sight. All spoke well of him, - " the best of all the Greeks" was the general opinion; but it is characteristic of the time that in spite of his valuable services to learning he spent his last years in obscurity and died poor ( $\mathbf{r}^{\circ} 45$ ).

Of the Italian scholars at the court of Nicholas $\mathrm{V}$ we have already mentioned several. Poggio Bracciolini, cleverest and most shameless of the half-heathen scholars of this generation, rounded out nearly a half century in the papal service until, in 1453 , a more attractive place opened for him in Florence. Filelfo was 
already well fixed at the court of Milan; but Nicholas, on the occasion of a visit of the poet at Rome, showed the greatest Poggio and interest in his work, made him a splendid present of Filelfo money, gave him the title of papal secretary, and held out the promise of great things in the future. The early death of the pope put an end to these prospects, but Filelfo never ceased to think of himself as one of the Roman learned circle.

Two other Italians out of the many deserve especial mention here, Leon Battista Alberti and Lorenzo Valla. The former, a Leon descendant of the famous Florentine merchant family Battiata whose interest in the higher things of life was shown in Alberti the Paradiso degli Alberti, we have already referred to, was born probably in 1404 , just a century after the birth of Petrarch. Like the great master also he was born in exile, following the political and financial ruin of his house. At the age of about thirty, under the favor of Cosimo dei Medici, he was permitted to return to Florence and henceforth was identified with her abundant intellectual life. Alberti interests us as perhaps the most remarkable specimen in his generation of what we are accustomed to call "the Renaissance man," the perfected individual. He is described as a universal genius. More than any one since Petrarch he appears as the man to whom all things are possible. Facility and versatility are his dominant traits. Noble in his personal appearance, he was the champion athlete in every variety of manly sport, - in riding, fencing, running, jumping, ball-playing. He could paint, model in clay, play upon musical instruments, and do all these well. His gift of observation and his sense for the beautiful led him early into the study of architecture. He became an accomplished linguist both in the classical languages and in his native Tuscan. While he shared the prevailing enthusiasm for antiquity, he was eminently up to date in every respect. Like Petrarch he studied law but was no jurist, took minor orders and held church benefices but was no priest. In the midst of a world of place-hunters and parasites he held himself erect and apart, as above all else a man. 
Alberti's literary product, whether in Latin or in Italian, is not of the first importance. It consisted primarily of expressions in In the prose and verse of his philosophy of life, a wellService of balanced application of his own principle of individuNicholas $\mathrm{V}$ ality to human conduct. What made him a force in his day was the influence of this individuality upon others. It is in this way that Alberti comes into relation with Nicholas V. His connections in Florence seem to have been rather with artists than with scholars, and Nicholas in his elaborate building schemes needed the advice of precisely such an all-round man. Alberti responded to this need with zeal and success. His principal work, "De $\operatorname{Re}$ Ædificatoria," giving his theories of architecture, was dedicated to the pope. The papal plans themselves as described by others correspond so closely to these theories that there seems little reason to doubt that they were essentially Alberti's work. In so far as they were carried out they are the most important monument to his artistic genius.

Lorenzo Valla was a native of Piacenza but spent his early youth in Rome and there gained the foundations of his wide and Lorenzo exact scholarship. What gives Valla his peculiar place Valla in the history of Italian humanism is his extreme development of the critical spirit. This quality had been clearly enough marked in all the humanist leaders from Petrarch down, but in none had it become so completely the dominant trait to which all others were subordinated. With Valla criticism in both the higher and the lower meaning of the word seems to have been not merely a means but an end in itself. Others had felt certain limits beyond which learning and cleverness might not go in attacking the most cherished traditions of the past; Valla was ready to go pretty nearly to any length if only sound learning and correct reasoning led him on.

His early years were spent in teaching in various universities in the north of Italy. Then he drifted, we do not know how, into the service of King Alfonso of Naples as a kind of literary 
attaché and became a prime favorite with this liberally minded ruler. It was owing to Alfonso's protection that Valla was able Criticism of to face the storm of persecution brought out by his Cicero attacks upon some of the most cherished privileges of the Church. His critical spirit delighted in tearing down the idols even of his own class. His earliest assault was upon the sacred name of Cicero, worshiped by his humanistic predecessors as the supreme standard of Latin elegance. It gave the young scholar intense joy to prove by the rules of the grammarian Quintilian, an author only recently brought to light, that Cicero as well as Homer could sometimes nod. We recognize the temper, but we feel also the value of what it might bring forth. Attacked for his irreverence, Valla replied that he was not concerned to diminish - the fame of Cicero, but only to set forth with the greater clearness the true principles of classic eloquence.

Valla's attitude toward the Christian traditions is indicated early by his treatise on "Pleasure" (De Voluptate), a title which he afterValla's ward amended by adding De vero Bono, "the highWorship of est good." His thesis is that what Nature dictates Nature. must be best. The pleasure of the senses comes from following the law of Nature; therefore it must be the highest good. In defending his thesis Valla allows himself to glorify the pleasure of sense at the cost of the Christian ideal of self-restraint. The mediæval teaching was, in practice, that whatever was natural was therefore wrong, and if this ideal of life was to be changed, it is clear that men were likely to go to an extreme in stating their new position. It was dangerous, but to such men as Valla the end seemed to justify the means. Of course he did not spare the monastic defenders of the mediæval principle. He accuses them of every kind of vice and hypocrisy. These were no new charges; the special sting in them was in the learned justification by which they were supported. Naturally Valla made enemies, but the king stood by him loyally and turned the force of the attack upon the persecuting monks. 
This early attitude of Valla toward the Church, or rather toward the men who were administering it, was never changed. It is shown especially in the work which has made Valla

He attacks the "Donation of Constantine"

famous far beyond his purely literary services, the "De Falso Credita et Ementita Constantini Donatione Declamatio." Until his time the right of the Papacy to its temporal possessions had been traced back to an alleged donation of land and power by the first Christian emperor, Constantine, to the Roman bishop Sylvester. The genuineness of the document supporting this claim had been unquestioned alike by friends and enemies of the papal system. Dante, for example, had not hesitated to describe Sylvester as the worst enemy of the Church because he had accepted that fatal gift. Even such fierce assailers of the Papacy as Marsiglio of Padua and John Wycliffe, while they tried in every way to weaken the force of the arguments drawn from this original transaction, accepted the fact itself as authentic. The literature of the Great Schism and the councils of Constance and Basel proceeds generally on the same assumption. The earliest serious doubts were expressed by Nicholas of Cusa, whom we have seen at first warmly defending the Basel council, then deserting it, and finally becoming the principal agent of Nicholas $\mathrm{V}$ in his restoration of papal authority.

The question of the Donation of Constantine was taken up by Valla as a purely historical and critical study. His method was His Critical simply that which had become familiar in classical Method scholarship. He examined the document on its merits in the light of history, grammar, law, and common sense, and from all these points of view was able to show that it must have been a much later forgery. The most interesting thing about the exposure is the amazing ease of it. It does not prove the great learning or cleverness of the author, for neither of these was needed. The moment that the bare facts were held up before the world of scholars the whole tissue of absurdities fell to pieces of its own weight. Since Valla's time no scholar has been found 
who would risk his reputation in its defence. Of course Valla, after the manner of his kind, could not resist the temptation to spice his exposition with violent abuse of the whole hierarchical system. This was in $144^{\circ}$, when Pope Eugenius IV was at loggerheads with the council at Basel, which was supported by King Alfonso of Naples, under whose protection Valla was living. The analogy of Marsiglio of Padua attacking the Papacy under the patronage of Ludwig the Bavarian is obvious.

How purely this production of Valla was a literary performance and how little it indicated a truly reformatory spirit was shown Reconciled three years later (I 447) when his patron Alfonso with the made terms with the pope. Immediately the canny Papacy scholar began to petition for a place in the papal service. Without explicitly withdrawing any of his statements he professed the greatest regret at the offence he had caused and promised all kinds of fidelity to the Roman See. Friends at the papal court made it possible for him to come to Rome, but his monastic enemies made the place too hot for him and he was glad to get back to Naples under the wing of the liberal Alfonso. The death of Eugenius IV and the accession of Nicholas V (I 447) marked an entire change in the character of the papal court. Almost at once we find Valla in Rome without, so far as we know, the slightest reference to his former offences. He was given the title of "apostolic scribe" and intrusted by the eager pope with the translation of Thucydides. Later he became professor of rhetoric and eloquence at the University of Rome in place of the Greek George of Trebizond. Under Calixtus III he was made a papal secretary, received several benefices, and ended his days in the full favor of the papal government (1457). It is easy to see in these shifts of fortune proofs of Valla's lack of personal character; but it is fair to ask why he should have hesitated to take favors from an institution which had no more respect for itself than to be willing to give them. Low in his standards as Valla seems to have been, he was quite as good as the patrons, 
lay and clerical alike, who were ready to overlook any moral baseness in the men whose talents reflected a borrowed glory upon themselves.

In the pontificate of Nicholas V occurred that event which has so often been given a quite undue prominence in the story of the The Fall of Constantinople, 1453 Italian Renaissance, the capture of Constantinople by the Ottoman Turks under Mohammed II. It used to be almost a formula of the history books that the fall of Constantinople was the most potent cause of the revival of classical studies in Europe. Troops of Greek scholars, it was said, loaded down with precious manuscripts came over into the West and gave its astonished inhabitants their first adequate conception of the treasures of the ancient literatures. Our own studies up to this point will have made it clear that the classical impulse was native to the Western world, not due to any outside influence. It came as the natural result of a long process of civilization, and whatever was contributed to it by the crisis in the East could do no more than furnish added material for a work that had already been going on for more than a full century.

Long before 1453 the Turkish forces had occupied the country to the west of Constantinople and had gone raiding up the Danube Christian and valley. Then had begun that extraordinary mingling Moslem in of Christian and Moslem in the middle lands of the the Balkans Balkan peninsula which has gone on to this day. The doctrine of the crusading age had been a very simple one : "Death to the infidel! - no compromise, no diplomacy, no mercy!" But since the disaster of St. Louis in 1270 the fervor of the crusading spirit had steadily abated. The nations of Europe had had their hands more than full with the struggle for national existence. The growth of a new method of thought, in which the individual was the central object, tended to weaken all appeals to the Christian consciousness as a whole. The Papacy as the representative of that general conscience of Western Christendom did indeed from time to time renew the ancient cry of loyalty to the cross; but the 
Papacy itself was as deeply involved as any other state in the political complications of the moment, and its appeals remained unanswered. Even the dramatic episode of the Union Council of 1439, the last despairing effort of the Christian East to win the support of the Christian West against its Moslem foe, made little impression upon Europe as a whole. The one power which by its very definition ought to have gathered up the forces of Europe into one great host and driven the infidels across the Bosporus, the Empire, was in the hands of a Frederic III more concerned to round out the Habsburg lands and secure the revenues of his clergy than to spill good Austrian blood in saving Europe from the Turk.

Worse yet, the inhabitants of the country already conquered were beginning to learn what all later time has shown, that the General Indif- Turk with all his faults could at any rate govern and ference to the that their rights were quite as likely to be well guarded Turkish Peril under his iron rule as under the weak and shifting policy of Christian princes. The catastrophe of 1453 was, therefore, the result of causes that had long been at work and were well enough understood by the peoples of the West. Yet when it came it appears to have come with an almost overwhelming shock. With the base of supplies once well secured, there seemed to be no reason why the victorious armies of Mohammed should not come sweeping up the Danube and carry all before them. Critics of Nicholas $\mathrm{V}$ began now to ask : Why all this vast outlay upon buildings and manuscripts when every ducat was needed for the coming struggle? Only the pope, it was said, could rouse men to a new sense of their duty to Christendom, and the pope was spending his time with poets and scholars, architects and painters, while Christendom itself was in mortal peril.

Nicholas gave way to the criticism so far as to invite the powers of Italy to a conference with a view to some common action in case of a Turkish invasion; but the mutual jealousies of the several Italian states made such action on a large scale impossible. 
The only useful result was the formation of a league for the public peace for twenty-five years among the five great powers of the peninsula. It was the most impressive demonstration that Italy was at last weary of perpetual strife and ready, for the moment at least, to accept the status quo as the basis for all future relations. This league was the crowning act of the papacy of Nicholas $\mathrm{V}$ and was in complete harmony with the peace-loving character of this first of the Renaissance popes. 


\section{CHAPTER X}

\section{THE NORTHERN RENAISSANCE}

The most common and the most obvious criticism of the Italian Renaissance is its lack of moral seriousness. The men of Italy

Italian Renaissance at best from its scientific, side. Then, as in our own Indifferent to day, the cry was "Art for art's sake!" and it was Religion

precisely because a return to sound principles both of study and of artistic production without reference to the state of men's souls was so sorely needed that the Renaissance was able so profoundly to influence the course of human thought. If, for example, Petrarch and his immediate followers had begun a crusade against the evils of the papal system, of which they were perfectly aware, it seems clear that the Church could never have made its peace with them. Still less is it likely that it would have become, as it did, one of the most active promoters of the revived intellectual culture they represented.

The moment, however, we begin to study this same movement in the northern countries, we feel the difference in tone. For

Northern one thing, the impulse here is felt much later. The Renaissance originality of the northern mind was expressing itself Later

in Petrarch's day far more effectively through works in the popular tongues, such, for example, as Chaucer's (d. 1400) immortal national poem, than in efforts to imitate the language of Cicero. It is not until a full century from the time of Petrarch's greatest activity that we find the spirit of a revived classic enthusiasm really taking hold upon Germany, France, and England. But meanwhile the preparation had been making. On the whole it would be fair to say that, so far as outward equipment went, the 
culture of the North had been steadily gaining during the fourteenth and fifteenth centuries. Schools had been established; monasteries had in many places kept up a tradition of learning, such as it was, yet always without that peculiar stimulating of the individual mind which was to be the special mark of the Renaissance. Learning was still avowedly in the service of the Church.

Gradually, however, we can trace the influence of Italian culture beyond the Alps, and wherever it came it found a soil ready Beginnings for it. Let us notice first the conditions in Germany. in Germany If we were to judge merely by outward development, we should describe this period as one of unusual activity. The division of German political power into many separate units had prevented the formation of any one or two great centers of education, such as Paris in France or Oxford and Cambridge in England. The several states, definitely fixed by the Golden Bull of $135^{6}$, strove to display their individuality in this as in other ways. The University of Prague was founded in 1348 , Vienna in 1365 , Heidelberg in 1386 , Cologne in 1388 , Erfurt in 1392 , Leipzig in 1409 , and Rostock in 1419 . That meant a deal of energy put into the mechanism of education; but the results for the advancement of a sound classical culture did not correspond. The method was still the mediæval scholastic one, and the aim was primarily theological.

Somewhat better was the outlook in the preparatory schools. The lead here was taken by the so-called Brethren of the German Common Life (Fratres Vitae Communis), a semiPreparatory monastic organization founded in 1376 by Gerhard Education Groot of Deventer, in Holland. Their object was first to live a conventual life withdrawn from the stress of society and its ties, and secondarily to occupy themselves with the copying of manuscripts and the teaching of the young. They spread widely through the Low Countries and northern Germany and produced some of the most noteworthy characters in the history of learning in our period. It is eminently characteristic of the 
difference between North and South that while in Italy the intellectual impulse came from above, a few great leading minds striking out a way for themselves and drawing others after them, in Germany the work began at the bottom with the slow building up of a system of elementary education, out of which leaders were to be developed. The process is long and obscure. No brilliant names mark its progress. Only here and there emerges some individual of exceptional talent and energy, who goes personally to the Italian fountainhead and brings back a more refined literary taste and an improved method of teaching. Such, for example, were Peter Luder, a wandering teacher of the classics at several German universities in the third quarter of the fifteenth century ; Alexander Hegius, headmaster of the school at Deventer when Erasmus of Rotterdam was a pupil there about 1480 ; and Rudolf Agricola, who was the most important teacher at the University of Heidelberg in the last years of the century. No one of these men can be called an original thinker or in any way a contributor to knowledge. They were essentially schoolmasters; they had little of the reforming spirit; but they mark the turning point in the movement of the German people from the narrow formalism of the scholastic world to the larger and freer methods of the New Learning.

The development of a new intellectual life in Germany was almost wholly a native process. Foreign, especially Italian, visiting Work of Con- scholars; such, for example, as Poggio and Chrysoloras rad Celtis, at the Council of Constance ( $\left.14^{1} 4^{-1} 4_{1}{ }_{9}\right)$ and Eneas 1497-1492 Silvius Piccolomini at the Council of Basel (1 431 I448), seem to have had little if any direct influence. They speak of the rude, barbarous character of the Germans; but much of that kind of criticism must be taken as purely conventional. To the Italian everything outside of Italy was " barbarous." A quite special work was that of Conrad Celtis, who in the years 1487I492 was chiefly occupied in founding in Poland and parts of Germany learned societies for the promotion and encouragement 
of classical studies. Doubtless modeled on the already flourishing "Academies" of Florence and other Italian cities, these associations were not destined to have any very great or prolonged influence. They serve, however, to show us how far the sense of a common interest had gone among the Germans of the first truly humanistic generation. Celtis, who during his life had taught at several universities and who has left a considerable volume of writings, seems to have impressed his serious fellow countrymen as rather too strongly tinged with Italian frivolity and indifference to religion. He marks the transition to that stage of German humanism when it was bound by its very serious nature to rouse the suspicions of the Church. Of this second stage the most important names are those of Johann Reuchlin and Desiderius Erasmus.

Reuchlin represents the type of the scholar pure and simple, the man whose interest is in learning all he can about the subject Johann

Reuchlin, I455-1522 he cares for without greatly concerning himself with its application to life and especially without inquiring what its effect is going to be upon himself or upon existing institutions. As a young man, after completing his Latin education, his first thought was to make himself master of Greek, and this accomplished he proceeded to take the almost unheard-of step of learning Hebrew as well. His difficulties in this effort were similar in kind and in degree to those of the earlier Italian scholars in acquiring a knowledge of Greek. There were no professional teachers of Hebrew, for the excellent reason that there had so far been no demand for their services. As far back as the early thirteenth century attempts were made to found chairs of oriental languages at several universities for the purpose of equipping missionaries to the Jews and Mohammedans, but these seem to have been practically without educational result. Not only had there been no scientific interest in Hebrew study but there had been a suspicion attaching to all occupation with the literature of the proscribed and hated people to whom, nevertheless, Christianity 
owed so important a part of its own sacred books. Reuchlin's purpose was undoubtedly at first to acquire a first-hand knowledge of the canonical Hebrew scriptures, but his scholar's spirit would not allow him to be satisfied merely with that. After he had, with the help of such teachers as he could get, mastered the mechanism of the language, he turned his attention to that mass of later Hebrew literature which, under the names of the Talmud and the Kabbala, had accumulated upon the canonical stock.

It was these writings which were the especial objects of suspicion to the unlearned, Jew-baiting orthodoxy of the dominant Reuchlin and Hebrew inquisitors of the district of Cologne an unusually Literature vicious assault was made upon these books in the years 1508-1510, and the support of the emperor Maximilian I was sought in this holy endeavor. Fortunately Maximilian, who prided himself upon his interest in all things of the intellectual life, had the good sense to intrust the matter to the general guidance of the enlightened bishop Uriel of Mainz, who in turn showed his practical wisdom by consulting Reuchlin as an expert in Hebrew. The question referred to him was whether the noncanonical books of the Hebrews contained matter dangerous to Christianity and ought therefore to be destroyed. His reply that it might safely be left in the hands of its possessors, since it was rather a confirmation than a danger to Christian faith, brought Reuchlin into a furious controversy with the Dominicans of Cologne, which was, without intention on any one's part, the opening up of all the long-gathered hostility to the system they represented. We are not concerned here with the theological questions or the race hatreds involved. Our only interest is to notice how this famous quarrel reflects the great intellectual stirrings of the humanistic age. Reuchlin's real offence was not in this or that opinion as to kabbalistic errors or crimes; it was in his attitude of fearless examination of all materials that might aid him in the search for truth. Above all, it became his duty 
as a faithful student of the Hebrew and Christian scriptures to show frequent errors in the Latin translation, the so-called Vulgata, the sole authorized form in which these scriptures had for centuries been used by Christian scholars. It was in many respects a defective translation, and it became Reuchlin's duty as an honest scholar to say so.

There has never been a more noble defence of toleration than Reuchlin's Memorial (Gutachten), written in German and sent to Bishop Uriel, October 6, 15 I 0 . It has its practical purpose - to show the value of Hebrew learning in preparing Jews to become so much the better Christians; but every now and then crops out the true spirit of religious liberty - the right of every man to his own form of faith.

"If the Talmud ought to be burned, it would have been burned hundreds of years ago; for our forefathers were more devoted to

Reuchlin's Memorial, 1510 the Christian faith than we are now-a-days. But, so far as I can recall, I have never read that any one demanded or wished to have the Talmud burned except the two brethren, Peter Nigri of the Dominican order and John Pfefferkorn, the baptized Jew, both of whom lived in my day and with both of whom I have spoken. I am not blaming them; for they are zealous in God's service, but not according to understanding. But the others who were before us, very learned men and far better instructed in languages, although they wrote bitterly against the Talmud, did not wish it to be destroyed. They felt about it like a noble huntsman whom I have seen chasing a stately deer of many points across a wide plain. Though he knew the deer could not escape him, yet he would not have him slain with spear or gun; he would rather chase him than kill him. So with the wise and learned, who desire to combat the Talmud with reason and skill. What praise could they win? How could they show themselves to be well proven scholars and masters of Christian learning, if the book were burned and gone? 
"People say that these books throw contempt upon Jesus, Mary, and the twelve Apostles, upon us and our Christian order. That were a serious charge, and so I examined first the books against which it was made, but could find only two. In the others I find no slanders. For, as to belief, they say their belief is right and ours is wrong. You will find some Jews who maintain that each nation ought to be protected in its own faith, and, as the laws of Moses are not binding. for us, so they are not subject to the commands of Jesus, but are bound to keep the law of Moses, since God gave it to them and to no one else, whereas we are bound by the law of Jesus, since God gave it to us. Therefore all their writing, that Jesus is not God and all that follows therefrom, this is their faith and no offense to any one. And this the Christian Church has borne for thirteen hundred years and has not taken it as an insult.

"If we had no outsiders to dispute with, such as Jews or heathen, we should be quarrelling among ourselves,- - since the human mind never stops working - setting up new opinions or raising the old squabbles, as is happening now with the question of the immaculate conception of our Dear Lady, and whether St. Paul had a wife, and whether St. Augustine was a monk and many another foolish thing. This is because we have no one who dare speak against us or against whom we have to fight.

"But now, even supposing the Talmud were the cause why the Jews do not become Christians, that does not give me the right to seize and burn what belongs to some one else; for that is not for me to decide. 'The Jew is God's man as well as I; if he stand he stands to his Lord, if he fall he falls to his Lord. Every man must give account of himself. How shall we condemn the soul of another? God must be strong enough to sustain him.

"In fact, I can give no better advice according to my poor understanding, than this :- That His Imperial Majesty for the sake of God and our Christian faith, give order that every university in the German lands shall maintain for ten years two masters to give the 
students and scholars instruction in the Hebrew tongue. Further, the Jews who live in our country shall lend us their books voluntarily and in neighborly fashion and under suitable safeguards, until by means of printing or hand copying we may procure our own copies. In this way I have no doubt that in a few years our students will be so learned in the Hebrew that they can teach the Jews with reasonable and friendly words and bring them over to us."

There followed a war of pamphlets, none too nice in their method on either side. It was not the fault of the Cologne inquisitors that Reuchlin, the Reuchlin was not regularly tried and perhaps put to Champion of death as an obstinate heretic. He was saved by the Enlighten- liberality or the indifference of the governing powers
ment and upheld by the enthusiastic approval of all men of enlightenment throughout the country. His most splendid service to learning and progress was in making perfectly clear that the real issue was between a timid clinging to antiquated and meaningless methods on the one hand and a full and free inquiry, with every possible means of enlightenment, on the other. Reuchlin was not the man to lead a crusade, but, without his own motion, he was put forward as the champion of all that was best and most forward-looking in Germany. Nothing quite like his position was held by any man in Italy. The name "Reuchlinists" was commonly used to distinguish the "men of light" from the men of darkness. To show how thoroughly the world of learning was on his side Reuchlin published in $\mathrm{r}_{5} \mathrm{I}_{4}$ and again much enlarged in 1519 a volume of letters received by him from distinguished scholars (clarorum virorum epistolae latinae, graecae et hebraicae variis temporibus missae ad Johannem Reuchlinum).

It was, perhaps, this title that suggested that of another far more famous collection of letters, the most remarkable and the most effective publication of the whole northern humanistic movement, the "Epistolae Obscurorum Vironum." These were satirical compositions addressed to a certain Ortuinus Gratius, professor of the 
classics at the University of Cologne. The first batch of them, which appeared in 1515 , was probably contributed by a group of The "Epis- the younger German Reuchlinists under the general tolae direction of Crotus Rubianus, at that time professor in Obscurorum Erfurt. It is probable also that the greater part of these

were written by Rubianus himself. Two years later appeared a second and larger volume of similar letters written by Ulrich von Hutten, the most brilliant of the German humanists and later one of the most ardent defenders of the Lutheran Reformation. These letters of men described as obscuri or "men of darkness" in distinction from Reuchlin's correspondents, the clari or " men of light," were humorous imitations of the old scholastic methods of disputation and definition. The imitation was so clever that at first it fairly puzzled the learned world, especially that part of it which was held up to ridicule. Rapidly, however, the joke came out, and a storm of applause arose from every quarter. It must be admitted that the "Epistolae Obscurorum Virorum" are coarse and vulgar in tone; but so was the taste of the day. They hit hard; but.they were striking at things that deserved exposure. They mingled personal abuse with learned criticism ; but they were aimed at a charlatanism of learning that was only too likely to serve as a cloak for personal folly or vice. Above all they served to array still more clearly over against the forces of mere conservatism all the hopeful and forward-looking elements of northern society. Men who were indifferent to serious criticism were acutely sensitive to this unsparing ridicule.

The following is a specimen of the less offensive of the Epistles (II, 23).

Magister Bertholdus Hackstro to Magister Ortuinus Gratius :

"Brotherly Love in place of Greeting! Honored Sir! According to the promise I made when I left you, that I would write you all about everything, and let you know how it goes with me, I must tell you that I have now been two months in Rome and have not 
been able to find a patron. There was one assessor of the Rota who was willing to take me on, and I was glad enough and said 'That would be fine, Sir; but will Your Magnificence kindly tell me what my duties will be?' He replied that I should work about the stable and should have to keep a mule in good shape, feed him and water him, curry him and clean him and have him all ready when his master wished to ride, with saddle and bridle and everything in order. Then I should have to run along with him to his audience and back home again.

"I said that was no job for me; I was a Master of Arts of Cologne and could not possibly do such things as that. He replied : 'Well, if you don't want to do it, so much the worse for you.' So I think I will go back to my own country. If 'I had got to curry a mule and clean out a stable : - the Devil take the mule and the stable too! But I believe it would be against the statutes of our university ; for a Magister must conduct himself like a Magister, and it would be a great scandal to the university if a Cologne Magister should do such things as that. So I want to come back to my country for the honor of the university. Besides, there are other things that don't please me at Rome. The copyists and court officials are impudent beyond belief. One of them said to me yesterday that he would just like to play a dirty trick on a Cologne Magister. "Play your dirty tricks on the gallows !".said I.

"Then he said he was a Magister, namely of the Curia, and a Magister of the Curia was a better man than a Magister Artium of Germany. 'Not possible,' said I. 'You think you are as good a man as I; but you have never stood an examination as I have, with five Magisters examining me strictly; you are only a Magister by diploma!' 'Then he began to argue with me and said: - 'What is a Magister?' I answered ' $\mathrm{He}$ is a qualified person, promoted and graduated in the seven liberal arts after a Master's examination, and he has the right to wear a gold ring and a silk lining to his gown and can treat his pupils as a king his people. And he is called Magister for four reasons: First from 
the words magis and ter, because a Magister must know three times as much as a plain person; second, from magis and terreo, because the Magister ought to be a terrible person in the eyes of his pupils; third, from magis and theron, that is station, for the station of the Magister should be higher than that of his pupil; fourth, from magis and sedere because the seat of the Magister should be higher than that of any one of his pupils.'

"Then he asked me:- 'Who is your authority?" I replied that I had read this in my vade mecum, and at once he began to abuse that work and said it was not authoritative. I answered him: 'You see fit to abuse those ancient authorities, but you don't know any better yourself. I never heard anybody at Cologne find fault with that book. Have you no shame in you ?' And in great wrath I left him.

"So take notice that I want to get back to Germany where Magisters are lords, - and with reason; I can prove it by the Gospel ; for Christ called himself Magister and not Doctor, saying:- 'Ye call me Master and Lord, and ye say well; for so I am.' But I cannot write any more, for I am out of paper, and it is a long way to the Campo di Fiore. Farewell.

"Given at the

"Court of Rome."

The following passage from Epistle I, 42, is a fair illustration of the satire against scholastic learning. The writer is supposed to be a medical student at Heidelberg, where he meets Erasmus of Rotterdam at dinner. He gives Master Ortuin his opinion as to the scholarship of the famous humanist.

"In a pause of the conversation he began preaching with a long preamble, but by the honor of my mother I never understood a word of it, he spoke in such a little voice; but I think it was about theology so that he might draw out that Magister Noster, a profound theologian, who was seated with us at table. So, when his 
preamble was at an end, Magister Noster began to discuss most subtly about being and essence, but I don't need to repeat this because you have thoroughly treated that subject. When he had finished Erasmus replied briefly and then all were silent. Then our host, who is a good humanist, began to speak about poetry greatly praising Julius Cæsar both for his writings and for his deeds. I saw my chance, because I had read and heard much about poetry from you when I was at Cologne and so I said:'Now since you are speaking of poetry I can contain myself no longer, and I must say in all simplicity that I do not believe Caesar wrote those Commentaries, and I will back up that opinion with this argument: "He who is continuously occupied with military affairs has no time to learn Latin. But it is certain that Caesar was always fighting and working hard. Therefore he could not learn Latin and be a learned man. So I am convinced that it was none other than Suetonius who wrote those Commentaries, for I have never known of any one whose style was more like Caesar's than is that of Suetonius." ' After I had said this and a great deal more which for brevity's sake I will not repeat here, — for you know the ancient saying: 'The moderns delight in brevity' - Erasmus laughed and made no reply, for I had conquered him with my subtle argument l"

Ulrich von Hutten, the acknowledged author of the second book of the "Epistolae Obscurorum Virorum," stands as the type Ulich von Hutten, I488-I523 of the man of the world under the spell of this revived interest in classical study. He was born in 1488 of a noble Swabian family. Educated at first for the military career, he was then placed in the ancient monastery of Fulda, but escaped from there in 1505 and thenceforth devoted himself to a life of literary knight-errantry. For a time he attached himself to the fortunes of the circle of pupils gathered about the famous Mutianus, the most popular of the Erfurt teachers, but it cannot be said that he ever had a fixed place or occupation in the 
world. His profession, so far as he had one, was that of "Poet." The crown of "Poet Laureate," given him by the emperor Maximilian in $\mathrm{I}^{\mathrm{I}} \mathrm{7}$, was better deserved than it was by most of the Latin rhymesters to whom the rather foolish custom of the time awarded it. He had command of a ready and accurate Latin style and, what was more to the purpose, he had something to say. Hutten interests us chiefly through his ardent sentiment for German nationality. Classicist though he was by profession and by taste, he was above all else a son of the Fatherland. He took a holy joy in the complication of events that was forcing Germany into the lead in the movement for religious freedom, and in him more than in any other man we can trace the process by which the New Learning was leading over into the New Religion. Hutten believed, and acted on the belief, that it was the duty of the scholar to apply his learning and his skill in the open partisan conflict of his generation.

Not so Desiderius Erasmus, the third in the great German humanistic triumvirate. Erasmus was born in Rotterdam about

Desiderius

Erasmus of

Rotterdam, 1466-1536 I 466 and died at Basel in Switzerland in 1536 . He was throughout life a man without a country and without a family, allied with no party, serving no single patron, affecting to despise all honors, yet with enough of the spirit of the reformer in him to keep him in a perpetual attitude of criticism against the social order in which his lot was cast. The best comparison we can make for him is with Petrarch in Italy four generations earlier. As Petrarch felt himself in his day qualified to be sole judge of all things by right of his learning in the ancient classics, so Erasmus in his day and in the north. $\mathrm{He}$ is the most marked type of the individual in the northern Renaissance. As a child he was put into the famous school of Deventer, where, as he says, under the direction of the excellent Alexander Hegius, the breath of the new spirit of "good letters" was just making itself felt. The teaching was still "barbarous," but the influence of Agricola and other young German scholars fresh from the Italian journey was working a gradual change. 
At seventeen Erasmus entered a house of Augustinian canons at Steyn near Gouda, in Holland, and spent there ten busy and not unhappy years. The plentiful leisure of the monastery, with an abundance of good books and sympathetic friends, gave him the opportunity for that thorough grounding in Latin style which was to be the foundation of his success in life. A persistent diligence, a real joy in work, a literary impulse which needed rather rein than spur, and an all-pervading common sense that flowered out continually into an irresistible humor - this was the equipment which carried Erasmus forward and upward to leadership among men.

His development was slow and uncertain. He was over thirty before he published the first compilation of classical and other Erasmus's quotations with a running commentary, the "Adagia," Personal by which he became known to the world of scholarDevelopment ship. His first great satirical work, the "Praise of Folly," he wrote at forty-three, and his monumental first edition of the Greek text of the New Testament he published at fifty. Meanwhile, however, he had been prolific in treatises on a great variety of subjects. He had written a mass of letters, many of them essays in themselves, addressed to an immense number and variety of persons, and he had traveled and resided for longer or shorter periods in all the principal countries of Europe. Following the keynote of independence struck from the beginning, he never, so long as he lived, placed himself in any position of permanent obligation. He was a priest, but he would accept no benefice with the cure of souls. He could discourse on the art of teaching with admirable sense, but personally he hated the work of the teacher and refused offers of honorable positions at the chief universities of Europe. He wrote extensively on the ills of human society, especially of the Church, but he would not associate himself with any organized effort to better them. He "enjoyed poor health" all his life; but he was no sooner fairly comfortable in one place with friends about him than he must be off to another circle of friends and some more - or usually less - congenial surroundings. 
In other words, Erasmus stands out from the society of his time as an independent figure, yet compelled by his very nature to seek Erasmus the sympathy and opportunity in contact with all the Preacher of dominant elements of the life about him. He was Righteous- not content to be a mere critic; he must needs apply ness

himself directly to helping in his own fashion towards a regeneration of the society he seemed to despise and to avoid. More like Petrarch than was any one of the later Italians, Erasmus was throughout the preacher of a righteousness that was to be based upon a true culture and upon a simple, unceremonial Christianity. From the outset he ranged himself on the side of the traditional dogma and of the institutions that went with it; only he would have both doctrine and institutions purified and simplified by going back to the spirit which, as he conceived, originally animated them. His earliest declaration of principles is

The made in the little book written in 1503 , called the " En"Enchiridion chiridion Militis Christiani," which means the "HandMilitis Christiani" book (or Dagger) of the Christian Gentleman." In this interesting little treatise Erasmus enlarges upon the theme of a sincere piety showing itself not by formal acts under the dictation of the Church but by a life lived in the spirit of Christ and the Apostles. During his first visit to England, in 1498-1 499, he found himself for the first time in a circle of scholars who were models of seriousness in their several professions, all of them filled with the spirit of Italian culture, but all bent also upon applying this culture to the moral and spiritual elevation of their people. From this moment the character of Erasmus seems to have been determined. He declined an urgent invitation from his friend John Colet to stay in England and work with him in the study and teaching of a pure theology. His restless temper prevented that. But it seems clear that he then and there made up his mind to devote his life to letters and always to place his learning at the service of an advancing ideal of Christian society. 
It was a resolution not easy for a man of Erasmus's quality to keep. His keen humor, his sound sense, his good taste, and his Erasmus in fatally ready pen were so many temptations leading the Service him over into the frivolous, pretentious, and indifferent of Religion humanism of the Italy of the Medici and the Borgias. It is his immortal fame that through a long life with many weaknesses and follies of its own, he held himself and others in the main true to his ideal of a humanism realizing itself in Christianity. His chief monument on his more serious side is his edition of the Greek New Testament with a Latin translation published in 1516 , just on the eve of the Lutheran Reformation. It was a service quite in line with that of Reuchlin in bringing men to interest themselves in accurate scholarship as applied to the original documents of the Christian faith. The work was none too well done. It was rushed ahead somewhat hastily and was deservedly criticized, but it had the great merit of opening men's minds to the idea that sound scholarship was not hostile to a reasonable faith, and thus gave an impulse to the study of all Christian literature, which has gone on to this day. In reply to his critics Erasmus made the noble defence that while they had waited for perfection he had done the work and in his own poor way had laid the foundation on which others more learned than he might build.

Erasmus lived in the time of the first great triumphs of the art of printing. He became an invaluable aid to publishers who Work as were trying to supply the world for the first time with Editor authentic texts of the greatest writers in both the classic and the Christian literatures. In Venice he lived for many months in the familia of Aldus Manutius, from whose press came repeated editions of his "Adagia." At Basel he spent years in close intimacy with Johann Froben, for whom he superintended the publication of the works of Jerome and of several other early Christian writers.

But meanwhile Erasmus was never altogether serious. $\mathrm{He}$ worked not merely with the weapons of theological scholarship 
but also, and at the same time, with those of satire and keen invective. Of all his writings the "Praise of Folly," written, as he tells The "Praise us, while he was on his way from Italy to England in of Folly," 1509 , is probably the most widely known and in its day 1509 was probably the most popular and effective. It is the natural complement to the "Epistolae Obscurorum Virorum," and soon brought upon its author the same kind of odium into which the "Reuchlinists" had fallen. Under the figure of an academic audience made up of fools Erasmus typifies the various sorts of weakness and folly that mark the several classes of human society. To this audience he makes the Genius of Folly personified as a female professor deliver a series of discourses adapted to the various groups of her hearers. All come in for their proper share, but none quite so completely as the clerical and monastic fools with their supporters, the scholastic theologians. For these he has only scorching satire, directed above all else at what seemed to him the hypocrisies of their position. It was their false learning, false piety, false logic, and sham morality that stirred him to attack. And yet for many of the classes of human folly he has a real and appealing tenderness. By "folly" he means in many places a true simplicity in contrast with a worldly prudence and sophistication. The type of this kind of foolishness is the child, in whom wisdom and prudence are monstrosities. Such also are women, whose impulses are worth more than the carefully considered policies of the philosophers.

The same prevailing motive of a sincere piety in distinction from the formalisms of authority runs also through the hardly less famous

The Colloquies
Colloquies or Dialogues, published in successively enlarged editions from 1500 to 1523. Here Erasmus lashes the obvious corruptness of the clerical life with unsparing ridicule. And yet he steadily insists that he is no enemy of Christian institutions, but only of their errors and abuses. He has a good word in reserve for everything - Papacy, monasteries, pitgrimages, confession, even miracle-working saints, provided only that all these things can be properly administered. They ought, 
he thinks, to be kept for the right use of the right sort of people. On the other hand, he had the natural scholar's dread of action, especially of any action that seemed to threaten the overthrow even of corrupt institutions. He professed to disapprove of the "Epistolae Obscurorum Virorum " on account of their violent and personally abusive tone. He defied any one to point out any word of his directed against any individual; he declared that he had nothing to do with the quarrel of the Reuchlinists, and when Luther began to pound away at the evils of the Church, Erasmus exhausted language to show that he not only disapproved of him, but that he had never so much as read a word of his writings.

Thus we see the three great pioneers of modern German culture, Reuchlin, Hutten, and Erasmus, each in turn and each in his The English own fashion applying his new intellectual energy to Humanists the service of religion. The same trait of intellectual seriousness is eminently to be seen in the contemporary group of English scholars in whose company we found Erasmus at the outset of his career. John Colet was the son of a merchant and ex-mayor of London. Born in the same year with Erasmus (1466?), he John Colet, received the best education possible in England, then ${ }_{1466-1519}$ spent some time in Italy, and on his return ( 1496 ?) began at once to give lectures at Oxford on the Epistles of Paul. So novel was the idea of a scientific and critical study of the Bible that Colet was not, it would appear, regularly appointed as a public teacher but taught privately; that is, probably without pay. Yet, says Erasmus some three years later, every person at the university, old and young, professors, doctors, and students, flocked to these lectures, so fresh and stimulating was Colet's method as compared to that of the earlier, purely scholastic interpretation. What distinguished Colet's view of scripture was the element of personal judgment and individual, spiritual insight. He published little, so that we are dependent for our estimate of him upon the praise and the criticism of his contemporaries; but both praise and blame emphasize the same point, and it is in this quality of individuatity 
that we recognize the full meaning of the New Learning. In 1504 Colet was made dean of St. Paul's cathedral at London and in the year following came into an ample property which he devoted almost entirely to founding a school for boys, the still existing St. Paul's School. This is the chief monument to his faith in the value of the new intellectual method. He watched over the fortunes of the school during his life, procured enlightened teachers, drew up statutes for its government which secured its liberal character, and saw to the making of sound classical textbooks for its pupils. The personality of Colet as it appears in the sketch of him written by Erasmus very soon after his death, in 1519 , is the perfect expression of the modest, sane, cautious but fearless Christian scholar as the fairest product of the Northern Renaissance.

Two friends of Colet deserve mention here as still further expressing the spirit of northern scholarship. William Grocyn

William Grocyn, 1446-1519 (c. $1446-1519$ ) is remembered chiefly as perhaps the first person known to have given instruction in Greek in England. He may have done this at Oxford even before his visit to Italy in 1488 , and he certainly taught there after his return in 1490 , and continued his work at intervals for about ten years, when he went to London and afterward held various church benefices elsewhere. Grocyn also published little, but appears in all accounts of the English literary revival as associated with all its important men and events. Erasmus frequently mentions him as a man of exact classical learning, so exact indeed that he could never satisfy himself in his compositions and therefore could not bring himself to the point of publication. Like Colet he adjusted himself easily to the prevailing system of church holdings and left a handsome property to his executor, Thomas Linacre, to be spent in the promotion of sound scholarship. It was afterward applied to the purchase of Greek books for Oxford students.

This same Linacre (1 460 ?-1524) illustrates another aspect of the practical English Renaissance scholar. He got his early education at Oxford, acquiring there perhaps the rudiments of Greek. 
and then went to Italy for a residence of several years. In Italy he was for a time in the company of Colet and Grocyn. Here

Thomas

Linacre, $1460 ?-1524$

his attention was given especially to the study of medicine. He took his M.D. at Padua and on his return received the same degree from Oxford. From about 1500 on he led a curious triple life, first as an ecclesiastic holding several important benefices, doing no work to earn the income from these holdings, but spending it in maintaining his two other qualities as humanist and physician. It is hard to say under which of these two aspects we are primarily to think of him, whether as a professional man pursuing learning as an avocation or as the scholar pure and simple. His contemporaries were equally enthusiastic about him in both characters. Yet he does not seem to have been a man of great original talent in either capacity. He was a master of the Latin tongue and had learned Greek well, but his chief Latin productions were translations from Greek medical writings and some not very important grammatical textbooks. Nor have we any record of his especial success as a practitioner. He was physician to the young prince Arthur, was then made one of the king's medical attendants, and finally physician to the five-year-old princess Mary, but none of these functions seems to have implied any very serious duties. The only service he rendered the baby princess was to write her a Latin grammar. The really important work of Linacre's life was the foundation and endowment of the College of Physicians, still existing as a monument to his far-seeing intelligence. The chief function of this college was the licensing of physicians, at first in the region immediately about London and then throughout the whole kingdom. The effect of this system could only be to redeem the practice of medicine from the foolish superstitions of previous ages and bring it once more, as it had been in the ancient world, to the test of a reasonable scientific method. The study of man as a part of the physical universe was thus elevated and dignified and set in its right proportion in the whole scale of intellectual occupations. 
The fourth and in many ways the most important member of this English group is Thomas More (1478-1535). He too was a

Thomas

More, $147^{8-1535}$ Londoner, the son of a successful barrister and given a good early education with a view to preparing him for the law. At Oxford he made the acquaintance of Colet and may have known Erasmus also at this time, but he was recalled to London by his father, who feared for him the too great attractions of classical study. He became a lawyer of great distinction, attaining in time the highest position possible to an English subject, that of Lord Chancellor of the realm. He was a man of many and varied interests of the most important kinds, leading always an exceedingly busy life but never losing for a moment his early love of pure literature. His especial happiness was in this side of his activities. His patronage of learning in his time of prosperity was generous and wise, and in his adversity he found his best consolation in the charm of learned intercourse. His correspondence with men of letters was wide, and his judgment on purely literary questions was sound. His most famous work is his immortal " Utopia," the fanciful description of an ideal state where the prevailing evils of English society were all to be avoided. It is a clever satire upon his own countrymen, but it is much more than that. It is a work of striking original suggestion along many lines of political and social progress that have never to this day been effectively followed. It is a clear illustration of the Renaissance spirit, because it is the expression of a pronounced individuality setting itself up in judgment upon the men and institutions of his time.

But More was a lawyer as well as a humanist, and it is this fact which probably more than any other determined his tragic fate. As a lawyer, trained in the practice of the most conservative of professions, he could not lend himself easily to ideas and policies that seemed to him likely to overthrow the institutions he had spent a lifetime in defending. He believed that King Henry VIII in trying to place himself above all other powers within the realm 
was going beyond his constitutional rights, and, being the man he was, he could not act against his belief. He died as he had lived, the steadfast defender of the faith and the religious system of his fathers. This is not the stuff of which most disciples of the New Learning were made.

The English group thus illustrates as well as the later Italian the application of humanistic studies to the several professions and to every form of public life.

\section{THE RENAISSANCE IN FRANCE}

The movement of the Renaissance in France is later in time and more independent in character than elsewhere in the North. French Clas- The energy of the French people seems to have spent sic Revival itself during the fourteenth and fifteenth centuries Late

largely in the great struggle for national unity. What interest in the intellectual life there was through this stormy period is expressed chiefly in a kind of dilettante enthusiasm on the part of kings and princes for fine books in beautiful bindings and with charming illustrations, the work of a school of miniature painters which was destined to influence profoundly the taste of the generations following. With the contents of books these courtly. patrons were less concerned. Of the glowing enthusiasm of contemporary Italians for the classic literatures there is little trace.

Influence The learned world of France was still dominated by of the University of Paris the University of Paris. That fatal concentration of French intellectual life in and about the capital city, which so often later was to react unfavorably upon the national development, was beginning already in this period to have its effect. The university, the stronghold of tradition, was still under the mediæval, scholastic spell and little inclined to change its methods or to allow free play for individual activity. To Petrarch in the fourteenth century, as later to Erasmus in the sixteenth, the prevailing tone of French culture seemed barbaric. 
Yet all this while there was developing in France a national literature in the native tongues which in its own way was the expression of a growing taste and refinement of thought more truly modern than any of the products of the artificial classicism of Italy.

Jean de Montreuil (c. $\left.1355^{-1} 418\right)$ is the earliest Frenchman to whom the name "humanist" can properly be applied. Born Jean de within a year of the battle of Poitiers, he passed his Montreuil, early life in the midst of the struggle for French c. $1355-1418$ nationality as against English supremacy. In the last stages of that conflict he lost his life at the capture of Paris by the Burgundian party, a victim to his loyal devotion to that OrléansArmagnac faction which seemed to him to represent most truly the national cause. Meanwhile he had spent his life mainly as a royal secretary. In this capacity he was called upon to write many and voluminous letters, which in true humanistic selfglorifying fashion, he collected and published. With very few exceptions these public letters are lost, but we are fortunate in having a considerable number of Montreuil's private epistles, from which we gain a fairly distinct impression of his quality.

The phrase which has been applied to him, "a Petrarch in little," gives this impression in brief. Like another Italian, his Montreuil's model in many respects, Coluccio Salutato the FlorenIndividuality tine secretary, he had an extravagant admiration for Petrarch as the restorer of ancient culture to a benighted world. He too was a man filled with the importance of his own interests, proud, contemptuous of others, boastful of his lofty ideals, but in practice far from living up to them. Like Petrarch he had no hesitation in accepting church benefices, provided only that he was not held to any duty connected with them. His attainments as a Latinist were limited at best, and he probably had no knowledge whatever of Greek. What distinguishes him among the Frenchmen of his day is this character of individual self-assertion. He was ready to pass judgment on all subjects according to the supposed standards of ancient culture. 
Montreuil is interesting also through his devoted patriotism. The indifferent cosmopolitan tone so marked in many of the Italian humanists gives place in him to an almost savage loyalty to France. He hates Englishmen and Germans and Italians chiefly because they are not Frenchmen. Charlemagne is to him the type of the French nation. Even the political distraction of his country cannot turn him from this ardent devotion. He travels and deals officially with men of other countries only to conclude that nowhere is so noble a race to be found as that of his beloved Frenchmen.

Nicholas de Clémanges (c. $1360-c$. 1434), secretary during several years to the Papacy at Avignon, might on first thought be Nicholas de compared to his contemporary Poggio Bracciolini, Clemanges secretary to the Papacy at Rome. Clémanges also was famous for a ready and refined Latinity and doubtless owed his official appointment to this accomplishment; but there the resemblance ceases. We have had to characterize Poggio as perhaps the worst type of the flippant and too clever humanism of the South. Clémanges is known to the later world chiefly through his unsparing criticism of the papal administration as he had seen it in the course of his regular occupation. His best-known work is a treatise on the corrupt state of the Church. As age drew on he withdrew himself more and more from contact with the world of affairs. His aim, he now declares, is to devote his learning and his skill in writing (eloquentia) to the service of religion. Only in his letters, addressed to Jean de Montreuil and to his university colleagues and examples, Jean Gerson and Cardinal Peter D'Ailly, do we find the liveliness and the humane literary quality which give to Clémanges a claim to be counted among the humanists.

Of Gerson and D'Ailly it must also be said that, while they were in their day the chief ornaments of French scholarship, Jean Gerson they cannot be described as essentially humanistic in and their attitude toward life. Their uncommon learning Pierre d'Ailly and talents were spent mainly in their reformatory activities during the conciliar period already noted. 
Thus in every European country, in varying degrees and in forms peculiar to the national genius of each, we find the spirit Triumph of the of the new scholarship making its way and gradually Humanistic chief of these obstacles was the conservative temper Culture of the dominant elements in the Church and in the universities. To these pillars of mediæval society the fearless curiosity, the unrestrained criticism, the biting humor of the "new," scholars seemed to presage the ruin of their most precious traditions. Many of these instincts of conservatism were amply justified. There was for a time and in many quarters a riot of "free thought" masquerading under the forms of the classic "culture" which threatened the very foundations of the Christian commonwealth. The Church itself was swept into the current of this heathenized thinking. It was saved, and European society was saved with it through the nobler interpretation given to the classic enthusiasm by the more serious and constructive scholarship of the North.

The universities, creations as they were of Church and state, clung longest to the scholastic forms and the traditional methods In the of the established order; but gradually this opposition Universities too gave way and chairs of advanced instruction in the classic languages and in Hebrew were incorporated into the ancient academic mechanisms. The new spirit of thoroughness and accuracy, the right to differ, the respectableness of curiosity, became the moving forces in that great readjustment of the European world to which, whether we face it from the conservative or from the progressive side, we give the name of the Reformation. 



\section{INDEX}

Adolf of Nassau, emperor, 76-78

"Africa," the, of Petrarch, 470-47 I

Agincourt, battle of (I4I5), 295297

Agricola, Rudolf, teacher at Heidelberg, 5 II

Aiguillon, English besieged at, 264

Albert I of Austria, emperor, 76, $77-81$

Albert II of Austria, emperor, 346, 356

Albert III, duke of Austria, defeated by the Swiss at Näfels, 184

Alberti, Leon Battista, universal genius, 501-502

Albizzi, noble family at Florence, 369,371

Albizzi, Rinaldo degli, leader of the aristocratic party at Florence, 369

Albornoz, Cardinal, successful administration of, at Rome, I 47-148, $234-235,436-443$; renders account of his stewardship, 440

Alexander V, pope, $163,317,318$, 428

Alexander VI (Rodrigo Borgia), pope, $415,433,455$

Alfonso III (the Magnificent), king of Aragon, 422-423

Alfonso $X$ (the Wise), king of Castile, claimant to the imperial throne, $57,61,63,66$

Alfonso I (V of Aragon, "the Magnanimous "), king of Naples, 357 . $398,399,412,429-43 \mathrm{r}$; ideal type of the Renaissance prince, 431 ; death of, 432

Alfonso II, king of Naples, 433, 452 ; abdicates, 456 .

Altopascio, Florentines defeated at; 362
Amidei, Ghibelline family at Florence, 222

Anagni, attack on Boniface VIII at, 120-1 21, 123

Andreas of Hungary, consort of Joanna I of Naples, 425-426, 427

Andronicus, pretender at Constantinople, 392

Anjou, house of, rules southern Italy, 233-234, 419-425

"Annates," papal tax, 132

Anne of Brittany, 450

Anziani (board of elders), at Florence, 236

"Apanages," 34-35

Appiano, Gherardo d', tyrant of Pisa, 366

Aragon, crusade preached against, 420 ; claims of Charles of Valois upon, 422

Archers, in the naval battle at Sluys, 261,262 ; at Crécy; 266; in the siege of Calais, 268 ; at Poitiers, 275; at Agincourt, 296; the "Free Archers " of Charles VII, 308

Armagnac, Bernard of, 291, 297

Armagnacs, French faction, 291292, 297, 298

Arras, Treaty of (1435), 305

Artavelde, Jacques van, Flemish leader, $205^{-206,258,278}$

Artavelde, Philip van, Flemish leader, 206-207

Asti, dower of Valentina Visconti, 406

Athens, western students at, 491

Athis, Treaty of (1305), 204

Augustine, influence of, on $\mathrm{Pe}$ trarch, 475,476

Aurai, battle of, 282

"Austrian Policy," the, 8r

Avignon, the Papacy at, 127-163 
"Babylonian Captivity" of the Papacy, the, 127-151

Baillis, French royal officials, 29-31 Bajuli, 19

Ball, John, English priest, 286

Bargello, palace at Florence, 245

Basel, Council of (1431-1449), 334, 337-352

Basel, Peace of (1499), I 87

"Battle of the Spurs," 204

Beatrice, Hohenstaufen princess, imprisonment of, 422

Beaufort, Cardinal Henry, leads a crusade against the Hussites, 336

Beaumanoir, Philippe de Remi, sieur de, French bailli and writer, 29-30

Bedford, duke of, English regent in France, 3or

Behuchet, French admiral, 26 I

Bella, Giano della, Florentine noble, 241,244

Benedict XI, pope (1303), 12I

Benedict XII, pope, erects great fortified palace at Avignon, I 40

Benedict XIII, schismatic pope at Avignon, 159; besieged by his cardinals, 162; withdraws to Spain, 163, 312 ; deposed, 315, 326-327

Bergen, captured by the Hansa, 193

Bernard of Clairvaux, 462

Berne, aided by the Forest Cantons, 179 ; extends its power, 183

Berry, duke of, brother of Charles the Wise, 286

Bianchi, popular party at Florence, 359

Bipartisan government at Florence, 237

Black Death, the, $355,365,402$

Boccaccio, Giovanni, the master of Italian prose, $480-48 \mathrm{r}$; the "Decamerone," $48 \mathrm{I}$; his classical studies, $481-482$; contrasted with Dante and Petrarch, 483

Bohemia, Henry VII and, $8_{3}-S_{4}$; religious war in (1419-1434), 335$337,341-34^{2}$

Bologna, seized by Milan, 408 ; belongs to the papal state, 434,436 , $446-447$
Bona of Savoy, duchess of Milan, 414,4 I5

Boniface VIII, pope, $111,113,136$, 424 ; attacks the Colonna, 114 ; in Italian politics, 114-116; conflict with Philip IV of France, 116-120; attacked at Anagni, I 20-121

Boniface IX, pope at Rome during the Great Schism, 162, 407

Bordeaux captured by the French, 306

"Bossism," at Milan, 230-231 ; at Florence, 370-372

Boucicault, French marshal, signor of Genoa, 410

Bourbon, Jacques de, consort of Joanna II of Naples, 429

Bourges, Pragmatic Sanction of (1438), 345-346

Bracciolini, Poggio, papal secretary, ${ }_{4} 86-487,500,532$

Brescia, party conflicts in, $91-92$; won by Venice, 368

Brethren of the Common Life, the, 510-511

Bretigny, Treaty of ( 1360$), 279-280$ Brienne, Walter of, "duke of Athens," president of the French nobles, 210; "Captain of the People" at Florence, $362-364$

Brittany, war of succession in, 263 ; victory of the Montforts, $282-283$; declared forfeited to the French crown, 285 ; internal conflicts in, 288

Bruges, importance of, 199; revolts against France, 203-204

Buondelmonte, Guelf family at Florence, 222

Bureaucracy, created by Frederic II, $17-22$; the bureaucratic state, 45

Burgundian-Armagnac conflict, in France, 290-294

Burgundy, duchy of, 35 ; increasing power of, 288, 305

Butchers of Paris, political activities of, under Simon Caboche, 292

Byzantine culture in southern Italy, 6 
Caboche, Simon, Parisian butcher and political leader, 292

Cabochiens, 292

Caen, pillaged by Edward III, 264

Cagliari, Venetian naval victory at, 386

Calais, besieged and taken by Edward III, 267-270; secured to England by the Treaty of Bretigny, 279

"Calimala," gild of the woolfinishers at Florence, 239, 240

Calixtus III, pope, 432

Calmar, Union of (1 397), 194

Cambio, Arnolfo, Florentine architect, 245

Camerarius (chamberlain), I9

Candia, revolts from Venice, $389-390$

Capitudini delle Arti, at Florence, 240

Capponi, Piero, spirited conduct of, 454

Carmagnola, Italian condottiere, 395-396, 4 I I

Carpentras, conclave at, 128 ; overturned by the Gascons, $12 S-129$

Carrara, noble family of Padua, 95, $233,3^{8} 4,385,403,4$ Io

Carrara, Francesco, lord of Padua, in conflict with Venice, 390-391, 393-394

Carrara, Francesco Novello, romantic career of, 394-395, 406

Carrara, Jacopo, executed, 395

Cassano, battle of (1259), 226

Castellanus, 19

Castracani, Castruccio, lord of Lucca, 36I-362

Catasto, tax revision at Florence, 369

Catherine of Siena, character and influence of, $150-152$; denounces the "false shepherds," 444

Celestine IV, pope, 225

Celestine V, pope, II I-I I2 ; resignation of, 113

Celtis, Conrad, German humanist, 5 II -512

Certosa, monastery at Pavia, 409

Cesarini, Giuliano, papal legate, 334, $337,338,340,344,345$

Cesena, slaughter of the citizens of, 445-446
Charles, son of John of Bohemia, vicar in Italy, 93-94, 95; elected emperor, as Charles IV, 99; character of, 99-100; issues the Golden Bull, 100-102; coronation of, I02-103, 403-404; his last journey to Italy, I03-IO4; escorts Urban V into Rome, 103-104; makes a treaty with Charles $\mathrm{V}$ of France, $28_{4}$

Charles IV, king of France, 36, 256 Charles V (the Wise), king of France, as Dauphin, $211-213$, $276-278,281$; as king, policy of, $28 \mathrm{I}-282$; alliances of, $283-284$; death of, 285

Charles VI, king of France, 286, $287,288-289,320$; madness of, 289 ; death of, 300

Charles VII (the Victorious), king of France, as Dauphin, 298-300; as "Roi de Bourges," 301-302; coronation of, 303 ; fails to save Jeanne d'Arc, 304; successes of, 305-306; military reforms of, 307309 ; administrative reforms of, 309

Charles VIII, king of France, 400, 416, 431, 433; Italian expedition of, $448-460$

Charles II (the Bad), king of $\mathrm{Na}$ varre, $27 \mathrm{I}-273,276,277,278$; ruin of, 285

Charles (the Bold), duke of Burgundy, 41 4, 449

Charles of Anjou, 66, 240; signoria of, at Florence, 238 ; king of Naples, 418, 419, 420-422

Charles of Blois, claimant to Brittany, 263

Charles of Calabria, given the signoria at Florence, 362-363

Charles of Durazzo, Neapolitan noble, 426, 427; king of Naples (as Charles III) and of Hungary, 427-428

Charles of Orléans, 291, 398, 400

Charles of Salerno, legislation of, $420-421$; defeated and captured by Di Loria, 42I-422; imprisoned, 422 ; king of Naples, as Charles II, 422, 423, 424-425 
Charles of Valois, 127, 359, 422, 423,424

Chaucer, Geoffrey, 509

Chioggia, War of (1378-1380), 391392

Chrysoloras, Manuel, earliest of Greek teachers in Italy, 492-493

Cimabue, Florentine painter, 246

Ciompi, tumult of the, at Florence, 365

Circles, division of Germany into, 74 Cities, treatment of, by Frederic II, 15-16; city leagues in Germany, 58-61; city life in Italy, 216-217

Clarence, duke of, marries Violante Visconti, 405

Clémanges, Nicholas de, French humanist, 532

Clement $V$, pope, $121-128$; remains in France, 122 ; creates Gascon cardinals, 122; abolishes the Templars, 126; characterized by Dante, 136

Clement VI, pope, 99, 270 ; representative pope of the Exile, 141 ; creation of cardinals by, 142; authorizes Jubilee of 1350,355 ; in conflict with Milan, 402 ; relations of, with Naples, 426-427

Clement VII schismatic pope at Avignon, 1 55-1 59, 289, 446

Clerical jurisdiction, 8 ; restraints on, in France, 37-42

Clericis laicos, bull of Boniface VIII, 117

Clisson, Olivier de, constable of France, 285, 287

Colet, John, English humanist, 523, 526-527

College of Cardinals, 52, 55, 71 ; establishment and development of, 107-108; at the Council of Pisa, 314-317

College of Physicians, founded by Linacre, 528

Colonna, Roman noble family, 110 , I I 4, 11 19, $120,139,333,34$ I

Colonna, Sciarra, I2 I

Columbus, Christopher, 415

Comines, Philippe de, French historian, $450,458,459$
Commerce, supremacy of Florence in, 239-240; expansion of German trade, 188-194; importance of Flemish commerce, 199; commercial rivalry of Genoa and Venice, $386-387,391-392$; beginning of the commercial decline of Venice, 400

Commission, government by, at Florence, 370

Committee of Public Safety at Florence, 236

Compact of Clergy, the, $186-187$

Compagni, Dino, Florentine historian, 246

Compiègne, meeting of the Lstates at, 213,277

Concordats, Age of the (1448-1 517), 354-355

Condulmier, Gabriel, cardinal, 312. See Eugenius IV

Conrad III, emperor, 47

Conrad IV, emperor, 56, 59

Conradin, see Corradino

Constance, Council of, 320-332; objects of, 321 ; parties in, 327 ; results of, 332

Constance, Peace of, 216, 220

Constance, daughter of Manfred, 418; saves Charles of Salerno, 422 ; withdraws support from Federigo, 423

Constantinople, fall of (1453), 400, 506

Constitutiones Egidianae, 440-443

"Constitutions of the Prince of Salerno," 420-42I

Copenhagen destroyed by the Hansa, 193

Corfu acquired by Venice, 393

Corradino, 63, 237; execution of, $5 \mathrm{I}, 422$

Correr (Corrario), Angelo, cardinal, 3II. See Gregory XII

Correr, Antonio, cardinal, 312

Corsica, 423, 430

Cortenuova, battle of, $16,48,224$

Cossa, Baldassare, papal legate, 410 . See John XXIII

Coucy, Enguerrand de, trial of, 42-44 
Council of Seventy, established at Florence, 379

Council of Ten, at Venice, $38 \mathrm{r}$, $382-383$

Council of Twelve, during the minority of Charles VI, 286

Councils, Age of the (1 508-1 548), 311-354; Council of Pisa, 314318 ; of Rome, 320; of Constance, 32I-333; of Basel, 337-352; Union Council, at Ferrara and Florence, 344-345 ; apparent failure of the conciliar period, 352353; permanent gains of, 353354

Courtrai, battle of (1 302$), 204,208$

Crécy, battle of (1346), 210, 264267

Cremona, defeat of the Milanese at, 368

Crusades, against Bohemia, 335336; against Faenza, 437-438 ; against Francesco Ordelaffi, $43^{8}$ $44^{\circ}$

Culture, true process of, $49 \mathrm{I}, 492$; enthusiasm of, 492-493

Cusa, Nicholas of, theologian, 337, $346,354,504$

D'Ailly, Pierre, French theologian, at Constance, . 323; letters of Montreuil to, 532

Dandolo, Venetian family, 397

Dante, 245-246, 44I, 468, 483 ; appeal of, to Albert of Austria, 82 ; to Henry VII, 85; the "De Monarchia " of, $134^{-1} 35$; his criticism of the Papacy, 135-137; driven from Florence, 359

"Decamerone" of Boccaccio, $48 t$

"Deputations" at the Council of Basel, 337

Doge, office of, at Venice, 246,247 ; limitations upon, 248

Domaine, royal, in France, 34-36

Doria, Luciano, Genoese admiral, 392

Doria, Pietro, Genoese admiral, 392

Du Guesclin, Bertrand, constable of France, 281, 283, 284, 285 , :
Eastern Church, negotiations for union with, 342-345

Eastern Empire, perilous position of, $343-345,391$

Edmund, son of Edward III of England, 283

Edward I, king of England, 422423

Edward III, king of England, claims crown of France, 36-37, 256-259; relations with Flanders, 206; im. perial vicar, 259-260; at war with Philip VI, 260-27I ; makes treaty of Bretigny with France, 279-280; death of, 286

Edward, the "Black Prince," at Crécy, 266; raids Languedoc, 272; at Poitiers, 274-275; cited to appear at Paris, 284

Eike of Repgow, German jurist, 54

Einsiedeln, monastery of, 176

Eleanor of Portugal, bride of Emperor Albert II, 357

Electoral body, papal, 52, 107-108; imperial, $5 \mathrm{I}-57$; at Venice, 248249

Electoral college, the, in Germany, , 51-57

Elizabeth, princess of Bohemia, 83

Empire, the new, 47-105; the "Hohenstaufen Policy," 47 ; causes of its failure, 47-50; the Norman marriage, 50 ; loss of German influence in Italy, 51 ; the electoral college, 51-57; the double election of 1198,54 ; the Interregnum, 56-58; city leagues for public defence, 58-6t ; Rudolf of Habsburg, 62-74; the Habsburg policy, 62-63; the electoral Willebriefe, $70-71$; the Landfrieden, $71-74$; the Reichsgut, 74-75; Reichs. burgen, 75-76; Adolf of Nassau, 76-78; Albert of Austria, 78-81 ; Henry VII of Luxemburg, 8I-88; his Italian expedition, 84-88; John of Bohemia's failure in Italy, $91-95$; the Golden Bull of 1356 , 100-102; Charles IV a type of the new order, 103; the Hussite wars, 335-337 
England, tributary to the Papacy, 130 ; relations with Flanders, 199,200 , 202-203, 205-206, 257-258; the Hundred Years' War with France, 252-310; royal power in, 253 ; industrial uprising of $1381,286-287$; the Renaissance in, 526-530

Enlightenment, of Frederic II, 25-27 Enquêteurs du roi (royal inquisitors), in France, reports of, 44-45

Enzio, marries the heiress of Sardinia, 225

Epistolae Obscuronum Vironem, 516 520

Erasmus, Desiderius, childhood and youth of, $52 \mathrm{I}-522$; his personal development, 522 ; the preacher of righteousness, 523; Enchiridion Militis Christiani, 523; in the service of religion, 524 ; the "Praise of Folly," 525; the "Colloquies," 525-526

Estates-General, history of, in France, 208-2 I4

Este, house of, rulers of Ferrara, 233,38 I

Este, Azzo d', lord of Ferrara, $38 \mathrm{I}$

Este, Beatrice d', bride of Ludovico Sforza, 4I 5

Este, Francesco d', uncle and rival of Fulco, 381

Este, Fulco d', claims sovereignty of Ferrara, $3^{8}$ I

Eugenius IV, pope, 334,338 ; at odds with the Council of Basel, $339,340-34 \mathrm{I}, 447$; and with Alfonso the Magnanimous, $43^{\circ}$

Evidence, reform in rules of, by Frederic II, 25-26

Expansion, Venetian policy of, $3^{8} 3^{-}$ 400 ; of Milan, $401-416$

"Expectatives," a source of papal revenue, I 32

Ezzelino da Romano, 49, 95 ; career of, 223-226

Faenza, crusade against, $437-438$

Faliero, Marino, conspiracy of, $387-388$

"False shepherds," in the Patrimonium Petri, 444-445
Federigo, king of "Trinacria," 423 424,425

Felix V, Basel pope, 347-348, 349, $35^{\circ}, 350-351,43^{\circ}$

Ferdinand I (the Just), king of Aragon, 326-327

Ferdinand II (III of Naples, V of Castile), king of Aragon and Sicily, 456

Ferdinand I, king of Naples, 430 , $43 \mathrm{I}, 432-433$

Ferdinand II, king of Naples, 456

Ferdinand I, king of Portugal, $28_{3}$

Ferrara, defeat of John of Bohemia at, 95 ; under the house of Este, 233,381 ; war over (1308-1310), $381-382 ;(1481), 400$

Feudalism, under Frederic II, I4; the French state and feudalism, 28-46

Filelfo, Francesco, classical teacher, 493-495, $50 \mathrm{I}$

Fillastre, French theologian, at Constance, 323

Flanders, democratic movement in, 199-201 ; seized by France, 202203; revolt, 203-204; alliance with England, 205-206; battle of Roosebeeke, 207

Florence, relations of, with Henry VII, $85-86,87$; partisan struggles in, 235-243; the gilds, $238-239$; Florentine commercial supremacy, 239-240; the Ordinances of Justice, 24I-244; progress in wealth and culture, 245; the "Age of Dante," 245-246; victory of the Neri, 359 ; foreign executives, 359-364; the Ciompi, 365 ; rise of the Medici, 368-378; administration of Lorenzo dei Medici, 378380 ; the Florentine League against the papal state, 444-446; relations with Charles VIII of France, 453-455, 456

Forest Cantons, the, $170,175,178,179$ Forli, war between Florence and Milan over, $367-368$

Fornovo, battle of (1 495), 457-459

"Four Articles of Prague," the, $34 \mathrm{I}-342$ 
France, development of the monarchy under Louis IX, 28-44; democratic influences in, 207-214; early French communes, 207-208; the Estates-General, 208-212, 272-274, 275-277 ; fall of Marcel, 213-214, 276-278; the Hundred Years' War with England, 252310; royal power in, 254-255; internal difficulties in, 286-287; civil war between Burgundians and Armagnacs, 290-300; military reforms of Charles VII, 307-309; administrative reforms, 309 ; luxury and dissoluteness, 310 ; the Renaissance in, 530-532 Fraticelli attack John XXII, 134

Frati Gaudenti, semireligious order, 237

Frederic I (Barbarossa), emperor, 47, 53; punishes Henry the Lion, 4 Frederic II, emperor, $42,44,47$, $50-51,63,64,67,71,75$; establishes in southern Italy the earliest modern state, $5-27$; relations with the Italian cities, 222-223; in conflict with Gregory IX, 224225

Frederic III, emperor, 349, 351, $35^{6-357,} 449$

Frederic of Austria, claimant to the imperial throne, 88-89

Frederic, son of Ferdinand $I$ of Naples, 433

"Free Archers," under Charles VII, 308

Free Companies, power of, in Italy, I 48, 437; enlisted by Charles the Wise, 282-283

"Gallican liberty," idea of, 1 1 9, 346 Gattamelata, Venetian general, 398

Gaza, Theodore, Renaissance scholar, 500

Gelnhausen, Conrad of, recommends a general council, 160

General Council, proposed, I57I 58,160

Genoa, disregards interdict, I 15 ; rival of Venice, 386-392

Genoa, Treaty of, 394, 407
Genoese crossbowmen, at Courtrai, 204 ; at Crécy, 266

George of Trebizond, Renaissance scholar, 499-500

Germany, development of political institutions in, 45; and the Empire, see Empire; democratic spirit in, 187-188; expansion of trade, 188-189; origin, rise, and political activity of the Hansa towns, 190-194; the Rhine Confederation, 194-195; the Swabian League, 195-196; the gilds, 197198; the Vehmgericht, 198-199; the Renaissance in, 510-526

Gerson, Jean, French scholar, 532

Ghent, a center of the wool industry, 199

Ghibelline party in Italy, 221-226

Gilds, power of, in Flanders, 206; in Florence, $23^{8-240}$

Giotto, Florentine painter and architect, 246; his bell tower, 245

Giustiniani, Venetian admiral, 392

Glarus, Swiss canton, 183 ; victorious over Austria, 184

Göllheim, battle of, 78

Gonfaloniere di giustizia, at Florence, 242-243

Gonzaga, ruling family at Mantua, 233

Gradenigo, Pietro, doge of Venice, 249, 382

Gratius, Ortuinus, 516-517

Great Council, at Venice, 247 ; closing of, 249-250; membership in, 250-25I; nature of, 251

Great Schism, in the Papacy, I 56163,446 ; brought to an end by the councils, $163,311-327$

Greek, mediæval ignorance of, 480 ; studied by Boccaccio, 482

Gregory IX, pope, 4I; in conflict with Frederic II, 224-225

Gregory X, pope, 64-66, 68, 1 10II 1

Gregory XI, pope, I49; influenced by Catherine of Siena, I 50-15I ; returns to Rome, I 52, 445 ; excommunicates the Florentines, 445 
Gregory XII, pope at Rome during the Great Schism, 162-163, 312, 314,428 ; deposed, 315

Grocyn, William, English humanist, 527

Groot, Gerhard, founds Brethren of the Common Life, 510

Guelf party in Italy, 220-226

Guicciardini, Florentine historian, $45 \circ, 454$

Guienne, conquered by the French, 306

Guy, bishop of Auxerre, $3^{8}$

Guy de Dampierre, count of Flanders, $201-202,203$

Guy of Namur, Flemish leader, 204

Hansa, league of German commercial cities, 190-194

Harfleur, taken by Henry V, 294-295

Hawkwood, John, English captain of mercenaries, 406

Hegius, Alexander, headmaster at Deventer, $5^{11}$, $5^{21}$

Helsingborg, 193

Henry VI, emperor, 47, 50

Henry VII of Luxemburg, emperor, $81-88,175$; character of, 81; Italian expedition of, $83-88,36 \mathrm{r}$; story of his death by poison, 88

Henry of Carinthia, king of Bohemia, 83, 9 I

Henry II (of Trastamare), king of Castile, ${ }_{28} 8_{3}$

Henry IV, king of England, 292, 294

Henry V, king of England, 294; victor at Agincourt, 295-297; conquers Normandy, 298; proclaims himself king of France, 298 ; enters Paris, 300 ; dies, 300 Henry VI, king of England, 300

Henry VIII, king of England, 529-530

Henry the Lion, punished by Frederic Barbarossa, 4

"Hohenstaufen Policy," the, 47-5I

Humanism, meaning of, 465 ; origin and place of, $467-468$; in Italy, 468-508; in Germany, 510-526; in England, 536-530; in France, $530-53^{2}$; triumph of the humanistic culture, 533
Hundred Years' War, the, between France and England, 252-310; character of the struggle, 252 ; results, 310

Hungary, relations with Venice, $389,390-391$; with Naples, 424$425,426,427-428$

Hus, John, trial and execution of, 322,335

Hussites, in Bohemia, 335-337; the "Four Articles of Prague," 34I ; defeat of the radical party, 342

Hutten, Ulrich von, German humanist and reformer, 517, 520-521

Île de France, outbreak of the Jacquerie in, 277

Imola, quarrel over, 375-376

Individualism, growth of, 46 i

Infeudation of the Habsburgers with Austria, 71

Innocent III, pope, 50, 54, 108, 234

Innocent IV, pope, 42, 225

Innocent $V$, pope, 66

Innocent VI, pope, electoral compact of, 145; sends Albornoz to restore order in the papal state. 146-1 48

Innocent VII, pope at Rome during the Great Schism, I62, 311

Innocent VIII, pope, 433

Interregnum, the, in the Empire, 56-6i

Invective, literature of the, 494

Isabella, queen of Castile, 456

Isabella, daughter of Philip IV of France, 36

Isabella the Bavarian, queen of France, 290, 298

-Isabella of Naples, 415

Isabella of Valois, 405

Italian language, emergence of, 246

Italy, southern, under Frederic II, 5-27; development of political institutions, $45-46$; relations of, to the Empire, 47-51, 65-66, 82-88, $9 \mathrm{I}-95,102-104$; the new papacy, $106-163$; the Italian republics to about 1300, 215-251; the age of the despots, 358-460; the Renaissance, $461-508$ 
Jacquerie, outbreak of the, 277

James, king of Sicily, later of Aragon, 423

Jean of Anjou, claimant to the Neapolitan throne, 432-433

Jeanne d'Arc, mission of, 302 ; relieves Orléans, $302-303$; capture and death of, 304

Jerome of Prague, trial and execution of, 322,335

Jews, tax levied on, 76

Joanna I, queen of Naples, 425427

Joanna II, queen of Naples, 428429

Jobst of Moravia, claimant to the imperial crown, 320

John III Palæologus, Greek emperor, cedes Tenedos to Venice, 39 I

John IV Palæologus, Greek emperor, 344

John XXI, pope, i I I

John XXII, pope, 89-9I ; election, 130 ; financial system of, $130-133$; contest with the Fraticelli, I33134; attacked as a heretic, 134; death of, 140

John XXIII, pope, 318, 428 ; early career of, 318 ; vices of, 319 ; disasters of, 320-321; tried and deposed, 325-326

John, king of Bohemia, $83,84,259$; expedition of, to Italy, $91-95$; its failure, 95; death of, at Crécy, 266-267

Jobn II (le Bon), king of France, 210-211, 405; as prince, besieges Aiguillon, 264 ; character of, 271 ; troublous reign of, 271-275; captivity of, $275,279,2 S_{1}$

John III, duke of Brittany, 263

John (the Fearless), duke of Burgundy, 290, 292; assassinates Louis of Orléans, 291 ; in alliance with England, 297-298; murder of, 299, 301

John of Gaunt, 206

John of Procida, vengeance of, 419 Joinville, Jean de, personal memoirs of St. Louis by, $3^{8-4 I}$
Juan of Navarre, king of Sicily, 432 Jubilee, papal, of 1450, 355-356 Judices, men learned in the law, 20 Justitiarius (justiciary), 19

Koninck, Peter, popular leader at Bruges, 203

Kunigunde, queen of Bohemia, 69

Kuttenberg, Hussite victory at, 336

Ladislaus, king of Naples, 315,319 , 428 ; occupies Rome, 321

Laification of culture, the, 466

Landfrieden, efforts to secure, 59, $71-75$

Landvögte (royal commissioners), in Germany, 75

Langenstein, Heinrich von, advocates a general council and ecclesiastical reform, 161

Languedoc raided by the Black Prince, 272

Laupen, battle of, 179

Lausanne, meeting of Rudolf and Gregory $\mathrm{X}$ at, 65

Iaw, Petrarch's views on, $477-478$

Lawyers, rise of, 46,225

League of Nobles, victorious in Bobemia, 342

League of the Italian powers against Charles VIII, $456-460$

Lecocq, Robert, bishop of Laon, 2 I I

Legnano, battle of, $48,216,224$

Leopold, duke of Austria, defeated by the Swiss at Morgarten, 177I 78

Lise-majesté, cases of, in France, 31

Licet juris, decree of $(1338), 97-98$

Limousin faction in the cardinalate, I 52-I 53

Linacre, Thomas, English humanist, 527-528

Lipau, Taborites defeated at, 342

Literature, mediæval idea of, $462-$ 463

Lombard League, of 1176,224

Lombard League, second, of 1226 , 224

Lombardy, Henry VII in, 86-87; John of Bohemia in, 91-95; Milan, 229-233, 401-416 
Loria, Roger di, admiral in the Aragonese service, 421 ; joins Charles II of Naples, 423

Louis IX (St. Louis), king of France, 208, 224, 418, 419; development of the French state under, $28-45$

Louis X, king of France, 36

Louis XI, king of France, 309, 414, 449

Louis XII, king of France, 406

Louis I (the Great), king of Hungary, 390-391, 392 ; seizes Naples, 426-427

Louis I of Anjou, breaks parole, 28I ; claimant to Naples, 427

Louis II of Anjou, 289, 320, 428

Louis III of Anjou, claimant to the throne of Naples, 429

Louis I (de Crécy), count of Flanders, 205

Louis II (de Male), count of Flanders, $207,28_{3}$

Louis of Orléans, brother of Charles VI of France, 289, 290, 406; murdered, 291, 398

Louis of Orléans, brother-in-law of Charles VIII of France, surrenders at Novara, 460

Loyalty, praised by Beaumanoir, 30

Lucca, at war with Florence, 93, 370 ; in alliance with Florence, 361 ; under Castracani, 361-362

Lucera, camp of mercenaries at, 24

Luder, Peter, wandering teacher, 51 I

Ludovico of Taranto, second consort of Joanna of Naples, 427

Ludwig IV (the Bavarian), emperor, $88-100,165,167,176$; visit to Italy, 91; ally of Edward III, $258,259-260$; killed while hunting, 100

Luxemburg-Bohemian royal family, the, 105

Lyons, conclave at ( 13 I6), I 29-1 30

Magister procurator curiae (royal proctor), 19

Magna Curia Rationum, 21

Malatesta, noble family of Rimini, 437

Malatesta, Carlo, papal proctor, 326
Manfred, son of Frederic II, 225, 237, 418

Manfredi, noble family of Faenza, 437

Mantua under the Gonzagas, 233

Marcel, Etienne, French popular leader, $210-214,276-278,293$

Marchfeld, battle of the, 69-70

Marcus of Ephesus, Greek bishop, 345

Margaret, daughter of Count Louis of Flanders, marries Philip of Burgundy, 283

Margareta Maultasch, daughter of Henry of Carinthia, first marriage of, 91 ; marriage annulled by $\mathrm{Em}$ peror Ludwig the Bavarian, 9899 ; marries Ludwig of Brandenburg, 99

"Marmousets," 289

Marsiglio of Padua, teacher at Paris, I65; the "Defensor Pacis" of, 167-170; defines the state, 168 ; and the Church, 169; advocate of modern notions of society, 169-170; protected by Ludwig the Bavarian, 170

Marsiglio, Luigi, Florentine humanist, 484

Martin IV, pope, 420, 422

Martin V, pope, $330-334,446-447$

Mary of Burgundy, heiress of the Low Countries, 450

Maximilian I, emperor, 4I6, 513; rival of Charles VIII of France, $450,452,456,460$

Medici, Cosimo dei, becomes head of the Florentine state, 369-374

Medici, Giovanni dei, popular leader at Florence, 368, 369

Medici, Giuliano dei, 374 ; assassinated, 377

Medici, Lorenzo dei (the Magnificent), 374, 4I5, 433, 453i attempted assassination of, $376-$ 378 ; tyranny of, established, 378 ; public policy of, 380

Medici, Piero dei, son of Cosimo, 374

Medici, Piero dei, son of Lorenzo, 453,455 
Medici, Salvestro dei, Florentine merchant and leader, 365

Medicine, Petrarch's criticism of, 477 ; Linacre founds the College of Physicians, 528

Mercenary troops, employed by Frederic II, 23-24; by the French, in the Hundred Years' War, 255; by the Florentines, 367,406 ; by Venice, $384,395-$ 396; by Charles VIII, 452, 457

Messina relieved by Pedro of Aragon, 419

Middle class, rise of a, 164-214

Milan, development of the signoria in, 229-23I ; growing power of, 232-233; expansionist policy of, 401-402; the Visconti, 402-412; the Sforza, 412-416

Miserabiles, 20-21, 43

Modern state, defined, 45

Mogliano, Gentile da, tyrant of Fermo, 437

Mohammed II takes Constantinople, 506

Molay, Jacques de, grand master of the Templars, 125

Monreale, captain of mercenaries, 147

Montaperti, battle of (1260), 237

Montereau, murder of Jean sans Peur at, 299

Montferrat, county of, 232

Montfort, John of, claimant to Brittany, 263; becomes vassal of France, 283

Montreuil, Jean de, French humanist, $531-532$

Mont Ventoux, Petrarch's ascent of, $474-476$

More, Thomas, English humanist, 529-530

Morgarten, battle of (1315), 177-1 78

Mortmain, laws of, 9

Mühldorf, battle of (1322), 89

Mutianus, German humanist, 520

Näfels, battle of $(1388), 18_{4}$

Naples, city, development of, under Charles of Anjou, 419; university founded at, 27
Naples, kingdom, administration of Frederic II in, 5-27; peculiar character of Neapolitan history, 417 ; parties in, 418; the "Sicilian Vespers," 419; houses of Anjou and Aragon, 420-425; the Hungarian party, 425-429; reign of Alfonso I, 430-432; of Ferdinand, 432-433

Nationality, principle of, how manifested, 215

National sentiment, beginnings of, 4

"Nations," at the church councils, $323,328,329,332,337$

Nature, Petrarch and, 474-476

Naval force created by the Sicilian kings, 24

Neri, conservative party at Florence, 359

Niccoli, Niccolo, book lover, $487-$ 488

Nicholas III, pope, 136, 419, 435436

Nicholas IV, pope, 422, 423

Nicholas V, first humanist pope, 350, 495-501; makes peace with the Baselers, 351-352 ; relations with Frederic III, 357; the papal state under, 447 ; building plans of, 497-498 ; collection of manuscripts, 498

Nobili, in the Italian cities, 217

Nobility made a disgrace at Florence, 243-244

Nogaret, William of, agent of Philip the Fair, 120-121, 123, 125

Nominalism, in philosophy, defined, 165

Normandy, revolt of Charles of Navarre, 273; conquered by Henry V, 298; reconquered by the French, 306

Nuremberg, Diet of (1274), 66-67

Oléron, Treaty of (1288), 422-423

Ordelaffi, noble family of Forll, 437 , $43^{8}$

Ordelaffi, Francesco, typical Italian tyrant, 438 ; crusade against, $438-$ 440 ; made papal vicar, $44^{\circ}$; later career of, 440 
Ordelaffi, Marzia, defends Cesena against the papal troops, 439

"Ordinances of Justice" at Florence, 24 I-245

"Ordonnance Cabochienne," the (1413), 292-294

Orsini, Roman noble family, Iro, 139

Orsini, Cardinal Napoleone, letter of, to Philip IV, I37

Otto IV of Brunswick, emperor, 50 , $53,54,64$

Otto of Brunswick, fourth consort of Joanna of Naples, 427

Ottokar, king of Bohemia, $63,67-70$

Oxford, Colet lectures at, 526

Padua, under the Carrara, 233; becomes subject to Venice, 233

Painting, rise of, in the Renaissance, 246

Papacy, champion of local rights, 5 ; in the "Hohenstaufen Policy," 47 ; the three powers of the Papacy, 88; the new Papacy, 106-163; establishment and development of the College of Cardinais, $107-108$; climax of papal power under Innocent III, 108; forces against the Papacy, 109; French influence, I12; Boniface VIII, I13I2I; his quarrel with Philip the Fair, 116-121; the bull Clericis laicos, 117; Unam sanctam, I18II9; "the crime of Anagni," 120-121; the French papacy, 12I-155; the bull Rex gloriae, I23; case against the Templars, 123-126; the "Babylonian Captivity," 127-128; John XXII and the papal finances, 130-133; "apostolic poverty," I 33-134; Dante's "De Monarchia," 134I 35 ; his criticism of the Papacy, I35-137; Petrarch and Orsini, I 37; Ubi Papa, ibi Koma, 138; the Roman republic, $13^{8-1} 42$; Cola di Rienzi, 142-1 45; administration of Cardinal Albornoz, 147148; Catherine of Siena and the return to Rome, $150-152$; election of Urban VI, 153-154; the Great Schism, 155-163; beginning of a new era with the Council of Pisa (1409), 163; the papal state, 234$235,434-448$; the age of the councils, 3 II -354 ; the age of the concordats, 354-355

Paradiso degli Alberti, 484,501

Parentucelli, Tommaso, see Nicholas $\mathrm{V}$

Paris, University of, $156,160,293$, 316-317, 530

Parliaments, establishment of, 22-23

Patrimonium Petri, 434

Patriotism, local, in Italy, 221 ; national, in France, 309

Pazzi, conspiracy of the, at Florence, 375-378

Peasantry cared for by Frederic II, 16-17

Pedro III, king of Aragon, 419; avoids duel with Charles of Anjou, 420 ; death of, 422

Pedro (the Cruel), king of Castile, 283

Pedro, king of Sicily, 425

Pepoli, Bolognese family, 402

"Perpetual Compact" of 1291, 172 ; renewed, 178

Personality of law, 6-7

Personal justice forbidden by Frederic II, 12

Petit, Jean, theologian, justifies assassination of Louis of Orléans, 29I

Petrarch, criticizes the Avignon papacy, 137 ; crowned poet laureate at Rome, $14 \mathrm{I}$; at the court of Milan, 403; a legend of his studies, 468-469; a "Poet," 469; as the restorer of Latin culture, 469; master of Italian poetry, 469,472 ; his "Africa," 470-47I; his coronation as "Poet," $47 \mathrm{I}-$ 472 ; collector of manuscripts, 472-473; archæologist, 473-474 ; his love of nature, $474-476$; double standard of faith, 479; his individualism, 479-480; contrasted with Dante and Boccaccio, 483 
Petrus de Vinea, legal adviser of Frederic II, 18

Philip II (Augustus), king of France, $28,35,208$

Philip III, king of France, 36, 63, 256, 422

Philip IV (the Fair), king of France, $36,208-209,256,359,422,423$; in conflict with Benedict VIII, $116-121$; relations with Flanders, 202-203

Philip V, king of France, 36

Philip VI, king of France, 36-37, 94, 256-257; at war with England, 258-271; internal policy of, 271

Philip (the Bold), duke of Burgundy, marries Margaret of Flanders, 283 ; regent of France, 286288 ; death of, 290

Philip (the Good), duke of Burgundy, 300 ; makes advantageous treaty with Charles VII, 305

Philip of Swabia, Hohenstaufen claimant to the empire, 50, 53, 54

Philippa of Hainault, queen of Edward III of England, 206; intercedes for the citizens of Calais, 270

Piccinnino, Milanese general, 398

Piccolomini, Eneas Silvius, at the Council of Basel, 349; crowned imperial "Poet," 349. See Pius II

Pisa, rival of Florence, 235, 237 ; comes under the control of Florence, 244, 366; garrisoned by Milan, 407; friendly to Charles VIII, 456

Pisa, Council of (1409), 163, 314318

Pisani, Vettore, Venetian admiral, 392

Pistoia, siege and destruction of, 361

Pius II, pope, 432, 492

Podesta, rise and powers of the, 217-218, 228-230

Poitiers, battle of (1356), $211,274-$

. 275

Pola, Genoese naval victory at, 392
Ponthieu, English territory in north ern France, 264, 265, 279

Popolo grasso, 219,310

Popolo minuto, 219,228

"Pragmatic Sanction of St. Louis," the, 41,42

Prague, 335

Prtuots, French royal officials, 29

"Priors," chiefs of the Florentine state, 240, 244

Private warfare, restrained by Louis IX, 31-33

Procopius the Great, Hussite leader, 336,342

Proveditori, Venetian military commissioners, 391

Raccommandati, $366-367$

Ragusa, John of, at Basel, 337

Realism, in philosophy, defined, $164-165$

Reichsburgen (royal castles), in Germany, 75-76

Reichsgut (royal domain), in Germany, 74-75

Religious toleration, under Frederic II, 27

Renaissance, the, in Italy, $46 \mathrm{I}-508$; "true " and "false," 466-467; in the northern countries, 509-533; triumph of the humanistic culture, 533

René I of Anjou, claimant to the throne of Naples, 429-430

René II of Anjou, claimant to the throne of Naples, 433

Rense, Kunverein at ( 1338$), 95-97$

"Republic of Saint Ambrose," at Milan, 412-413

"Reservations," in clerical appointments, 131-132

Reuchlin, Johann, German humanist, 512 ; his controversy with the Dominicans, $513-516$

Rhenish cities, league of the (1254), 58-6r

Riario, Girolamo, conspirator, 375, 376

Richard II, king of England, 286

Richard of Cornwall, claimant to the imperial throne, 57,61 
Rienzi, Cola di, 142, 235; attempts to restore the Roman republic, I 43; "Tribune of the People," I 44; constitutional reforms, 144 ; overthrown, 145 ; second administration of, 147,437

Robert of Anjou, king of Naples, 140, 360-361, 424-425; examines Petrarch, $47 \mathrm{I}$

Robert of Artois, Count, 204

Robert, count of Flanders, 204

Robert Guiscard, in Italy and Sicily, 6

Roccasecca, victory of Louis of Anjou at, 428

Roger, king of Sicily, IO-1 I

Romagna, the, $367,375,378,435$

Roman Law, influence of, in France, 29

Roosebeeke, battle of (1382), 207

Royal Chamberlains, of Frederic II, 2 I

Rubianus, Crotus, Reuchlinist, 517

Rudolf of Habsburg, emperor, 61 76 ; character of, $62-63$; relations with the Papacy, 63-66, 435; acquires the Austrian lands, $67-70$; the Landfrieden, 71-74

Ruprecht of the Palatinate, emperor, $104,407,408$

"Rütli Council," described in the "White Book of Sarnen," I 74

"Sachsenspiegel," compilation of North German laws, 54-56

St. Louis, see Louis IX

Salic Law, the, in France, $36-37$

Salutato, Coluccio, Florentine secretary, $484-486,531$

Salviati, Francesco, archbishop of Pisa, $375,376,377-378$

San Felice, battle of (1332), 94

San Germano, peace of, 5

Santa Maria dei Fiori, cathedral at Florence, 245

Santo Spirito, Academy of, in Florence, 484

Sanuto, Marino, Venetian historian, $45 \mathrm{I}, 459$

Sapienza, Genoese naval victory at, 387
Saracens, mercenaries of Frederic II, 24, 225

Sardinia, 225, 423, 430

Savonarola, Girolamo, Florentine reformer, 45I, 453, 459

Savoy, county of, 232

Scala, or Scaliger, Veronese noble family, 92-93, 95, 232, $3^{8} 4-3^{8} 5$, $393,403,412$

Scala, Can Grande della, prince of Verona, 384

Scala, Mastino della, Veronese prince, 92

Scholares vagantes, 467

Scotland, in the Great Schism, 1 56; alliance of, renounced by France, 280

Seigneurial jurisdiction, in France, 29 ; encroached upon by royal jurisdiction, 31-32

Sempach, battle of ( 1386$), 182$

Sempach Compact, the, I85-186

Sénéchaux, French royal officials, 29-3I

Senlis, Treaty of (1493), $45^{\circ}$

Serfdom abolished by Frederic II in domain lands, $16-17$

Sforza, Bianca, $416,45^{\circ}$

Sforza, Caterina, 376

Sforza, Francesco, duke of Milan, $373,398,399,412,413-4$ I 4

Sforza, Galeazzo Maria, duke of Milan, infamous career of, 414 ; assassinated, $4 \mathrm{I} 5$

Sforza, Gian Galeazzo, duke of Milan, 415,450 ; death of, $416,45^{2}$

Sforza, Ludovico (Il Moro), regent of Milan, 415-416; duke, 400, $4 \mathrm{I} 6,433,450,452$

Shield and staff, combat with, 33

"Sicilian Vespers," the, II 5, 234, 242, 419

Sicily, seized by Aragon, I1 5, 234, 419 ; at war with Naples, $421-424$ Siena, ancient enemy of Florence, 407

Siena, Council of (1423-1424), 333

Sigismund, emperor, 104, 297, 32 I, 397 ; betrays Hus, 322 ; routed by Ziska, 336; coronation of, 339 ; death of, 346 
Signoria, rise of the, in Italy, 227-231

Simonetta, adviser of Bona of Savoy, 415

Simony, 132

Sixtus IV, pope, 375,378

Slavery, 17

Sluys, naval battle of ( 1340 ), 260-262

Sovereign powers, mediæval division of, $3-5$

Spolia, ecclesiastical, 329

Superstition, opposed by Frederic II, 26-27

Supreme court, established by Frederic II, 20-2I; at Venice, 247

Switzerland, formation of, 170-187; quarrels with the Habsburgs, $171-$ I86; occasion for the struggle for freedom, 173; Chronicle of Tschudi, I 74; the "Rütli Council," 174 ; aggressive attitude of Schwyz, 176-1 77; battle of Morgarten, 177I 78 ; of Sempach, 182 ; complete establishment of the Confederation, 187

Taxation, under Frederic II, 24-25; in France, 209, 210

Tell, William, legend of, $8 \mathrm{I}$

Templars, prosecution of, $123-126$; the order abolished, I 26

Tenedos, ceded to Venice, 391

Thorote, Jean de, French advocate, 43, 44

Tiepolo, Bajamonte, Venetian conspirator, 382

Torre, Guelf family at Milan, 229

Torre, Martino della, Milanese leader, 226, 229

Torre, Napoleone della, podestà del popolo at Milan, 229-230

Torre, Philippo della, podesta del popolo at Milan, 229

Towers, age of the, in Italy, 2 I9

"Translations," arbitrary, forbidden, 329

Traversari, Ambrogio, humanistic monk, 489-490

Treviso, taken by Can Grande della Scala, 384 ; incorporated with Venice, 385

Treviso, March of, 388, 393
Trieste, war between Venice and Austria over, 390

Troyes, Treaty of (1420), 299-300

Tschudi, Ægidius, patriotic Swiss Chronicle of, 174

Tunis, tributary to Charles of Anjou, 4 I9

Turks, conquests of, 506-507

Tuscany, 235

Tyler, Wat, English rebel, 286

Uberti, Ghibelline family at Florence, 222, 245

Uberti, Farinata degli, Florentine patriot, 237

Ubi Papa, ibi Roma, 138

Ubi periculum, papal bull, I IO-I I I

Unam sanctam, bull of Boniface VIII, II 8-119, 146

Union Council, at Ferrara and Florence, 344-345

Universities, German, founding of, 5 I0

Urban V, pope, 103, 104, 283; issues bull against the Free Companies, I48; temporary return of, to Rome, 149 ; death of, at Avignon, 149

Urban VI, elected pope, I54, 446; revolt of the French cardinals, 155; the Great Schism, 156; conflict with his new cardinals, 1 58-1 59

Uriel, bishop of Mainz, 513, 514

Valla, Lorenzo, humanist and critic, 502-506; attacks the "Donation of Constantine," 504; becomes "apostolic scribe," 505

Venice, 232, 233; origins of, 246; establishment of the Great Council, 247; ducal elections, 248-249; closing of the Great Council, 249250, 380; the "Golden Book," $25 \mathrm{I}$; nature of the Great Council, $25 \mathrm{I}$; conflicts with Milan, 368 , 393-400; continental expansion, $380-386$; rivalry with Genoa, $386-389,391-392$; revolt of Candia, 389-39o; beginning of commercial decline, 400 
Verona, under the Scalas or Scaligers, 92, 95, 232, 384-385, 393, 403

Vienna, Concordat of, 354-355

Vienne, Council of (13 1 2$), 126$

Villani, Giovanni, Florentine historian, 246, $44 \mathrm{I}$

Visconti, noble family of Milan, 94, 104, 230-23I, 232, 366, 385

Visconti, Azzo, lord of Milan, 92

Visconti, Bernabò, lord of Milan, 402-405; overthrown, 405

Visconti, Filippo Maria, duke of Milan, $367,398,409,4$ I0 4 I I

Visconti, Gabriele Maria, lord of Pisa, $366,409,410$.

Visconti, Galeazzo, capitano del popolo at Milan, $23^{\circ}$

Visconti, Galeazzo (the second), lord of Milan, 403-405

Visconti, Gian Galeazzo, lord of Milan, 289, 366, 394 ; overthrows Bernabo, 405 ; vigorous rule of, 406-409

Visconti, Gian Maria, duke of Milan, 409; murder of, 4 10

Visconti, Giovanni, archbishop and lord of Milan, 402-403; his dealings with Clement VI, 402

Visconti, Lucchino, 402

Visconti, Matteo, capitano del popolo at Milan, 230, 23 I

Visconti, Matteo (the second), 403

Visconti, Otto, archbishop and "boss" of Milan, 230
Visconti, Valentina, marries Louis of Orléans, 289, 290, 406; her rights of succession, 398

Wager of battle, ordinance of Louis IX against, 33-34

Waldemar IV, king of Denmark, at war with the Hansa, 192-193

Wenzel, emperor, 104, 320, 408 ; character of, 407

Willebriefe, 70-7I

William II, king of Sicily, 8, II, I9

William of Holland, claimant to the imperial throne, $56,59,67$

William of Juliers, Flemish leader, 204

William of Ockham, English Franciscan, 165; teacher at Paris, 165; his "Dialogus," 166; his theory of a council, 166-167

Winkelried, Arnold of, legend of, $18 z-183$

Wisby, attacked by Waldemar IV of Denmark, 192-193

Wittenberg, Johann, beheaded, 193

Wool, indispensable to Flemish industry, 201, 258

Wycliffe, John, 161, 167, 187, 504

Ypres, a center of the wool industry, 199

Zeno, Carlo, Venetian admiral, 392 Ziska, John, Hussite leader, 335, 336 Zürich, importance of, 180 


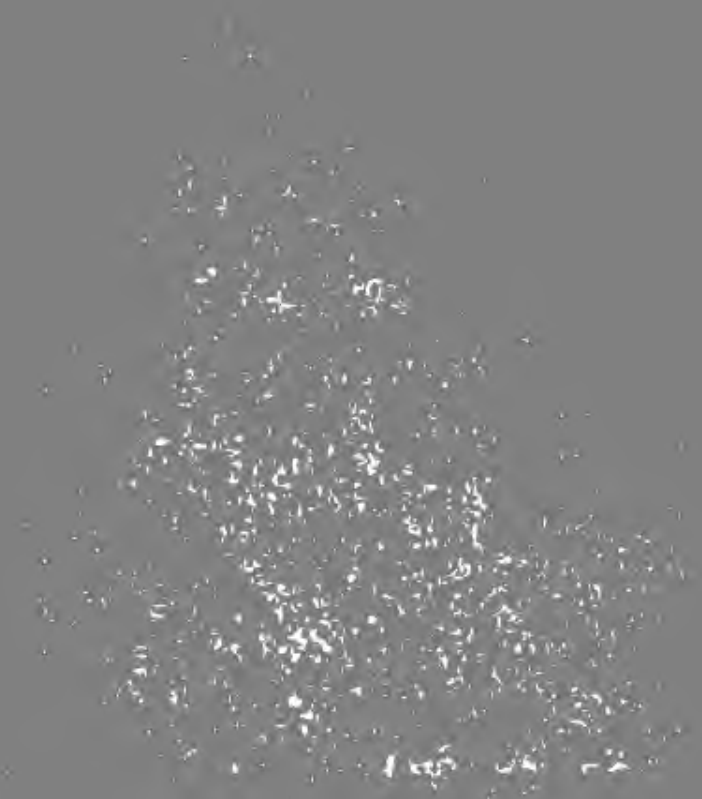





\section{JAN 31966}

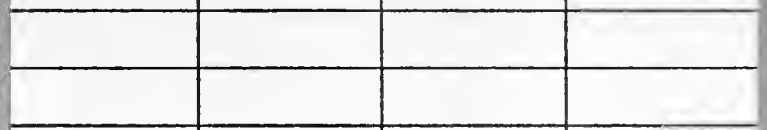

\section{D202 \\ E5 \\ C. 2}


